\title{
ДРЕВНИЕ ПАМЯТНИКИ, КУЛЬТУРЫ И ПРОГРЕСС
}

\author{
A caelo usque ad centrum \\ A potentia ad actum \\ Ad honores
}



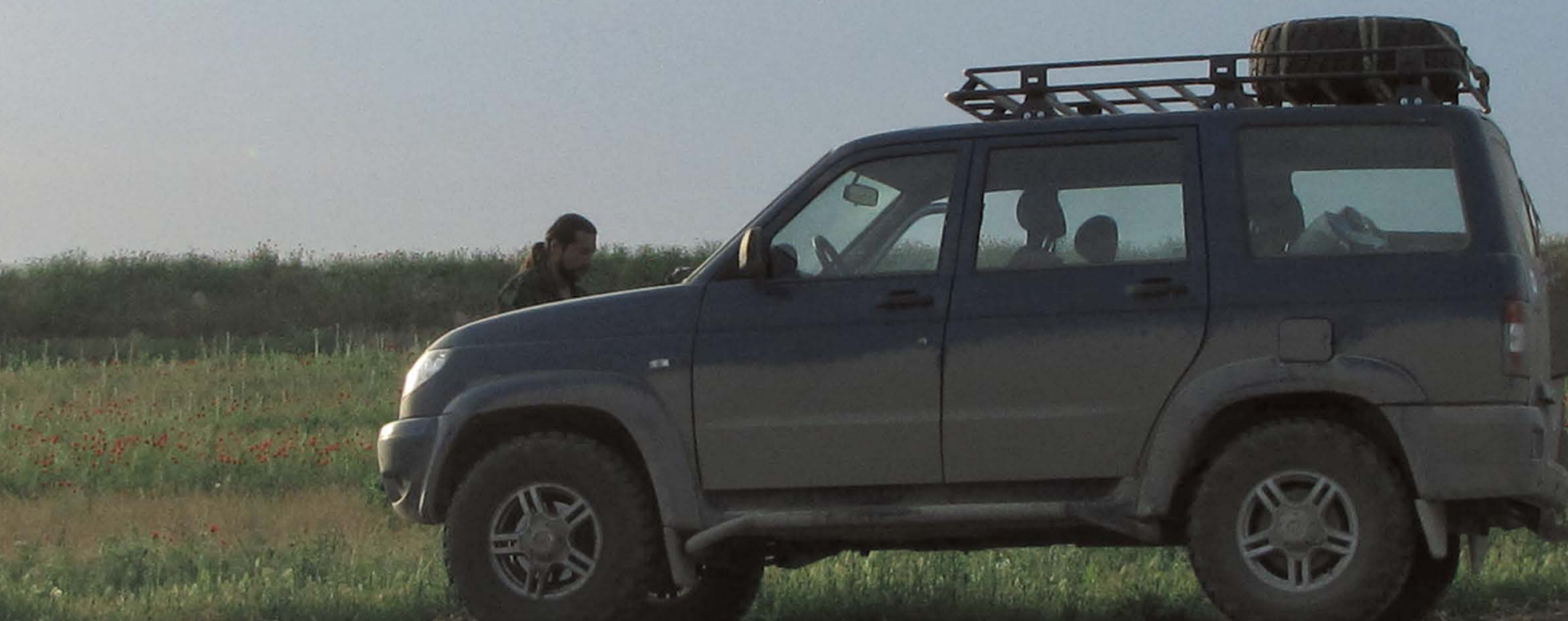

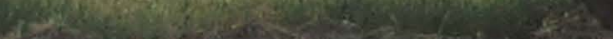

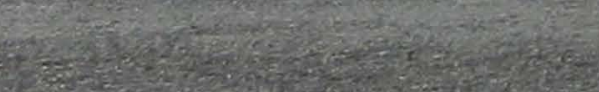

(6.

and

20

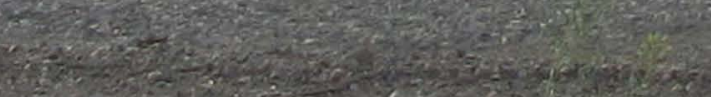

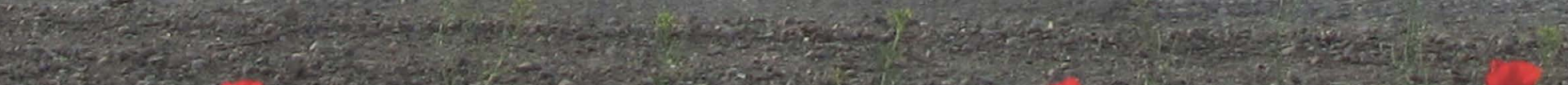

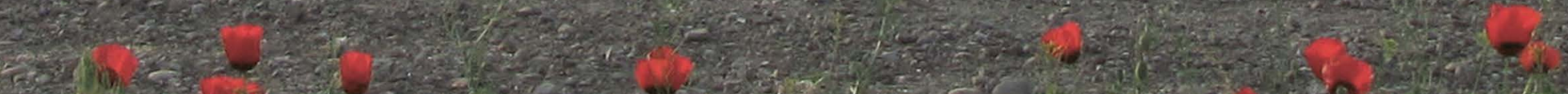

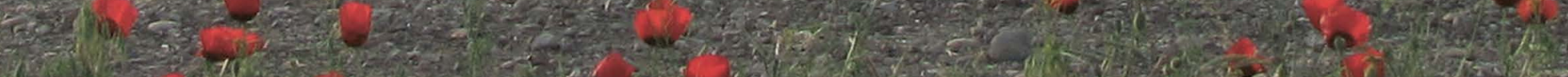
s. 1. 1. 2.

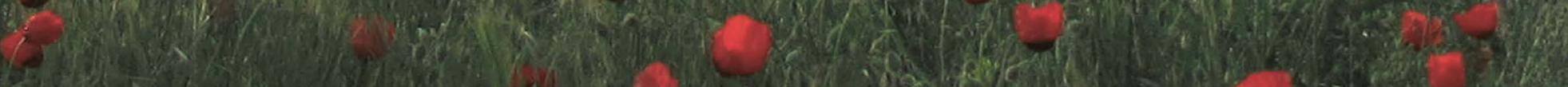
C. 


\section{Институт \\ археологии \\ Российской \\ академии наук}

\section{ДРЕВНИЕ ПАМЯТНИКИ, КУЛЬТУРЫ И ПРОГРЕСС}

A caelo usque ad centrum

A potentia ad actum

Ad honores

СБОРНИК, ПОСВЯЩЕННЫЙ Д. В. РУКАВИШНИКОВУ 
УДК 902/904

ББК 63.4

$\Gamma 70$

\author{
Утверждено к печати \\ Ученым советом Института археологии РАН \\ Редакционная коллегия: \\ И. В. Рукавишникова, О.А. Радюш (ответственные редакторы) \\ И. А. Дружинина, В.Н. Чхаидзе \\ Рецензенты: \\ С. В. Демиденко, О. А. Хомякова
}

\begin{abstract}
Древние памятники, культуры и прогресс. A caelo usque ad centrum.
\end{abstract} A potentia ad actum. Ad honores. - M.: ИA PAH, 2020 - 288 c.

ISBN 978-5-94375-317-6

Сборник научных статей посвящён Д.В.Рукавишникову (1977-2017). В сборник вошли работы представляющие результаты археологических исследованиях на территории России, Сирии, Египта, Монголии, Узбекистана. В составлении сборника приняли участие специалисты из Института Археологии РАН, Института Истории Материальной культуры, Государственного Исторического музея, Института истории археологии и этнографии ДВО РАН, Института Востоковедения РАН и др. научных организаций.

Данное издание вводит в научный оборот как новейшие материалы, так и результаты обработки музейных коллекций.

Для археологов, историков, культурологов, музейных сотрудников.

УДК 902/904

ББК 63.4

ISBN 978-5-94375-317-6

DOI: $10.25681 /$ IARAS.2020.978-5-94375-317-6

(C) Федеральное государственное бюджетное учреждение науки Институт археологии РАН, 2020

(C) Авторы статей, 2020 


\section{Оглавление}

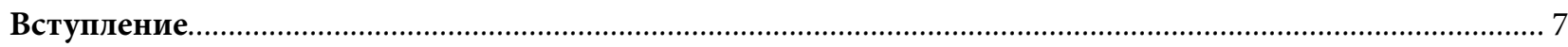

Рукавишникова И. В., Коробов Д. С. Когда бог создавал время, он создал его достаточно ..........................7

Канторович А. Р. Памяти Дмитрия Рукавишникова ……….......................................................................... 9

мунчаев Р. М., Амиров Ш.Н. Телль Хазна............................................................................................ 10

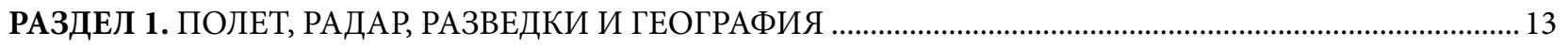

Рукавишников Д. В., Рукавииникова И. В., Морозов П. А. Применение низковысотной аэрофотосъемки и геофизических методов при исследовании каменных курганов скифского времени в Турано-Уюкской котловине (Тува) ................................................................... 14

Чугунов К. В. Курган Аржан-5: взгляд с птичьего полета ............................................................................5

Двуреченская Н. Д., Двуреченский О. В., Морозов П. А., Гладченков А. А. Георадарные

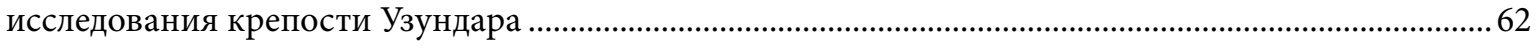

Вальчак С. Б., Гладченков А. А., Клюев Н. А., Слепцов И. Ю., Ласкин А. Р. Разведки и раскопки в Николаевском и Ульчском районах Хабаровского края в 2002 году..................................................9.

Радюш О. А. Исследования 2011 гг. поселения черняховской культуры у пос. им. К. Либкнехта

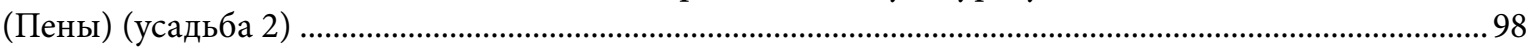

Ветохов С. В., Лебедев М.А., Мальх С. Е. Жизнь у подножия пирамид: из истории одной

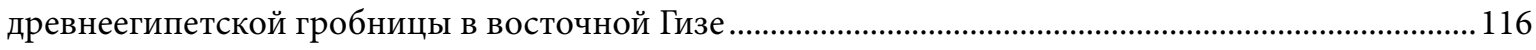

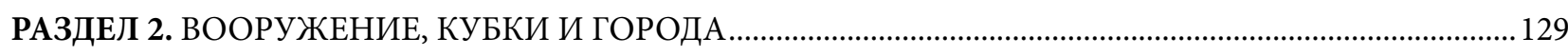

Рукавишников Д. В., Рукавишникова И. В. К вопросу изучения доспехов евразийской степи раннего железного века (поиск аналогий, взаимовлияний и происхождений) ................................130

Канторович А. Р. Образы восточноевропейского скифского звериного стиля и категории вооружения скифов (с учетом новых материалов) 136

Румянцева О. С. Конические кубки в ареале черняховской культуры: коллекция Исторического музея и отходы мастерской в Комарове.

Меньшиков М. Ю., Рукавишникова И. В., Горболь Н. Ю., Юнкин Ж. А. Впускные кочевнические погребения XII-XIII вв. в курганах Керченского полуострова, исследованные в 2017 г................. 180

Каинов С. Ю., Меньшиков М. Ю., Рукавишникова И. В. Шлем из комплекса 3 могильника

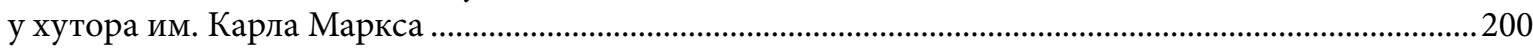

Дружинина И. А., Чхаидзе В. Н. Шестопер из аланского святилища Реком...............................................2212

Кулешов Ю. А., Веселитская В.В. Переделанный «бацинет» из коллекции отдела оружия Государственного исторического музея ..................................................................................................226

Черкасов А. Н., Веретюшкин Р. С., Пастухов А. М. Маньчжурские наконечники стрел

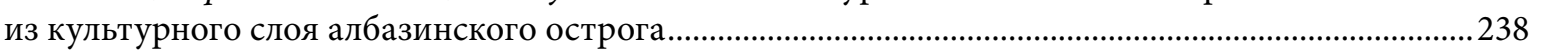

Мадуров Д. Ф. Вопросы средневековой географии Нижнего Поволжья.....................................................250

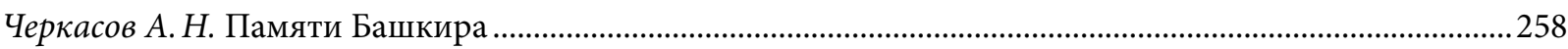

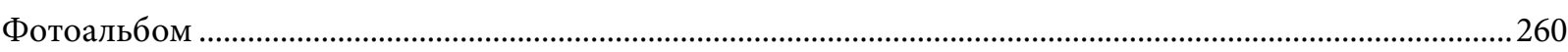

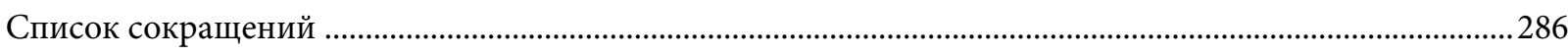

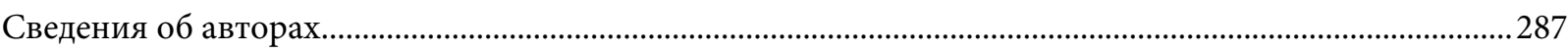




\section{Когда бог создавал время, он создал его достаточно}

5 марта 2017 года не стало Дмитрия Валерьевича Рукавишникова, нашего друга и коллеги, однокурсника и товарища по экспедиционной и московской жизни. Чрезвычайно одаренного и много успевшего, но так несправедливо мало прожившего. Дима, Башкир, Индеец - под этими именами и дружескими прозвищами разные люди видели разные грани его характера, а иногда и его разные интересы и увлечения.

Этот сборник собирался не быстро, долго, потому что мы все по отдельности учились жить без Димы. Сейчас уже не просто писать о том, каким он был, так как мы уже другие, не те, которые жили с ним, были его современниками, мы уже знаем наш мир на 3 года больше. Мы уже старше. Дима остался частью нас, с кем жил. Остались его слова, выражения, шутки, привычки, навыки, присказки, мудрости. Меньше всего о Диме хочется говорить высокопарно. К нему подобное выражение абсолютно не подходит, но он один из тех людей, о которых в древности слагали песни, приукрашивали и заостряли образы и черты. Эти строки Дима не прочтет. Они для нас, с кем проживаем дальше, для тех, кто помнит и скучает. С кем хочется говорить: «А помнишь?». И подновлять образы в памяти. Эти статьи - посвящения археологов преданному другу, товарищу и коллеге, с которым работали, мечтали и творили. Это были бы скульптуры, если мы были бы скульпторами.

Мы знаем Диму со времен учебы в МГУ: веселый археологический однокурсник. Мы вместе работали в Институте археологии - в разных экспедициях, по разным направлениям. Он оставил себя, свои мысли, силы, надежды нам, с кем работал. А мы пишем.

«Когда бог создавал время, он создал его достаточно» - его любимая присказка, мудрость, насмешка, самооправдание. Мы торопимся чтото сделать, форсируем и не успеваем. Он сохраняет спокойствие, улыбку, силу кочевника, созерцание мира.
После защиты диплома в 2000 году Дима работал с нами в новостроечной экспедиции в Предкавказье. Поступил в заочную аспирантуру к Геннадию Евгеньевичу Афанасьеву, под руководством которого в последующие два года проводил раскопки на р. Таволжанке разновременного поселения раннеславянской и салтовомаяцкой культуры. Идея состояла в том, чтобы стратиграфически разделить уровни залегания каждого фрагмента керамики как одной, так и другой культуры, проанализировать это распределение статистическими методами, получить четкую характеристику последовательности жизни на поселении. Для этой задачи Дима разрабатывал целый ряд интересных методических приемов раскопок и фиксации находок. Но исследование застопорилось, фрагменты были стратиграфически перемешаны, и четкой картины получить не удалось.

После были майские выезды в разведки в Курскую и Белгородскую области. Искать был его обязательный способ жизни. С 2001 года Диму отправляют в Сирийскую экспедицию Института археологии РАН, он начинает говорить по-арабски и на языке энеолитической экспедиции Телль-Хазны, где работает под руководством Р. М. Мунчаева и Ш.Н. Амирова. В 2002 году принимает активное участие в работе отряда проводящего разведку на острове Сахалин по трассе строительства нового нефтепровода. Ближний Восток становится Диминой стихией. С 2005 года он работает в Гизе в экспедиции Древнего Царства под руководством Э. Е. Кормышевой. Попутно участвует в разведках в Саратовской области (2010 г.) вместе с О.В. и Н.Д. Двуреченскими (с 2012 г.), с которыми продолжает работу в составе Бактрийского отряда. В 2012 и 2014 гг. отрядом проводятся разведки в Пашхурдской котловине; в 2013 г. в Узбекистане Дима участвует в локализации крепости Узун-дара, в 2014 г. с его участием проводятся раскопки памятника бронзового века Газ-кала - крепости на скале. 
С 2012 года начинаются наши совместные работы в Республике Тыва, где Дима участвует в разведках и раскопках Тувинской археологической экспедиции ИА РАН, а в 2013 г. эти работы продолжаются в Монголии. За несколько сезонов были обследованы курганы Долины царей и курган Аржан 5, а также курган Туннуг, начаты раскопки Аржана 5.

Последние экспедиции, в которых Дима принимает участие: на новостройках в Краснодарском крае и Республике Крым в 2015 и 2016 гг. Перед этим он на короткое время возвращается в Египет, где со своим соратником Сергеем Ветоховым совершает поездку по местам былых работ, осматривает гробницы Гизы и Луксора.

Здесь перечислены Димины вехи в полевой археологии. Все эти проекты были с друзьями и близкими коллегами. Это ли не счастье - paботать с близкими по духу людьми. Но этим списком отнюдь не исчерпывается активная деятельность Димы в науке. Следует сказать еще как минимум о двух направлениях деятельности, в которых Дима был пионером, основателем, практиком и первопроходцем. Это работы в области оружиеведения и геоинформатики. В обеих этих областях Диму интересовала, прежде всего, практическая сторона. При этом в обоих случаях он стоял у истоков - у истоков реконструкторского движения и применения аэрофотосъемки со специальных устройств для полевой археологии, у истоков геоинформационных систем и цифровой компьютерной археологии. Все, к чему прикасался Дима, он хотел сотворить своими руками. Этот путь практика и творца позволял Диме раскрываться в разных областях, порой далеких от академической, кабинетной археологии. Последним местом его деятельности стала работа архитектора сложных компьютерных систем в одной из IT-компаний. Но везде, где бы ни оказывался Дима, он был окружен большим количеством друзей, единомышленников, соратников

Он просто все знал, ему не нужно было ничего доказывать, ничего зарабатывать, ничего писать, защищать диссертации. Он остался во всех работах, которые представлены в этом сборнике, собранном друзьями, где в каждой статье есть какое-то отражение Диминой многогранной натуры: полевая археология и изучение предметов вооружения, археология Месопотамии, Египта, Средней и Центральной Азии, классические полевые раскопки и новейшие компьютерные технологии, взгляд на археологию из глубины раскопа и с высоты птичьего полета...

Глубокая печаль заключается в том, что, уходя из-за стремительно развившейся болезни, он осознал, что так много не сделал, что было им запланировано и должно было быть завершено.

«Хочешь рассмешить бога - расскажи ему о своих планах», - говорил Дима и импровизировал. Он был атеистом и верующим во все силы природы одновременно. Не любил ханжества религиозных учений и уважал традиции верующих. Был «своим» на Ближнем Востоке, в Центральной Азии, на Урале, в Европе, в Крыму и в Москве.

Дима - человек, который, уходя, оставляет ничем невосполнимую пустоту.

Друзья, однокурсники, соратники, коллеги, товарищчи:

Ирина Рукавичникова Дмитрий Коробов

\section{Список работ, написанных по итогам наших совместных исследований:}

Рукавишников Д. В., Рукавишникова И. В. Пластинчатый доспех из погребения №2 кургана №4 могильника Филипповский - 1. Интерпретация комплекса и реконструкция первоначального облика// Ранние кочевники Волго-Уральского региона. Под ред. Л. Т. Яблонского. Оренбург, 2008. С. 105-116.

Рукавишников Д. В., Рукавишникова И. В. Доспех из кургана № 28 могильника Филипповка-1. Предварительные результаты исследования // Историко-археологический альманах. Вып. 9. Армавир-Краснодар-Москва, 2009. С. $42-49$.

Рукавишникова И. В., Обломский А.М., Рукавишников Д. В. Разведки в зоне проектируемой трассы Москва - Симферополь // АО-2007. М., 2010, С. 89-90.

Рукавишникова И.В., Рукавишников Д. В. Методика аэрофотосъемки курганных могильников в Долине царей Тувы// Международная научно-практическая конференция «Историко-культурное наследие народов Центральной Азии: перспективы развития и проблемы сохранения» (14-15 сентября 2012 г., г. Кызыл). Кызыл: Издательство Тувинского государственного университета, редакционно-издательский отдел ТувГУ, 2013. С. 179-180.

Двуреченская Н.Д., Двуреченский О. В., Мокробородов В. В., Рукавишникова И. В., Рукавишников Д. В. Маршрутные исследования на юге Узбекистана в 2013 году// КСИА. 2014. Вып. 236. С. 69-81. 
Рукавишникова И. В., Рукавишников Д. В., Гладченков А. А. Работы Тувинской экспедиции ИА РАН// АО 2010-2013. М, 2015. С. 722-724.

Рукавишникова И. В., Рукавишников Д. В., Морозов П. А. Применение низковысотной аэрофотосъемки и геофизических методов при исследовании каменных курганов скифского времени в Турано-Уюкской котловине (Тува)// Археология и геоинформатика. Вторая Международная конференция. Тезисы докладов. М.: ИА РАН, 2015. С.30.

Рукавишникова И. В. Исследования разрушенного кургана Аржан-5 - памятника начала эпохи ранних кочевников в Туве (архитектура, результаты применения естественнонаучных методов, перспективы дальнейших работ)// Ранний железный век Евразии от архаики до рубежа эр. Центры, периферия и модели культурных взаимодействий. Материалы тематической конференции. СПб: «Скифия-принт», 2015. С. 92-94.

Рукавишникова И. В. Памятники ранних кочевников Тувы //Институт археологии: новые экспедиции и проекты. Под ред. Н.А. Макарова. М.: ИА РАН, 2015. С. 32-35.

Рукавишникова И. В., Мокробородов В. В., Горин А. Н., Гладченков А. А. Газкала - новый памятник древнейшей в Средней Азии цивилизации БМАК // КСИА. 2015. № 239. С. 72-86.

Рукавишникова И. В., Гладченков А. А. Что скрывают древние курганы Тывы // Природа. 2016. № 1, (1205). С. 80-81.

Рукавишникова И. В., Меньшиков М.Ю., Воробьев И. И., Воронков И.А. Новый античный памятник сельской округи древней Горгиппии, публикация материалов// Древности Боспора. Т. 20. М.: ИА РАН, 2016. С. 365-381.

Рукавишникова И.В., Гладченков А. А. Исследования Аржана-5 в Турано-Уюкской котловине// КСИА. Вып. 243.2016. C. $49-58$.

Рукавишников Д. В., Рукавишникова И. В., Морозов П. А., Гладченков А. А. Применение низковысотной аэрофотосъемки и геофизических методов при исследовании каменных курганов скифского времени в Турано-Уюкской котловине (Тува)//Археология и геоинформатика. Выпуск 8. М.: ИА РАН, 2017. (DVD-ROM)

Рукавишникова И. В., Рукавишников Д. В. Погребально-поминальный комплекс Аржан-5 (Республика Тыва, Пийхемский район)// Города, поселения, некрополи. Раскопки 2016 г. Материалы спасательных археологических исследований. Т. 19. М.: ИА РАН, 2017. С. 168-174.

Рукавишникова И.В., Переводчикова Е.В., Меньшиков М.Ю. Раскопки античного поселения Тасуново-7 в Восточном Крыму// Исторические Исследования. Журнал Исторического факультета МГУ. 2017. № 8. Материалы научной конференции «Чтения памяти И.В. Яценко». С. 301-312.

Рукавишникова И. В., Меньшиков М. Ю., Воробьев И. И. Исследования нового биритуального могильника хазарского времени на Северо-Западном Кавказе // Кавказ в системе культурных связей Евразии в древности и средневековье. XXX «Крупновские чтения» по археологии Северного Кавказа. Материалы Международной конференции. Карачаевск. 2018. С. 361-364.

\section{Памяти Дмитрия Рукавишникова}

Три года тому назад, 5 марта 2017 года ушел из жизни Дмитрий Валерьевич Рукавишников яркий, талантливый, добрый и самоотверженный человек, выпускник кафедры археологии МГУ имени М.В. Ломоносова.

Дима родился 8 мая 1977 года в Москве, в семье научных работников. Он рос в подмосковном наукограде Троицке, где в 1994 г. закончил гимназию и уже школьником проявил большие способности в науке, - в частности, в программировании. В 1995 году Дима поступил на исторический факультет Московского университета, где он специализировался по кафедре археологии под руководством выдающегося отечественного археолога профессора Германа Алексеевича Федорова-Давыдова. Дима окончил кафедру в 2000 году, написав дипломную работу по материалам могильников нижневолжских средневековых кочевников домонгольского времени. Эта работа, предельно краткая и очень интересная, была высоко оценена кафедрой и рецензентами, одним из которых был заведующий кафедрой археологии, крупнейший ученый академик Валентин Лаврентьевич Янин.

Еще до окончания МГУ, с 1999 года Дима начал трудиться в Институте археологии РАН, где до 2007 года он работал штатным сотрудником, а затем, до конца жизни - по трудовым договорам в экспедициях.

Дима - как студент, который слушал мои лекции, сдавал мне зачет и экзамен, - остался в моей памяти немногословным и в то же время пытливым, компетентным и чрезвычайно доброжелательным человеком. Будучи проездом в Донской экспедиции кафедры археологии МГУ у профессора Натальи Борисовны Леоновой, я наблюдал Диму как студента-практиканта и полевика. Это было лишь самое начало его полевого опыта, но и тогда уже Дима был воплощенная надежность, а полевая работа была для него абсолютно естественным и любимым занятием, что в дальнейшем 
подтвердилось на его чрезвычайно обширном и разнообразном экспедиционном пути.

После окончания Димой кафедры я с радостью узнавал о его новых успехах - о работах Димы в области компьютеризации археологии, о разработке ГИС в археологии, о сконструированном им дирижабле для видеосъемки археологических объектов, о других его изобретениях и остроумных выдумках, о поездках в экспедиции в самые разные части света и, конечно, о создании им семейного союза с не менее замечательным археологом - выпускницей нашей кафедры Ирой Тришиной, ставшей Ирой Рукавишниковой.

Увы, я нечасто виделся с Димой после его выпуска, но всегда получал от этих встреч большое удовольствие, поскольку, общаясь с Димой, я всегда чувствовал его внутреннюю цельность, силу, собранность и, не боюсь повториться, надежность. Я сознавал, что к такому яркому и позитивному человеку должны непременно тянуться люди, и потому меня совсем не удивило, что на прощании с Димой в марте 2017 года я увидел множество людей самых разных возрастов, профессий и интересов - и археологов, включая руководство Института археологии, и специалистов из других наук, и «айтишников», и реконструкторов, и, конечно, Диминых родных и близких, так его любивших ...

За свою недолгую жизнь Дима сумел очень много сделать для археологии и для смежных с ней наук, для Науки как таковой. Об этом прекрасно и емко написано в предваряющей этот сборник заметке Ирины Рукавишниковой и Дмитрия Коробова.

Дима оставил нам всем большое наследство: интереснейшие мысли, открытия, изобретения, свое душевное тепло и сочувствие, и мы должны быть достойны этого наследства и Диминой памяти.

Заведуюший кафедрой археологии исторического факультета МГУ А.Р. Канторович

\section{Телль Хазна}

Телль Хазна 1 - это памятник рубежа первобытности и ранней цивилизации (IV-III тыс. до н.э.), расположенный в северо-восточной Сирии. Он представляет собой телль площадью около 2 га и имеет максимальную мощность культурного слоя 17 м. Памятник в настоящее время широко известен благодаря исключительной сохранности монументальной архитектуры из сырцового кирпича.

Раскопки этого поселения проводились в 1988-2010 гг. В конце 90-х годов ХХ в. это был один из наиболее масштабных проектов ИА РАН. На поселении раскопано более $5000 \mathrm{~m}^{2}$ площади, в ряде мест исследование слоя доведено до материка.

Следует отметить, что археологические исследования Телля Хазна 1 1990-х гг. в значительной степени пришлись непосредственно на время «компьютерной революции» в археологии. Это был период качественных изменений в полевой фиксации материала, связанной с внедрением цифровой техники в работу археологов. На тот момент в институте не было специалиста, более подготовленного в области цифровых технологий, чем Дмитрий Рукавишников. Помимо личных опытов использования компьютера в полевой работе, он в то время выполнял и работу системного администратора института и был определенно лучшим среди наших археологов в этой области.

Уже к началу 1990-х гг. стало понятно, что Телль Хазна представляет собой экстраординарный культовый комплекс уникальной сохранности. Отдельные сооружения этого комплекса сохранились на высоту до 5-8 м. Монументальность сооружений и их исключительная сохранность ставили перед экспедицией ряд задач повышенной сложности, связанных с фиксацией исследуемых материалов и трехмерным моделированием культурного слоя памятника.

В этой ситуации было очевидно, что Сирийской экспедиции ИА РАН необходим археолог, который мог бы помочь с решением этих задач. Именно с этой целью в 2002 г. к участию в работе экспедиции был приглашен Дмитрий. С его помощью был решен ряд практических полевых вопросов - от цифрового фотографирования объектов для создания объемных образов методом фотограмметрии до аэрофотографирования всей вскрытой площади поселения. 


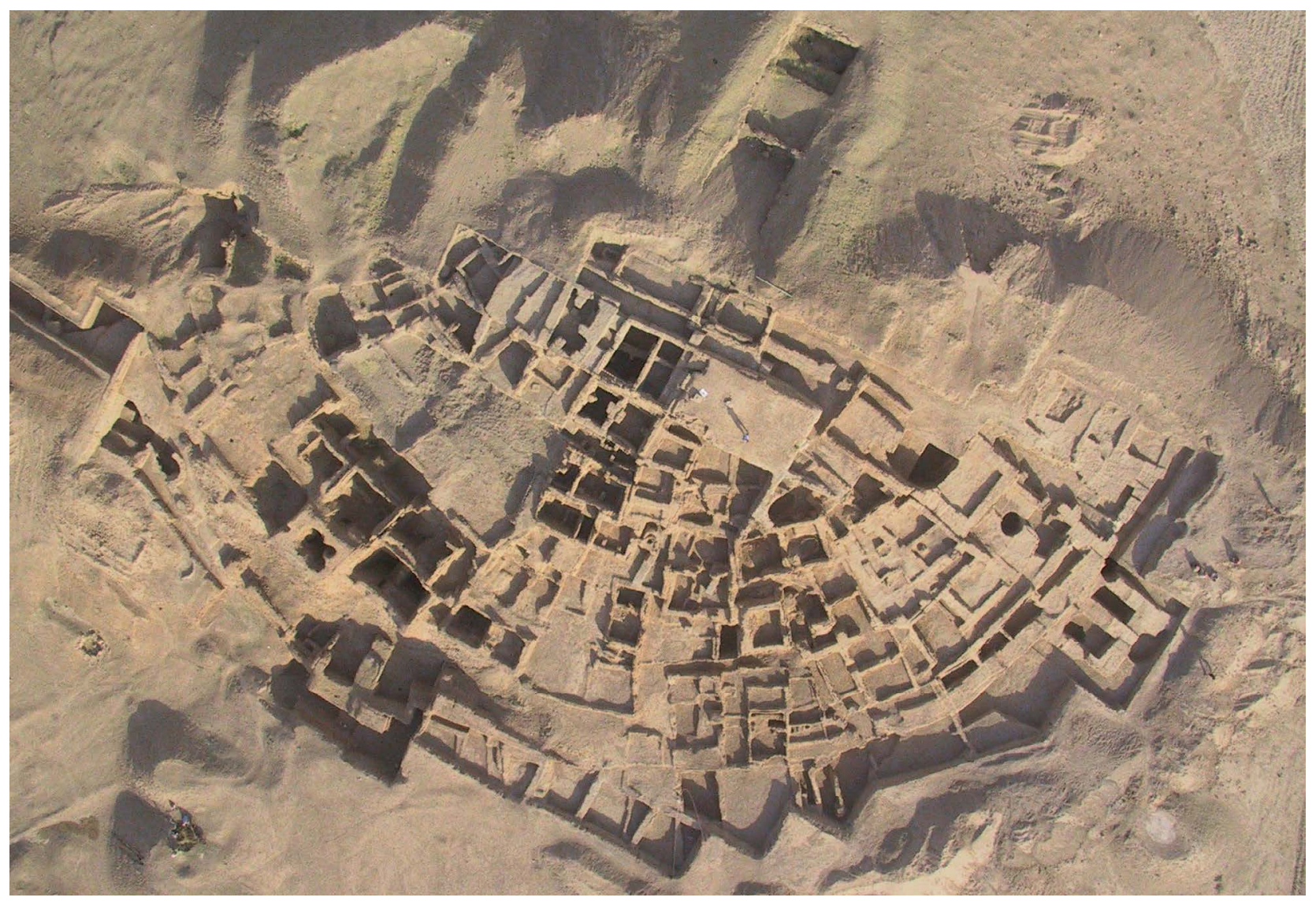

Рис. 1. Тель-Хазна съемка Д. В. Рукавишникова с дирижабля 2004 г.

Здесь следует отметить, что аэрофотографирование в течение нескольких лет начала XXI в. прошло путь стремительного развития от первых опытов до рутинной практики. В настоящее время, когда использование квадрокоптера стало обычным делом полевых археологических исследований, даже сложно представить, что еще несколько лет назад археологическая аэрофотография была редкостью и была связана с рядом технических сложностей.

В месопотамской полевой археологии, если не считать фотографии, сделанные в 2030 гг. XX в. с борта самолета, первые аэроснимки делались с помощью дельтаплана с зафиксированной под крылом камерой еще в конце 1990-х гг. Следующим шагом, уже в начале 2000-х гг, было использование аэростатов, заполненных гелием. Собственно единственной археологической миссией в Сирии, которая использовала аэростат для этих целей, была наша экспедиция. Использовать для фотографирования генерального плана поселения Телль Хазна 1 аэростат предложил Дмитрий Рукавишников, он полностью и реализовал этот проект, который уложился в две фотосессии, в 2005 и 2006 гг.

Дмитрий настолько уверенно создавал слагаемые этого проекта, что казалось, что он уже имеет большие знания в использовании аппаратов легче воздуха в археологии. На самом деле это был его первый опыт аэрофотосъемки. Помимо покупки в Москве оболочки баллона, который получил гордое имя «Винни-Пух», и создания дистанционного управления камерой, было необходимо заказать в Дамаске нужное количество емкостей с гелием, создать раму, к которой должна крепиться камера. Все это было сделано и собрано лично Дмитрием, который и руководил процессом фотосъемки. Участие остальных членов экспедиции сводилось к тому, чтобы держать стропы аэростата, по команде перемещать его к разным участкам поселения, поднимать или опускать его на различную высоту. Таким образом, широко известные в настоящее время аэрофотографии Телля Хазна 1 - это полностью заслуга Дмитрия. Для нулевых годов XXI в. это была новаторская технология, которая обгоняла возможности других археологических миссий в Сирии. 


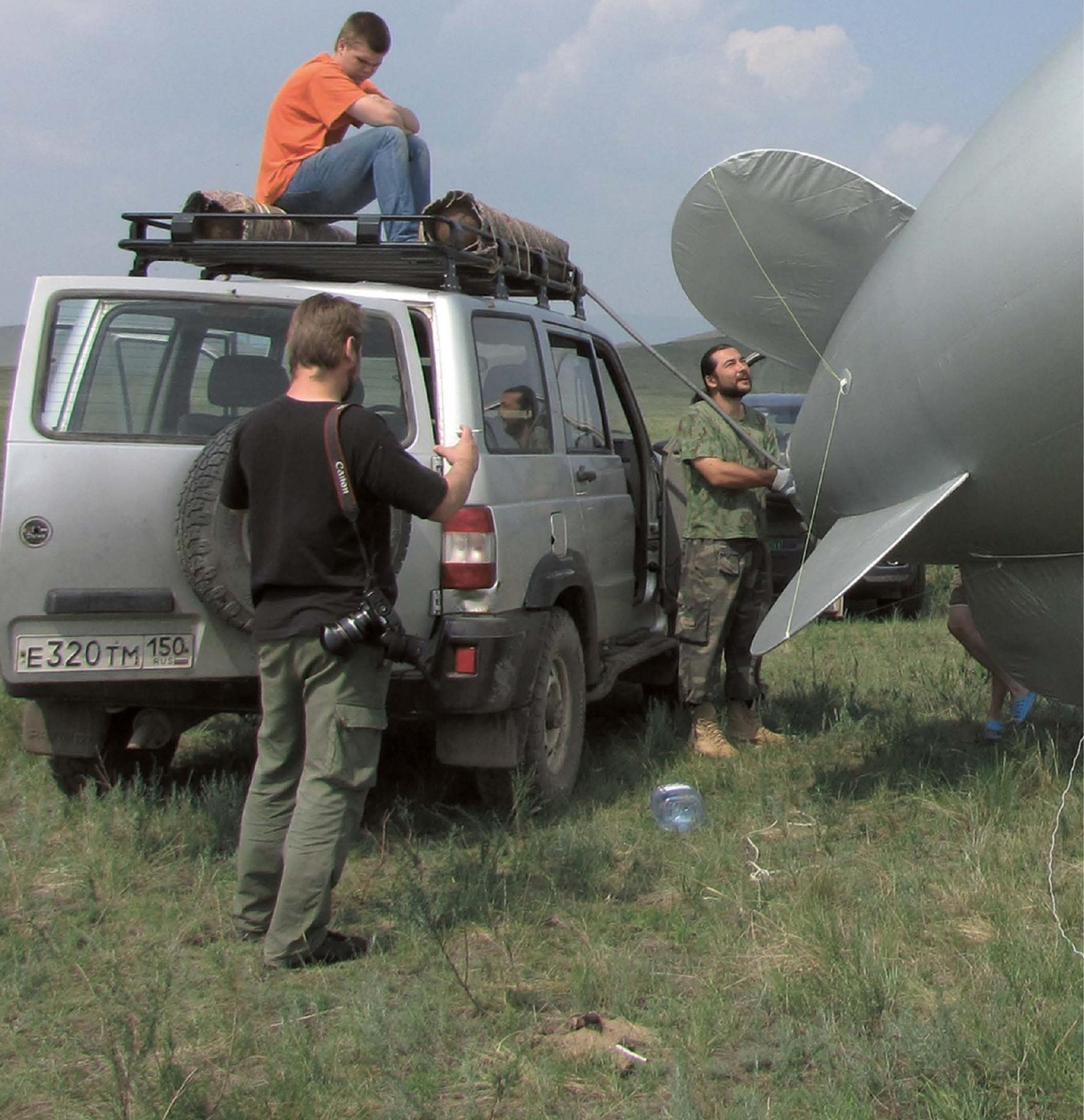




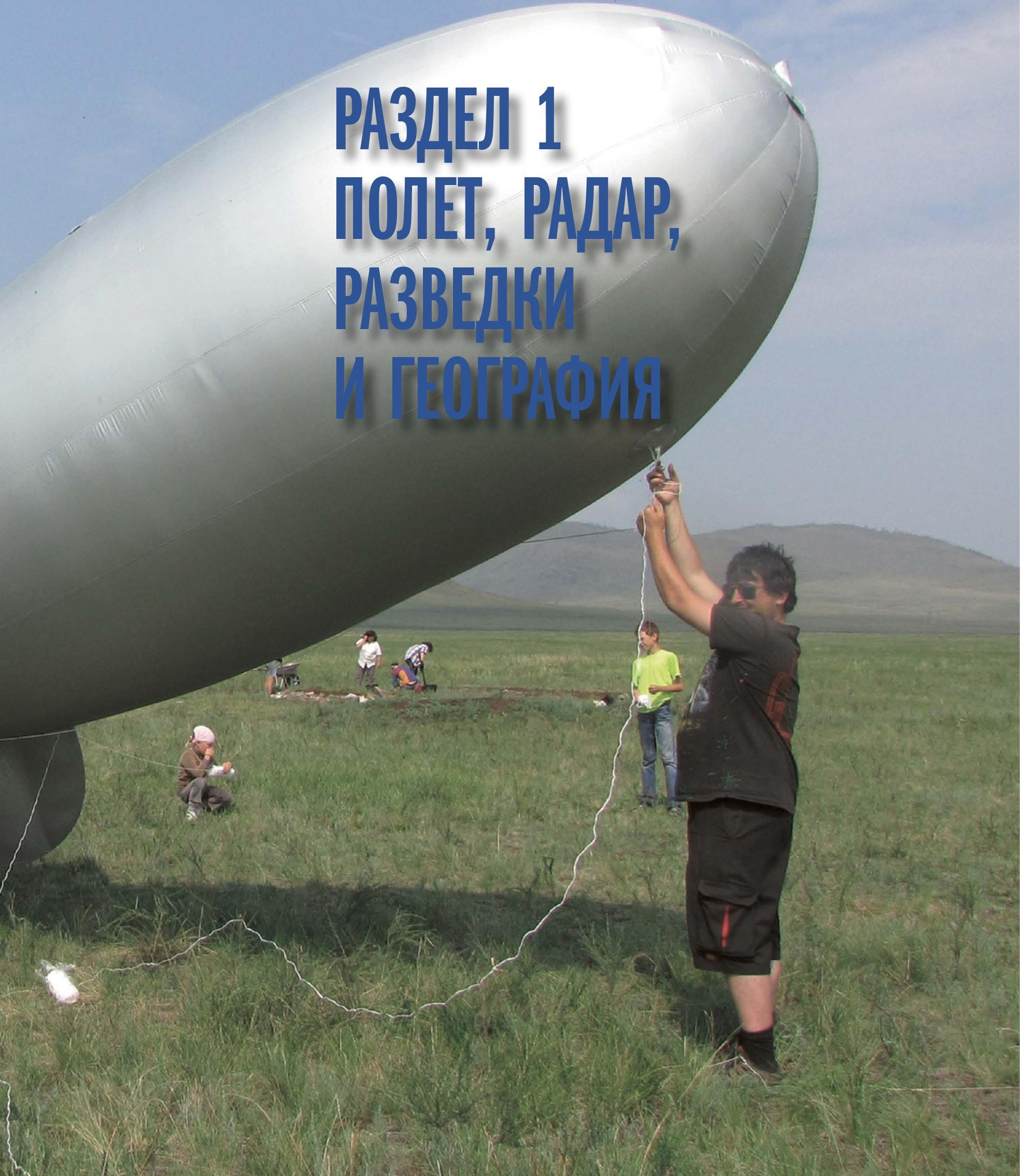

$(5)$ 


\section{ПРИМЕНЕНИЕ НИЗКОВЫСОТНОЙ \\ АЭРОФОТОСЬЕМКИ И ГЕОФИЗИЧЕСКИХ МЕТОДОВ \\ ПРИ ИССЛЕДОВАНИИ КАМЕННЫХ КУРГАНОВ \\ СКИФСКОГО ВРЕМЕНИ В ТУРАНО-УЮКСКОЙ \\ КОТЛОВИНЕ (ТУВА)}

\section{Д. В. Рукавишников, И. В. Рукавишникова, П. А. Морозов}

Авторы благодарят летчика-энтузиаста B. А. Митрохина (2. Туран) за неоценимую помощь в проведении работ в 2012-2015 г2.

Замыслом описанных ниже работ и их результатов (рис. 1-20) было исследовать курганные поля Турано-Уюкской котловины (рис. 1-3), используя разные летательные аппараты и геофизические методы. Это территория расположения знаменитых курганов знати древней Тувы, таких как Аржан и Аржан-2 (Грязнов, 1980; Чугунов, 2002). В меридиональном направлении вдоль всей котловины простираются курганные могильники, состоящие из цепочек курганов разных размеров и форм (рис. 4,5 ).

Исследования в долине начал первый археолог в Туве - А. В. Адрианов (2008), пытаясь вскрыть самый большой холм на западе долины. И первые раскопки в долине р. Уюк были проведены А. В. Адриановым в 1916 г., а также С.А. Теплоуховым в 1927 и 1929 гг. (Кызласов, 1980). Но самый большой и интереснейший комплекс - курган Аржан - исследован в 1970-х гг. М. П. Грязновым и М. Х. Маннай-оолом (рис. 13). В 1947 и 1955 гг. Л. Р. Кызласов обследовал курган Аржан и сделал замеры (1980. С. 34). В 1971 г. М. П. Грязнов и М.Х. Манай-оол приступили к раскопкам кургана Аржан. В ходе этих исследований был открыт самый значительный памятник истории Тувы раннего железного века. Материалы работ (Грязнов, 1971-1972; 1973-1974) опубликованы в монографическом исследовании (Грязнов, 1980). В 1990-х гг. в долине работала Тувинская экспедиция ИИМК под

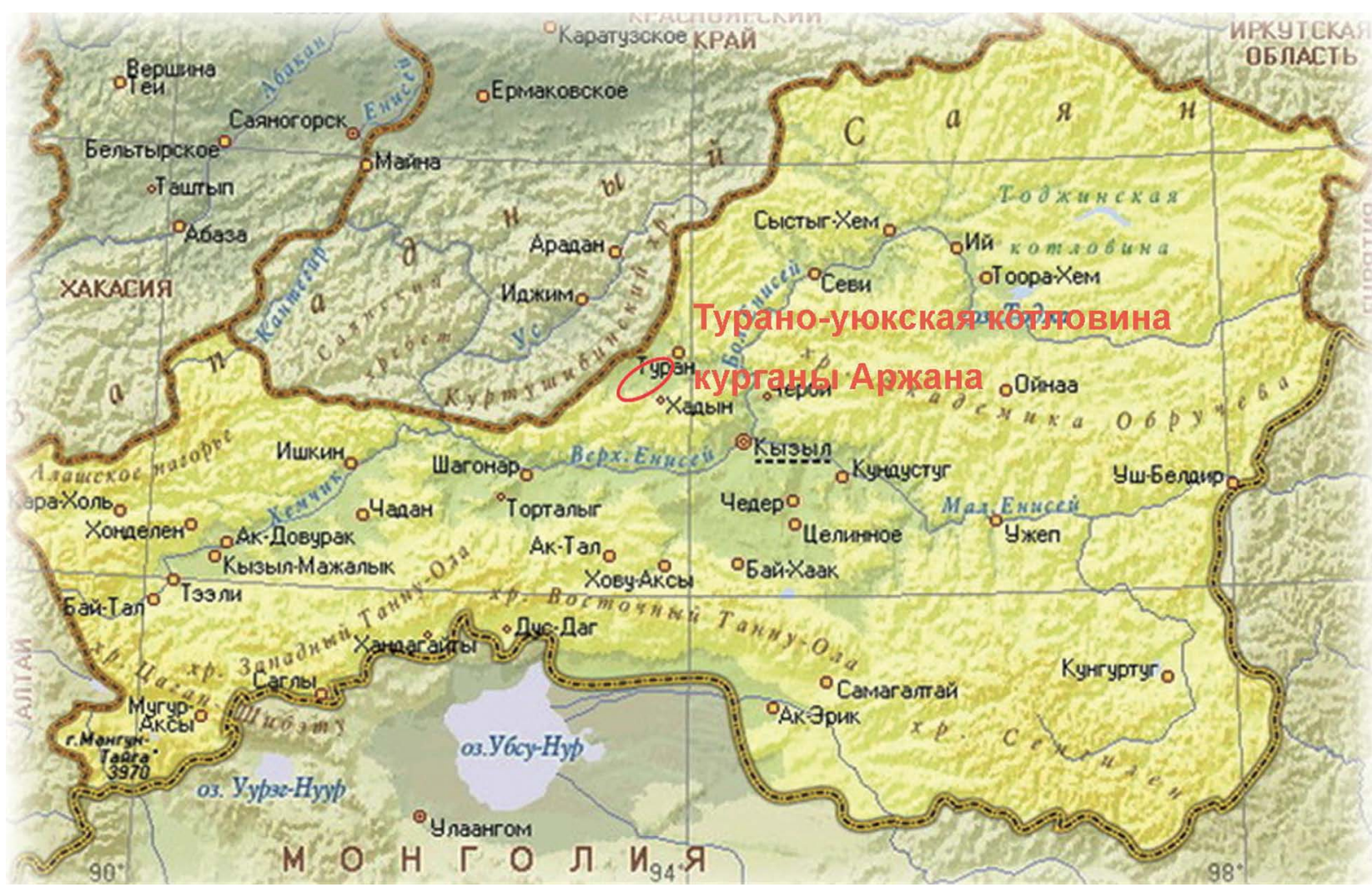

Рис. 1. Карта Республики Тыва. Турано-Уюкская котловина. Курганы Аржана 
руководством Вл.А. Семенова (Семенов, 1992, 1995, 1996, 1998, 2000), были изучены курганы могильника Кош-Пей (Семенов, 2015), относящегося к середине I тыс. до н. э.

В 1998 г. памятники долины обследованы Центрально-Азиатской экспедицией во главе с К. С. Чугуновым. Выполнены инструментальная съемка и генеральный план погребально-поминального комплекса Аржан-2 с примыкающими к нему поминальными выкладками на трассе Туран - Аржан (Чугунов, 1999). В 2000 г. Центрально-Азиатская экспедиция совместно с группой специалистов из Евразийского отделения Германского института археологии начала работы на погребально-поминальном комплексе Аржан-2. Раскопано несколько каменных колец на западной периферии комплекса. С 2001 по 2004 г. экспедицией проводились исследования кургана знати Аржан-2 (Чугунов, 2002, 2003, 2006). В нем обнаружен ряд погребений, содержавших нетронутые комплексы захоронений кочевой элиты I тыс. до н. э. (Чугунов и др., 2002; Cugunov et al., 2010; Чугунов, 2011).

Таким образом, в общей сложности в долине к настоящему времени выявлено несколько сотен погребально-поминальных сооружений, входящих в три последовательно простирающихся с запада на восток курганных поля: Ченгитэйское (рис. 6-8), Кектонское, Аржанское (рис. 9), исследовано два выдающихся памятника, относящихся к начальному периоду раннего железного века Тувы. Исследователи отмечали особую сложность конструкций каменных курганов, а также насыщенность поминальных сооружений в околокурганных пространствах.

Большая часть площади могильников котловины, занимающих несколько кв. км, не подвергается антропогенному воздействию. Часть памятников находится на территории пос. Аржан, где каменные выкладки постоянно разбираются на строительный материал.
Низковысотная аэрофотосъемка.
Основные цели работ:

- получение данных по планиграфии памятников;

- выявление деталей подкурганных конструкций;

- выявление околокурганных сооружений
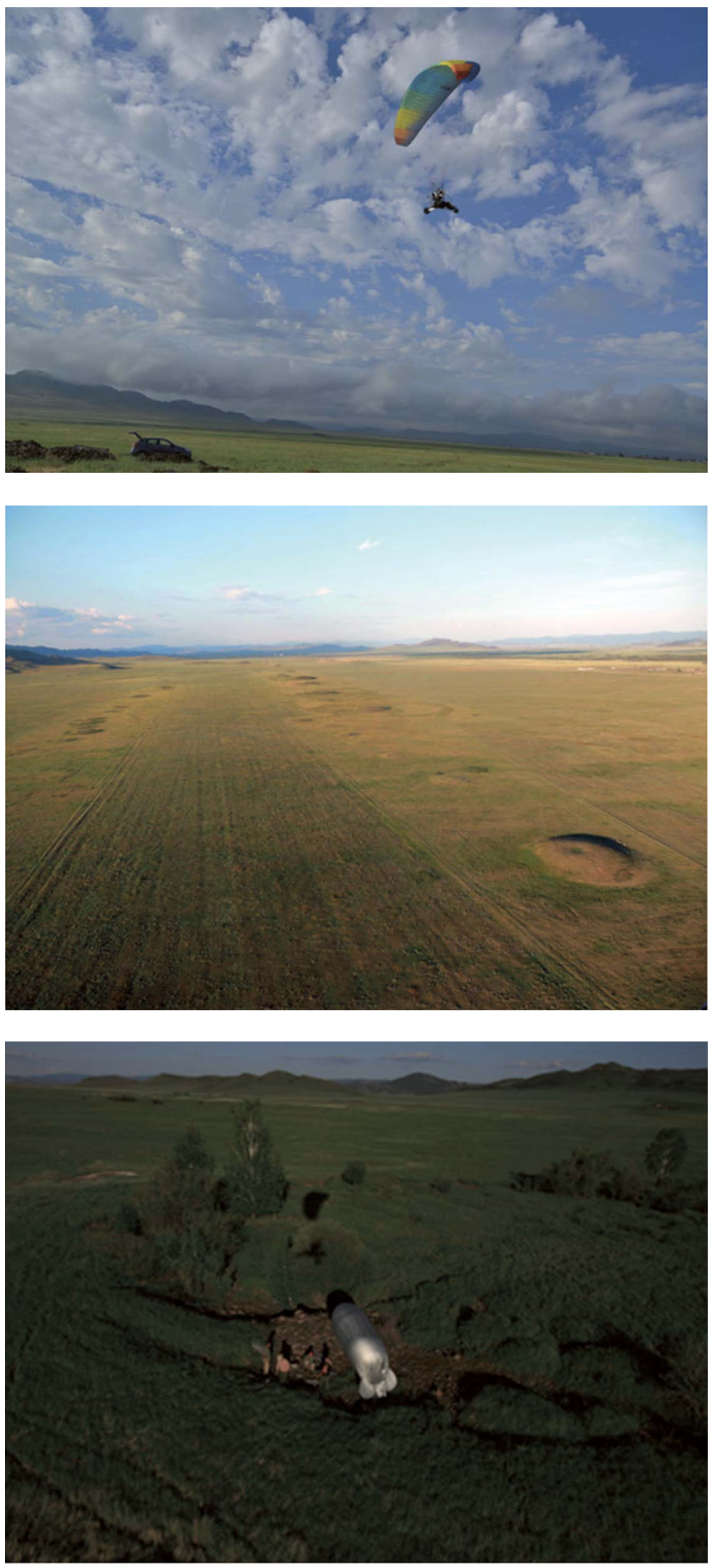

Рис. 2. Низковысотная аэрофотосъемка 


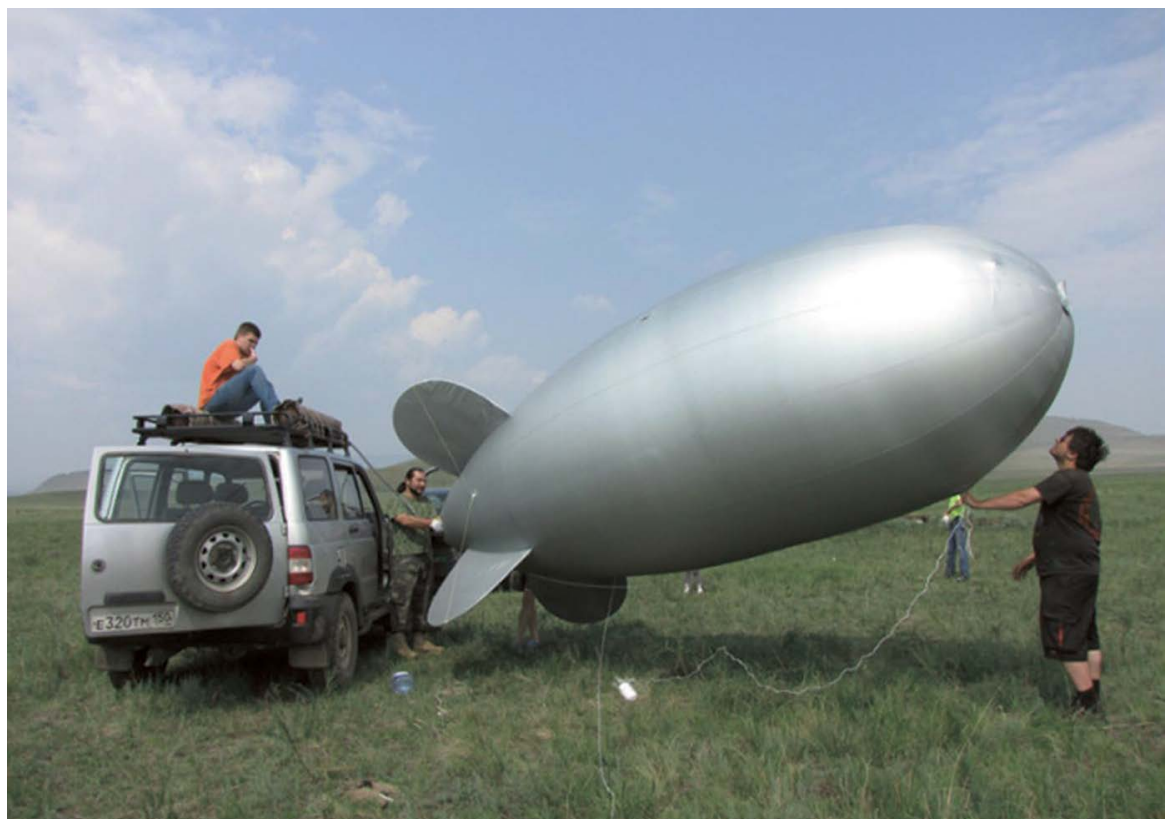

Съемки производились с гелиевого аэростата АСГ-10 и мотопароплана, с разных высот, основная высота съемки -150 метров. Для съемки использовался цифровой фотоаппарат со встроенным GPS приемником, что дало возможность для каждой фотографии получить привязку снимка к реальным географическим координатам.

Рис. 3. Гелиевый аэростат, с которого велась съемка

В 2008 г. А.Г. Акуловым созданы топопланы курганов долины. В ходе этих работ выделены упомянутые выше Аржанское курганное поле, включающее в себя курганы и выкладки от кургана Аржана на западе (пос. Аржан) до погребально-поминального комплекса Аржан-2 на востоке, Кектонское курганное поле, расположенное между пос. Аржан и д. Чкаловка, и Чингетэйское курганное поле, расположенное от комплекса Чинге-Тэй на западе и до крайних курганов у д. Чкаловка.

Впоследствии данные планы были использованы при систематизации результатов проводимой низковысотной аэрофотосъемки. (Авторы

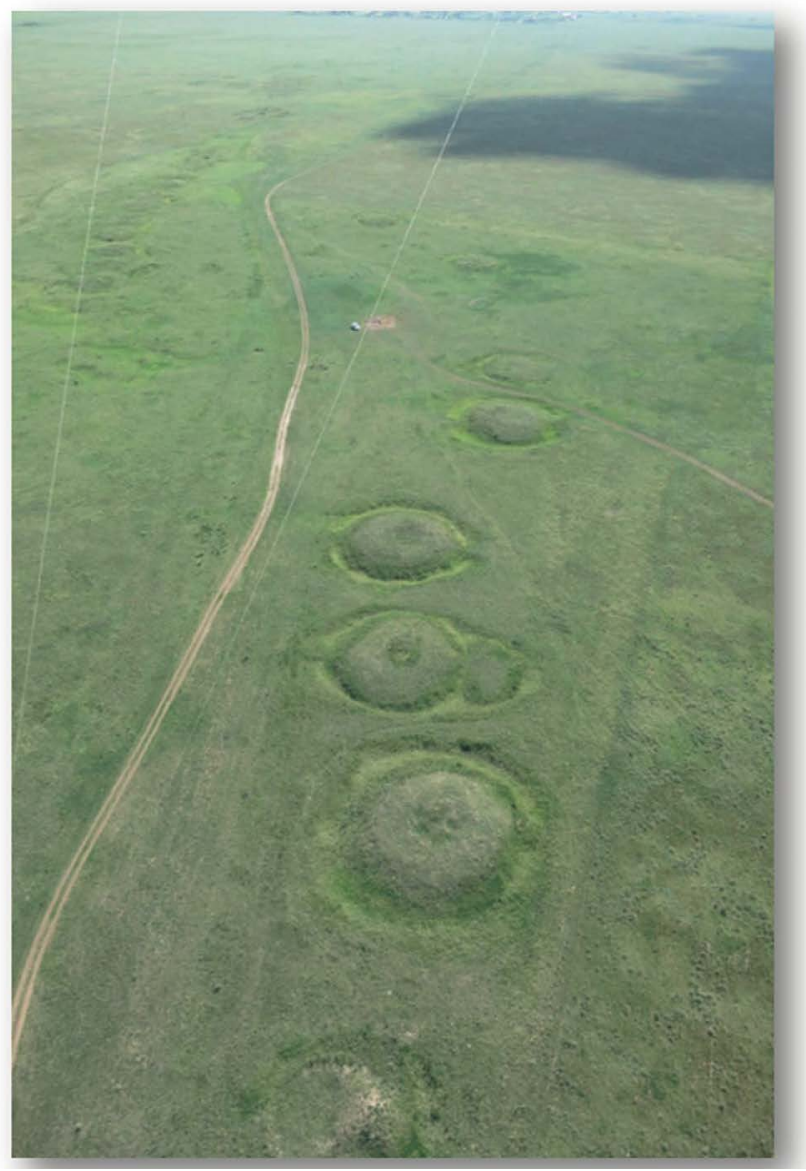

Чингетэйское курганное поле

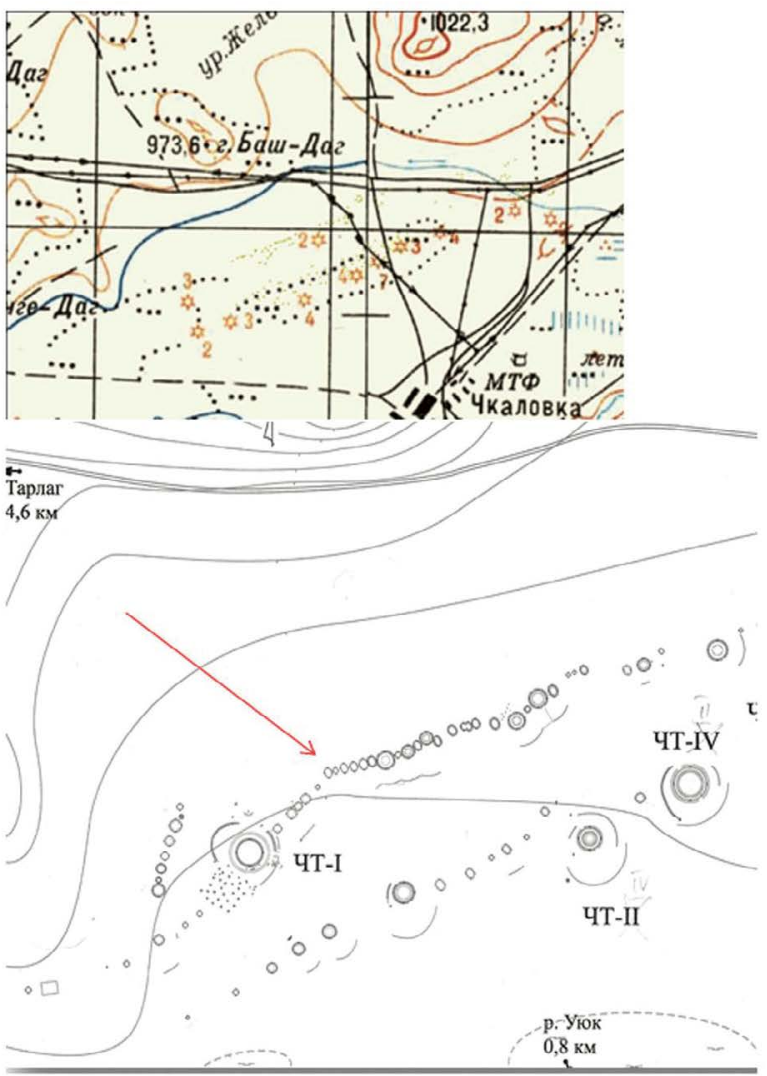

Pис. 4. Чингетэйское курганное поле (аэросъемка, врезка карты, план) 


\section{Курган Чинге-Тэй 1. Детали околокурганных конструкций}
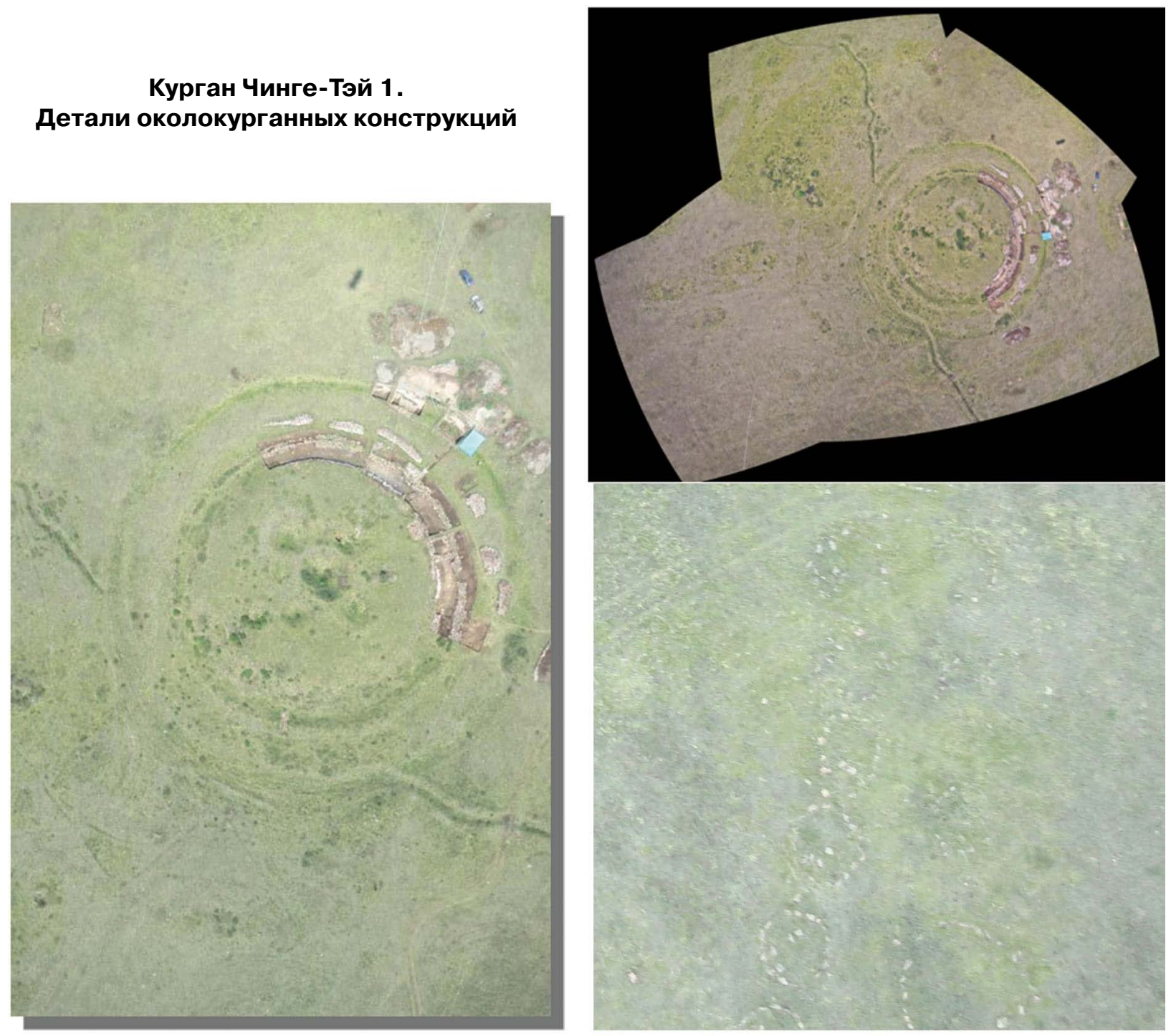

Рис. 5. Курган Чинге-Тэй І. Детали около курганных конструкций

выражают большую благодарность А. Г. Акулову и К.В. Чугунову.)

Работы с применением данного метода были начаты в 2012 г. отрядом Института археологии РАН (рис. 3). В 2012-2015 гг. отрядом Тувинской экспедиции ИА РАН проводились аэрофотосъемка и археологические изыскания в зонах расположения курганных полей Аржан и Чинге-Тэй (рис. 4-10) (Рукавишникова, 2013; 2014a, б; 2015a, б; Рукавишникова, Рукавишников, 2013; Рукавишникова и др., 2015). В 2013 г. проводились исследования и отдельно стоящего кургана в урочище Туннуг (рис. 11, 12).

В ходе работ проводилась низковысотная аэрофотосъемка с целью создания аэрофотоснимков интересующих объектов для получения дополнительной информации о структуре курганных насыпей, подкурганных сооружений и периферии (рис. 5-10). Отдельной целью работ было проведение георадарных исследований интересующих объектов (см. Приложение 1, 2).
Съемки велись с гелиевого аэростата АСГ-10, с разных высот, основная высота съемки 150 м. Для съемки использовался цифровой фотоаппарат со встроенным GPS-приемником, что дало возможность для каждой фотографии получить привязку снимка к реальным географическим координатам. Материалы, полученные в результате выполненных работ, позволили выявить новые памятники археологии, уточнить их внешнюю и внутреннюю структуры, используя неразрушающие методы исследования.

Съемка проводилась на площади около

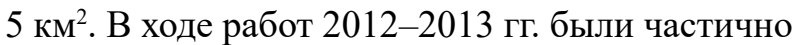
отсняты Чингетэйское курганное поле (рис. 4-8) и западная часть Аржанского курганного поля (рис. 9, 10).

Съемка выполнялась в разное время суток для получения снимков в различном освещении, что позволяет увидеть изменения деталей рельефа, связанные с архитектурными поминальными конструкциями. Этот метод позволил получить 

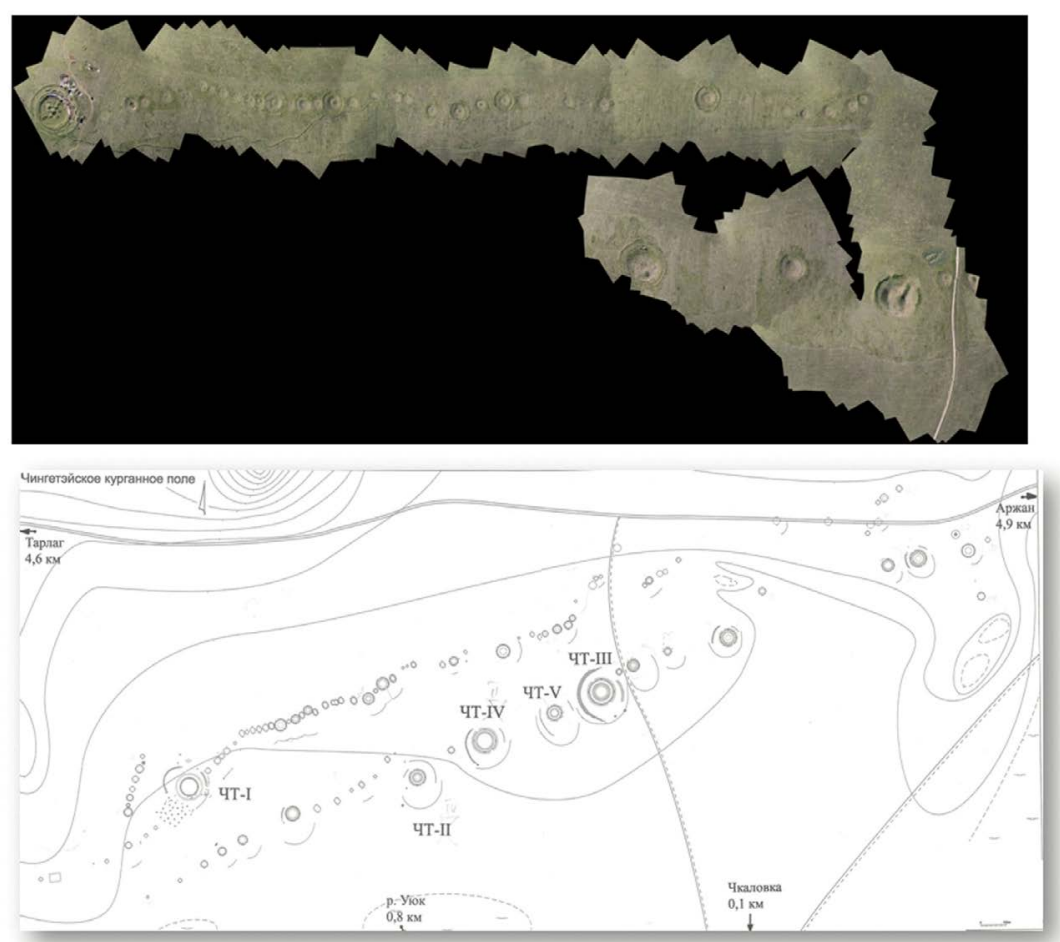

Рис. 6. План Чингетэйского курганного поля (сост. А. Г. Акулов) и склейка аэрофотосъемки курганов снимки курганных конструкций высокого разрешения, что предоставляет возможность провести максимально эффективную дешифровку деталей объектов. Этот этап работ проводился при помощи программных продуктов GlobalMapper, ESRI ArcInfo и ERMapper, в итоге выделены и зафиксированы в системе координат археологические объекты: курганы, рвы, каменные поминальные выкладки.

При совокупности результатов съемки и тахеометрического плана получается максимально точная схема курганных полей. В ходе работ исследованы следующие зоны: северная цепочка курганов Чингетэйского курганного поля, курган Чинге-Тэй-1 (рис. 4-7) и его периферия; курганы Аржанского могильного поля (рис. 9-11).
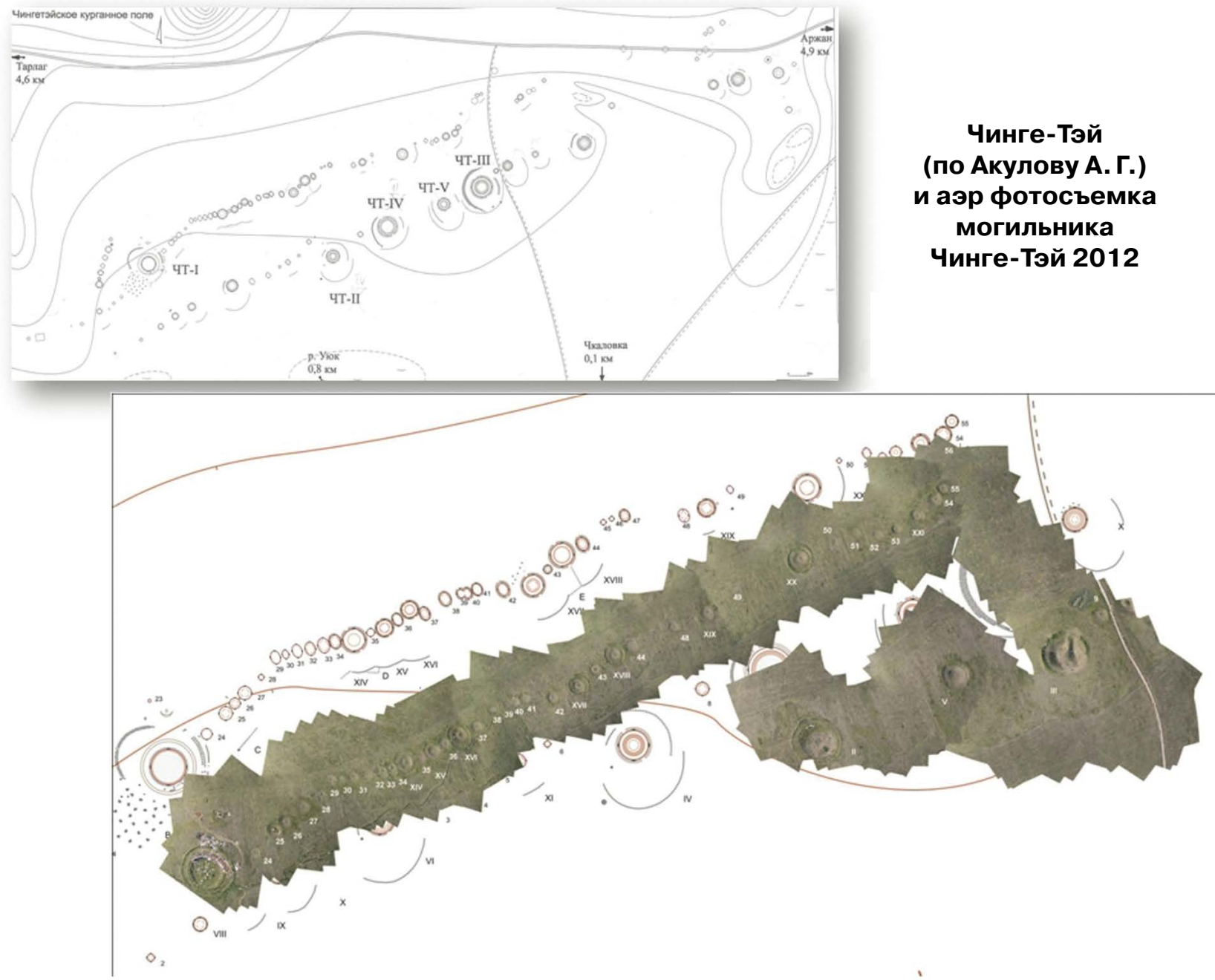

Рис. 7. План Чингетэйского курганного поля (сост. А. Г. Акулов) и аэрофотосъемка могильника Чинге-Тэй. 2012 г. 
Один из итогов анализа аэрофотоснимков насыпей ряда курганов - выделение зон с радиальным расположением западов камней, что предположительно может свидетельствовать о наличии в структуре насыпи кургана деревянных подкурганных сооружениях (рис. 9).

В ходе разведочных работ обследован погребально-поминальный комплекс Аржан-5, а также осмотрен ранее не обследованный курган в урочище Туннуг (рис. 11), где были отмечены описанные выше характеристики насыпи.

\section{Курган в урочище Туннуг}

Одиночный курган в урочище Туннуг (рис. 11), упоминавшийся М.П. Грязновым (Грязнов, 1980), был обнаружен А.Г. Акуловым при проведении разведочных работ в пойме p. Уюк и бессточной р. Туннуг, в рамках работ экспедиции К.В. Чугунова в 2000-х гг. Детальное исследование данного кургана ранее не проводилось, так как его месторасположение абсолютно не характерно для погребальных памятников подобного типа. Для повторного обнаружения месторасположения кургана в 2013 г. В.А.Митрохиным проведена аэроразведка с мотопараплана, что позволило локализовать курган на местности и наметить маршрут через заболоченную пойму р. Туннуг.

В отличие от всех ранее известных курганов подобного типа ТураноУюкской котловины, данный курган расположен не на возвышенных равнинных склонах котловины, а в болотистой пойме реки, в центре котловины, на небольшом возвышении. Курган труднодоступен из-за наличия мокрого болота на протяжении более километра от сухих участков поймы. Судя по косвенным данным, при разливах рек данный курган оказывается практически полностью перекрыт водой. Он расположен в 6,5 км к юго-западу от окраины пос. Аржан и в 3,2 км к юго-востоку от окраины пос. Чкаловка, в пойме, на правом

\section{Курганы Чингетэйского курганного поля. Аэрофотосъемка}

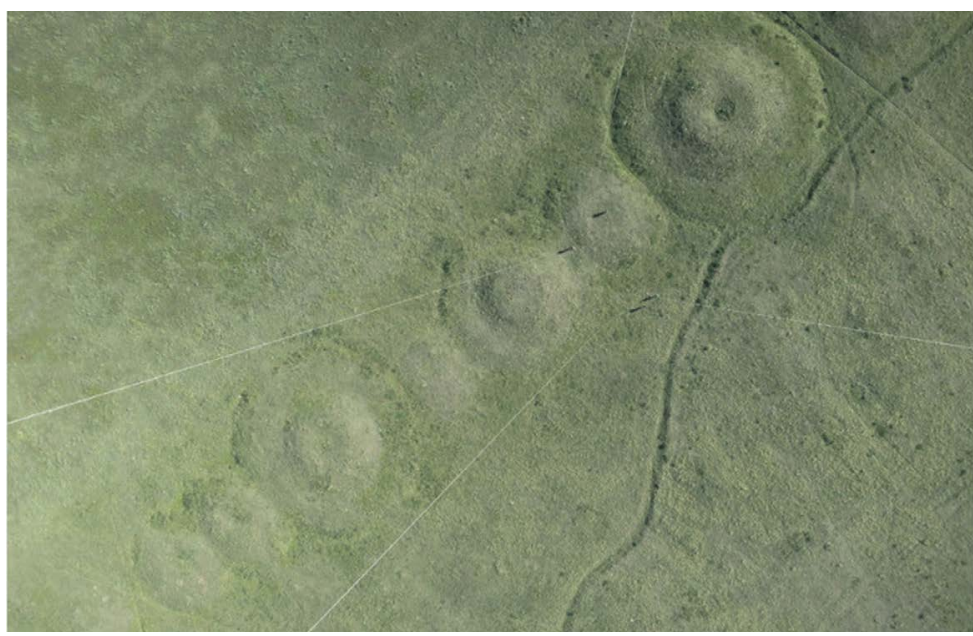

Рис. 8. Курганы Чингетэйского курганного поля. Аэрофотосъемка (а-в)

\section{Курганы Чингетэйского курганного поля. Аэрофотосъемка}

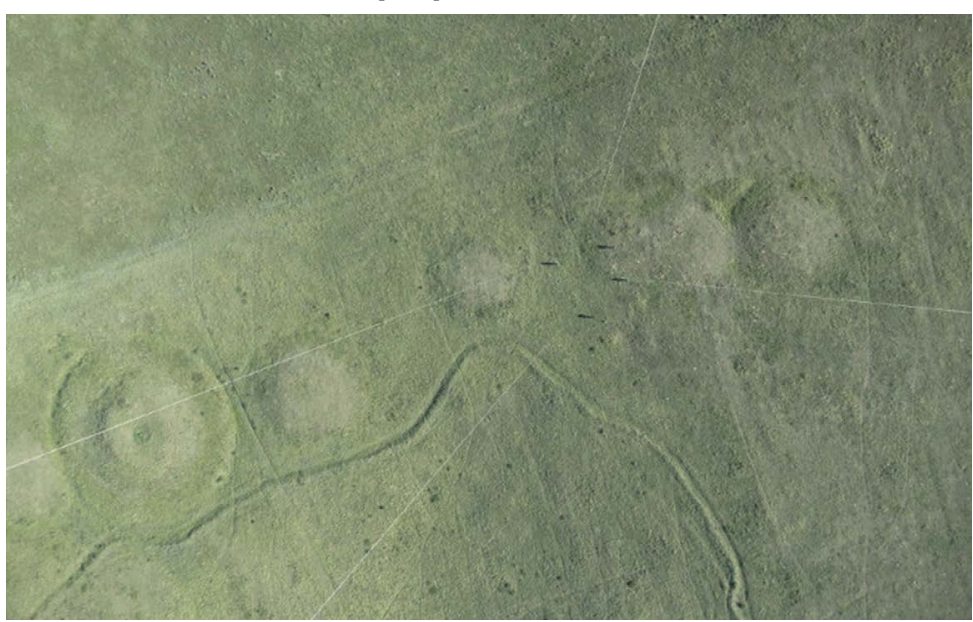

Рис. 9. План Аржанского курганного поля (сост. А. Г. Акулов) и аэрофотосъемка курганов Аржан-5 (слева) и Аржан-3 (справа)

\section{Курганы Чингетэйского курганного поля. Аэрофотосъемка}

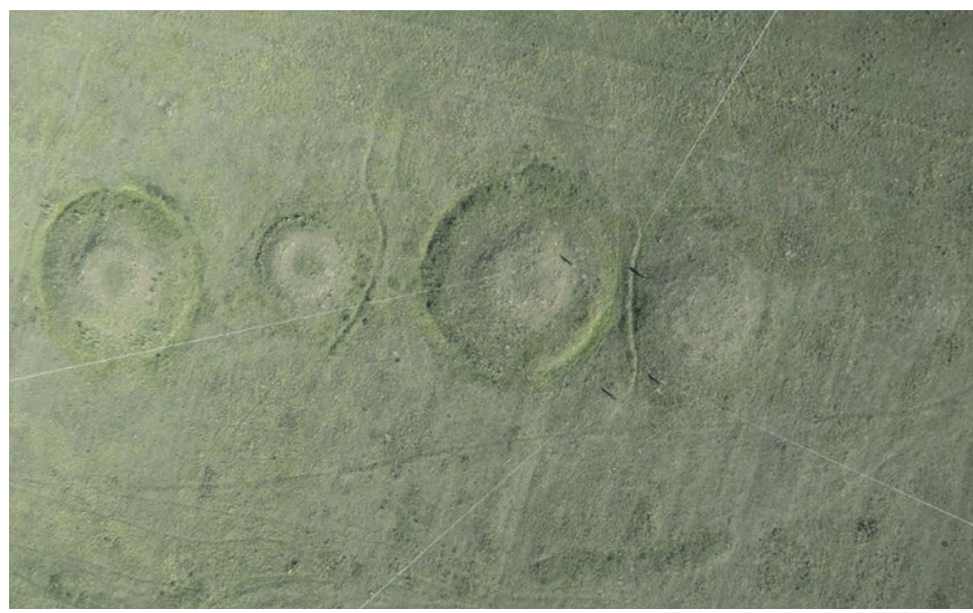

Рис. 10. Курган Аржан-3. Аэрофотосъемка. Периферия 


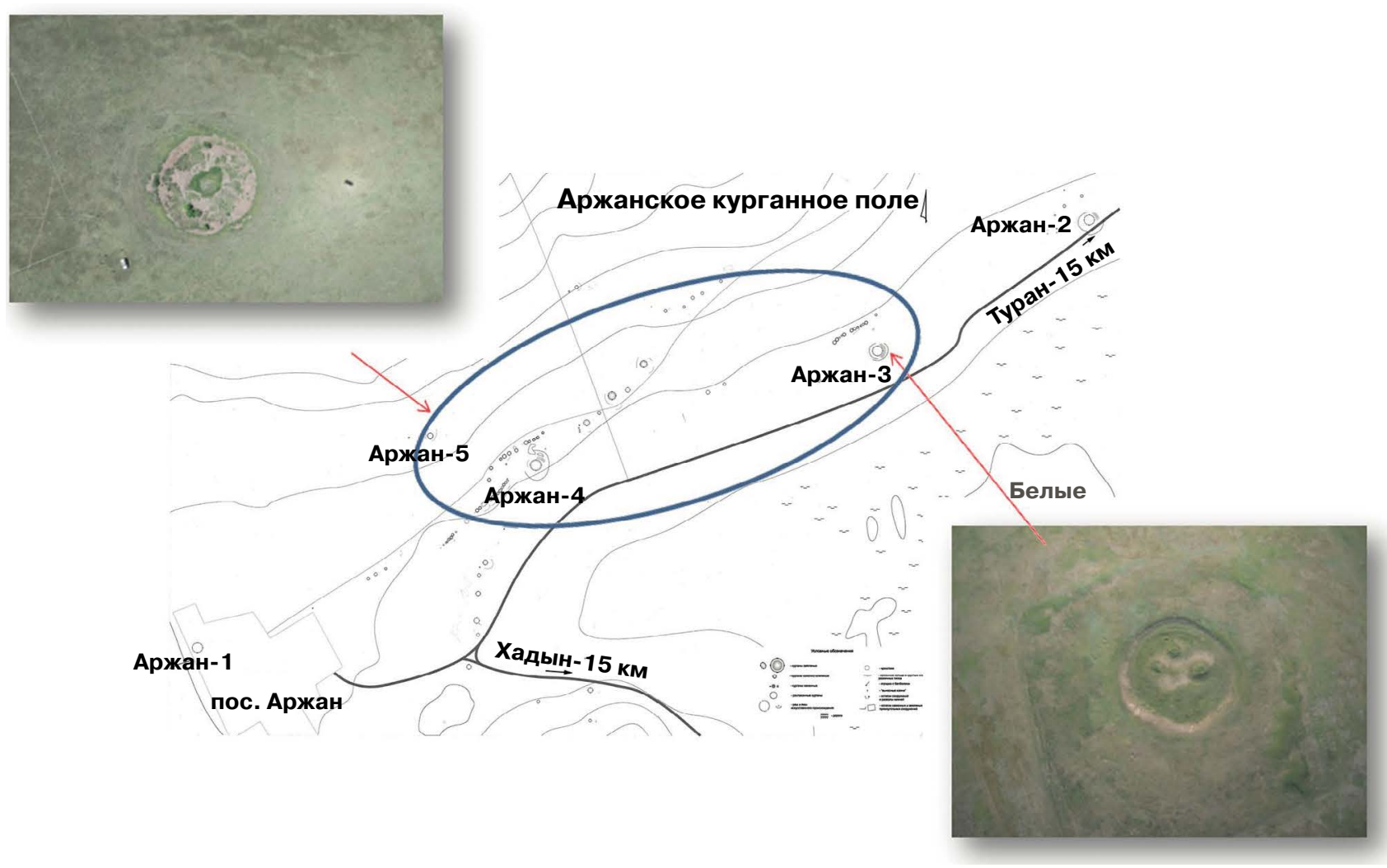

Рис. 11. Курганы с радиально расположенными подкурганными конструкциями. Аэрофотосъемка. Аржан-1, Аржан-5, Туннуг

берегу р. Уюк, в районе одной из проток р. Туннуг, в одноименном урочище. Координаты кургана $-52^{\circ} 00^{\prime} 25,3 ”$ СШ и 9332' 50,3” ВД (рис. 11).

Курган представлен каменной насыпью, высотой около 1 м и диаметром 80 (рис. 12). В отличие от остальных курганов Турано-Уюкской котловины, его насыпь состоит не из плит девонского песчаника, а из крупных фрагментов тяжелого красного камня, напоминающего гранит (петрографический анализ камней насыпи не проводился). Поверхность панциря кургана сложена из очень крупных камней и частично задернована и производит впечатление специально выровненной при возведении кургана. На отдельных плоских фрагментах верхней поверхности панциря кургана при проведении геодезической съемки, на достаточно больших участках, был отмечен перепад высот всего в несколько миллиметров. Часть насыпи (в периферийной ее части) была разрушена местными жителями при строительстве зимней дороги (зимника) через болото поймы, однако в целом насыпь кургана не пострадала от антропогенного воздействия (рис. 14, 15).

На поверхности насыпи кургана отсутствуют видимые повреждения и следы грабительских выкидов, аналогичные другим крупным курганам котловины. Имеющиеся нарушения поверхности панциря кургана (которые выделяются в достаточно большом количестве) производят впечатление просадки камней насыпи при разрушении ниже лежащих структур, предположительно деревянных конструкций сооружений внутри кургана, как в кургане Аржан (рис. 12: б; 13). В пользу данной гипотезы говорит конфигурация имеющихся нарушений (ям) первоначальной поверхности панциря кургана, которые образуют «сетчатую» структуру, близкую к структуре деревянных конструкций раскопанного кургана Аржан (рис. 13).

Анализ аэрофотоснимка существующего состояния кургана, при общей задернованности поверхности насыпи, позволяет выделить несколько зон с отсутствием дернового покрова, которые образуют характерную «сетчатую» структуру, и зоны более интенсивной растительности на территории насыпи кургана, что может быть связано с подкурганными сооружениями (рис. 12; Приложение 1).

Для оценки состояния внутренней структуры насыпи и поиска предположительно остающихся там подкурганных сооружений была проведена площадная георадарная съемка (Приложение 1). Работы выполнялись с применением георадара «Лоза-V», разработанного отечественными радиофизиками из Института земного 


\section{Курган Аржан-3}

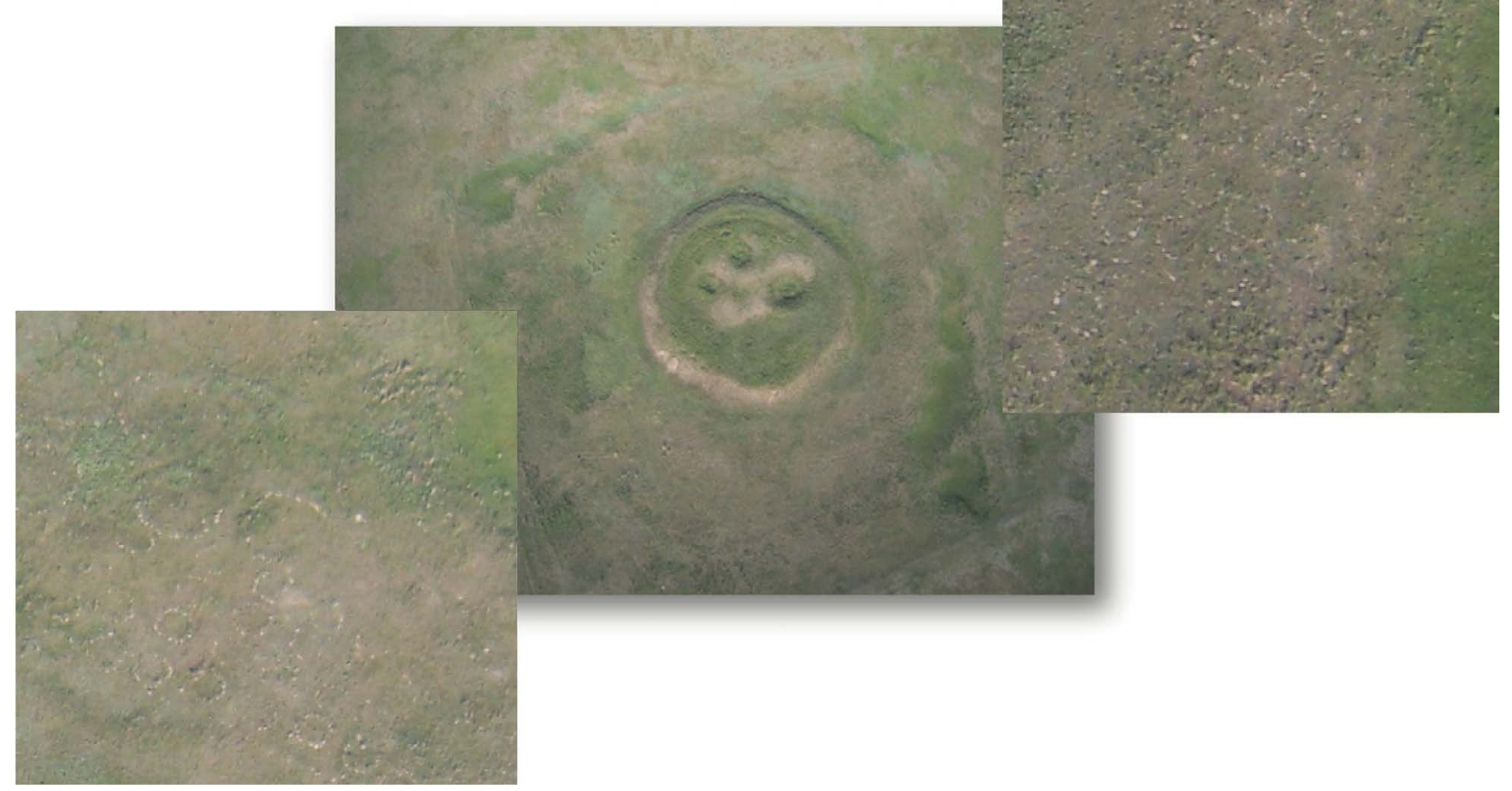

Pис. 12. Курган Туннуг. Аэрофотосъемка (а, б)

магнетизма и распространения радиоволн РАН (ИЗМИРАН) (рис. 14, 15). Работы велись непосредственно одним из разработчиков георадара - к. ф.-м. н. П. А. Морозовым, имеющим большой опыт геофизических работ на различных памятниках археологии (см. Приложение 1 и 2).

Целью съемки на кургане Туннуг была проверка гипотезы, согласно которой внутри насыпи кургана должны быть деревянные конструкции из хорошо сохранившихся в мокром слое стволов деревьев, которые должны были быть отчетливо видны на радарограммах. Однако результатом стало выделение протяженного, радиально расположенного объекта по типу «стена» (предположительно каменного) и полное отсутствие следов предполагаемого дерева. Это позволило сформулировать гипотезу о разрушении деревянных протяженных конструкций в связи с нестабильной влажностью окружающего ландшафта. В результате этого произошло нарушение поверхности панциря кургана при обрушении верхних камней в образующиеся пустоты.

Дополнительно сделаны два перпендикулярных георадарных профиля в зоне с наименее потревоженной поверхностью панциря кургана. По результатам анализа данных сканирования внутри сохранившейся насыпи выделен крупный объект (предположительно подкурганные захоронения - человеческие или сопровождающие их конские) по аналогии с раскопанными ранее курганами в данном регионе.

Детальное описание георадарного исследования участков насыпи кургана Туннуг и результаты дешифровки данных приведены в Приложении 1.

\section{Аржан-5 - центральный объект исследований 2013-2015 гг.}

Аэрофотоснимок памятника показал, что насыпь имела круглую в плане форму (рис. 16). По центру была расположена большая аморфная западина грабительской воронки около 10 м шириной. Анализ аэрофотоснимка состояния кургана позволяет выделить несколько зон более интенсивной растительности на территории насыпи кургана, что может быть связано с внутренними сооружениями кургана, аккумулирующими влагу и позволяющими выживать растениям в данном засушливом регионе.

По всей окружности выделялся крепидный валик (рис. 16). При более внимательном изучении аэрофотоснимка отмечено, что на площади между центральной воронкой и крепидным валиком фиксируются радиально расположенные линии западов камней, вероятно связанные 


\section{Курганы с радиально расположенными подкурганными конструкциями}

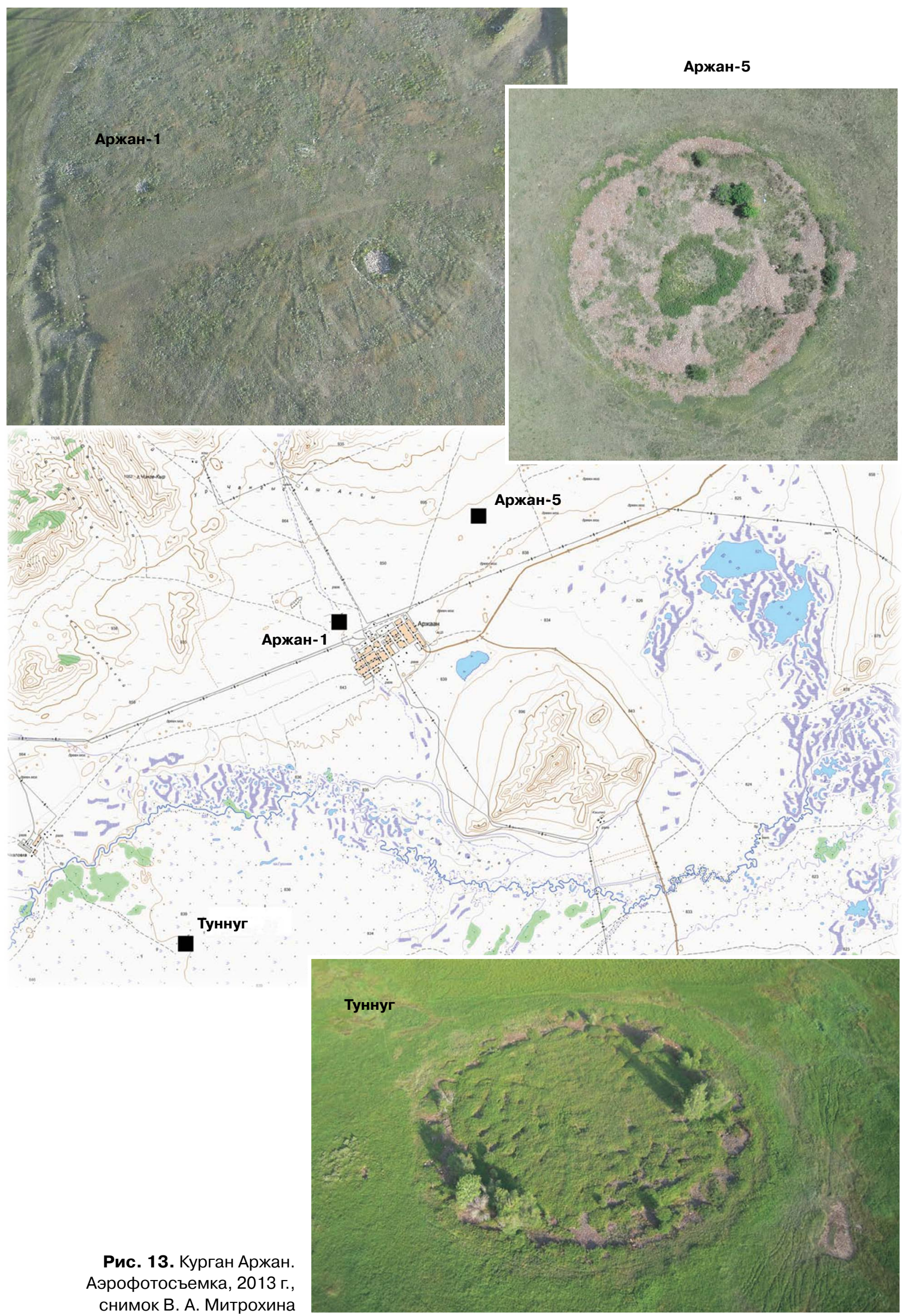




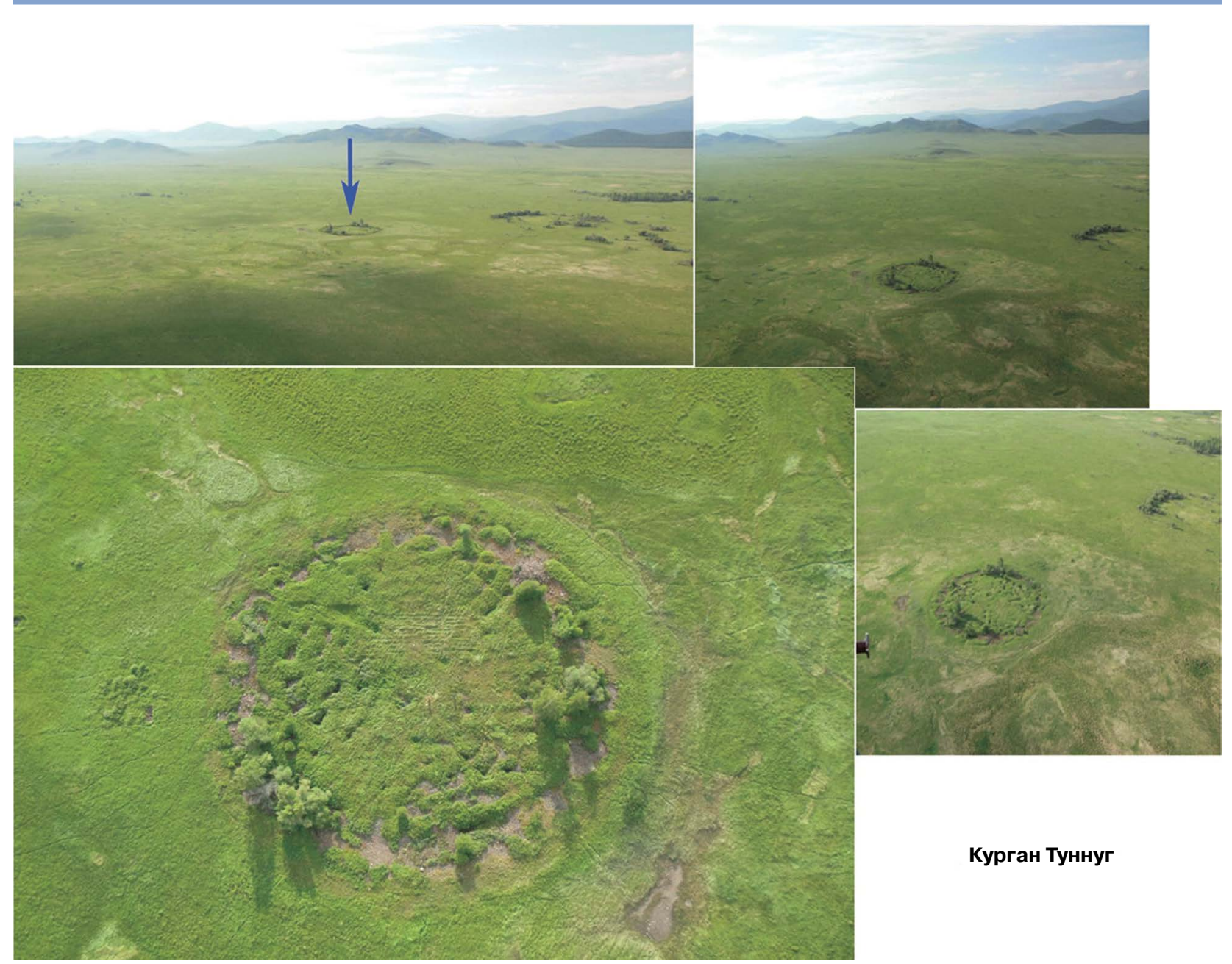

Рис. 14. Георадарарные исследования структуры курганных насыпей

с подкурганной конструкцией. Таким образом, можно было предположить, что под каменной насыпью, возможно, расположены радиально сконструированные строения из деревянных бревен или плах. Также возникло предположение, что нижний слой насыпи кургана остался непотревоженным. Косвенно в пользу потенциальной взаимосвязи зон интенсивной растительности и подкурганных сооружений свидетельствует подпрямоугольная форма ряда выделенных зон (Приложение 2).

Отдельно проводилась аэрофотосъемка с мотопараплана (рис. 2), что позволило получить часть перспективных снимков, используемых в дальнейшем для свода отдельных снимков в общие панорамы.

Георадарное обследование комплекса Аржан-5 (Приложение 2). Георадарное сканирование местности позволяет получить радарограмму на основе отраженного от границ различных сред внутри структуры грунта, что обеспечивает данными о внутренней стратиграфии объекта без проведения земляных работ. Особо эффективно георадары работают при наличии внутри исследуемого объекта пустот и искусственных сооружений. Георадарное сканирование проводилось в виде получения линейных профилей с шагом замеров в 10 см. Для выявления протяженных объектов велось площадное сканирование в виде параллельно расположенных профилей сканирования, что позволило в дальнейшем объединить получаемые данные в условную трехмерную модель, пригодную для анализа.

По результатам анализа данных георадарного сканирования внутри сохранившейся насыпи выделены протяженный объект (предположительно стена внутренних архитектурных сооружений кургана) и ряд объектов, потенциально могущих быть сохранившимися подкурганными захоронениями (человеческими или сопровождающими их конскими), как и в случае с курганом Туннуг - по аналогии с раскопанными ранее курганами в данном регионе.

Георадарная разведка подтвердила предположения о каменных конструкциях кургана (платформы с вертикальным краем, примыкающей 

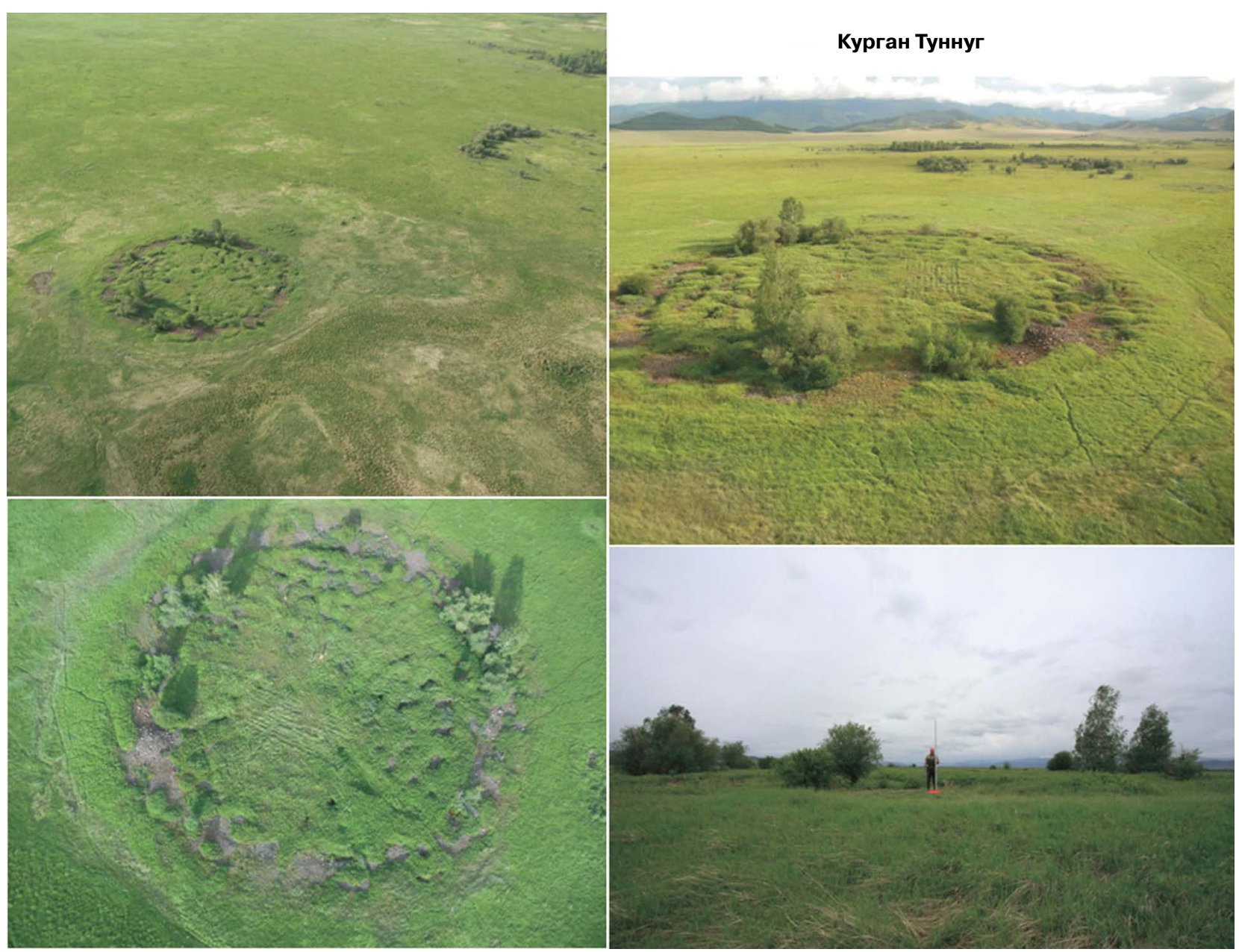

Рис. 15. Георадарные исследования структуры насыпи курган в урочище Туннуг

к вертикальной стене) и предоставила новую информацию для размышления о подземных конструкциях. Детали георадарного исследования насыпи кургана Аржан-5 приведены в Приложении 2.

Судя по известным данным об архитектуре погребально-поминальных комплексах Тувы и Центральной Азии, такие объекты, как курган Аржан и соотносимые с ним исследователями (Грач, 1980. С. 62; Семенов, 1997. С. 34) херексуры не имели подземных строений, а лишь наземные сооружения: клети, срубы, каменные ящики и цисты. Для более поздних курганов алдыбельской и саглынской археологических культур характерны ямы с каменными ящиками, колодами и срубами.

Таким образом, в результате различных методов разведки был получен следующий результат: разрушенный памятник, несомненно, очень древний по архитектуре, относящийся либо к кругу памятников (неизвестных до сих пор) кургана Аржан или же к переходному типу от Аржана к Аржану-2 (Cugunov et al., 2010). Как известно, эти два наиважнейших памятника для истории Центральной Азии разделены временем в 150 лет (по дендрохронологическому определению) (Евразия..., 2005) и относятся к разным, сменившим друг друга культурам.

Главным аспектом исследования стало выявление памятников переходного периода от эпохи бронзы к эпохе раннего железа - времени сложения кочевых культур. Выявленные памятники, видимо, относились к самому началу эпохи ранних кочевников, к памятникам типа Аржан, наиболее важным и дискуссионным для понимания возникновения материальной культуры и искусства ранних кочевников Евразии.

Исследуемый памятник Аржан-5 разрушен не полностью и содержит уникальную информацию, несмотря на поврежденную, как оказалось не полностью, каменную насыпь.

Для проверки результатов анализа аэрофото- и георадарных данных в полевом сезоне 2014 г. были начаты археологические раскопки памятника Аржан-5, находившегося в 2,5 км. ксеверо-востоку от месторасположения 
Аэрофотосъемка кургана Аржан. 2013 г., снимок В. А.Митрохина, г. Туран

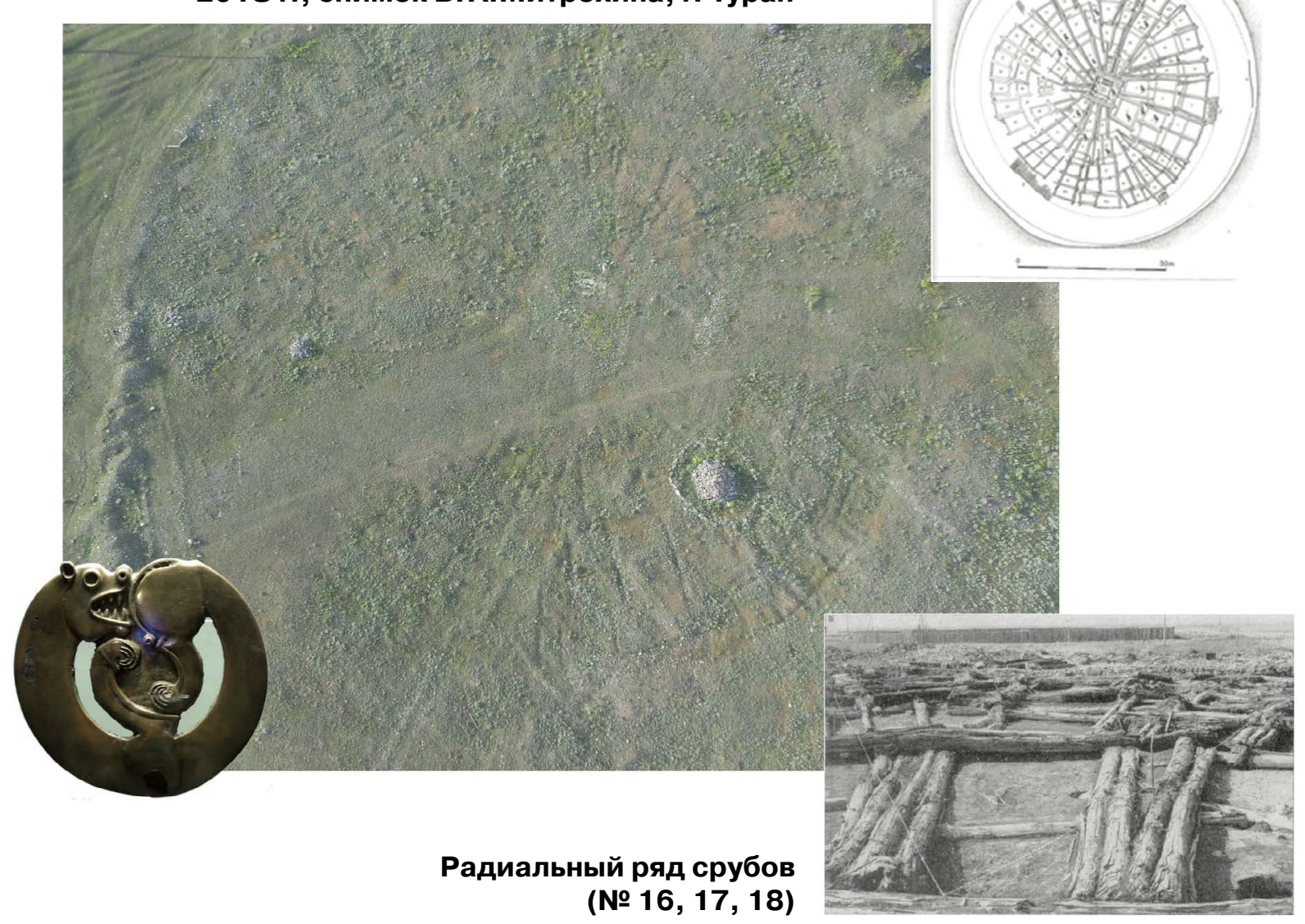

Рис. 16. Реконструкция деревянной конструкции Аржана по М. П. Грязнову, 1980; фото деревянных клетей по М. П. Грязнову (справа внизу), 1980;

бляха в виде свернувшейся пантеры из кургана Аржан, раскопки М.П.Грязнова, фото автора (слева внизу)

раскопанного кургана Аржан (рис. 11) (Рукавишникова, 2015a).

Работы носили спасательный характер, так как насыпь каменного кургана Аржан-5 (диаметром 50 м) была сильно разрушена строительной техникой (рис. 17). По свидетельствам местных жителей в конце 80-х гг. XX в. насыпь была разобрана на строительство дороги, камни насыпи превращены в щебень. К моменту исследования на месте кургана был нижний слой камней насыпи с кучами щебня и волнами сдвигаемых отвалов на площади окружности диаметром около 60 м. Отвалы заросли травой и кустами, несколькими деревьями. Нигде вблизи по степи нет такой растительности, что указывало на образование среди камней специфических влажных условий, благоприятствующих росту растений, возможно, пустоты (рис. 16).

Памятник исследовался секторами (рис. 17), с максимальным количеством разрезов, по выработанной методике К. С. Чугунова, автора раскопок (как уже упоминалось) таких памятников Турано-Уюкской котловины, как
Аржан-2 и Чинге-Тэй. В ходе исследования были выявлены:

1. Частично сохранившаяся в нижних слоях первоначальная насыпь кургана (рис. 18, 19), состоявшая из крупных плит девонского песчаника и базальтовых пород. Многие очень крупные плиты сильно вдавлены в материк под углом. Среди камней много колотого камня и щебня, в том числе и куски белого кварца разного размера и остатки вулканических пород, кипевшего базальта. Видимо, плиты в кургане были принесены из места древнего извержения, а насыпь кургана была украшена белым кварцем, что отмечено еще на ряде курганов долины. Был найден фрагмент, похожий на базальтовую стелу.

2. Крепида насыпи кургана, состоящая из горизонтальной кладки, видимо, по всей окружности, зафиксированная георадарными исследованиями, и нескольких рядов вертикальной стены, плотно примыкающей снаружи (рис. 20). Крепидная стена проходила по окружности около 20 м от центра кургана и была расположена по всем секторам. Сохранилась кладка высотой 


\section{Георадарарные исследования структуры курганных насыпей. Выполнялись с применением георадара «Лоза-V».Основные цели работ: выявление деталей подкурганных конструкций}
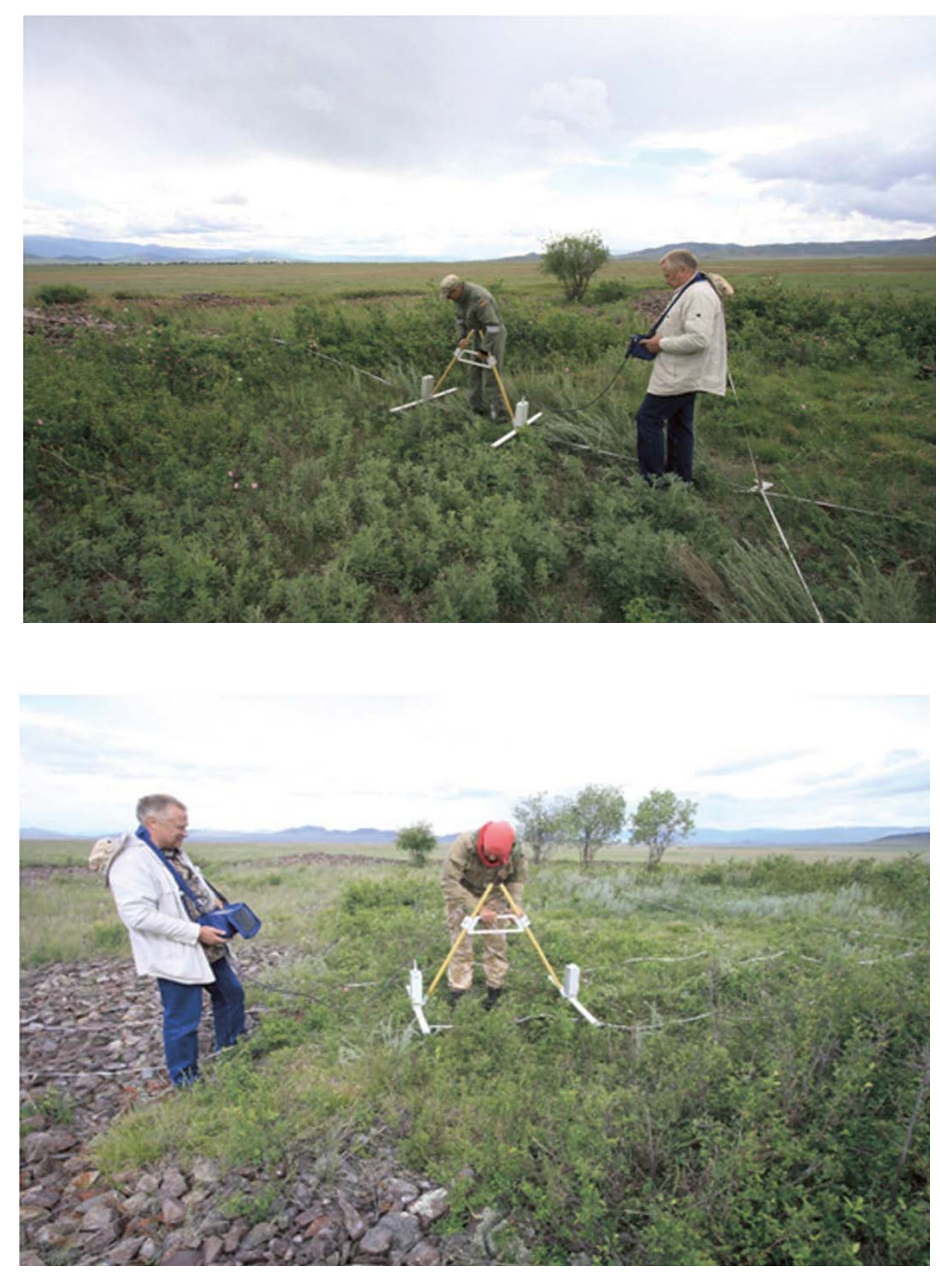

Рис. 17. Курган Аржан-5. Геофизическое исследование 2014 г. порядка 50-60 см, шириной около 90. Плитки разного размера по площади были сложены всухую, плотно пригнаны друг к другу. Толщина плиток была близка. Судя по сделанным нами разрезам, эта стена была возведена изначально на выбранной поверхности, так как ее основание находится ниже (порядка $15 \mathrm{~cm}$ ) поверхности подошвы кургана. Внешняя вертикальная стена была пристроена к горизонтальной позже. Вертикальная стена в исследованных секторах была сильно разрушена техникой, поэтому плиты завалились и обломались. Высоту их трудно зафиксировать (около 30 см от поверхности). Также трудно установить точно число рядов (4-5) вертикальных плит. Между этими рядами находилась забутовка мелким камнем.

Характер конструкции этой стены соответствует по структуре кромлехам, которые расположены на расстоянии от основной насыпи. Судя по описаниям М.П. Грязнова насыпи Аржана, конструкцию комплекса также окружала подобная стена (Грязнов, 1980). В секторе J был зачищен фрагмент кладки из подквадратных в сечении блоков около 40 см длиной, продольно уложенных над горизонтальной кладкой. В этом сегменте стена не была разобрана, поэтому остается предположить, что это либо заложенный вход, либо отдельное впускное

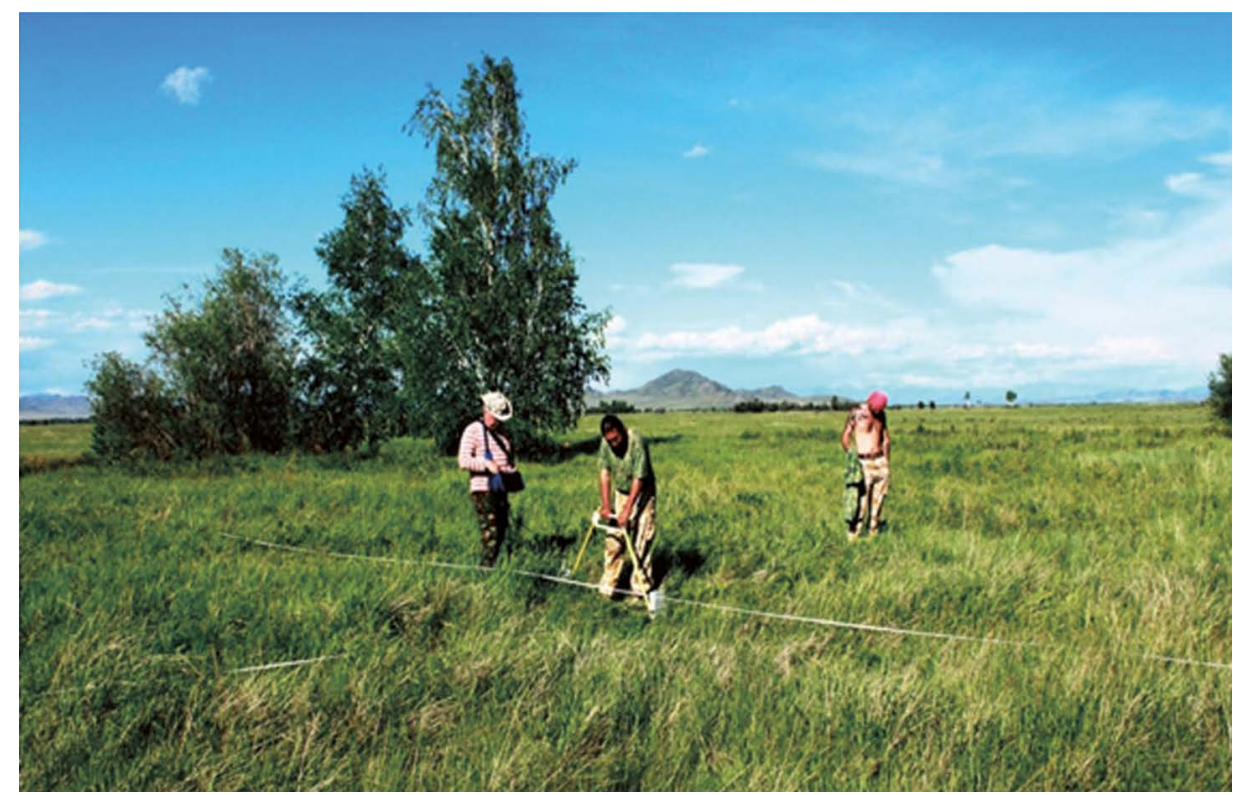

Рис. 18. Курган Аржан-5. Геофизические исследования 2014 г. 

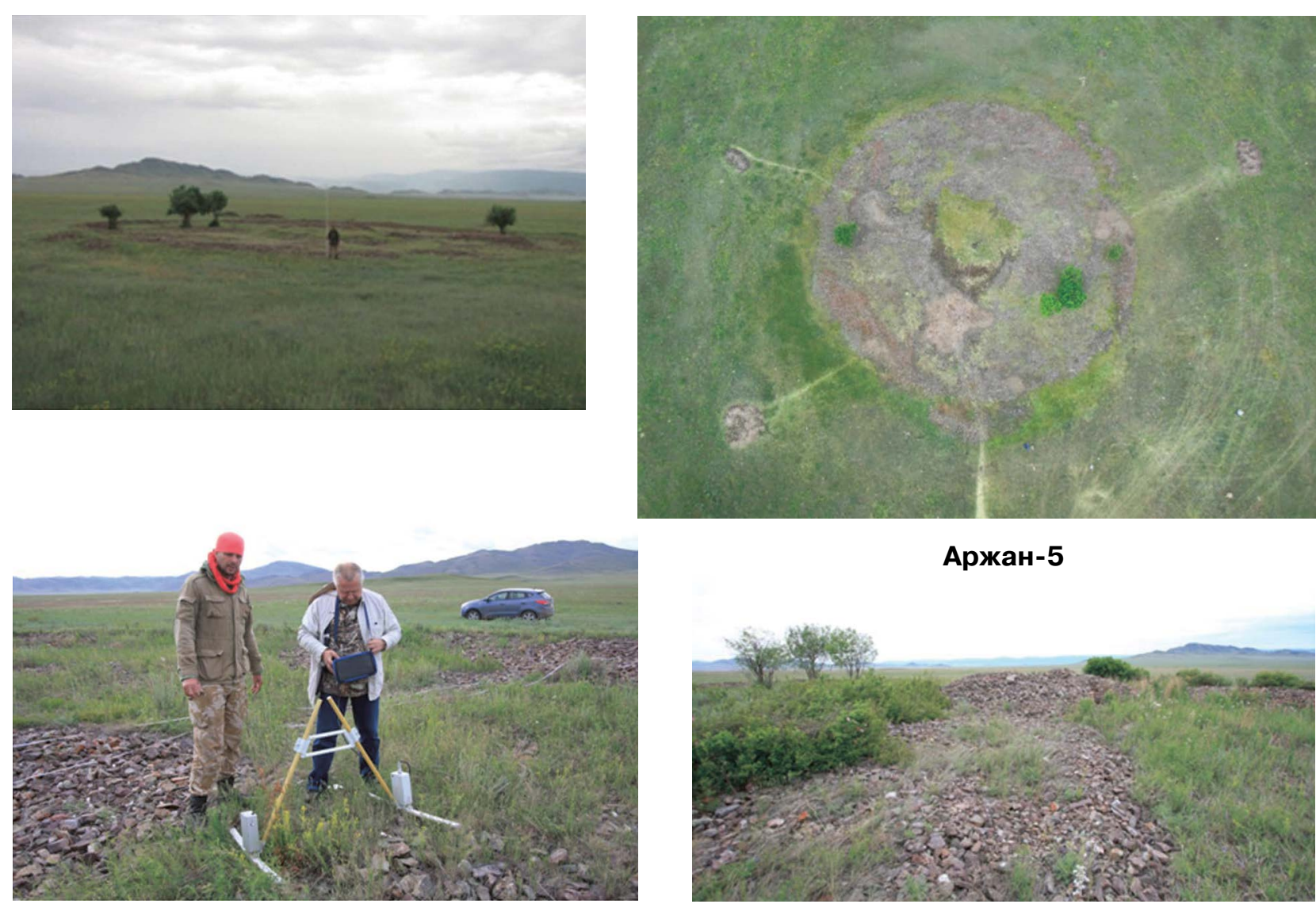

Рис. 19. Исследование конструкций Аржана-5

сооружение. Рядом среди камней вертикальной стены найдены фрагменты сероглиняной лепной керамики с штампом-орнаментом на слабоотогнутом венчике.

3. Остатки деревянных конструкций, подпрямоугольных клетей, расположенных в зоне вокруг центра в зоне до 15-16 м по кругу (рис. 18). Их направляющие, сгнившие деревянные плахи, шли от центра. Именно на их местах образовались пустоты, что послужило провалам с теми же направлениями, которые мы увидели при аэрофотосъемке. Хорошо видна в слое «подушки» большая плаха, заложенная по направлению 3-В. По анализу породы дерева, проведенном в Институте археологии РАН Л.Н Соловьевой, это сосна (Приложение 3). Выше уровнем расчищены две клети, у которых в северной части, примыкающей к зоне центра зафиксированы три параллельные плахи. Западнее три параллельные линии изогнуло, видимо, в результате сдвига камней насыпи техникой. Сразу под оставшимися камнями насыпи зачищено деревянное перекрытие - раздавленный настил из дерева, которое продавлено камнями. Можно судить, что нижний слой насыпи частично сохранился почти in situ и был вдавлен в раздавленные конструкции.

4. Центральное сооружение, содержавшее погребение было исследовано в основном уже в полевой сезон 2015 г. Предварительно можно сделать вывод, что, несмотря на полное разрушение конструкции погребения, зафиксированы основные параметры строения. Так, погребение людей и лошадей было сделано на помосте из глиняной основы и блоков из гальки, илистых отложений и деревянных плах, выводящих поверхность практически на уровень дневной поверхности кургана. Видимо, была основная деревянная конструкция, ориентированная углами по сторонам света с незначительным отклонением, и пристройка с юго-восточной стороны, откуда происходят разрозненные кости человека и лошади.

Найденные кости человека принадлежат одному взрослому индивидууму, что установлено в антропологическом отчете, сделанном в Институте археологии РАН Т.Ю. Шведчиковой. Доследования разрушенного погребения дали информацию о, возможно, еще одном индивидууме (материал на определении). Кости животных принадлежат лошадям и мелкому рогатому скоту. Судя по исследованиям 2015 г., в погребении было несколько лошадей, тогда как кости мелкого рогатого скота и обожженные кости лошадей, 
Курган Аржан-5. Археологическое исследование 2014 г.

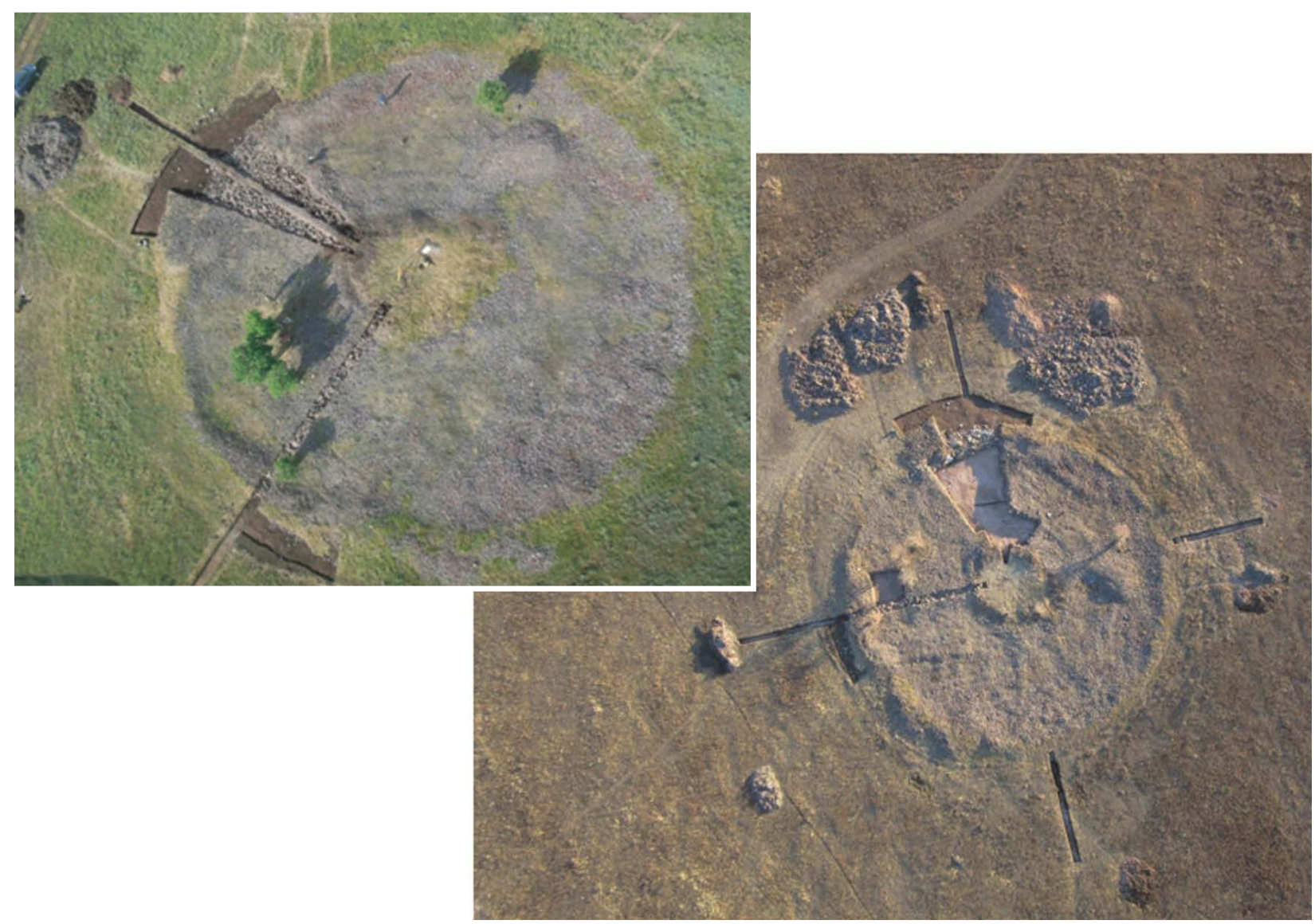

Курган Аржан -5. Археологическое исследование 2014 г. Остатки деревянных конструкций в насыпи кургана
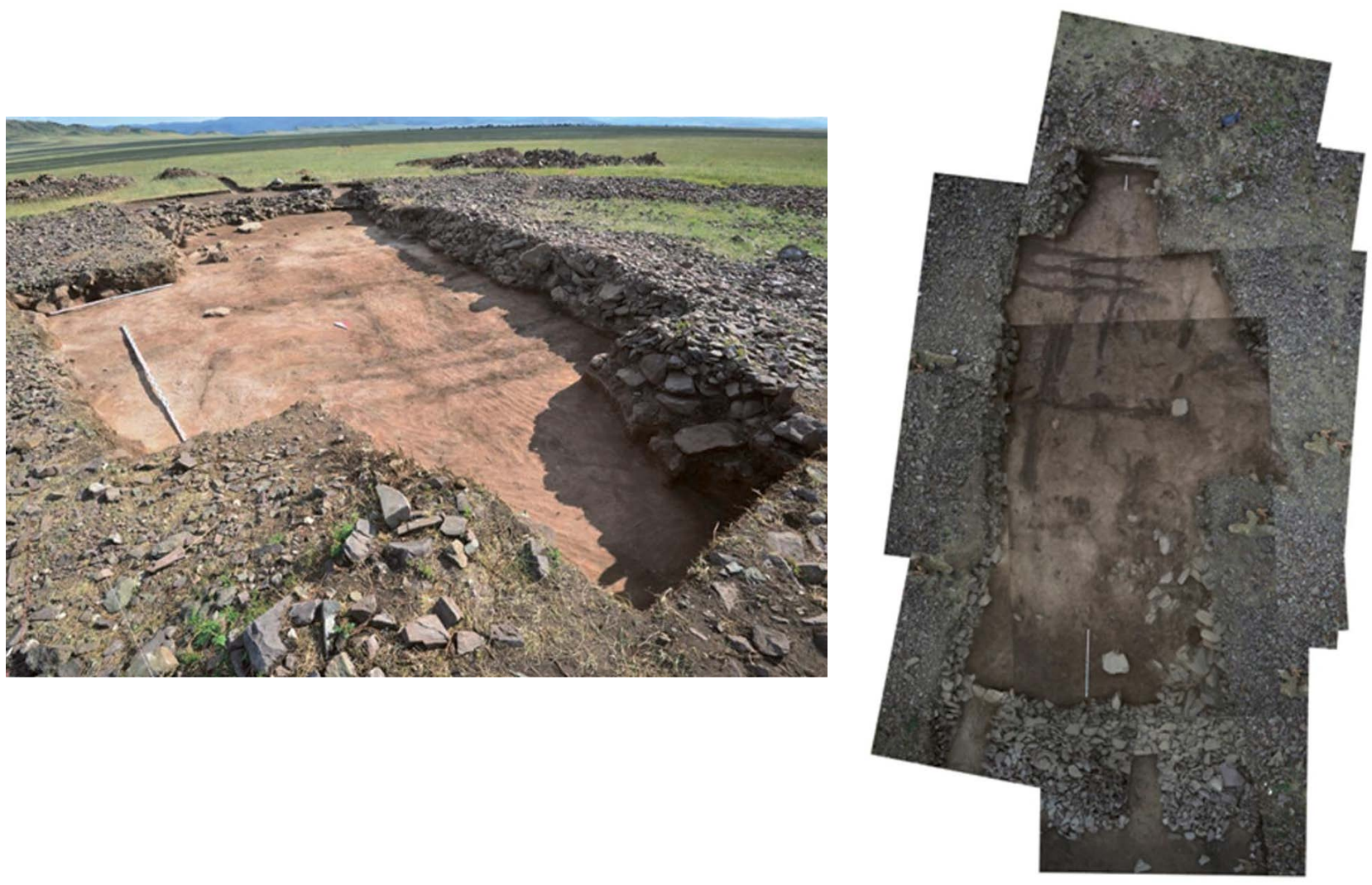

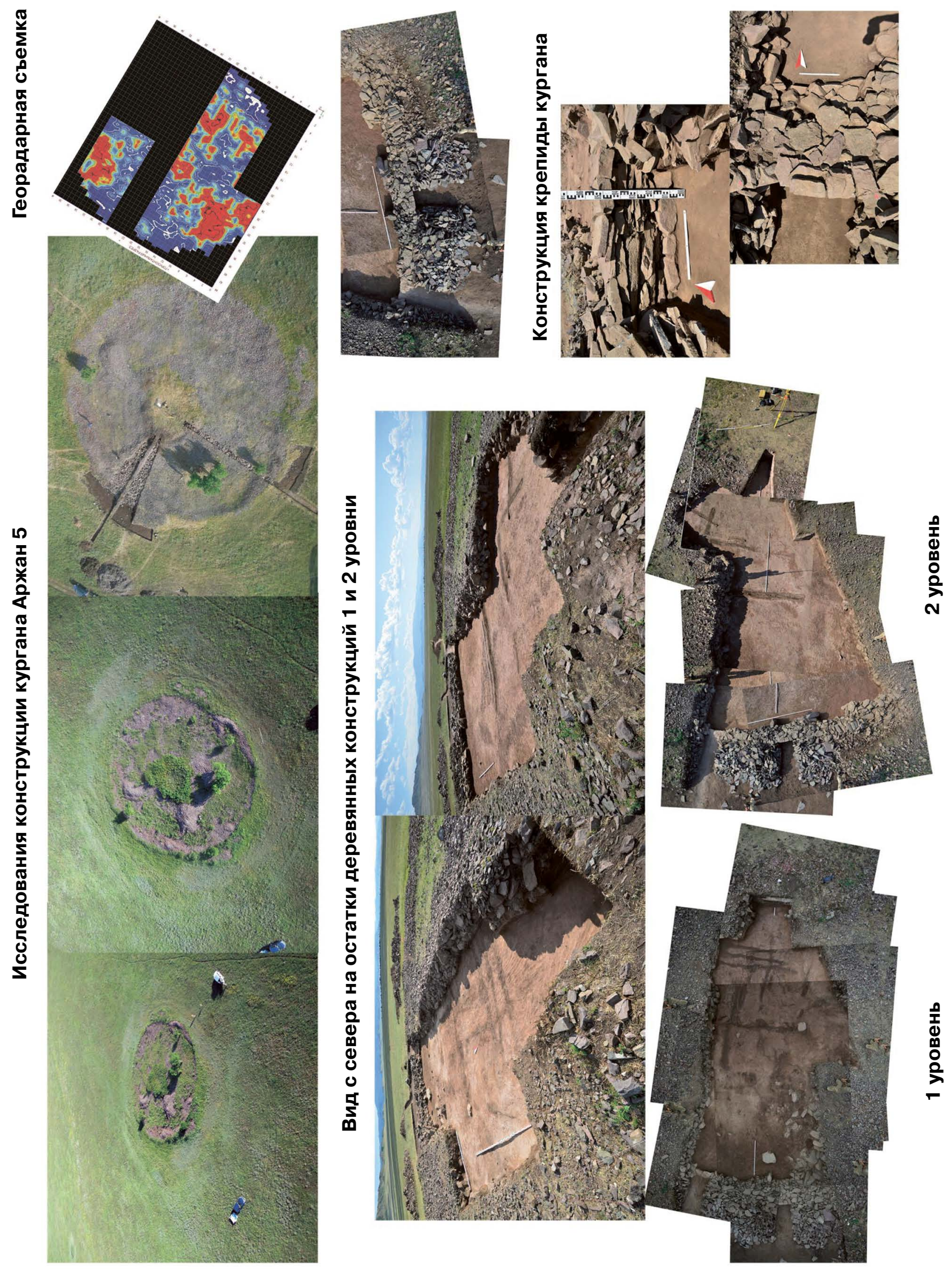


\section{Аржан-5. \\ Результаты исследования, 2015 г.}
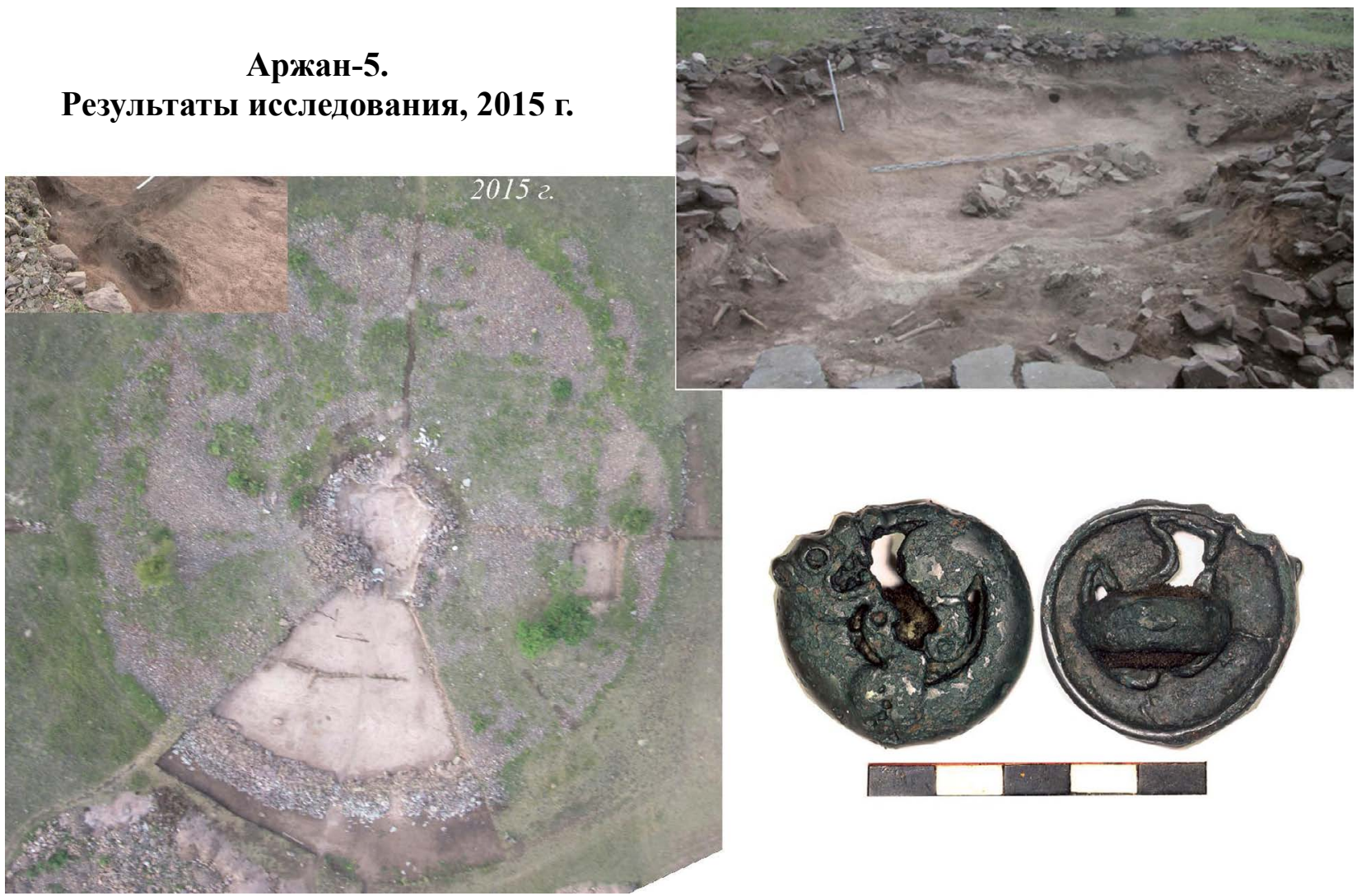

Рис. 23. Аржан-5. Результаты исследования, включая уздечную бляху в виде свернувшейся пантеры, 2015 г.

а также кости хищников происходили из более поздних зольников и ям, которые были совершены после разграблений памятника в углублении воронки.

Среди находок в центральном погребении - две подвески из клыка кабана, а также найденные в 2015 г. бронзовые предметы узды: бляшка в виде свернувшейся пантеры, две «подпружные» пряжки, две пронизи. Бляшка в виде пантеры (рис. 20) аналогична знаменитой бляхе из Аржана (рис. 13), представляющей образец самого раннего периода в развитии такого художественного направления, как звериный стиль, наряду с майэмирской пантерой и пантерой из Сибирской коллекции (Руденко, 1966; Грязнов, 1980; Баркова, 1983; Переводчикова, 1994; Богданов, 2006).

Копательное орудие - кирка из рога марала, найденное в начале исследования погребения, по выводам Я. И. Сунчугашева (1969. С. 69), могли принадлежать и древним копателям, и строителям кургана. Недалеко от центральной воронки в зоне сдвинутых клетей были найдены фрагменты роговых подвески узды и псалия с отверстием.

Подобные предметы характерны ранним комплексам I тыс. до н. э. Тувы.
Предварительно в результате анализа раскопанных секторов насыпи, полученных разрезов можно представить следующую конструкцию сооружения.

Аржан-5 был своеобразным каменным мавзолеем около 50 м в диаметре, который был возведен на глиняной подушке, обнесен стеной, сложенной из горизонтальных плит и вертикальных. В центре было основное погребение, в деревянной конструкции на подсыпке из гальки, обложенное каменными плитами. Впоследствии оно было ограблено, в результате чего образовалась большая аморфная затекшая воронка. Здесь были найдены кости человека и животных, а также бронзовые и костяные предметы узды (о самой яркой находке уже сказано выше).

Вокруг центрального погребения по кругу диаметром до 15 м, площадью 5-6 м² были сооружены деревянные клети в 2-3 венца, пристроенные друг к другу, имевшие общие направляющие в конструкции, перекрытые деревом.

После совершения погребения была возведена каменная насыпь, возможно, плоская. С внешней стороны была сооружена стена из четырех рядов вертикальных плит с забутовкой из камней между ними. Эти вертикальные плиты вплотную подходили к горизонтальной, 
углубленной каменной кладке, тем самым защищая насыпь от разваливания. Здесь найдены фрагменты керамики, кости животных и костяная подвеска. Четкая граница насыпи и вертикальной стены была зафиксирована георадарным обследованием по всей площади разрушенной насыпи.

Таким образом, в процессе изучения погребально-поминального комплекса Аржан-5 расчищена и зафиксирована часть площади кургана (на данный момент три сектора и центр), под остатками насыпи которой выявлены деревянные конструкции и глиняная подушка платформа, на которой была возведена первоначальная насыпь. Глиняная подушка создавалась на выбранной и зачищенной поверхности, глубиной до 20-30 см от дневной поверхности. Возможно, она заполняла пространство между нижними плитами горизонтальной кладки и крайними нижними направляющими деревянных клетей. Выявленные деревянные остатки - радиально расположенные клети с несколькими венцами, схожи с деревянными конструкциями, выявленными в кургане Аржан.

Центральное погребение было возведено на отдельном возвышении из глиняных блоков практически на уровне дневной поверхности в деревянной конструкции и на галечной подсыпке. Сооружение было ориентировано углами нестрого по сторонам света. Само погребение было разграблено в древности. При том, что основные характерные составляющие конструкции выявлены и исследованы, памятник нуждается в дальнейшем полном изучении, так как относится к раннему (начало I тыс. до н.э.) типу крупных погребальных комплексов долины р. Уюк, сходных по конструкции с Аржаном. Это косвенно подтверждает и комплекс находок из кургана.

По результатам радиоуглеродного анализа остатков деревянных конструкций получены даты, в основном, рубеж IX-VIII вв. до н. э.:
Ле-10727

Аржан 5, Сектор J, дерево.

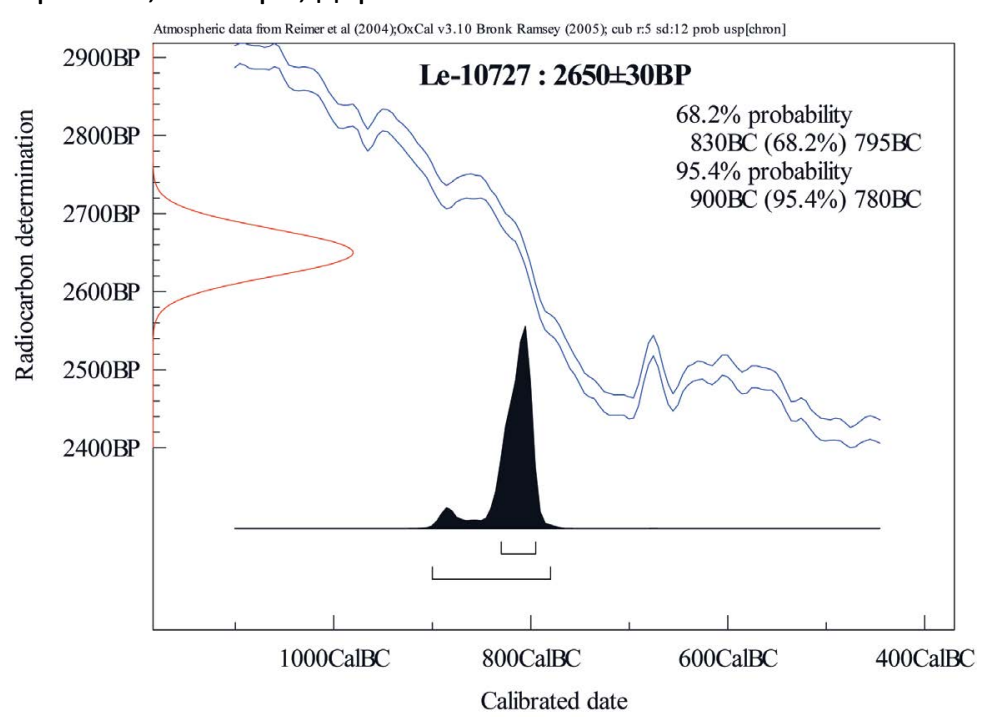

Ле-10725

Аржан 5, Сектор D (№ 15), дерево.

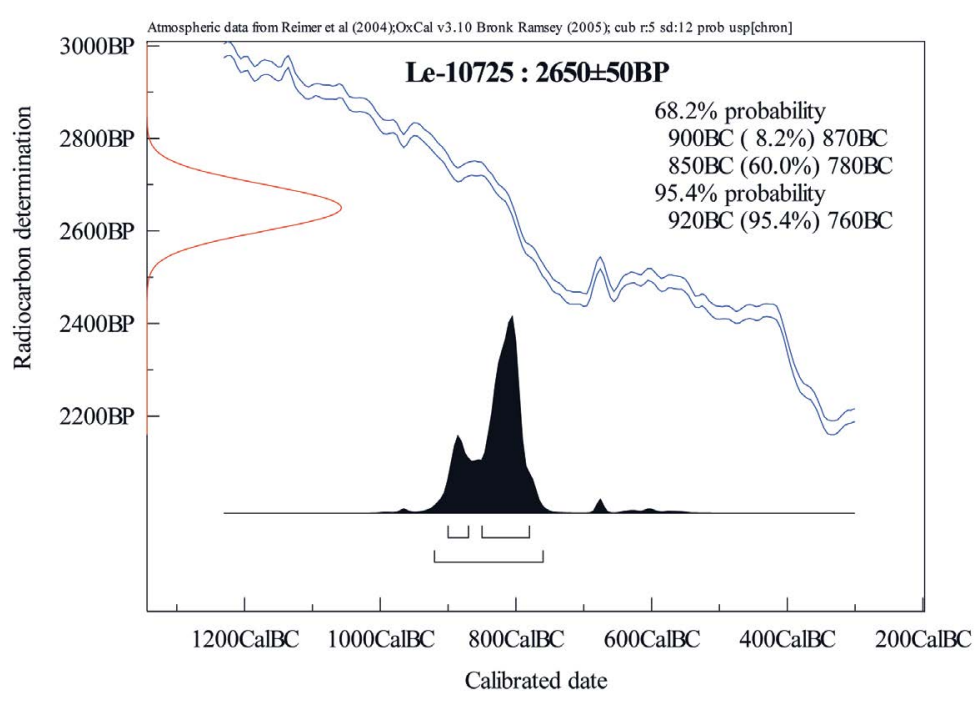

Ле-10726

Аржан 5, Сектор H, дерево.

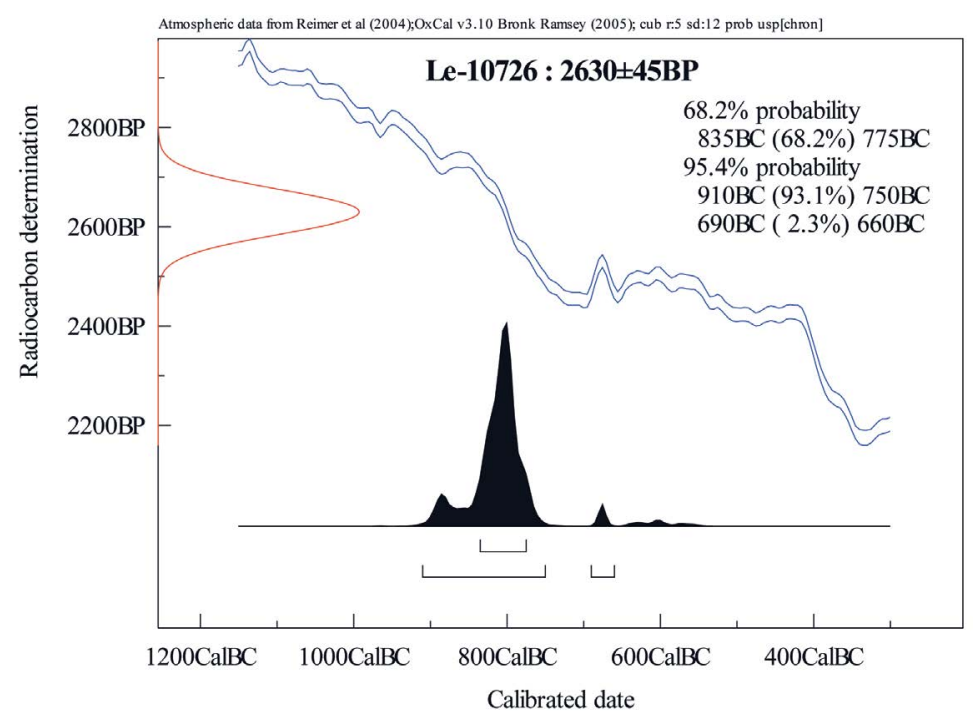


Наши исследования позволяют отнести этот памятник к самому раннему этапу сооружения больших курганов Турано-Уюкской котловины - времени Аржана, ключевого памятника ранней истории кочевников.

До сих пор существует два мнения по датированию памятника: IXVIII вв. до н.э. и VII в. до н.э. (Боковенко, 1994. С. 48; Членова, 1997. С. 38; Евразия..., 2005, С. 100). Бляха с изображением пантеры и предметы из комплекса Аржана-5 относятся к самым ранним объектам материальной культуры и искусства скифо-сибирского мира, а архитектура не имеет аналогов. Новые данные о нахождении подобных комплексов очень важны для разрешения одной из загадок уникального единства евразийских кочевых племен скифского времени.

\section{Ле-10728 \\ Аржан 5, Сектор J (3 шурф), дерево.}

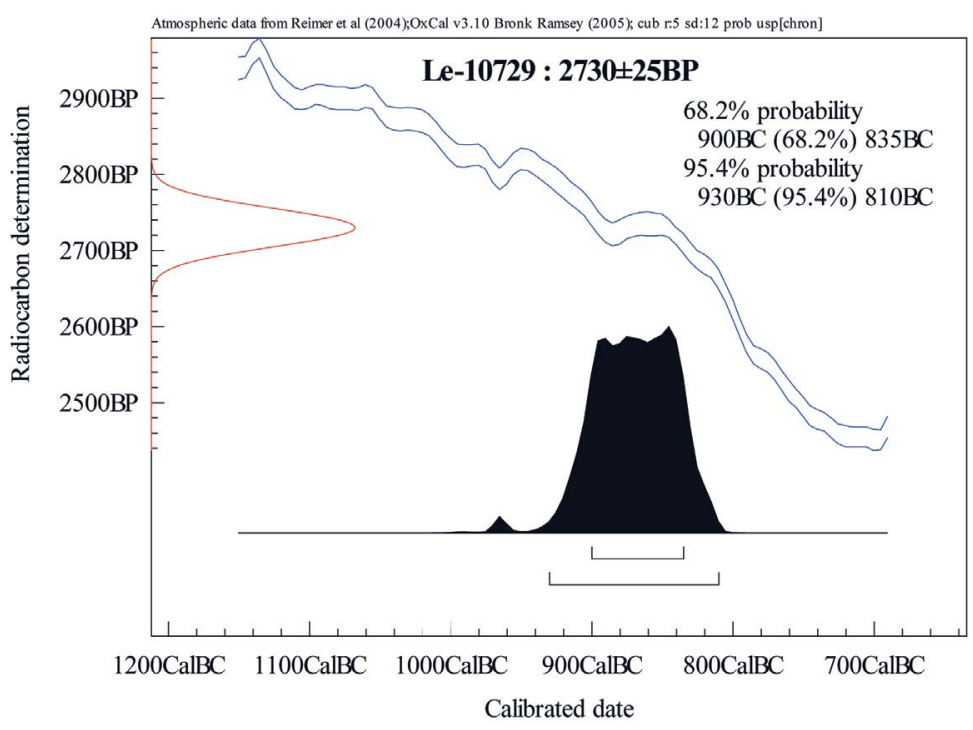

\section{Литература}

Адрианов А.В., 2008. Дневник археологических исследований 1915-1916 гг. в Урянхайском крае (Тува). Томск: Изд-во Томского ун-та. $146 \mathrm{c}$.

Баркова Л. Л., 1983. Изображения свернувшихся хищников на золотых пластинах из Майэмира // АСГЭ. Вып. 24. Л.: ГЭ. С. 19-31.

Богданов Е. С., 2006. Образ хищника в пластическом искусстве кочевых народов Центральной Азии. Новосибирск: Изд-во ИАЭТ СО РАН 240 с.

Боковенко Н., 1994. Проблемы генезиса погребального обряда раннекочевой знати Центральной Азии// Элитные курганы степей Евразии в скифо-сарматскую эпоху / (материалы заседаний «круглого стола» 22-24 декабря 1994 г., СанктПетербург)./ Археологические изыскания. Вып. 18. СПб: 1994. 207 с. Фонд фундаментальных исследований РАН C. 41-48.

Грач А.Д., 1980. Древние кочевники в Центре Азии. М.: Наука. 256 с.

Грязнов М.П., 1980. Аржан. Царский курган раннескифского времени. Л.: Наука. 61 с.

Евразия в скифскую эпоху, 2005. Радиоуглеродная и археологическая хронология. СПб., «Теза». 290 с.

Кызласов Л.Р., 1980. Древняя Тува. М. М.: Изд-во МГУ: 206 с.

Переводчикова Е.В., 1994. Язык звериных образов. Очерки искусства евразийских степей скифской эпохи. М.: Изд-во Вост. лит-ры. 206 с.

Руденко С. И., 1962. Сибирская коллекция Петра І. М.; Л.: АН СССР. 79 с. (САИ; вып. Д3-9).

Рукавишникова И.В., 2014. Комплексные исследования памятников ранних кочевников в Турано-Уюкской котловине (новые методики исследования и материалы)/ тезисы опубликованы на диске: Школа молодых археологов стран СНГ «Современные междисциплинарные подходы к изучению археологического наследия: изотопный анализ в археологии», октябрь 2014 г.

Рукавишникова И.В., 2015. Исследования разрушенного кургана Аржан-5 - памятника начала эпохи ранних кочевников в Туве (архитектура, результаты применения естественнонаучных методов, перспективы дальнейших работ) // Ранний железный век Евразии от архаики до рубежа эр. Центры, периферия и модели культурных взаимодействий. Материалы тематической конференции / Отв. ред. Савинов Д.Г. СПб.: «Скифия-принт». С. 92-94.

Рукавишникова И. В., Рукавишников Д. В., Гладченков А.А., 2015. Работы Тувинской экспедиции ИА РАН //АО 20102013 гг. М.: ИА РАН. С. $722-724$.

Семенов В.А., 1997. Монгун-Тайга. СПб.: Изд-во ИИМК РАН 52 с.

Семенов В.А., 2000. Этапы сложения культуры ранних кочевников Тувы // Мировоззрение, археология, ритуал, культура / Сборник статей к 60-летию М. Л. Подольского, Отв. ред. Чугунов // СПб: 2000. 240 с. 16. Семенов В. А., 2015. Искусство варварских племен. СПб.: ООО «Типография "НП-Принт"». 400 с. 
Применение низковысотной аэрофотосъемки и геофизических методов...

Сунчугашев Я. И., 1969. Горное дело и выплавка металлов в Древней Туве. М.: Наука, 1969. - 139 с. 18. Членова Н. Л., 1997. Центральная Азия и скифы. Дата кургана Аржан и его место в системе культур скифского мира. М РАН. Ин-т археологии. $98 \mathrm{c.}$

Чугунов К. В., 2001. Отчет о работе Центрально-Азиатской археологической экспедиции в Республики Тыва в 2001 г. // Архив ИА РАН. Р-1, № 25294, 25295.

Чугунов К. В., 2002. Отчет о работе Центрально-Азиатской археологической экспедиции в Республики Тыва в 2002 г. // Архив ИА РАН. Р-1, № 22822, 22823.

Чугунов К. В., Париингер Г., Наглер А., 2002. Элитное погребение ранних кочевников в Туве // Археология, этнография и антропология Евразии. № 2. С. 115-124.

Чугунов К. В., 2011. Дискретность постройки «царских» мемориалов Тувы и хронология раннескифского времени// «Terra Scythica». Новосибирск. С.358-369.

Cugunov K., Parzinger H., Nagler A., 2010. Der skythenzeitliche Fürstenkurgan Aržan 2 in Tuva. Mainz: Verlag Philipp von Zabern. 330 S. (Archaologie in Eurasien; Bd. 26). 


\section{Приложение 1. Отчет о результатах георадарных работ} на одиночном кургане в урочище Туннуг

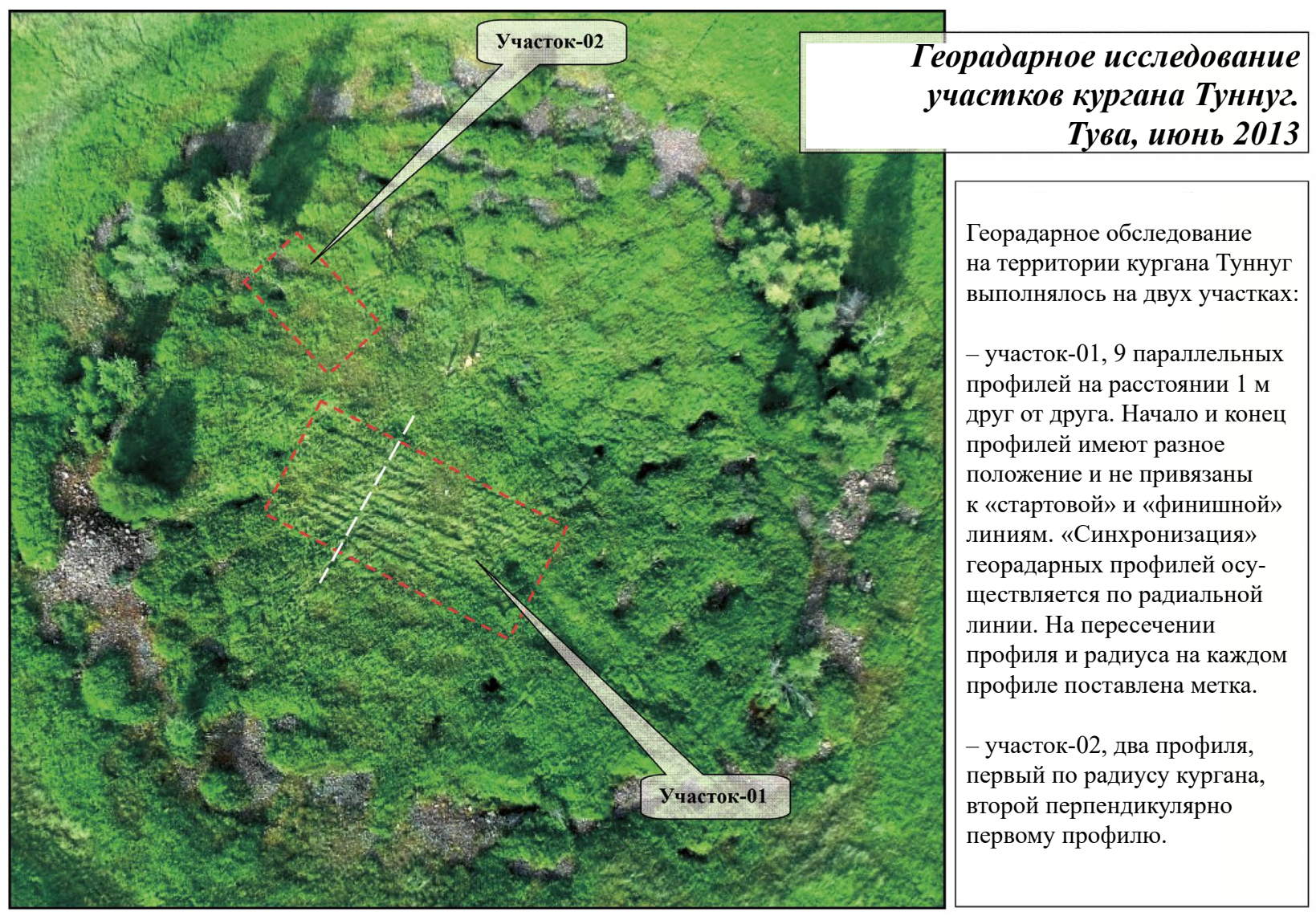

Рис. 1. Георадарное исследование участков кургана Туннуг, 2013 г.

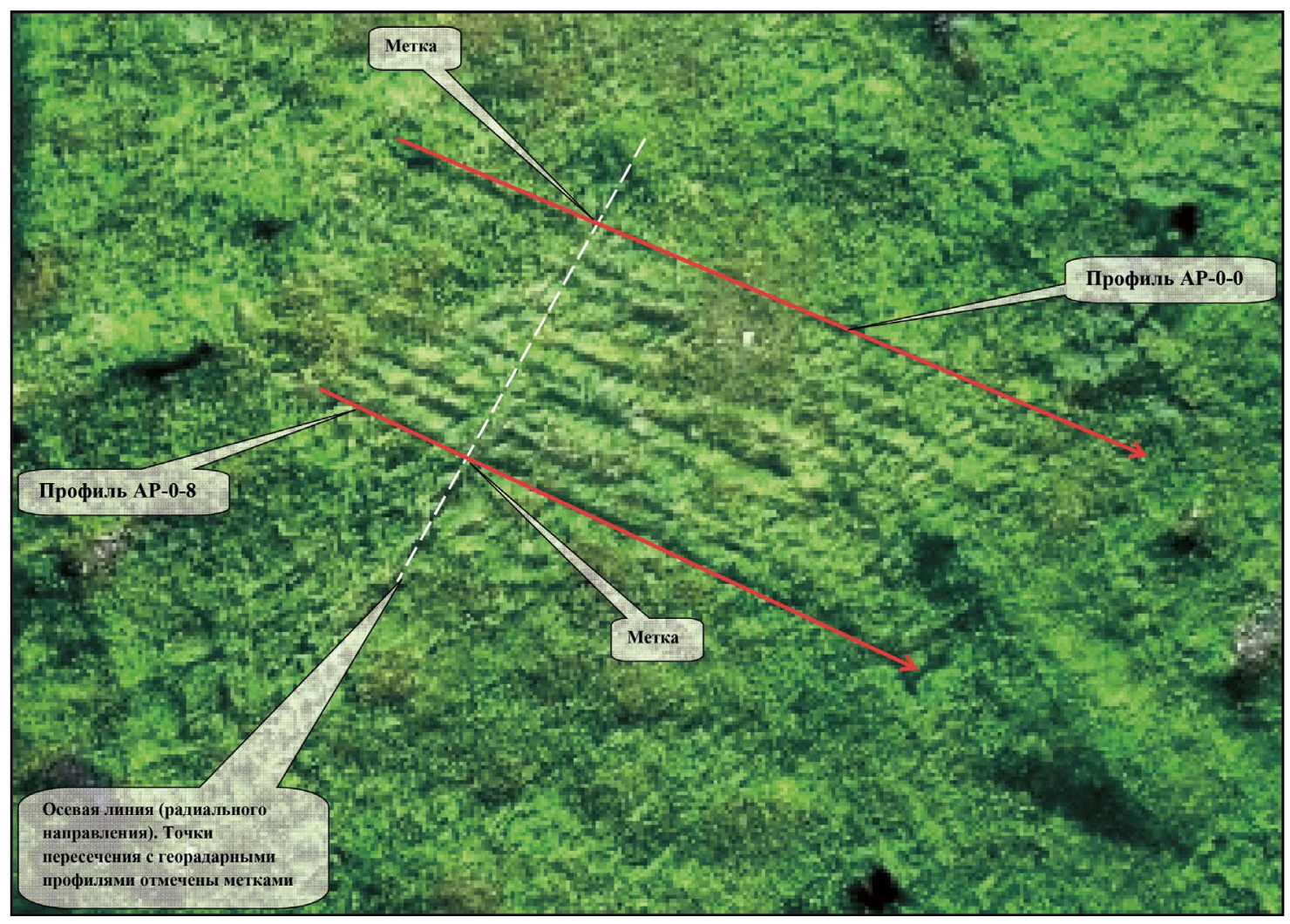

Рис. 2. Геофизические профили на кургане Туннуг. Участок 1 


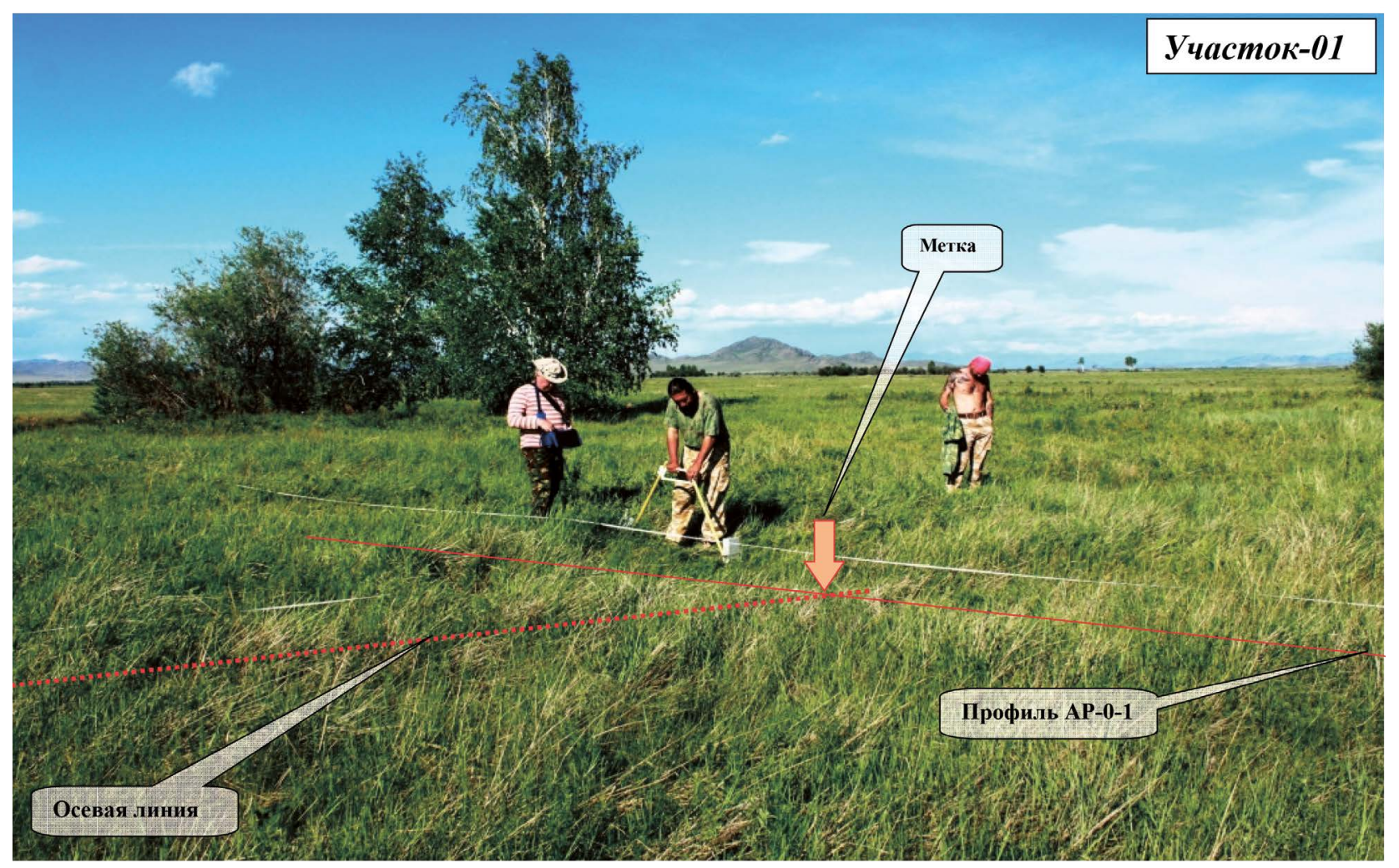

Рис. 3. Геофизические исследования на кургане Туннуг в 2013 г. Участок 1

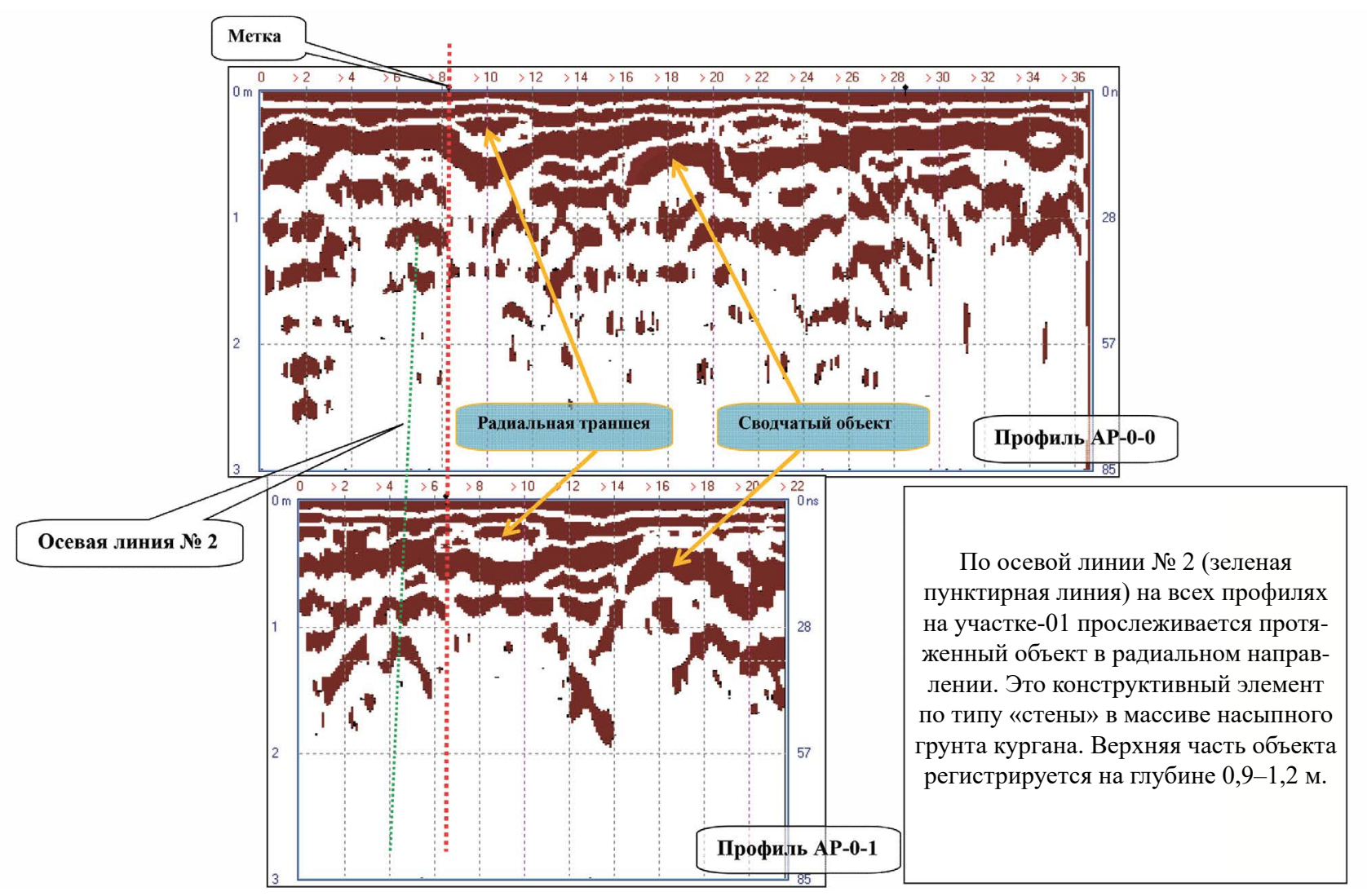

Рис. 4. Профиль георадарного исследования кургана Туннуг. Участок 1. Остатки деревянных конструкций в насыпи кургана 


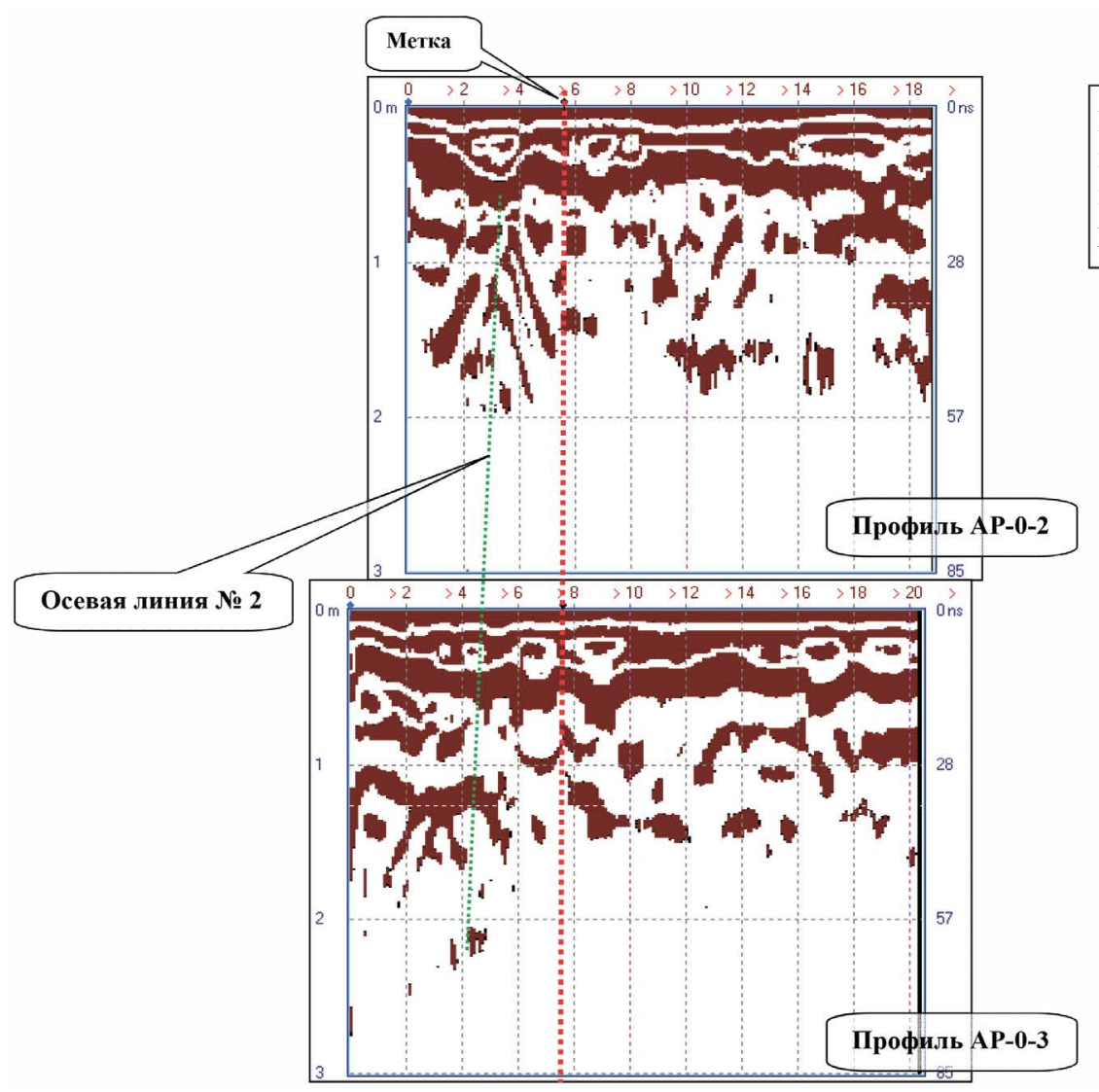

\begin{tabular}{|l|}
\hline На георадарных профилях № 2 \\
и 3 сечения конструктивного элемента \\
по типу «стены» по осевой линии № 2 \\
регистрируются наиболее четко.
\end{tabular}

Рис. 5. Профиль георадарного исследования кургана Туннуг. Участок 1

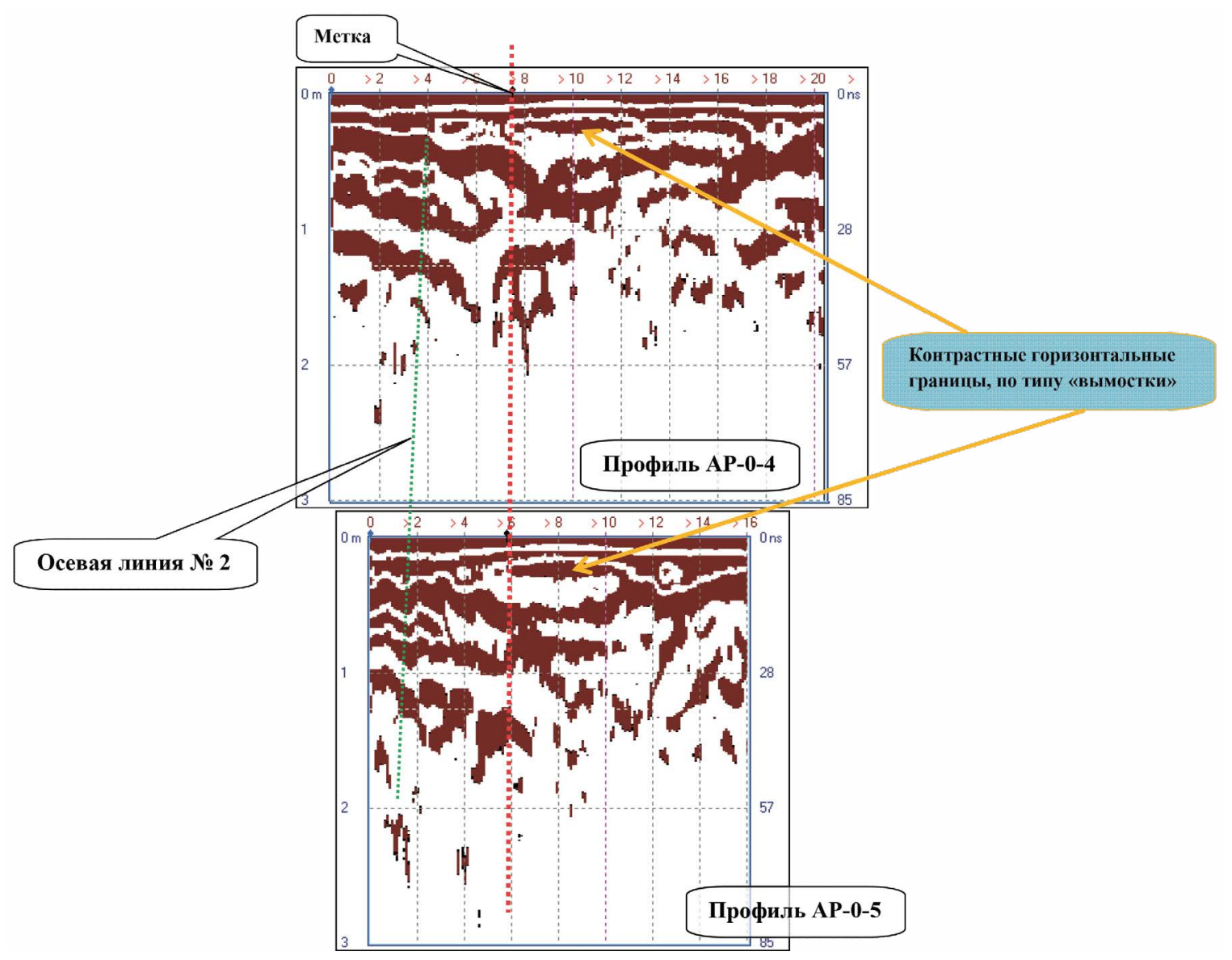

Рис. 6. Профиль георадарного исследования кургана Туннуг. Участок 1 


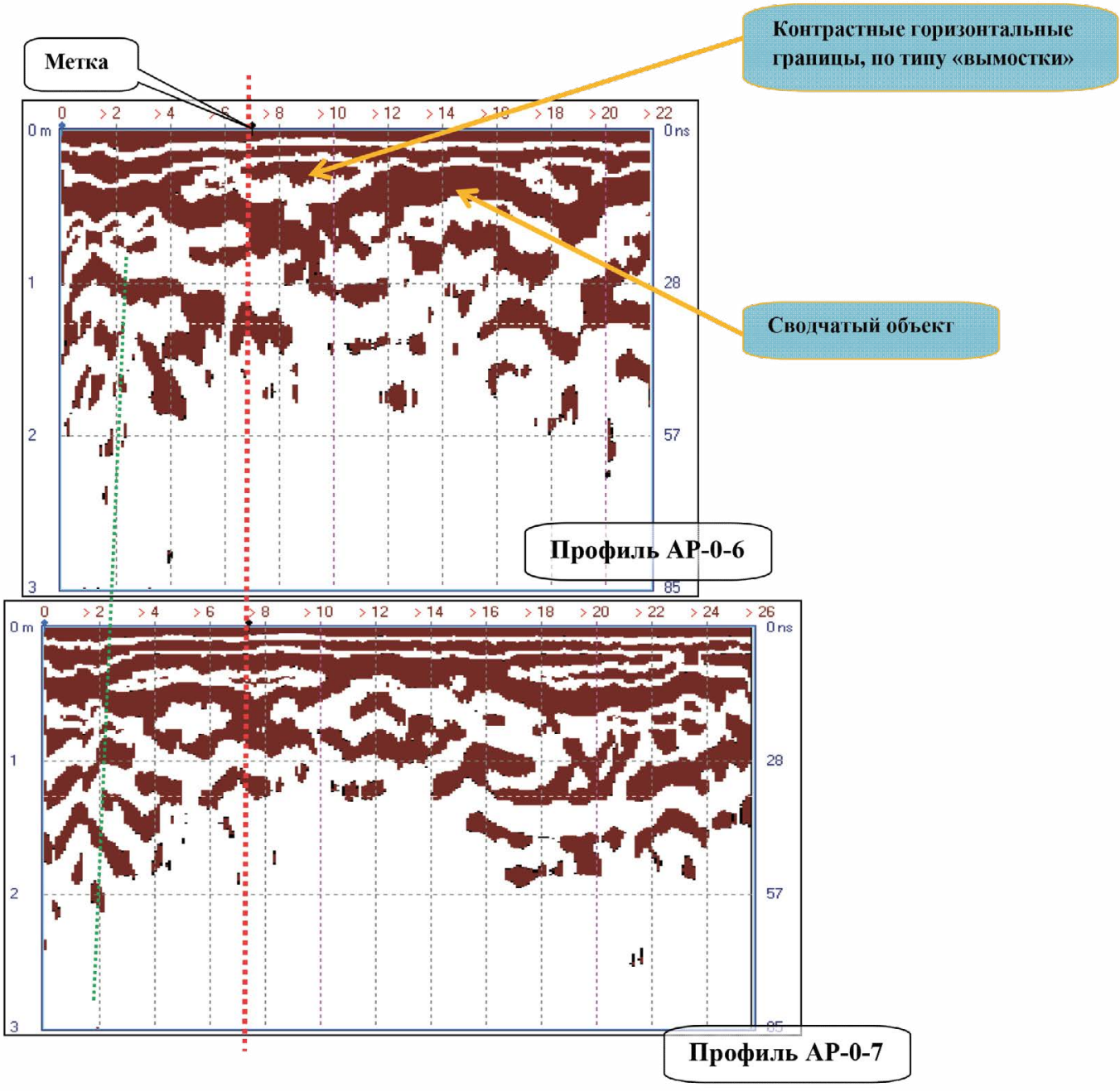

Рис. 7. Профиль георадарного исследования кургана Туннуг. Участок 1

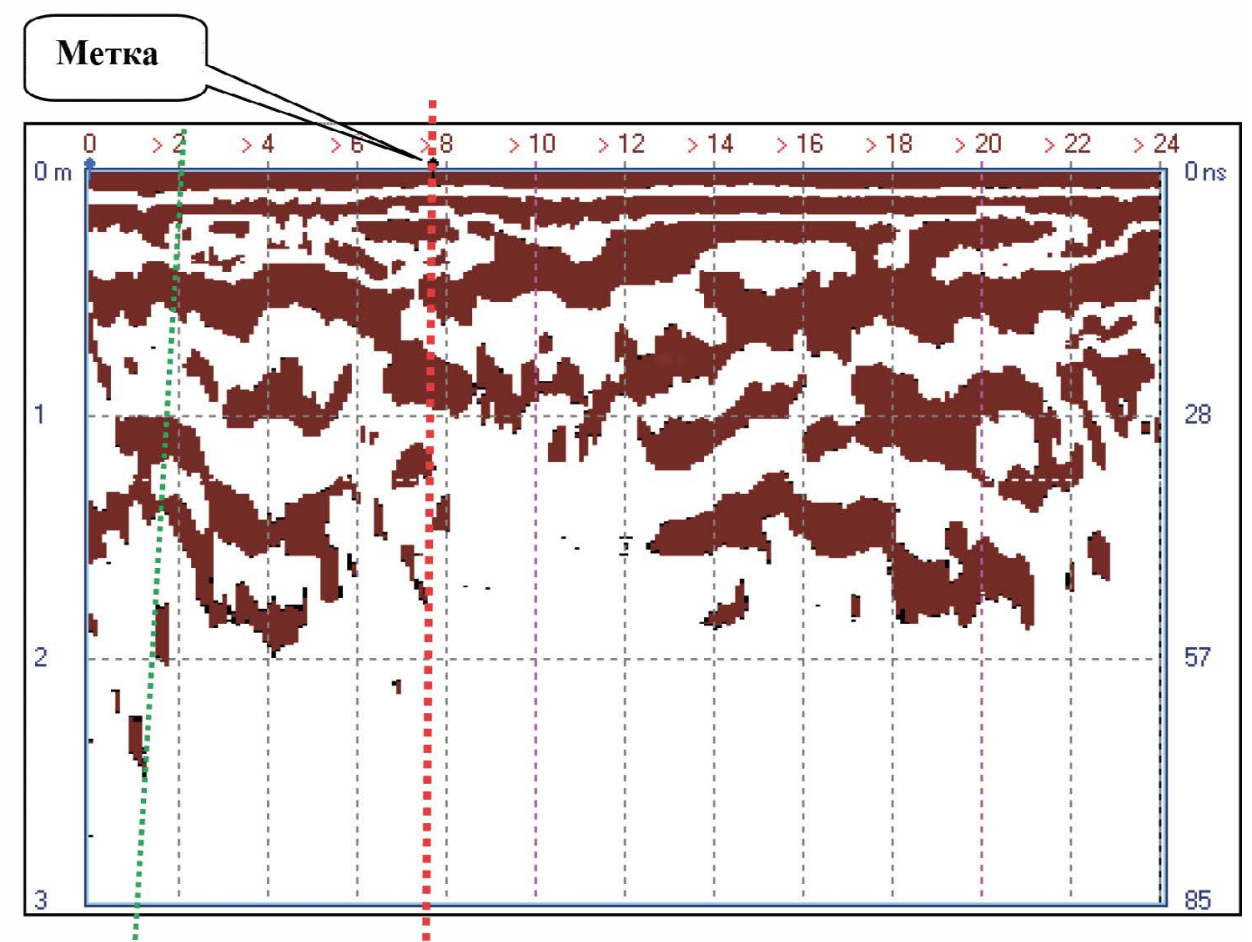

Рис. 8. Профиль георадарного исследования кургана Туннуг. Участок 1 


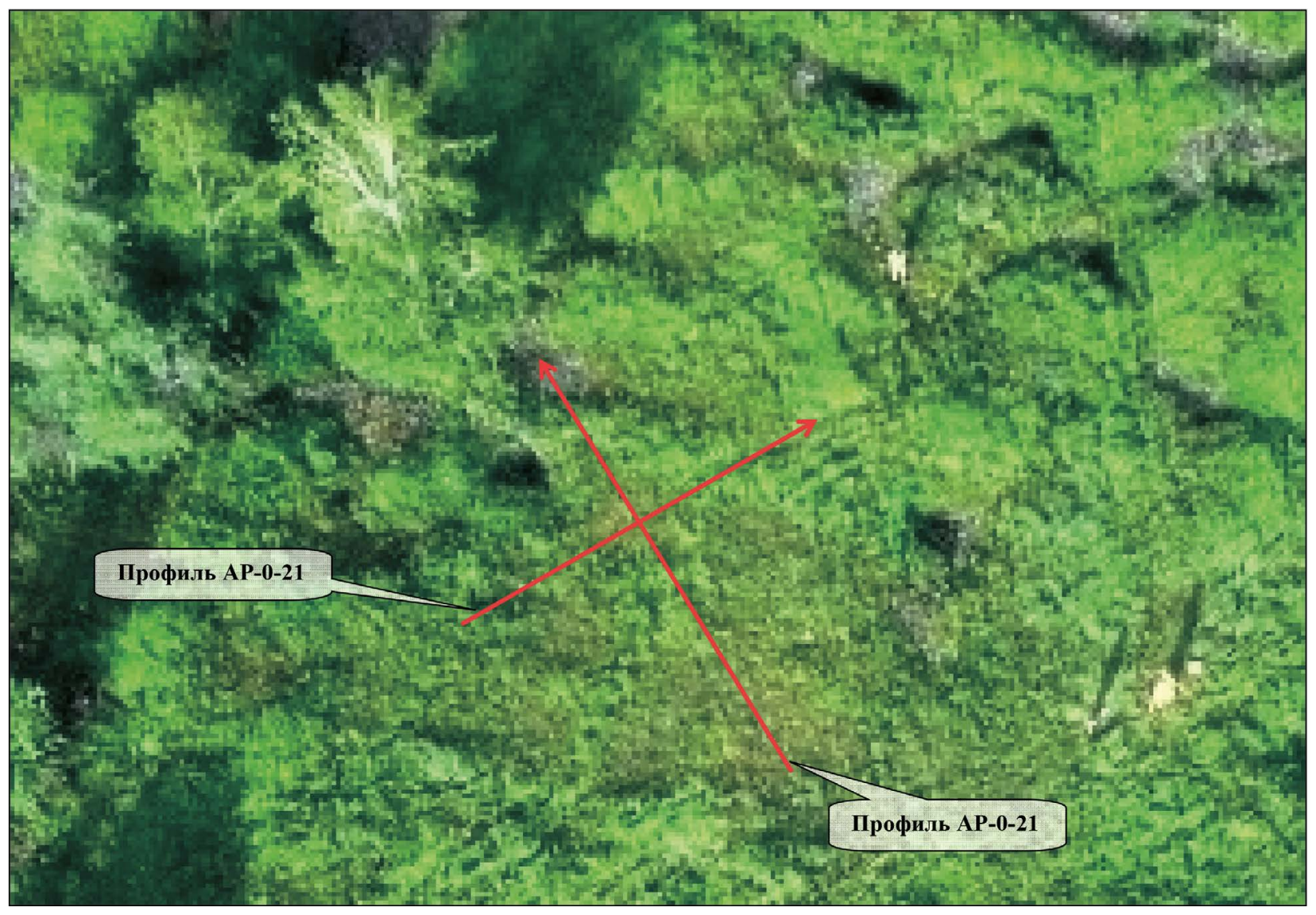

Рис. 9. Схема профилей георадарного исследования участка 2

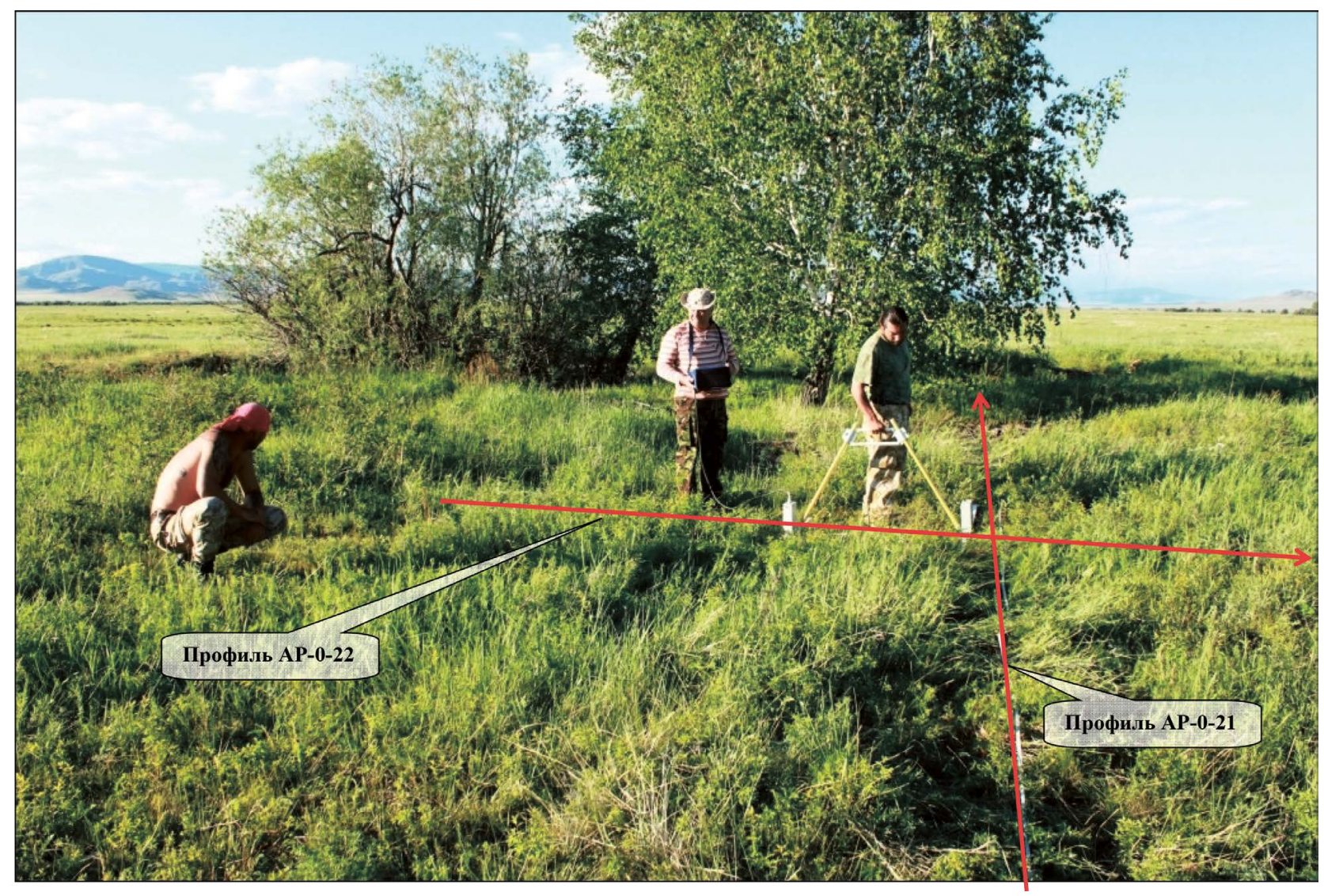

Рис. 10. Георадарное исследование участка 2 


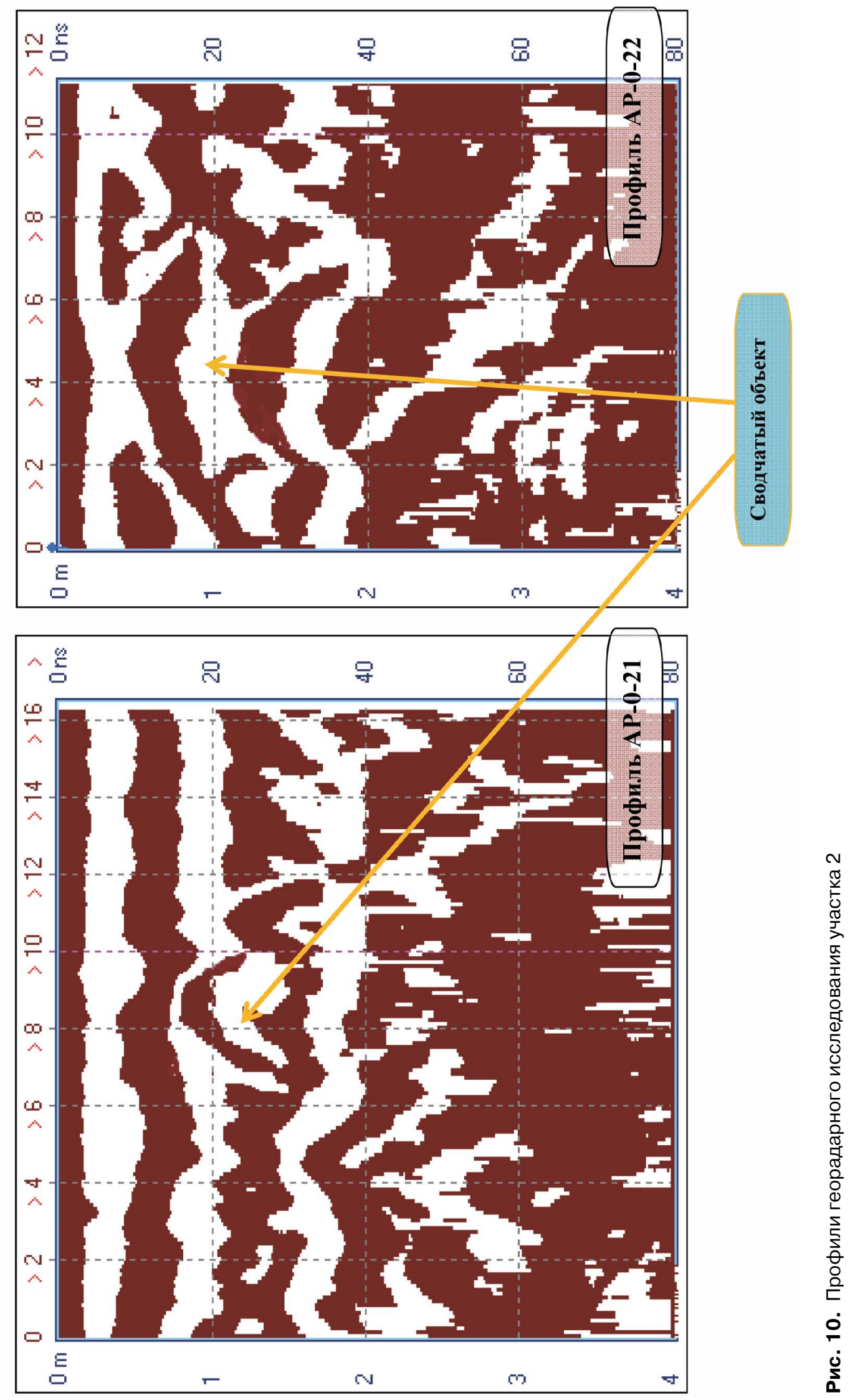


Приложение 2. Отчет по георадарному обследованию погребально-поминального комплекса «Аржан 5» на территории Турано-Уюкской котловины в Пий-Хемском районе Республики Тыва в 2014 г.
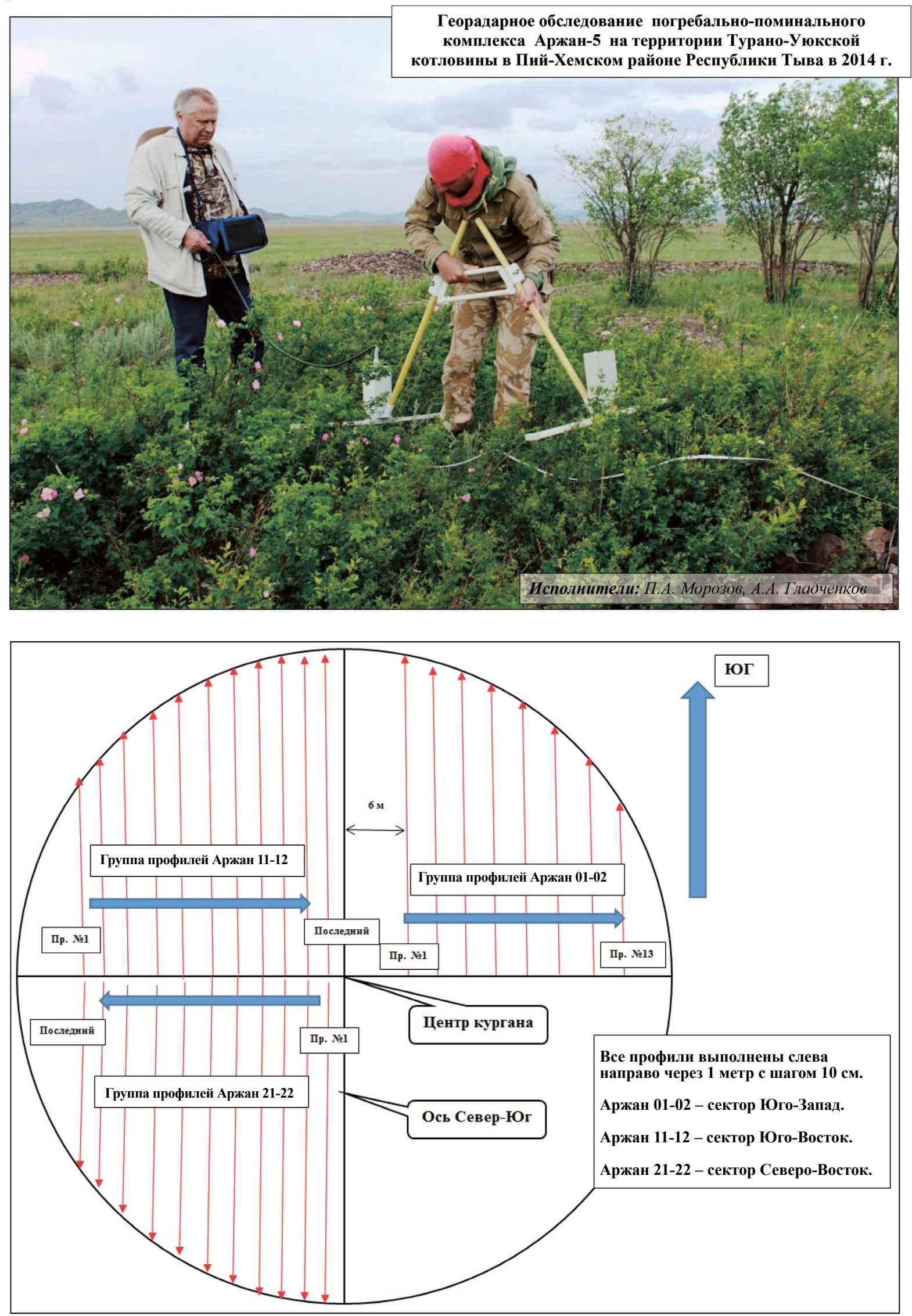

Рис. 1. Схема георадарного обследования 


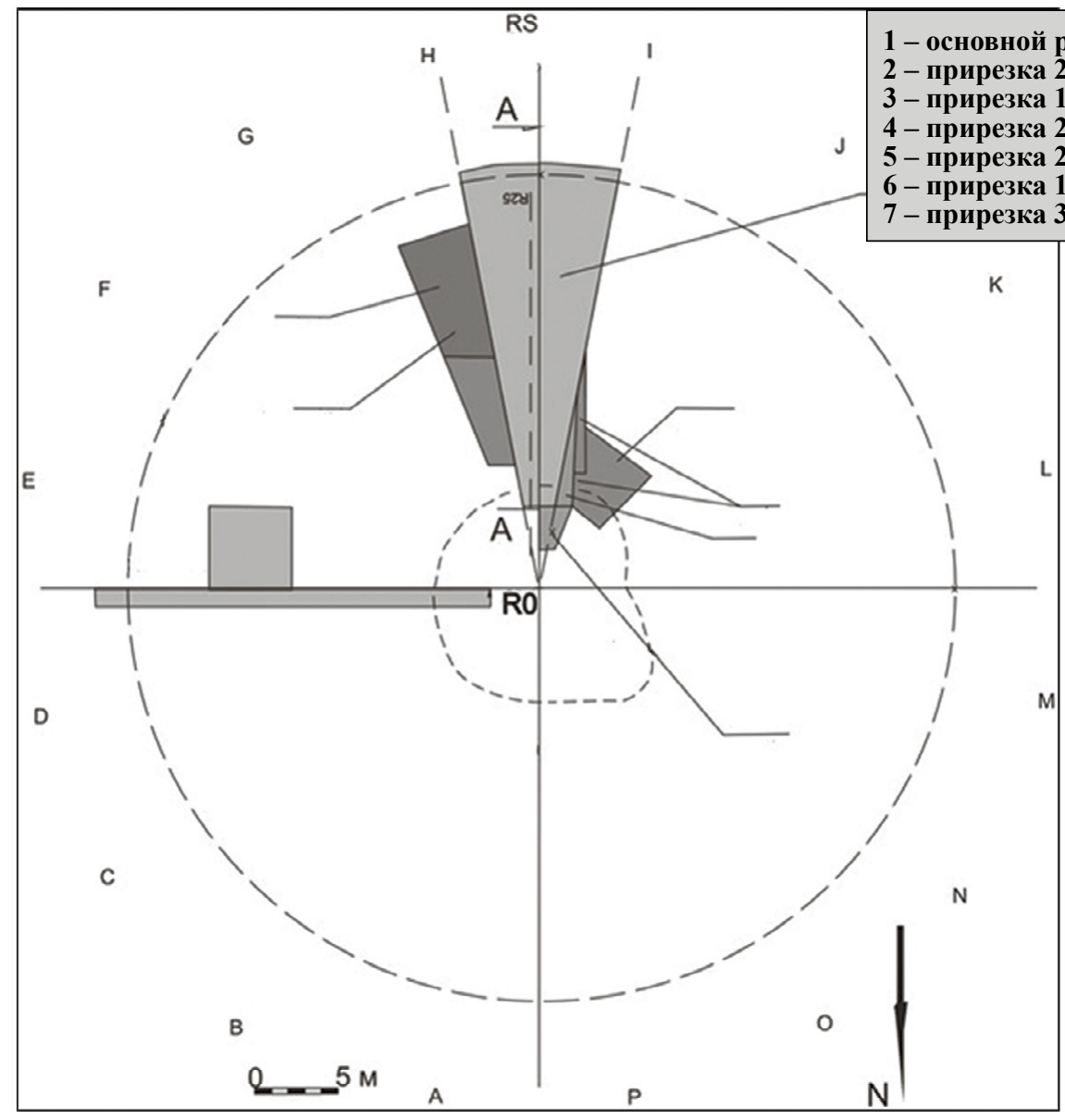

Рис. 2. Схема

основного раскопа и прирезок. 2014

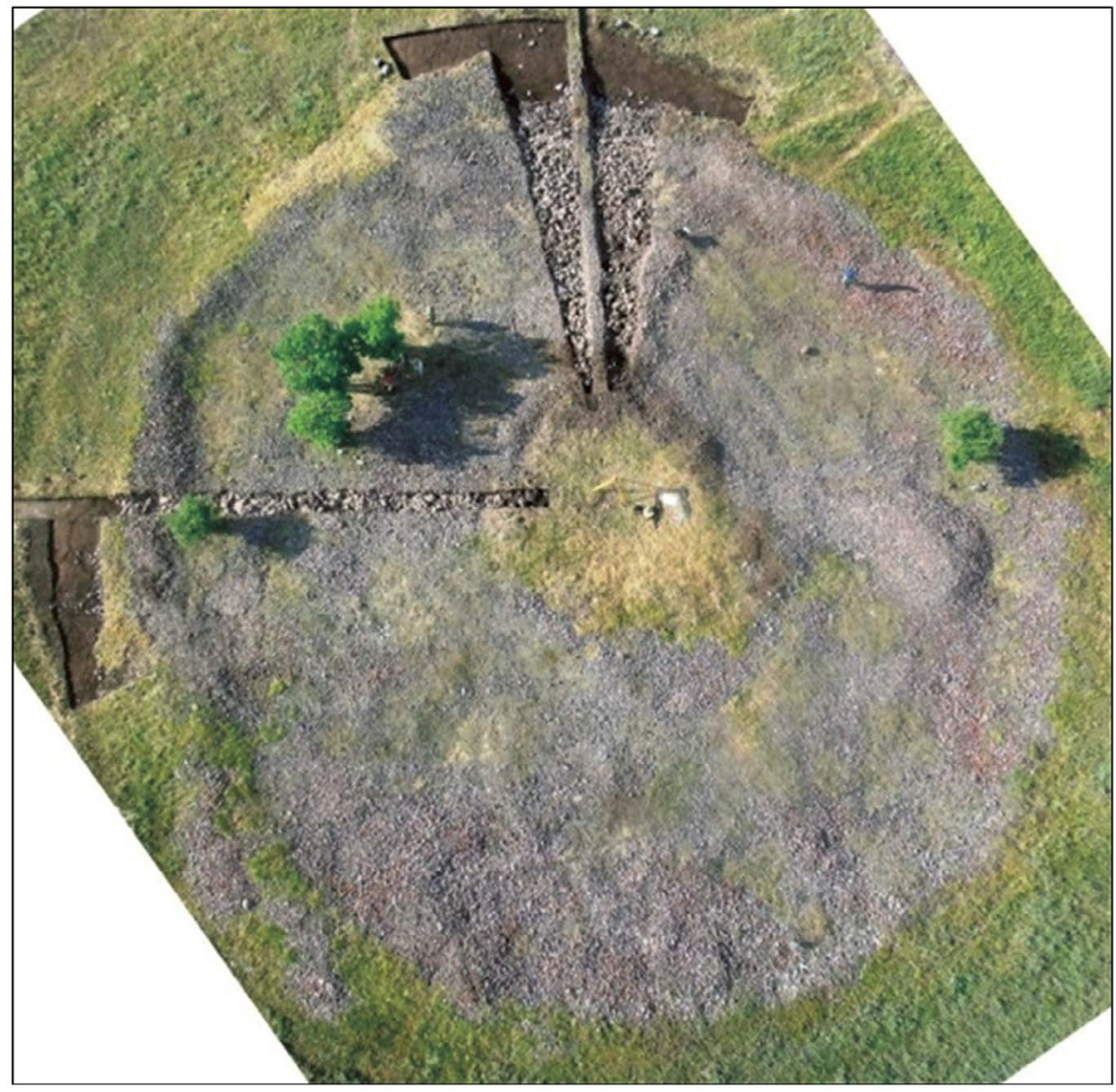

Рис. 3. Схема

зачистки основного раскопа. 2014 


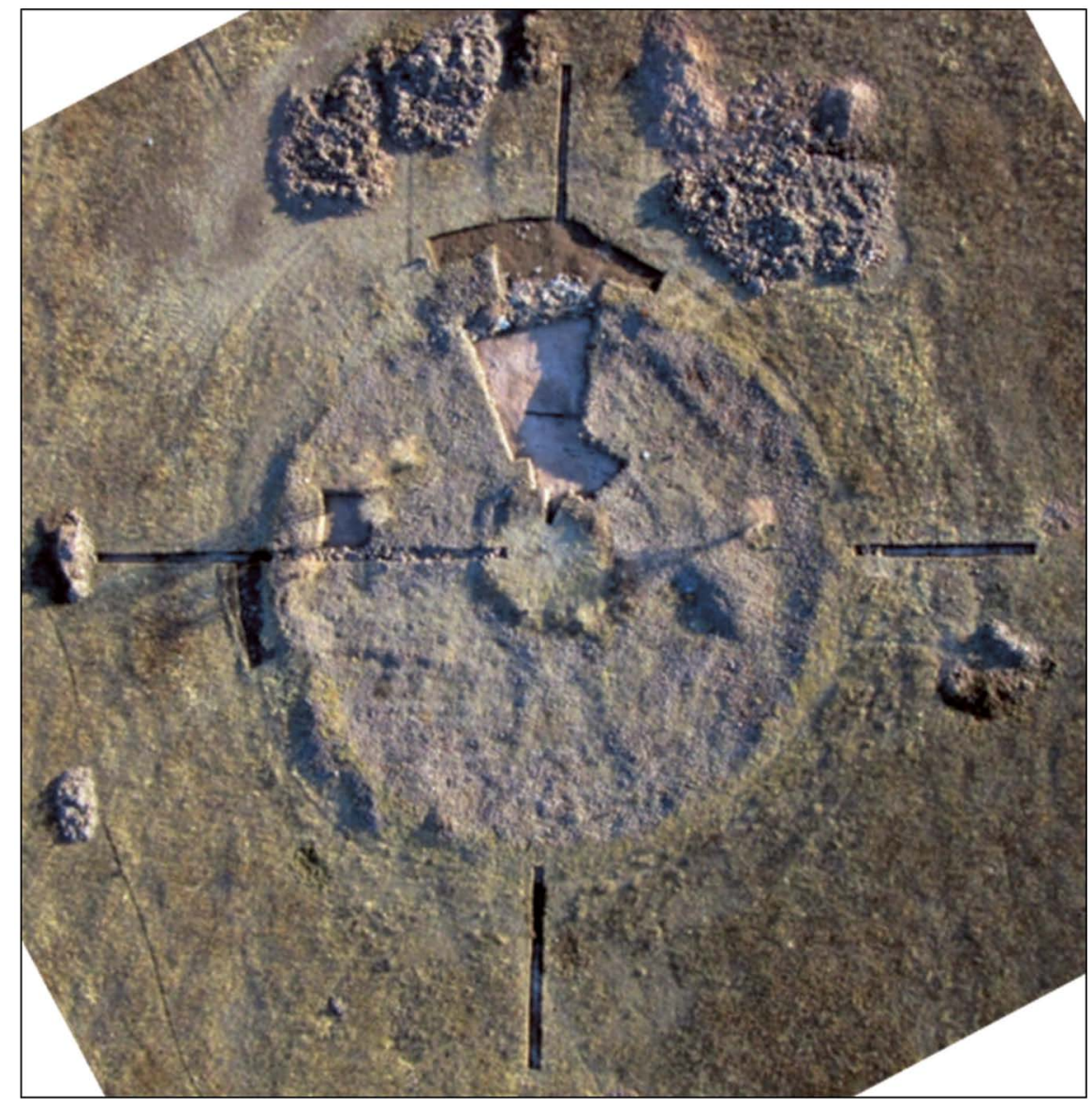

Рис. 4. Фото

основного раскопа и прирезок. 2014

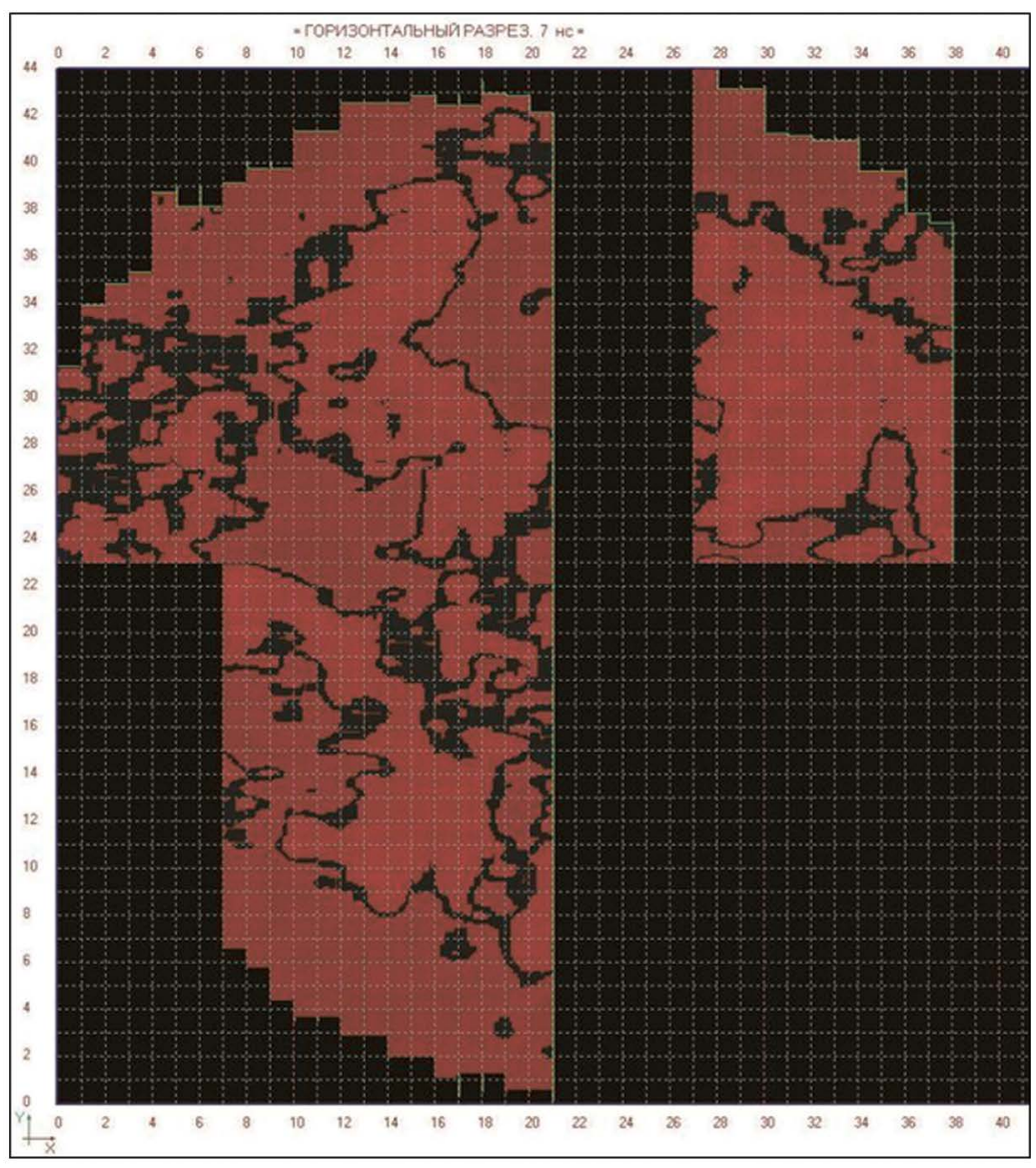

Рис. 5. Горизонтальное сечение на глубине $\sim 40 \mathrm{~cm}$. Ориентация по сторонам света такая же, как на схеме (рис. 1-2) и на аэрофотоснимках (рис. 3-4). Черные линии отражают границы завалов камня в верхнем слое. Цвет на картинке не отражает свойств грунта. Значение имеет контрастность и изменение цвета, означающие границу массивов грунта с различными свойствами (плотности, раздробленности, влажности) 

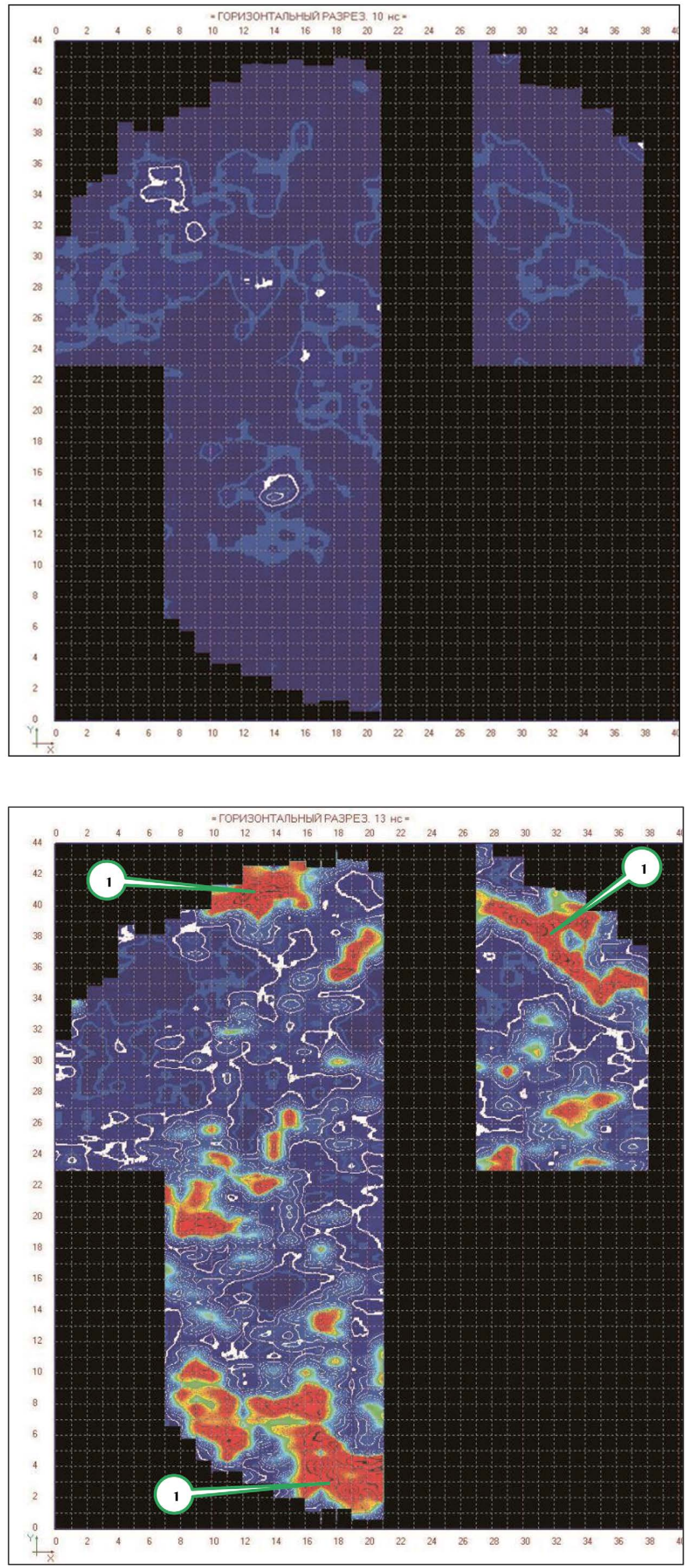

Рис. 6. Горизонтальное сечение на глубине $\sim 60$ см. Синие линии отражают границы завалов камня в верхнем слое
Рис. 7. Горизонтальное сечение на глубине $\sim 80 \mathrm{~cm}$. На этом сечении начинают проявляться конструктивные элементы кургана - крепиды (1) (организованная кладка камней по окружности кургана) 

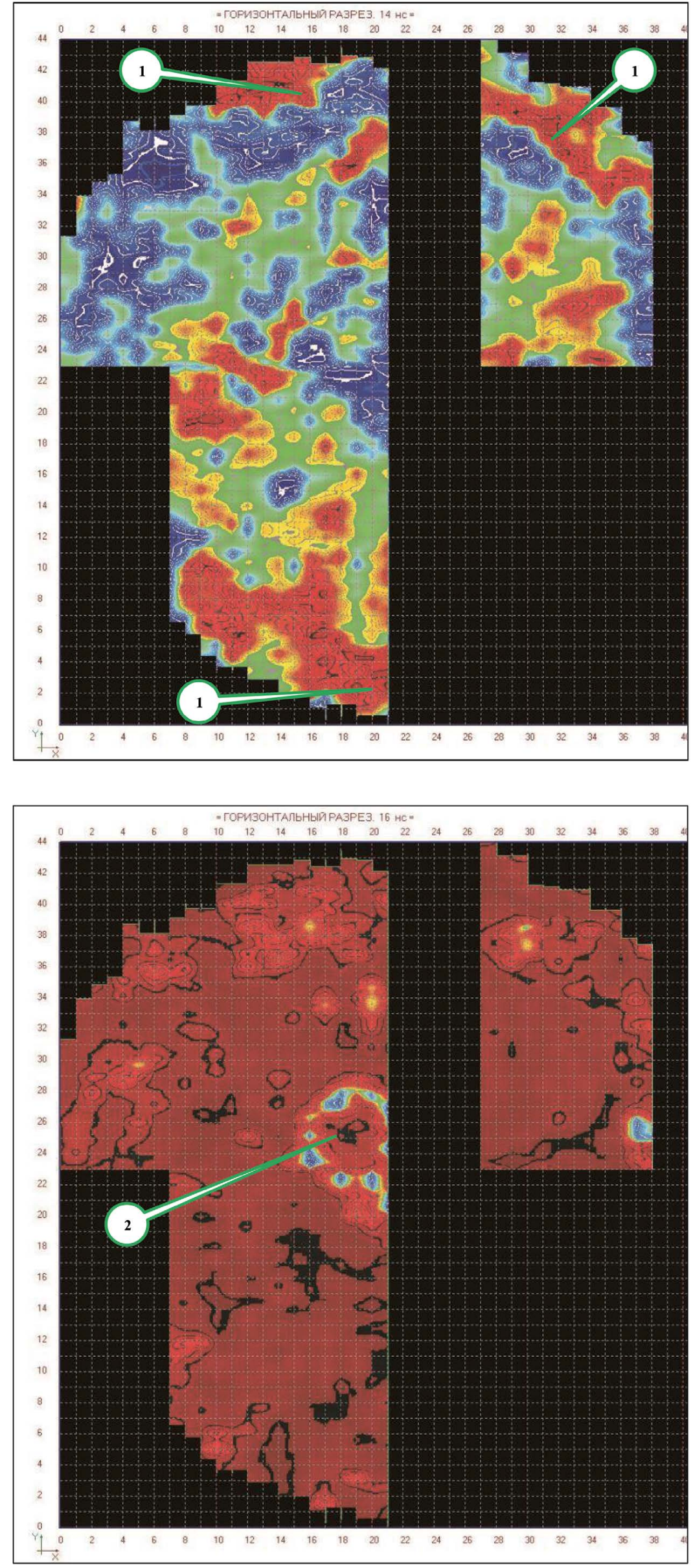

Рис. 8. Горизонтальное сечение на глубине $\sim 85 \mathrm{~cm}$. По периметру кургана регистрируются фрагменты конструктивных элементов кургана - крепиды (1) (организованная кладка камней по окружности кургана)
Рис. 9. Горизонтальное сечение на глубине $\sim 100 \mathrm{~cm}$. На этом сечении регистрируется кольцевая структура (2). Вероятно, это контур засыпки грабительской ямы 


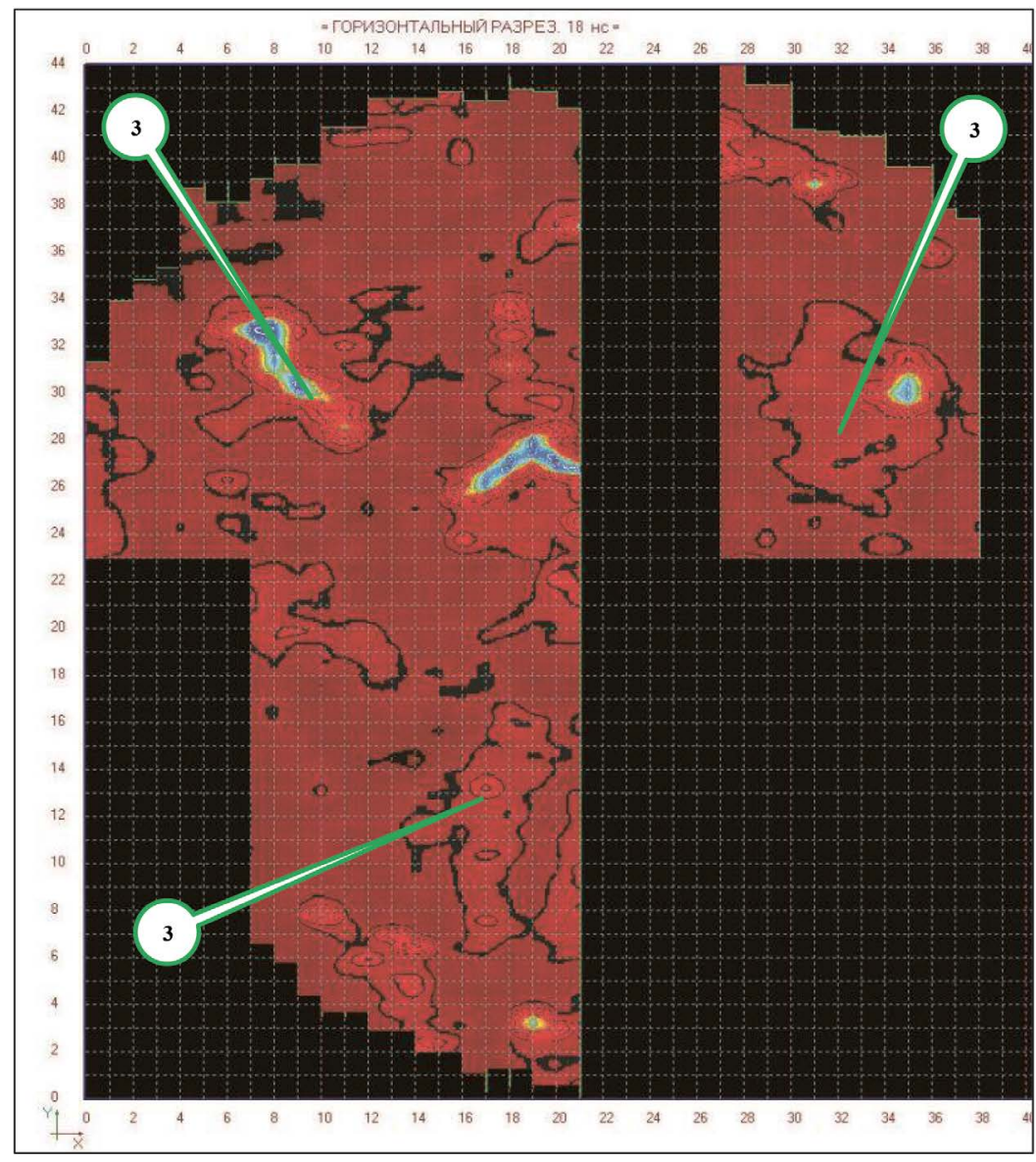

Рис. 10. Горизонтальное сечение на глубине $\sim 110 \mathrm{~cm}$. На этой глубине начинают проявляться три локальных (замкнутых) нарушения грунта (3). Глубже, под этими нарушениями проявятся подземные объекты

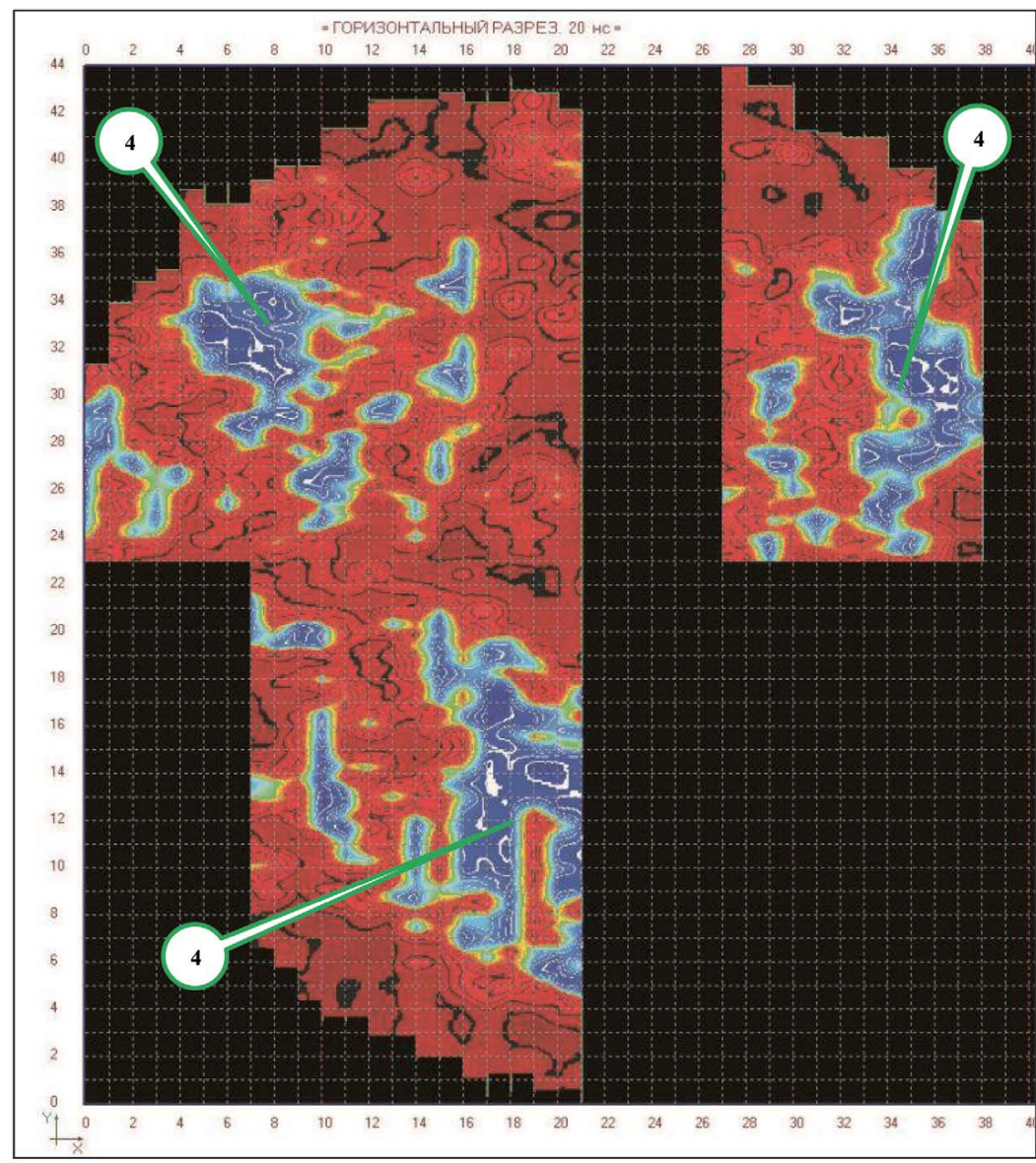

Рис. 11. Горизонтальное сечение на глубине $\sim 120 \mathrm{~cm}$. На этой глубине проявляются первые сечения трех значительных подземных объектов (4) 


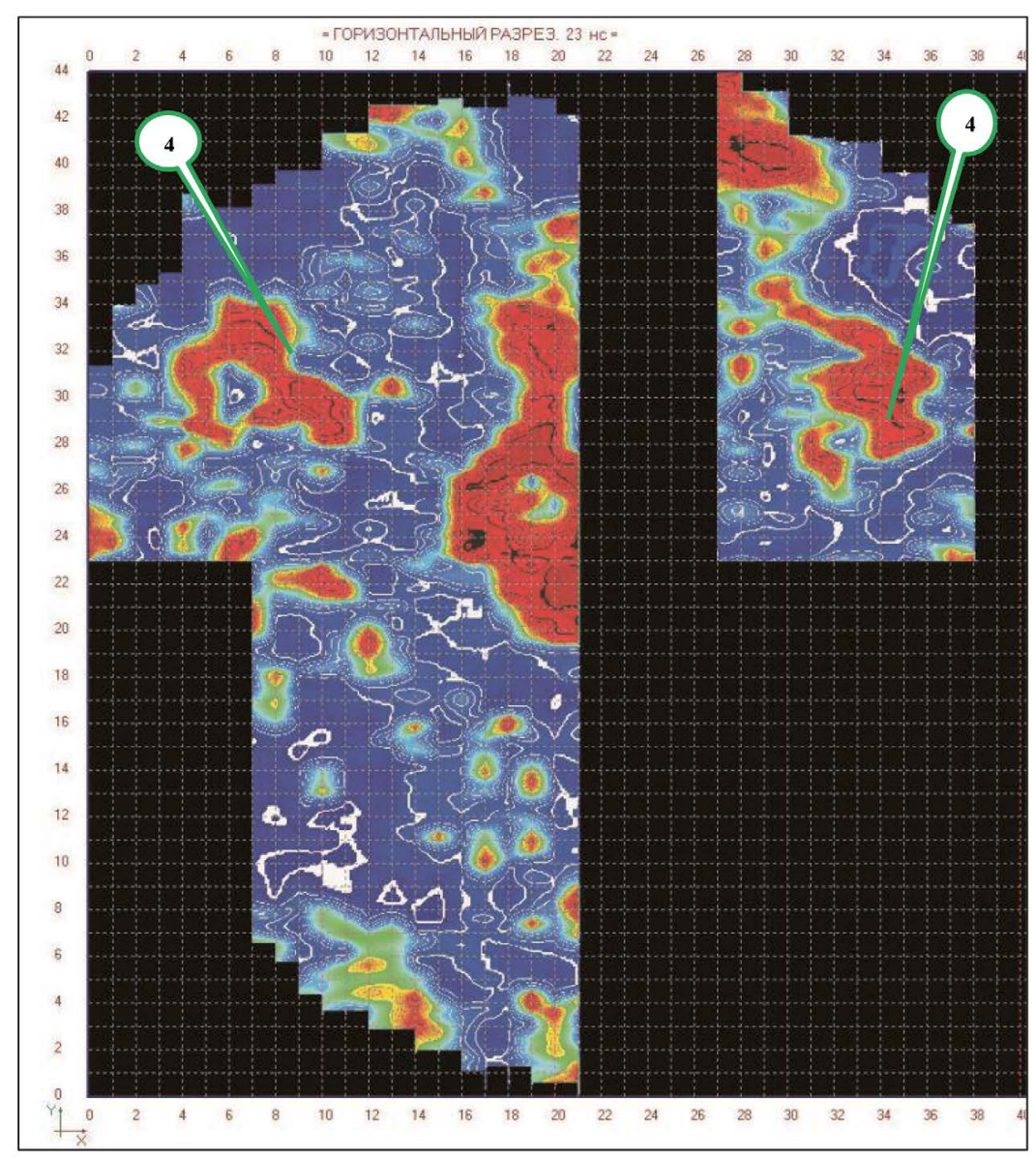

Рис. 12. Горизонтальное сечение на глубине 140 см. Сечения подземных объектов (4) становятся более четкими

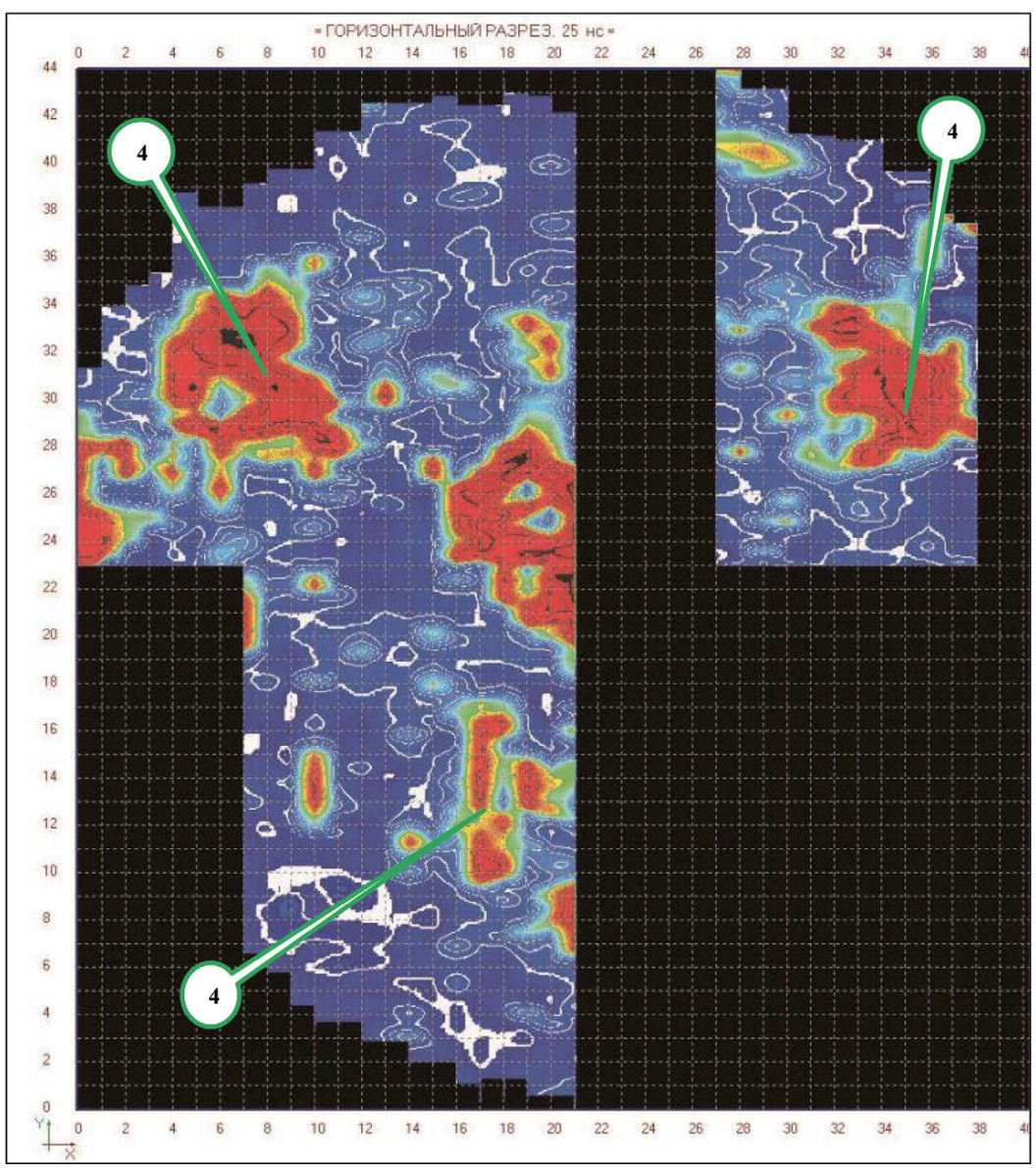

Рис. 13. Горизонтальное сечение на глубине 150 см. Сечения подземных объектов (4) становятся более четкими 

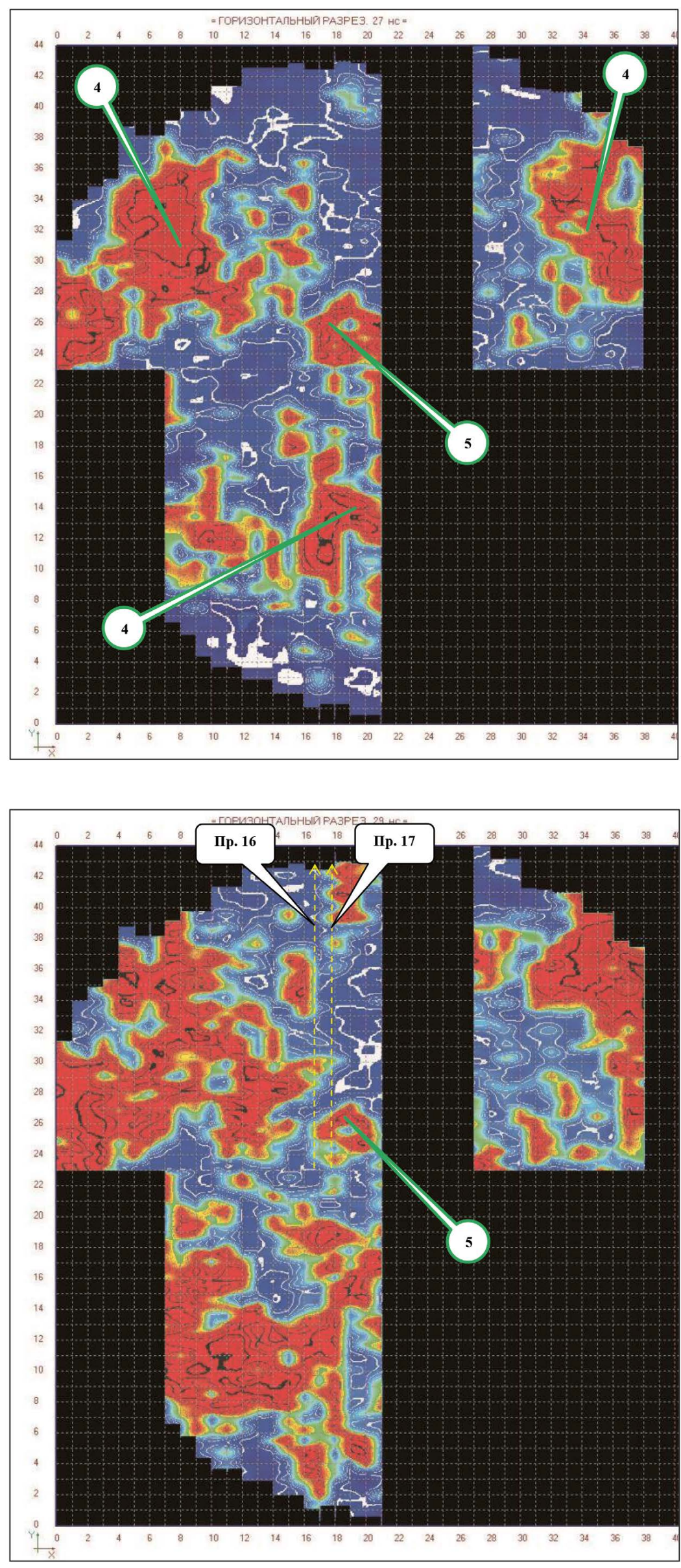

Рис. 14. Горизонтальное сечение на глубине $\sim 165$ см. Сечения подземных объектов (4) становятся более четкими.В центральной части кургана в юго-восточном секторе появляется локализованное подземное образование (5). Структура этого объекта будет проанализирована на вертикальных разрезах № 15-16, проходящих через это место

Рис. 15. Горизонтальное сечение на глубине $\sim 180 \mathrm{~cm}$. В центральной части кургана в юго-восточном секторе продолжает регистрироваться локализованное подземное образование (5). Структура этого объекта будет проанализирована на вертикальных разрезах №16-17, проходящих через это место. Очертания объектов (4) размываются и становятся менее заметными на фоне неоднородностей структуры грунта 


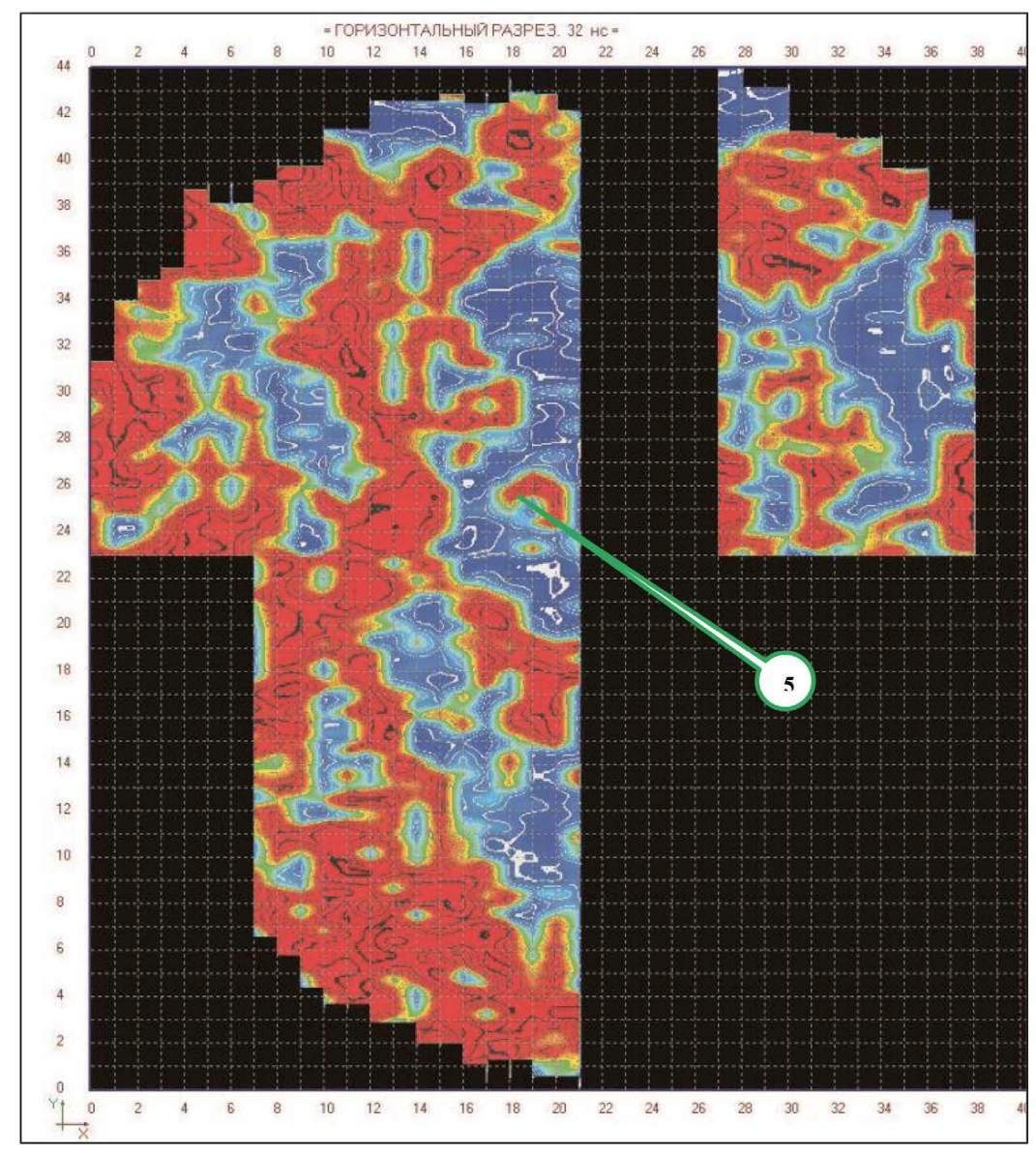

Рис. 16. Горизонтальное сечение на глубине 195 см. В центральной части кургана в юго-восточном секторе продолжает регистрироваться локализованное подземное образование (5). Структура этого объекта будет проанализирована на вертикальных разрезах № 16-17, проходящих через это место

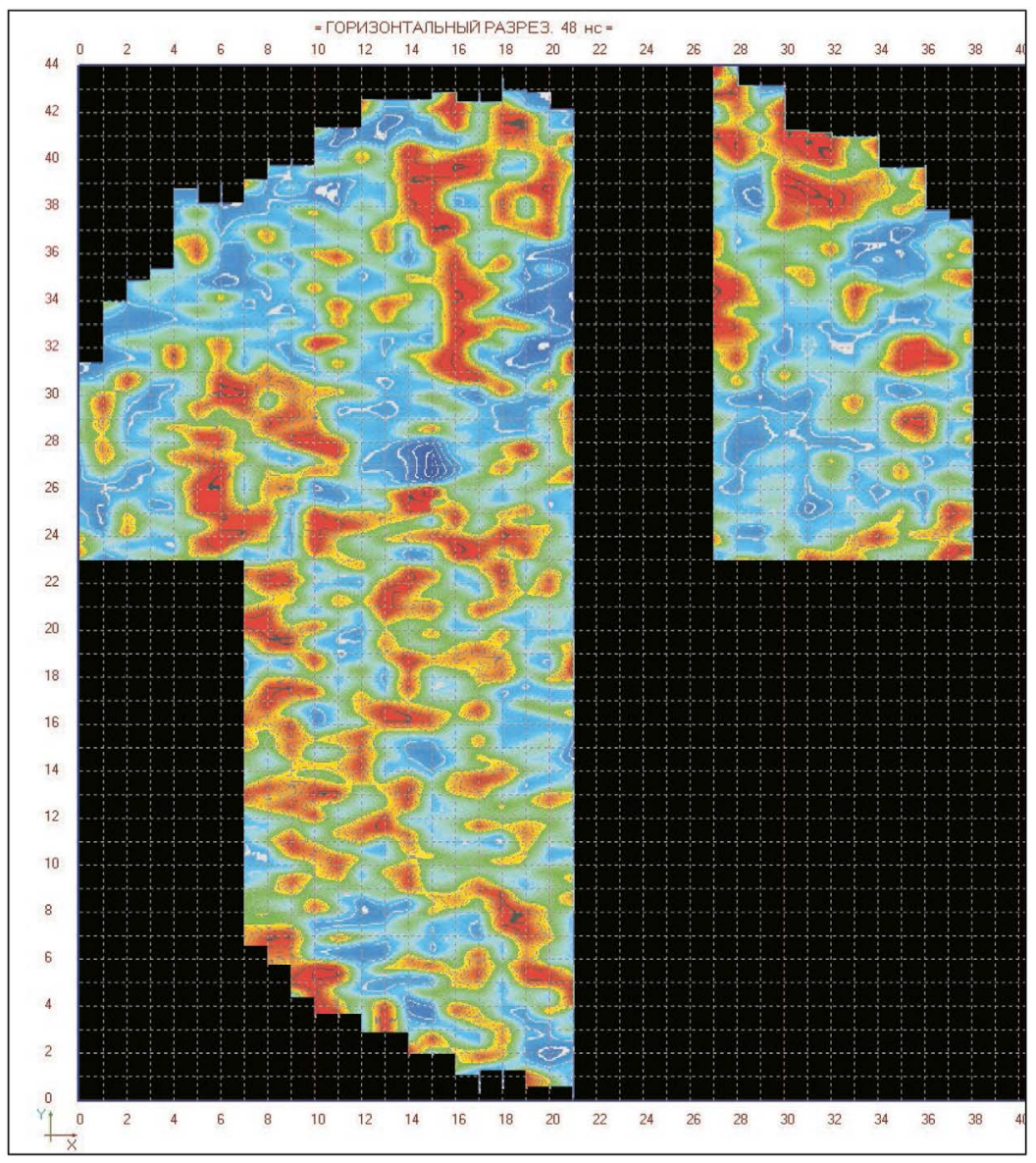

Рис. 17. Горизонтальное сечение на глубине $\sim 240$ см. На этом сечении очертания выявленных выше подземных объектов исчезают 


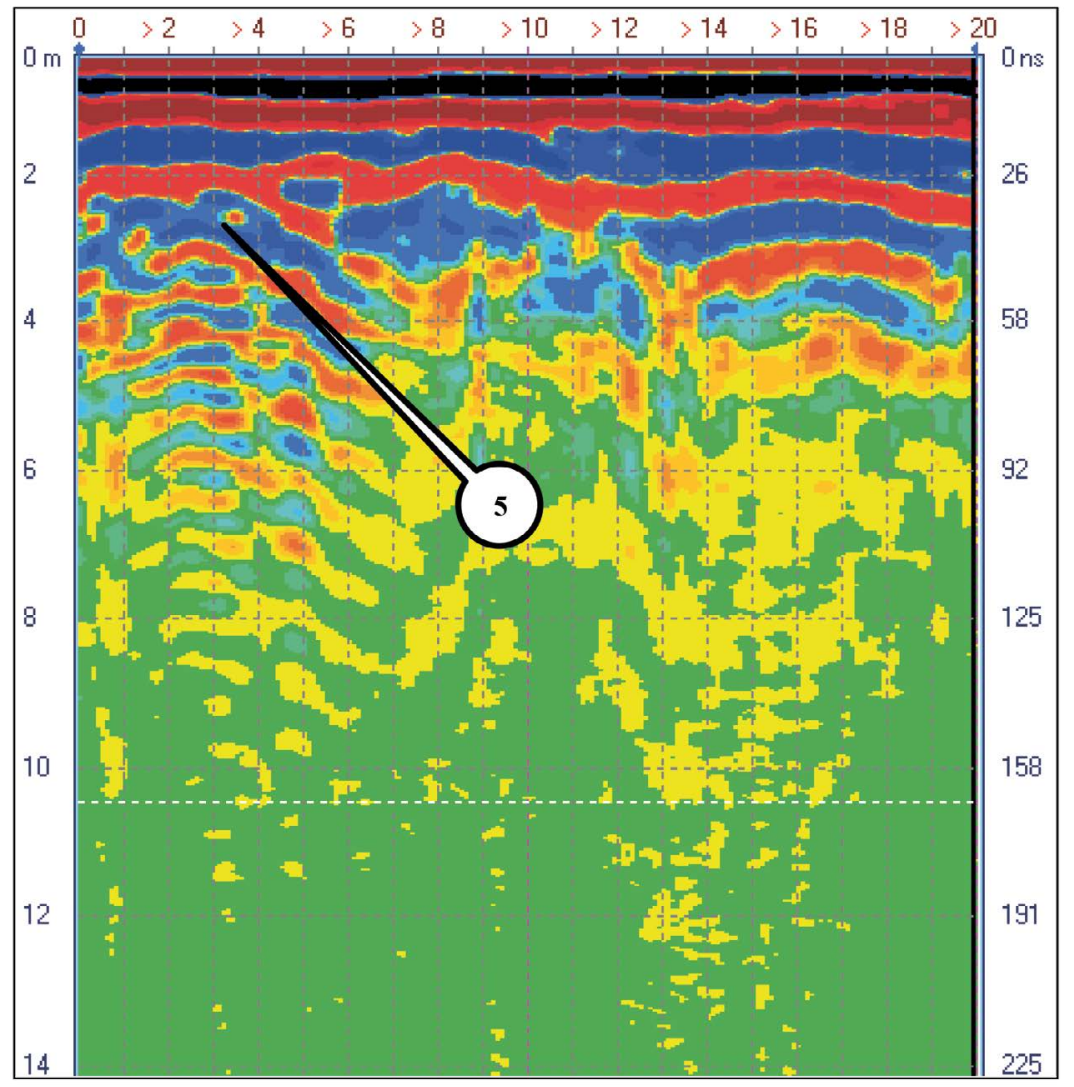

Рис. 18. Вертикальное сечение по профилю 16. На 3-4 метре на глубине 1,8 - 2,0 м (верх) регистрируется подземный объект. Характерный радиообраз (повторяющиеся гиперболы) свидетельствует о наличии внутри объекта сильно разуплотнённого грунта или пустоты

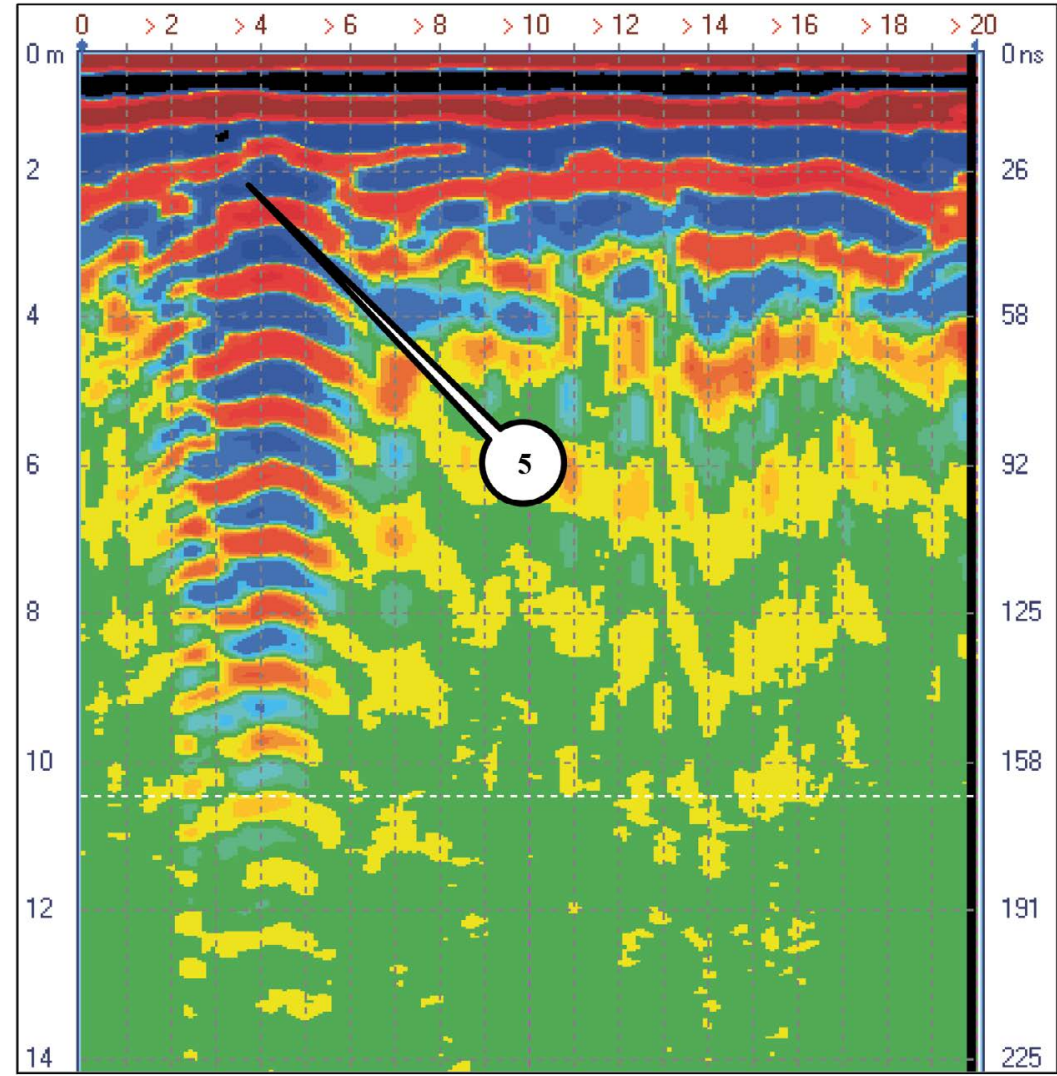

Рис. 19. Вертикальное сечение по профилю 17. На 3-4 метре на глубине 1,8 - 2,0 м (верх) регистрируется подземный объект. Характерный радиообраз (повторяющиеся гиперболы) свидетельствует о наличии внутри объекта сильно разуплотнённого грунта или пустоты 


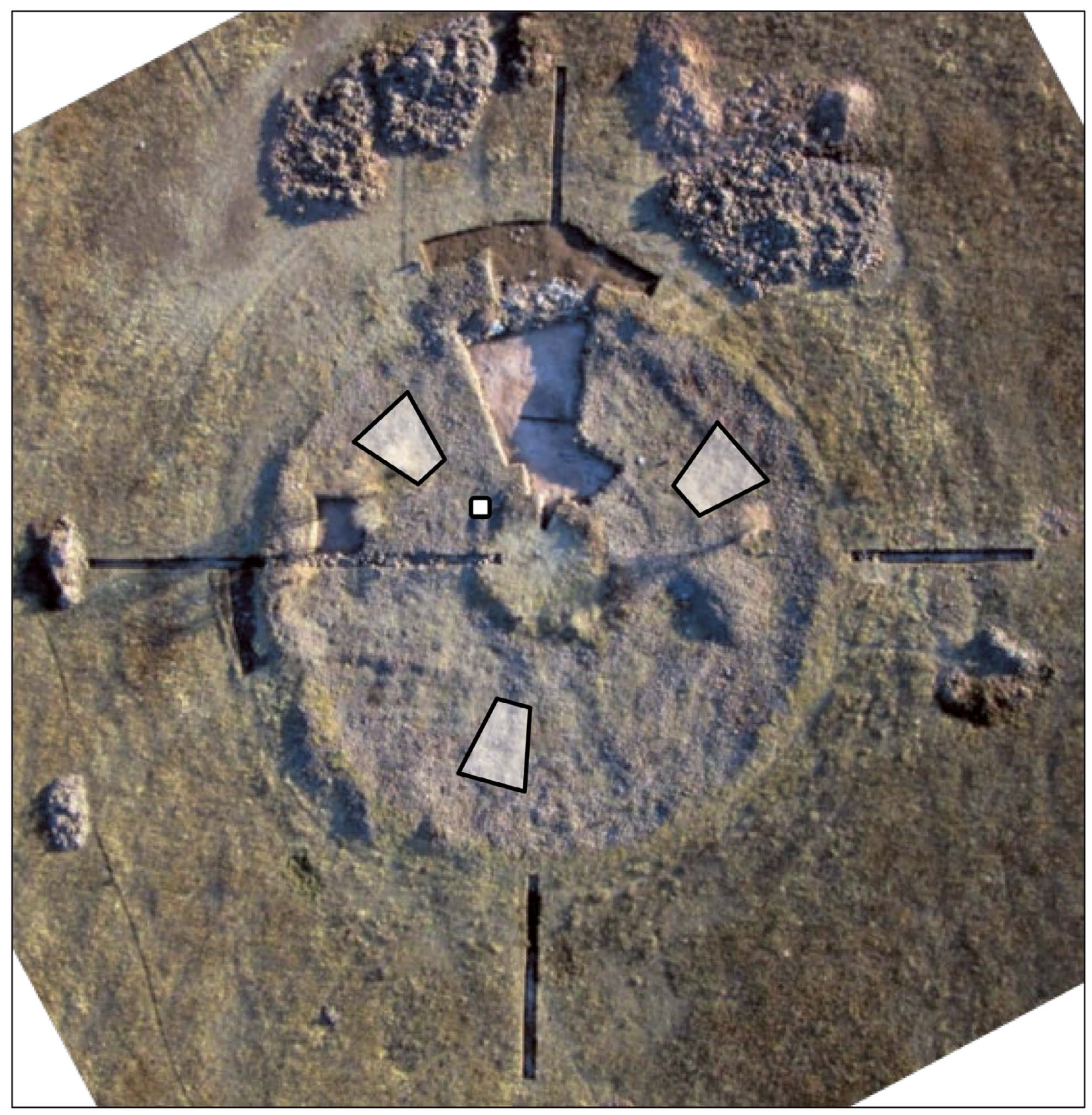

Pис. 20. Сводная схема расположения выделенных объектов (4-5) 


\section{Приложение 3. Заключение}

Из материалов археологических работ Тувинской археологической экспедиции РАН (курган Аржан-5) в 2014 г. в лабораторию естественнонаучных методов ИА РАН на определение породы древесины были переданы фрагменты деревянных конструкций (всего 21 образец). Сохранность дерева носила неоднородный характер: в большинстве случаев в руки к исследователям попал уже древесный тлен с включениями небольших кусочков ссохшейся древесины. Только образец № 1 представлял собой довольно крепкий фрагмент дерева, однако его структура была так сильно деформирована, что получить с него правильно ориентированный срез не удалось.

Тем не менее методика определения породы древесины осталась прежней и дополнительная обработка для сохранившихся фрагментов не потребовалась. Для каждого образца было изготовлено три среза в поперечном, радиальном и тангенциальном направлениях. Анализ строения древесины осуществлялся по подготовленным срезам при помощи бинокулярного микроскопа с целью выявления характерных признаков породы. В ходе исследования установлено, что остатки древесины из кургана Аржан-5 принадлежат к хвойным породам, а именно лиственнице сибирской (Larix sibirica) и ели обыкновенной (Picea excelsa). Древесина лиственницы и ели имеет сходное строение, ряд микроскопических признаков у них неустойчив, что затрудняет их определение. Поэтому в ряде случаев при условии плохой сохранности образцов их различить не удалось (Приложение 3.2).

Микроскопические признаки ели (Рicea). На поперечном срезе видны четко выраженные годичные слои. Ранние трахеиды имеют правильную прямоугольную форму, чуть вытянутую в радиальном направлении. Поздние трахеиды квадратные или прямоугольные.
Переход от ранней древесины к поздней постепенный. Смоляные ходы расположены как одиночно, так и попарно. Полость смоляного хода выстилают 4-8 толстостенных клеток эпителия. Сердцевинные лучи однорядные (Приложение 3.1, рис. 1). На радиальном срезе сердцевинные лучи гетерогенные. Внутренние паренхимные клетки лучей на радиальных стенках несут по 4-6 мелких пицеоидных пор (Приложение 3.1, рис. 2). На тангенциальном срезе сердцевинные лучи однорядные и многорядные с горизонтальными смоляными ходами. Многорядные лучи веретеновидные, имеют однорядный «хвост» длиной в 1-2, реже в 3-5 клеток (Приложение 3.1, рис. 3).

Микроскопические признаки лиственницы (Larix). На поперечном срезе заметно, как резко выражен переход от ранней древесины к поздней. Поздние трахеиды толстостенные, у границы слоя сплющены, с щелевидными полостями. Ранние трахеиды широкополостны и тонкостенны, в отличие от трахеид ели имеют угловатое строение. Смоляные ходы в большинстве своем расположены в поздней древесине, имеют ширину в 3-4 клетки трахеид. Сердцевинные лучи однорядные (Приложение 3.1 , рис. 4). На радиальном срезе ранние трахеиды имеют одиночные или расположенные в два ряда окаймленные поры. Спиральные утолщения отсутствуют. Сердцевинные лучи гетерогенные. На полях перекреста радиальные стенки трахеид несут по 2-6 пицеоидных поры. Горизонтальные трахеиды гладкие и волнистые. На тангенциальном разрезе наблюдаются однорядные сердцевинные лучи высотой 6-10 клеток, а также многорядные лучи со смоляными ходами. Многорядные лучи веретеновидные, с длинным однорядным «хвостом» в 10 и более клеток. Смоляные ходы устланы 8-10 толстостенными клетками эпителия (Приложение 3.1 , рис. 5). 
Приложение 3.1. Макросъемка образиов дерева из конструкиий кургана Аржан-5

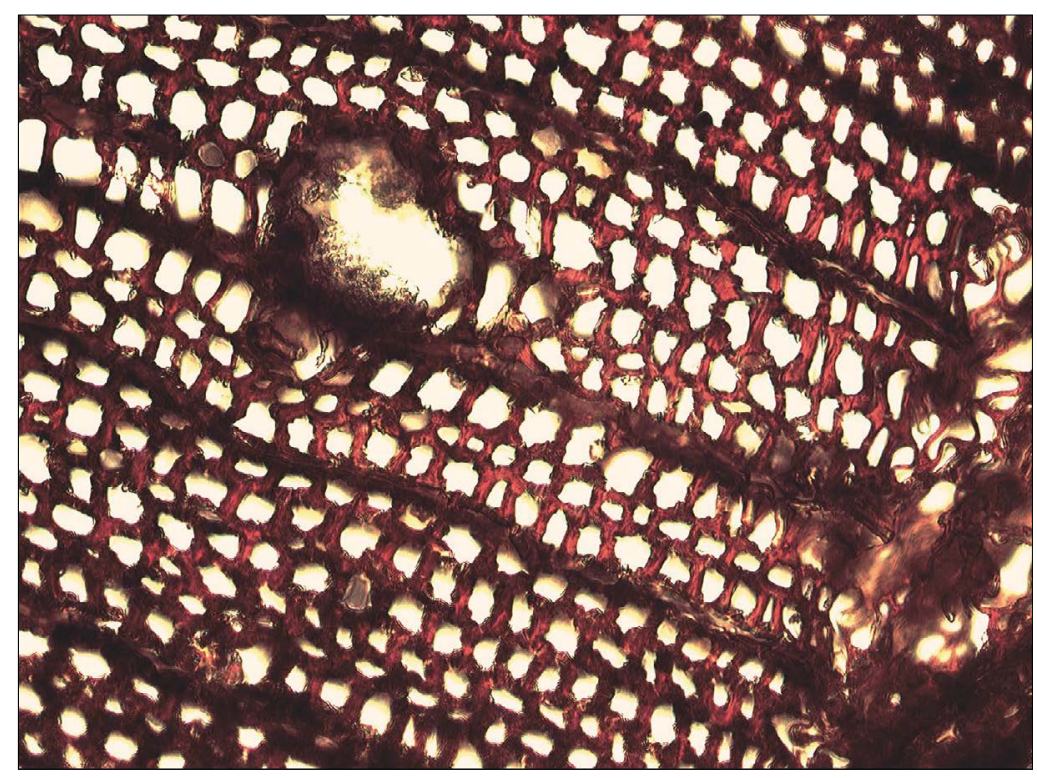

Рис. 1. Курган Аржан-5, образец № 3.Поперечный срез, ув. 40x

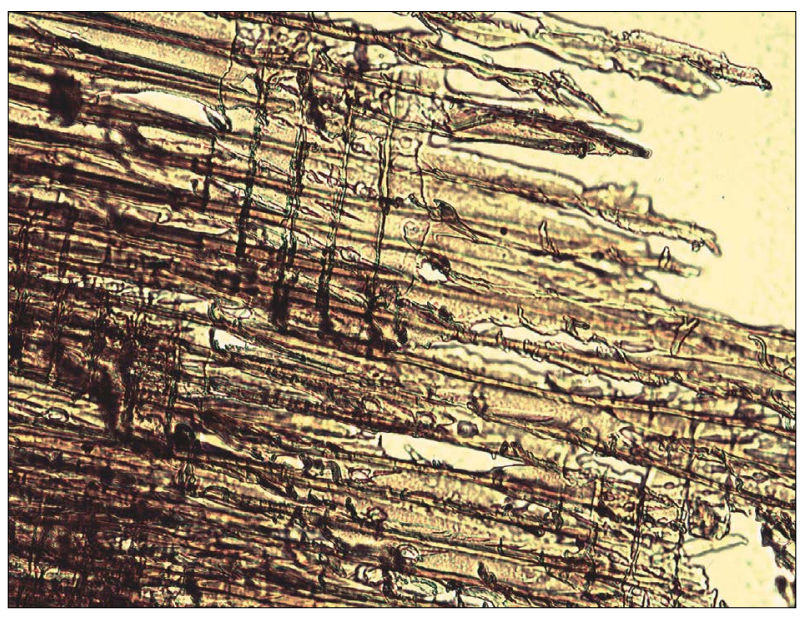

Рис. 2. Курган Аржан-5, образец № 3.

Радиальный срез, ув. 40x

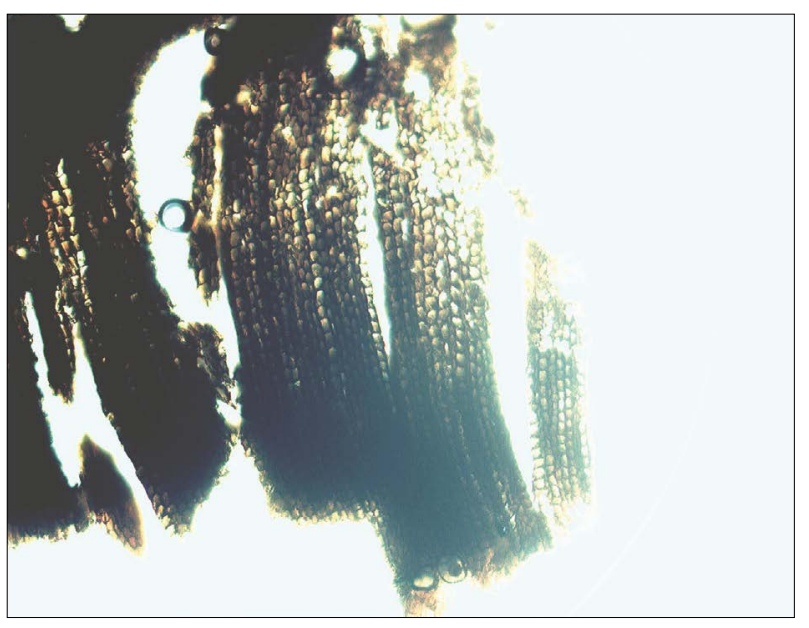

Рис. 4. Курган Аржан-5, образец № 15. Поперечный срез, ув. 10x

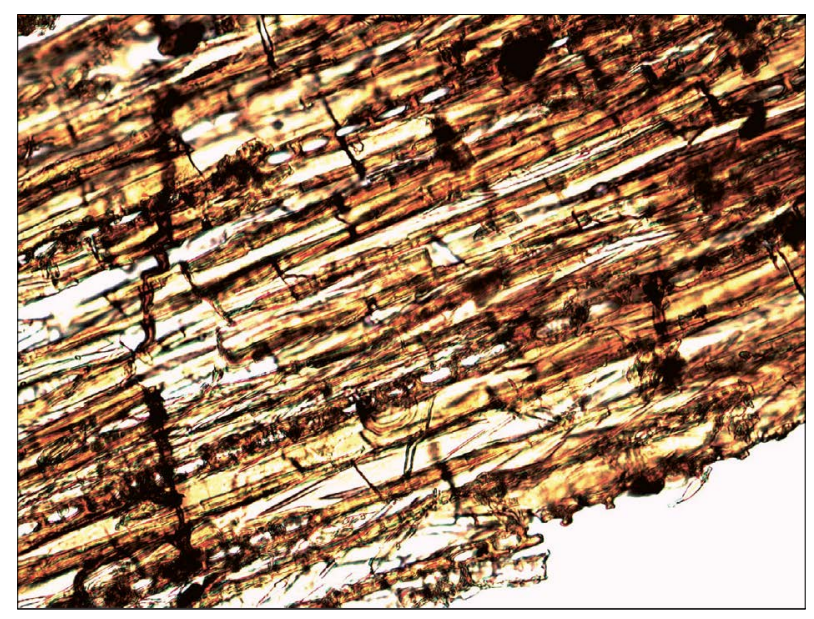

Рис. 3. Курган Аржан-5, образец № 3.

Тангенциальный срез, ув. 40x

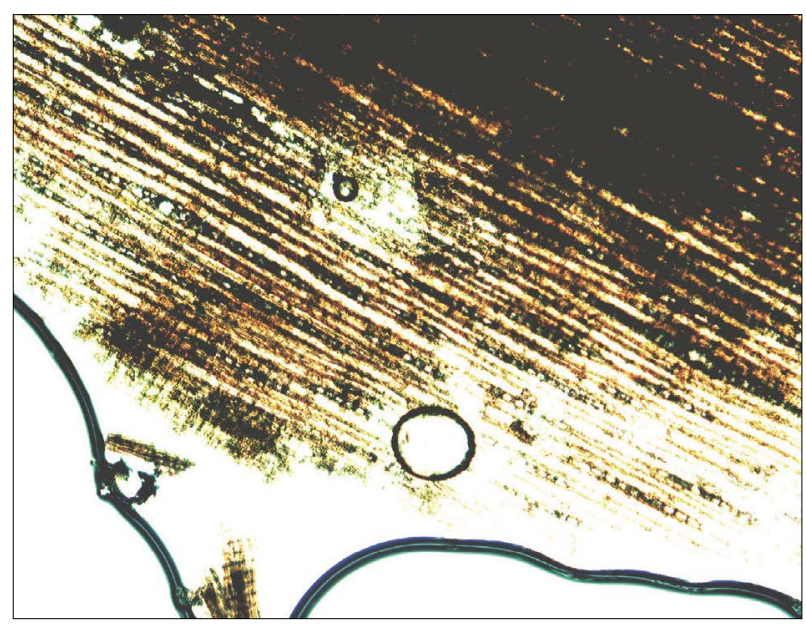

Рис. 5. Курган Аржан-5, образец № 15.

Тангенциальный срез, ув. 10x 


\section{Приложение 3.2. Таблица}

\begin{tabular}{|c|c|c|c|c|c|}
\hline № $n / n$ & Год & Курган & Погребение & Сектор & Порода \\
\hline 1 & 2014 & Аржан-5 & & & $?$ \\
\hline 2 & 2014 & Аржан-5 & & & Ель \\
\hline 3 & 2014 & Аржан-5 & & & Ель \\
\hline 4 & 2014 & Аржан-5 & Дерево из бровки & & Ель \\
\hline 5 & 2014 & Аржан-5 & Дерево из бровки R-S & $\mathrm{H}$ & Хвойное \\
\hline 6 & 2014 & Аржан-5 & $12 \mathrm{M}$ & $\mathrm{H}$ & Ель \\
\hline 7 & 2014 & Аржан-5 & Уголь под бровкой д9 & & Лиственница \\
\hline 8 & 2014 & Аржан-5 & & 1 & Ель? \\
\hline 9 & 2014 & Аржан-5 & Т-ка Д 1, 2, 3, 4, 5 код 8 & Д & Лиственница \\
\hline 10 & 2014 & Аржан-5 & & & Ель? \\
\hline 11 & 2014 & Аржан-5 & Под бровкой & $\mathrm{H}$ & Лиственница \\
\hline 12 & 2014 & Аржан-5 & & & Лиственница \\
\hline 13 & 2014 & Аржан-5 & Под бровкой, т-ка Д90 код 7 & $\mathrm{H}$ & Лиственница \\
\hline 14 & 2014 & Аржан-5 & Т-ка Д6 код 8 & $\mathrm{H}$ & Лиственница \\
\hline 15 & 2014 & Аржан-5 & Прирезка & I & Лиственница \\
\hline 16 & 2014 & Аржан-5 & Прирезка & $\mathrm{H}$ & Лиственница? \\
\hline 17 & 2014 & Аржан-5 & & I & Хвойное \\
\hline 18 & 2014 & Аржан-5 & Т-ка Д21 код 8 & $\mathrm{H}$ & Хвойное; ель? \\
\hline 19 & 2014 & Аржан-5 & Прирезка & 1 & Хвойное \\
\hline 20 & 2014 & Аржан-5 & & & Лиственница \\
\hline 21 & 2014 & Аржан-5 & Прирезка & $J$ & Хвойное; ель? \\
\hline
\end{tabular}




\section{КУРГАН АРЖАН-5: \\ ВЗГЛЯД С ПТИЧЬЕГО ПОЛЕТА}

\section{К. В. Чугунов}

Мне кажется, что Дима Рукавишников любил смотреть на мир сверху. Я не могу похвастаться давней дружбой с ним - мы познакомились и стали друзьями только в 2012 г., когда он приехал в Туву с любимой женой Ириной и привез дирижабль для съемки могильных полей нашей «долины царей» (рис. 1). Сейчас, когда почти в каждой экспедиции имеется дрон для фиксации памятников с воздуха, такое приспособление кажется экзотичным. Однако надо иметь в виду, что задолго до их появления именно Дмитрий Рукавишников был одним из первых, кто внедрял в полевой российской археологии низковысотную ортофотосъемку. Аппараты, которые для нее использовались, были результатом собственного технического творчества, и применение этих, во многом несовершенных, изделий требовало значительного труда. Я помню как непросто было удержать дирижабль на нашем степном ветру, как лопались его баллоны и приходилось ездить за 400 км через горы в Абакан, чтобы добыть гелий для их наполнения. Однако несмотря на все это, Дима и Ира Рукавишниковы выполнили свою задачу - в этот сезон были получены первые низковысотные снимки курганных полей тувинской «долины царей» (Рукавишникова, Рукавишников, 2013).

Так совпало, что в этом же году мы подружились и с Владимиром Митрохиным, парапланеристом из Турана, который с энтузиазмом включился в нашу работу. Наблюдая за работой с дирижаблем, он понял важность и информативность фотосъемки археологических объектов с воздуха. Именно благодаря его съемке,

Рис. 1а. Дмитрий и Ирина Рукавишниковы в «долине царей» с шофером Южно-Сибирской экспедиции Гос. Эрмитажа Анатолием Лубошниковым. Фото В.И. Никифорова, 2012 г.

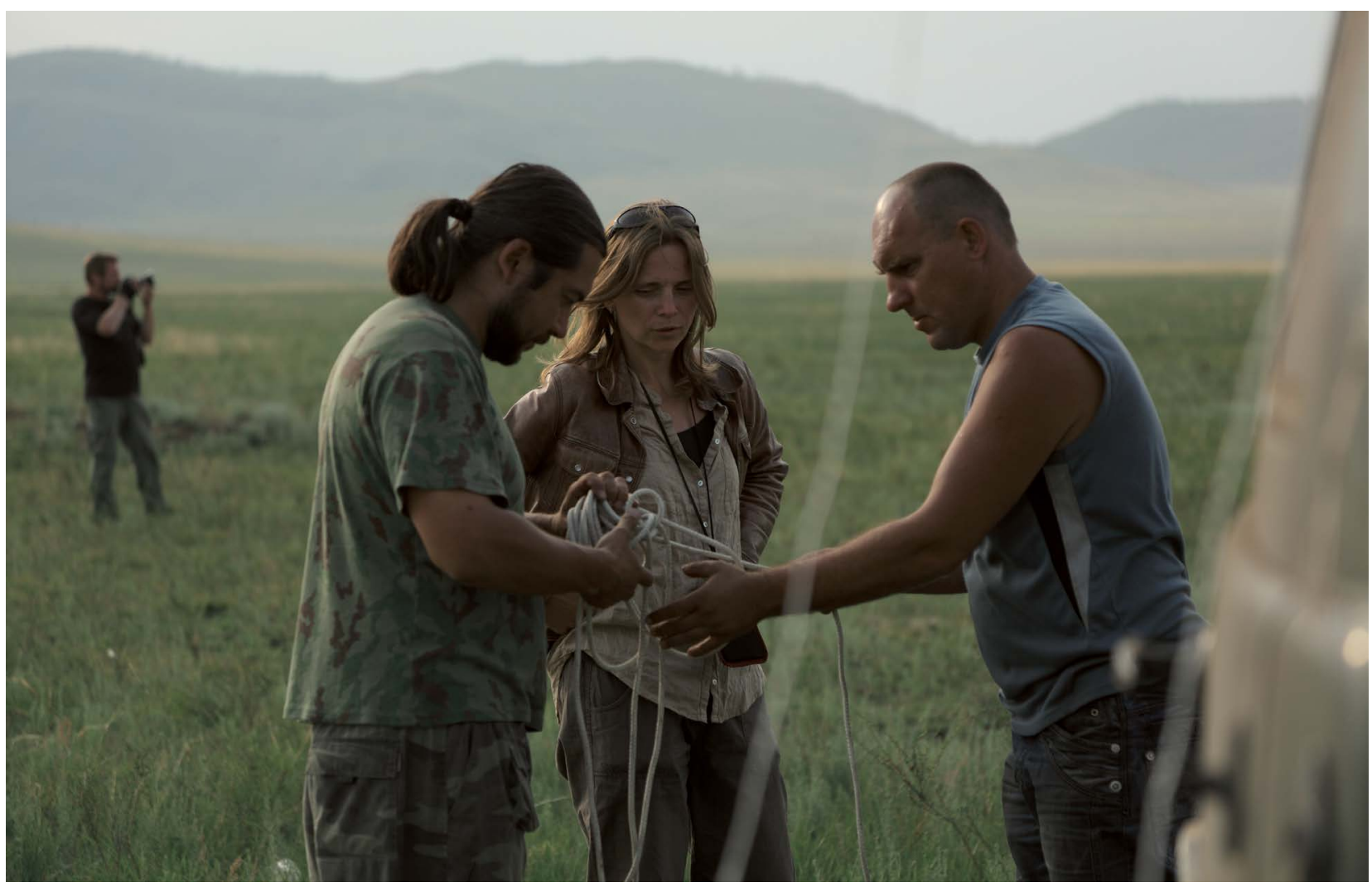


сделанной с мотопараплана, мы впервые увидели сверху Туннуг - огромный курган в пойме p. Уюк, где сейчас проводит раскопки экспедиция ИИМК РАН совместно с РГО. Фотография этого памятника в утренних лучах солнца неожиданно показала радиальную внутреннюю структуру, проявившуюся благодаря косому свету и теням в неровностях его разрушенной поверхности (рис. 2). Я помню, как мы обсуждали это с Димой, сидя перед компьютером в нашей юрте на берегу Уюка. Помогли понять суть этого феномена снимки с воздуха местоположения знаменитого кургана Аржан-1 (рис. 3).

Известно, что нижний уровень деревянных клетей, радиально построенных вокруг центрального сруба, после окончания исследований в середине 1970-х гг. был засыпан отвалом. Выяснилось, что на фотографиях сверху в косом свете очертания этих конструкций хорошо заметны. Очевидно такой эффект можно объяснить тем, что после удаления в результате раскопок (или разрушения) каменного наземного сооружения деревянные конструкции, сохранявшие свой объем до этого, стали быстро деградировать и проседать. В результате на поверхности образовались ложбины, которые при соответствующем освещении хорошо заметны сверху.

Именно такая картина была отмечена на снимках с воздуха разрушенного кургана Аржан-5 (рис. 4), раскопки которого были начаты экспедицией ИА РАН под руководством И.В. Рукавишниковой в 2014 г. (Рукавишникова, 2015. С. 92). Исследования этого интереснейшего памятника проводились в течение трех полевых сезонов и, хотя еще не закончены, дали чрезвычайно интересные материалы. Их публикации (Рукавишникова, Гладченков 2016;

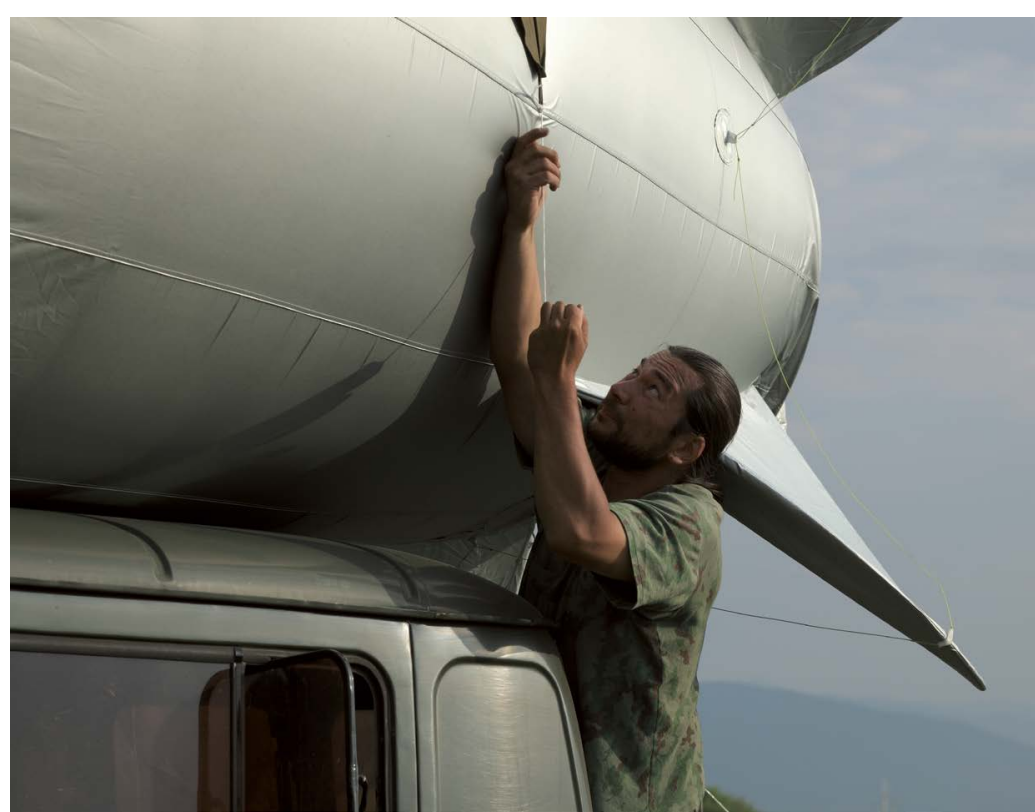

Рис. 1б. Д. Рукавишников готовит дирижабль к транспортировке в лагерь. Фото В.И. Никифорова, 2012 г.

Рис. 1в. Перегон Москва - Тува закончен, дирижабль к работе готов

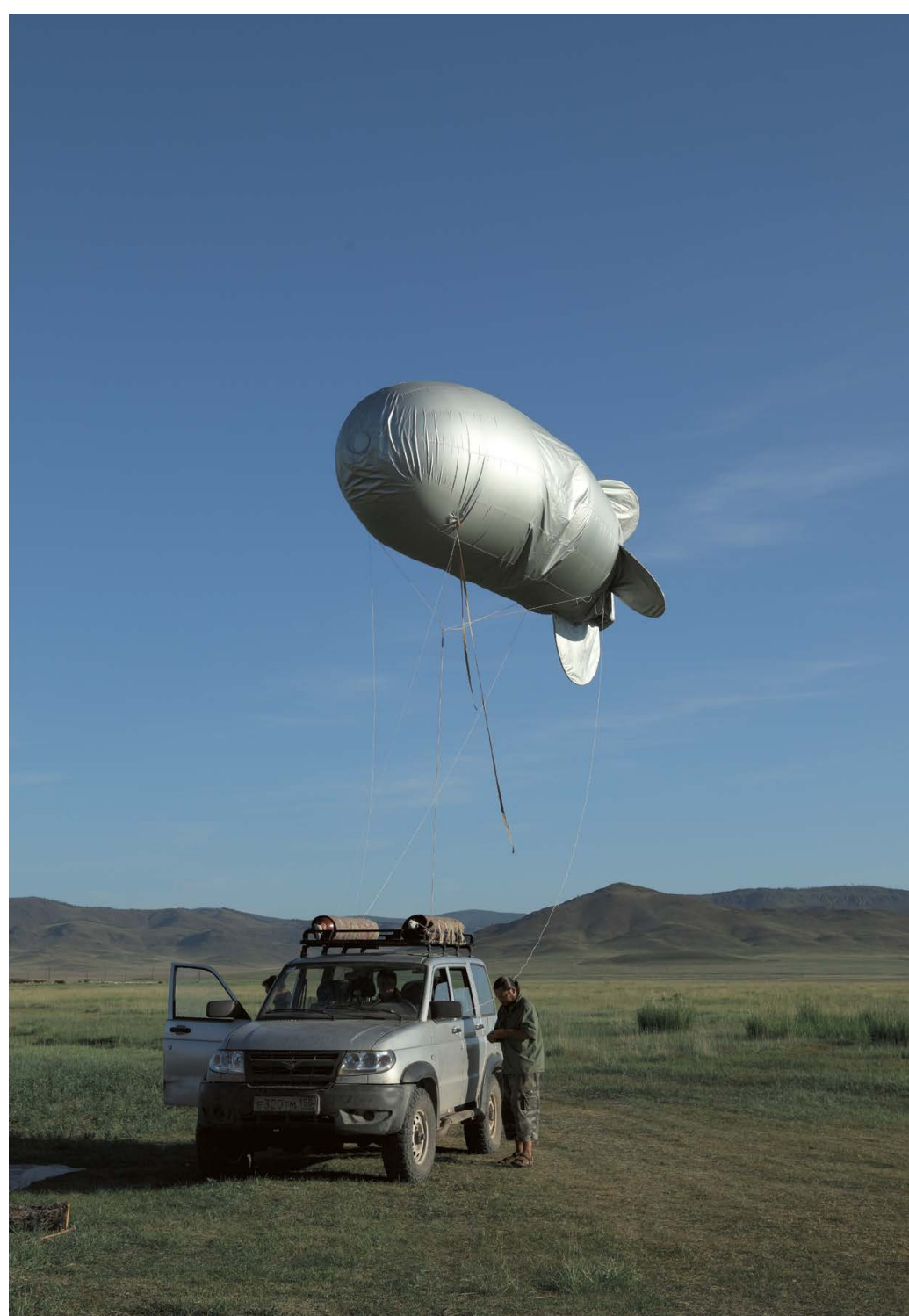


Рукавишникова 2017) позволяют высказать некоторые соображения, часть из которых уже была озвучена в ходе дискуссии на семинаре «Звериный стиль сквозь века», проходившем в Москве в декабре 2016 г., когда я последний раз (кто бы мог об этом тогда подумать!) кратко встретился с Димой Рукавишниковым.

Наземное сооружение кургана Аржан-5 было почти полностью разобрано, вероятно, еще в 50-е или 60-е годы XX в., когда в пос. Аржаан шло активное строительство хозяйственных построек образованного здесь совхоза Уюк. Я предполагаю, что именно

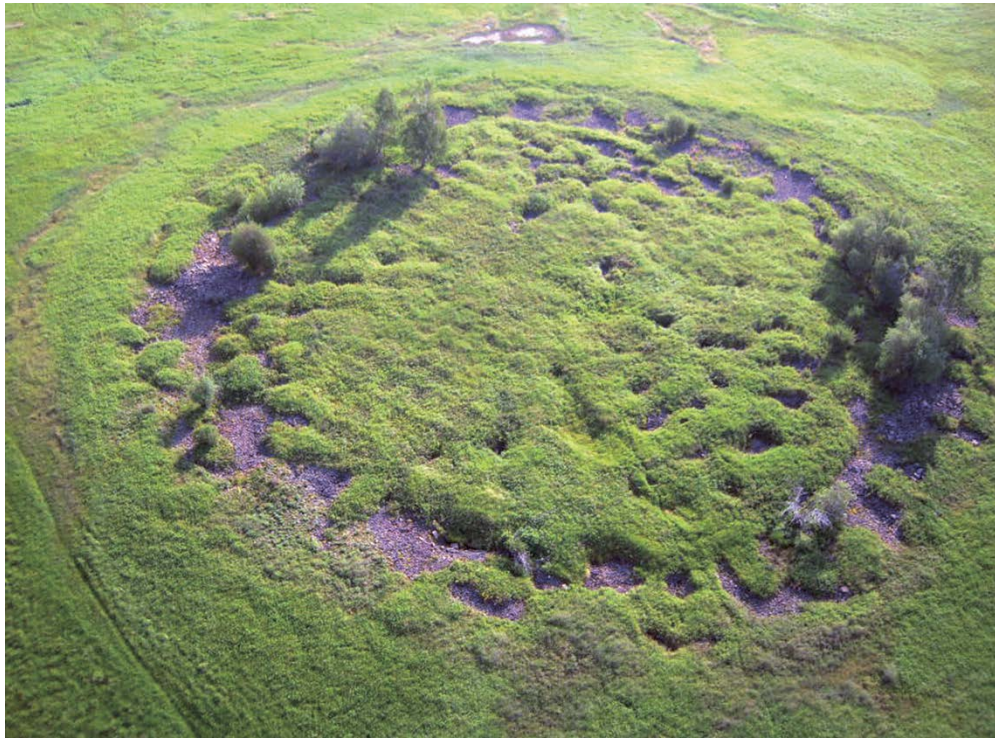

Рис. 2. Курган Туннуг. Фото В. Митрохина, 2012 г.

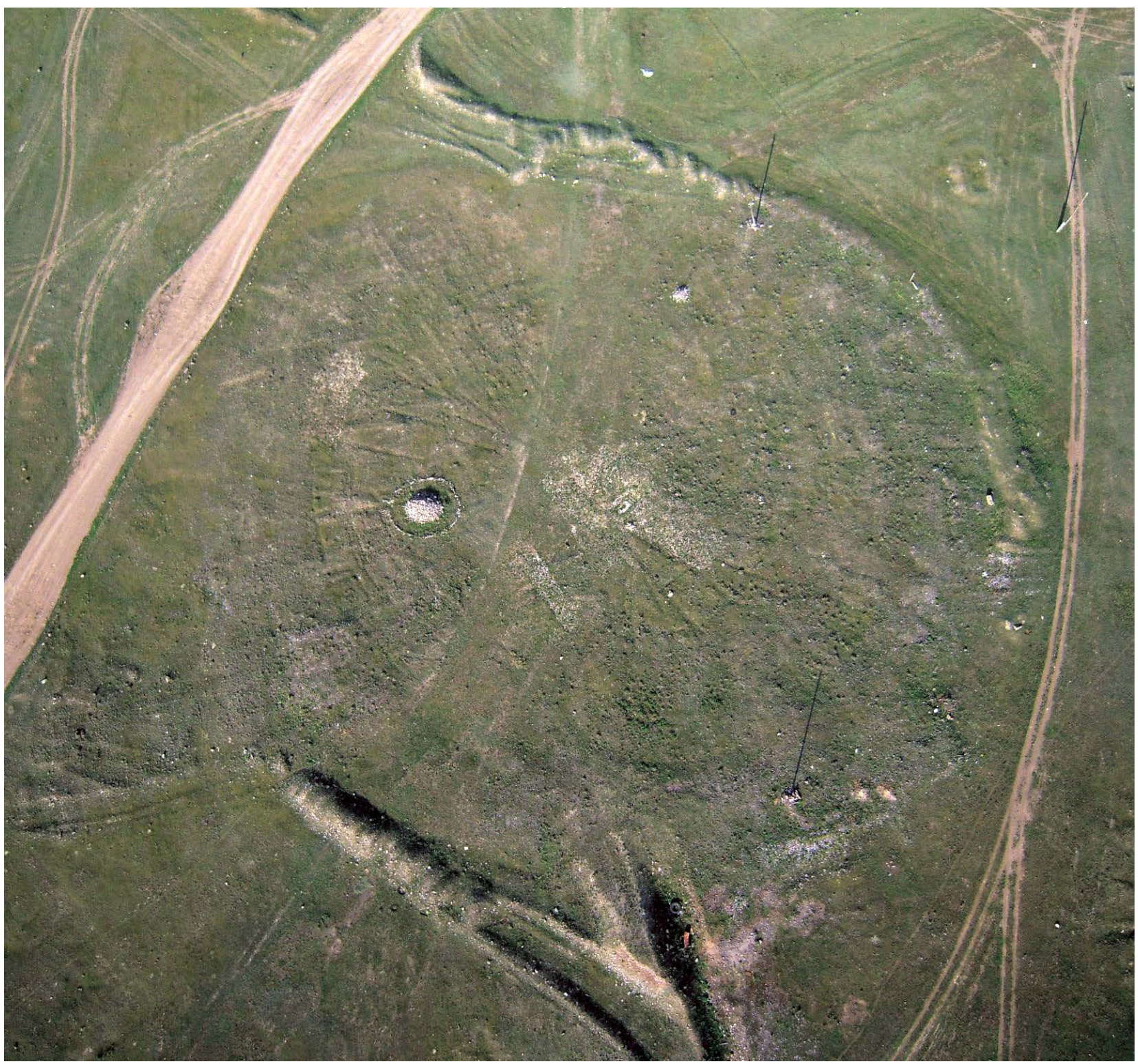

Рис. 3. Курган Аржан-1. Фото В. Митрохина, 2012 г. 
об этом памятнике шла речь, когда М.П. Грязнову рассказывали про бревна, которые видели бульдозеристы в процессе добычи камня (Грязнов, 1980. С. 5). Когда Михаил Петрович записал эти сведения, с момента разрушения прошло уже более 10 лет, курган практически не был заметен в степи, а сами разрушители уже не помнили его место. Скорей всего местные жители случайно указали ученому на Аржан-2, который тоже был к тому времени сильно поврежден при добыче камня. Как известно, дальнейшие исследования не подтвердили наличие здесь наземных деревянных конструкций.

Сплошная распашка уничтожила почти все сопроводительные конструкции вокруг Аржана-5, а расположение памятника в стороне от курганных «цепочек» способствовало тому, что он долгое время оставался незамеченным специалистами-археологами, посещавшими долину.

Впервые Аржан-5 был осмотрен и зафиксирован А.Г. Акуловым в 2009 г., проводившим работу по составлению генерального плана могильных полей в рамках исследований ЮжноСибирской экспедиции Государственного Эрмитажа и Тувинской экспедиции ИИМК РАН. Свежие воронки свидетельствовали, что остатки наземного сооружения памятника время от времени продолжали использоваться для добычи камней, поэтому решение о его раскопках, принятое Ириной и Дмитрием Рукавишниковыми, было совершенно оправдано. Несмотря на риск, связанный с отсутствием гарантированного финансирования, экспедиция ИА РАН приступила к этой работе, предварительно проведя геофизические исследования. Первые результаты

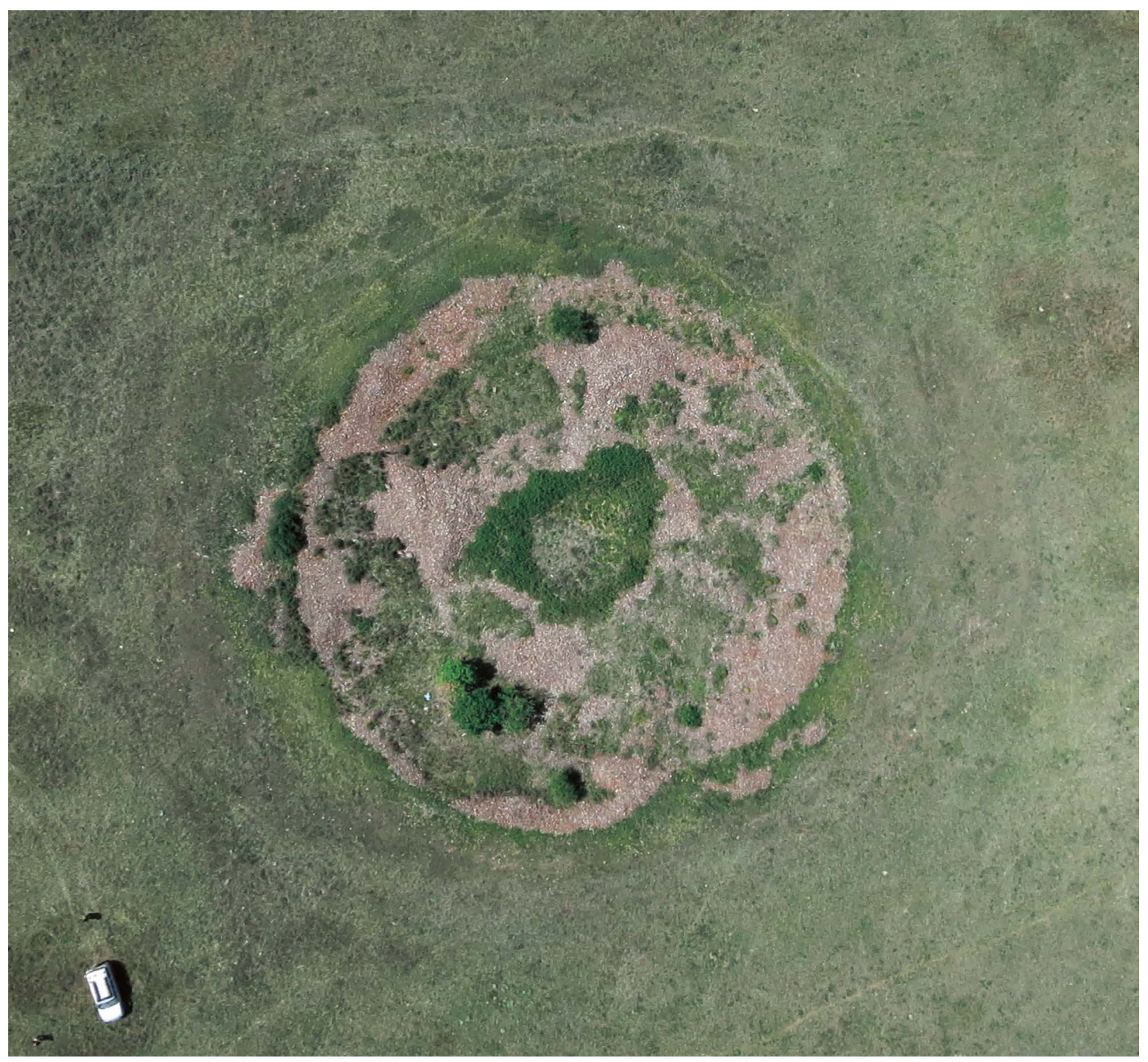

Рис. 4. Курган Аржан-5 до раскопок. Фото Д. В. Рукавишникова, 2012 г., предоставлено И. В. Рукавишниковой 
освещены в указанных выше публикациях, и уже сейчас можно сказать о чрезвычайно большом значении материалов Аржана-5 для понимания культурноисторических процессов в Центральной Азии в начале I тыс. до н. э.

Основным результатом можно считать то, что впервые был открыт памятник, который по всем компонентам погребального обряда полностью соответствует кургану Аржан-1. Материалы последнего, имеющие многочисленные соответствия в предскифском пласте древностей Восточной Европы, с одной стороны демонстрировали начало эпохи ранних кочевников в Туве как минимум на полтора столетия ранее, чем в западных регионах «скифского мира», с другой - его уникальность долгое время затрудняла его оценку внутри региона, так как культурный контекст «царского» мемориала был неясен.

Дискуссии, которые развернулись после раскопок Аржана-1, общеизвестны. В основном они касались хронологической позиции комплекса и не прекратились даже после проведенного радиоуглеродного датирования большой серии образцов. Все попытки связать с аржанским горизонтом другие памятники в той или иной степени уязвимы, так как в них отсутствует полный набор компонентов, представленный в Аржане-1. Например, курганы шанчигского типа тесно связаны с монгун-тайгинской культурой и соотносятся с Аржаном-1 только по сильно скорченной погребальной позе и устройству захоронения на уровне дневной поверхности. Единичные комплексы, включающие погребения с конем на горизонте (Баданка IV, к. 17; Догээ-Баары II, к 40), не сохранили (или не имели изначально?) изделия, выполненные в зверином стиле и, по мнению их исследователей, могут относиться ко времени, предшествующему элитному мемориалу (Боковенко, 1995. С. 89; Кисель, 2015. С. 65).

Курган Аржан-5 демонстрирует все главные составляющие погребального обряда и вещевого комплекса Аржана-1 и по праву может занять место рядом с ним. Дальнейшие исследования, направленные на изучение устройства наземного сооружения этого памятника, несомненно, должны пролить свет на многие вопросы, не выясненные при раскопках в начале 1970-х гг. В частности, выявленная сохранность кромлеха Аржана-5 позволяет надеяться, что можно,

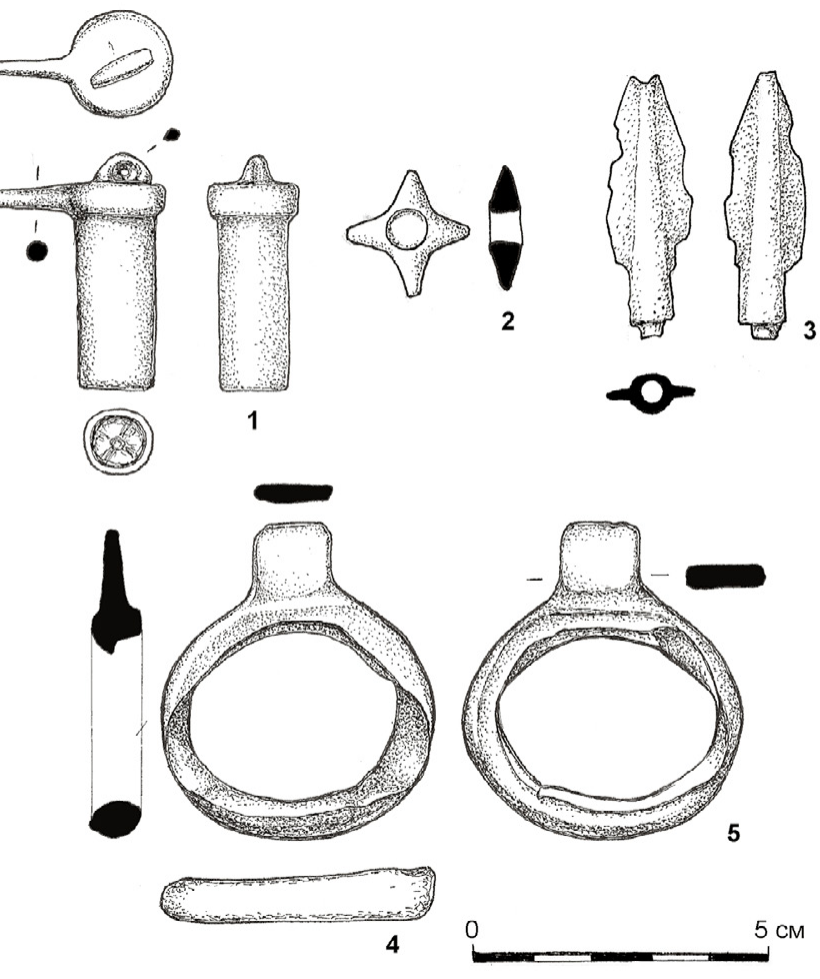

Рис. 5. Курган Аржан-5: некоторые находки. Оригиналы рисунков И. В. Рукавишниковой предоставлены автором

наконец, установить последовательность постройки наземного сооружения и, вполне вероятно, некоторую продолжительность функционирования памятников аржанского типа, как это удалось сделать при исследовании Аржана-2 (Чугунов, 2011a) и прослеживается при раскопках Чинге-Тэя I (Чугунов, 2011б). Перспективным представляется и продолжение анализа уже полученных материалов - изотопное изучение костных остатков, палеогенетические исследования костей людей и лошадей и т. п. Будем надеяться, что все это произойдет в скором будущем, а здесь мне хотелось бы лишь кратко обратить внимание на некоторые уже сделанные находки.

Как следует из описания авторов раскопок (Рукавишникова, Гладченков, 2016. С. 56), центр кургана был сильно ограблен еще в древности, но некоторые предметы все же сохранились. Изделия, выполненные в зверином стиле, уже были проанализированы и справедливо сопоставлены с зооморфным искусством Аржана-1 (Рукавишникова, 2017). Другие находки пока не привлекли внимания специалистов, однако именно они, на мой взгляд, указывают на то, что традиции населения, оставившего Аржан-5, уходят своими корнями в предшествующую эпоху.

Уникальна находка небольшого бронзового навершия (рис. 5: 1), котороеИ. В. Рукавишникова 
трактует, как наконечник плети (Рукавишникова, 2017. С. 170. Рис. 2: 6). Предмет выполнен в виде втулки, закрытой с одной стороны округлой шляпкой с выступающими краями и петлей сверху. От шляпки под прямым углом отходит в сторону шип, равный по длине ее диаметру. Последняя особенность заставляет предположить, что такое изделие могло использоваться как стрекало или стимул (от латинского stimulus, букв. «заостренная палка»). Петля в верхней части - так же уникальна для наконечников плетей из комплексов раннескифского времени, которые обычно имеют петли для кнутовища сбоку. Аналогии такой морфологической особенности можно найти далеко на западе, в комплексах предскифского времени Восточной Европы, где известны роговые рукояти плетей или их детали (Дубовская, 1997. С. 57-60. Рис. 1: 1-5, 10, 11). Показательно, что некоторые восточноевропейские изделия имеют на конце металлическое острие и могли также иметь дополнительную функцию стрекала или стимула (Дубовская, 1997. C. 59).

Стрекало едва ли использовалось при верховой езде, для которой применялась плеть. Оно, по сути, является аналогом плети, но использовалось для стимулирования тягловых упряжных животных. Палки с острым, загнутым вбок окончанием часто изображались на изваяниях чемурчекской культуры эпохи бронзы (Ковалев, 2012. C. 14, 36, 72, 108, 117), причем иногда рядом с фигурами быков (рис. 6). Само по себе

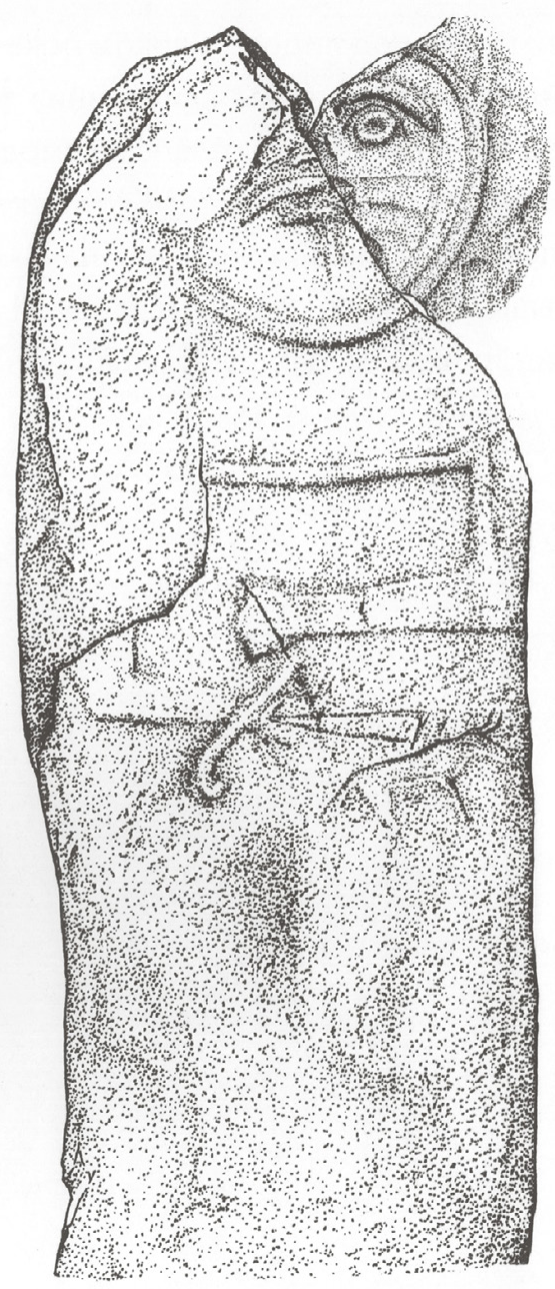

Рис. 6. Изваяние чемурчекской культуры. Комплекс Кайнар 1, статуя № 3 (по: Ковалев, 2012)
Возможно, что стрекала применялись для стимулирования колесничных упряжек, которые, несомненно, еще использовались (возможно, уже только в церемониальных целях) в ранних кочевых обществах. На связь этих атрибутов с колесницами прямо указывает стрекало, украшенное золотыми накладками и нефритовыми наконечниками, найденное в Аньяне, в могиле 164 Сяотуня (рис. 7). Показательно, что здесь оно обнаружено в комплексе с чрезвычайно архаичным снаряжением коня (рис. 8), зафиксированном прямо на черепе лошади и больше напоминающем приспособление для управления быком (King Wu Ding, Lady Hao, 2011. P. 196, 200).

Присутствие колесничных упряжных лошадей предполагается в Аржане-1 (Савинов, 2002. С. 65), и, возможно, что в Аржане-5 тоже была захоронена колесница. Не исключено, что деталями колесничной упряжи являются найденные в Аржане-5 бронзовые пряжки в виде кольца с плоским выступом-язычком (рис. 5: 4, 5). Изделия подобной конструкции известны в камере 26 Аржана-1, найденные там вместе с навершиями (Грязнов, 1980. С. 27. Рис. 23: 4). Уже указывалось, что изделия такого типа происходят из памятников эпохи поздней бронзы (Чугунов, 2015. С. 472. Ил. 4). Они найдены в одном из мавзолеев Северного Тагискена (Итина, Яблонский, 2001. С. 288. Рис. 123) и в поселении Кент (Варфоломеев, 2011. С. 218. Рис. 19).

Подкрепляет предположеприсутствие этого атрибута на стелах говорит о его высокой значимости и символизме в культуре первых скотоводов. Можно предположить, что в начальный период освоения лошади под верховую езду функции стрекала (в том числе символические) были перенесены на плеть. Не случайно, согласно Авесте, первый царь ариев Йима получил от Ахура-Мазды два орудия для расширения земли, одним из которых была плеть, украшенная золотом (Авеста..., 1997). ние о связи этих предметов с колесницами то, что далеко на западе пряжки в виде кольца с боковым выступом найдены in situ рядом со скелетами четырех жеребцов среди фурнитуры их упряжки в кургане 6 Краснознаменского могильника (Петренко, 2006. С. 69-71. Табл. 61: 180; 63: 195; 124: 2). В.Г. Петренко реконструирует их использование для закрепления ярма скифской церемониальной колесницы (Петренко, 2006. С. 79, 80). В.Р. Эрлих считает такой тип 
пряжек одним из индикаторов колесничной упряжи и связывает их с ремнями постромков пристяжных лошадей (Эрлих, 1994. С. 47. Табл. 9: 5-7). Высказано предположение, что такой тип пряжек появляется в Закавказье из Ирана в самом начале I тыс. до н.э. (Есаян, Погребова, 1985. С. 116-121). По-видимому, поскольку восточные аналогии при анализе предкавказских и закавказских находок не использовались, то вопрос генезиса этой категории конского снаряжения требует дальнейшего рассмотрения. Здесь важно отметить, что между востоком и западом степного мира наметилась еще

Рис. 7. Детали стрекала. Могила 164, Сяотунь, Аньян. Провинция Хэнань, КHР (по: King Wu Ding, Lady Hao, 2011) одна линия связей. Так же, как это произошло при анализе материалов Аржана-1, она уводит нас в древности, предшествующие по времени сложению культур скифского типа в степях Евразии.

Среди находок в Аржане-5 интересен и необычен маленький предмет, не имеющий прямых аналогий. Это небольшая бронзовая пронизь в виде ромба с вогнутыми сторонами и приостренными окончаниями четырех «лучей», отходящих от круглого отверстия в центре (рис. 5: 2). Функционально такой предмет мог быть закреплен на любом тонком ремешке где угодно. В качестве варианта его назначения можно предположить, что он был использован в качестве утяжелителя кнутовища плети (в том случае, если рассмотренное выше навершие было надето на предмет, совмещающий функции стрекала и плети, как на западе). Так это или нет - не столь важно, но по своим очертаниям эта пронизь ассоциируется с солярными знаками окуневской изобразительной традиции эпохи бронзы. Возможно, здесь мы имеем подтверждение того, что окуневский солярный знак сохра-

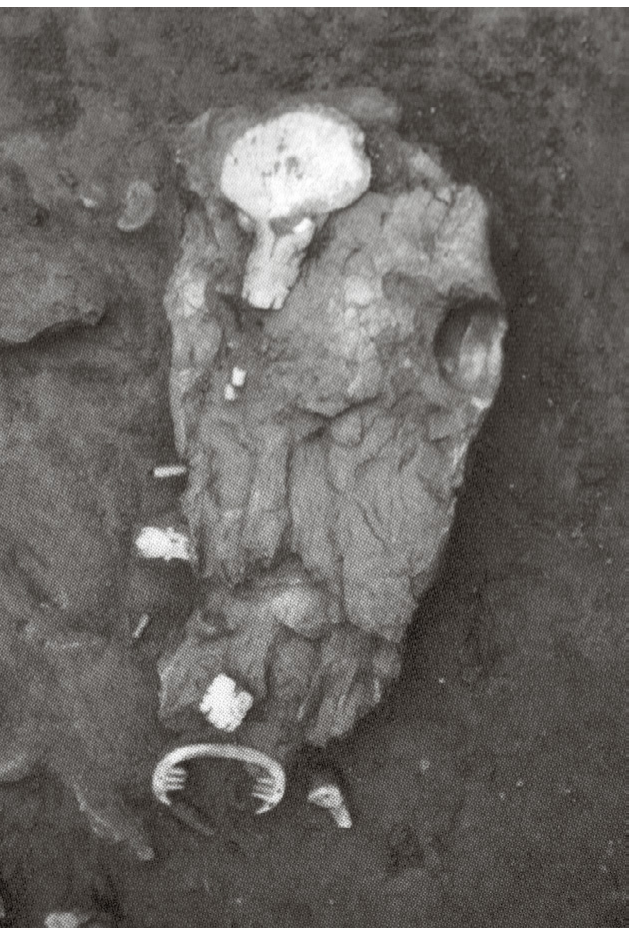

Рис. 8. Череп лошади in situ. Могила 164, Сяотунь, Аньян. Провинция Хэнань, KHP (по: King Wu Ding, Lady Hao, 2011) так называемых киммерийских ромбовидных знаков с окуневской символикой указывала Т.В. Рябкова, показавшая их развитие в предскифской и раннескифской культурной среде (Рябкова, 2008; 2010. Рис. 1).

Как видим, в предметном комплексе Аржана-5 большинство находок восходит к традициям предшествующей эпохи, и аналогии им обнаруживаются на территориях к западу от Тувы. Единственный бронзовый двухлопастной втульчатый наконечник стрелы (рис. 5: 3) также типологически соответствует стрелковому набору, характерному для рубежа II-I тыс. до н. э. На это указывает такой признак, как максимальное расширение листовидных лопастей в нижней части и доходящая до острия нервюра втулки. Интересно, что в наборе стрел Аржана-1 нет ни одного такого экземпляра. Конечно, на основании единичной находки, обусловленной случайностью выборки в ограбленном памятнике, какие-либо выводы делать невозможно. Бунялся у населения Центральной Азии на всем протяжении времени, отделяющем эту культуру от начала эпохи ранних кочевников. На связь дем ждать завершения исследований памятника, который, несомненно, подарит новые открытия и дискуссии. 


\section{Литература}

Авеста в русских переводах (1861-1996) / Ред. И.В. Рак. Санкт-Петербург, 1997.

Боковенко Н. А. Новый памятник аржанского этапа в центре Азии // Южная Сибирь в древности. Санкт-Петербург, 1995 (Археологические изыскания № 24). С. 85-90.

Варфоломеев В. В. Бегазы-дандыбаевская культура степей Центральной Евразии // Археология Казахстана в эпоху независимости: итоги, перспективы. Т. 1. Алматы, 2011. С. 210-240.

Грязнов М.П. Аржан. Царский курган раннескифского времени. Ленинград, 1980.

Дубовская О.Р. Плеть как возможный атрибут предскифских погребений // Памятники предскифского и скифского времени на юге Восточной Европы. Москва, 1997 (Материалы и исследования по археологии России; № 1). С. 57-61.

Есаян С.А., Погребова М.Н. Скифские памятники Закавказья. Москва, 1985.

Итина М.А., Яблонский Л. Т. Мавзолеи Северного Тагискена. Поздний бронзовый век Нижней Сырдарьи. Москва, 2001.

Кисель B. А. Начало кочевнической культуры в Центре Азии // Археологический сб. Гос. Эрмитажа. Вып. 40. СанктПетербург, 2015. С. 54-67.

Ковалев А. А. Древнейшие статуи Чемурчека и прилегающих территорий. Санкт-Петербург, 2012.

Петренко В.Г. Краснознаменский могильник. Элитные курганы раннескифской эпохи на Северном Кавказе. Москва; Берлин; Бордо, 2006.

Рукавишникова И. В. Исследования разрушенного кургана Аржан-5 - памятника начала эпохи ранних кочевников в Туве (архитектура, результаты применения естественно-научных методов, перспективы дальнейших работ) // Ранний железный век от архаики до рубежа эр. Центры периферии и модели культурных взаимодействий: материалы конф. Санкт-Петребург, 2015. С. 92-94.

Рукавишникова И. В. Звериный стиль Аржана-5 (комплексный подход в изучении предметов, декорированных в зверином стиле) // КСИА. 2017. Вып. 247. С. 163-175.

Рукавишникова И. В., Гладченков А. А. Исследования Аржана-5 в Турано-Уюкской котловине // КСИА. 2016. Вып. 243. C. $50-59$.

Рукавишникова И. В., Рукавишников Д. В. Методика аэрофотосъемки курганных могильников в Долине царей Тувы // Международная научно-практическая конференция «Историко-культурное наследие народов Центральной Азии: перспективы развития и проблемы сохранения» (14-15 сентября 2012 г., г. Кызыл). Кызыл, 2013. С. 59-60.

Рябкова Т. В. Ромбические знаки на предметах раннескифского времени» // Отражение цивилизационных процессов в археологических культурах Северного Кавказа и сопредельных территорий (Юбилейные XXV «Крупновские» чтения по археологии Северного Кавказа). Владикавказ, 2008. С. 324-327.

Рябкова Т.В. Классификация изображений с ромбовидными знаками на предметах предскифского и раннескифского времени // Проблемы хронологии и переодизации археологических памятников и культур Северного Кавказа (XXVI «Крупновские» чтения по археологии Северного Кавказа). Магас, 2010. С. 309-312.

Савинов Д.Г. Ранние кочевники Верхнего Енисея (археологические культуры и культурогенез). Санкт-Птербург, 2002.

Чугунов К. В. Аржан-2: реконструкция этапов функционирования погребально-поминального комплекса и некоторые вопросы его хронологии // Российский археологический ежегодник. № 1. Санкт-Петербург, 2011а. С. $262-335$.

Чугунов К. В. Дискретность постройки «царских» мемориалов Тувы и хронология раннескифского времени // Тerra Scythica: материалы междунар. симпозиума. Новосибирск, 2011б. С. 358-369.

Чугунов К. В. Формирование культур ранних кочевников в Казахстане и Саяно-Алтае (к постановке проблемы) // Археология без границ: коллекции, проблемы, исследования, гипотезы. Санкт-Петербург, 2015 (Труды Гос. Эрмитажа; т. 77). С. $457-486$.

Эрлих В.Р. У истоков раннескифского комплекса. Москва, 1994.

King Wu Ding, Lady Hao. Art and Culture of the Late Shang Dinasty. Exhibition Catalog. National Palace Museum. Beijing, 2011. 


\section{ГЕОРАДАРНЫЕ ИССЛЕДОВАНИЯ КРЕПОСТИ УЗУНДАРА}

\section{Н. Д. Двуреченская, О.В.Двуреченский, \\ П. А. Морозов, А. А. Гладченков}

До начала работ на высокогорной крепости Узундара Бактрийским отрядом Среднеазиатской археологической экспедиции Института археологии РАН (в дальнейшем САЭ) был пройден немалый путь в девять лет полевых исследований на юге Узбекистана. Работая совместно с коллегами из Института искусствознания $\mathrm{AH}$ РУз, а также Музея Востока (Россия) под эгидой бессменного руководителя Тохаристанской археологической экспедиции (в дальнейшем ТАЭ) Эдварда Васильевича Ртвеладзе, мы знакомились и проникали в тонкости эллинистической культуры Бактрии на примере богатых археологических материалов раннеантичной крепости Кампыртепа. Этот великолепный памятник, расположенный на краю древнего Окса, был открыт в 1972 г. Э.В. Ртвеладзе. Благодаря широте взглядов первооткрывателя памятник стал кузницей для профессионального роста многих археологов из разных стран мира. Работая на эллинистических объектах Кампыртепа, мы получили важные данные по материальной культуре региона, но для объективации картины и выхода на более широкие исторические обобщения требовалось расширение источниковой базы. Э. В. Ртвеладзе, который в свое время маршрутными разведками обследовал весь юг Узбекистана и прекрасно владел исторической топографией всей Сурхандарьи, понимал эту необходимость как никто другой и предложил попробовать нам свои силы на найденной им в 1991 г. крепости Узундара, расположенной высоко в горах Байсуна.

Необходимость выхода на новый памятник и качественно новые и более развернутые работы обсуждалась и нашим Бактрийским отрядом. Совместно с О.В. Двуреченским, А. В. и В.З. Ильяевыми мы готовили материально-техническую базу для работ в горах и в первую очередь решали вопрос с автотранспортом, который смог бы выдержать нагрузки непростого бездорожья в горах и постоянную работу под большим весом. Живое участие в разработке наших планов и обосновании необходимости разворачивания более широких археологических исследований, как раскопок, так и разведок на юге Узбекистана, включая Пашхуртскую котловину, приняли Д.В. и И.В. Рукавишниковы. Вместе мы анализировали условия, необходимые для предстоящего рывка. Дима и Ирина планировали провести серию разведок и выбрать объекты для дальнейших стационарных исследований. После первого знакомства с Сурхандарьей весной 2013 г. было решено создать отдельный Пашхурдский отряд с двумя объектами для археологических раскопок. Так, на открытом Бактрийским отрядом весной 2013 г. памятнике эпохи бронзы Газ-кала планировала вести раскопки Ирина. На раннеантичном поселении Гишттепа должен был возобновить археологические исследования В.В. Мокробородов под руководством Н. Д. Двуреченской. Финансирование обоих объектов практически полностью ложилось на чету Рукавишниковых. Помимо расширения полевых исследований одна из важнейших задач, которые мы ставили перед собой, - необходимость возрождения среднеазиатской археологической школы с привлечением как российской, так и узбекистанской молодежи, нехватка которой уже давно и остро ощущалась. Для этого планировались самые разные совместные узбекско-российские мероприятия от выставок и популяризации результатов археологических работ до всесторонней поддержки конкретных ребят, планирующих стать среднеазиатскими археологами.

Вовлекаясь в дело, Д.В. Рукавишников, как показывает весь его жизненный путь, вкладывался максимально всеми своими силами, несмотря на предсказуемые риски. Первого мая 2013 г., после череды неурядиц и аварии, мы совершили первый подъем на вершину горы Сусизтаг, где и располагалась крепость Узундара. Дорога, на которой любая техника идет на пределе возможностей, после весенних селей представляла собой вполне обозримую опасность. Дима Рукавишников оказал неоценимую помощь при 
подъеме как опытный водитель и знаток УАЗов 469. Достаточно сказать, что с высоты 1700 м он спускал нас на машине без сцепления, на одних тормозах. Этот подъем, несмотря на краткосрочность, показал весь объем и сложность задачи по разворачиванию раскопок на крепости Узундара, необходимость подбора команды из людей, способных выдержать большие нагрузки.

В осенний сезон полевых исследований 2013 г. на крепости Узундара было установлено, что памятник относится к эпохе эллинизма, не перекрыт поздними наслоениями и доступен для работ на широкой площади. Сохранность каменной архитектуры позволяет выявить не только основную планировку, но и предварительно визуализировать в реконструкции основные фортификационные узлы по топографическому плану (Ртвеладзе, Двуреченская, 2015). Необходимость разворачивания здесь стационарных раскопок стала совершенно очевидной. И уже весной 2014 г. на своей машине УАЗ-патриот с грузом оборудования и несколькими участниками экспедиции Д. В Рукавишников выехал из Москвы более чем за 4000 км в помощь нашему Бактрийскому отряду. К работам на Узундаре он сумел привлечь своих друзей, специалистов в разных сферах наук. Физик П.А. Морозов провел на памятнике георадарную разведку на совершенно альтруистических началах. Археолог и художник А.А. Гладченков был основным помощником по проведению георадарной разведки и впоследствии влился в Бактрийский отряд и ведет раскопки на разных объектах Узундары.

Надо понимать, что временные возможности Димы были очень ограничены, ведь он давно уже не работал в Институте археологии и тратил на экспедиции свое отпускное время, тем более что параллельно он был включен в работы в Туве, а также Монголии. И, тем не менее, все намеченные планы выполнялись. Пашхурдский отряд провел маршрутные разведки и опубликовал их результаты (Двуреченская и др., 2014). На Газ-кале были проведены рекогносцировочные работы, их результаты также опубликованы (Рукавишникова и др., 2015).

В весенний сезон следующего 2015 г. Ирина и Дима Рукавишниковы вновь приезжают на своей машине из Москвы в Сурхандарью и за семь полных световых дней снимают тахеометрический план всей крепости Узундара и близлежащих участков (более $900 \times 800 \mathrm{M}$ ), а это тысячи точек на площади около 2 га при рельефе с перепадом высот более 80 м (Двуреченская, 2018. Рис. 3).
Самоотверженность, при внешней невозмутимости и спокойствии, проглядывалась во многих поступках Димы. Он торопился жить, был скор на подъем, и его необычайно манила красота. Он успел побывать, а главное поработать, вложиться всеми своими силами и знанием во многие места с прекрасной и богатой историей от Сирии и Египта до Монголии и Тувы, ну и, конечно, до благословенной Сурхандарьи. Первые самые трудные шаги в закладке принципа комплексных археологических исследований на крепости Узундара были осуществлены при его широкой и разносторонней поддержке.

Памяти нашего друга Димы Рукавишникова посвящаем переработанную и дополненную статью по сравнительному анализу итогов проведенных в 2014 г. георадарных исследований с результатами археологических раскопок на крепости Узундара 2018 г.

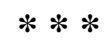

Как упомянуто выше, открытая академиком Э.В. Ртвеладзе в 1991 г. крепость Узундара, находящаяся на северных границах древней Бактрии (Ртвеладзе, 2001; 2002. С. 97, 98, 100, 104), в силу своего высокогорного расположения не исследовалась археологами до 2013 г. После полученных Бактрийским отрядом САЭ ИА РАН совместно с сотрудниками ТАЭ результатов рекогносцировочных работ и археологических разведок о преимущественно эллинистическом времени функционирования этой крепости было принято решение о разворачивании комплексных стационарных исследований на этом уникальном памятнике с каменной архитектурой (Двуреченская, 2015).

Весной 2014 г. помимо закладки трех археологических раскопов на крепости Узундара был проведен цикл георадарных исследований при помощи прибора «ЛОЗА». Среднечастотный импульсный георадар «ЛОЗА-1В» работает в полосе частот 50-300 МГц и обладает потенциалом около 120 дб. Это позволяет зондировать грунт в средних условиях до глубин 10 м и в легких грунтах до глубин 15-20 м.

Отличительная особенность приборов серии «ЛОЗА» по сравнению с известными зарубежными и отечественными аналогами - большой энергетический потенциал, позволяющий работать в средах с высокой проводимостью. С целью достижения высоких энергетических показателей была полностью пересмотрена классическая схема построения радара. Так, 
импульсная мощность передатчика была увеличена более чем в 10000 раз, а стробоскопическое преобразование заменено прямой регистрацией сигнала, без преобразования его в область низких частот. В качестве антенн (или их основных излучающих элементов), в георадарах серии «ЛОЗА» используются резистивно-нагруженные диполи. Это гарантирует отсутствие в принимаемом сигнале «звона». Новые возможности георадаров существенно расширили границы их применения в археологии (Копейкин и др., 2011; Fantusati et al., 2012).

В течение четырех дней исследований георадаром «ЛОЗА» было отсканировано 26 профилей на разных участках памятника: 13 - на крепостных стенах, 3 - на башнях, 4 - на внутренней площадке крепости и 6 - с цитадели (рис. 1).

Полученные серии профилей георадара можно сопоставить с данными трех археологических раскопов. Раскоп I расположен в юго-восточном углу основного четырехугольника крепости. Он представляет собой ориентированный по сторонам света прямоугольник размерами $8 \times 10$ м. В 2 м к югу от южного борта раскопа I, параллельно ему был отсканирован профиль 26. Протяженность профиля - 13 м, направление - с запада на восток (рис. 2). Радар показал резкое падение скального основания в восточном направлении (более 1 м на протяжении 6 м).

Раскоп I весной 2015 г. в квадратах 3, 4, 7, 8 был доведен до материка. Стратиграфия бровки и открытая параллельно идущая стена показали также резкое падение скального материка, на 3,5 м - более 0,5 м, полностью подтвердив данные георадиолокационной съемки (рис. 2).

Раскоп II расположен на участке западной крепостной стены у юго-западной башни. Здесь стену прорезает современная дорога, пробитая в советский период. Используя существующий разрез стены, была проведена зачистка торца и вскрытие стены с внешнего фаса на 3 м, с внутреннего фаса на 10 м плюс примыкающий

\section{Крепость УЗУНДАРА}

(топографический план Г.П.Иванова)

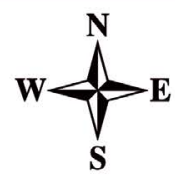

условные обозначения:

- место и направление георадарного профиля 

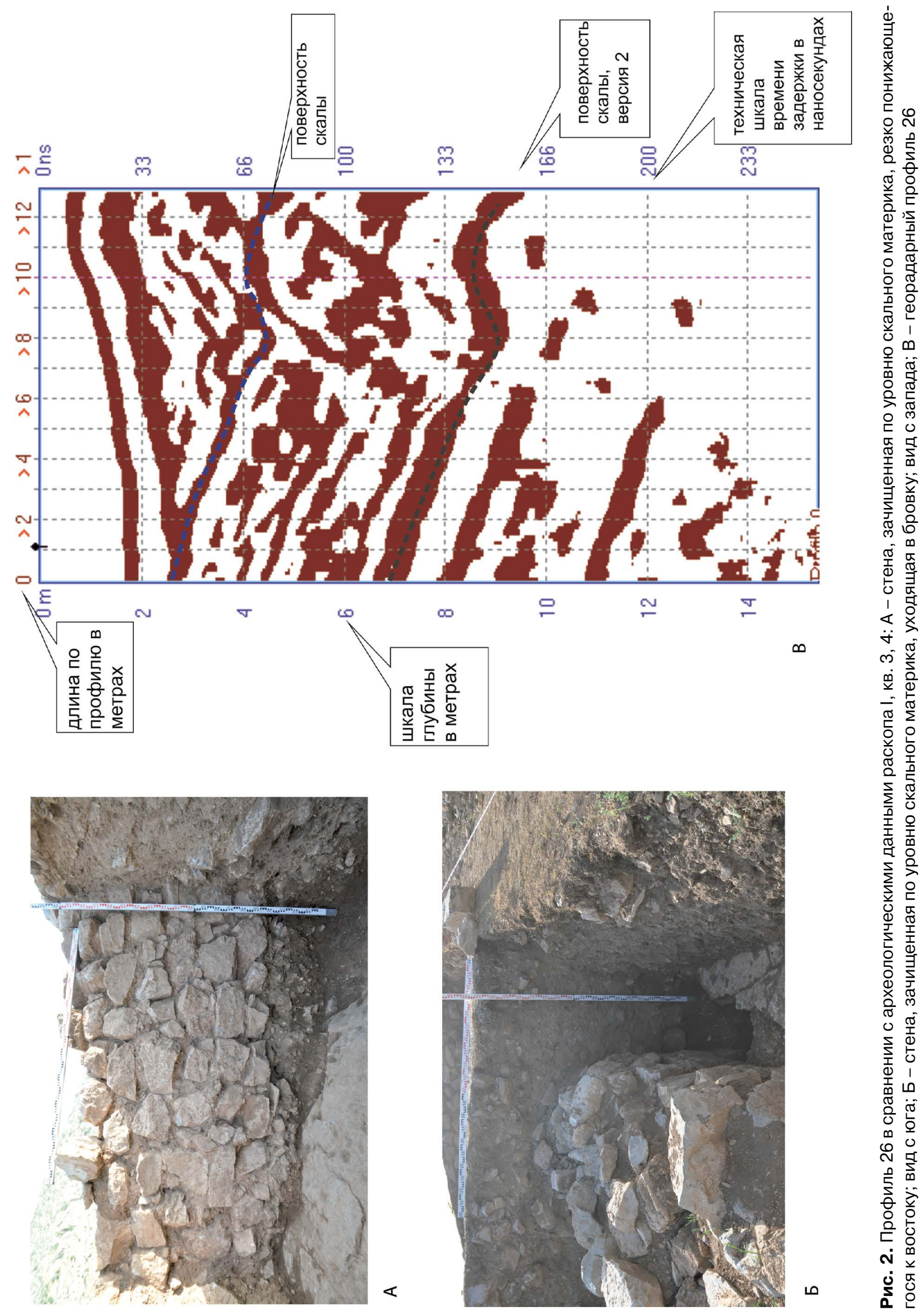

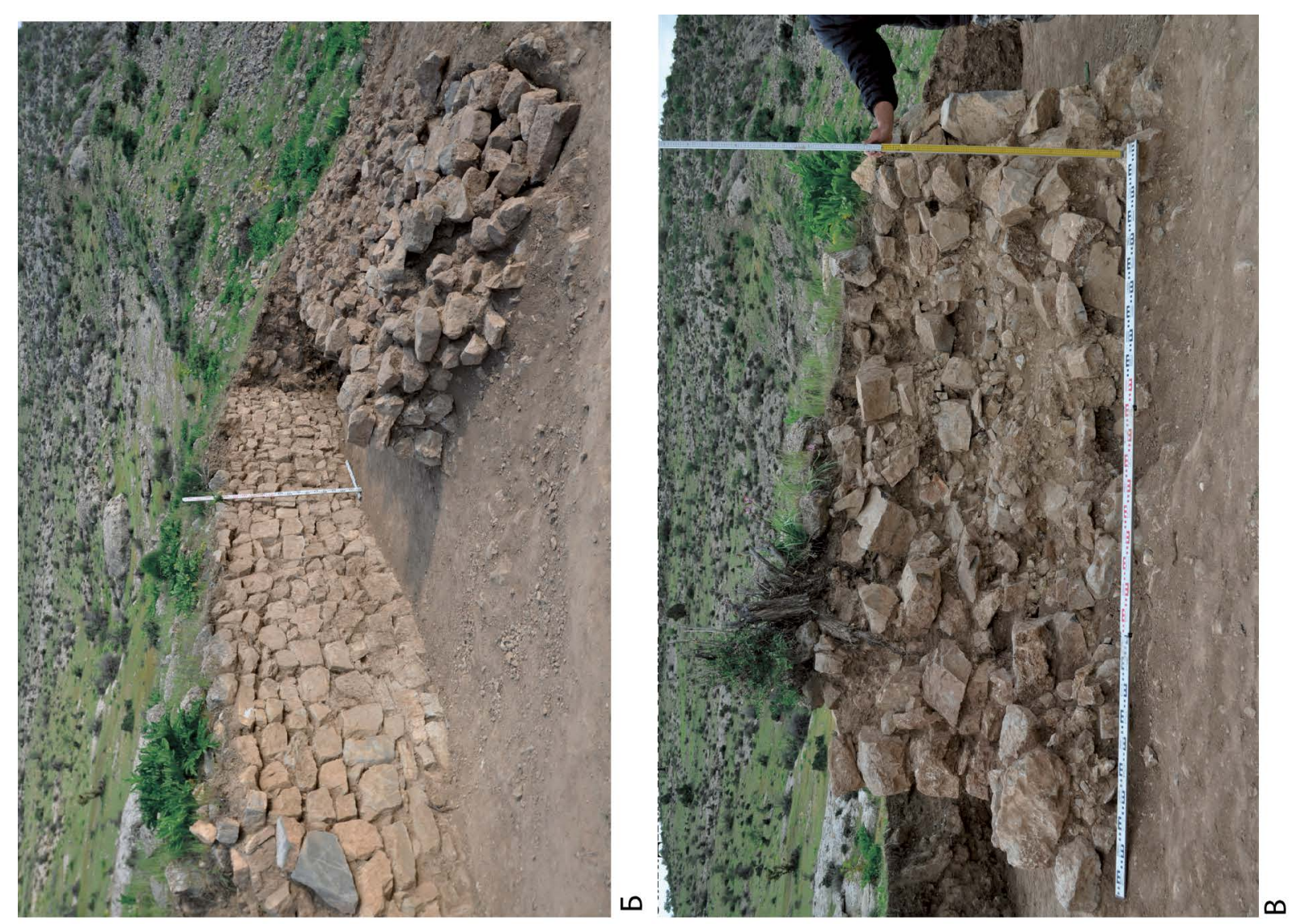

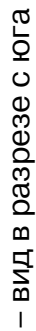
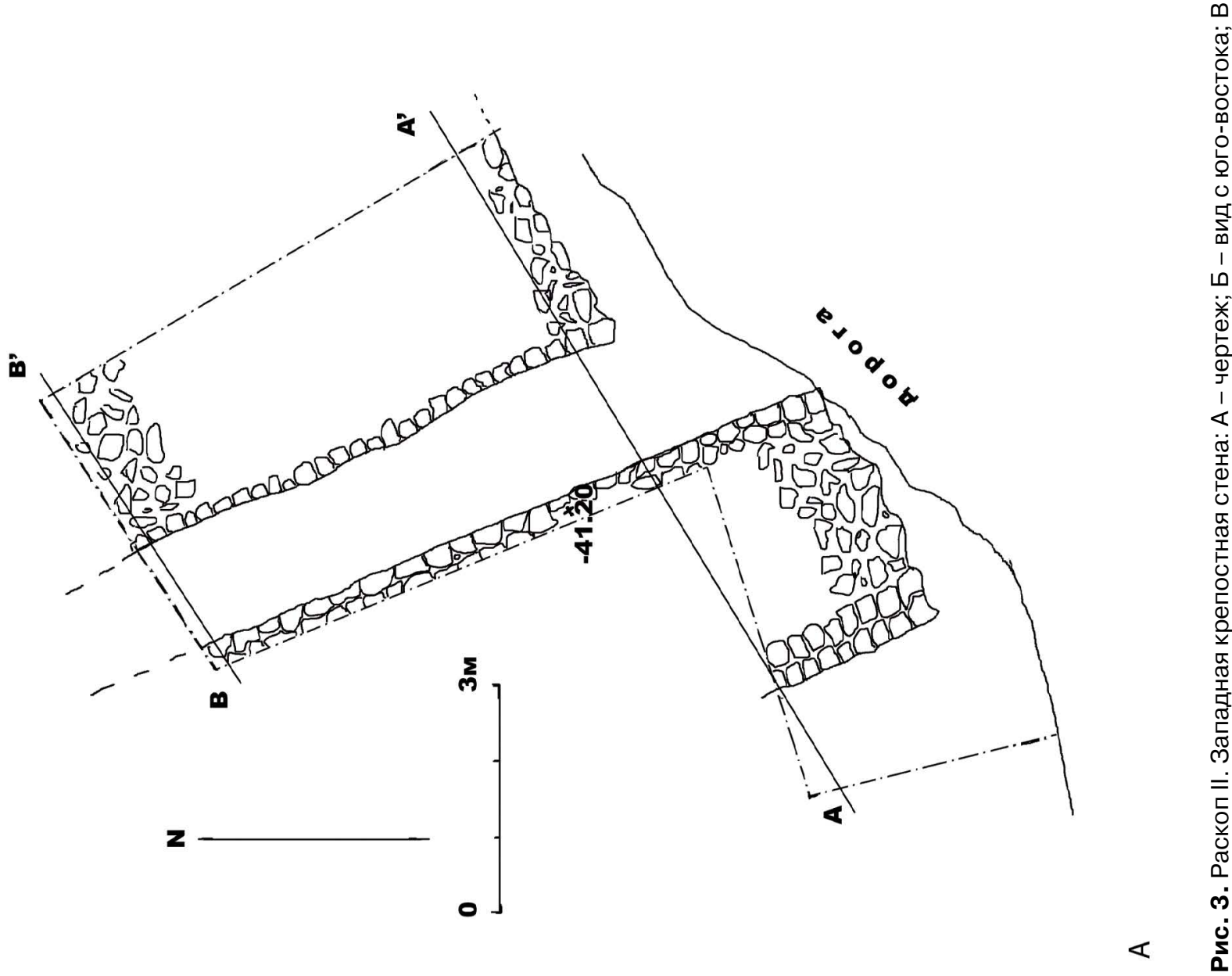
с внешнего и внутреннего фасов мощностью до 1 м и плотной забутовкой из камня, гравия и глины между ними. Это выглядит как два более мелких параболических всплеска в рамках одного общего, отражающего всю стену в целом.

Кроме стен в профиле 27 четко высвечивается участок заглубления перед крепостной стеной с внешнего фаса, проявленный также на дневной поверхности в микрорельефе в виде легкой выемки с максимальным разлетом между бортами до 7 м (рис. 4). Глубина этого сооружения, которое весьма вероятно является рвом, составляет более 3 м. Однако насколько это соответствует действительности, предстоит узнать из последующих археологических раскопок.

Таким образом, георадарные исследования, проведенные в непосредственной близости от раскопа II, показали, что данные георадара «ЛОЗА» практически совпадают с результатами археологических раскопок. В связи с этим для дальнейших исследований крепости Узундара крайне важен анализ полученных георадарных профилей (помимо выше описанных, было выполнено еще 12) на разных участках крепостных стен. Профили крепостных стен, идущих вдоль края обрыва урочища Кара-Камар, как у основного четырехугольника (профили 21-23, 33), так и на участках выносных стен (профили 31 , 32), а также вдоль края ущелья Узундара (профиль 36) представляют с небольшой вариацией не два, а в основном три четко выраженных параболических всплеска, интерпретируемых как стены. Причем если два наиболее ярко выраженные и лучше сохранившиеся имеют разлет между своими пиками от 4,5 до 5,5 м, то третья, как правило, значительно меньше по высоте, разлет от ее пика до центра ближней стены не более 3 м. Эта третья стена, возможно, подпорная, расположена, как правило, с внутренней стороны $(21,33,36)$ (рис. 5, 6).

В случае с выносными стенами на северозападе крепости, а также с восточной стеной ее основного четырехугольника необходимо отметить, что возведены они в условиях резкого перепада рельефа. Так, выносные стены стоят на скале, где на расстоянии 80 м понижение составляет более $30 \mathrm{~m}$, а на участке восточной крепостной стены оно превышает 17 м на расстоянии 70 м. Столь сложный рельеф для возведения стен требовал контрфорсных крепежных конструкций, что и демонстрируют нам георадарные профили, где отчетливо видно до четырех параболических всплесков стен (профили 16, 17, 31), при этом два наиболее мощных - в центре, и два существенно меньших - с внешнего и внутреннего фасов крепостных стен на более близком к ним расстоянии (рис. 7,8 ).

В 2018 г. была доследована цитадель или филактерион крепости (ранее раскоп III). Прак-

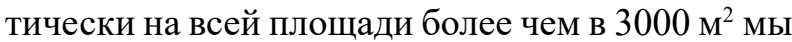
вышли на уровень материковой скалы (рис. 9). Подтреугольный в плане, филактерион со всех сторон был опоясан мощными крепостными стенами общей протяженностью 180 м и укреплен пятью башнями. Три из них угловые, еще две, расположенные на северной стене, имели выносные отрезки стен, создавая лабиринтообразные «ловушки», маскирующие настоящее месторасположение входа в цитадель. Вдоль крепостных стен на юго-западной стороне, обращенной к ущелью, т.е. в сторону предполагаемого противника, находилась стрелковая галерея, разделенная перегородками на отдельные помещения, в которые можно было попасть изнутри филактериона через три калитки. Здесь в хорошо сохранившейся внешней крепостной стене были впервые обнаружены девять стрелковых бойниц, предназначенные для ведения подошвенного боя (рис.10).

В центре цитадели был размещен дом фрурарха (командующего гарнизона). Это было крупное здание с двумя объемными подвалами, в которых, по всей видимости, хранились запасы продовольствия и, возможно, льда на случаи долговременной осады. Вокруг скального комплекса находились открытые площадки и дворы. К крепостным стенам изнутри по периметру примыкало 12 хозяйственных и жилых помещений. Изнутри в башни и внутристенную галерею можно было попасть через калитки. Входной комплекс на филактерион был также сильно укреплен, он имел взаимосвязанные вход на цитадель и проход в основной четырехугольник крепости.

Полное вскрытие архитектурной планировки на цитадели (ранее раскоп III) позволяет нам продолжить и завершить сравнительный анализ результатов георадарной разведки 2014 г. и итогов археологических раскопок 2018 г. (рис. 11).

Два георадарных профиля 24 и 25 прорезали гребень южной крепостной стены цитадели по направлению с северо-востока на юго-запад и имели длину в 9 и 10 м соответственно (рис. 11-13). Оба профиля прорезали стену по направлению с северо-востока на юго-запад, т.е. изнутри филактериона наружу. Разрезы зафиксировали по два четких параболических всплеска с расстоянием между их пиками в районе 

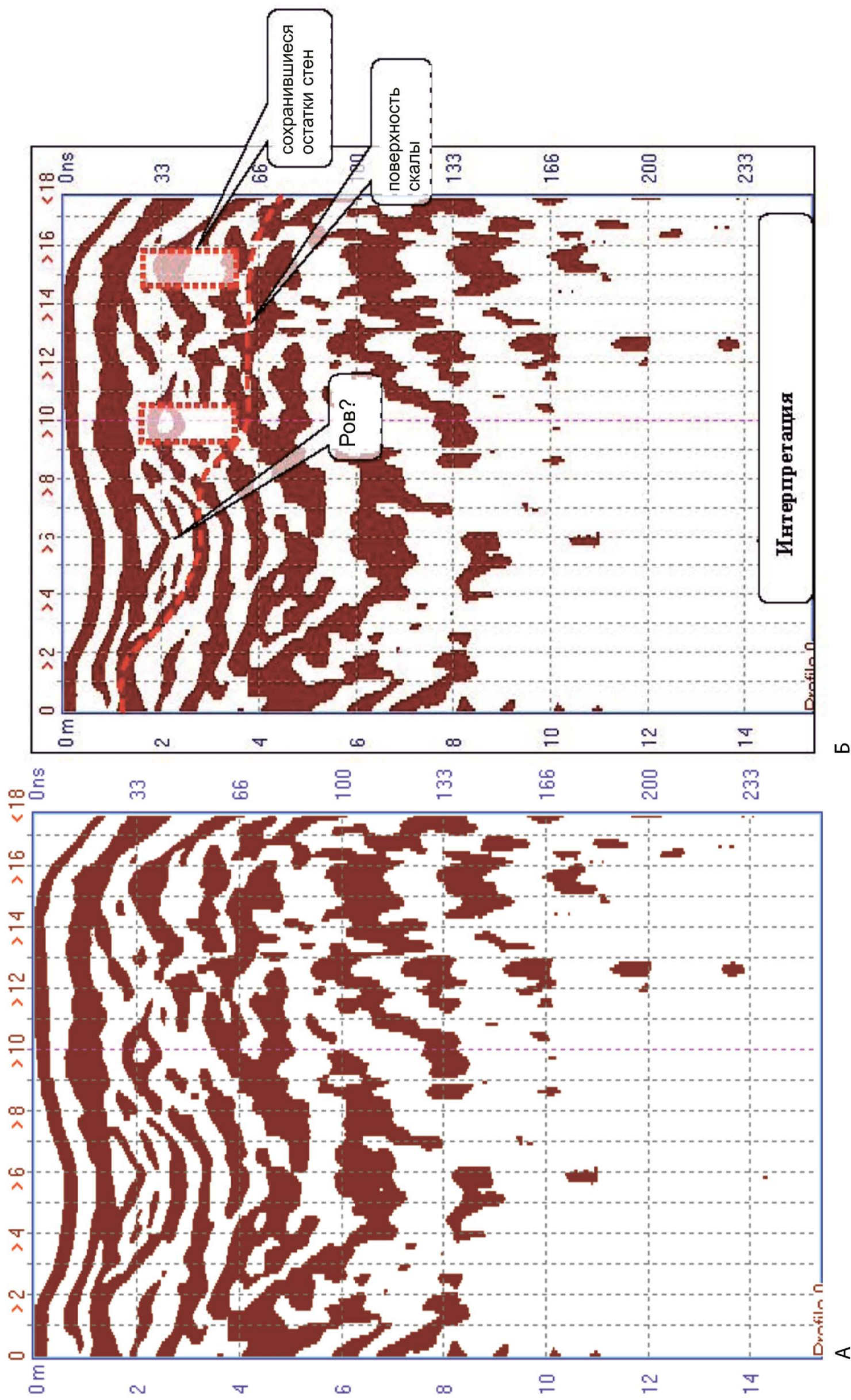

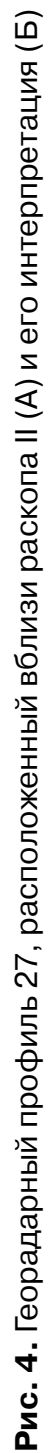



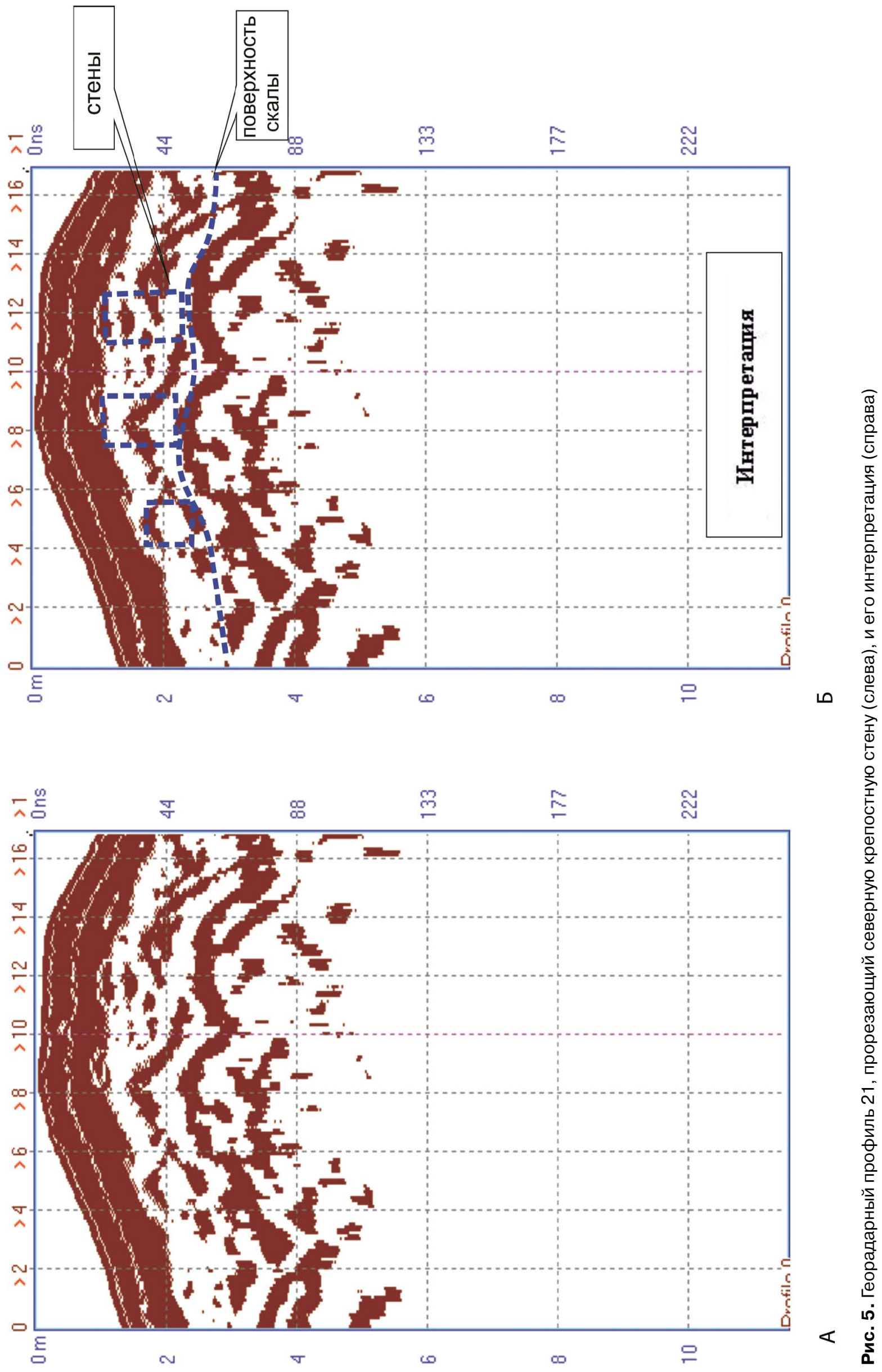


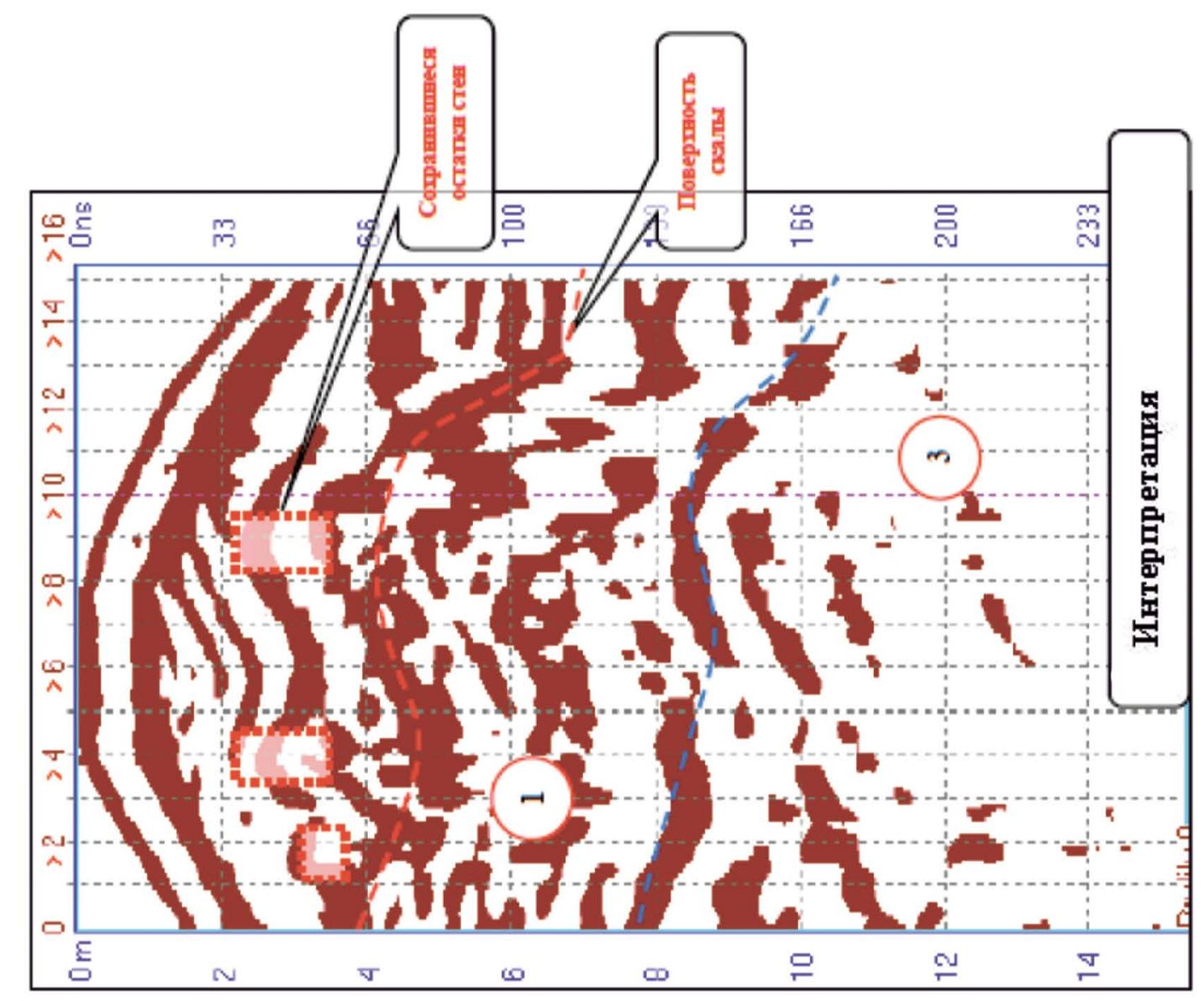

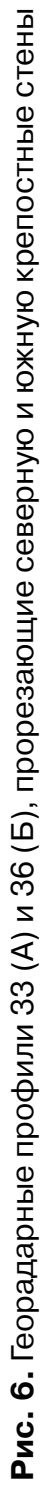



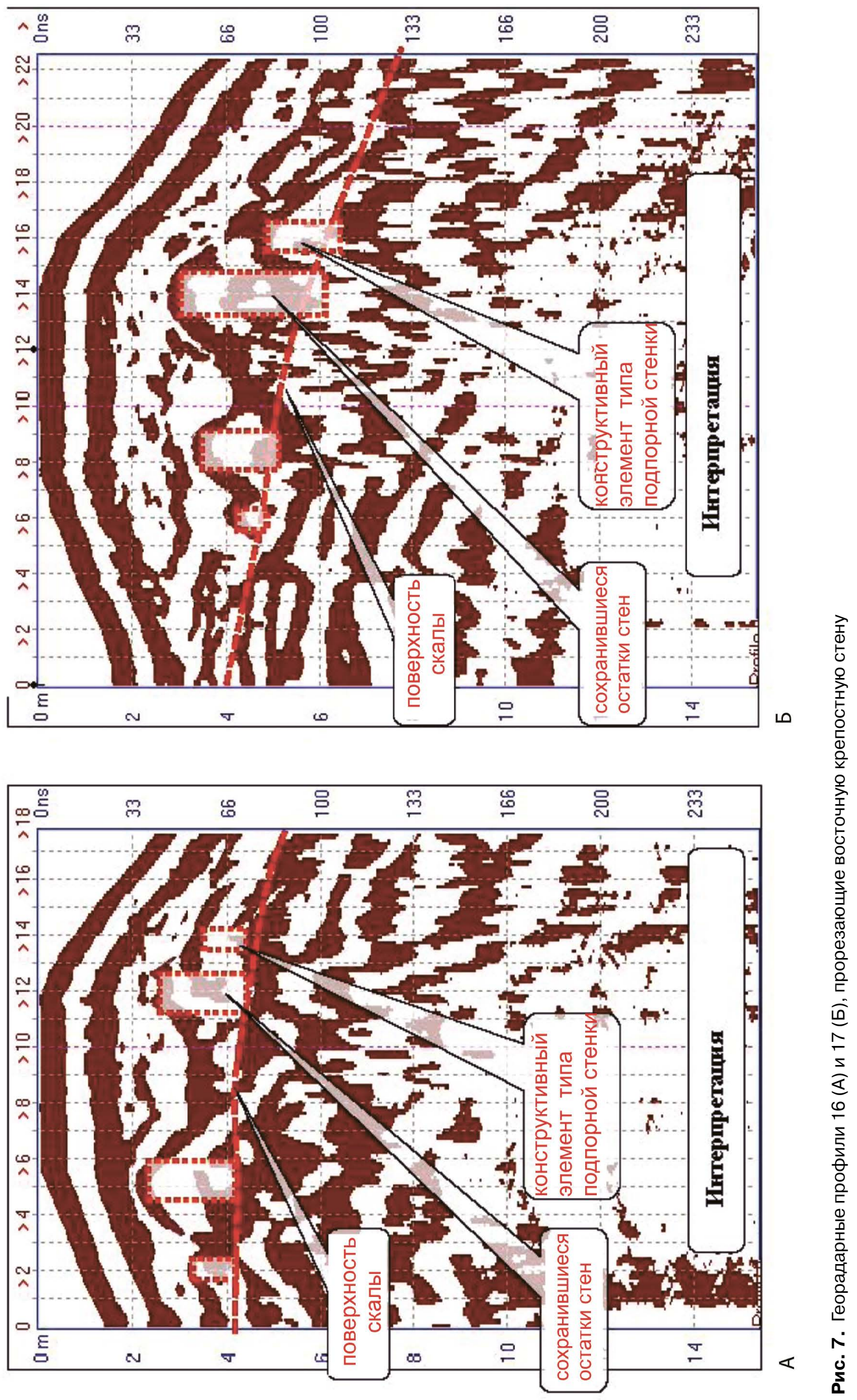


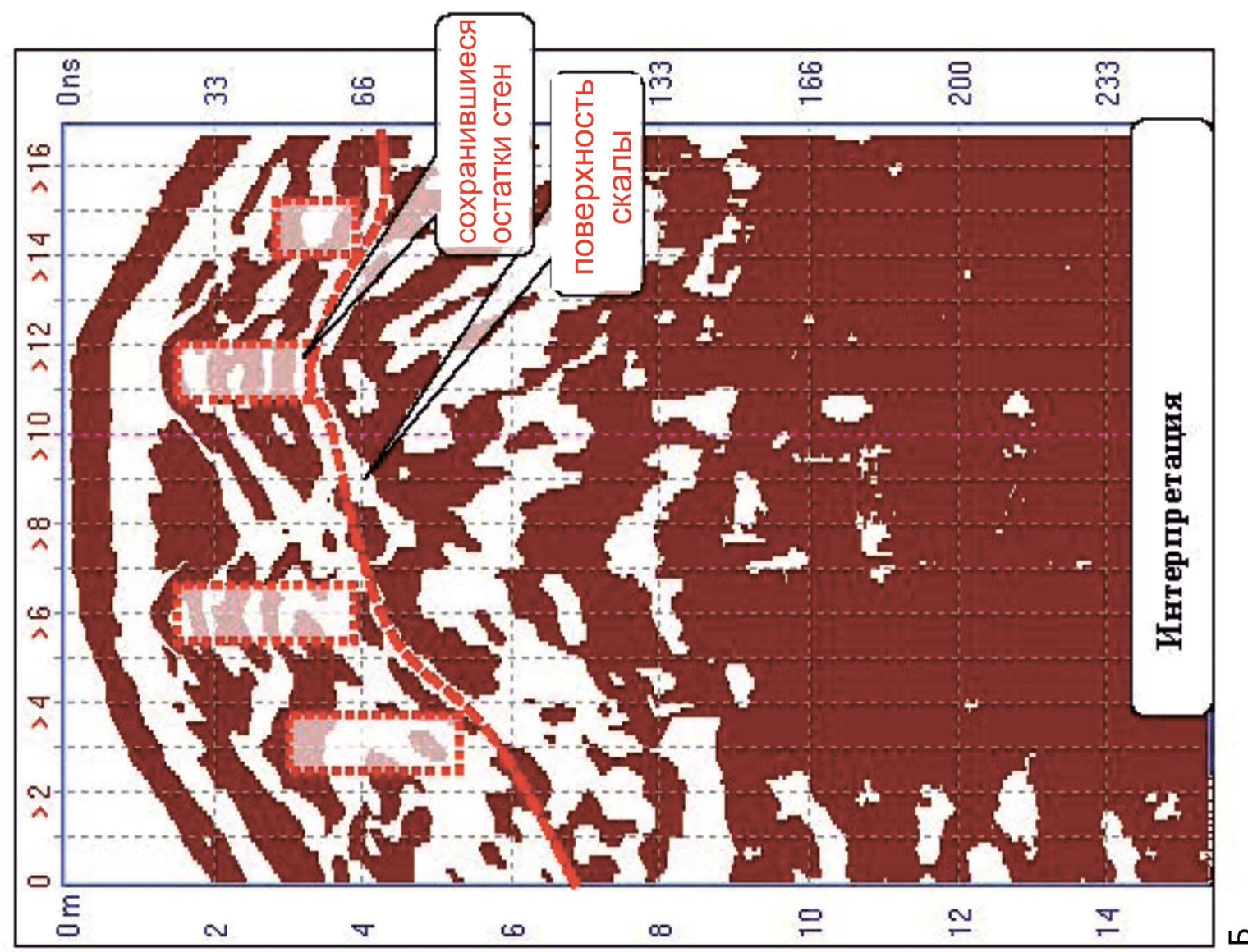

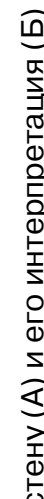

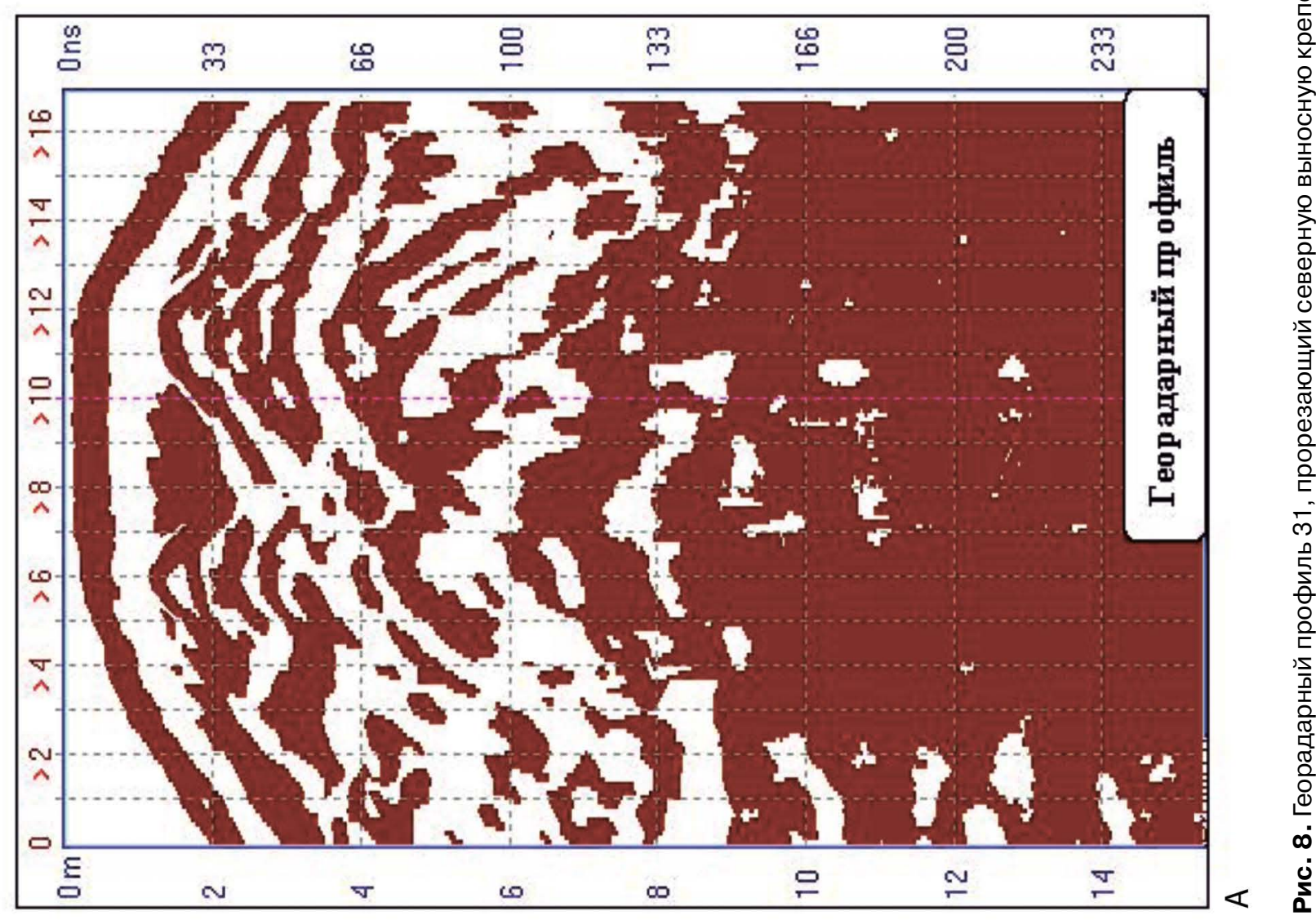




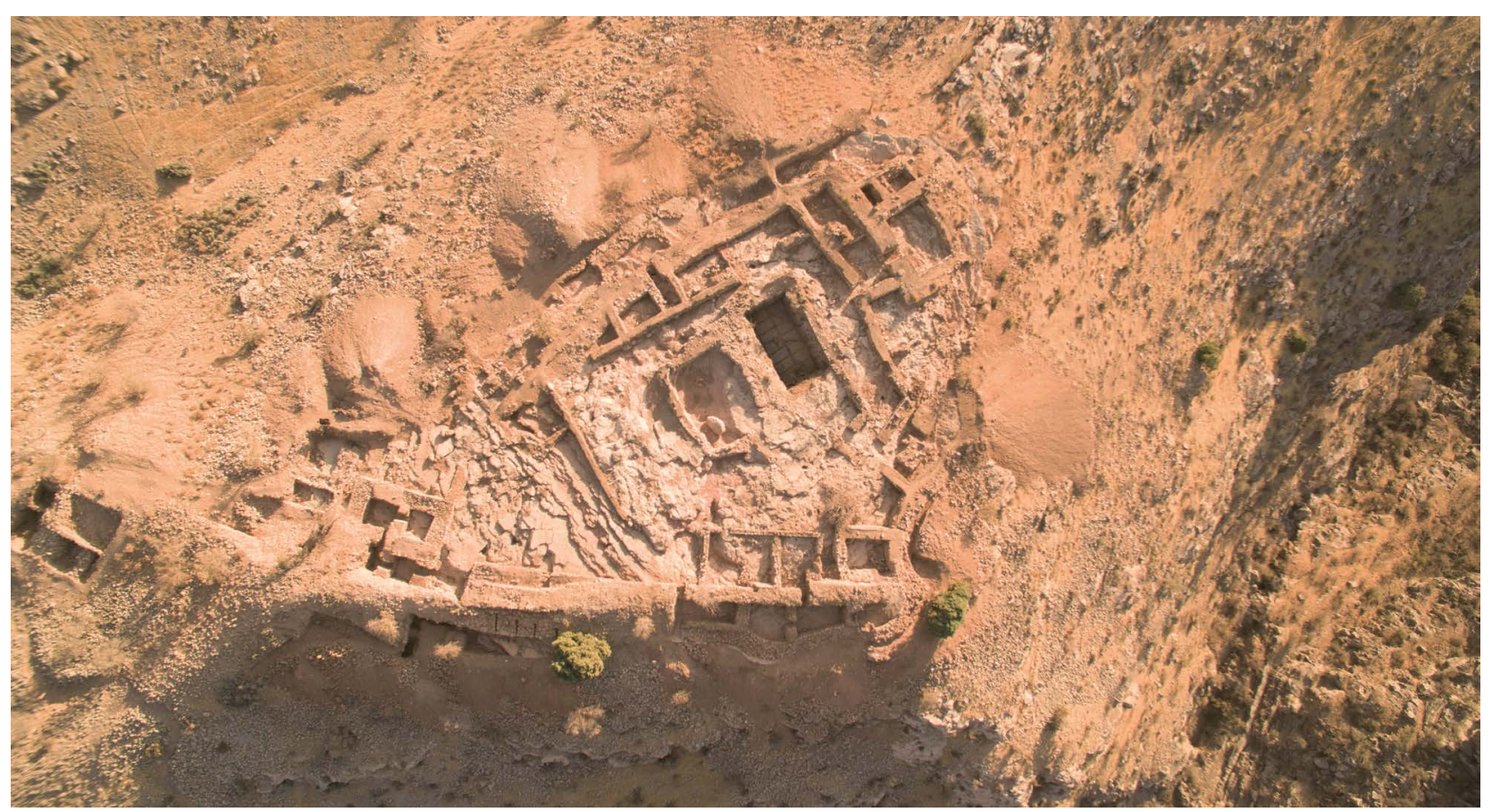

Рис. 9. Цитадель крепости Узундара по итогам археологических исследований 2018 г.

от 3 до 5 м. Эти аномалии интерпретируются как остатки фундаментов крепостных стен.

По итогам раскопок 2018 г. южная крепостная стена цитадели Узундары в отличие от восточной и северной имела внутристенную стрелковую галерею, разделенную на глухие отсеки, вход в которые осуществлялся изнутри цитадели посредством трех калиток во внутренней южной крепостной стене. Внешняя крепостная стена в отличие от внутренней шла не прямо, a имела плавные зигзагообразные расширения и сужения (рис. 9, 11, 12). Это объясняется стремлением максимально использовать всю площадь скальной поверхности, пригодной для возведения укреплений, ограниченной отвесными скальными обрывами.

Георадарный профиль 24, как показали археологические раскопки, прошел через южную угловую башню (рис. 9, 11, 13). Башня подпрямоугольная в плане, со скругленным внешним

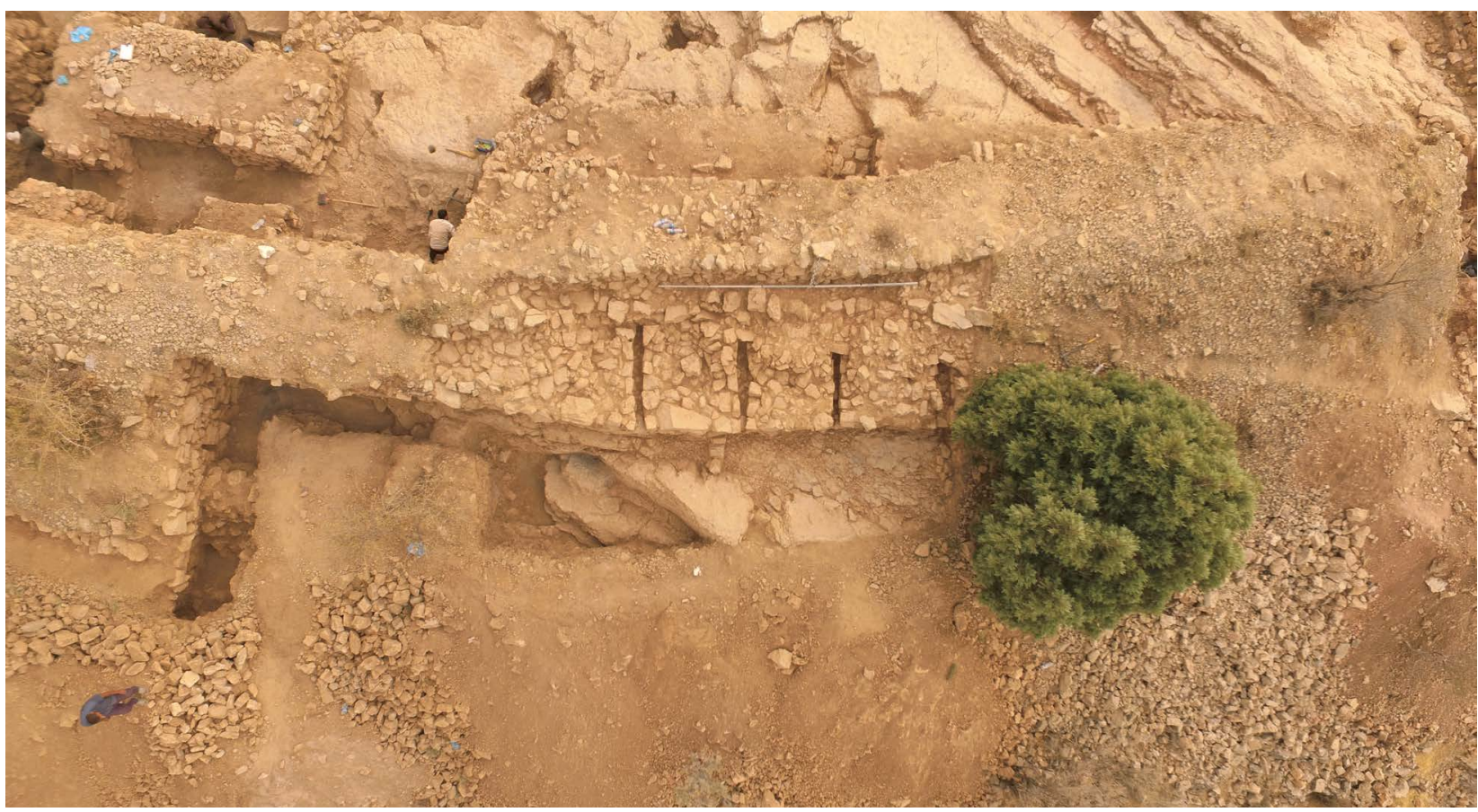

Рис. 10. Южная крепостная стена цитадели со стрелковыми бойницами 


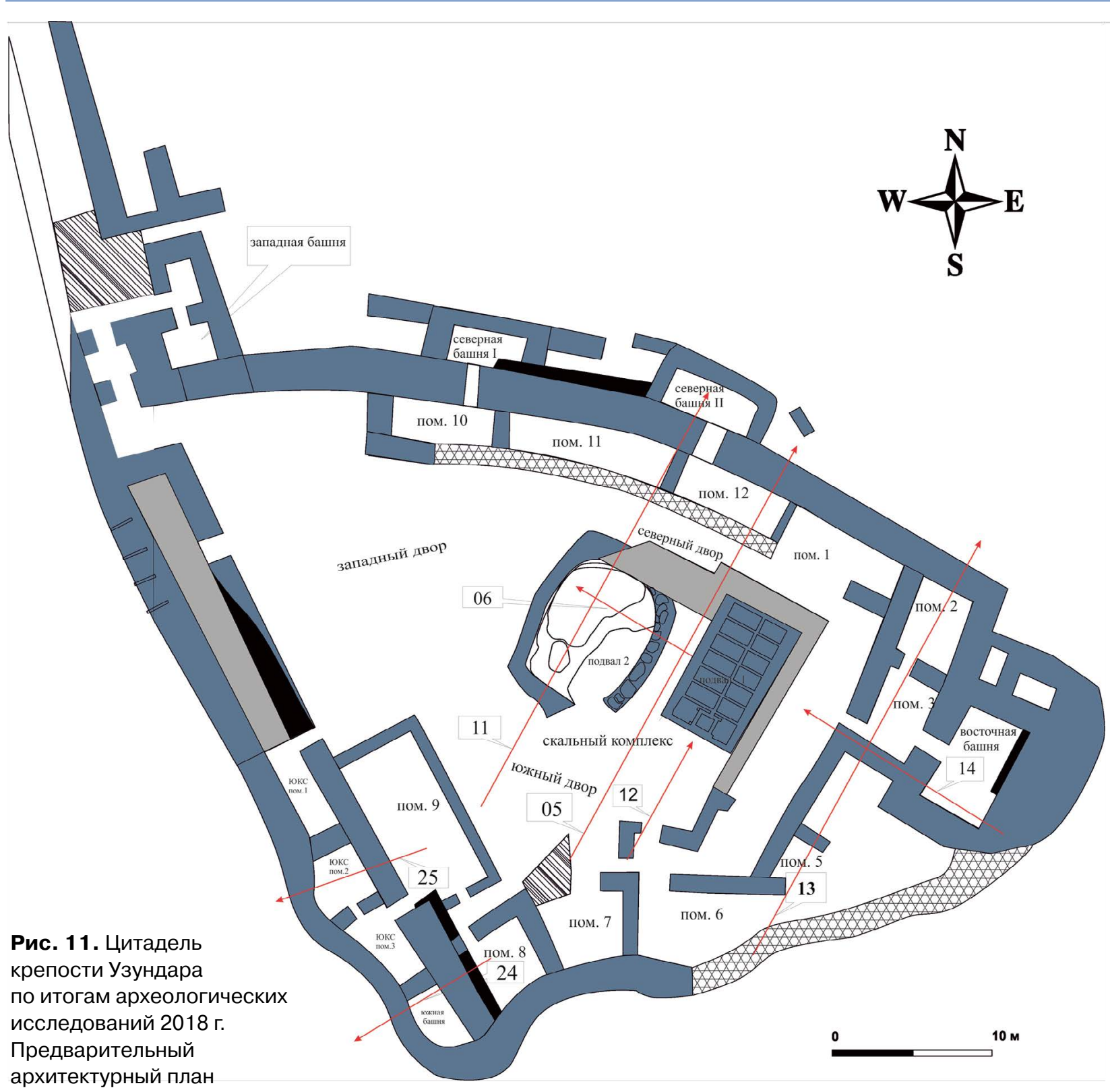

выступающим углом (рис. 14). Профиль порезал ее в северо-западной части, где расстояние между внешней и внутренней крепостными стенами составляло 2,5 м. Именно это расстояние хорошо заметно на снимке между основаниями фундаментов стен. Необходимо также отметить, что указанные основания находились на глубине около 2 м от дневной поверхности, что также практически совпадает с реально сохранившейся высотой внутренней крепостной стены, тогда как сохранность высоты внешней крепостной стены значительно меньше, не более 1 м, однако эта разница в высоте стен на георадарном профиле не прослеживается.

Георадарный профиль 25 был расположен в 5 м к северо-западу от профиля 24 и прорезал тот же гребень стены (рис. 11, 13, 14). В отличие от предыдущего профиля расстояние между улавливаемыми фундаментами стен на георадарном снимке было значительно больше и составляло не менее 3,5 или 5 м от центра обеих стен (рис. 13). Совмещение георадарного профиля 25 с вскрытым архитектурным планом показывает, что профиль пришелся на помещение 2 южной крепостной стены в месте наибольшего расширения до 4,1 м и вполне совпадает с планом. Высота внутренней стены сохранилась на 2,1 м, тогда как внешняя стена сохранилась всего на 0,6 м. Однако и на 25-м георадарном профиле эта разница не заметна.

Таким образом, необходимо констатировать практически $100 \%$ фиксирование георадаром местоположение архитектурных объектов, в частности остатков южной крепостной стены со всеми ее особенностями, за исключением разницы в сохранности высоты стен. 


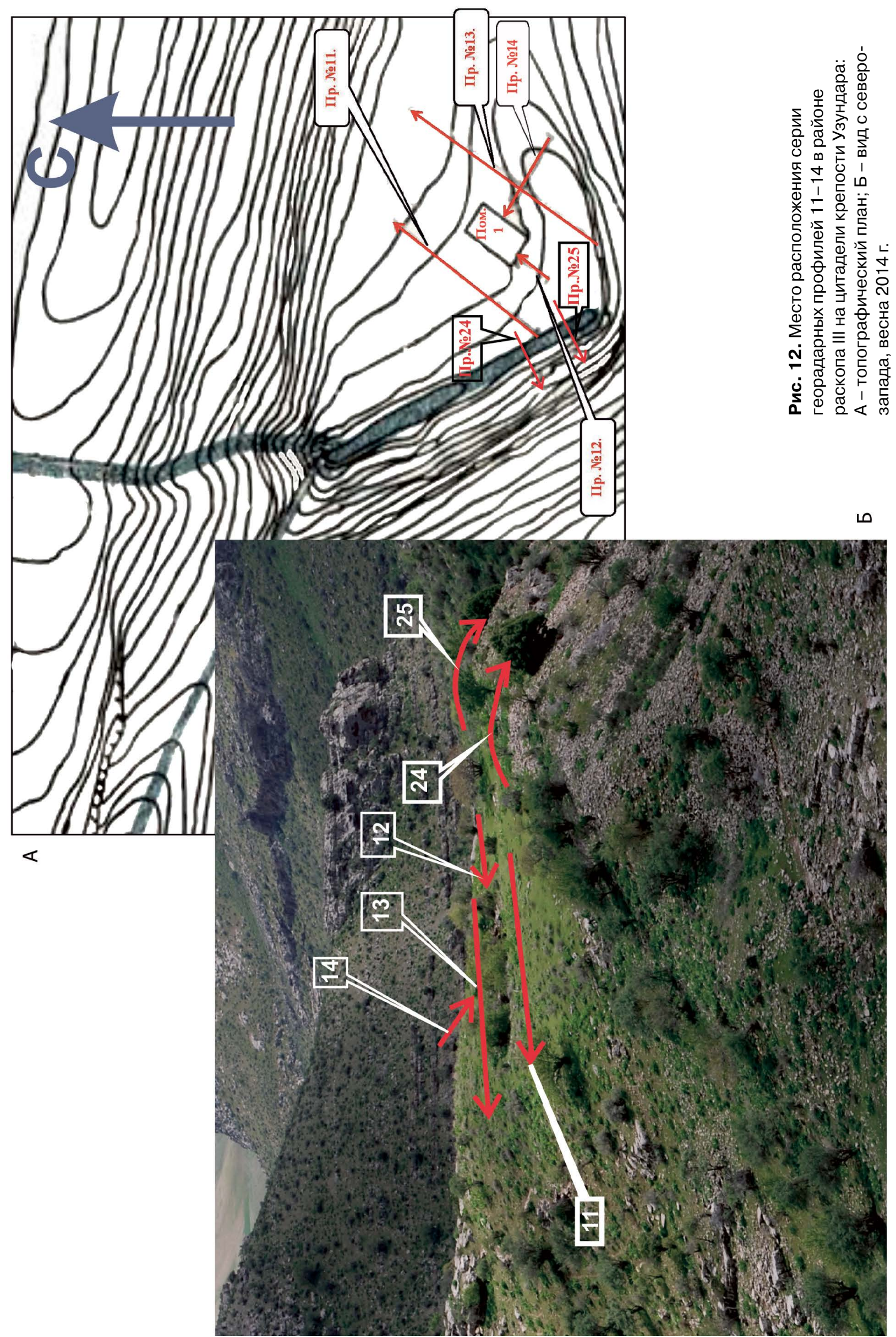




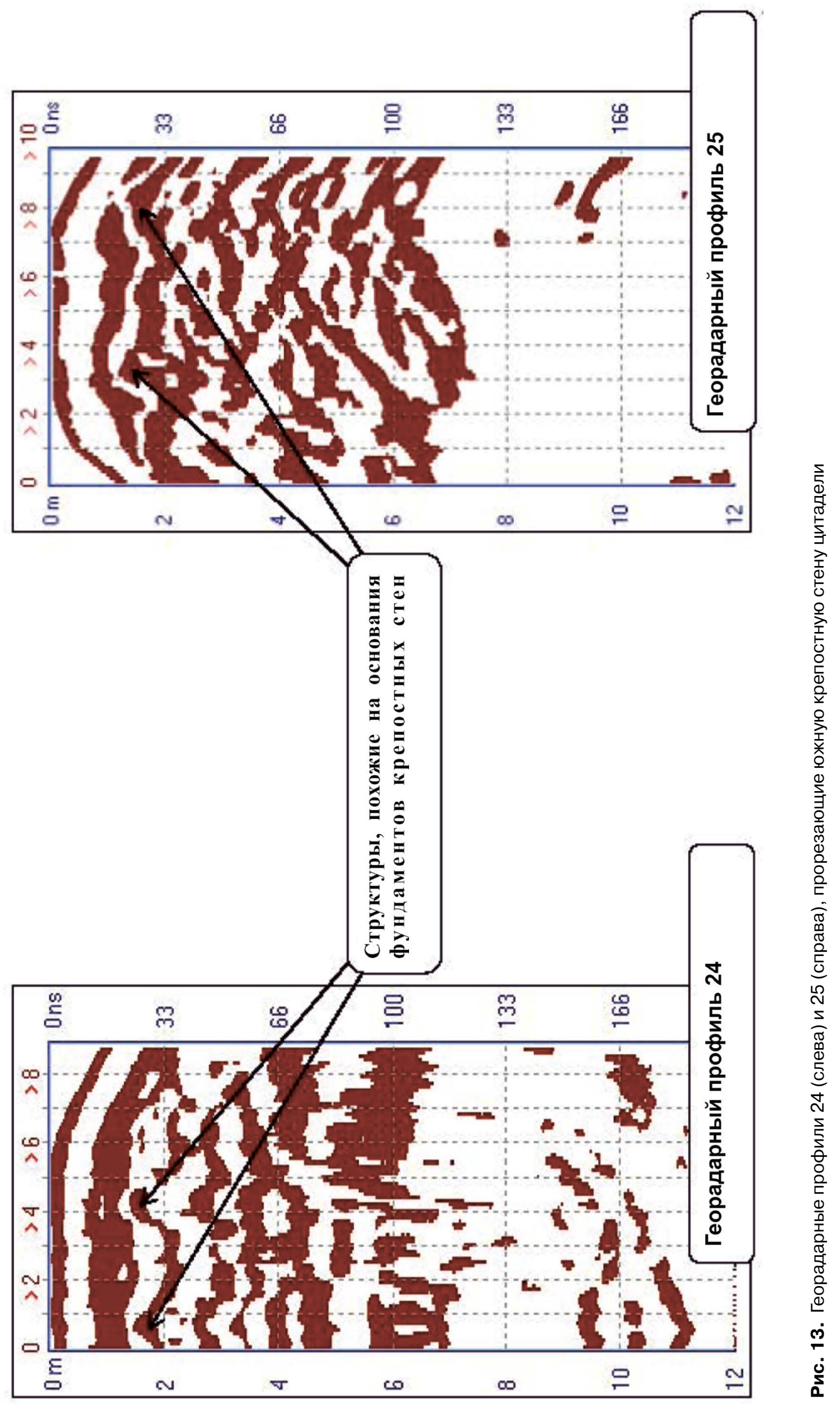




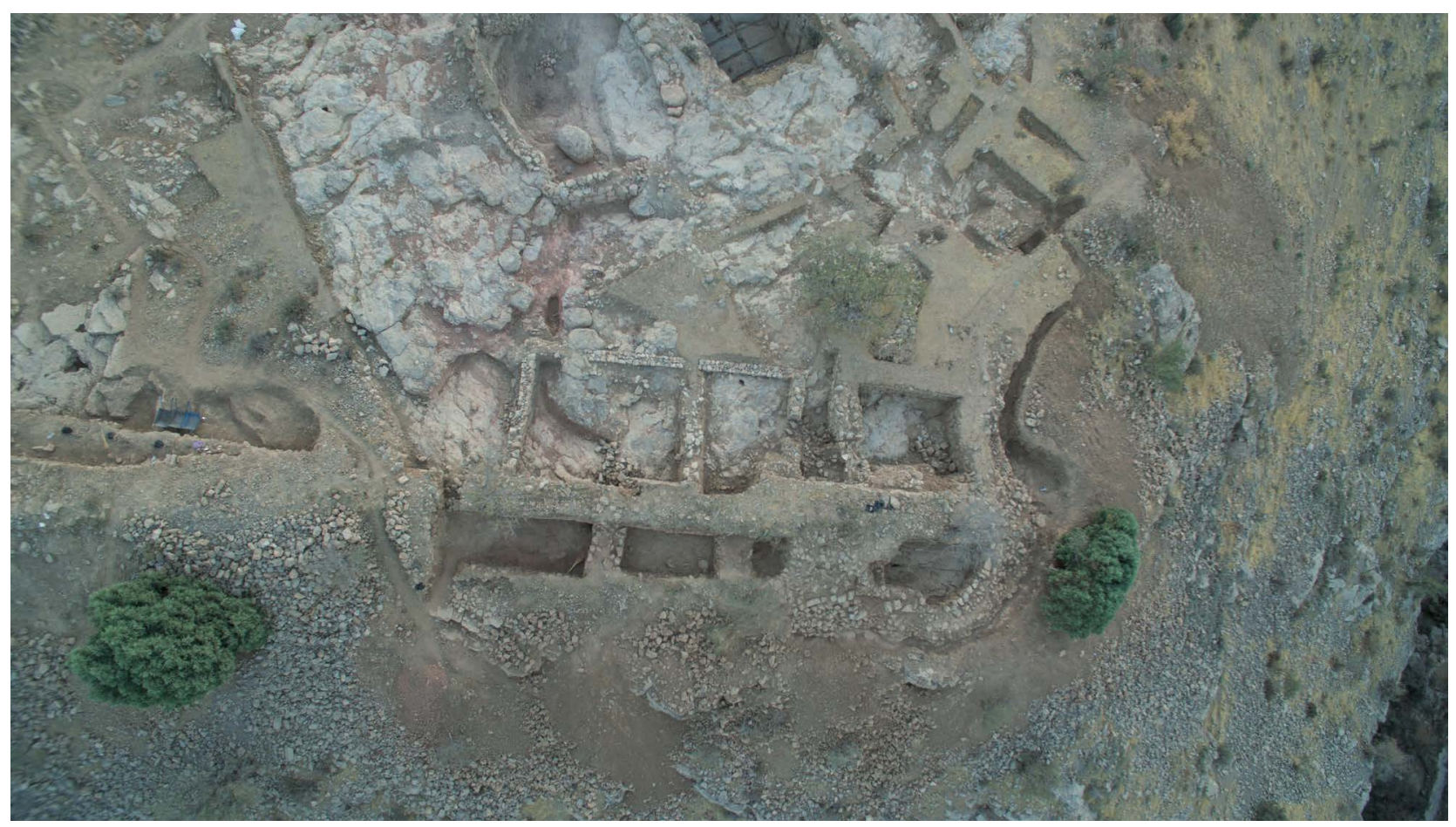

Рис. 14. Южная угловая башня цитадели

Значительно сложнее выглядят результаты сопоставления данных георадара и археологических раскопок на центральной площади цитадели (раскоп III) (рис. 12). В 2014 г. раскоп III включал в себя Скальный комплекс, где исследовалось подвал 1, вырубленный в скале, размерами $10 \times 5$ м и глубиной 3,5-4 м. К северу от северного борта подвала 1 была заложена траншея 1, к востоку от восточного борта помещения 1 траншея 2, к югу от южного борта был заложен шурф 2. В 2015 г. на восточном крае траншеи 2 был разбит дополнительный участок раскопок «Юго-восточная башня цитадели».

В непосредственной близости и на площади раскопа III в 2014 г. было отсканировано шесть георадарных профилей по невскрытой раскопками дневной поверхности (№ 05, 06, 11, 12, 13, 14) (рис. 11, 12).

Профили 05, 11 и 13 выполнены с юго-югозапада на север-северо-восток. Они идут параллельно длинным сторонам подвала 1 , на расстоянии 1 и 6 м к северо-западу и 7 м к юго-востоку от его бортов соответственно. Длина каждого профиля - около $28 \mathrm{м}$.

Перпендикулярно этим профилям заложено еще два - 06 и 14. Они направлены с востока на запад, их длина -8 и 14 м соответственно. Профиль 06 имеет две точки пересечения с профилями 05 и 11. Профиль 14 имеет одну точку пересечения с профилем 13. Профиль 12 длиной 8 м направлен с юга на север и подходит вплотную к середине южного борта подвала 1 (рис. 12).

Профили, расположенные к западу от подвала 1, - 05, 11 пересекают Южный двор, подвал 2, Северный двор, а также помещения 1, 12 и Северную крепостную стену цитадели (рис. 15). Перпендикулярный им профиль 06 пересекал подвал 2 (рис. 16). Позднее по этой линии был заложен стратиграфический разрез, и мы можем сравнить оба профиля ${ }^{1}$. Очевидно, что все три рассматриваемые геораданые профили не смогли отразить реальную картину застройки этого участка, в том числе наличие крупной полости подвала 2 глубиной до 2,6 м и размерами $11 \times 7,5$ м (рис. 17 ).

Профили ( № 13 и 14), расположенные к востоку от подвала 1 , также не выявили реальной ситуации. Профиль 13 пришелся на помещения 2-5, расположенные изнутри вдоль крепостной стены восточного сектора цитадели (рис. 11, 12, 18). Сохранность стен на этом участке, как правило, не превышала 1,5 м. Пересечение с ними должно было наблюдаться на 1213 м и на 16-17 м профиля. Значительно более мощная западная крепостная стена пришлась

\footnotetext{
1 Разница лишь в том, что георадарный профиль отражает ситуацию с востока на запад, а археологический разрез - в обратном направлении.
} 
на самый край профиля на 27-28 м. Однако эти стены не получили четкого отражения при георадарном сканировании.

Профиль 14, заложенный перпендикулярно, прошел через восточный двор, помещение 3 и восточную башню. Стены этих объектов также не получили отражение на георадарном профиле 14, тогда как археологическая траншея 2, заложенная осенью 2014 г. на этом участке, выявила серию стен на глубине от 0,1 до 0,5 м от дневной поверхности (рис. 19). Скальный материк был выявлен повсеместно на глубине не более 1,2 м. Было также зафиксировано постепенное естественное снижение уровня поверхности

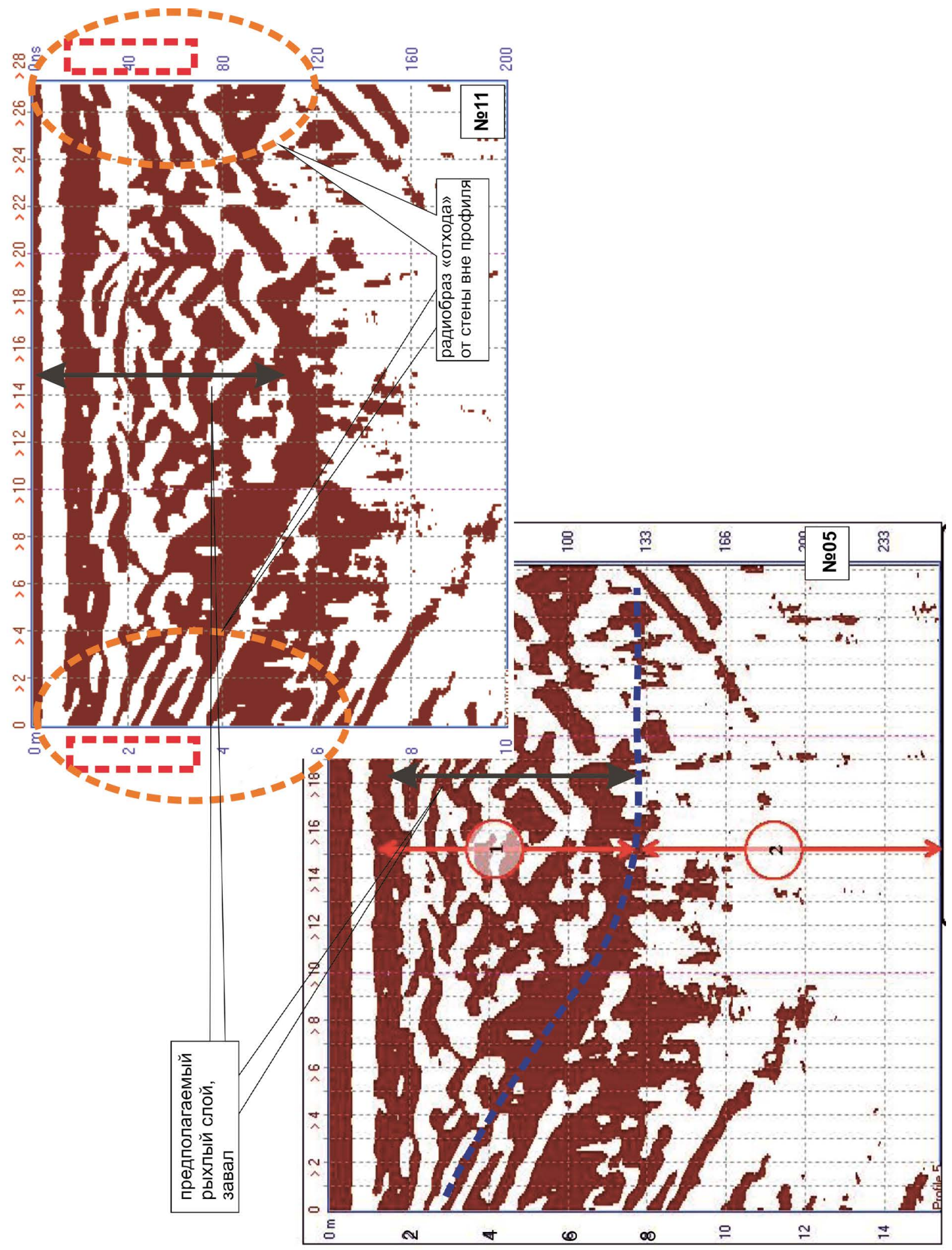

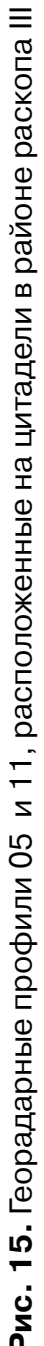


скалы на восток, составившее на отрезке в $21 \mathrm{~m}$, вскрытом траншеей 2 до $2,51 \mathrm{м}$, без каких-либо резких перепадов. В точке пересечения георадарных профилей 13 и 14 высота культурного слоя составляла чуть более 1 м (рис. 19). В связи с этим приходится полностью опровергнуть первоначальную интерпретацию - наличие рыхлого слоя или полости с завалом камней и культурным слоем мощностью в 4-6 м, что демонстрируют профили 13 и 14 (рис. 18).

Кроме того, в ходе раскопок полностью вскрытого весной 2015 г. подвала 1 зафиксировано четыре профиля его стен, четко характеризующих состав скалы от дневной поверхности

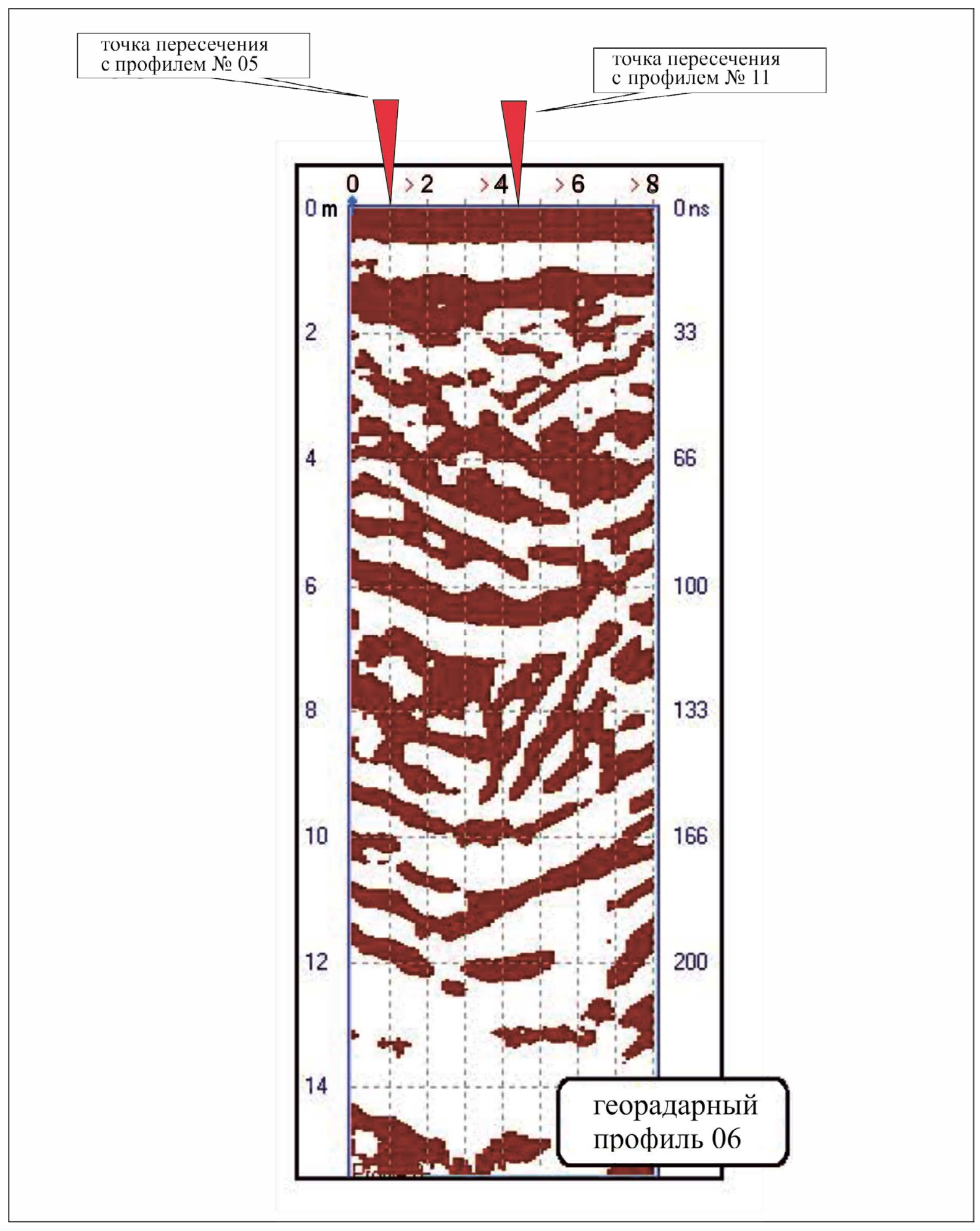

Рис. 16. Георадарный профиль 06, расположенный на цитадели в районе подвала 2 


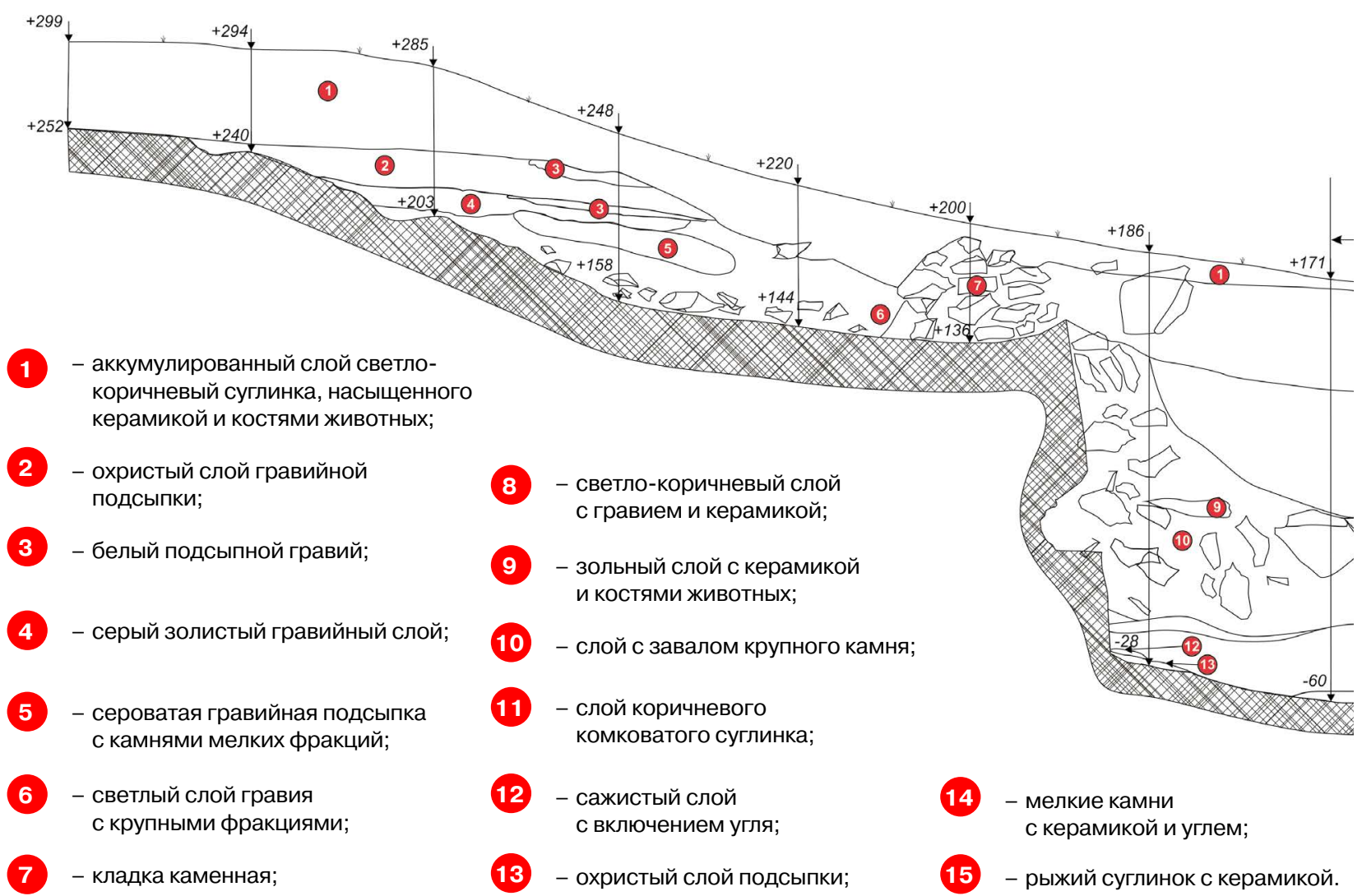

до 4 м глубины (рис. 20, 21). Стены подвала 1 ярко демонстрируют слоистый характер скалы с развитой трещеноватостью и рыхлостью на разных участках разной мощности и направления. Надо отметить, что, как правило, мощность верхнего слоя с развитой трещиноватостью составляет около 2 м, но не более 3 , тогда как георадарные профили 11 и 13 дали глубину этого слоя до 4 м и более.

Эти расхождения позволяют уточнить погрешность данных георадара «ЛОЗА» по глубине залегания, составляющую 1-1,5 м. Однако при этом необходимо отметить, что мощность завала камней не обязательно отражает мощность всей зоны трещиноватости. Возможно, именно с этим связано то, что на георадарных профилях отчетливо читается поверхность монолитной скалы в этом месте на глубине именно в 4 м и более.

К сожалению, подвал 1 был вскрыт до начала георадарных исследований, вследствие чего нет возможности сопоставить данные на этом участке. Отметим лишь, что о характере его заполнения можно судить по профилям заложенного в 2013 г. шурфа 1 (рис. 22: 1) и по стратиграфическому разрезу, полученному в результате вскрытия половины объема подвала 1 осенью 2014 г. (рис. 22: 2). Необходимо отметить, что стратиграфия заполнения подвала 1 представляет вначале этап, скорее всего, естественного затягивания полости открыто стоящего помещения (слой с глиной намывной с мелкими камнями мощностью до 0,6 м в центре, с характерным повышением к краям, достигающим 1,4 м), а затем этап разрушения окружающих подвал 1 сооружений и самих стен, так как второй слой содержит помимо глины и гравия значительное число очень крупных камней (в том числе более 1 м в диаметре).

Сопоставление данных археологических раскопов с результатами геофизического обследования с помощью георадара «ЛОЗА» позволило избежать ряда ошибочных интерпретаций по структуре скальных пород, подстилающих памятник. Сложность заключалась в том, что слой выглядел очень близко по характеру к культурному слою, как насыпной грунт с камнями. Но при перекрестном сопоставлении данных стало ясно, что это не простая скала, а с сильно развитыми трещинами, со всеми блоками, находящимися на своем природном месте, но уже не представляющих монолита. Слой разбитый хорошо развитой трещиноватостью у геологов получил название «кора выветривания».

В свою очередь наблюдения за этим слоем скалы с развитой трещеноватостью позволило исключить одну из выдвинутых профессором П.Леришем интерпретаций подвала 1 Скального комплекса цитадели крепости Узундара как 


\section{Участок, соответствующий георадарному профилю № 06}

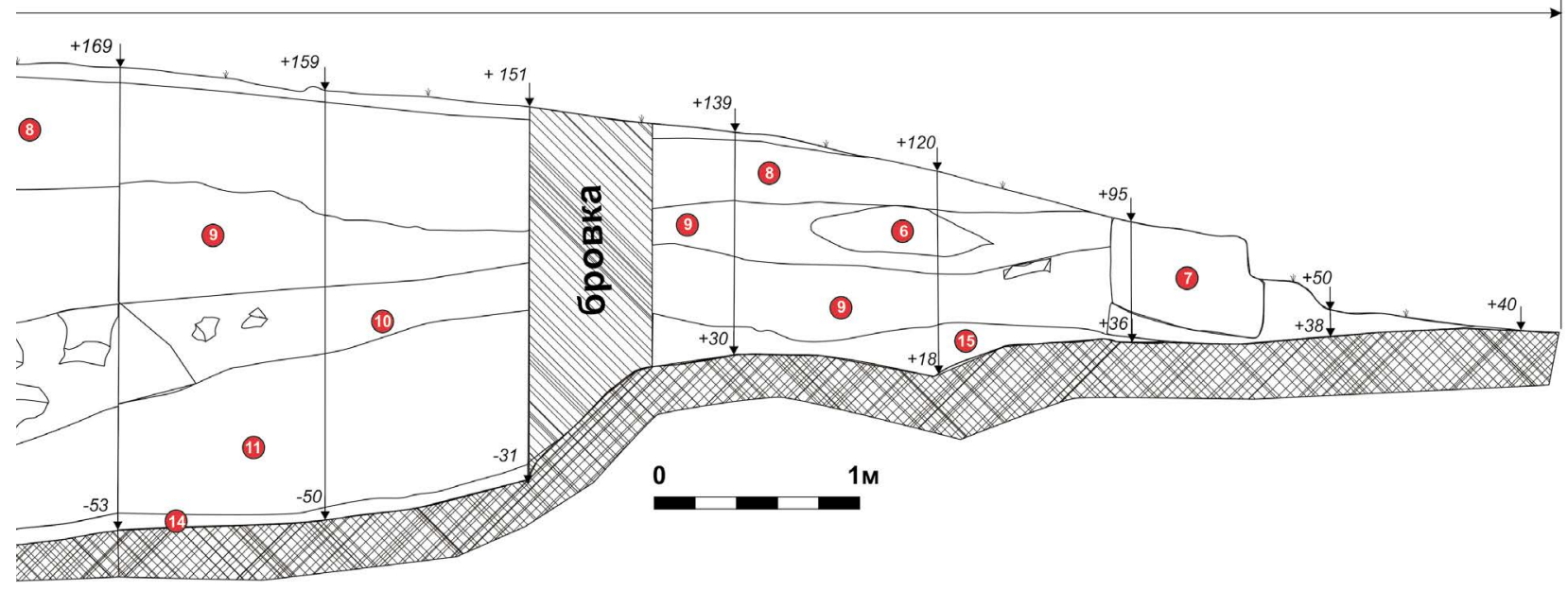

Рис. 17. Раскоп III. Скальный комплекс. Подвал 2 и примыкающий с запада двор.

Стратиграфический разрез. Условные обозначения лучше перенести сюда

штольни по добыче каменных блоков². Кроме того, полное вскрытие подвала 1 весной 2015 г. позволило увидеть, что даже на глубине в 4 м на дне сооружения присутствует серия трещин разной глубины и мощности, что также позволяет полностью опровергнуть этот вариант интерпретации функционального назначения подвала 1 (рис. 23).

Серия георадарных профилей была расположена вне зоны археологических раскопок. Наиболее интересна с точки зрения дальнейшей перспективы изучения крепости Узундара серия из четырех профилей (№ 01, 02, 03, 04), расположенная у предполагаемых входных ворот, в середине восточной крепостной стены. Изучение топографии и микрорельефа, так же как и флоры, позволило при первой рекогносцировке весной 2013 г. обратить внимание на то, что именно здесь, в самой низкой точке крепости, находится наиболее удобное и рациональное место под размещение водосборника. Напротив входа имеется подтреугольная, вытянутая вершиной к западу площадка, которая упирается в скальные выступы. Это вершина естественной лощины. С юга она ограничена почти отвесно возвышающейся узкой террасой, идущей вдоль всей южной и части западной крепостной стены. С северной стороны рельеф без террасы с пологим, но существенным понижением к югу и востоку. Осенью при полном обезвоживании всей поверхности и высыхании травяной растительности здесь отмечался подпрямоугольный в плане участок с наиболее плотной и высокой травой, что позволяло предполагать естественную концентрацию воды, которая сохранялась здесь дольше (рис. 24).

Профиль 01 имеет длину 32 м, направлен с востока на запад. На седьмом метре располагается его точка пересечения с профилем 02, который в свою очередь имеет длину 16 м и направление с севера на юг. Профиль 02 дал интересный абрис сечения дна лощины на глубине чуть более 6 м, а также дно хауза под двумя метрами отложений (рис. 25).

В профиле 01 четко фиксируются три объекта. Сильным параболическим всплеском выделяется тело возможно насыпной конструкции, типа дамбы, далее вытянутые по направлению профиля наслоения, интерпретируемые как разные по времени уровни дна хауза и, наконец,

\footnotetext{
2 Осенью 2015 г. в ходе ознакомления с результатами археологических исследований на крепости Узундара и осмотра подвала 1 Скального комплекса на цитадели крепости профессор П. Лериш сопоставил его с известными памятниками Сирии и предложил свою интерпретацию его как штольни по добыче камня.
} 


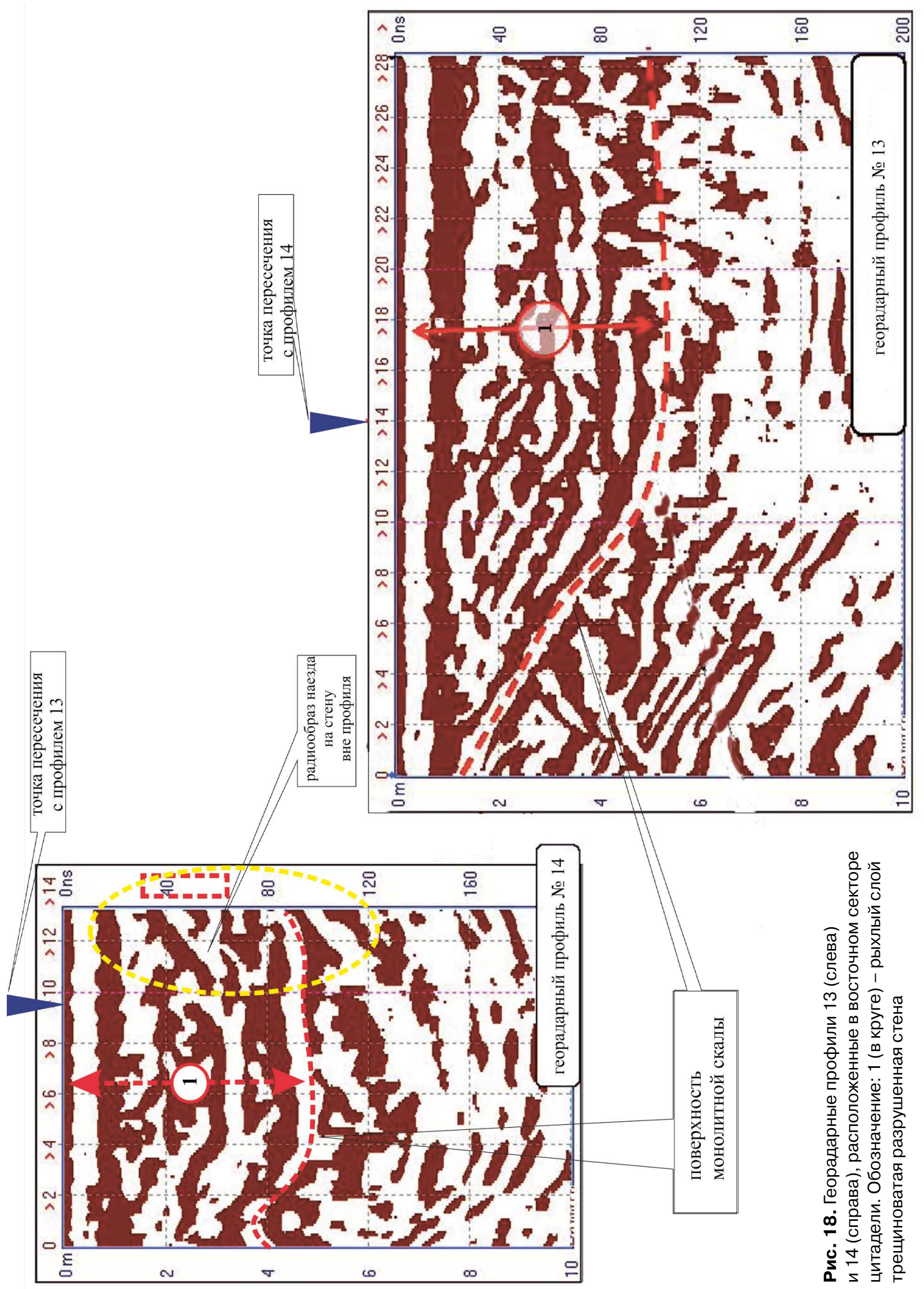




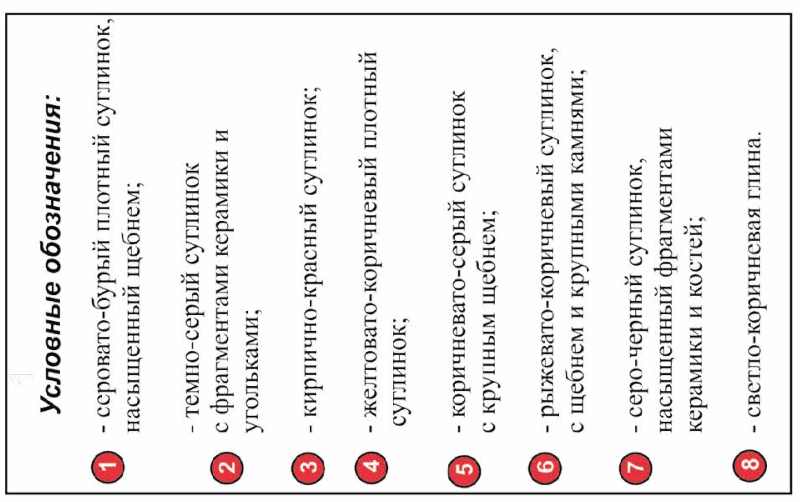

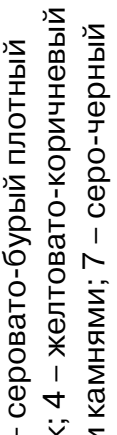

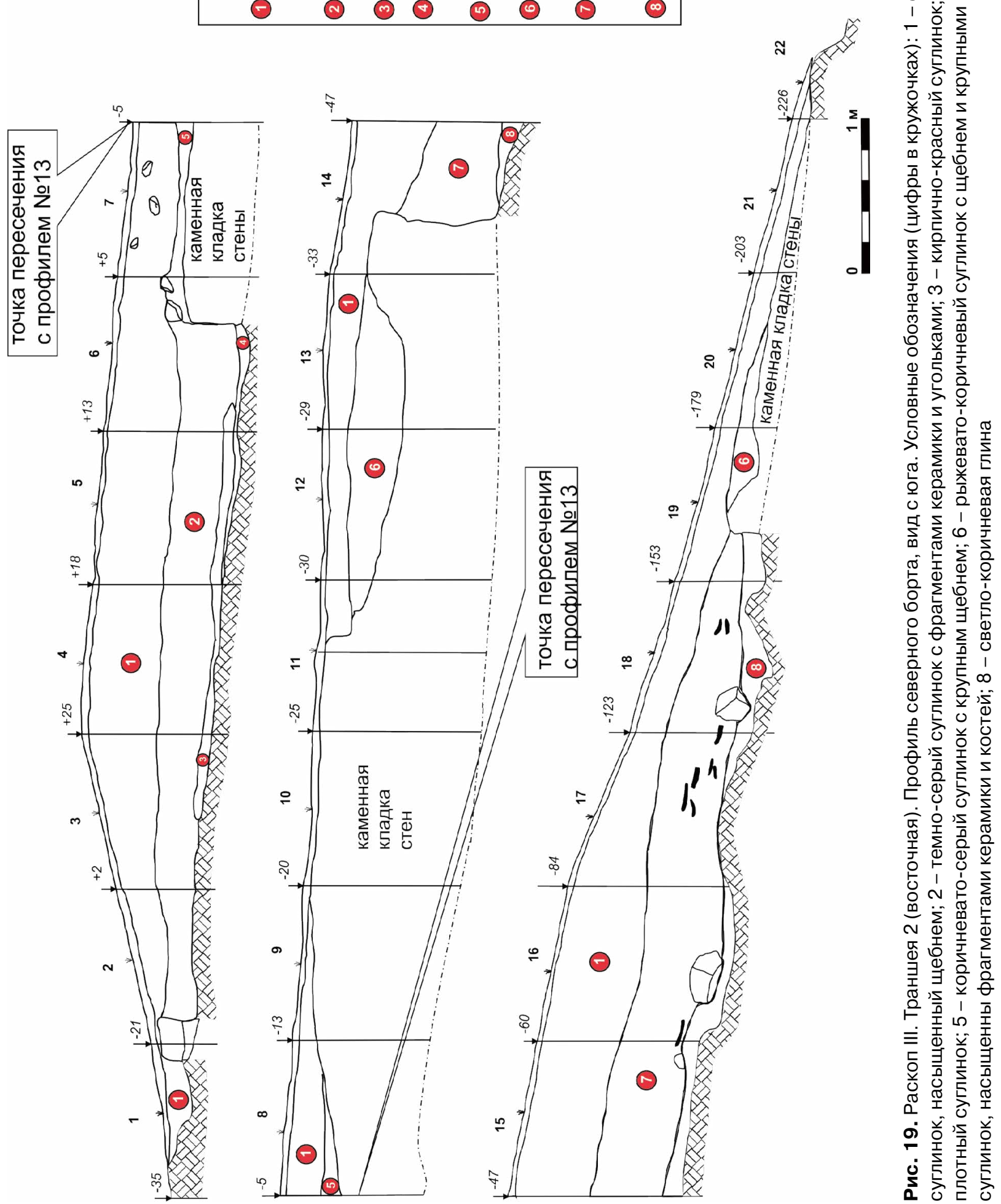




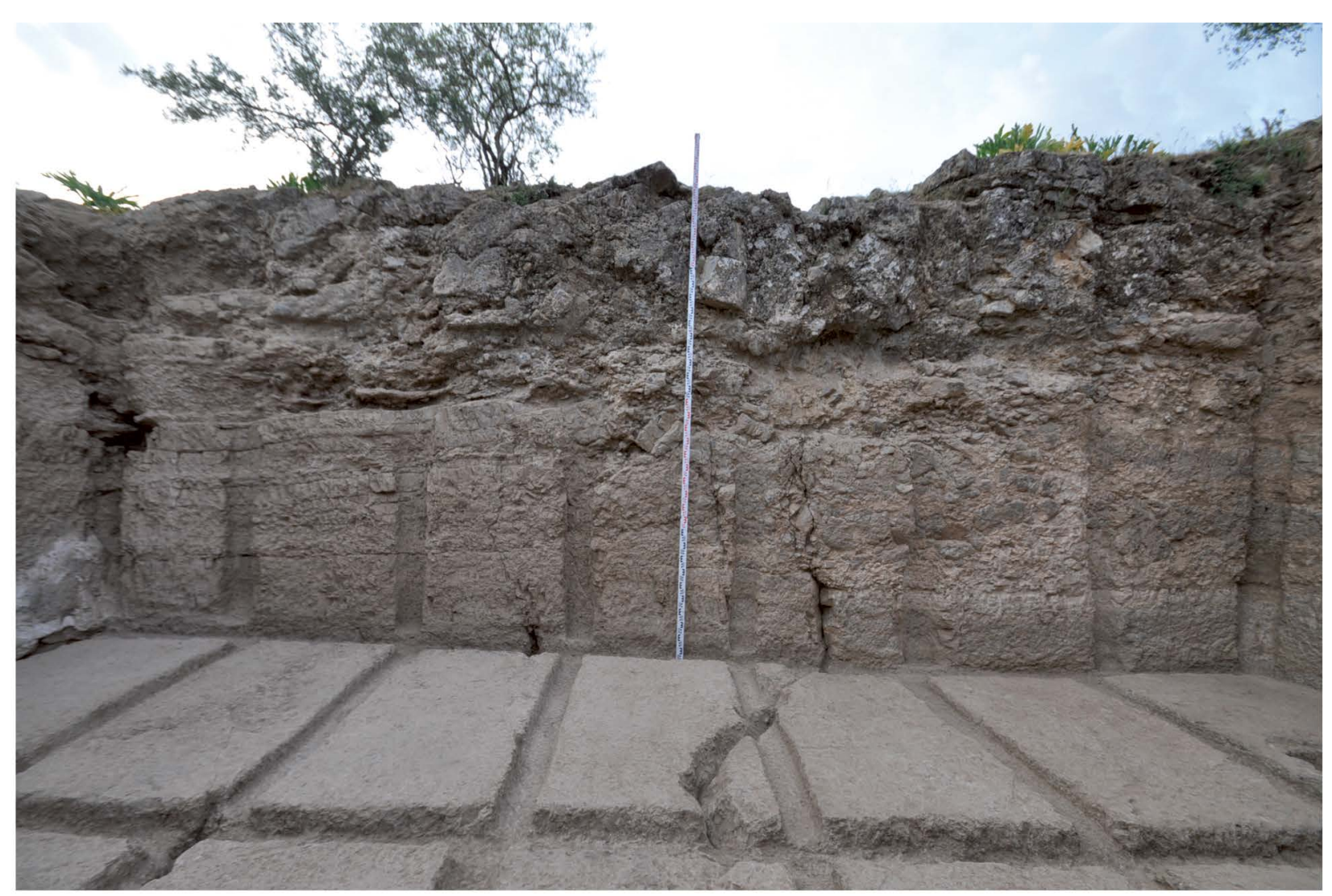

A

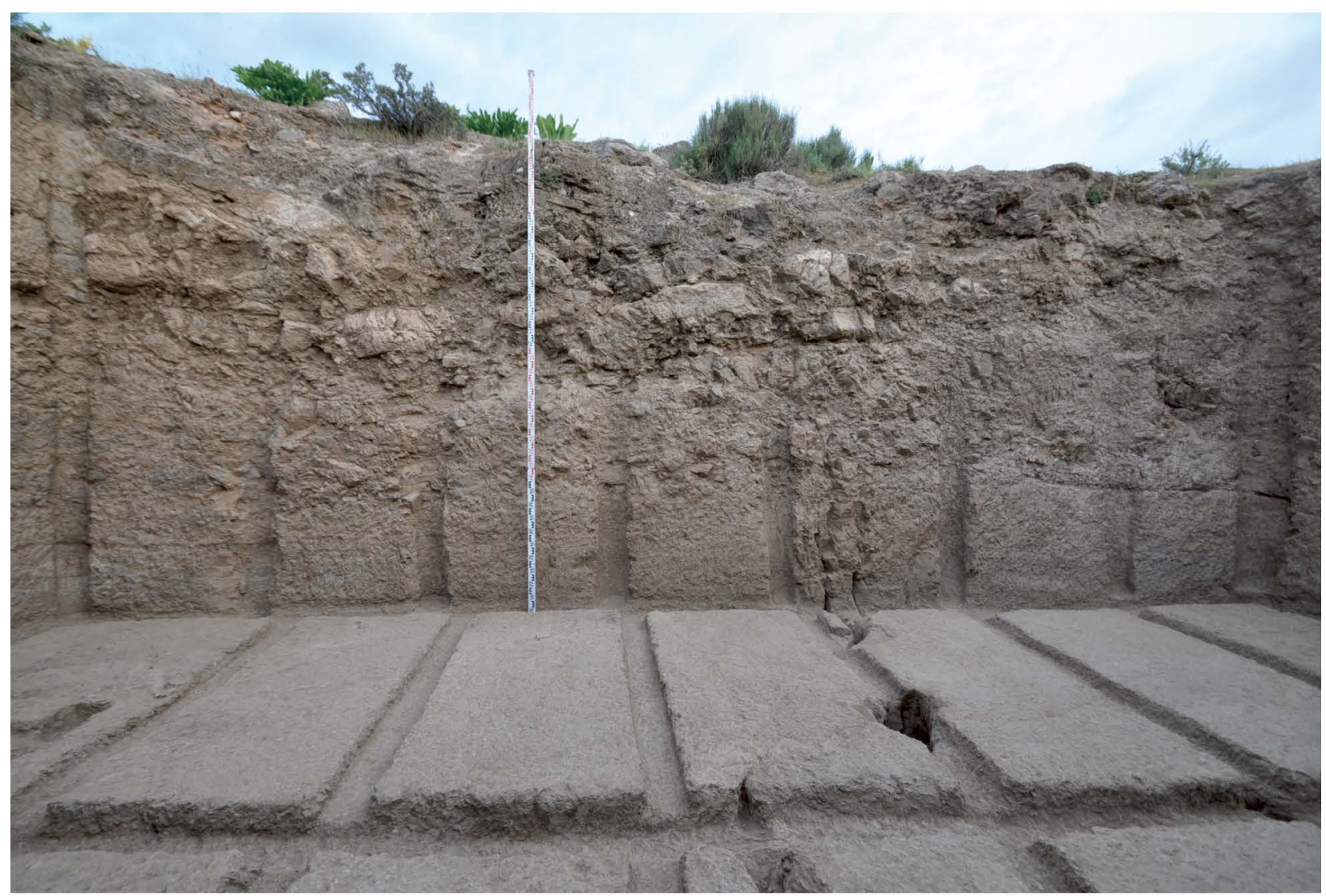

Б

Рис. 20. Раскоп III. Скальный комплекс. Подвал 1. Западная (А) и восточная (Б) стены помещения 1 


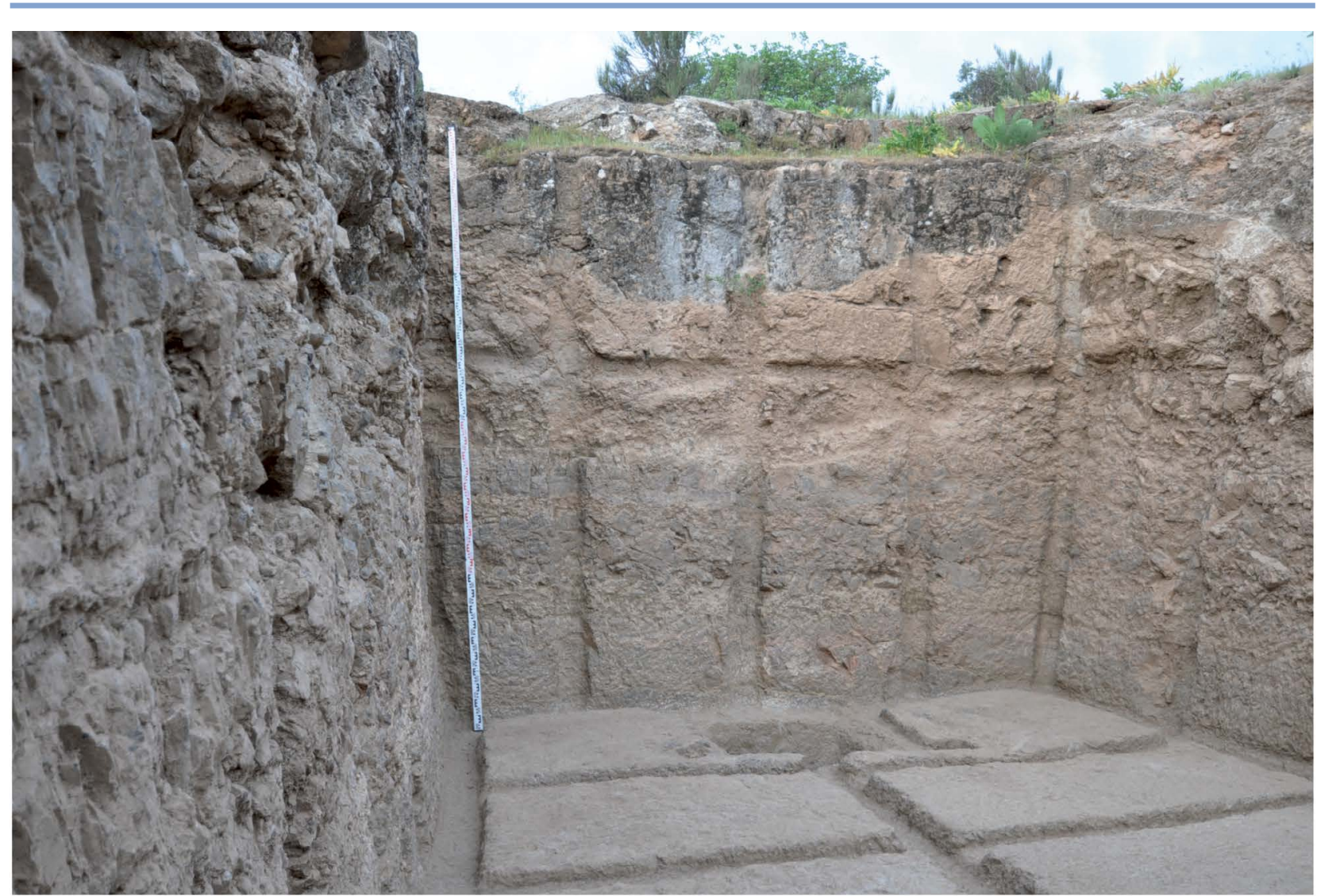

A

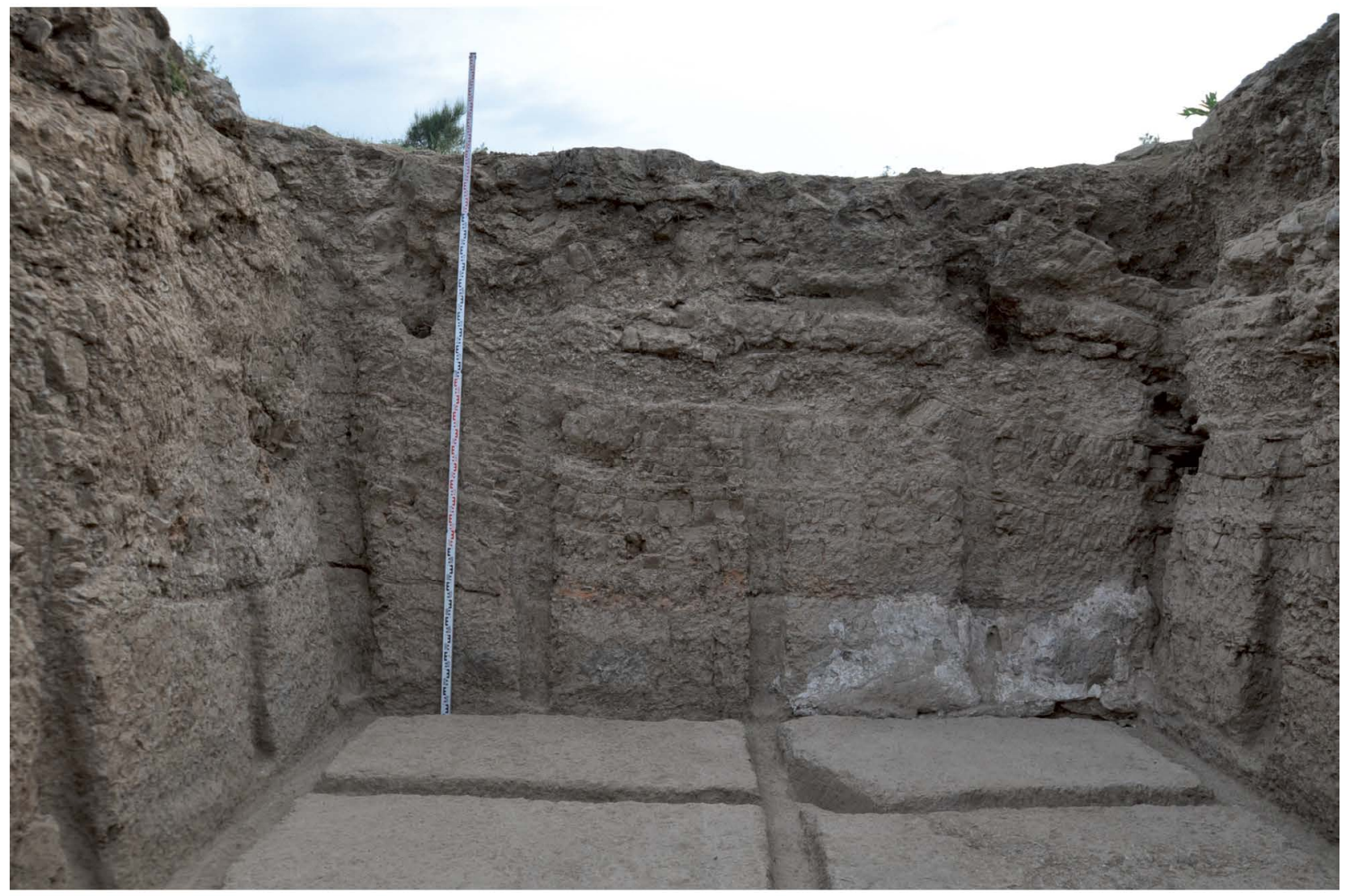

Б

Рис. 21. Раскоп III. Скальный комплекс. Подвал 1. Южная (А) и северная (Б) стены помещения 1 
аномалия с обратным направлением не вверх, а вниз с максимальной шириной до 6 м и глубиной более 10 , которая интерпретируется как колодец. Именно так выглядят ранее исследованные колодцы в Тамани и Гизе с применением прибора «ЛОЗА» (рис. 26).

Также важное значение имеет серия профилей, дающих представление о северо-восточной (профиль 15) и о северо-западной (профиль 34) угловых башнях основного четырехугольника крепости Узундара. Надо отметить, что северо-восточная угловая башня - одно из крупных фортификационных сооружений крепости. Профиль 15 , проложенный вдоль крепостной стены по ее гребню с запада на восток с небольшим отклонением к югу, имеет всего 22 м в длину и пересекает все сооружение. Георадаром зафиксированы два четко выделенных параболических всплеска, вероятно, стен. Однако расстояние между их пиками составляет всего 4 м, что мало согласуется с характером оплывов и визуально читаемым всхолмлением на месте башни значительно большего размера (рис. 27).

Северо-западная башня была обнаружена георадаром в профиле 34, визуально она практически не читалась, за исключением некоторой
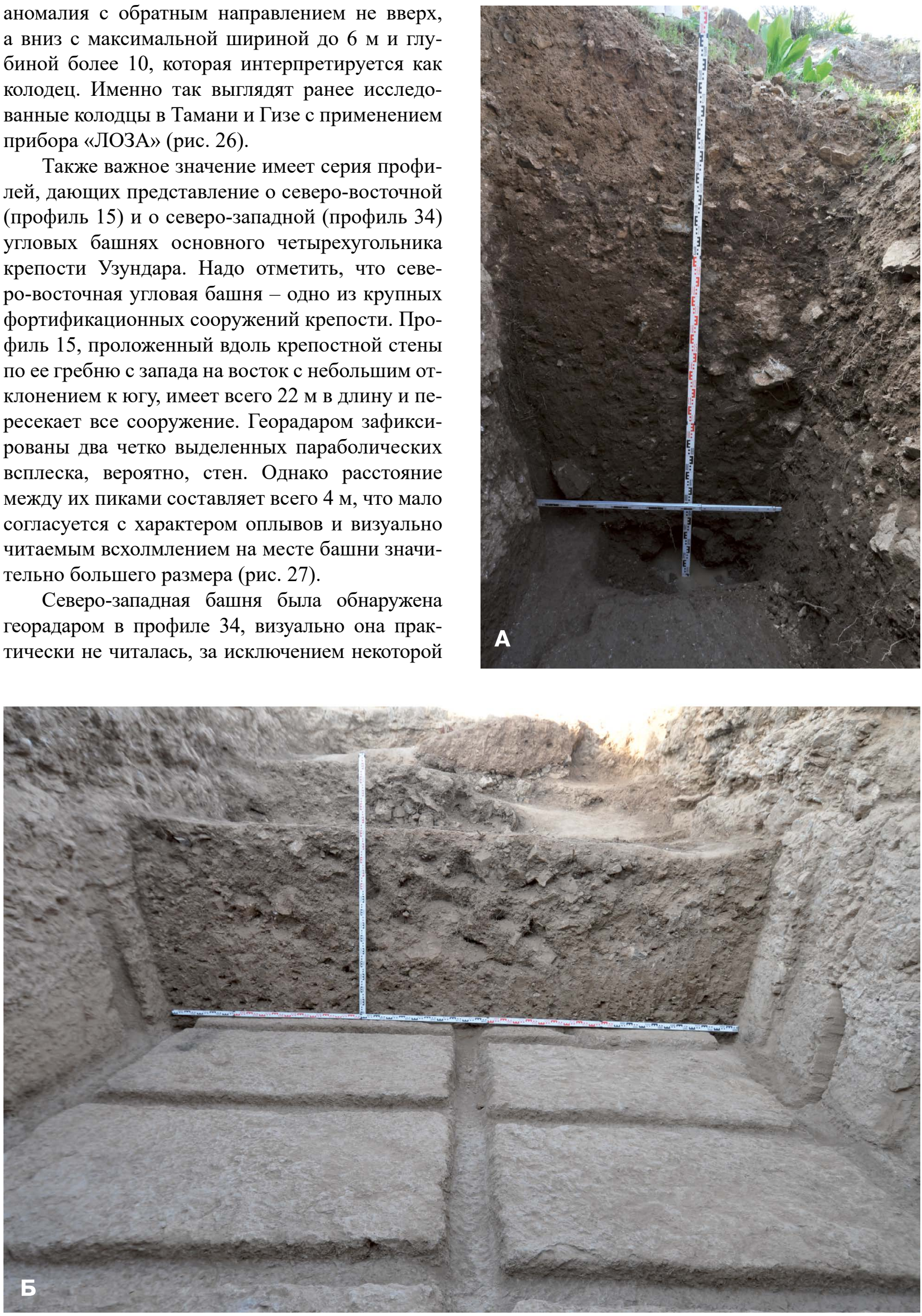

Рис. 22. Раскоп III. Скальный комплекс. Подвал 1. Стратиграфия заполнения:

А - западный профиль шурфа 1, вид с востока; Б - северный борт разреза, вид с юга 


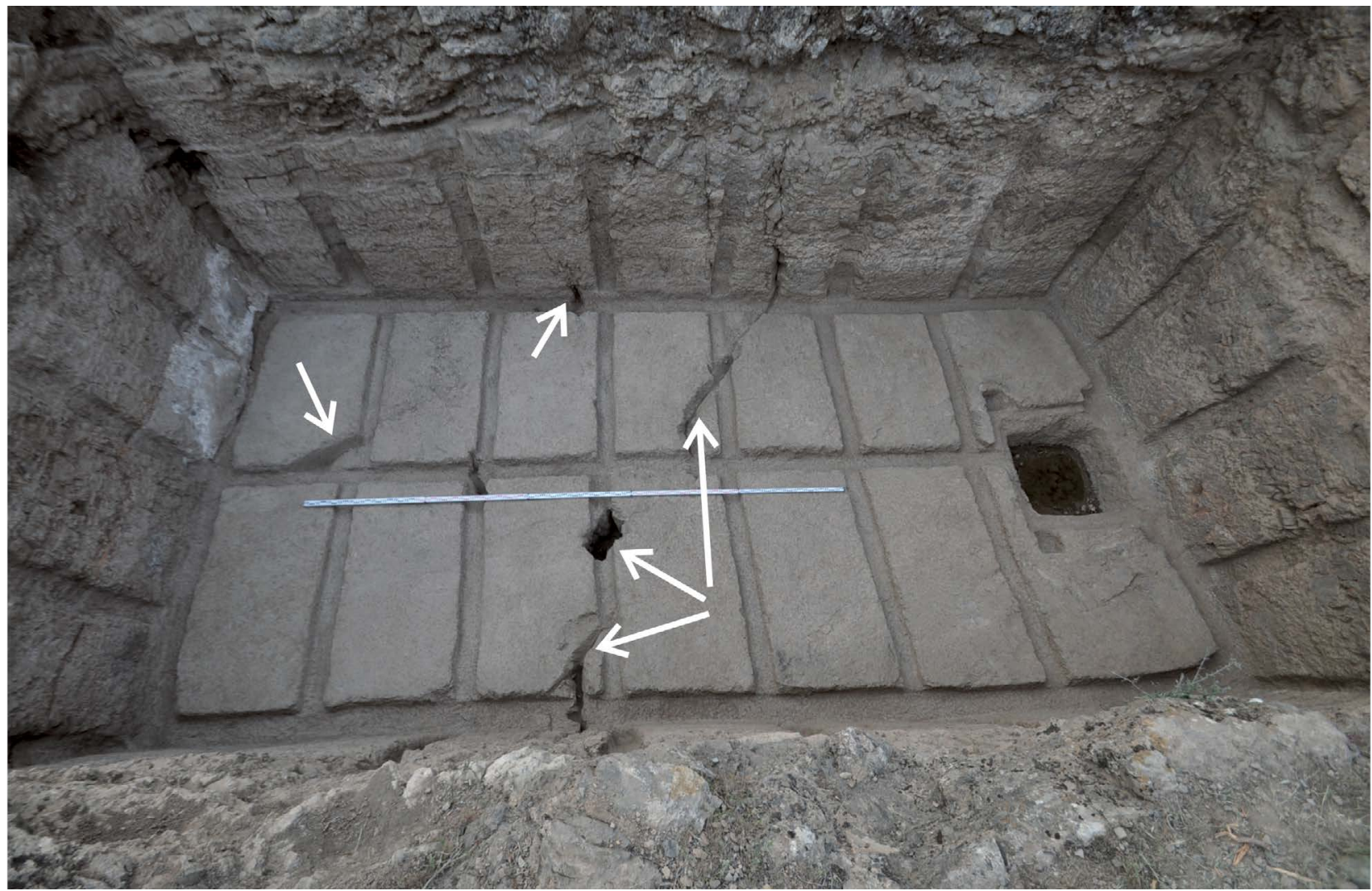

Pис. 23. Раскоп III. Скальный комплекс. Подвал 1. Дно и стены помещения на глубине 4 м с ярко выраженными трещинами и полостями. Вид сверху с западного борта

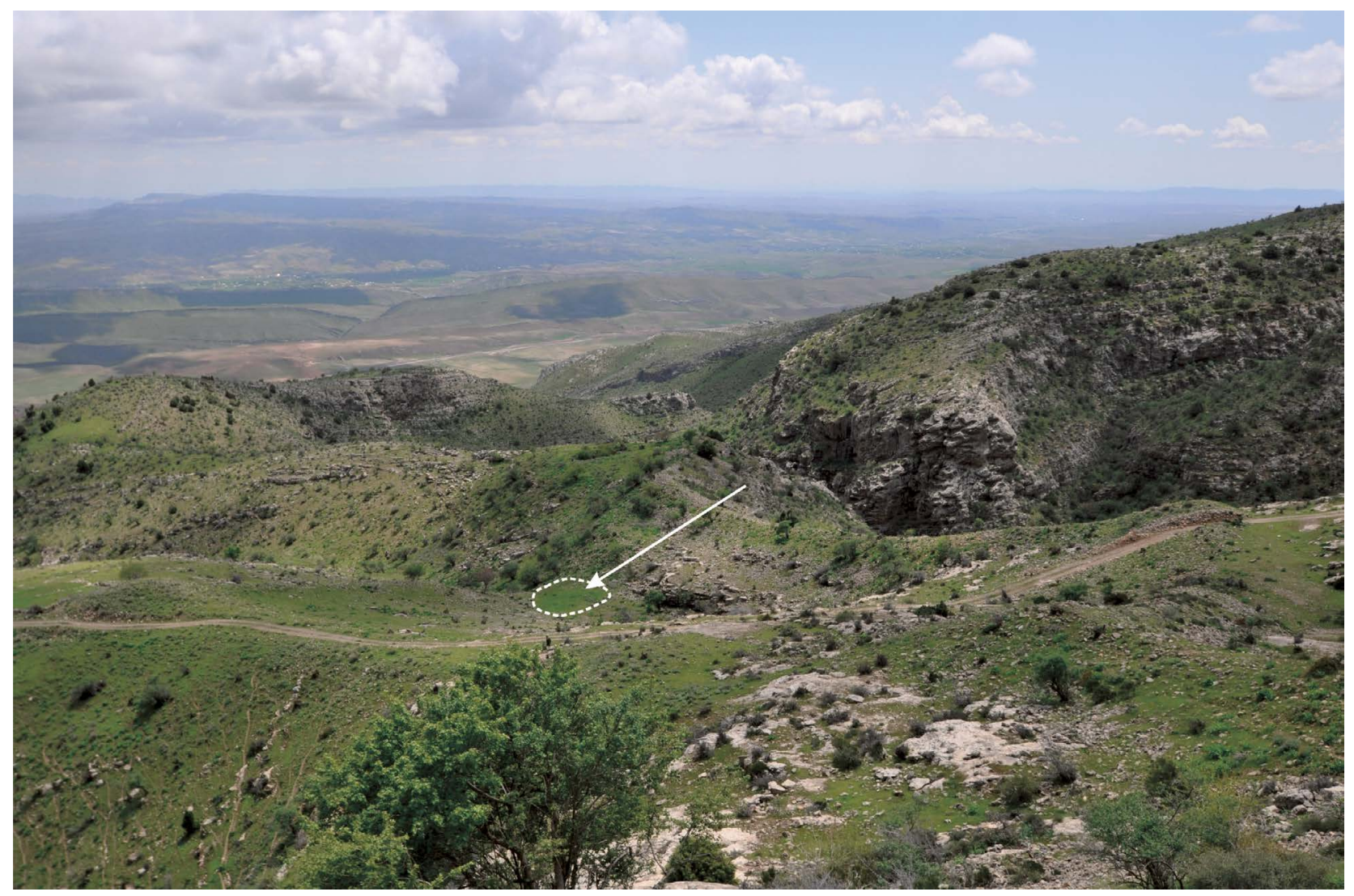

Рис. 24. Нижняя площадка у восточной крепостной стены основного четырехугольника крепости Узундара. Место наибольшей концентрации воды, вид с северо-запада с верхней башни. 2013 г. 

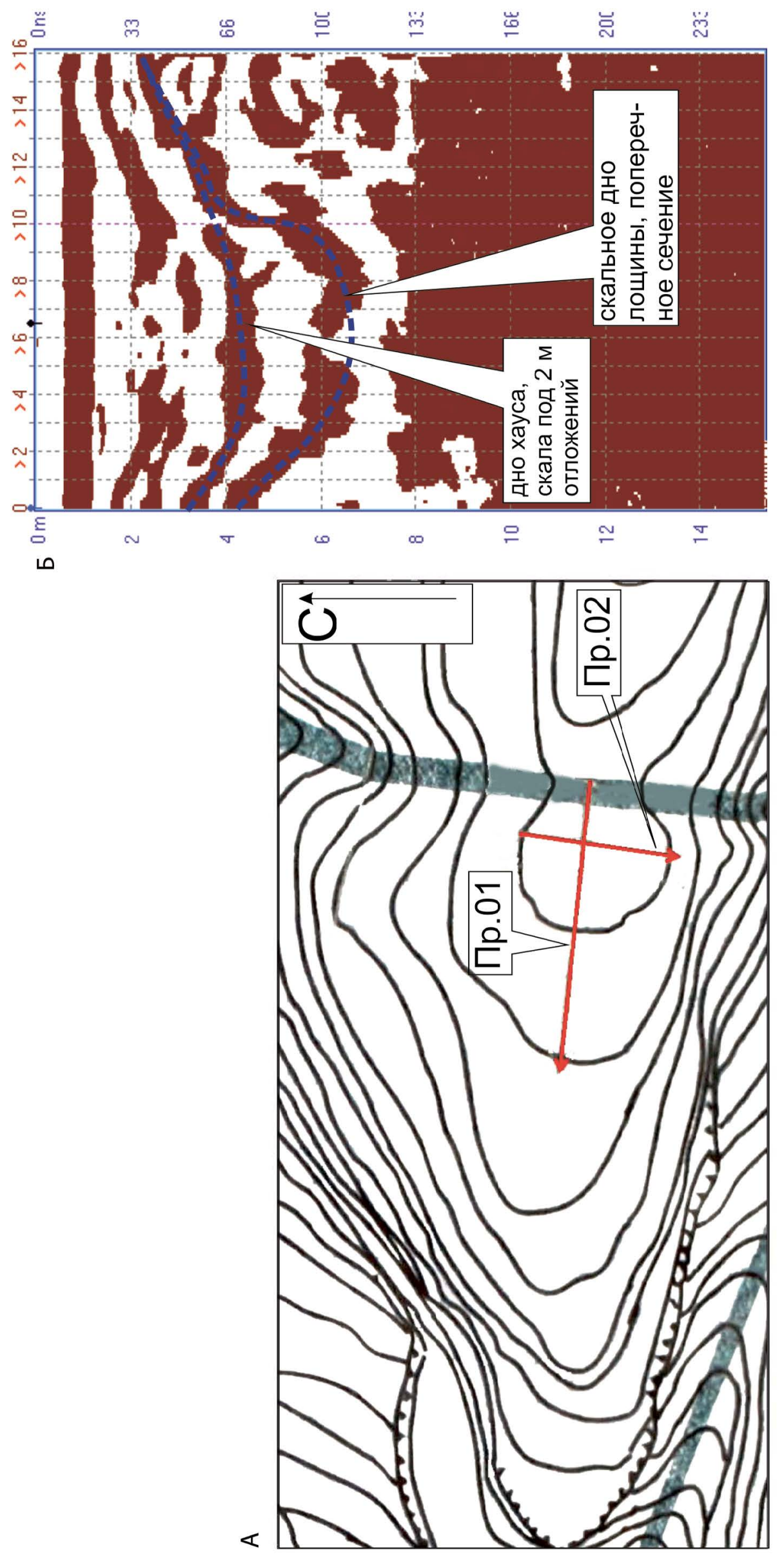

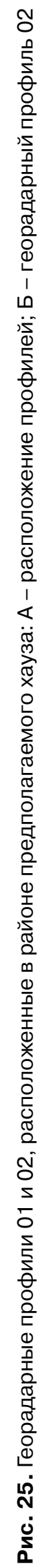




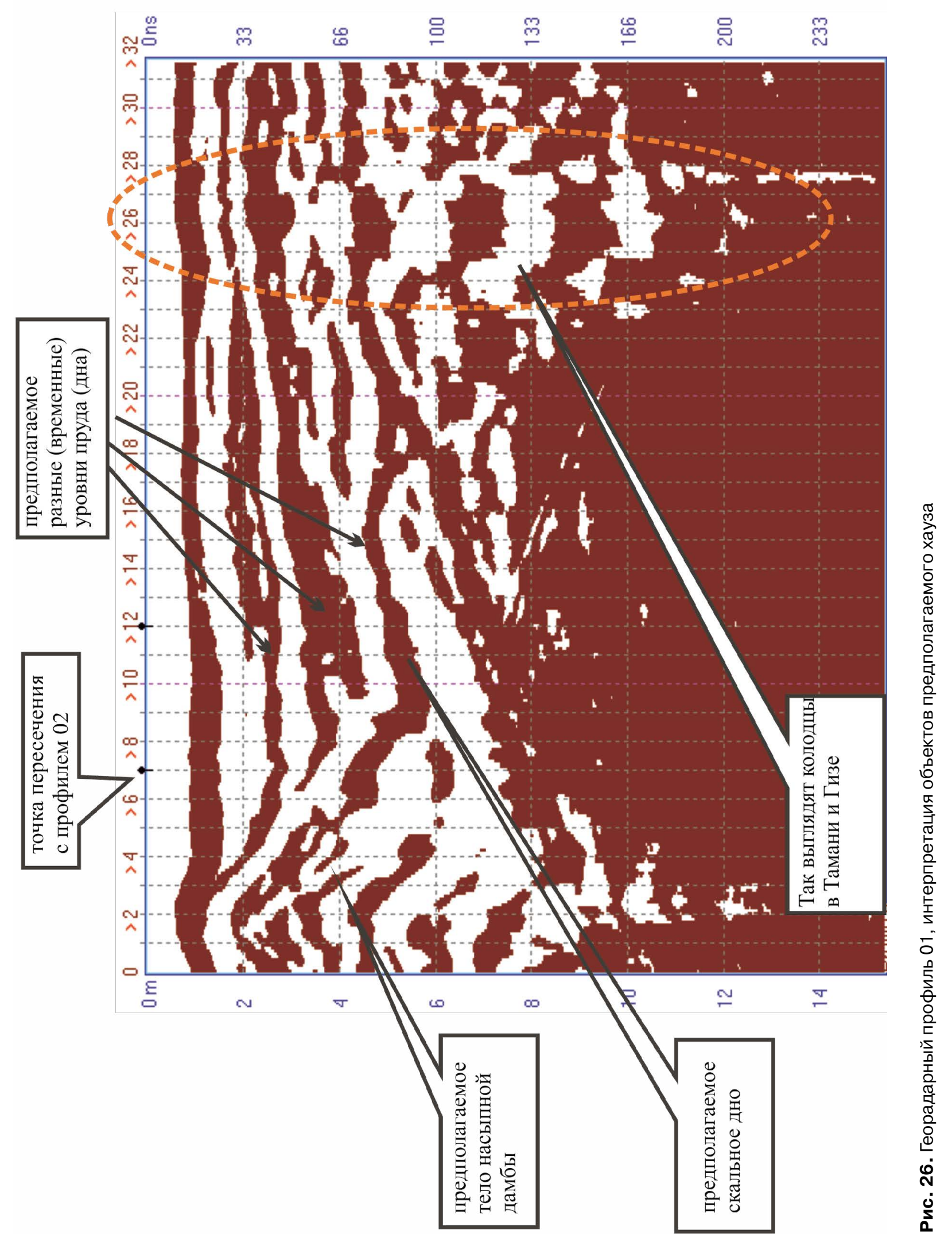




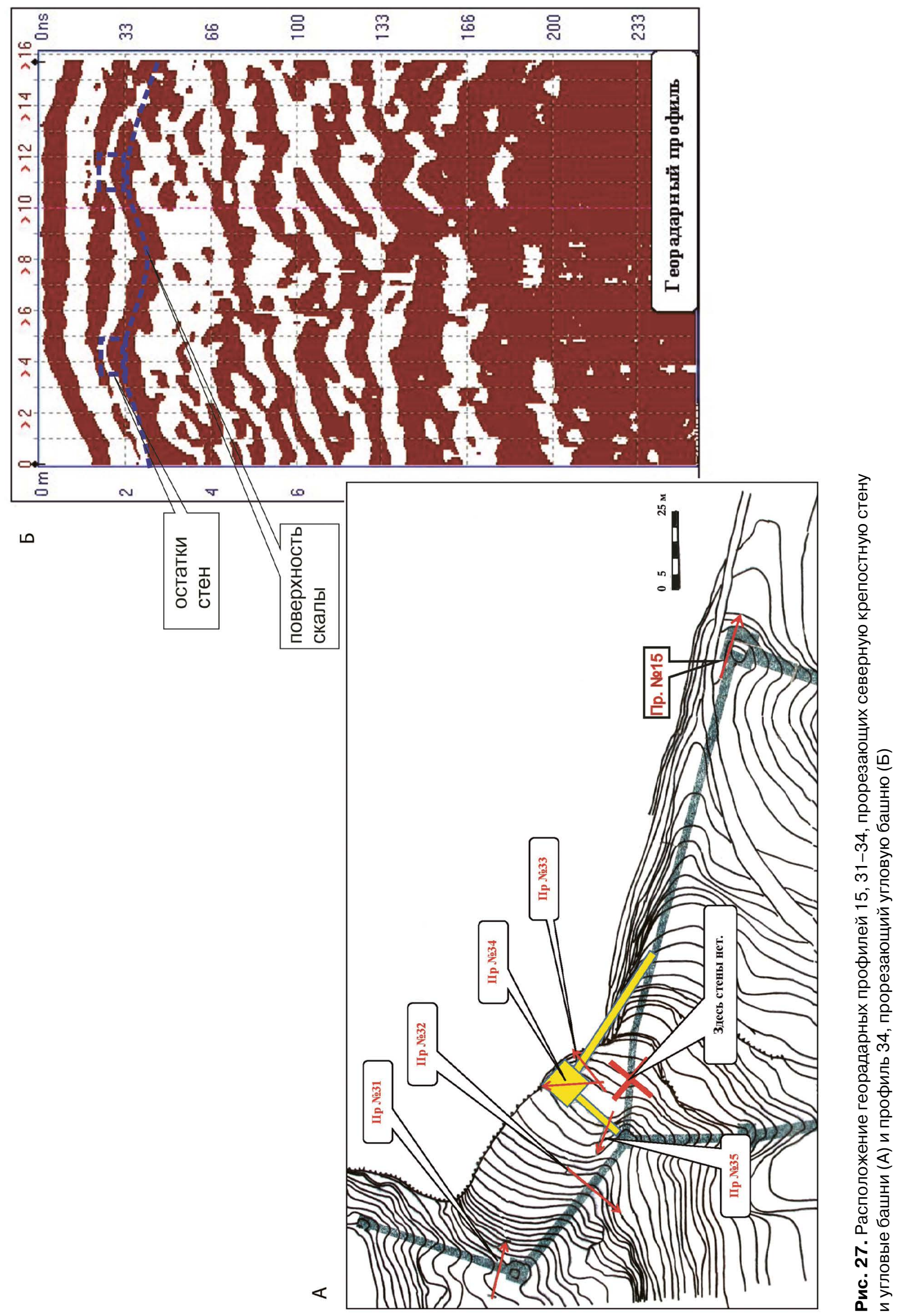




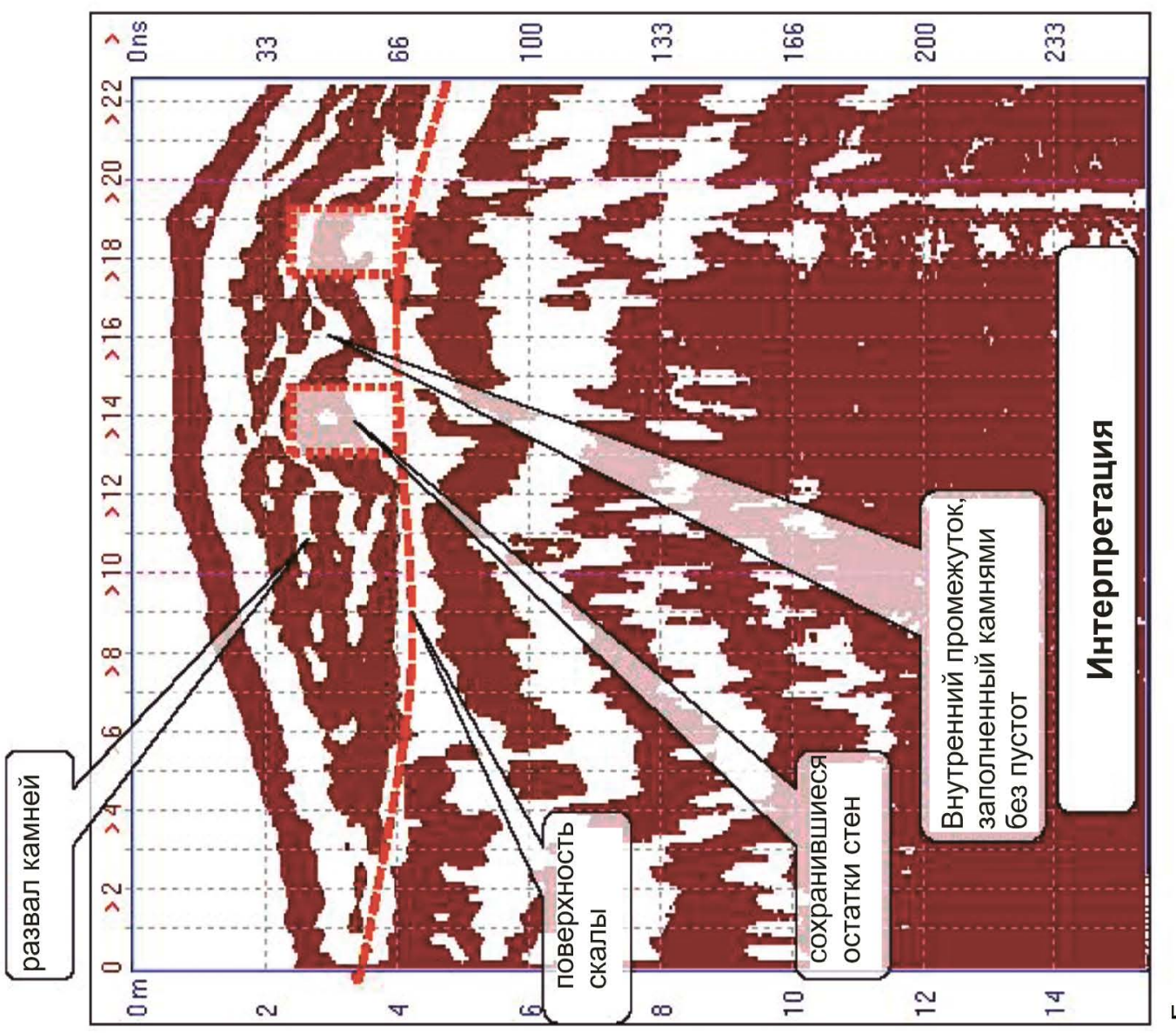

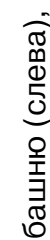

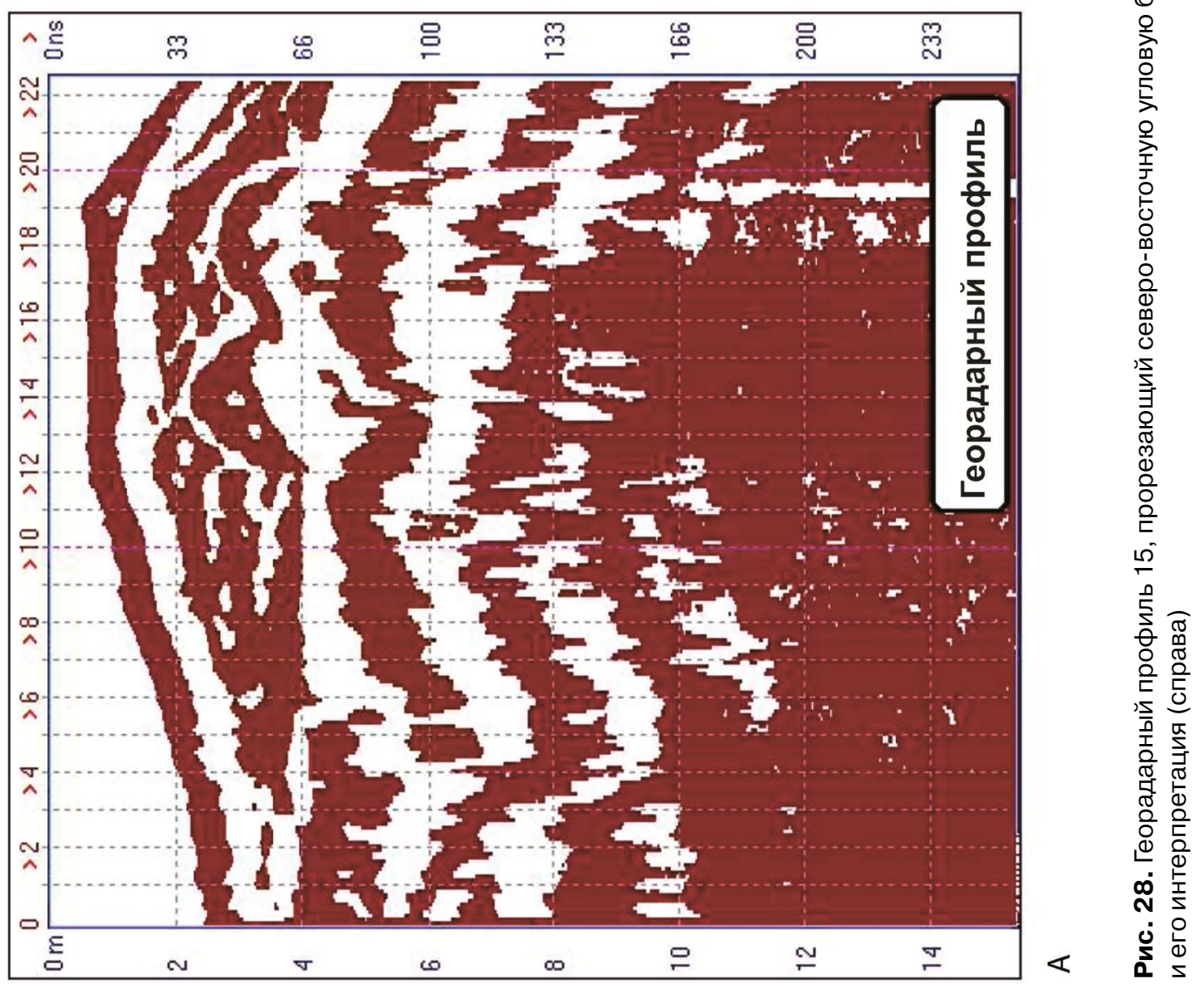


концентрации керамики на поверхности. Участок ее расположения находится у самого края отвесного обрыва урочища Кара-Камар. Профиль 34 имеет длину 16 м и направление с юга на север. Два небольших параболических всплеска, вероятно, свидетельствуют о наличие остатков стен.
Расстояние между их параболическими всплесками на профиле составляет 7 м. Исходя из логики рельефа, ограниченного с восточной стороны отвесным краем урочища Кара-Камар, можно предположить, что профиль отражает расстояние по диагонали от углов башни, по всей видимости,

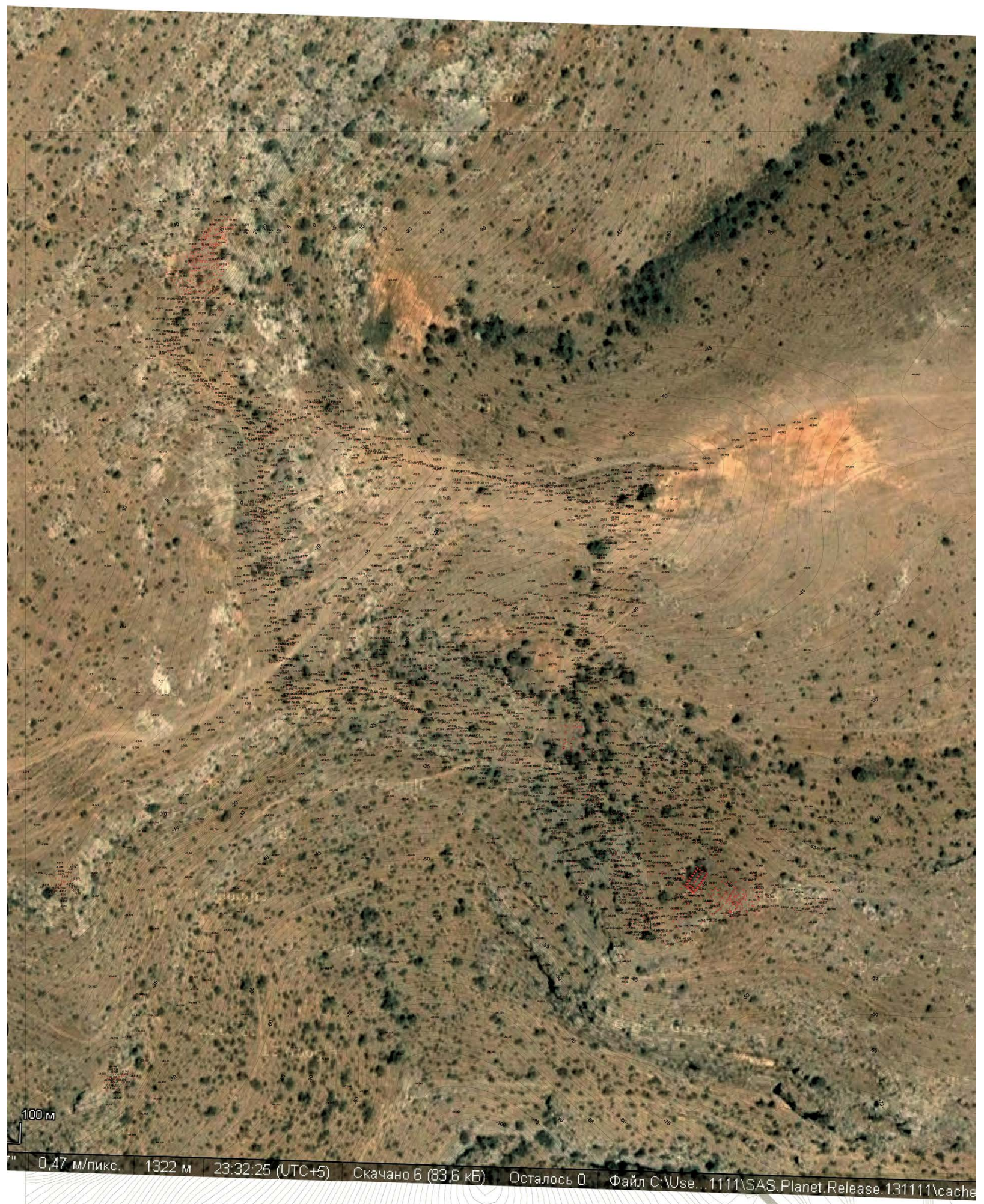

Рис. 29. Топографический план крепости Узундара.

Съемка тахеометром выполнена Д. В. и И. В. Рукавишниковыми, 2015 г. 
четырехугольной формы, что говорит о небольших размерах этого сооружения (рис. 28).

Сравнительный анализ данных археологии и георадара ярко высветил наиболее перспективные стороны применения метода, но и оконтурил его недостатки и ограничения. Так, данные профилей, сканированных на основных объектах фортификации, в частности на крепостных стенах и башнях, археологические раскопки в значительной мере подтвердили. Данные профилей, сканированных на цитадели в районе Скального комплекса, а также к востоку от него показали отрицательный результат. По всей видимости, скалы с развитой трещиноватостью являются серьезным препятствием для отражения адекватной картины и не позволяют выявить многочисленные остатки архитектурных объектов.

Исследования археологических объектов в условиях ярко выраженного горного рельефа требуют внесения некоторых новшеств в методику георадарного сканирования. В частности, сопоставление данных георадара и археологии будут в значительной мере более точными, если отойти от условной схемы прямолинейного георадарного профиля и попытаться наносить его данные на топографическую подложку исследуемого реального рельефа, отснятого теодолитом или тахеометром.
Неразрушающий принцип георадарного обследования, оперативность получения и наглядность результатов оказали большую помощь при решении задач рекогносцировки, а также в создании трехмерной модели всей крепости. Были внесены существенные коррективы в предварительную реконструкцию, основанную на инструментальном топографическом плане, в частности в рисунок северо-западного фортификационного угла крепости, где было изменено направление крепостной стены (рис. 27).

Многие узловые строения крепости еще предстоит открыть археологическими методами, и можно будет проверить данные георадарной разведки. Пока же мы имеем ряд проявившихся закономерностей в конструкции крепостных стен, башен, Скального комплекса и других объектов крепости. Данные георадаpa, полученные весной 2014 г., в долгой перспективе многолетних стационарных исследований памятника станут важным подспорьем при проектировании мест закладки новых раскопов. Кроме того, на основе более точного тахеометрического топографического плана, отснятого весной 2015 г. Д.В.и И.В. Рукавишниковыми, они по-прежнему важны в дальнейшей работе над $3 \mathrm{D}$-моделью крепости Узундара (рис. 29).

\section{Литература}

Двуреченская Н. Д., Двуреченский О. В., Мокробородов В. В., Рукавишникова И. В., Рукавишников Д. В. Маршрутные исследования на юге Узбекистана в 2013 году // КСИА. 2014. Вып. 236. С. 69-81.

Двуреченская Н.Д. Предварительные материалы археологических работ 2014 г. на крепости Узундара // Проблемы истории, филологии, культуры. 2015. № 1 (47). С. 124-133.

Двуреченская Н. Д. К методике полевых исследований в горной местности (на примере эллинистической крепости Узундара) // КСИА. 2018. Вып. 251. С. 168-180.

Двуреченская Н.Д., Морозов П. А. Результаты георадарной разведки на крепости Узундара в 2014 году // Археология и геоинформатика. Вторая междунар. конф. АГИС. Вып. 8. Москва, 2017 (DVD): file://D:/Dvurech/page1.html).

Копейкин В. В., Морозов П.А. Кормышева Э. Е., Мальх С. Е. «Возможности георадиолокации в археологии. Результаты георадарных обследований в Гизе (Каир) и Абу Эртейла (Судан)». 15-я Международная археологическая конференция «Сабейские встречи», Гос. музей Востока, Москва, 28 мая 2011 г. Доклад.

Ртвеладзе Э. В. К вопросу о петрах // Древняя и средневековая культура Сурхандарьи / Под ред. Э. В. Ртвеладзе, Ш. Р. Пидаева. 2001. Ташкент, 2001. С. 7-11.

Ртвеладзе Э. В. Александр Македонский в Бактрии и Согдиане. Историко-географические очерки. Ташкент, 2002.

Ртвеладзе Э. В., Двуреченская Н.Д. Узундара - эллинистическая крепость в Бактрии (материалы рекогносцировочноразведывательных работ 2013 г.) // Археология Узбекистана. 2015. № 2 (11). С. 37-46

Рукавишникова И.В., Мокробородов В. В., Горин А. Н., Гладченков А. А. Газкала - новый памятник цивилизации Бактрийско-Маргианского археологического комплекса // КСИА. 2015. Вып. 239. С. 72-85.

Fantusati E., Kormysheva E., Malykh S. GPR Survey and archaeological excavations at Abu Erteila (the Republic of Sudan) // New research in archaeology and epigraphy of South Arabia and its neighbors. Proceedings of the «Rencontres sabéennes 15» held in Moscow, May 25-27, 2011. Moscow, 2012. P. 165-208. 


\title{
РАЗВЕДКИ И РАСКОПКИ В НИКОЛАЕВСКОМ И УЛЬЧСКОМ РАЙОНАХ
ХАБАРОВСКОГО КРАЯ В 2002 ГОДУ
}

\author{
С. Б. Вальчак, А. А. Гладченков, Н. А. Клюев, \\ И. Ю. Слепцов, А. Р. Ласкин
}

Хабаровский отряд экспедиции Отдела охранных раскопок ИА РАН (нач. С.Б. Вальчак), в состав которого входили научные сотрудники Института истории, археологии и этнографии (ИИАЭ) народов Дальнего Востока Дальневосточного отделения (ДВО) РАН и НПЦ по ОИПИК Хабаровского края, а также, Амурский отряд (нач. Н.А. Клюев), организованный ИИАЭ ДВО РАН, в том же составе исследовательских организаций и участников экспедиции летом и осенью-зимой 2002 г. проводили разведочные работы и раскопки в Николаевском и Ульчском p-нах Хабаровского края (рис.1), которые проводились в рамках проекта «Сахалин 1» по трассе проектированного строительства нефтепровода (Вальчак, 2002; Вальчак и др., 2003; Клюев, 2002; Клюев и др., 2003) ${ }^{1}$.

Одновременно на о. Сахалин в рамках этого же проекта проводились работы отряда, деятельное участие в котором принимал Д. В. Рукавишников. Маршрут этого отряда пролегал с юга на север острова, параллельно движению наших отрядов на материке. Следует заметить, что в результате работ на материке и Сахалине были исследованы ранее малоизвестные с точки зрения археологии территории и открыты новые археологические памятники.

Данная статья посвящена результатам работ авторов по открытию и исследованию археологических памятников на территории Хабаровского края. При сплошном обследовании охранной зоны вдоль трассы нефтепровода экспедиционный отряд прошёл около 50 км. Маршрут лежал до мыса Каменный, который находится недалеко от впадения р. Нигирь в Татарский пролив (рис. 1; 2: 1), и по таёжной зоне, иногда в 10-25 км на запад от побережья Татарского пролива, западнее единственной грунтовой дороги Лазарев - порт Де-Кастри. Ранее в этом регионе детальные археологические исследования не проводились.

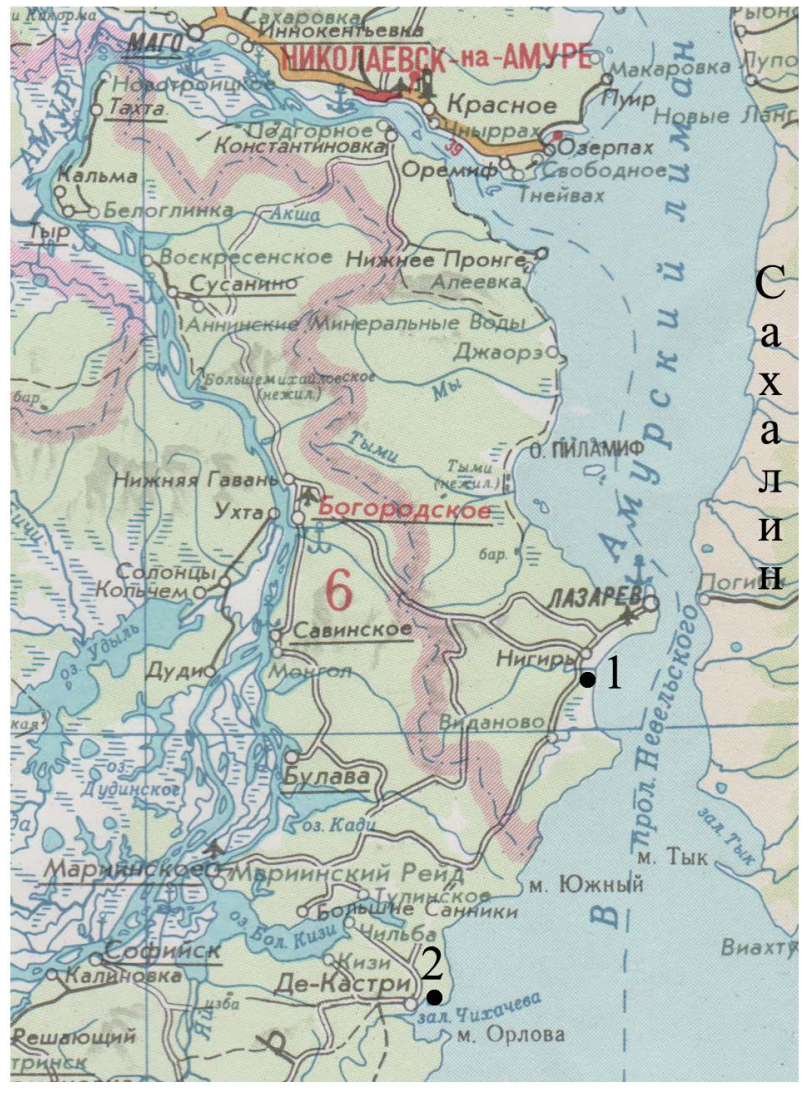

Рис. 1. Расположение исследованных памятников на побережье Татарского пролива

Цель исследования заключалась в выявлении возможных мест расположения археологических памятников. Поиск археологических памятников осушествлялся закладкой шурфов в местах вероятного нахождения памятников. Для привязки шурфов к пикетам нефтепровода и составления археологической карты в практически незаселённой тайге использовались приборы GPS.

В результате на покрытым таежным лесом южном склоне мыса Каменный была открыта стоянка Нигирь 1. Она расположена на обрывистом скалистом берегу бухты Невельского (высота над уровнем моря около 20-40 м). Стоянка

\footnotetext{
Коллектив экспедиции сердечно благодарит нашего водителя - Владимира Николаевича Стрельбицкого, вывозившего нас из сложных ситуаций и непосредственно участвовавшего в раскопках.
} 
не имела внешних признаков, вся территория заросла плотным хвойным лесом и подлеском (рис. 2: 1). Заложенные шурфы позволили выявить границы стоянки, общая площади ко-

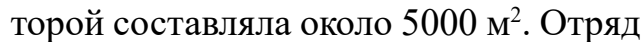
работал на площади в отведенном заказчиком «коридоре», и возможность обнаружения других вероятных местонахождений памятников археологии на прилегающих территориях у нас отсутствовала.

Среди находок в шурфах на стоянке Нигирь следует отметить заготовку микронуклеуса из ороговикованного сланца (рис. 3: 1), отщепы из яшмы с ретушью - нож (рис. 3: 2) и резец с микросколами (рис. 3: 3). Кроме того, найдены изготовленные из яшмы наконечник стрелы (рис. 3: 4) и отщепы. Всего на территории памятника (в шурфах) найдено 53 отщепа из камня разных пород и 13 мелких фрагментов $(1,5 \times 0,3$ см $)$ неорнаментированной керамики, очень «обмытой» и не представляющей возможности для какой-либо реставрации форм сосудов. В тесте керамики содержались минеральные и органические примеси, иногда наблюдались следы заглаживания на поверхности. Стоянка отнесена к неолитическому периоду.

В задачи наших исследований входило и обследование зоны строительства нефтепровода от мыса Каменного до пос. Де-Кастри (общая длина 80 км), а также территории терминала на п-ове Клыкова площадью 97 га (рис. 2: 2).

В ходе проведённой разведки обнаружен один археологический памятник - стоянка ДеКастри 3. Он располагался на краю 10-метровой террасы вдоль восточного, обрывистого берега бухты Северная в 3,75 км к северо-востоку от пос. Де-Кастри, на территории ныне существующего нефтегазового терминала (рис. 1; 2: 2).

Стоянка имела внешние признаки в виде двух округлых западин, предположительно от жилищ. Одна из них, по итогам раскопок, оказалась техногенной ямой, связанной со строительством военных сооружений в 1930-1950 гг. Их руины (бетонные бункеры, обложенные камнем или имеющие бетонную заливку окопы, траншеи, капониры артиллерийских позиций, заброшенные воинские могилы с железобетонными памятниками и т. п.) еще сохранялись во время нашего исследования.

Вторая же западина, более крупная, имела на современной поверхности диаметр 6 м и глубину до 0,4 м. Следует отметить, что на этом участке, заросшем хвойными породами деревьев, поверхностный слой не имел современных нарушений. По результатам шурфовки памятник предварительно отнесен к эпохе палеометалла. Для проведения работ участок леса пришлось вырубить, что обычно для археологических исследований в таёжной зоне.

В результате раскопок под руководством Н. А. Клюева памятник исследован полностью. 
Общая площадь раскопов и контрольных траншей составила

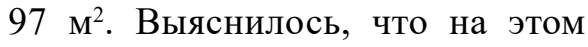
месте находилась сезонная стоянка, состоявшая из одного небольшого жилища с вынесенным за его пределы очагом. Вероятно, здесь обитала одна семья, вполне обеспечивавшая свое существование в результате охоты и собирательства в окружающей тайге, рыболовства и сбора морепродуктов на шельфе бухты Северной, богатые природные ресурсы которых были очевидны и во время наших работ. Мощность культурного слоя памятника составляла около 0,4 м от современной поверхности, что позволяет предполагать наземную конструкцию жилища, может быть, лишь слегка углублённую ниже поверхности древнего горизонта. Никаких следов древней наземной конструкции нам зафиксировать не удалось.

Археологическая коллекция с памятника включала в себя исключительно фрагменты керамических сосудов (около 250 экз.). По форме это были плоскодонные изделия со слегка отогнутым венчиком, невысокой хорошо выделенной горловиной, плавно переходящей в выпу-
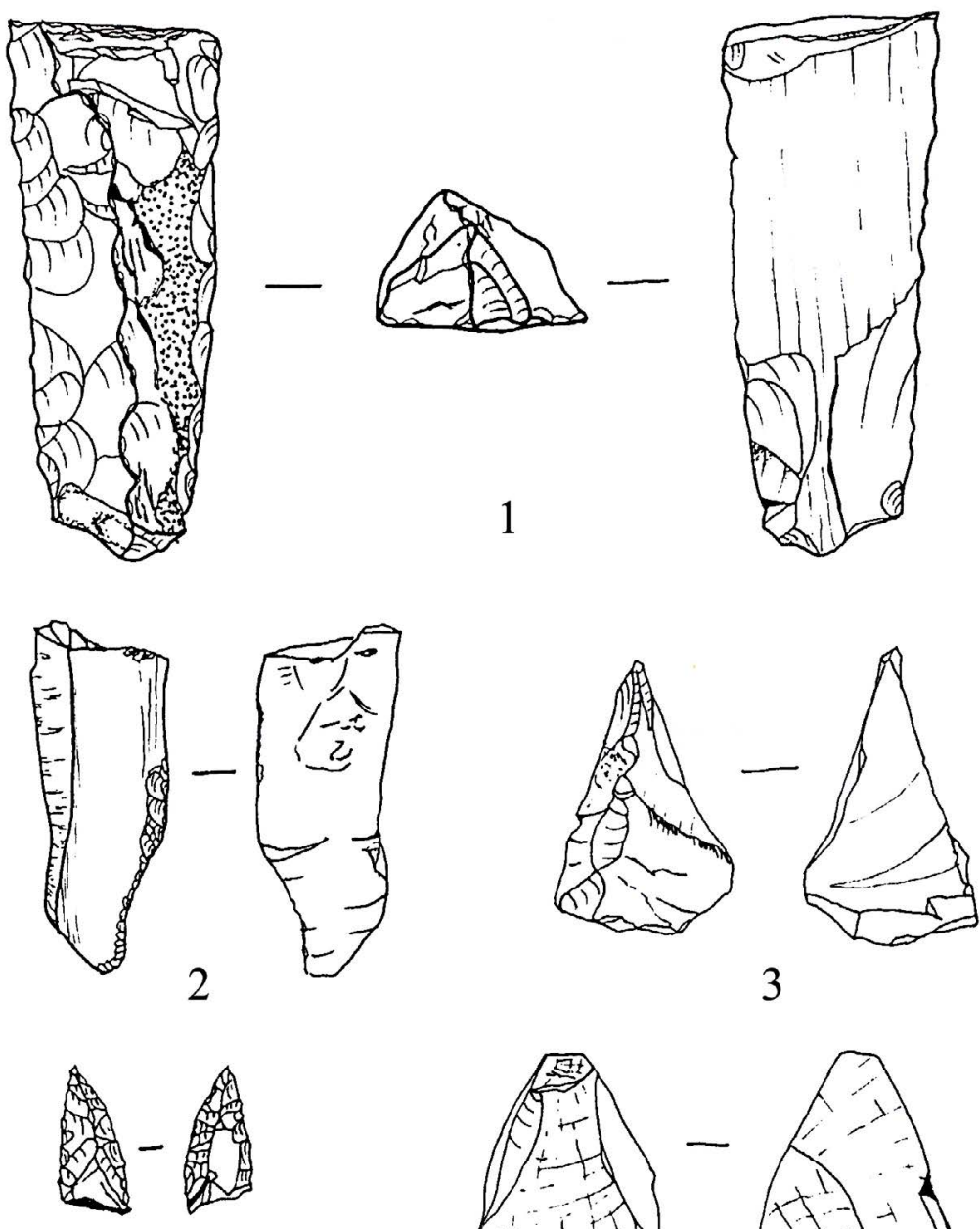

4
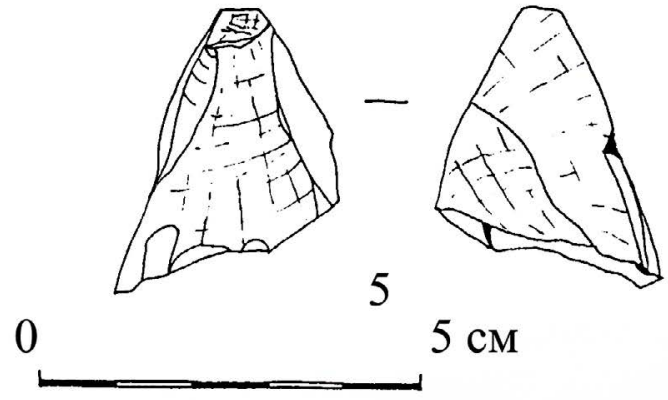

$5 \mathrm{~cm}$

клое тулово. Верхняя часть сосудов орнаментирована. Отмечен декор в виде полосы коротких и пересекающихся прямых, сверху оконтурен-

Рис. 3. Находки на стоянке Нигирь 1 ных двумя прочерченными линиями.

Иногда на уплощённую часть венчика наносились оттиски штампа-лопаточки или насечки. Встречаются и налепные валики, акцентированные сверху прочерченными линиями. Интересно заметить, что валики имитировали шнур, что достигалось нанесением на них наклонных насечек или вмятин, расположенных в шахматном порядке. Зона стыка горловины и тулова орнаментировалась единообразно, здесь обычно располагался поясок из двух прочерченных линий (рис. 4).

Описанная керамика из раскопанного памятника Де-Кастри 3 по морфологии и оформлению верхней части сосудов близка к одному из типов керамики тэбаховской археологической культуры, памятники которой известны на северо-востоке Хабаровского края, в приустьевой части Амура. Этот тип керамики получил название «эноури А» и датируется последними веками I тыс. н. э. (около VIII-IX вв.). Керамический комплекс стоянки Де-Кастри 3 очень компактен и единообразен, в нем найден один тип керамики, что позволяет предполагать его возможное культурное своеобразие.

Наличие сходных типов керамики на западном побережье Татарского пролива и юге о. Сахалин документирует миграционные процессы в сторону Сахалина носителями керамической традиции, сложившейся на материке в результате унификации традиций керамики польцевской археологической культуры эпохи палеометалла под влиянием мохэской культуры периода раннего средневековья. 


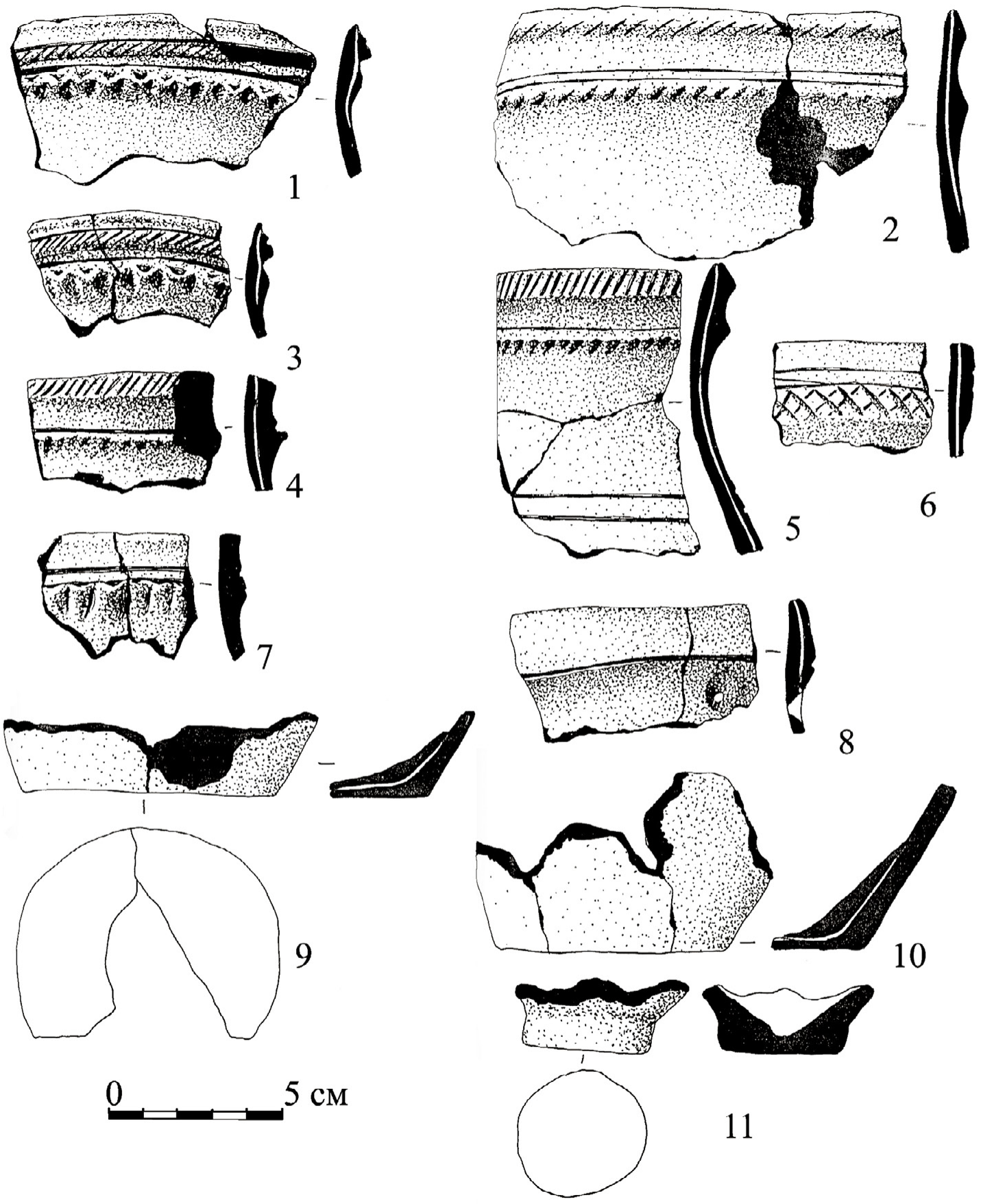

Рис. 4. Находки на стоянке Де-Кастри 3

\section{Литература}

Вальчак С.Б. Отчет об археологической разведке в Николаевском районе Хабаровского края в 2002 году // Архив ИА РАН. Р-1, № 27019.

Вальчак С.Б., Клюев Н.А., Ласкин А.Р., Слепцов И. Ю. Разведка в Николаевском районе Хабаровского края // Археологические открытия 2002. Москва, 2003. С. 339-340.

Клюев Н.А. Отчет об охранных археологических работах в Ульчском районе Хабаровского края в 2002 году // Архив ИА РАН. Р-1, № 27541.

Клюев Н.А., Вальчак С. Б., Гладченков А. А., Ласкин А.Р., Слепџов И. Ю. Охранные работы в Ульчском районе Хабаровского края // Археологические открытия 2002. Москва, 2003. С. 372-373. 


\section{ИССЛЕДОВАНИЯ 2011 ГГ. ПОСЕЛЕНИЯ ЧЕРНЯХОВСКОЙ КУЛЬТУРЫ У ПОС. ИМ. К. ЛИБКНЕХТА (ПЕНЫ) (УСАДЬБА 2)}

\section{О. А. Радюш}

Специализированные исследования, посвященные «раннеславянской», позднеримской и переселенческой проблематике, были возобновлены в Курской области после почти десятилетнего перерыва в 2003 г․ С 2005 г. по настоящее время проводятся регулярные разведки этого региона силами Сейминско-Суджинской экспедицией ИА РАН под руководством автора статьи ${ }^{2}$. Основной задачей работ стало обследование ранее неизученных территорий, выявление новых поселений и могильников и уточнение данных о ранее известных объектах. Кроме того, ряд памятников в Льговском, Рыльском, Кореневском, Беловском р-нах были выявлен курскими коллегами, ведущими хоздоговорные работы по области.

В настоящее время комплекс памятников Пены у пос. им. Карла Либкнехта является, наряду с селищем Выдрин в Большесолдатском районе, наиболее крупными из изученных за последние годы научными раскопками памятниками черняховской культуры в регионе. Несомненно, что материалы этих исследований необходимы для уточнения сложной культурной ситуации на северо-восточной границе черняховского ареала. Настоящая публикация вводит в научный оборот результаты раскопок сезона 2011 года.
Памятники III-IV вв. расположены по обеим сторонам ручья Пенка, впадающего в Сейм с юга на западной окраине посёлка им. Карла Либкнехта. Фактически поселение Пены-1 расположено на правом берегу ручья в Курчатовском районе, поселение Пены-2 и могильник Пены-3 находятся на левой стороне ручья в Льговском районе. Все изученные усадьбы располагались на вершине узкой возвышенности, тянущейся вдоль берега ручья, с северной стороны которой начиналось плавное понижение в сторону небольшого заболоченного сезонного озерца, с южной более крутое понижение в сторону поймы реки. На отдельных участках фиксировались материалы эпохи бронзы, наиболее масоовые находки были на его северной оконечности, занимающей высокую пойму Сейма, вероятно к этому же периоду можно отнести и многочисленные кремневые отщепы в раскопах. Следует отметить, что глубокая распашка участков, исследованных раскопками, была начата относительно недавно, около 10 лет назад. Во второй половине XX века здесь находились фруктовые сады, а ранее, в 1990-х - начале 2000-х гг., на этом месте были огороды местных жителей. Со второй половины 2000-х гг. распашка ведется дисковыми боронами, что ускорило разрушение верхней части культурного слоя.

\footnotetext{
Р Раннеславянской экспедиции ИА РАН под руководством А. М. Обломского, который в 2003-2004 гг. обследовал нижнее и среднее течение р. Свапы, и несколько памятников в верховьях реки Прутище (Веретюшкин, Обломский, Радюш, 2005).

2 Хочется особенно отметить, что в первых разведках, связанных с черняховской и раннеславянской тематикой, которые были начаты автором в 2004 году, активное участие принимал Дмитрий Рукавишников. Фактически эти работы, начиная с 2004 по 2007 гг., выполнялись нами совместно одним отрядом, часть разведки проводилась на памятниках в Воронежской и Белгородской областях на Тихой Сосне и Осколе, представлявших научный интерес для Димы, вторая часть выездов была посвящена Посеймью. Дружба связала нас и с курчатовским краеведом Александром Афанасьевичем Катуниным, в сотрудничестве с которым были обследованы первые поселения в Курчатовском районе. Так в 2005 году было зафиксировано одно из крупнейших поселений черняховской культуры на Сейме на границе Курчатовского и Льговского районов на балке Пенка, получившее название Пены (пос. Им. К. Либкнехта). В 2006 году нами были открыты вторая часть поселения и могильник на противоположной стороне балки. Практически все полевые работы в это время планировались совместно и результаты их и перспективы также обсуждались с Дмитрием. Последний такой выезд состоялся весной 2007 года и был связан с разведкой по проектируемой трассе дублеру М-2, где отряд под руководством Димы и Ирины Рукавишниковых обследовал Белгородский отрезок, наш отряд - Курский и Орловский, после чего мы встретились в урочище Красная Горка под Орлом, где несмотря на сильный дождь мы традиционно отметили день рождения Димы. Позже, уже в 2011 году, он как гость приезжал в экспедицию на Пенах, а в 2014 году на новый памятник в Большесолдатском районе. Осенью 2013 года благодаря Диме и П. Л.Воровскому (ООО «ВНИИСМИ») удалось провести первые геофизические исследования на поселении Выдрин и на месте находки «Старосуджанского клада» 1918 года в д. Большой Каменец. В 2014 г. мы последний раз встретились в поле во время раскопок нового поселения Дальний (Выдрин) у д. Большой Каменец.
} 


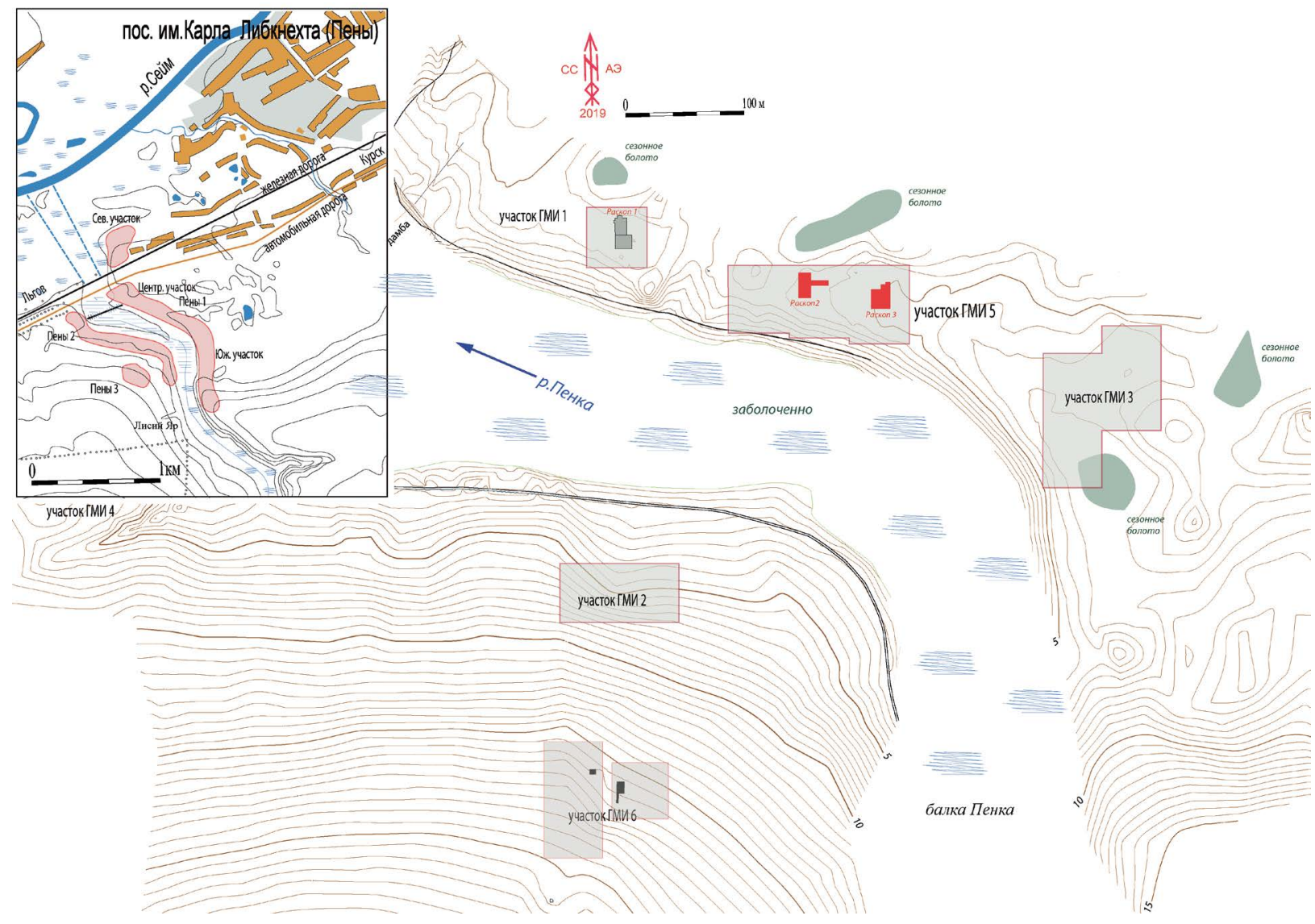

Рис. 1. План Поселения и могильника Пены (пос. им. К. Либкнехта) с указанием участков, обследованных В.Г. Бездудным геофизическими методами

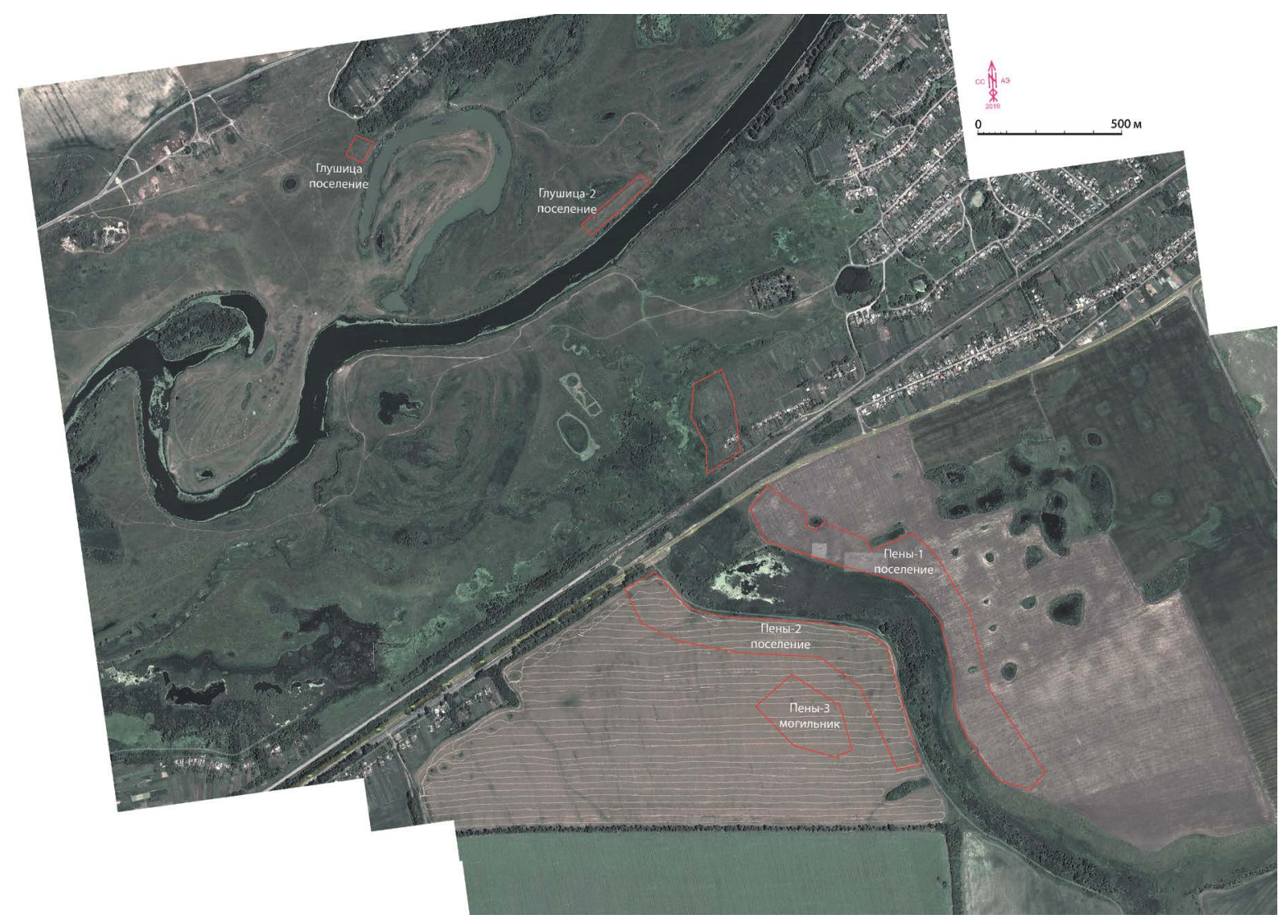

Рис. 2. Комплекс памятников Пены на космоснимке (сервис Google maps) 
Все три раскопа велись на правой стороне (Пены-1), тогда как на левом берегу раскопками изучался только могильник. Каждый из них находился на расстоянии 50-100 метров от другого, что позволило обозначить каждый из них как условную усадьбу $(1,2,3)$.

Усадьба 1 раскопана в 20072008 гг. общей площадью 324 кв. м. Подробные результаты первых двух лет раскопок (2007-2008) на поселении Пены были опубликованы $(\mathrm{Pa}$ дюш, 2010). В дальнейшем, в 2009-

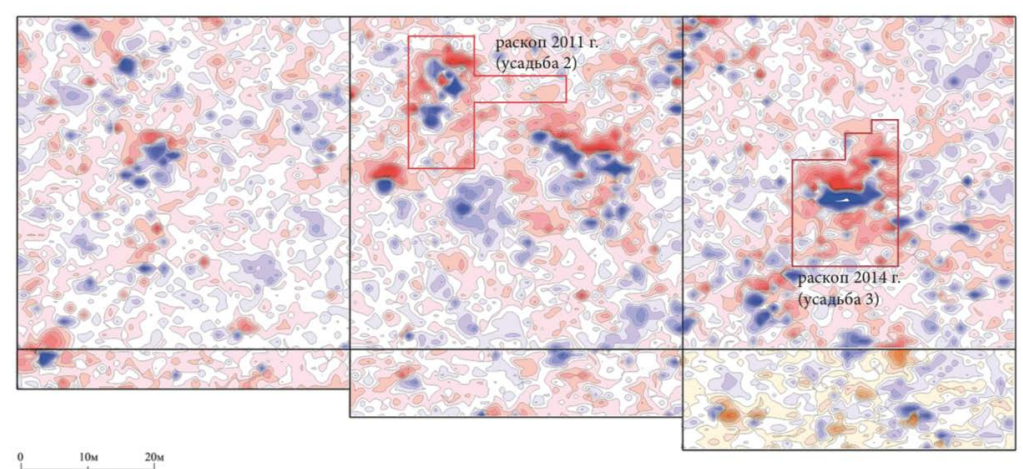

Рис. 3. Участок 5 геофизических исследований с контурами раскопов «усадеб» 3 и 4
2013 гг. были раскопаны участки

усадеб 2 и 3 , а также исследованы 4 погребения по обряду кремации, обнаруженные на территории близлежащего могильника (Радюш, 2011). В настоящей публикации приводятся сведения об основных результатах раскопок этих двух усадеб.

Усадьба 2 раскопана в 2011 г. общей площадью 256 кв.м. Раскоп имел Т-образную форму. Магнитометрическая съемка (Рис. 3) точно показала крупные скопления обмазки размерами, которые были близки к реальным контурам сгоревшей обмазки от стен на месте постройки $(10-13 \times 8-9$ м $)$.

Стратиграфия Раскопа 2 (рис. 4). Поверхностный слой представлен дерновой прослойкой толщиной $0,1-0,2$ м. Под ним располагался слой темно-серого чернозема мощностью 0,1-0,2 м, относящийся к пахотному горизонту. Наиболее насыщенный культурный слой в виде темнобурой гумусированной супеси имел толщину 0,4-0,8 м. Именно в нем располагались основные скопления обмазки постройки. Пол постройки стратиграфически не прослеживался. Остатки стен в виде прослоек плотно спрессованных фрагментов обожженной обмазки выявлены на глубине 0,2-0,4 м от современной дневной поверхности. Наибольшее количество находок относилось к первому, второму и в меньшей степени третьему пластам. В четвертом встречались единичные находки, в пятом-седьмом, который относится уже к предматерику, фрагменты керамики и индивидуальные находки могли быть принесены грызунами. Предматериковый слой желтая слабогумусированная супесь. Нижние пласты - 0,2-0,5 от материковой поверхности были в практически полностью перемешаны деятельностью землероев. Мощность культурных напластований в целом достигала 1,4 м. Распространение фрагментов сосудов в этом горизонте неравномерно, наиболее насыщены квадраты к югу юго-запада от завала стен постройки (42 188 фр-тов), и восточные (кв. 6,19, 20, 24 - от 70 до 100 фр-тов). Насыщенность слоя составила в среднем 10-15 фрагментов на метр квадратный, до 25-45 фрагментов в нескольких квадратах.

После зачистки первого пласта на поверхности отчетливо прослеживались полосы мелкодисперсной обмазки, оставшиеся от верхней части глинобитных стен постройки, подвергавшиеся распашке, имевшие ширину 1540 см. Зафиксированы они были как по линии север-юг, так и по линии запад-восток. Все выявленные полосы располагались в центральной части основного раскопа в кв. 40-43, 45, 46, 48. $\mathrm{B}$ отличии от постройки на усадьбе 1 , слой завала обмазки стен оказался менее мощным, в то же время он образовывал достаточно ровное скопление по всей площади. Судя по отсутствию мощных руин от стен, аналогичных постройке 1 усадьбы 2, в данном случае стены могли быть лёгкими плетнёвыми с небольшим слоем обмазки.

В первом пласте находки немногочисленны, и представлены шестью предметами (нож (Рис. 14:26): пряжка (Рис. 14:8), три грузила (Рис. 8:5), массивный фрагмент жернова (Рис. 12:5). Расположены они были равномерно по всей площади раскопа. Курпные фрагменты круговой и лепной посуды были отмечены по южной линии основного раскопа. Обнаружена одна амфорная стенка.

На уровне второго пласта выявлена основная часть завала обмазки постройки (рис.4), который был заполнен обмазкой в основном средней (3-5 см) и мелкой фракции (0,52 см), встречались и многочисленные обломки крупной фракции (10-20 см). Пятно обмазки вытянуто по линии север-юг, достаточно четко прослеживалась вся границы завала. Размеры пятна $12 \times 7,5$ м. В южной части завала в кв. $2,3,41$, 


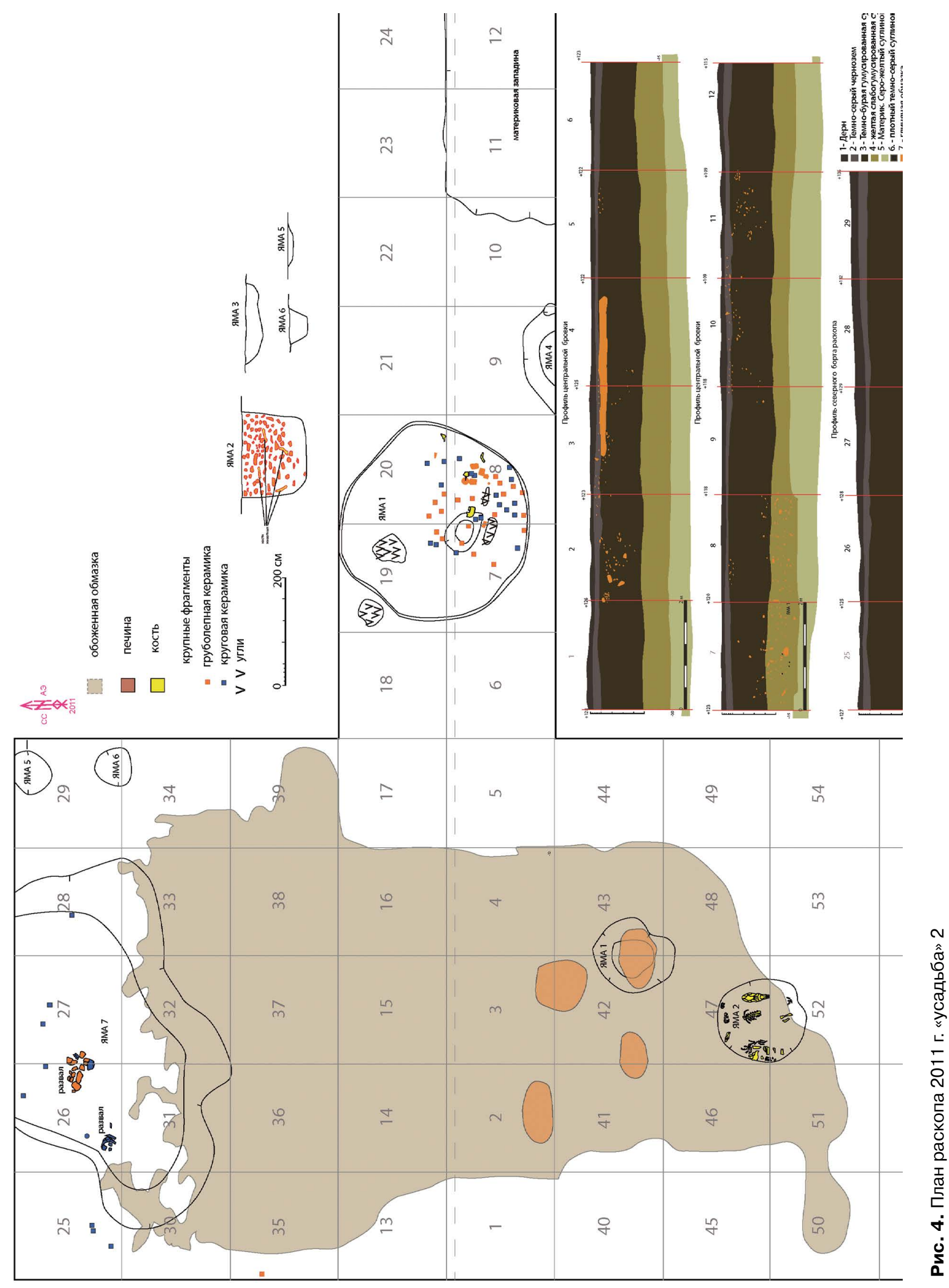


42, 43 непосредственно на поверхности выявлены четыре глиняных вымостки, которые имели размеры: $1,2 \times 0,7$ м (кв. 2 ); 0,8 $\times 0,8$ м (кв. 3 , $42) ; 0,6 \times 0,4$ м (кв. 41, 42); $0,8 \times 0,7$ м (кв. 42, 43). Мощность обмазки здесь достигала 0,2-0,4 м, более плотная верхняя часть толщиной до $10 \mathrm{~cm}$, была частично задетая распашкой, ниже обмазка представлена мелко и среднедисперсными фракциями с встречающимися отдельно крупными (до 20 см фрагментами). После расчистки поверхность бугристая. Вымостки представляли площадки подовальной формы из обоженной глины (рис.4), мощностью 5-7 см. Судя по их расположению над завалами стен, нельзя исключить того, что они были созданы уже после разрушения постройки. К сожалению, зафиксировать эти конструкции удалось лишь частично, так как они были разрушены местными мародерами, которые в одну ночь после их расчистки уничтожили часть бровки и все вымостки.

Массовый материал распространялся равномерно, наибольшая насыщенность в центральных и северных квадратах (кв. 35-37, 39), в районе самой постройки (кв. 41-44, 46-47), и на ряде квадратов восточной прирезки (кв. 6-8, $10,11,19)$. Наименьшее содержание фрагментов в квадрате 50, 55, 9, 21 (0 экз), наибольшее в кв. 42 (172 экз). Слой вокруг завала стен постройки в целом однороден, следует отметить лишь два углистых пятна пятна в кв. 19 восточной прирезки, мощностью 3-5 см. Размеры пятен $40 \times 45 \mathrm{~cm}$ и $65 \times 75$ см. В квадрате 26 в северной части раскопа в 1 и 1,5 м от края обмазки обнаружены развалы лепных и сероглиняных круговых горшков, кувшина, тарных сосудов (скопление 1, pис. 5: 1, 7). При этом остатки широкогорлого кувшина (рис. 7:1), находящиеся на юго-западе кв. 26, располагались компактно, скопление же остальных сосудов были растянуты на площади $70 \times 50$ см (рис.4). К северу от постройки также встречались отдельные крупные фрагменты сероглиняной круговой посуды в кв. 25-27.

Непосредственно в слое завала обмазки обнаружены: кремневый отщеп; обломок лезвия железного ножа (Рис. 14:25); пять обломков грузил (Рис. 8:4); пряжка железная (Рис. 14:9). Кроме вышеперечисленных вещей к второму пласту также относились: кольцо железное (Рис. 14:16), кремневый отщеп, клюковидная булавка (Рис. 14:17), двенадцать грузил и их небольших обломков (Рис. 11:2; 11:8), заготовка из кости, пряслице (Рис. 13: 7).

Дальнейшая разборка слоев шла с сохранением останца завала обмазки для изучения и фиксации стратиграфии под объектом. Слой ниже завала также оставался практически однородным, сильно разрушенным деятельностью землероев, без каких-бы то ни было объектов. Ниже 0,8-1 м слой из черноземного переходил в желтоватую слабогумусированную супесь, значительно разрушенную землероями (пестроцвет). Фактически уровень дневной поверхности находился, вероятно, на уровне - 40-60 см от современной поверхности, на котором были выявлены развалы и скопления фрагментов посуды. Практически на аналогичном уровне фиксировались мусорные выбросы вокруг постройки 1 усадьбы 1 (раскопки 2007 г.). Дно постройки в раскопе не удалось проследить, по всей видимости она не была долговременной, и вероятнее всего не являлась
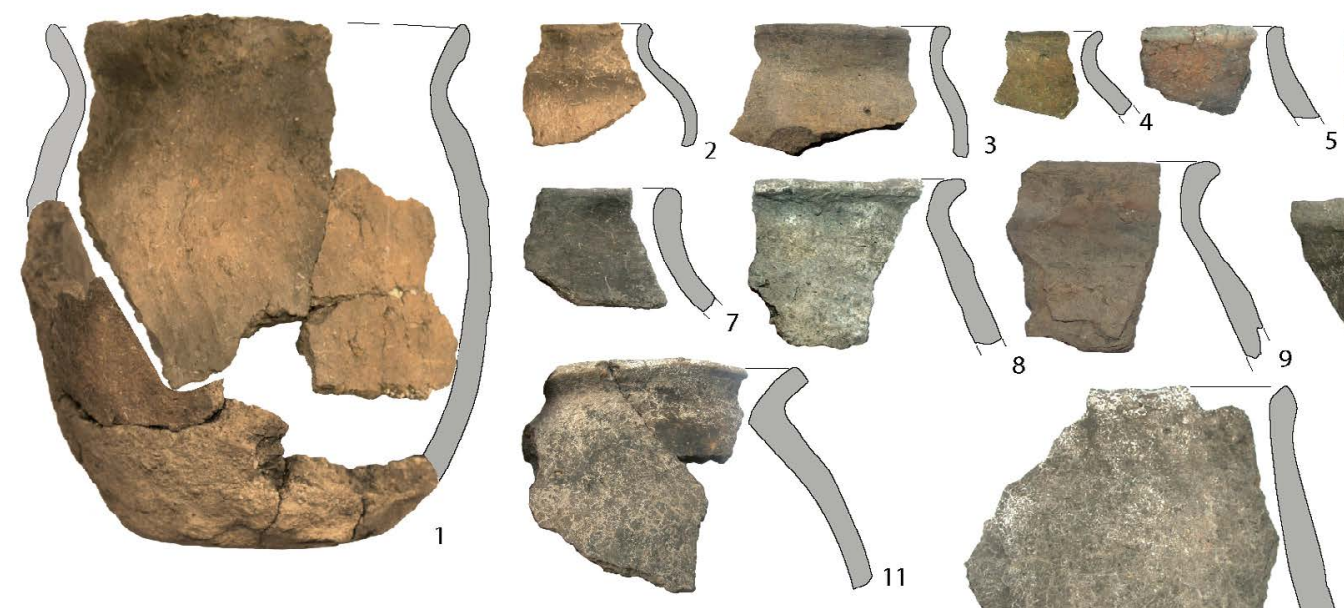

0 $10 \mathrm{~cm}$

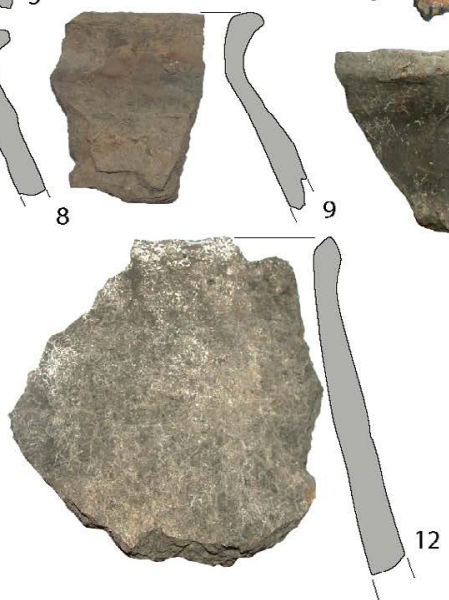

Рис. 5. Профильные фрагменты груболепной посуды позднеримского времени 


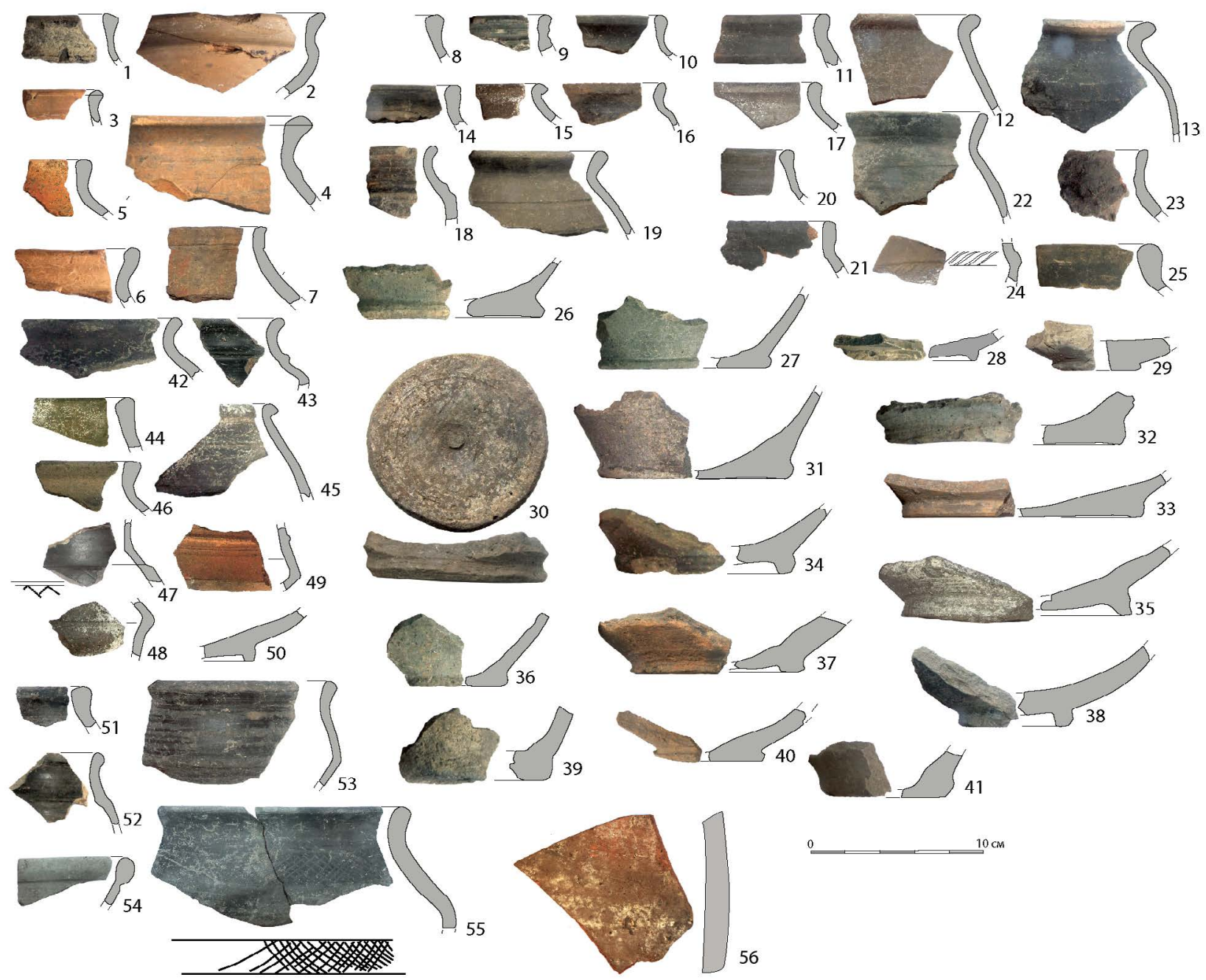

Рис. 6. Профильные фрагменты круговой шероховатой, серо- и чернолощеной посуды черняховской гончарной традиции

жилой. Нельзя исключить, что эта особенность связана и с большей глубиной раскопа 2011 г.

На уровне третьего пласта прослеживались очаги мелкодисперсной обмазки под постройкой 1 , однако все они были аморфными и не создавали каких бы то ни было конструкций. В восточной прирезке в кв. 19 и 7 отмечено углистое пятно, размерами $0,8-1 \times 0,7$ м. В кв. 38 отмечен развал лепного горшка (Рис. 5: 1), а на границе кв. 47, 48 скопление фрагментов от круговых и лепного сосудов. Концентрация массового материала неравномерная. Полностью отсутствовали находки во многих квадратах, расположенных под завалами обмазки (кв. $31,32,14,15,16$, $4,2,41)$, повышенные концентрации материала отмечены к северо-востоку от границ обмазки (кв. 33, 38, 39), в южной части основного раскопа (кв. 50,56$)$ и в квадратах, расположенных над ямой 1 и соседних с ними (кв. 18-22, 5-9).

Небольшие концентрации находок можно отметить под завалами постройки 1 в центральной и южной ее частях, а также к юго-западу от нее (кв. 3,40$)$; в восточной прирезке над ямой 1 в кв. 19, 20, 7, 8. Под обмазкой были найдены: одно целое и три обломка от пирамидальных грузил (Рис. 8:2). Семь находок отмечено над ямой 1 в восточной прирезке: три обломка от пирамидальных грузил; ножеподобное изделие или заготовка (Рис. 14:23), обломок кольцевидного грузила (Рис. 11:6); нож (Рис. 14:24).

Кроме того, в заполнении третьего пласта были найдены: обломки двух кольцевидных (Рис. 11:9) и семи пирамидальных грузил, биконическое пряслице с насечками (Рис. 13:2), обломок бронзовая пластинки, обработанная кость (Рис. 14:33), подвеска секировидная железная (Рис. 14:3).

На уровне пласта 4, как описывалось выше, никаких новых объектов выявлено не было. Характер слоя сохранялся аналогичный пластам 2 и 3 - чернозем с незначительными включениями мелко и среднедисперсной обмазки. Количество фрагментов керамики значительно уменьшилось. Они практически отсутствовали 


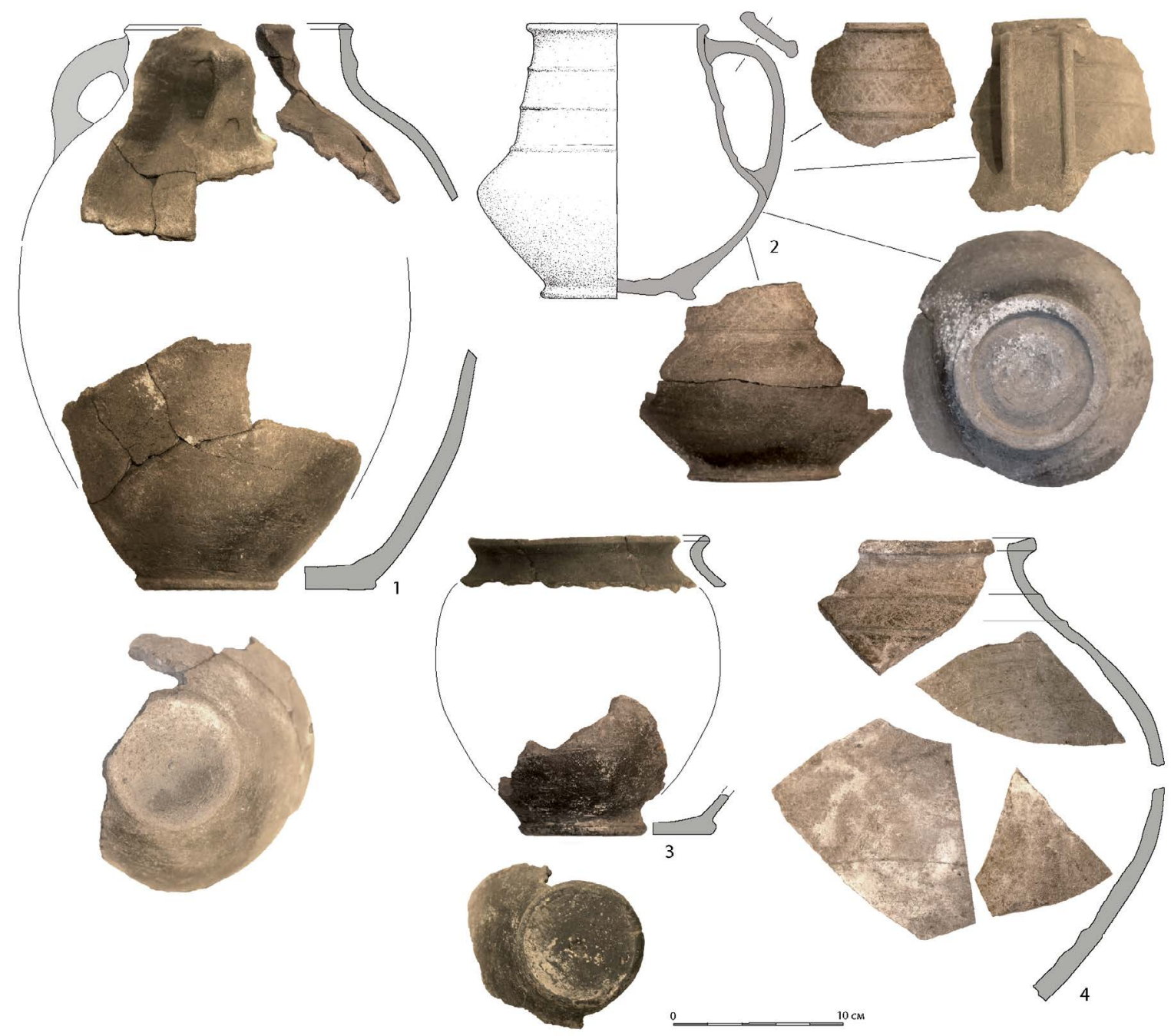

Рис. 7. Реконструкции форм шероховатой и серолощеной круговой посуды черняховской традиции из скопления 1

на месте расположения завала стен постройки и в половине остальных квадратов также. Индивидуальные находки также располагались к северо-западу от завала обмазки, или к югу от него, кроме того скопление находок отмечено над ямой 1 в восточной прирезке в кв. 6-8, 20, где найдены: пять обломков от кольцевидных грузил (Рис. 11:3; 12:4); костяная проколка (Рис. 14:28); клинок с вырезами был найден на границе 3 и 4-го пласта (Рис. 14:27).

Кроме того, к этому слою относились находки обломков тринадцати кольцевидных (Рис. 10:3; 11:5), одного целого и двух обломков пирамидальных грузил (Рис. 8:1; 9:1), пряслице (Рис. 13:3), кольцо железное (Рис. 14:4), шиловидный наконечник (Рис. 14:11), диск железный с отверстием, ведерковидная подвеска железная (Рис. 14:1), клюковидная булавка (Рис. 14:18), миниатюрный фрагмент тонкостенного стеклянного сосуда, подвеска из зуба животного (Рис. 14:32), небольшой фрагмент крицы.
На уровне пластов 5-7 стал отмечался переход к предматерику, слой начал менять окраску на желтоватый. Глубины на разных участках были неоднородными. На основной части раскопа материк был зафиксирован после зачистки основания 6-го пласта, но в восточной прирезке и на некоторых других участках раскопа отдельные очаги культурного слоя фиксировались на уровне 7-го пласта (до -140 от современной дневной поверхности). Отчетливо выделялись норы и ходы грызунов, которые фактически перемешали весь предматерик. Количество фрагментов керамики стало значительно меньше, чем в предыдущих пластах, в том числе и по сравнению с 4. На уровне 5-го пласта керамика полностью отсутствовала на основной части раскопа, за исключением юго-восточных квадратов 58, 59, 62-64, а также кв.40 к западу от завала стен. В то же время большинство квадратов в восточной постройке продолжало сохранять насыщенность материалами, но не столь 


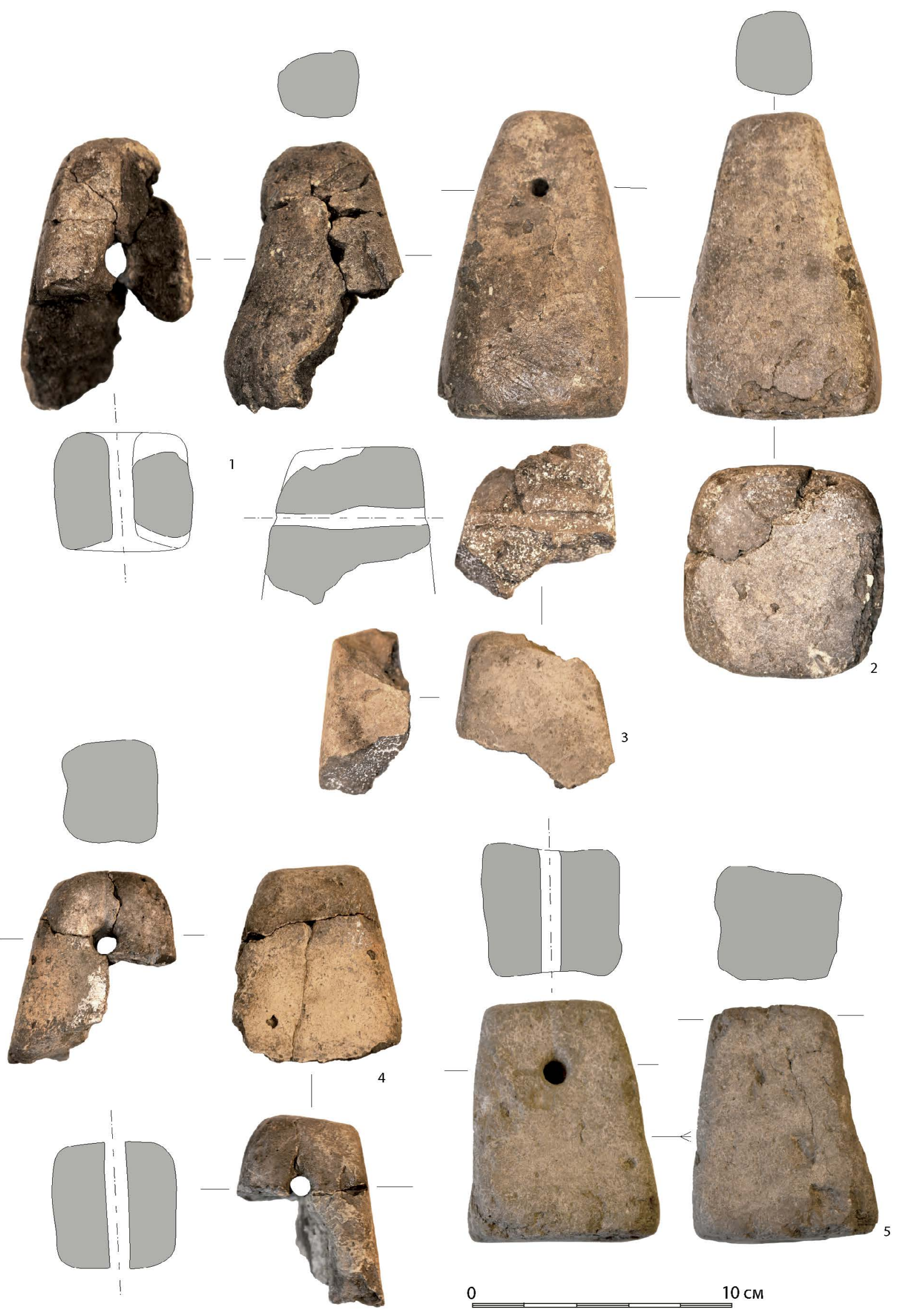

Рис. 8. Пирамидальные глиняные грузила от ткацкого станка 

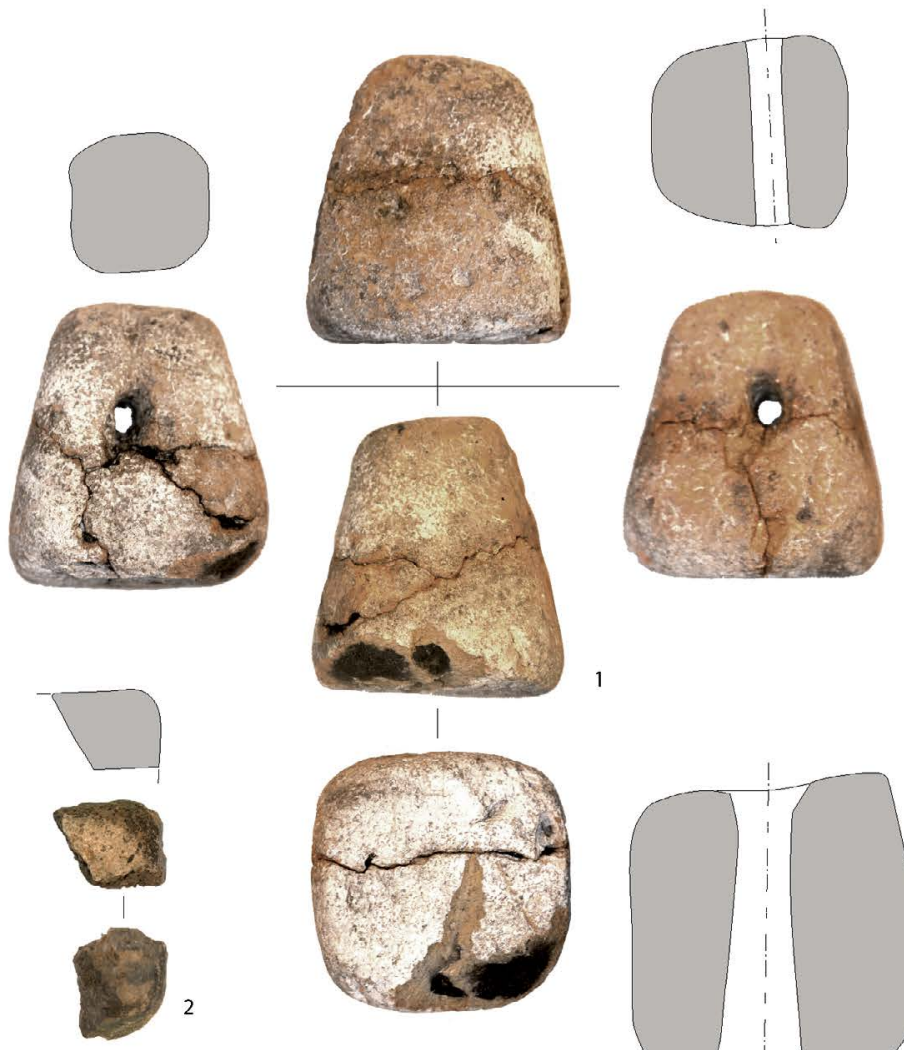

(1)
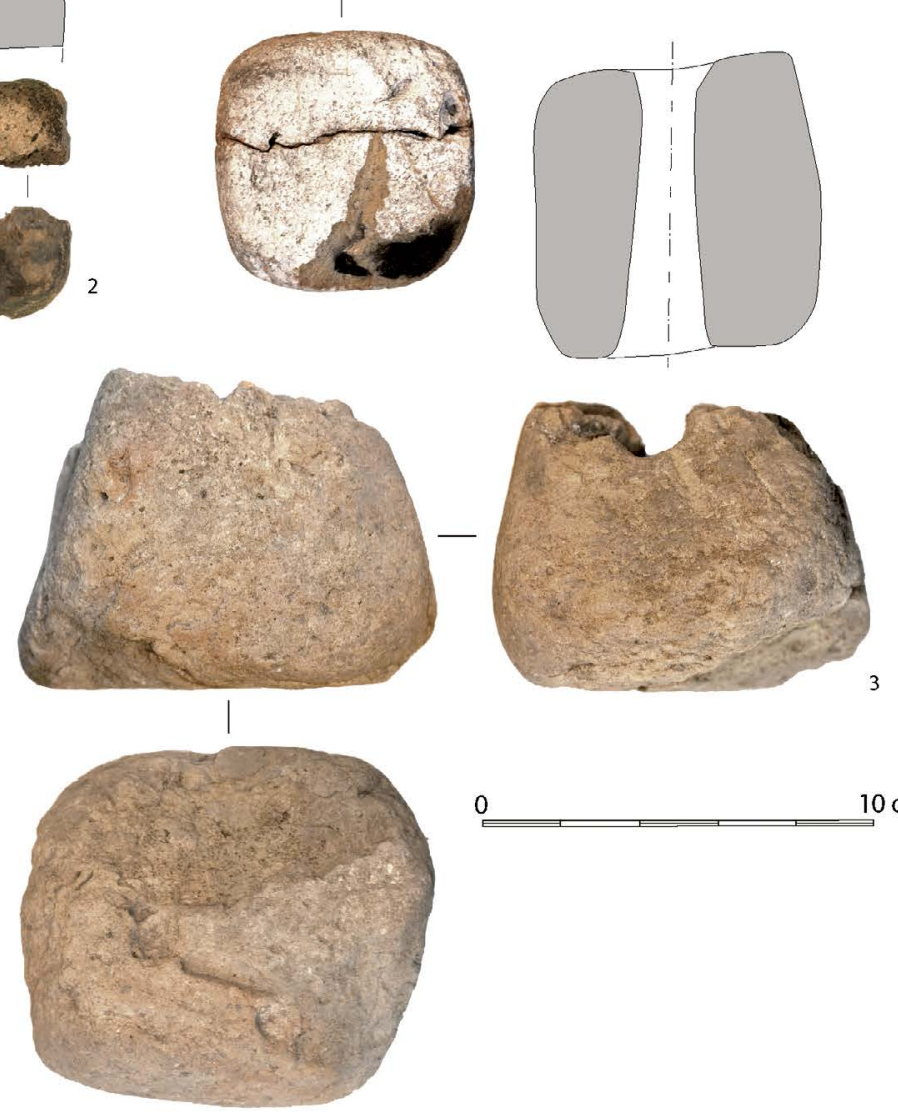

0 $10 \mathrm{~cm}$

Рис. 9. Пирамидальные глиняные грузила от ткацкого станка материала сохранялось практически по всей ее протяженности с увеличением концентрации над ямой 1 и в восточных квадратах $(23,24,11,12)$.

Индивидуальные находки были довольно равномерно распространены в основной части раскопа и образовывали концентрации в районе выявленной ямы 1 (кв. 19, 20, 7, 8) и шлейф вокруг этой ямы. Здесь были найдены: восемь кольцевидных грузил во фрагментах (Рис. 10:5; 11:1; 12:6) и три обломка от пирамидальных (Рис.9:3); биконическое пряслице (Рис. 13: 4); нож (Рис. 14:22), железная пружина от фибулы (Рис. 14:6); фрагмент кости с просверленным отверстием. К пятому пласту также относились: три фрагмента от кольцевидных (Рис. 12:7, 8), и три обломка от пирамидальных грузил (Рис. 8:3); игла железная, клюковидная булавка (Рис. 14:19), обломки кованных гвоздей, железное шильце (Рис. 14:13), две костяные проколки (Рис. 14:29, 30), наконечник ремня (Рис. 14:10), фрагмент сильно ошлакованной керамики. В шестом пласту найдены: пряжка железная (Рис. 14:8), фрагменты пяти кольцевидного грузила, обломок лезвия железного ножа и более крупный фрагмент (Рис. 14:21), дисковидное пряслице с насечками (Рис. 13:1). Из седьмого пласта происходили: три пряслица (Рис. 13:5, $6,8)$, три фрагмента кольцевидных грузил (Рис. 10:4; 12:2, 130, 157) и фрагмент массивного пирамидального грузила и несколько мелких фрагментов пирамидальных грузил (Рис. 12:1).

значительную, как указанная выше. Уже на уровне пласта 3-4 стало очевидным наличие крупного объекта в восточной прирезке, пластовые планы четко фиксировали концентрацию как находок, так и обмазки и массового материала в кв. 18-22, 6-10. На уровне пласта 6 и местами 7 (фактический предматерик) керамика встречалась на основной части раскопа, в квадратах, где были выявлены ямы 2 (кв. 52, 56, 57) и 7 (кв. 27). В восточной прирезке распространение
Пятна ям вследствии сильного разрушения культурного слоя фиксировались только на уровне предматерика - 6 и 7 й пласты. Выявление их в пестроцветном грунте представляет определенные сложности в виду обилия кротовин. Всего на раскопе 2013 года после итоговой зачистки зафиксированы 7 ям и 1 материковая западина в восточной части восточной прирезки (рис.4). Из них 2 столбовые среднего диаметра до 0,7-0,8 м (№ 5 и яма 6), столбовая крупного размера - до 
1,2 м (№ 3), хозяйственная яма, заполненная животными останками (№ 2), яма 7 - неясного предназначения, возможно, являлась материковой западиной (выбрана в пределах раскопа, частично уходит в северный борт раскопа), яма 1 , представляющая остатки нижней части хозяйственной постройки, столбовая (?) яма 4 выбрана также в пределах раскопа, частично уходит в южный борт восточной прирезки.

Заполнение всех ям остается смешанным и отделяется от материка только небольшим отличием в плотности грунта.

Яма 1. В плане - подокруглая (с достаточно прямой северо-восточной стороной, которая в кв. 20 переходит почти под прямым углом в юго-восточную стенку), размерами по верхнему краю $3,7 \times 3,8$ м, общие размеры дна в нижней части составляли $3,6 \times 3,7$ м. Максимальная глубина ямы 1 в приямке составляла $0,37 \mathrm{M}$, она полностью углублена в материк. Борта ровные, почти отвесные. Пятно ямы прослежено на поверхности предматерика, оно имело размеры 3,8×4 м. Стратификация ямы выражена незначительно, верхний слой темно серый гумусированный суглинок, заполняющий её до углубления, которое, в свою очередь заполнено темно-бурым гумусированным суглинком. В южной части прослежены два небольших пятна с золистым заполнением. Значительное количество находок располагалось над ямой очевидно в непрослеживаемом вследствии особенностей смешанного грунта заполнении слоев 2-6. В верхней части заполнения на уровне 5-7 пластов и в самом заполнении ямы ниже уровня бортов были найдены 4 венчика, 1 донце и 34 фрагментов стенок от сероглинянной круговой «шероховатой» посуды; 2 венчика,
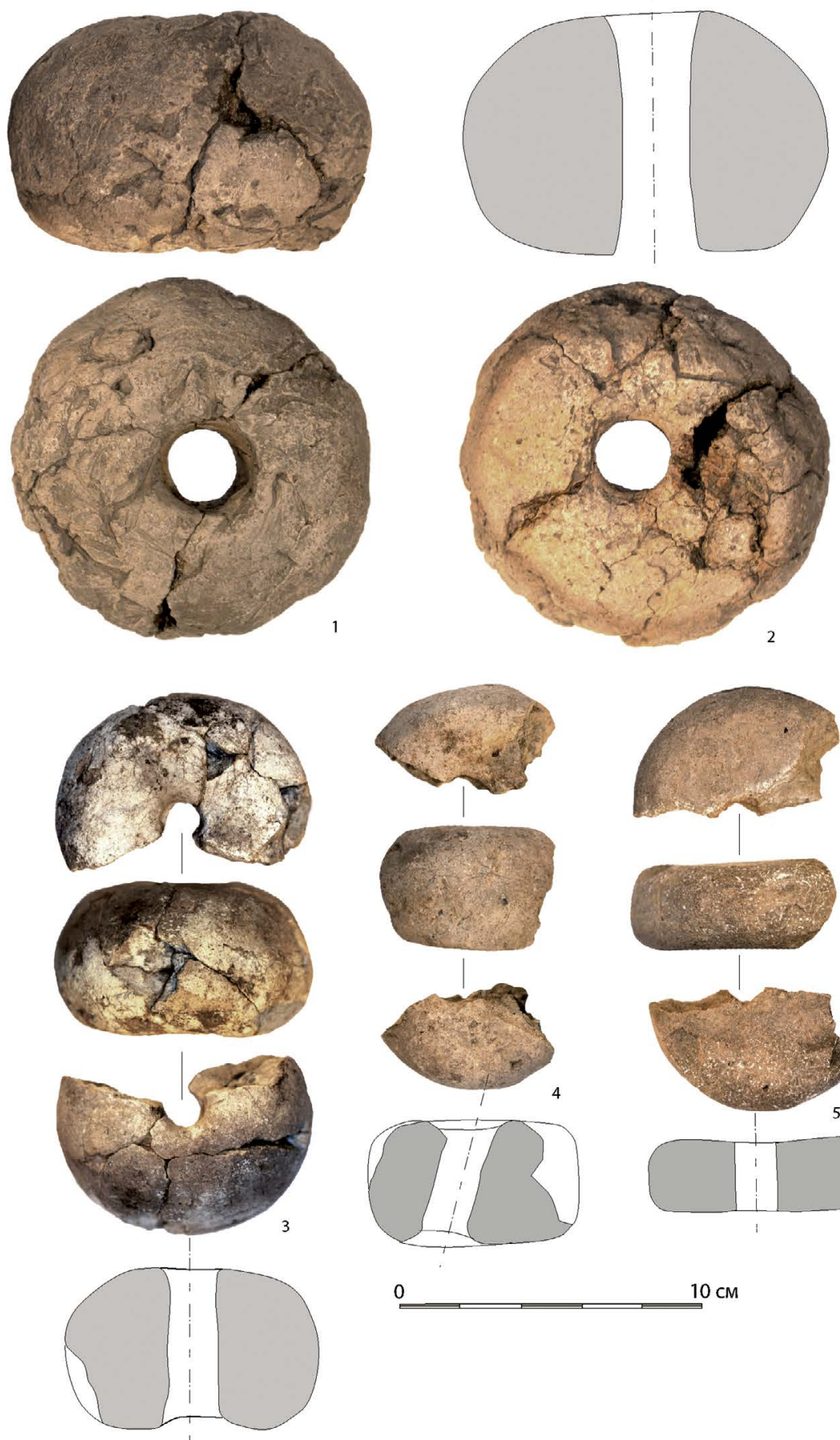

0 $10 \mathrm{~cm}$

Рис. 10. Кольцевидные глиняные грузила

4 стенки и 1 донце от круговой серолощеной посуды; 4 стенки от круговой чернолощеной посуды; 5 венчиков, 8 донцев, 52 стенки от груболепных горшков. Кроме этого встречено значительное количество костей животных, в том числе: крупный фрагмент челюсти крупного рогатого скота, и несколько позвонков. Все индивидуальные находки располагались выше уровня краев ямы.

Яма 2. Форма округлая с небольшим выступом в юго-восточной части. Размеры 

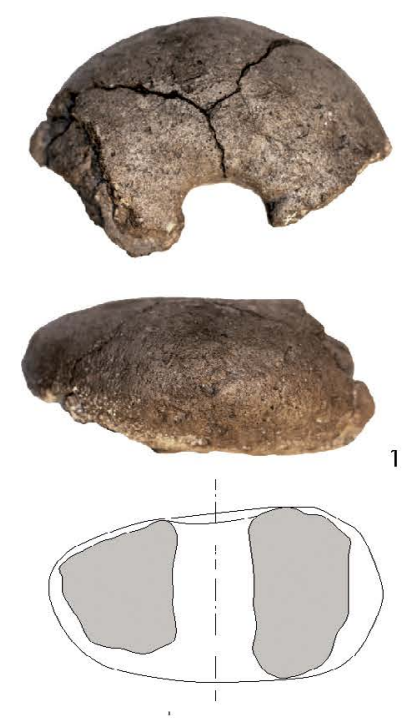

0
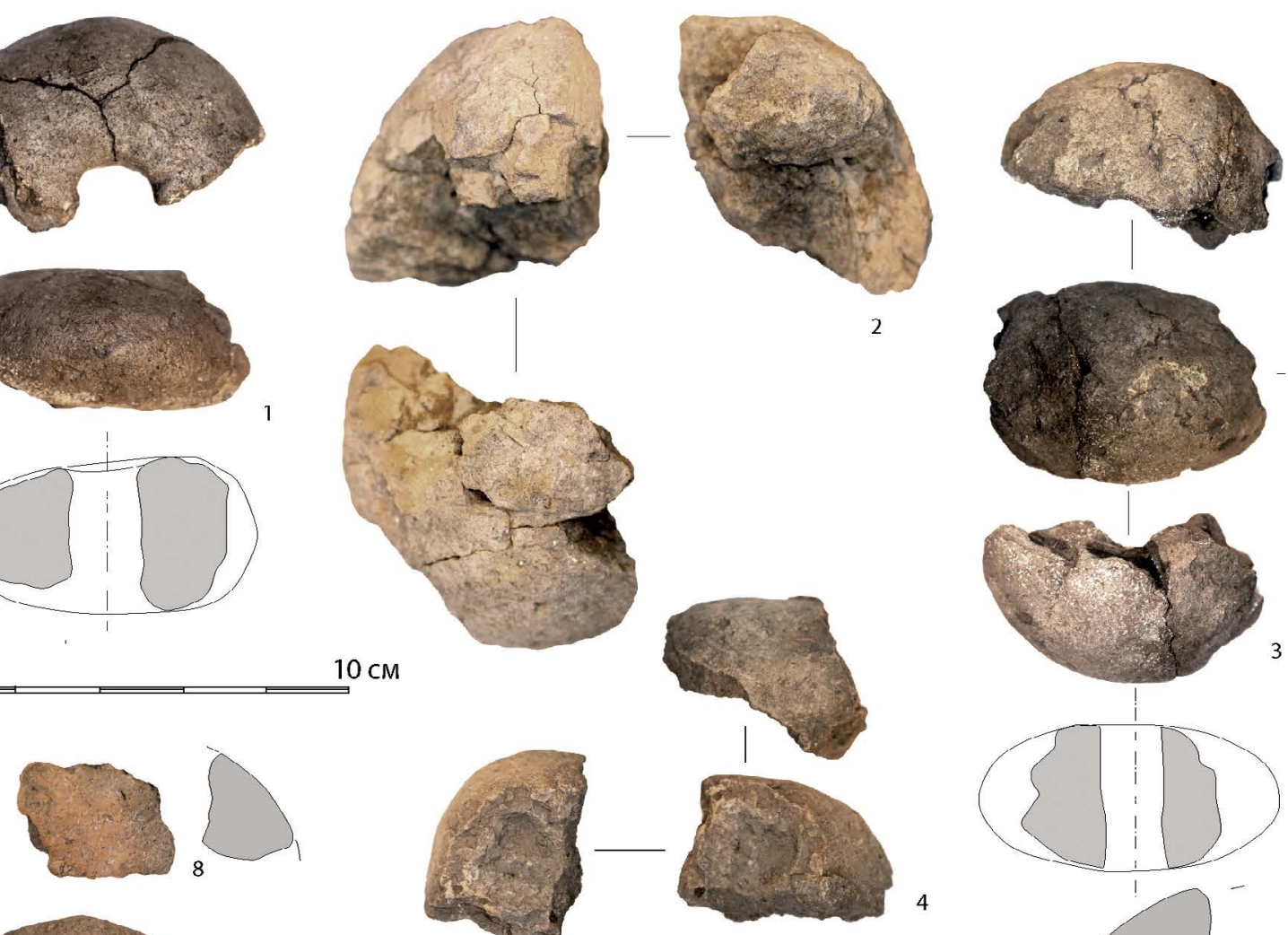

$10 \mathrm{CM}$
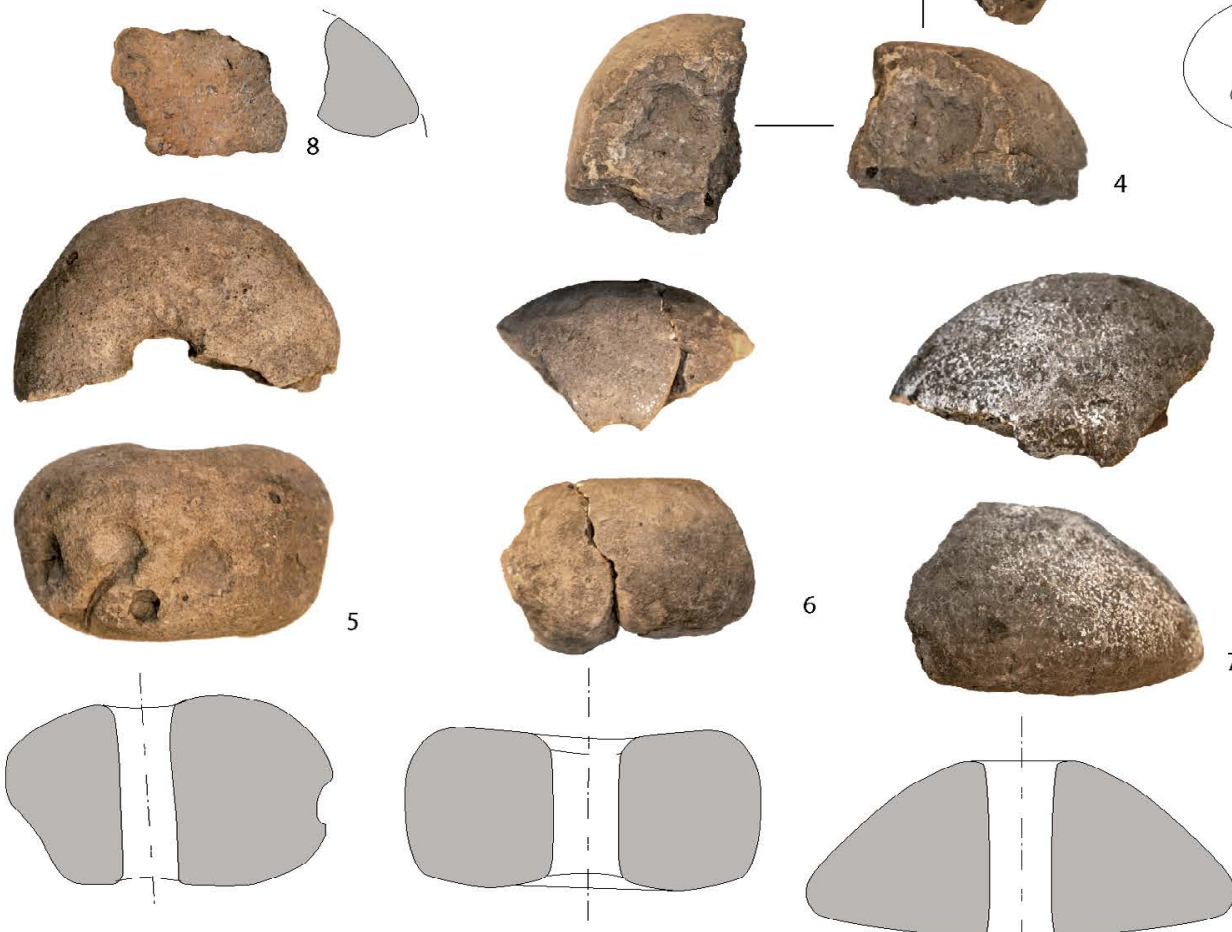

6
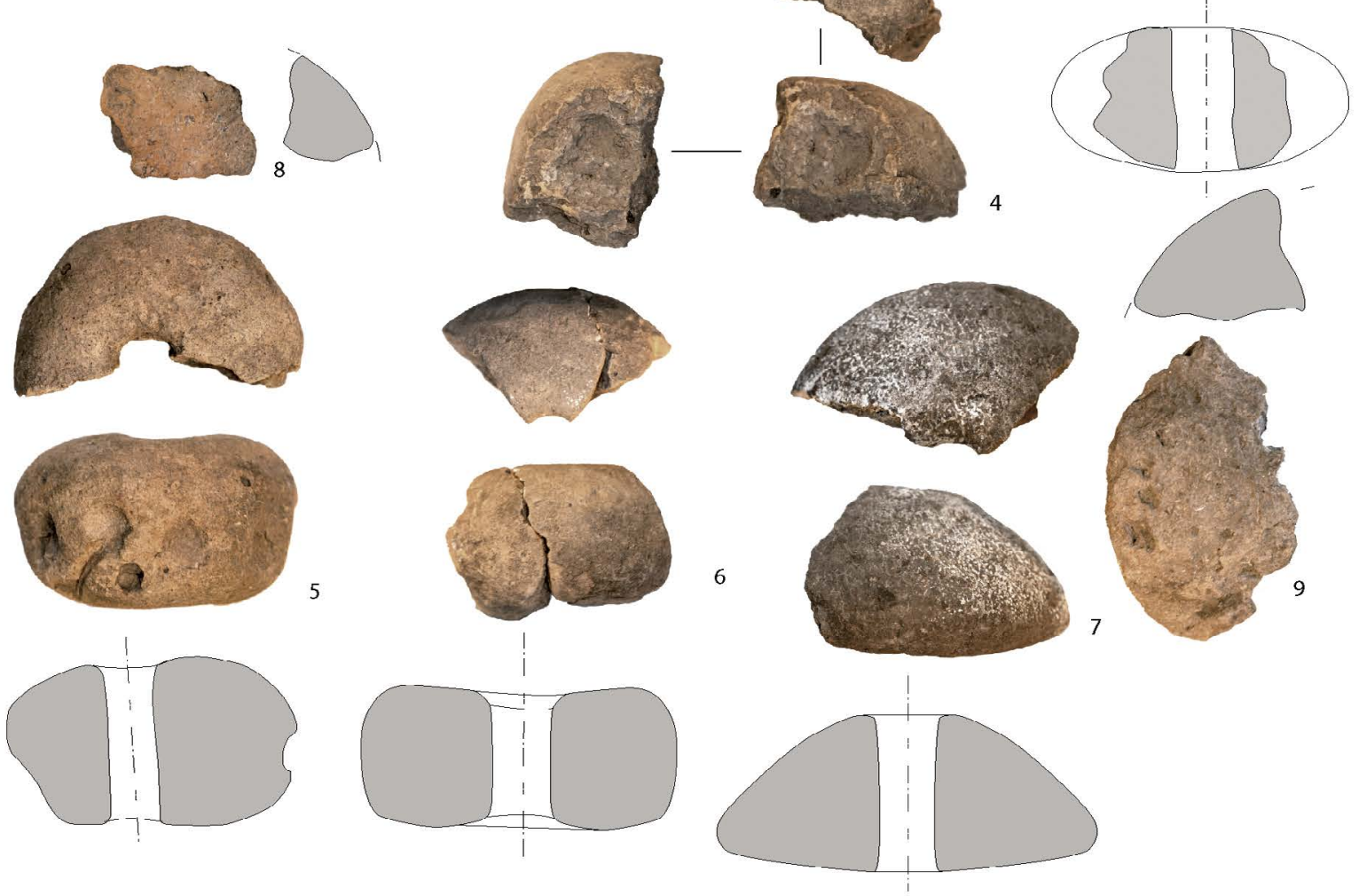

Рис. 11. Фрагменты глиняных грузил

по верхнему краю 1,7×1,6 м. Наибольшая глубина $-1,14$ м. Заполнение - смешанная суглинок с многочисленными фрагментами обмазки. Дно ровное округлой формы, с небольшим подъемом по краям. В заполнении обнаружены 1 донце, 1 венчик и 2 стенки от груболепных толстостенных сосудов; венчик, два венчика и одна стенка от круговых сосудов «кухонного» типа с шероховатой поверхностью; 1 стенка от кругового серолощенного сосуда.. Также найдены фрагмент черепа лошади, в яме также были положены скелеты небольших собак и кошки.
Яма 3. Форма неправильная подовальная, с выступом в юго-восточной части. Размеры по верхнему краю $1,4 \times 1,6$ м. Общая глубина ямы достигала 0,17 м. Заполнение на всей глубине ямы было однородным - смешанный суглинок с включениями мелких фрагментов обмазки сильно изрытый землероями. Заполнение из пестрого суглинка изрытого землероями находок не обнаружено.

Яма 4. Выбрана частично в пределах раскопа, уходит в южный борт восточной прирезки. Размеры по верхнему краю $2 \times 0,7$ м. Размеры 
по дну $2,1 \times 2$ м. Общая глубина ямы достигала 0,27 м. Заполнение смешанный суглинок сильно изрытый землероями. Заполнение из пестрого суглинка изрытого землероями находок не обнаружено.

Яма 5. Форма неправильной подвальной формы ориентированная длинной стороной по линии северо-восток - юго запад. Выбрана частично в пределах раскопа, своим краем уходит в северный борт основного раскопа. Размеры по верхнему краю $1 \times 0,8$ м. Общая глубина ямы 13 см. Заполнение из пестрыого суглинка изрытого землероями находок не обнаружено.

Яма 6. Форма неправильной подтреугольной формы ориентированная углами по линии северюг запад-восток. Размеры по верхнему краю $0,8 \times 0,8$ м. Общая глубина ямы 34 см. Заполнение из пестрыого суглинка изрытого землероями находок не обнаружено.
Яма 7. Форма неправильная с аморфными краями. Выбрана частично в пределах раскопа, в северной части уходит в северный борт раскопа. Максимальные размеры по верхнему краю $7 \times 0,8$ м. Общая глубина ямы 53 см. Заполнение - пестрый суглинок изрытый землероями. В заполнении найдены 2 венчика и 2 стенки от груболепных горшков.

Культурный слой раскопа был в целом обильно насыщен фрагментами керамики ( 2504 ед.) и костьми ( 700 ед.). Индивидуальных находок - 158 ед. (рис. 8-14).

Массовый материал. Основные концентрации обломков посуды отложились по сторонам от завала постройки, внутри завала и под ним количество находок керамики значительно меньше.

Керамический комплекс, включает в себя 2504 фрагмента от лепных и гончарных сосудов. В целом преобладают остатки гончарной

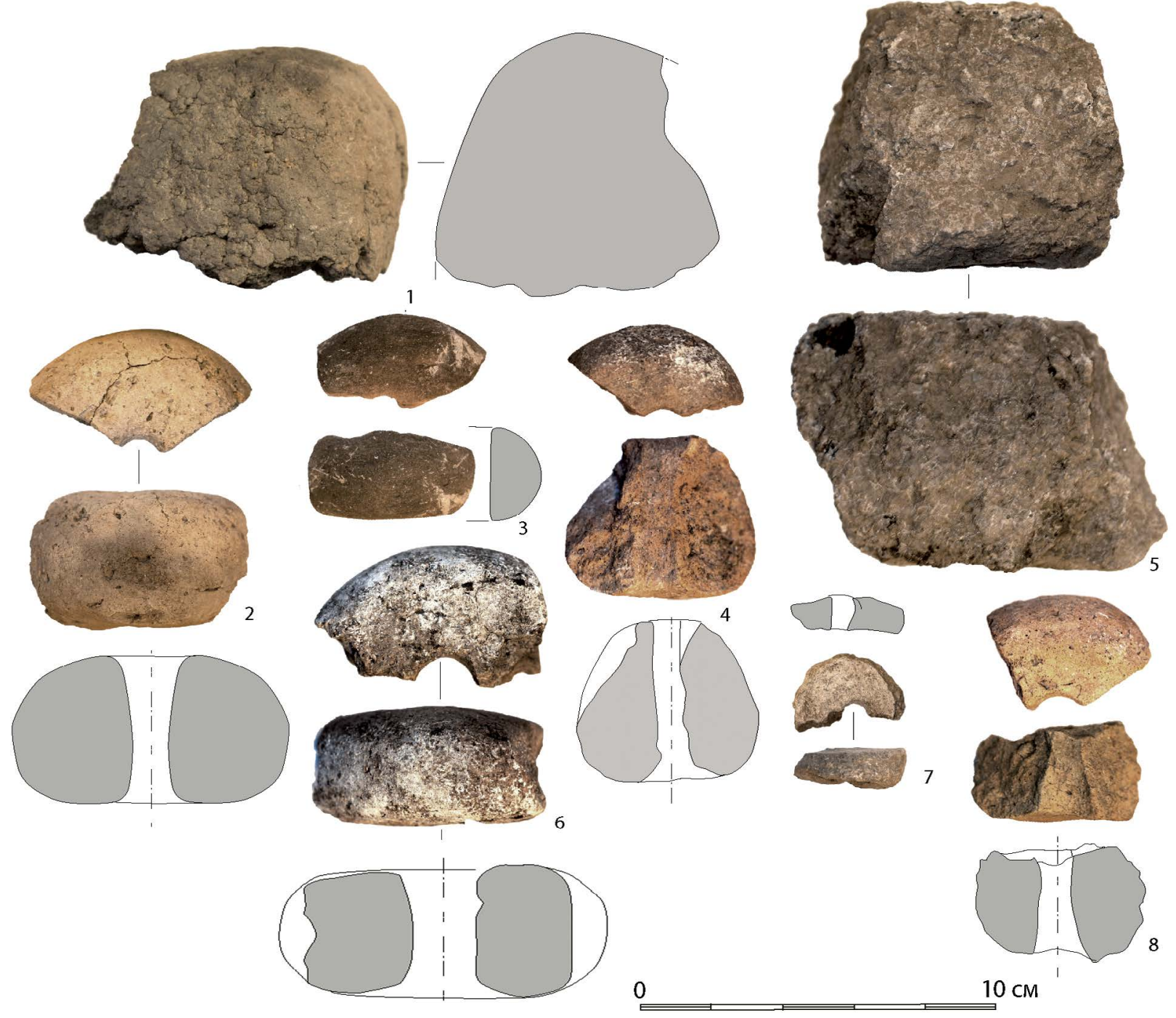

Рис. 12. Фрагменты глиняных грузил и обломок жернова (5) 
круговой посуды - 59 \%, (в том числе 9\% составляет керамика «столовая» серолощенная, $5 \%$ «столовая» чернолощеная и $46 \%$ фрагментов «кухонных» с шероховатой поверхностью), менее $1 \%$ - керамика нового и новейшего времени, найден 1 крупный фрагмент стенки от амфоры, фрагментов груболепных горшков и др. лепных сосудов около $40 \%$.

Столовая посуда (с лощеной поверхностью) представлена мисками с закрытым и открытым профилем, широкогорлыми кувшинами (Рис. 6: 1-12, 14-25, 42, 43, 47, 49, 51-55). Венчики мисок вертикальные с закруглённым верхом, слегка отогнутые наружу, встречаются экземпляры отогнутые наружу с вогнутым внутрь верхней частью. Фрагменты стенок серого лощения, от сосудов в том числе и очень большого диаметра (Рис. 6:55). Однако, большинство фрагментов мелкие. Цвет черепков от светло-бежевого, до темно серого и черного. Лощение поверхности имеет разную степень тщательности обработки, встречаются плохо пролощеные участки, но в большинстве своём качество обработки высокое.

Некоторое увеличение процента чернолощеной посуды фиксируется в нижних пластах (5-6). Там же были найдены крупные фрагменты чернолощенных «столовых» мисок большого диаметра (свыше 250 мм) (Рис. 6: 53, 55). Миски с расширенным туловом и коротким слабоотогнутым венчиком. В одном случае в верхней части тулова располагалась горизонтальная орнаментированная полоса украшенная пролощенным сетчатым орнаментом. Следует отметить, что и на раскопах усадьбы 1 отмечалось увеличение количества крупных фрагментов чернолощёной «столовой» посуды к нижним пластам.

Кухонная (с шероховатой поверхностью) представлена в основном горшками на кольцевом и плитчатом поддоне (Рис. 6: 13, 26-41).

В скоплении расположенном возле северной стены завала постройки реконструируются четыре круговые формы. 1. Высокий «кухонный» горшок с расширенным туловом, коротким
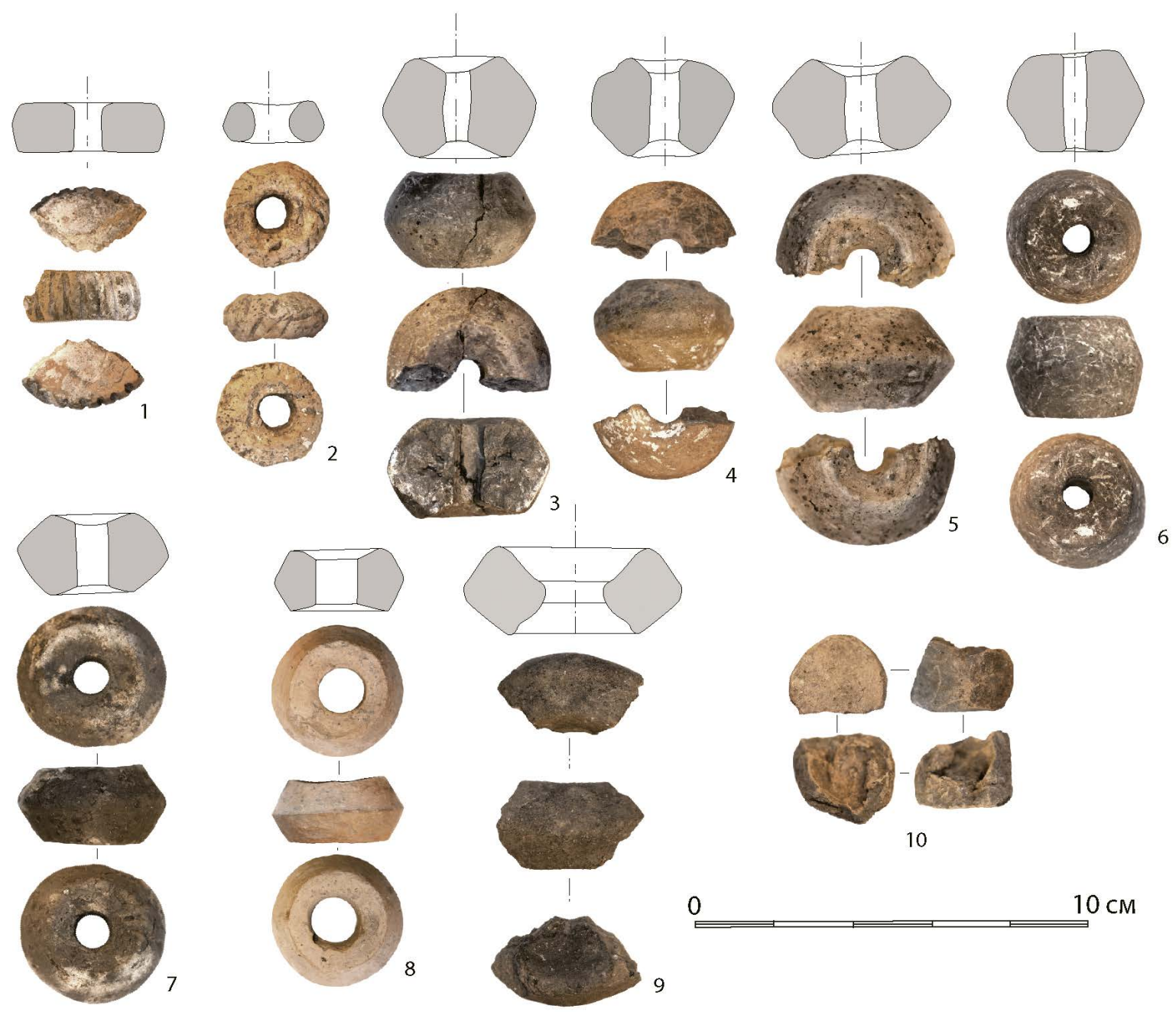

10

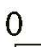

$10 \mathrm{~cm}$

Рис. 13. Керамические пряслица и изделие из керамики (10) 
отогнутым наружу венчиком со срезанным краем (Рис. 7:3) диаметром по верхней части около 12 см. 2. Тарный «кухонный» сосуд с ручками высотой около 33 см. Форма тулова расширенно вытянутая, с короткой шейкой и вертикальным венчиком со срезанным краем и валиком в срединной части. Две ручки уплощённо-овальные в сечении крепились в верхней части тулова и под срезом венчика (Рис. 7:1). 3. Кувшин сероглиняный серолощенный широкогорлый, высотой 16 см, с диаметром тулова 10,5 см (Рис. 7:2). Тулово расширенное с выраженным профилем, донце на кольцевом поддоне. Шейка широкая, высокая, на ней расположены три горизонтальных валика. Венчик каплевидный отогнутый наружу. Ручка уплощенно-овальная с двумя валиками по краям, закреплена у перегиба тулова и в верхней части под срезом венчика. Шейка между валиками украшена пролощенным сетчатым орнаментом, типичным для черняховской гончарной традиции. 4. Сероглиняный лощеный тарный сосуд с диаметром по венчику около 15 см (Рис. 7:4). Реконструируется верхняя часть сосуда, высотой свыше 35 см. Тулово сильно расширенное округлое, венчик короткий Г-образный отогнутый наружу. Под венчиком в верхней части тулова шейка не прослеживается, расположены два симметричные горизонтальные валика. Поверхность сосуда хорошо залощена, однако заметны следы от разглаживания. Толщина стенок сосуда достигает 15 мм.

Амфоры представлены единственным крупным фрагментом стенки. Тесто плотное, тщательно отмученное, с примесями, цвет фрагмента светло-коричневый. Толщина стенки 8-10 мм (рис. 6:56).

Лепные сосуды в основном в виде мелких обломков толстостенных горшков, профильные формы практически отсутствуют. Изготовлены из жирной глины с добавлением шамота мелких и средних фракций, поверхность ровная, заглаженная, обжиг неравномерный, цвет после обжига разный, варьируется от серо-коричневого до светло оранжевого. Поверхность на тонкостенных фрагментах обычно хорошо заглажена, толстостенные сосуды, напротив грубо обработаны. Толщина колеблется от 3 до 22 мм. Крупные фрагменты позволяют реконструировать формы верхней части тонкостенного горшка с плавно отогнутым наружу венчиком части тулова. Донца в большинстве случаев массивные, толщиной 8-20 мм.

В большинстве случаев представлены типы слабопрофилированных горшков. В скоплении
1 был найден развал лепного толстостенного горшка изготовленный из плохо подготовленного теста с примесями крупного шамота (Рис. 5:1). Высота горшка 225 мм. Сосуд имеет $\mathrm{S}$-видный профиль в верхней и равномерное расширение в средней части. Тулово диаметром около 200 мм. Венчик короткий прямой отогнутый наружу верхняя часть закруглена, диаметр около 180 мм. Дно массивное толщиной до 15 мм, стенки горшка имели толщину до 10 мм. Там же найден фрагмент от небольшого горшка с выраженным перегибом от тулова к шейке в верхней части (Рис. 5:6). Тесто с примесями шамота, наружная поверхность заглажена. Венчик короткий несколько отогнутый наружу.

Индивидуальные находки. Все вещи были достаточно равномерно распределены по площади раскопа, в основном вокруг периметра стен постройки и в районе ямы 1. Наибольшее количество находок относилось к второму, третьему и четвертому стратиграфическом пластам. Следует выделить несколько основных категорий предметов

Детали одежды и украшения: Фибула бронзовая прогнуто подвязного типа (Рис. 14:4) с дуговидной спинкой с сечением в виде треугольника. Пружина короткая, бронзовая игла круглая в сечении. Длина 40 мм, ширина спинки 6 мм. Датируется фазой С3. Близкие по типу фибула найдена во время работ 2007-2008 года на полу постройки 1 и в яме 10 усадьбы 1. Фрагмент корпуса железной фибулы с остатками пружинного аппарата с широкой спинкой плоской в сечении (рис. 14:5). Датировка- фазы C3-D1 римского времени (Гороховский, 1988. С.44). Обломок железной пружины от фибулы. Длина 35 мм, пружина широкая, с верхней тетивой, игла в сечении округлая (рис.14:6). Пряжка железная с овальной рамкой шестиграннной в сечении и загнутым на конце коротким язычком треугольного сечения (рис. 14:8), датируется фазами C3/D1 (Гороховский, 1988. С.44) . Железная секировидная подвеска, высотой 30 мм, с остатками закрученной проволоки от подвсеки (Рис. 14:3). Может быть отнесена к типу I/5 плоских подвесок по О.Гопкало. Появляются в черняховской культуре не ранее последней трети III в. (Гопкало, 2008. С. 63). В целом имеют широкий ареал распространения в германских, сарматских культурах и позднеантичных древностях. Конусовидная подвеска из латуни высотой 25 мм (Рис. 14:2). Относится к типу II/8 подвесок по О. Гопкало, появление которых автор относит ко времени не ранее последней 
трети III в., а бытование продолжается вплоть до гуннского времени (Гопкало, 2008. С. 65). Железная миниатюрная ведерковидная подвеска диаметром 8-9 мм (Рис. 14:1). Относится к типу II/2a по классификации О.Гопкало (Гопкало, 2008. С. 63), датировка по всей видимости предполагается достаточно широкая от ранних черняховских памятников до финала классической черняховской культуры. В целом секировидные, ведерковидные подвески являются характерной деталью черняховского костюма и встречаются на всей территории распространения культуры. На территории Курского Посемья известны аналогичные находки из раскопок усадьбы 3 поселения Пены, и поселения Выдрин в Большесолдатском районе, расположенного в верховьях реки Суджа в бассейне Псла..

Латунный наконечник пояса (?) длиной 50 мм шириной 12 мм (Рис. 14:10). Бронзовый пинцет (Рис. 14:7), длина 65 мм, ширина дужек 5 мм, ширина лопаток 9 мм. Находки пинцетов типичны для круга позднеримских древностей и широко распространена на памятника черняховской культуры, в том числе левобережья днепра, датировка при этом может быть широкой C2/ D1 (Магомедов, 2001. С. 83).

Оружие: Одной из наиболее интересных находок из раскопа 2013 года являлся клинок с вырезами у основания рукояти (Рис. 14:27). Длина клинка - 250 мм, ширина 32 мм, толщина 3 мм, длина хвостовика -60 мм. В верхней части хвостовик сильно сужается. Сечение клинка после реставрации - шестигранное уплощённое. В нижней части лезвия сделаны симметричные вырезы глубиной 7-8 мм. Сужение к острию плавное, начинается в нижней трети. Поверхность клинка ровная, следов дамаскированной стали визуально не прослеживалось. Сохранность достаточно высокая. Также не отмечены следы от рукояти. В первой публикации его изображение и описание давались до реставрации (Радюш, 2012. Рис. 2:3), после её проведения уточнилось сечение клинка.

Относительно происхождения подобных клинков высказывались несколько мнений: Р. Хархою связывал их появление с Боспорским Царством, В. Н. Каминский - с Крымом, А. М. Хазанов - с Северным Кавказом, эта теория была поддержана позднее В. Супо (Левада 2013. С. 174). В данный момент ее придерживается большинство исследователей, связывая их появление с воинским делом аланов. М. Е. Левада, между тем, не исключает, что эта категория могла возникнуть в Западном Прикаспии на рубеже III-IV вв. Распространение клинков в Причерноморье и на Кавказе, достаточно хорошо изучено, однако на севере, за пределами зоны черняховской культуры, их находки единичны и обычно не связаны с погребениями (Радюш, 2014. С. 234-236). С территории Курской области известны также находки связанные с черняховскими поселениями в Кореневском, Обоянском, Солнцевском районах (разведки автора), (Радюш, 2014. С.238. Рис. 1:1, 2; Биркина, Камелина, 2019. Рис. 3). Датировка подобных находок обычно принимается в пределах конца III первой половины $\mathrm{V}$ вв. Однако для памятников черняховской культуры следует предположить ее более поздней от второй половины IV в. до начала V в. Материалы раскопа, позволяют датировать разрушение постройки последней четвертью IV в.

Попадание кинжалов с вырезами далеко на север может быть связано с ситуацией конца IV - начала V вв., когда письменные источники фиксируют тесный контакт аланов и готского союза. И если на территориях, заселенных выходцами с Кавказа в Крыму и Причерноморье, они обычно попадают в качестве приношений в погребения, то на остальных территориях по моему мнению они вероятнее всего могут быть связаны с проводимыми ритуальными действиями (Радюш, 2014. С. 242). В целом находки предметов вооружения на поселениях черняховской культуры крайне немногочислены по всей её территории.

Орудия труда, инструменты и пр. железные изделия. Среди металлических предметов железный кованный гвоздь и несколько обломков от них. Их отношение к позднеримскому времени пока не доказано, а учитывая наличие на исследуемом участке огородов и садов, вполне может быть связано с XIX-нач. XX вв. Обломки железных клюковидных булавок, которые могли быть частями веретена (Рис. 14: $17,18,19)$. Две находки возможно являющиеся металлическими наконечниками «шиловидного» типа длиной около 20 мм (Рис. 14: 11, 12). Три больших обломка от ножей (Рис. 14: 21-22, 26) длиной до 100 мм, и три обломка лезвия и острия от ножей (Рис. 14:24-25). Один предмет (Рис. 14:23) может быть интерпретирован как заготовка для ножа или ножниц. На площади раскопа найдены четыре железных кольца - два сведенных (Рис. 14:14), сваренное (Рис. 14:15) и возможно заклепанное (Рис. 14:16) диаметр колец от 12 до 20 мм. Возможно последнее относится к кольчужному плетению кольчуги. 


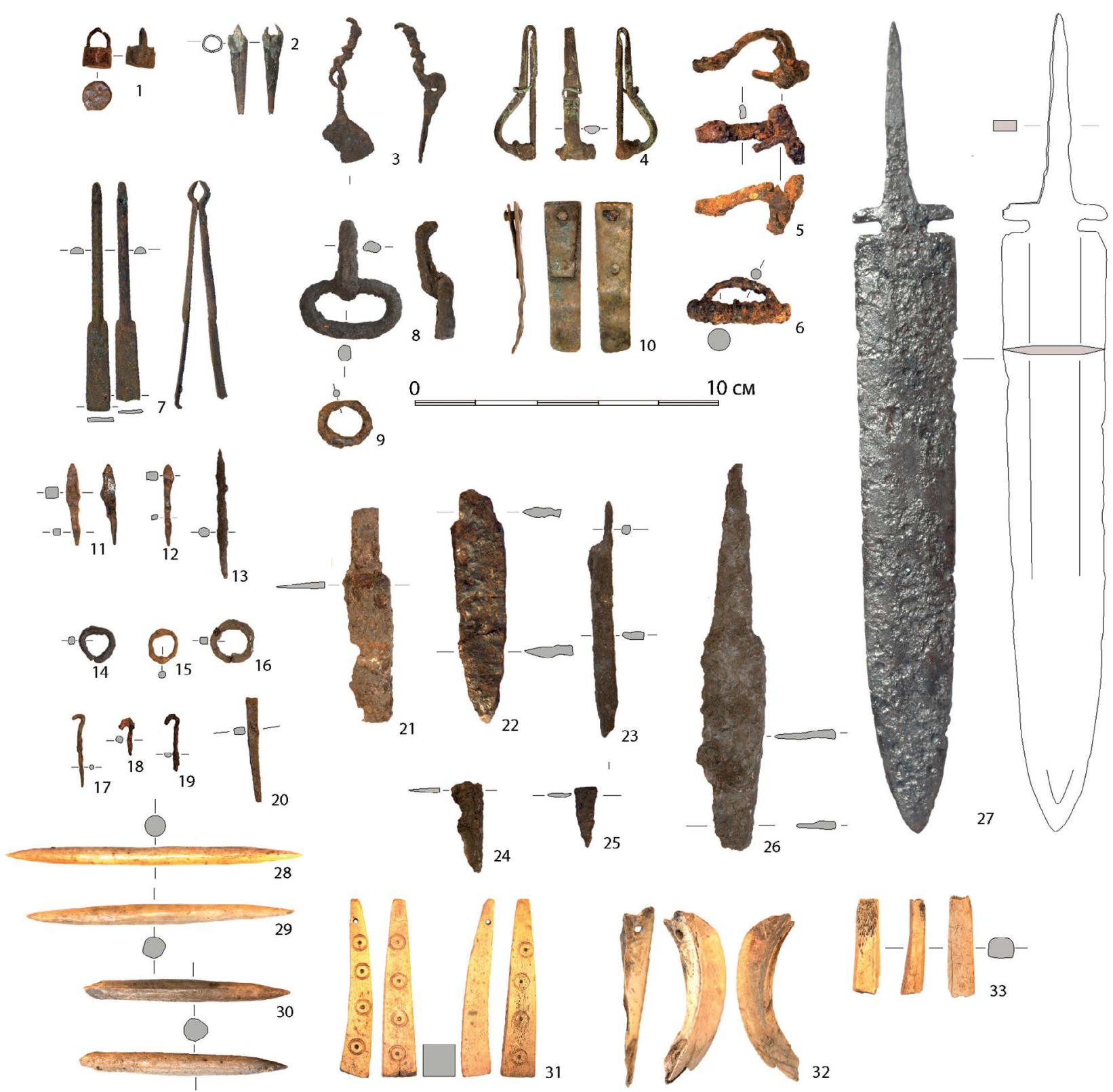

Рис. 14. Индивидуальные находки из железа $(1,5,6,8,9,11-27)$, бронзы $(2,4,7,10)$, кости (28-33)

Изделия изаготовки из кости. Среди находок три целых изделия - костяные проколки- «стилусы» (Рис. 14:28-30). Длина 60-80 мм диаметр около 8-10 мм. Находки подобного тиипа часто встречаются как на памятника черняховской культуры, так и на поселениях «киевской» культуры. Ранее подобные изделия и заготовки под них были найдены при раскопах усадьбы 1. Пирамидальная подвеска из рога слабо изогнутая по всей длине. (Рис. 14:31), Размеры 55×10×10 мм. Три стороны орнаментированы циркульным орнаментом состоящим из композиций по четыре круга с точкой посередине одинакового диаметра. Подобные находки характерны для черняховских древностей фаз C3/D1, по наблюдениям О.Гопкало появляются не раньше второй трети
IV в. (Гопкало, 2008. С. 80). На трех заготовках из кости прослеживаются следы обстругивания и шлифования (Рис. 14:33), опиливания, и сверления. Найдена подвеска изготовленная из обломка клыка с отверстием (Рис. 14:3).

Предметы связанные с ткаиким производством. На раскопе найдены 9 пряслица (4 целых и 5 обломков). К эпохе бронзы отнесены обломок шайбовидного пряслица оранментированного поперечными насечками по внешней стороне диаметром 40 мм (Рис. 13:1) и пряслице биконической формы, грубое по уровню изготовления с диагональными насечками на сторонах диаметром 30 мм (Рис. 13:2). Остальные пряслица и их обломки биконической (Рис. 13: 3-9) формы с заглаженным ребром, отличия заключаются 
в размерах и пропорциях. Наиболее крупное по размерам пряслице - диаметром 50 мм, диаметр отверстия 15 мм (Рис. 13:5). Остальные пряслица имеют диаметр 35-40 мм и диаметр внутреннего отверстия 7-8 мм. Верхние площадки как ровные да и воронковидные. Аналогии подобным пряслицам многочисленны на памятниках позднеримского времени в Поднепровье, в том числе значительное количество их было найдено при раскопках усадьбы 1 (Магомедов, 2001. С. 104; Радюш, 2010. С. 203, Таб. Х:14-30).

Помимо пряслиц найдено большое количество обломков глиняных грузил, от ткацкого станка (81 ед.) (Рис. 8-12). Из них целых пять: три - пирамидальной формы (Рис. 8:2, 5; 9:1) и два кольцевидной (Рис. 10:1, 2). Среди крупных фрагментов 3 пирамидальных (Рис. 13:1; $8: 1,3,4)$ и 17 кольцевидных (Рис. 10: 3-5; 11:19; 12: 2-6, 8), остальные обломки миниатюрны. Аналогии находкам хорошо известны среди древностей позднеримского времени, и были также известны из раскопов на усадьбе 1 (Paдюш, 2010. С.203. Таб. Х:1-12).

Изделия из камня. Фрагмент по всей видимости нижней части каменного жернова (Рис. 12:5). Размеры $50 \times 80 \times 80$ мм. Изготовлен из зернистого камня, по всей видимости был пережжен в сильном огне. На верхней поверхности слабо прослеживаются канавки углубления. Найдены два изделия из обработанного кремня: ножевидная микролитическая пластина длиной 40 мм и возможно заготовка под стрелу с частично отбитыми краями - ромбической формы. По всей видимости данные находки связаны со слоем бронзового века.

Изделия из стекла: Миниатюрный фрагмент тонкостенного стеклянного изделия прозрачный с зеркальной патиной, что позволяет предположить античное происхождение. Но до настоящего времени находки фрагментов стеклянных античных изделий на памятниках черняховской культуры в Курском Посемье остаются единичными, что отличает регион от более южных регионов.

Классический период черняховской культуры от конца III- до третьей четверти IV в. в верховьях Сейма и Псла в III-IV вв. представлен многочисленными поселениями, в настоящее время их насчитывается свыше 150. В 2008 году были открыты первые погребения черняховского типа совершенные по обряду кремации на могильнике рядом с поселением Пены (пос. им. К. Либкнехта) (Радюш, 2011. С 233-242), в 2017-2019 могильник Дальний (Выдрин) и Дичня, следы могильников черняховского типа выявлены и возле ряда других поселений. Фактически поселения и могильники «классического» черняховского периода занимают всю территорию между Сеймом и Пслом, включая центральную часть междуречья. Северо-восточная граница в данное время фиксируется несколько севернее Курска, однако разведки в верховьях Тускаря и Сновы до сих пор не производились. Именно эти памятники образуют основу для структуры расселения конца III - IV вв. Поселенческие памятники синхронных культур в регионе - киевской и черняховской кардинально различаются, и вполне возможно они были антагонистичны на момент своего столкновения в III в. и большую часть времени своего сосуществования. Мало оснований и для гипотезы о т.н. «чересполосице» (Щукин 1979, 83; Обломский 2004, С. 124127; Обломский 2007. С.11), предполагавшей сосуществование двух различных культур, совместно на одной территории. Можно предполагать возможные случаи перекрытия и смешивания более ранних слоев киевской культуры на окраинных пойменных участках крупных черняховских поселений.

Раскопки второй усадьбы поселения Пены позволили получить новый объем материалов для изучения черняховских древностей на северо-восточной границе культуры.

Исследованы остатки нежилой каркасной постройки крупного размера с примыкающей к ней небольшой наземной слабозаглубленной постройкой в которой мог располагаться ткацкий станок, на что указывает обилие обломков грузил различной формы. Очевидно отличие в характере культурного слоя, находках и особенностях постройки по сравнению с усадьбами 1 и 3, что связано скорее всего с более коротким периодом функционирования объектов. В отличии от усадеб 1 и 3 расположенных по соседству, в пределах изученных раскопом площадей не было найдено материалов надежно датирующихся второй половиной III нач. IV вв., напротив большинство находок позволяет отнести участок ко второй третей четверти IV в., то сеть классическому черняховскому периоду. По итогам раскопок поселения в 2007-2013 гг. возможно выделение более ранних и более поздних участков и усадеб на поселении, что естественно, с учетом значительных его размеров. Облик поселения в целом не отличается от большей части черняховских памятников левобережья Днепра, и типичен для пойменных участков крупных селищ. Население использует костюм, круговую и лепную посуду обычную для черняховцев. 


\section{Литература}

Археологическая карта России. Курская область 1. Москва, 1998.

Археологическая карта России. Курская область 2. Москва, 2000.

Биркина Н.А., Камелина Г.А. 2019. Работы на поселении Серповка 2. // Археологические исследования в Центральном Черноземье 2018. Липецк. С. 101-102.

Гопкало О.В. 2008. Бусы и подвески черняховской культуры. Киев. 250 с.

Левада M.E., 2013. О влиянии аланских военных традиций на восточногерманские народы. // Крым в сарматскую эпоху. (II в. до. н. э. - IV в. н.э.) 1. Симферополь-Бахчисарай. С. 171-187.

Ляпушкин И. И. 1950. Памятники культуры «полей погребений» первой половины I тыс. н. э. Днепровского Левобережья. СА 13. С. 7-32.

Ляпушкин И.И. 1961. Днепровское лесостепное левобережье в эпоху железа. // МИА, 104. С. 159-180

Магомедов Б. В. 2001. Черняховская культура. Проблема этноса (Monumenta Studia Gothica I). Lublin. 290 c.

Обломский А.М. 2001. О памятниках лесостепного Подонья позднеримского времени. // Верхнедонской археологический сборник 2. Липецк. С. 122-140.

Обломский А. М. 2002. Днепровское лесостепное Левобережье в позднеримское и гуннское время (Раннеславянский мир. Вып. 5). М. 255 с.

Обломский А. М. 2004. О территориальных границах двух групп памятников киевской культуры в Среднем и Верхнем Посемье. // Восточная Европа в средневековье: к 80-летию Валентина Васильевича Седова. Москва. С. 117-128

Обломский А.М. 2007. Территория, общие сведения о поселениях. // Памятники киевской культуры в лесостепной зоне России (III - начало V вв. н.э.). (Раннеславянский мир 10). Москва. С. 5-9.

Радюш. О.А. 2010. Поселение черняховской культуры у пос.им.Карла Либкнехта (Пены). // GERMANIA-SARMATIA II. Курск-Калининград. С. 179-213, таб. VI-X

Радюш О. А. 2011. Могильник у пос. Им. Карла Либкнехта (Пены) // Черняхівська культура (Оium I). Київ. С.233-242.

Радюш О. А. 2012. Вооружение III- нач. V вв. н. э. с черняховских поселений Курского Посемья. // Stratum plus: от римского лимеса до великой китайской стены. Вып.4. Кишинев. С. 139-155

Радюш О. А. 2014. О Северной границе распространения так называемых «кинжалов с вырезами». // Stratum plus: Римские орлы и сарматские драконы. №4. Кишинев. С. 231-245

Радюш О.А. 2015. Исследования памятников рубежа поздней античности и раннего средневековья (III-V вв. н. э.) в верховьях реки Суджа. // Суджа и суджане в отечественной и зарубежной истории и культуре. Курск. С. 18-39.

Радюш О. А. 2018. Черняховская и киевская культуры: соотношение и проблемы в интерпретации памятников на востоке днепровского левобережья. // Ранний железный век Евразии от рубежа эр до середины I тыс. н. э. Динамика освоения культурного пространства. Тезисы международной научной конференции. Спб. С. 119-125

Разуваев Ю.Д. 1993. Случайные археологические находки в бассейне Красивой Мечи. // Древности Волго-Донских степей 3. Волгоград. С. 111-115.

Сымонович Э. А., 1983 Північно-східне пограниччя памя`ток черняхівської культури. // «Археологія». С. 71-85

Сымонович Э. А., 1964. Северная граница памятников черняховской культуры. // Древности эпохи сложения восточного славянства. (Материалы и исследования по археологии СССР 116). Москва. С. 7-43.

Щукин М.Б. 1979. К предыстории черняховской культуры. Тринадцать секвенций. //Археологический сборник государственного Эрмитажа 20. Ленинград. С. 66-89

Щукин М.Б. 2005. Готский путь: готы, Рим и черняховская культура. СПб. 592 с.

Gavritukhin I., Radyush O. 2018. A polychrome brooch from Konevo (Kursk oblast / rus) and its context. // Lebenswelten zwischen Archäologie und Geschichte festschrift für Falko Daim zu seinem 65. Geburtstag, T. 1. Monographien des RGZM, bd. 150, 1. Mainz. S. 137-160

Soupault V. 1996. A propos de l'origine et de la diffusion des poignards et eppees ă encoches (IV-VII ${ }^{\mathrm{e}}$ s.). // МАИЭТ, 5. Симферополь. С. 60-76, 486-492. 


\section{ЖИЗНЬ У ПОДНОЖИЯ ПИРАМИД: \\ ИЗ ИСТОРИИ ОДНОЙ ДРЕВНЕЕГИПЕТСКОЙ ГРОБНИЦЫ В ВОСТОЧНОЙ ГИЗЕ}

\section{С. В. Ветохов, М. А. Лебедев, С. Е. Малых}

Дмитрий Рукавишников работал в составе Российской археологической экспедиции ИВ РАН в Гизе (Египет) с 2005 по 2009 г. (рис. 1). С его появлением экспедиция перешла на новый качественный уровень: Дима внес свежую струю в раскопки, привел новых специалистов - геофизиков, антропологов, археолога-художника. Отличаясь хорошей археологической подготовкой и методической базой, он предоставил нам возможность иначе посмотреть на то, что мы делаем, с другой стороны взглянуть на участок работ, на отношение к египетским землекопам, подход к выбору места работ. И результат - обнаружение целого гробничного комплекса в южной части российской концессии в Гизе, жемчужиной которого стала гробница Ченти I.
Димин опыт раскопок в Сирии, умение общаться с арабскими рабочими, знакомство с новейшими методами в археологии и неистощимый оптимизм серьезно помогли развитию экспедиции. Светлым, добрым и надежным человеком он останется не только в нашей памяти, но и в памяти многих египетских рабочих и инспекторов (рис. 2). В конце каждого сезона они неизменно просили, а кто не знает, тот и сейчас просит передать Диме привет: «Дима тамам? Салимли Алейх!» Скажут так и улыбаются.

На песке у подножия пирамид навсегда сохранятся Димины следы - следы, оставленные хорошо знакомой здесь твердой поступью археолога. А рядом с ними много других следов - грабителей, исследователей, охотников за сокровищами,

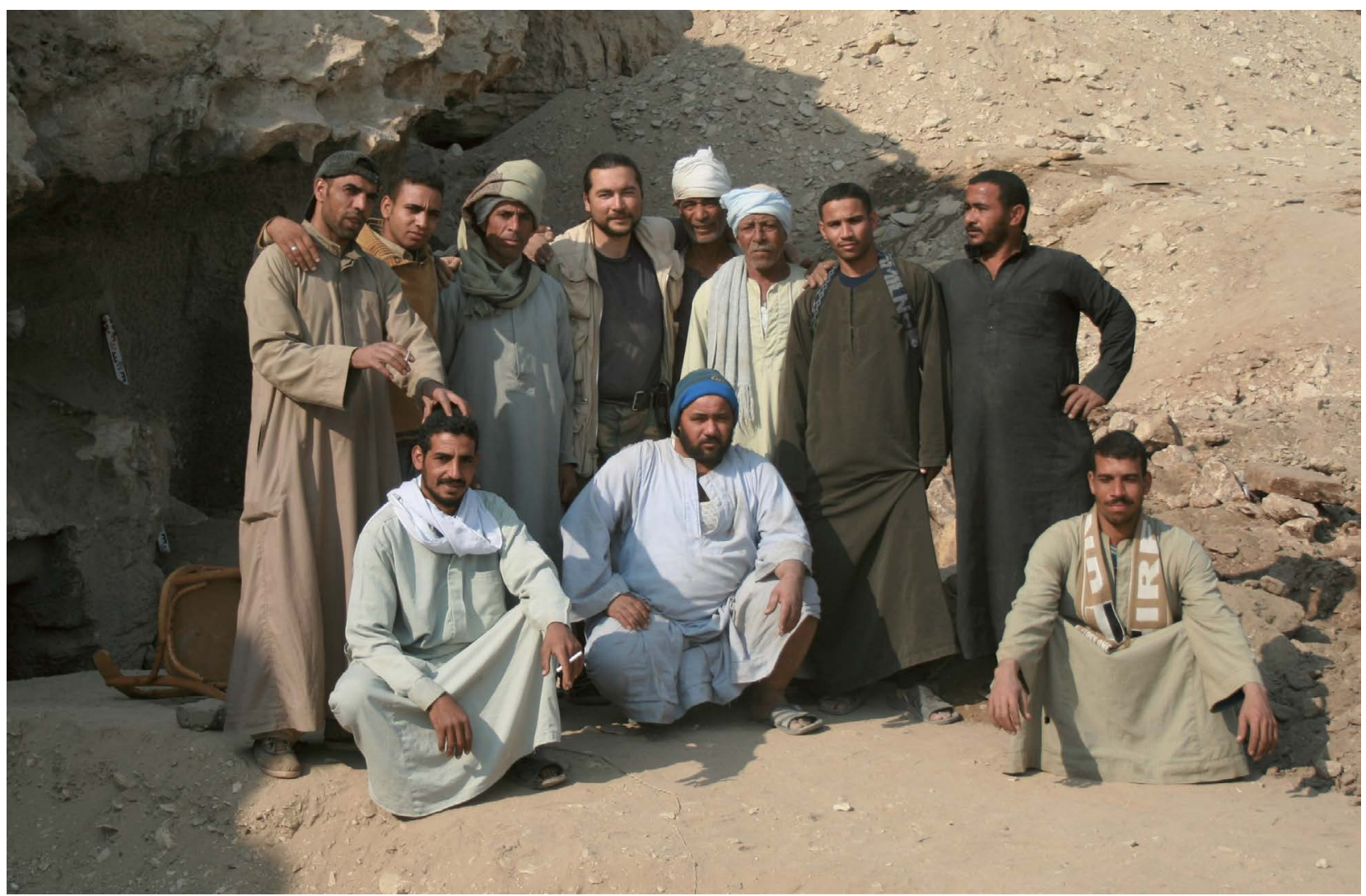

Рис. 1. Дима с рабочими во время раскопок скального некрополя в южной части российской концессии в Гизе. Фото С.Е. Малых 


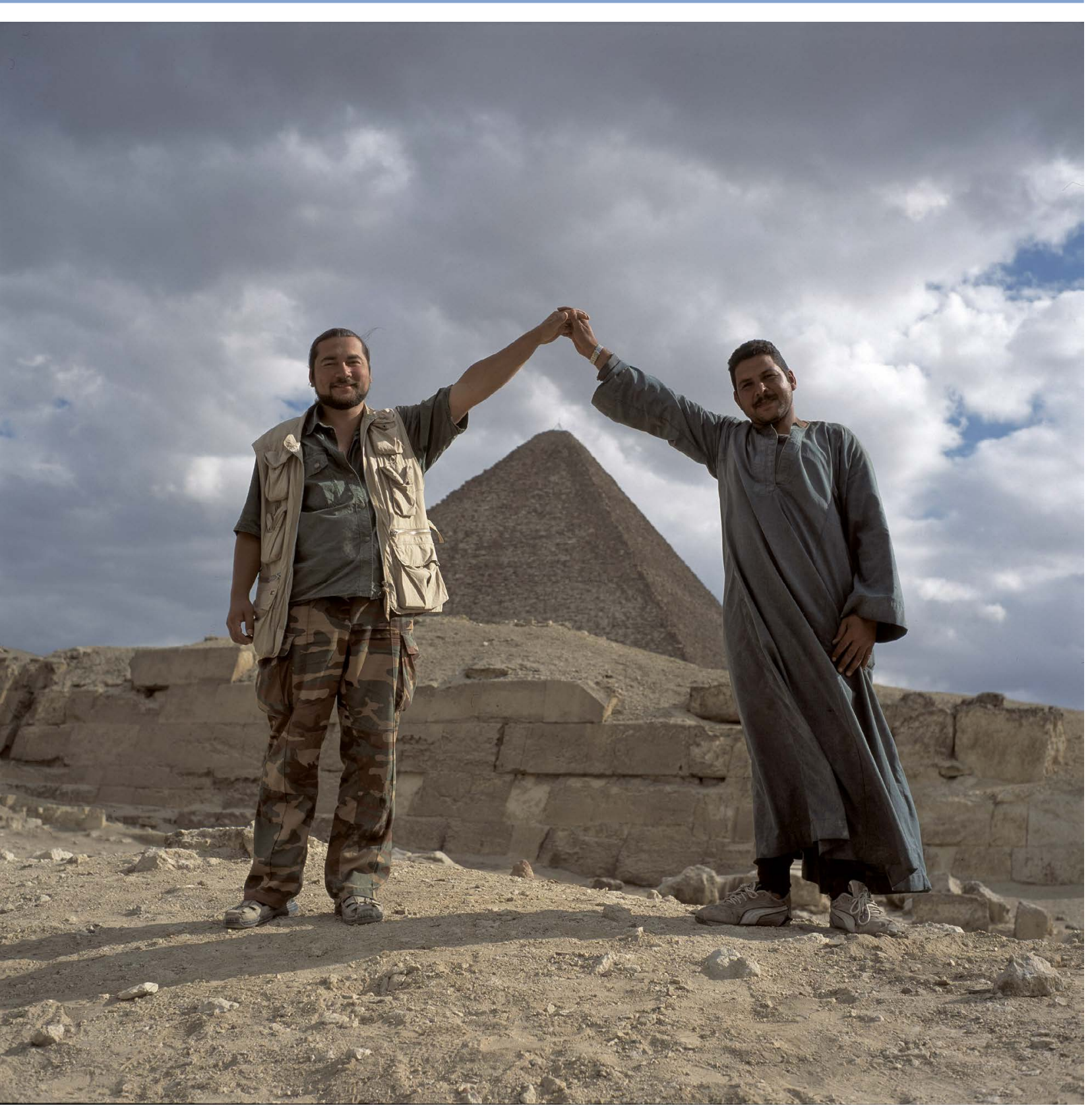

Рис. 2. Дмитрий и Рагаб - сегодняшний раис (начальник рабочих) Российской археологической экспедиции в Гизе. Фото С. В. Ветохова

художников, которые ходили по Гизе теми же тропами и дышали тем же воздухом. И наша статья не столько об истории одной гробницы, сколько о затейливом переплетении судеб различных людей, разделенных веками и континентами. А еще это привет Диме из Гизы от всех, кто его знает и помнит: «Ассаляму алейкум, Дима!»

Гробницы в южной части концессии (рис. 3), найденные в значительной степени благодаря Диминым усилиям, обеспечили нас работой на многие годы вперед. Даже сегодня далеко не все памятники, исследованные им, остаются полностью опубликованными. Среди них главное место, без сомнения, занимает гробница Ченти I. Этот скальный комплекс был вырублен на восточной окраине плато Гизы во второй половине Древнего царства, когда на плато уже возвышались знаменитые пирамиды царей IV династии - Хуфу, Хафра и Менкаура. Изначально гробница состояла из богато декорированной скальной часовни и трех шахт, которые вели в погребальные камеры владельца гробницы и его родственников. История гробницы Ченти I - лишь небольшой фрагмент сложной исторической мозаики Восточного плато Гизы. Однако этот фрагмент в полной мере и до конца разделил с Восточным плато его судьбу: от древних египтян эпохи строительства пирамид до грабителей, первых археологов и современных обитателей гробниц. 


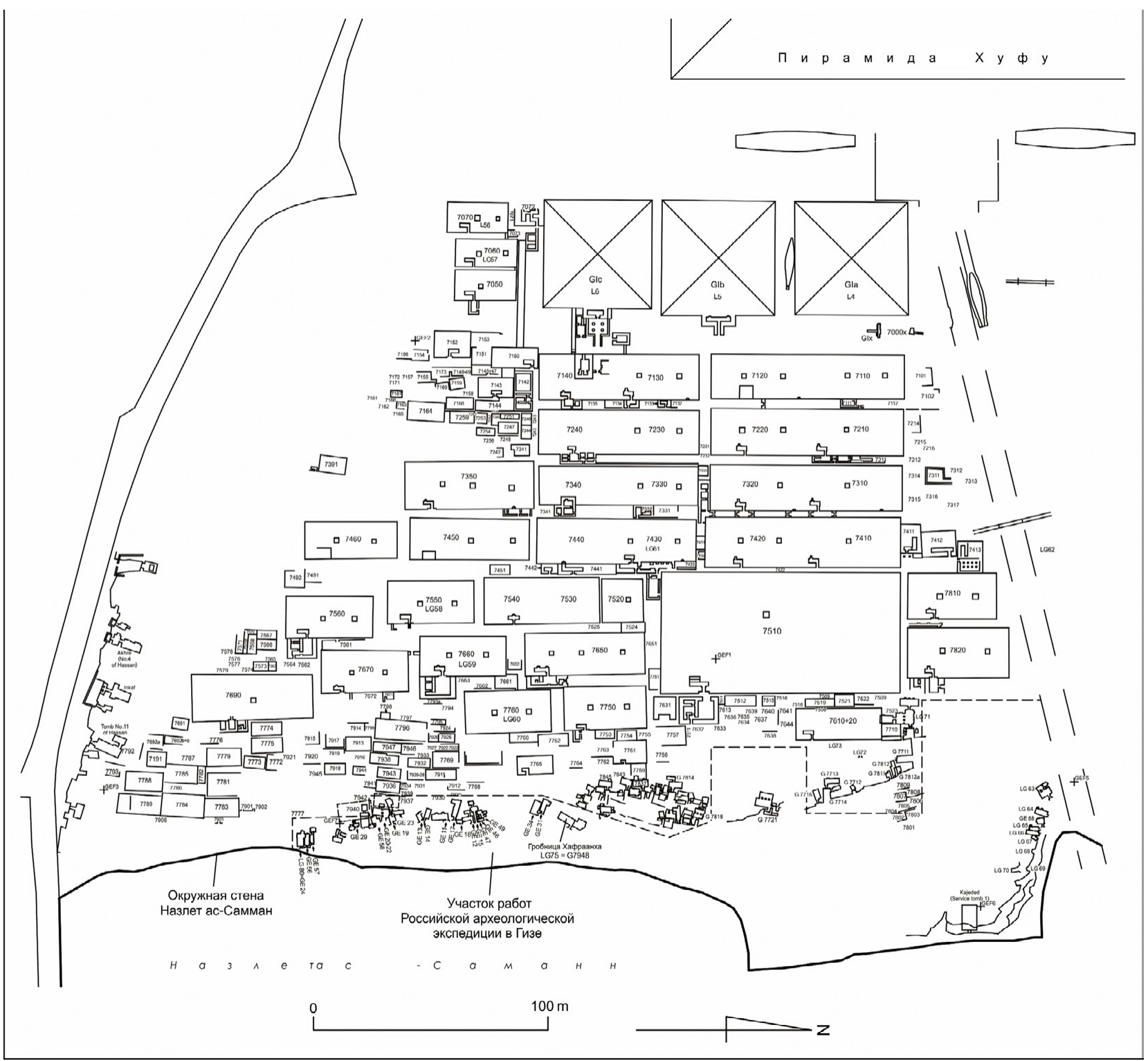

Рис. 3. План Восточного некрополя Гизы (С. В. Ветохов)

\section{История в образах и текстах: Ченти и его судьба}

Когда в скалах у подножия пирамид была вырублена гробница Ченти I, получившая в нашей документации номер GE 11? Об этом лучше всего позволяют говорить рельефы. Иконография изображений в часовне указывает на то, что Ченти строил свою гизехскую гробницу во второй половине правления $\mathrm{V}$ царской династии (XXIV в. до н.э.). Будучи обладателем статуса «знакомого царя», он входил в элиту древнеегипетского общества. Второй сохранившийся титул Ченти - «начальник царского имения» указывает на то, что он трудился в составе администрации царских хозяйств.

Имя Ченти было весьма популярным в эпоху Древнего царства, причем использовалось оно как среди мужчин, так и женщин. Из одной только Гизы до нас дошли сведения о почти сорока различных Ченти (Лебедев, 2015). Популярность имени, видимо, определялась его значением: с древнеегипетского его можно перевести как «Ты-являешься-избранным».

Гробница чиновника была богато украшена барельефами и надписями, которые покрывали все четыре стены часовни. Увы, не все рельефы сохранились одинаково хорошо. Как и другие скальные гробницы Восточного плато Гизы, гробница Ченти I была высечена в известняке мокаттамской геологической формации. Особенность этих эоценовых известняков - их большая неоднородность. Часть гробницы Ченти была вырублена в относительно мягком слое, который впоследствии разрушился. 


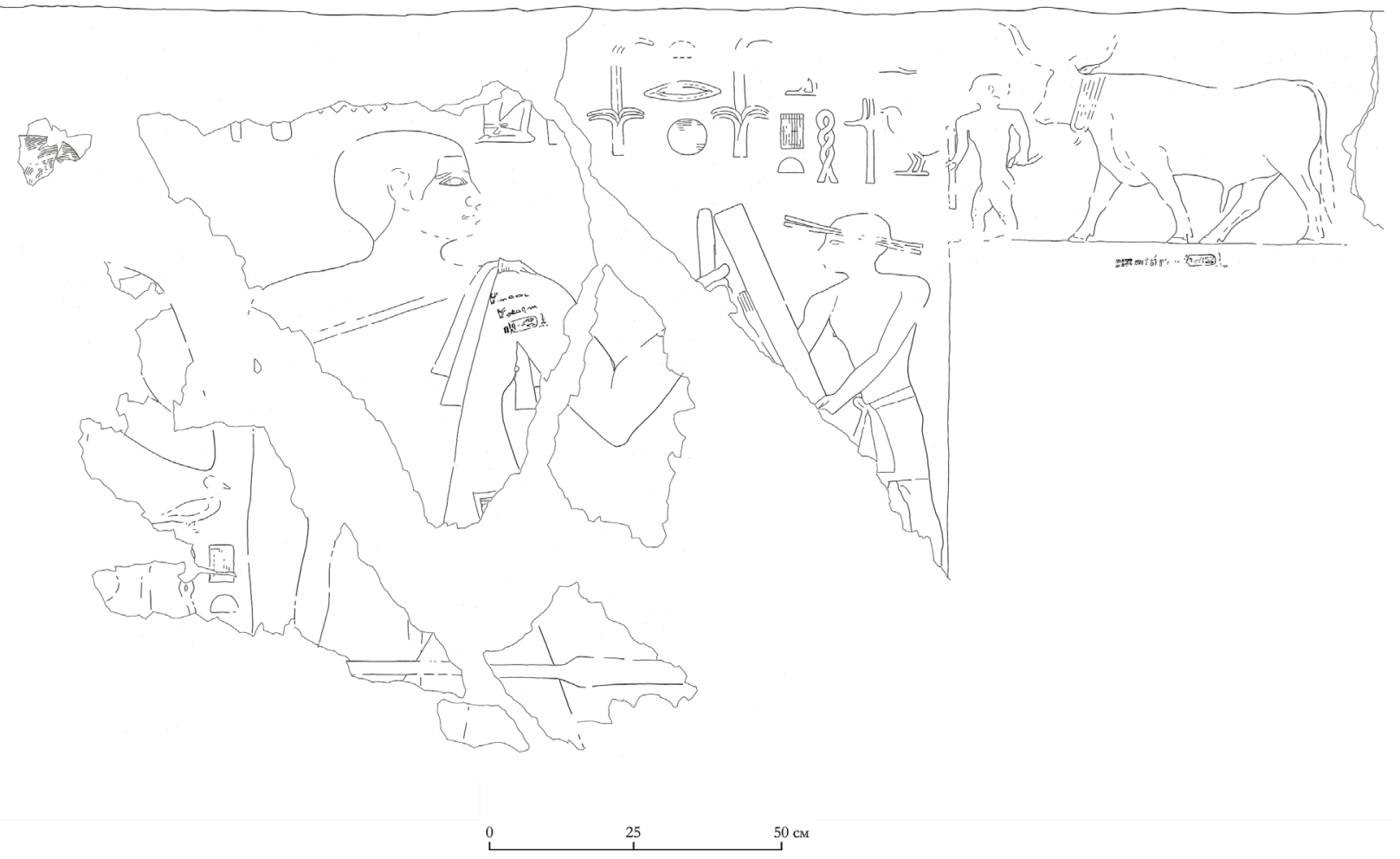

Рис. 4. Северная стена часовни Ченти I (С. В. Ветохов с добавлениями М. А. Лебедева)

Тем не менее на северной и восточной стенах часовни все же сохранились изображения самого Ченти. В первом случае перед владельцем гробницы в образе писца стоит его сын Усерптах, который зачитывает двойнику своего отца ${ }^{1}$ список приношений или передает документ, связанный с поминальным культом (рис. 4). Во втором случае Ченти изображен вместе со своей женой, имя и титул которой, к сожалению, были высечены в мягком участке породы и не сохранились. В северной части восточной стены супруги изображены стоя, а в южной части пара сидит перед жертвенными столом, наблюдая за разделкой туши быка и процессией дароносцев: так древние египтяне представляли себе счастливую жизнь после смерти.

Архитрав над двумя ложными дверями ${ }^{2}$ на западной стене часовни сохранил длинную надпись, выполненную крупными врезанными иероглифами: «Жертва, которую дает царь, и жертва, которую дает Анубис, находящийся перед святилищем³: погребение в пустыне западной (после достижения) великой старости. Господин почтения при боге великом, начальник царского имения Ченти. Жертва, которую дает царь: жертва голосом ${ }^{4}-$ хлеб, пиво [...]». Этот текст необычен тем, что в конце него начинается вторая жертвенная формула, предназначавшаяся то ли для жены Ченти I, то ли для какого-то другого родственника, похороненного в этой же гробнице, - например для сына или брата.

\section{История в камне: архитектура гробницы Ченти I}

Уже при беглом взгляде на часовню Ченти I видно, что пострадала она от времени значительно сильнее, чем многие близлежащие гробницы. Так, весь верх восточной и южной стен разрушен, барабан над входом отсутствует,

\footnotetext{
1 Египтяне эпохи Древнего царства верили в то, что гробница является миром, где пребывает двойник умершего. Этот двойник мог получать жертвы через свои изображения на стенах часовни и при этом функционировал как самостоятельное и вполне независимое от своего «оригинала» существо (Большаков, 2001).

2 Ложная дверь - традиционный элемент оформления египетских гробниц. Это символическое изображение реальной двери, через которое осуществлялась связь мира двойника с миром живых. Ложные двери занимали важнейшее место в поминальных ритуалах, часто именно у ложной двери совершались жертвоприношения

3 Традиционный эпитет Анубиса - бога-покровителя некрополя.

4 Чтобы возыметь действие, древнеегипетские жертвенные формулы (по сути - перечни жертвенных даров) должны были произноситься вслух.
} 


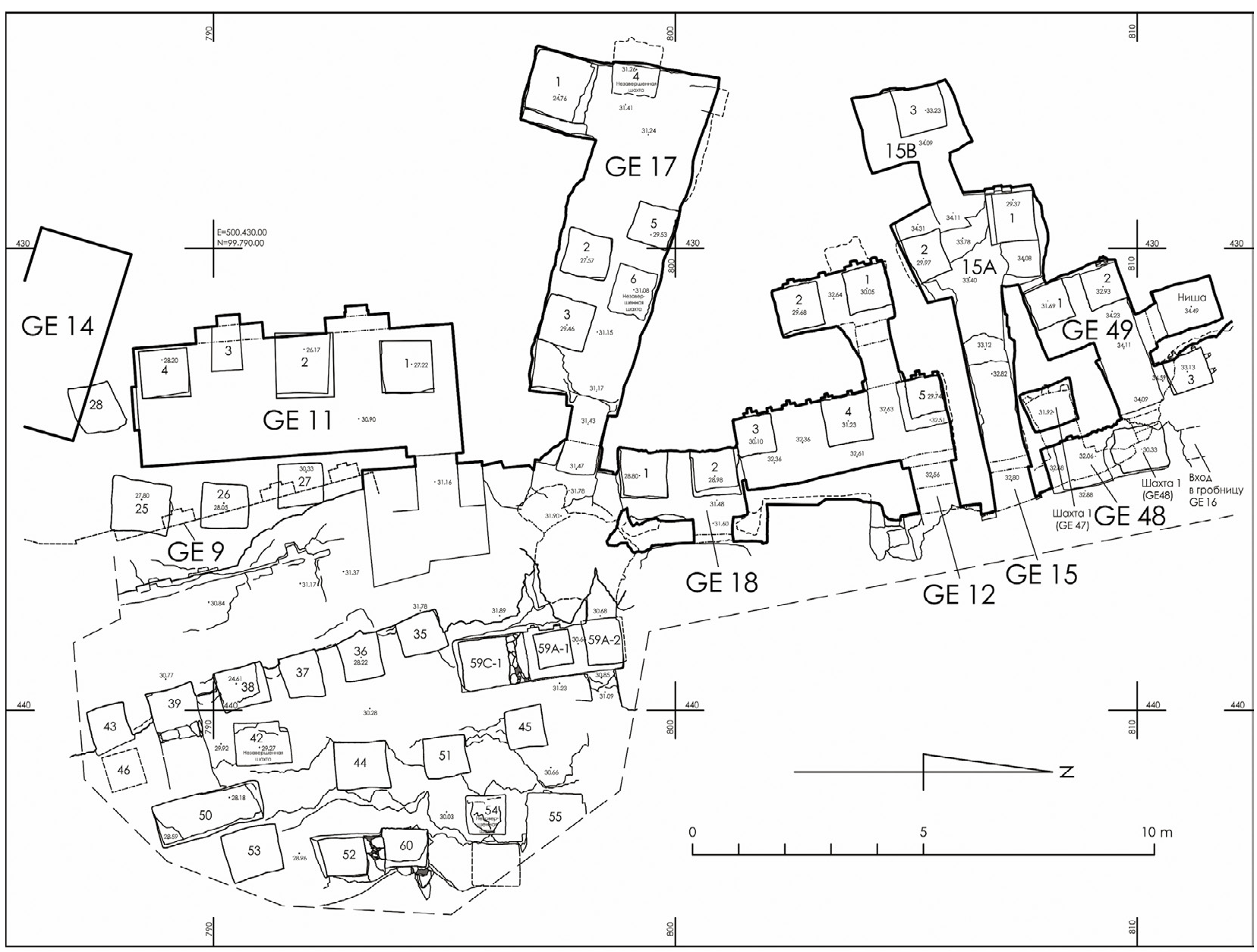

Рис. 5. Скальный некрополь около гробницы Ченти I (С. В. Ветохов)

посередине западной стены была грубо вырезана, но так и не завершена ниша непонятного назначения, в полу имеется заделанный пролом.

Часовня гробницы Ченти I, представляющая собой прямоугольное помещение L-образной формы в плане (длина 7,1 м, ширина 2,6, высота $2,64)$, вытянутое по оси С-Ю и имеющее проход в северном конце восточной стены. Несмотря на то что комплекс Ченти I был «гробницей-ядром» ${ }^{5}$ и появился первым на данном участке некрополя, заняв лучшее возможное место (рис. 5), качество скалы, в которой он вырублен, оказалось далеко не самым подходящим для сооружения большой по размеру часовни и малопригодным для изготовления рельефов. Впрочем, сохранившиеся фрагменты оформления и грандиозность архитектурного решения западной стены (рис. 6, 7) говорят о том, насколько впечатляющим могло быть убранство гробницы в древности. При этом вырубалась гробница без должного запаса прочности. Так, восточная (внешняя) стена часовни изначально имела в верхней части толщину всего около 0,3-0,4 м, а пристроенные снаружи еще в эпоху Древнего царства три погребальные шахты (GE 25-27) (рис. 8) привели к еще большему ее истончению, местами до 0,17 м. Впоследствии это неминуемо вызвало обрушение всего ее верха. О том что шахты были вырублены еще в древности, когда культ в часовне Ченти I продолжал функционировать, говорит не только их устройство, отвечающее канонам Древнего царства, но и аккуратно заделанный пролом между часовней гробницы и погребальной камерой 27А шахты GE 27. Первоначально погребальную камеру в шахте 27 планировали прорубать на запад, но, не рассчитав глубину, древние мастера разрушили пол в часовне Ченти I. Образовавшийся в итоге пролом в полу гробницы был качественно закрыт каменными блоками, швы замазаны раствором, а погребальную камеру прорубили в другом направлении - на север.

Возможно, обрушения восточной стены можно было избежать, дополнительно заглубив часовню в скальный утес, но для этого

\footnotetext{
5 Подробнее о термине см. Ветохов, 2016.
} 


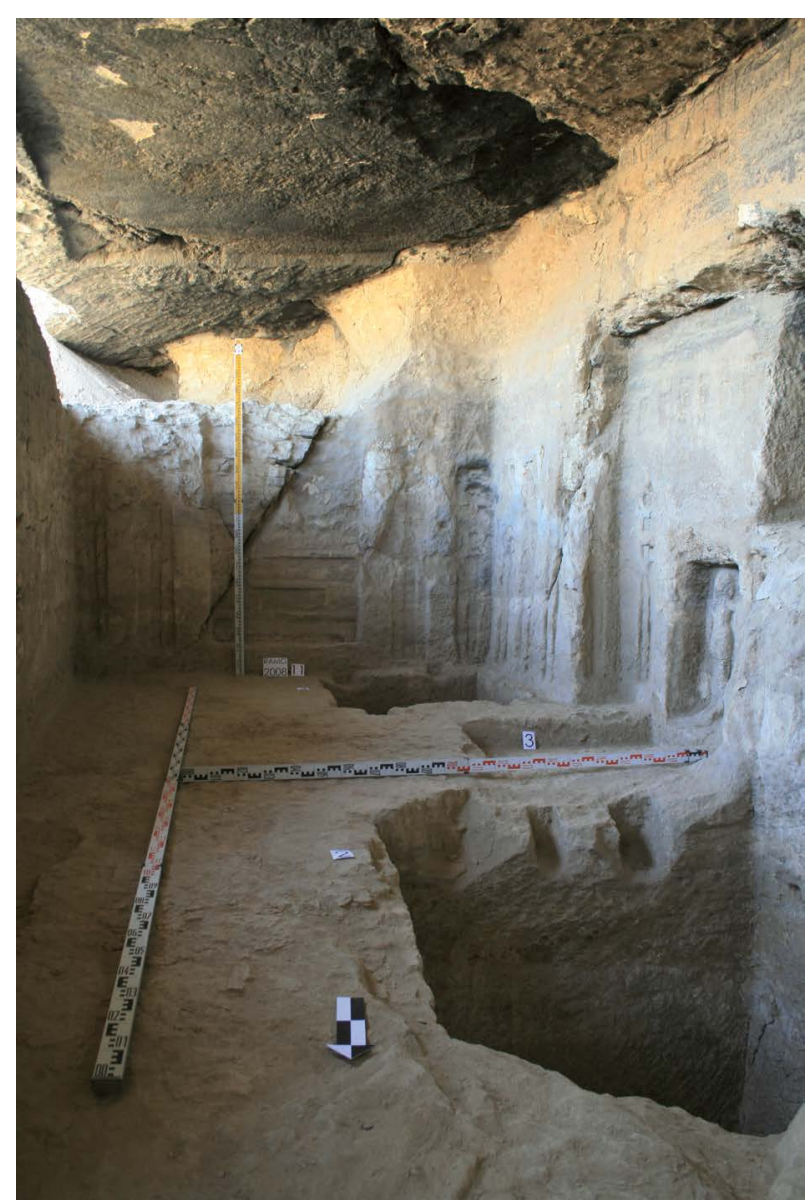

Рис. 6. Часовня Ченти І: вид на юг. Фото С. В. Ветохова

пришлось бы делать более длинный вход, что, по-видимому, не рассматривалось строителями как решение проблемы, тем более что длина входов в скальных гробницах, как и их ширина, имела сложившиеся стандарты.

Оформление входа в часовню. Верхняя часть входа в часовню, где должны были размещаться архитрав и барабан ${ }^{6}$, разрушена. О вероятном наличии в древности архитрава говорит статистика: в Гизе почти нет примеров, чтобы при уцелевшей скале над входом отсутствовал архитрав (даже без надписей) или, по крайней мере, его следы (если он был изъят позднее). Важность архитрава косвенно подтверждается тем, что в Гизе чаще встречаются гробницы с архитравами, пусть и без барабана, нежели наоборот. Например, это можно видеть в таких скальных комплексах как гробницы Хапеннебти (G 7815), Итисена или Хуфухотепа (GE 15 / LG 76).

О существовании ранее вставного барабана, утраченного к настоящему времени, говорят

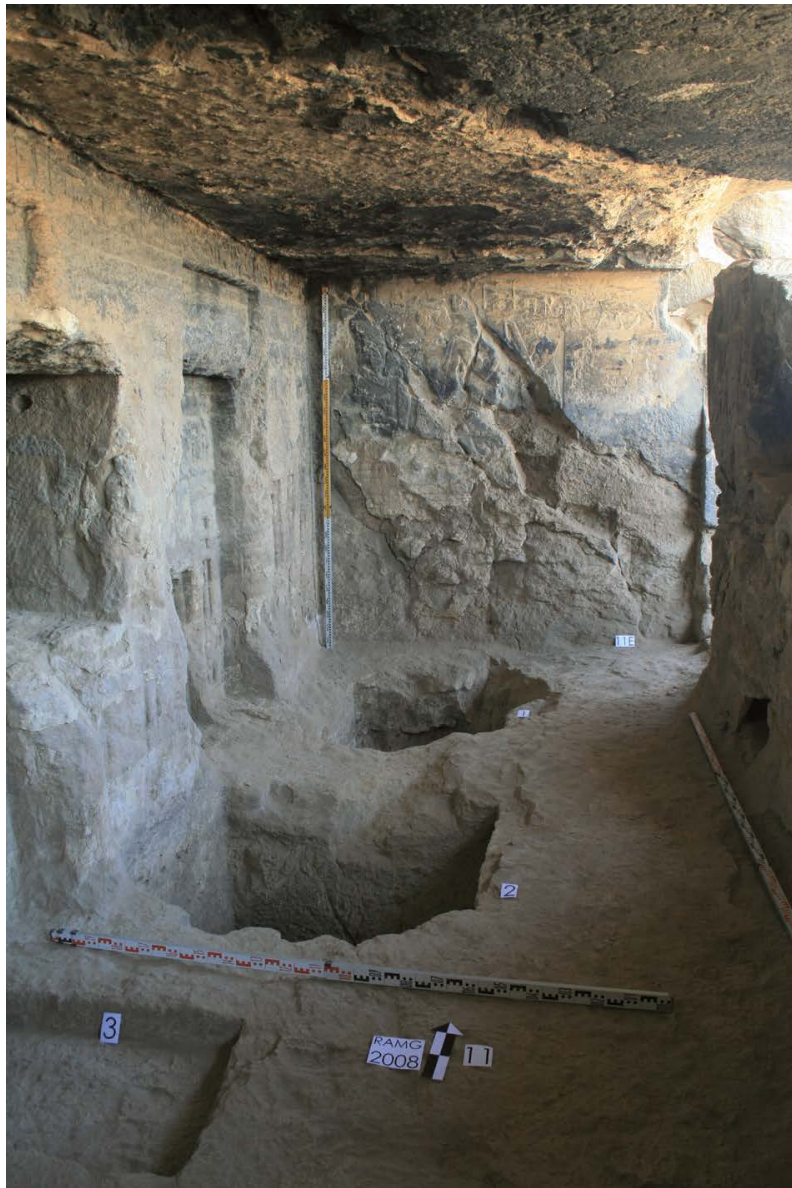

Рис. 7. Часовня Ченти I: вид на север. Фото С.В. Ветохова

выровненные площадки по бокам прохода на уровне 1,91-1,96 м от пола часовни. Более точно установить высоту прохода в часовню трудно изза повреждения оригинального пола в проходе: он был высечен на участке материнской скалы плохого качества. Решение изготовить вставной барабан из отдельного блока, принятое строителями часовни, также указывает на изначально невысокое качество скалы в данном месте.

Поскольку первые скальные гробницы в Гизе принадлежали членам царской семьи, размеры и богатство этих комплексов тоже были «царскими». Только при входе в такие часовни встречаются вставные гранитные барабаны как исключительная прерогатива царя и его родственников (например, в гробнице царевича Каиджедеда). В богатых скальных гробницах лиц нецарской крови барабаны также бывали вставными, однако вырезали их, как правило, не из гранита, а из белого известняка более высокого качества, чем материнская скала, в которой была вырублена сама

\footnotetext{
6 Так называемый барабан над проходом перед дверью - важный элемент часовен как в мастабах (см. ниже), так и в скальных гробницах. По форме он имитирует свернутый в рулон занавес из циновки, который еще в додинастическом Египте использовали для закрытия дверных проемов в жилых домах..
} 
гробница. Обычно такой известняк добывали в каменоломнях Туры на противоположном берегу Нила. Не исключено, что сама традиция размещать вставной барабан восходит к мастабам ${ }^{7}$ (для которых он всегда изготавливался из отдельного каменного блока) и продолжилась она лишь в богатых скальных гробницах, форма часовен которых также подражала часовням мастаб. Несомненно, что именно возможность изъятия вставных барабанов и стала причиной утраты большинства из них. Барабаны вынимали как в древности и средневековье для вторичного использования при строительстве, так и в XIX в. для комплектования музейных и частных коллекций, ведь на барабанах часто были надписи. Такова судьба, к примеру, входного барабана из гробницы Хафраанха, вывезенного из Египта Прусской экспедицией К.Р. Лепсиуса и хранящегося ныне в Египтологическом музее Берлина (Kormysheva et al., 2010. P. 49).

Дверь. Сразу за проходом, внутри часовни, в полу у северной стены сохранилось характерное углубление для подпятника двери. Это позволяет предположить, что оригинальная деревянная дверь в часовню была одностворчатой. Подпятник, выполнявшийся, как правило, из твердых пород камня (базальта, гранита и др.), на который устанавливалась дверь, так же как и сама дверь, не сохранился.

Грабительский ход. Вдоль западной стены гробницы располагаются три погребальные шахты (№ 1, 2 и 4) (рис. 8). Кроме того, между шахтами 2 и 4 было высечено прямоугольное углубление, предназначавшееся, возможно, под жертвенный стол или бассейн. В документации оно получило номер 3. Все шахты были размещены таким образом, чтобы сохранить широкие площадки между ними и предоставить свободный подступ к ложным дверям - основным культовым элементам гробницы. Шахта 1 завершается проходом, ведущим в западном направлении в погребальную камеру 1А. Сама камера задумывалась прямоугольной по форме, но не была завершена. В ее юго-западном углу располагается грубо вырубленная ниша с проходом в полу, ведущим в пещерообразное пространство, бывшее, по всей видимости, грабительским ходом. Ход высотой около 1,2-1,9 м и шириной $0,9-4,0$ прорублен в мягком глинистом слое, тафле, в западном направлении на 7,5 м вглубь скалы (рис. 9). Целью его создателей, вероятно,

\footnotetext{
7 Мастаба - традиционный тип гробниц в эпоху Древнего царства. Основное различие между скальной гробницей и мастабой проявляется в конструкции и взаимном расположении часовни и шахтных погребений, которые ведут в погребальные камеры. Мастаба сооружалась из каменных блоков, а скальная гробница вырубалась в скальном массиве. Шахты в мастабе располагаются вне часовни и размещаются в основном массиве мастабы, в то время как в скальной гробнице шахты располагаются внутри поминальной часовни.
} 


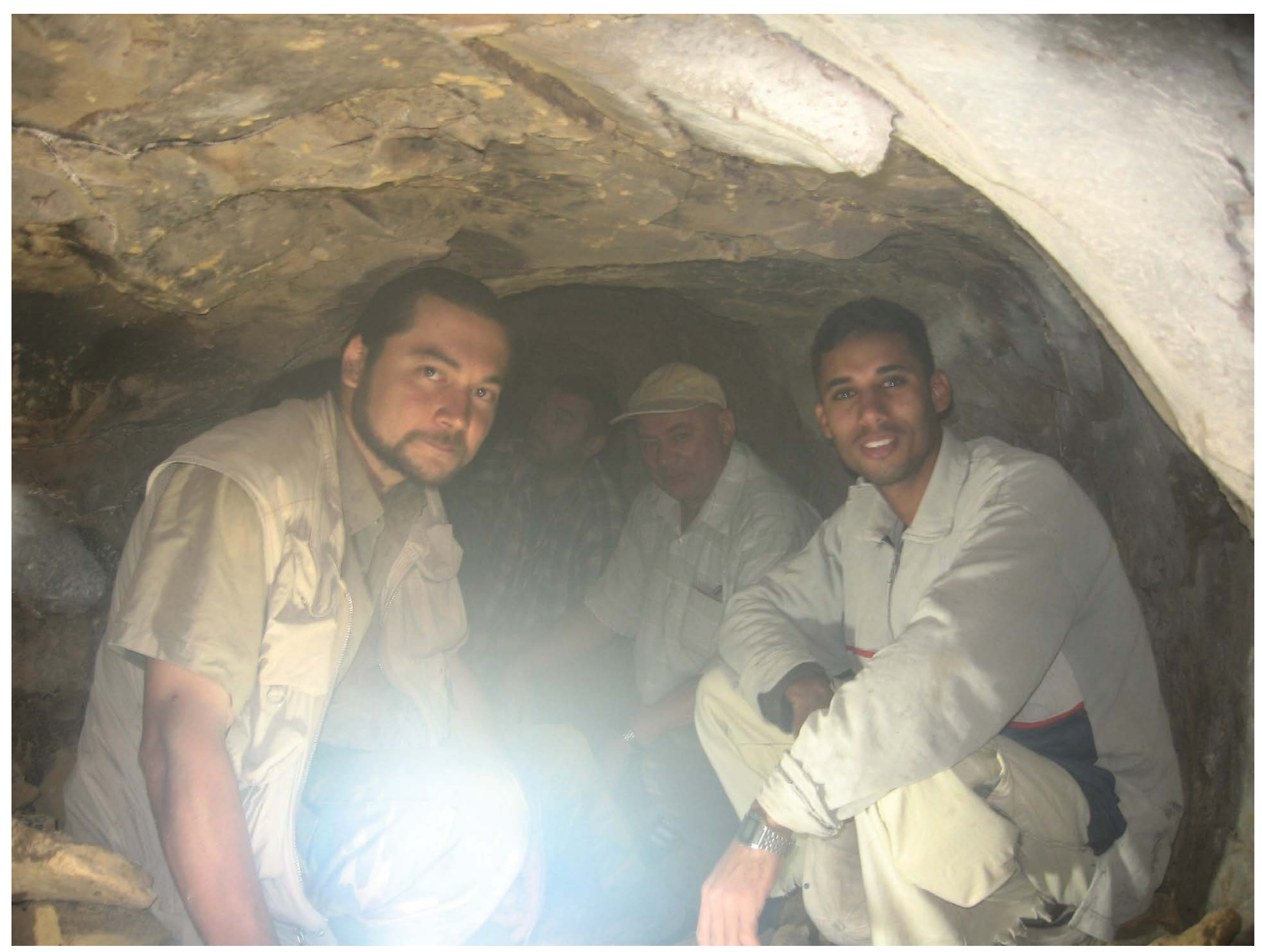

Рис. 9. Слева направо: Дмитрий Рукавишников, Павел Воровский, Владимир Копейкин и землекоп Махмуд в грабительском ходу в гробнице Ченти І. Фото С. Е. Малых

было добраться до шахтных погребений каменных мастаб, которые вплотную примыкают к скальному откосу на восточной окраине Восточного плато некрополя Гизы, где вырублена гробница Ченти I. Каменные мастабы обычно имели больший размер шахт и шахтных погребений, чем скальные гробницы, а потому традиционно рассматривались грабителями как более перспективные в деле обнаружения богатого погребального инвентаря. В связи с этим остается неясным, почему ход из погребальной камеры $1 \mathrm{~A}$ прорублен на 4,1 м еще и в юго-восточном направлении, где располагаются шахтные погребения небольших и как следствие небогатых скальных гробниц. Говорить о датировке сооружения данного хода трудно. Однако он может относиться к периоду, когда гробницы на Восточном плато Гизы использовались как жилье, т.е. к эпохе раннего Средневековья или Нового времени.

\section{Гробница Ченти I и история египтологии}

Несмотря на наличие богатого оформления - ложных дверей, статуй, рельефов, надписей, гробница Ченти I каким-то невероятным образом ускользала от внимания исследователей вплоть до 1930-х гг. При этом она вполне была доступна европейским любителям древностей уже, по крайней мере, со второй четверти XIX в., о чем свидетельствуют оставленные на стенах гробницы граффити (рис. 10)

Первым европейским исследователем, увидевшим гробницу Ченти I, возможно, был Джованни Батиста Кавилья (1770-1845). Этот итальянец забросил морское дело и из капитана корабля превратился в одного из самых увлеченных охотников за древностями. Он много копал по всей Гизе, в том числе на территории современной

\footnotetext{
8 Одну из путешественниц, выбивших надпись на северной стене часовни, судя по всему, можно идентифицировать. Надпись «Reine Bonfort», видимо, была оставлена родственницей некоего месье Бонфора, эксперта, который служил при Мухаммеде Али-паше, занимаясь сельским хозяйством и озеленением Каира (Muskau, 1845. P. 97, 197, 216, 224).
} 
российской концессии, и обустроил себе настоящую квартиру в гробнице Ипи, расположенной примерно в 55 м к югу от гробницы Ченти (Лебедев, 2018. С. 60).

Еще одним европейским исследователем, который, вероятно, видел гробницу Ченти I, был Эдвард Вилльям Лэйн. В 1825 г. он несколько раз посетил плато Гизы и во второй свой приезд долгое время жил в одной из скальных гробниц, которая, по его описанию, была около 8 футов в ширину и примерно в два раза больше в длину9. Стены гробницы были покрыты рельефами, которые, однако, по словам Лейна, были сильно разрушены временем. Часовня имела одно помещение, но оно было разделено современной стеной на две комнаты. Слева от входа было три отверстия, которые служили окнами. Перед гробницей находилась скальная терраса, на которой Лейн по вечерам пил кофе и курил трубку. В соседней гробнице жил со своей семьей водонос Али, зарабатывавший на жизнь тем, что охранял сложенные у него дома древности, откопанные Кавильей, а также носил воду из колодца перед гробницей Ипи (Lane, 2000. Р. 162-165). Все эти детали вполне подходят под описание гробницы Ченти I, если не считать длины часовни, которую Лейн, возможно, не мог точно оценить из-за наличия в его время стены, делившей основное помещение на две части. Впрочем, не исключено, конечно, что Лейн жил в одной из гробниц, расположенных выше по склону и раскопанных американскими археологами.

В 1828 г. в гробнице Ченти I побывали или даже жили в ней два художника - Нестор Л'От (1804-1842) и Эдуард-Франсуа Бертен (1791-1871), участники знаменитой франко-тосканской экспедиции под руководством Жана-Франсуа Шампольона (1790-1832), расшифровавшего незадолго до этого путешествия египетские иероглифы, и Ипполито Розеллини (1800-1843). О пребывании Л'Ота и Бертена в гробнице свидетельствуют две уникальные надписи, выполненные черной краской или чернилами на северной стене часовни Ченти I. Первая надпись сохранилась хорошо:
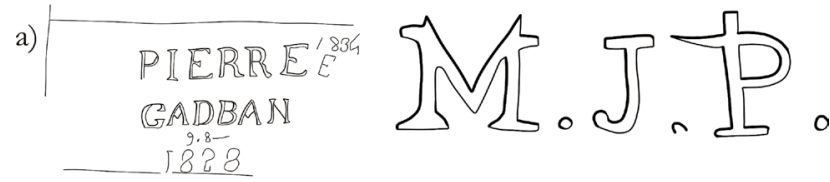

REINE BONFORT
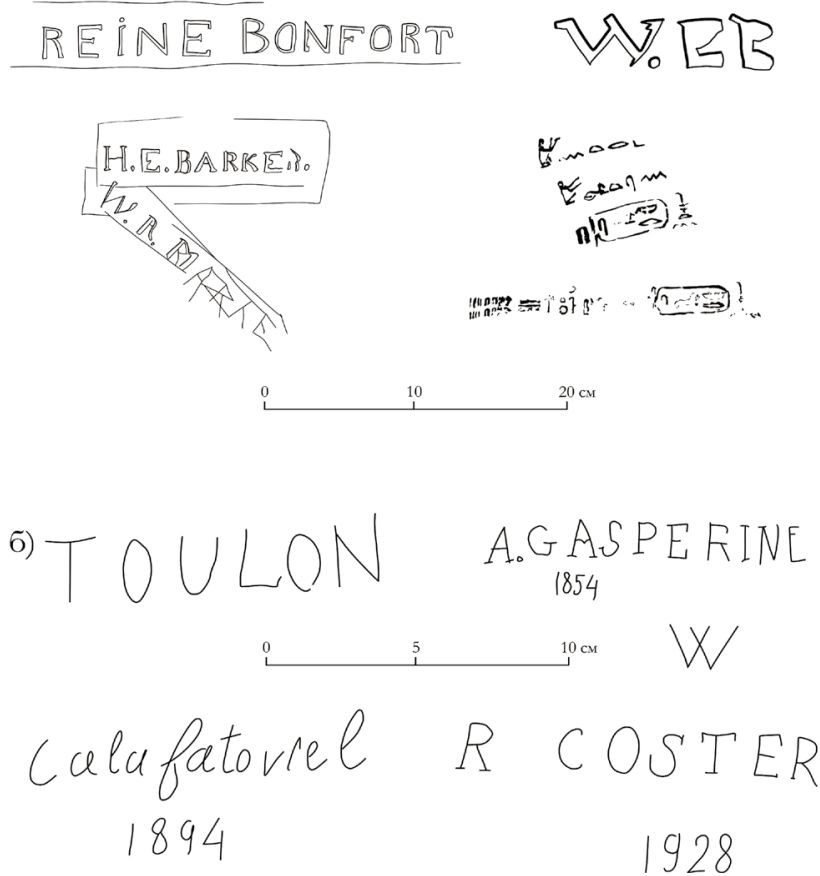

Рис. 10. Поздние граффити в гробнице Ченти I:

а) северная стена; б) восточная стена (прорисовка надписей - В. З. Куватова, обводка надписей - М. А. Лебедев)

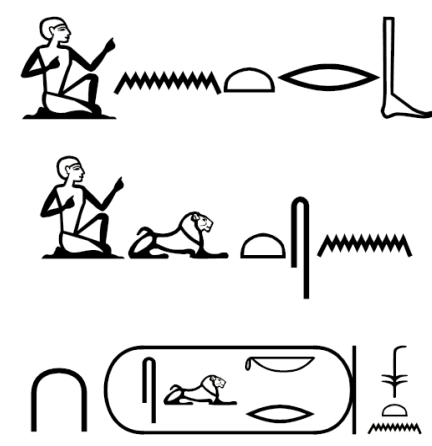

«1) Бертен. 2) Нестор. 3) Царь Карл $X »^{10}$.

Вторая надпись сохранилась хуже, однако она ценна тем, что содержит, судя по всему, попытку датировать текст на древнеегипетском языке годом от рождества Христова: «Царь Карл [...]. Год Спасителя мира ${ }^{11} 1828 »$.

\footnotetext{
9 Современные измерения показывают, что размеры часовни Ченти I составляют 2,6 м в ширину и 7,1 м в длину $(8,53 \times$ 23,29 футов).

${ }^{10}$ Карл X - последний правивший Францией король из династии Бурбонов, который спонсировал французских участников франко-тосканской экспедиции.

${ }^{11}$ Судя по всему, автор надписи постарался передать на древнеегипетском языке распространенное во французском языке определение Христа как «Спасителя мира» (Sauveur du monde).
} 


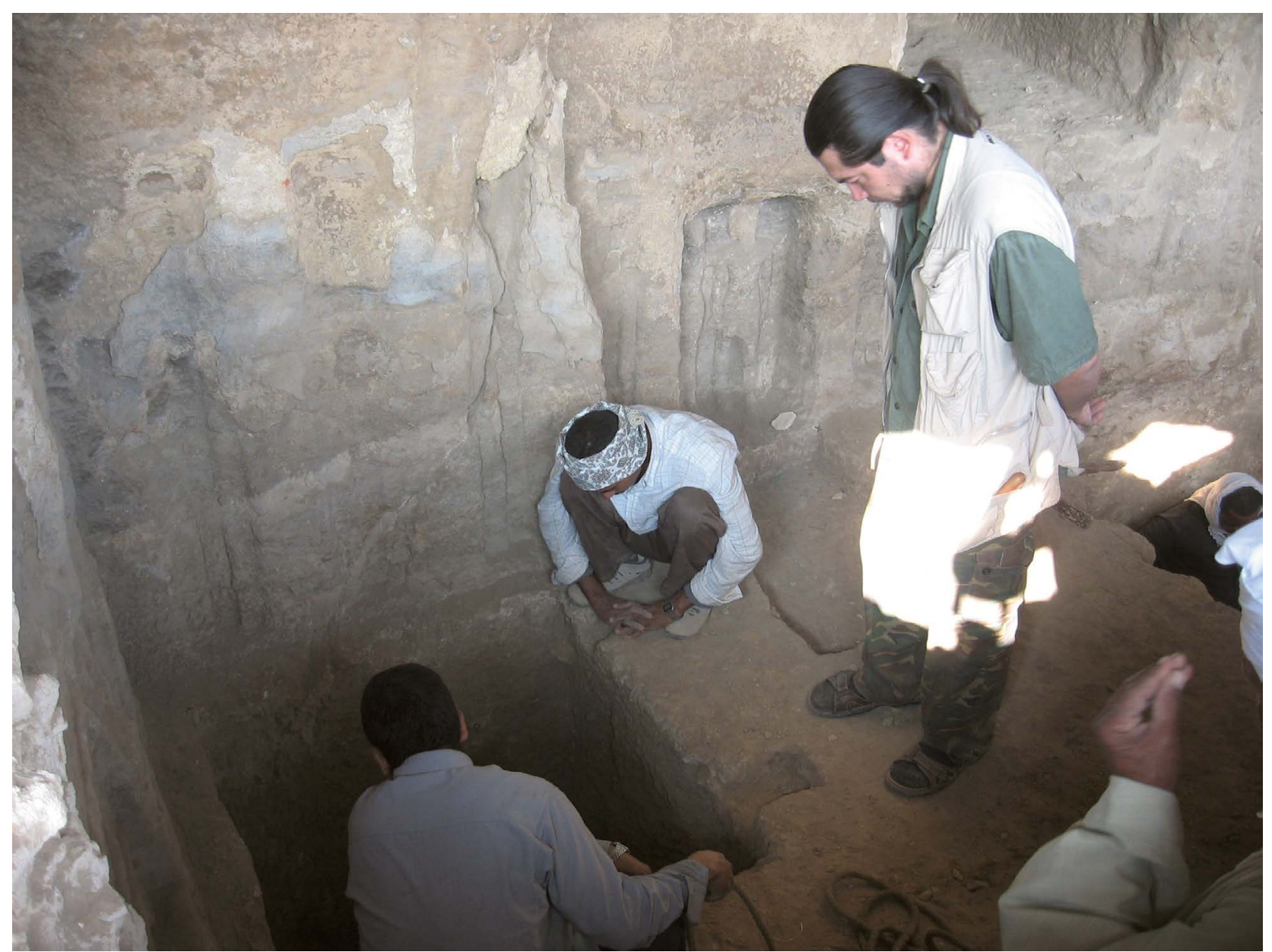

Рис. 11. Дмитрий руководит раскопками в шахте 4 гробницы Ченти І. Фото С. Е. Малых

В этих двух коротких текстах отразились самые первые шаги в изучении древнеегипетского языка. Они не только были созданы в полном соответствии с грамматикой египетского языка, опубликованной позднее (Champollion, 1836), они еще стали, насколько нам известно, первыми примерами нового жанра, полюбившегося со временем египтологам, - посланий потомкам на древнеегипетском языке.

Для Нестора Л'Ота путешествие в Египет станет судьбоносным: покоренный древней цивилизацией, он совершит еще несколько продолжительных поездок на берега Нила, став одним из первых египтологов и археологов, способных читать древнеегипетские надписи. Однако еще более судьбоносным это путешествие станет для самой египтологии. В 1842 г., после очередной поездки в Египет, Л'От тяжело заболел и умер, а его бумаги попали в руки его двоюродного брата - молодого человека по имени Огюст Мариетт (1821-1881). Разбирая письма своего родственника, он увлекся Египтом и начал с жаром изучать иероглифику, коптский, сирийский и арамейский языки.
Оказавшись в Гизе в качестве начальника раскопа, Мариетт облюбовал для жилья одну из скальных гробниц, расположенную всего в 20 м к югу от гробницы Ченти I, - гробницу Персенеба (LG 78 / GE 20-24). Так начал свой длинный путь в археологии человек, которому было суждено раскопать Серапеум в Саккаре, Сфинкса и долинный храм царя Хафра в Гизе, первым в истории начать планомерные раскопки в Карнаке, Абидосе, Дейр эль-Бахри, Танисе и Гебель Баркале, а еще основать первый музей древнеегипетской цивилизации и, наконец, египетскую Службу древностей. Удивительно, но живя всего в паре десятков метров от гробницы Ченти I, Мариетт, судя по всему, так ни разу там и не побывал и не увидел надписей своего брата.

В год смерти Нестора Л'Ота в Гизе работали сотрудники Карла Рихарда Лепсиуса, организовавшего первую комплексную экспедицию в Египет со времен Шампольона. Однако они либо не получили доступа в гробницу Ченти I, в которой в то время могли жить местные арабы, либо внутреннее оформление часовни их по какой-то причине не заинтересовало. В итоге почти все менее 
значительные гробницы с рельефами и надписями на восточной окраине Гизы были описаны Лепсиусом, а гробница Ченти - нет.

Первым археологом, обратившим внимание на часовню Ченти I, стал Джордж Эндрю Райзнер. В 1936 г. его экспедиционный фотограф подробно отснял гробницу. На одном из снимков $^{12}$ в северо-западном углу часовни оказалась запечатлена грубая постройка из камней и, возможно, сырца, покрытая обмазкой. Судя по фотографии, это была печь, которая полностью закрывала устье шахты 1. В южной части постройки, возможно, была использована более ранняя каменная стена, не исключено, что та самая, о которой в своем описании сообщал Лейн. Увы, постройка была полностью разобрана рабочими Райзнера для того, чтобы было удобнее фотографировать рельефы. Датировка ее неизвестна. А наши исследования выявили присутствие в засыпке поминальной часовни небольшого количества фрагментов керамики времени правления V и VI царских династий (XXV-XXII вв. до н. э.) и Византийского времени (фрагменты египетской винной амфоры типа Late Roman 7 Византийского периода (395-641 гг.)).

Раскопки 2011 г. во дворе перед входом в гробницу выявили следы прокала на скальном основании, сбросы печины и золы. Обнаружение среди печины железного изделия говорит о том, что слои эти, вероятно, были весьма поздними, возможно, XIX-XX вв. Обломки печины как раз и могли происходить из разрушенной Райзнером конструкции (печи?) внутри часовни, остатки которой рабочие выносили через внутренний двор гробницы.

Американская экспедиция ограничилась фиксацией рельефного оформления часовни, а затем гробница Ченти I оказалась на многие годы скрыта под песком и щебнем из бывшего американского отвала, сползшего вниз по склону в результате строительства окружной дороги вдоль восточной окраины плато.

\section{Раскопки гробницы Ченти I: история в стратиграфии}

Гробница Ченти I была вновь обнаружена благодаря Диме Рукавишникову в 2006-2007 гг. после георадарной разведки и последовавших затем раскопок. Он же руководил изучением шахт и погребальных камер в гробнице в 2008 г. (рис. 11). В 2011 г. эти работы были дополнены раскопками перед входом в часовню, в результате которых удалось обнаружить внутренний двор гробницы. В тот же год восточная и южная стены гробницы были полностью восстановлены, а на входе установлена металлическая дверь.

В результате современных исследований удалось выяснить, что все три шахты в гробнице, вероятно, неоднократно раскапывались грабителями. На первом метре заполнение почти не было стратифицировано и состояло в основном из серой супеси с известняковой крошкой и щебнем. Далее каждая шахта обладала своими особенностями. Так, нижняя часть шахты 1 была заполнена в основном битым известняком. В заполнении как верхней, так и нижней части шахты был обнаружен керамический материал, значительно разнящийся по датировке: Древнее царство, Римский период (в том числе фрагмент небольшой чаши асуанского происхождения с барботиновым декором), значительное количество фрагментов сосудов Византийского периода и раннего Арабского времени, но также несколько фрагментов более поздних чаш с зеленовато-желтой поливой (XV-XVIII вв.).

Нижняя часть заполнения шахты 2 состояла из коричневой супеси с крупными камнями. Внутри погребальной камеры был найден фрагмент железного предмета, предположительно зубила. В заполнении также выявлены фрагменты керамики различного времени: Древнего царства, Третьего Переходного периода, Позднего периода, Византийского и раннего Арабского времени, а также значительно более поздние фрагменты чаш с зеленой поливой (XV-XVIII вв.).

Заполнение шахты 4 единственное из всех демонстрирует лучшую сохранность: поздняя керамика (Византийского и раннего Арабского времени, в том числе фрагменты кипрских винных амфор типа Late Roman 1) выявлена только на первом метре, а далее присутствовали редкие черепки сосудов эпохи Древнего царства. Нижняя часть шахты 4 была засыпана известняковой крошкой и щебнем, которые явно принадлежали к остаткам оригинального заполнения Древнего царства. В камере находился вырубленный из скалы саркофаг. В древности его перекрывали две плиты. Первая найдена прислоненной к западной стене камеры, вторая была разбита и лежала внутри саркофага. Все погребения в гробнице были ограблены. Но если в погребальной камере шахты 4 грабители, судя по всему, побывали лишь в конце Древнего царства или в Первом Переходном периоде (около

\footnotetext{
12 Фото A7440_NS. URL: http://www.gizapyramids.org (дата обращения 29.10.2018).
} 
2216/2166-2025/2020 гг. до н.э.), то две другие шахты неоднократно раскапывали и впоследствии, вплоть до XVIII в.

Присутствие в заполнении трех погребальных камер и ведущих в них шахт гробницы Ченти I значительного количества бытовой утвари Византийского времени, а также раннего и позднего Средневековья и Нового времени (котлов, тарелок, кипрских винных амфор типа Late Roman 1, египетских винных амфор типа Late Roman 7, винных кувшинов, кувшинов-фильтров для воды, чаш с зеленой и зелено-

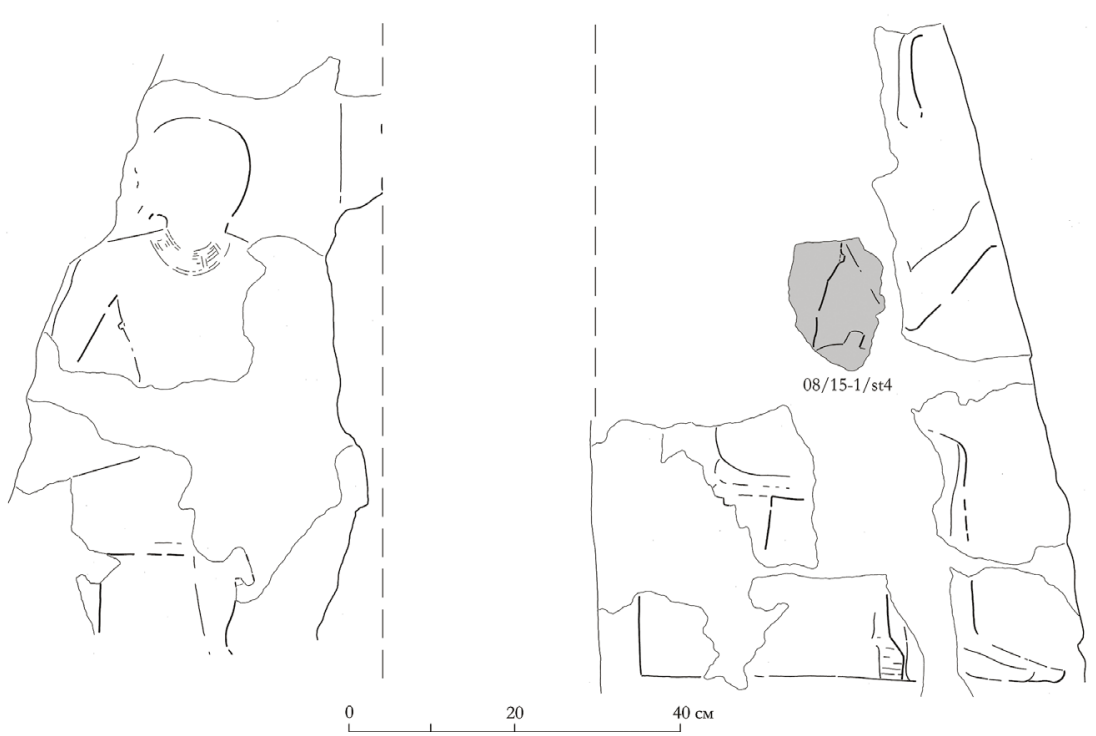

Рис. 12. Рельефы на входе в часовню Ченти I и фрагмент 08/15-1/st4 из гробницы Хуфухотепа (GE 15) (М. А. Лебедев) вато-желтой поливой) демон-

стрирует активную человеческую деятельность: подземные помещения не только подвергались неоднократному проникновению с целью ограбления, но также и часовня гробницы использовалась как жилое помещение, а верхние части шахт, по всей вероятности, как ямы для сброса бытовых отходов.

Еще один любопытный штрих к истории гробницы Ченти I добавили раскопки в гробнице Хуфухотепа, расположенной всего в 11 м к северу. В 60 см от дна шахты 1 гробницы Хуфухотепа в 2008 г. найден фрагмент рельефа, который откололся или был сбит с северного портала прохода в гробницу Ченти I (рис. 12). Но на этом связь двух гробниц не заканчивается. В западной части погребальной камеры все той же шахты 1 гробницы Хуфухотепа был обнаружен грабительский лаз, аналогичный лазу в камере 1 А гробницы Ченти I (Kormysheva et al., 2015. Р. 96). Видимо, грабительские ходы в гробницах Ченти I и Хуфухотепа появились в один период. Не исключено даже, что это свидетельства работы одной и той же группы грабителей, пытавшихся по подземным лазам в мягком глинистом слое проникнуть в погребальные камеры крупных мастаб, расположенных к западу от скального некрополя. Тогда же в шахту 1 гробницы Хуфухотепа мог попасть и рельеф из гробницы Ченти I. Интересно, что такие же подкопы используют и сегодня жители близлежащей деревни Назлет эль-Самман, ведущие нелегальные раскопки под фундаментами своих домов.

\section{Литература}

Большаков А. О. Человек и его Двойник. Изобразительность и мировоззрение в Египте Старого царства. Санкт-Петербург, 2001.

Ветохов C. В. Египетские скальные гробницы Древнего царства в Гизе: архитектурные элементы как инструмент датировки // Вестник древней истории. 2016. № 2. С. 245-263.

Лебедев М.А. История одной жизни у пирамид: гробница Ченти II в Гизе (GE 12) // Эпиграфика Востока. 2015. Вып. 31. C. 83-97.

Лебедев М.А. Франко-тосканская экспедиция в Гизе (Египет): новые данные // Вестник Института востоковедения РАН. 2018. № 3. C. 153-164.

Champollion J.-F. Grammaire égyptienne ou principes généraux de l'écriture sacrée égyptienne appliquée à la représentation de la langue parlée. Paris, 1836.

Kormysheva E., Malykh S., Vetokhov S. Giza. Eastern Necropolis I. The Tomb of Khafraankh. Moscow, 2010.

Kormysheva E., Malykh S., Lebedev M., Vetokhov S. Giza. Eastern Necropolis III. Tombs of Tjenty II, Khufuhotep, and Anonymous Tombs GE 17, GE 18, GE 47, GE 48, and GE 49. Moscow, 2015.

Lane E.W. Description of Egypt: notes and views in Egypt and Nubia, made during the years 1825, -26, -27 and -28: chiefly consisting of a series of descriptions and delineations of the monuments, scenery, \&c. of those countries; the views, with few exceptions, made with the camera-lucida. Cairo, 2000.

Muskau P. Egypt under Mehemet Ali. Vol. 1. London, 1845. 


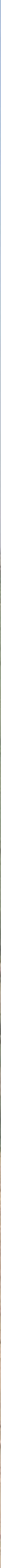




\section{PA3ДEU 2 BOOPY出EH保, hysth प IOPOIA}

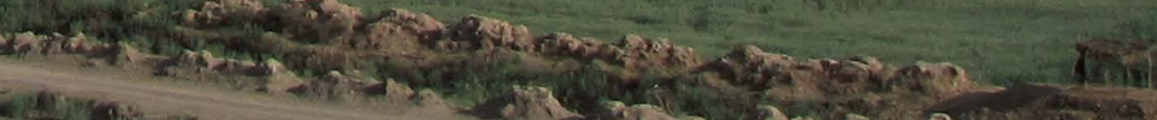

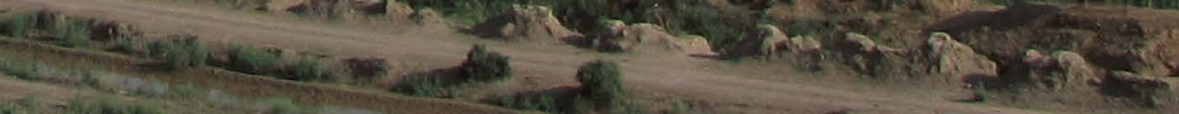

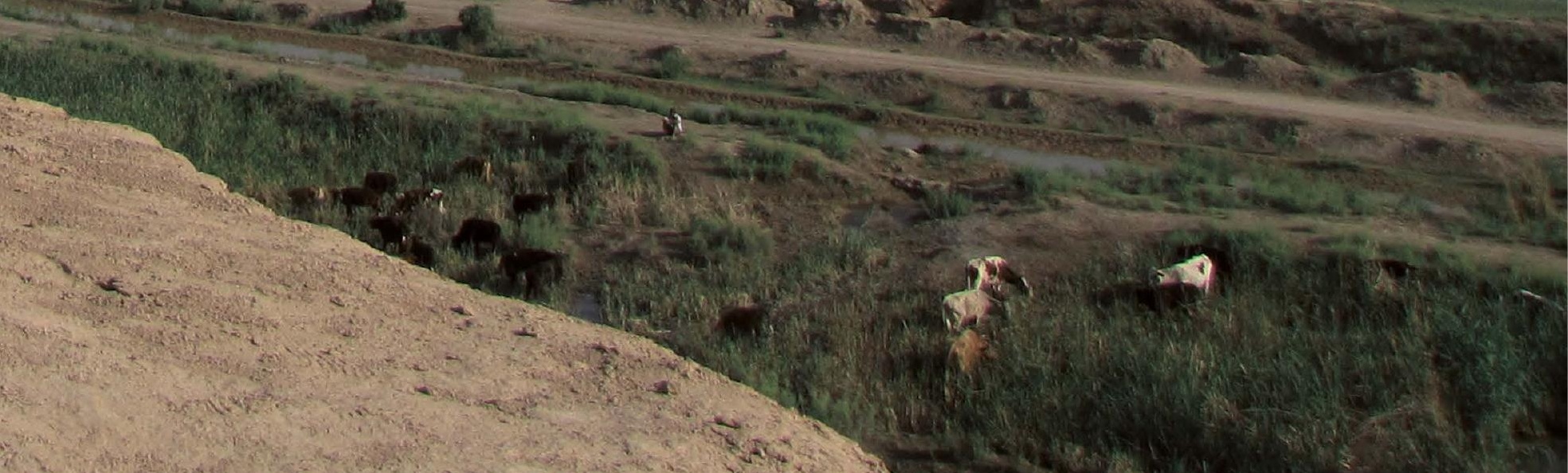




\section{К ВОПРОСУ ИЗУЧЕНИЯ ДОСПЕХОВ \\ ЕВРАЗИЙСКОЙ СТЕПИ РАННЕГО \\ ЖЕЛЕЗНОГО ВЕКА}

\section{(ПОИСК АНАЛОГИЙ, ВЗАИМОВЛИЯНИЙ И ПРОИСХОЖДЕНИЙ)}

\section{Д. В. Рукавишников, И.В.Рукавишникова}

Доспехи - важный источник по истории материальной культуры древних обществ. Изучение изменений в структуре и конструкции защитного вооружения и технологии его производства демонстрирует как эволюцию защитного вооружения, так и наступательного. Развитие вооружения тесно соотносится с военной историей обществ. Как в современных, так и в древних сообществах в развитии защитного и наступательного вооружения присутствовали инновации, отражающие их наиболее прогрессивные идеи, такие как использование различных материалов, в развитии дизайна и технологии. Подобные идеи распространялись широко в древние времена, например, появление боевых колесниц в Древнем Китае в бронзовом веке (Кожин, 1977). Общества ранних кочевников были мобильны, широко и легко обменивались своими идеями в разработке вооружения. Они контактировали с цивилизациями и контролировали торговые пути.

Источники для изучения защитного вооружения можно разделить на три категории:

- Текстовые. Записи об оружии в различных письменных источниках.

- Образные. Изображения вооружения, включая рельефы и статуи.

- Материальные. Фрагменты вооружения в виде археологических находок в культурном слое поселений или из погребений.

Среди последнего типа источников большинство разнообразных находок - это комплексы разрозненных конструктивных частей погребального инвентаря из захоронений. И как археологический источник, который дает нам закрытый археологический комплекс, и может быть соответственно хорошо продатирован $u$, как, более важно, основываясь на таких комплексах, мы можем так говорить о структуре индивидуальных частей доспеха, материале для его изготовления, соотношении его компонентов и т.д. Во всех типах источников для изучения доспехов всегда есть элементы для анализа и выводов.
В середине первого тысячелетия до н.э. кочевые культуры южного Приуралья создали свои курганы знати, такие как Филипповка 1. Вслед за мнением исследователей этого памятника мы отталкиваемся от идеи, что кочевники были наемниками в Древней Персии и получали дары в виде различных элитных вещей за службу, которые были найдены в их погребениях (Яблонский, Балахванцев, 2009; Яблонский, Рукавишникова, Шемаханская, 2011). Среди различных артефактов во всем могильнике были найдены порядка 11 различных комплексов защитного вооружения. Это делает материалы из могильника Филипповка 1 уникальным источником для изучения защитного вооружения (Мещеряков, 2011).

Доспехи из Филипповки были сделаны из различных материалов (железа, бронзы и кости) и в различных техниках (биметаллического доспеха, чешуйчатого железного доспеха, костяного ламеллярного доспеха, чешуйчатого железного доспеха с ламеллярными элементами). Два из этих доспехов были специально изучены автором и соавтром (Рукавишникова, Рукавишников, 2008; Рукавишников, Рукавишникова, 2010), тогда как ряд других проанализированы В.Васильевым (Васильев, 2002, Васильев, 2004). Остальные не изданы и не изучены.

В двух исследованных автором доспехах можно выделить наиболее важные аспекты в изучении конструкции. Так один из доспехов представлял собой железную кирасу из пластин с большими, широкими наплечниками, которые заходили на кирасу, с дополнительными деталями защиты на груди. Все пластины были нашиты на органическую основу, возможно кожу, и части доспеха в выкройке были соединены также органическими деталями, ремнями. Но несмотря на это окончание наплечников были сделаны из больших пластин, соединенных между собой дополнительно через боковые отверстия. Bce эти технологические аспекты уникальны в сочетаниии. Другой доспех, при том, что 
он неполный, был сформирован из рядов разных по форме крупных железных пластин, дополнительно скрепленных железной проволокой через пробитые отверстия. Он, по-видимому, также имел органическую основу и застегивался сбоку справа, чему свидетельствовала находка двух железных ворворок и крюка in situ.

\section{Доспех из погребения 2, кургана 4, могильника Филипповка 1}

Корпусная защита состояла из 20 рядов чешуи на спине и предположительно от 10 до 13 рядов на груди. Наиболее полно сохранилась правая боковая сторона доспеха и стыкующаяся с ней наспинная часть с четко выраженным верхним краем, отороченным кожаной полосой. Это дает максимальный размер доспеха в наспинной части (20 рядов пластин, около 40 см.) и полный размер боковой части (10 рядов пластин около $20 \mathrm{~cm}$ ), а также говорит о ом, что правый край и наспинная часть были сформированы единой конструкцией, а доспех застегивался предположительно на груди. Набрюшная и нагрудная части корпусной защиты сохранились в виде отдельных фрагментов, однако удалось выделить смежную с правым боком корпуса часть и по окантовке кожаной полосой подтвердить гипотезу о том, что доспех был распашным и застегивался на груди. Набрюшная часть защиты также состояла из 10 рядов пластин, как и боковая. Нагрудная часть была сформирована дополнительными тремя рядами пластин, образовывавших «лямки», через которые очевидно

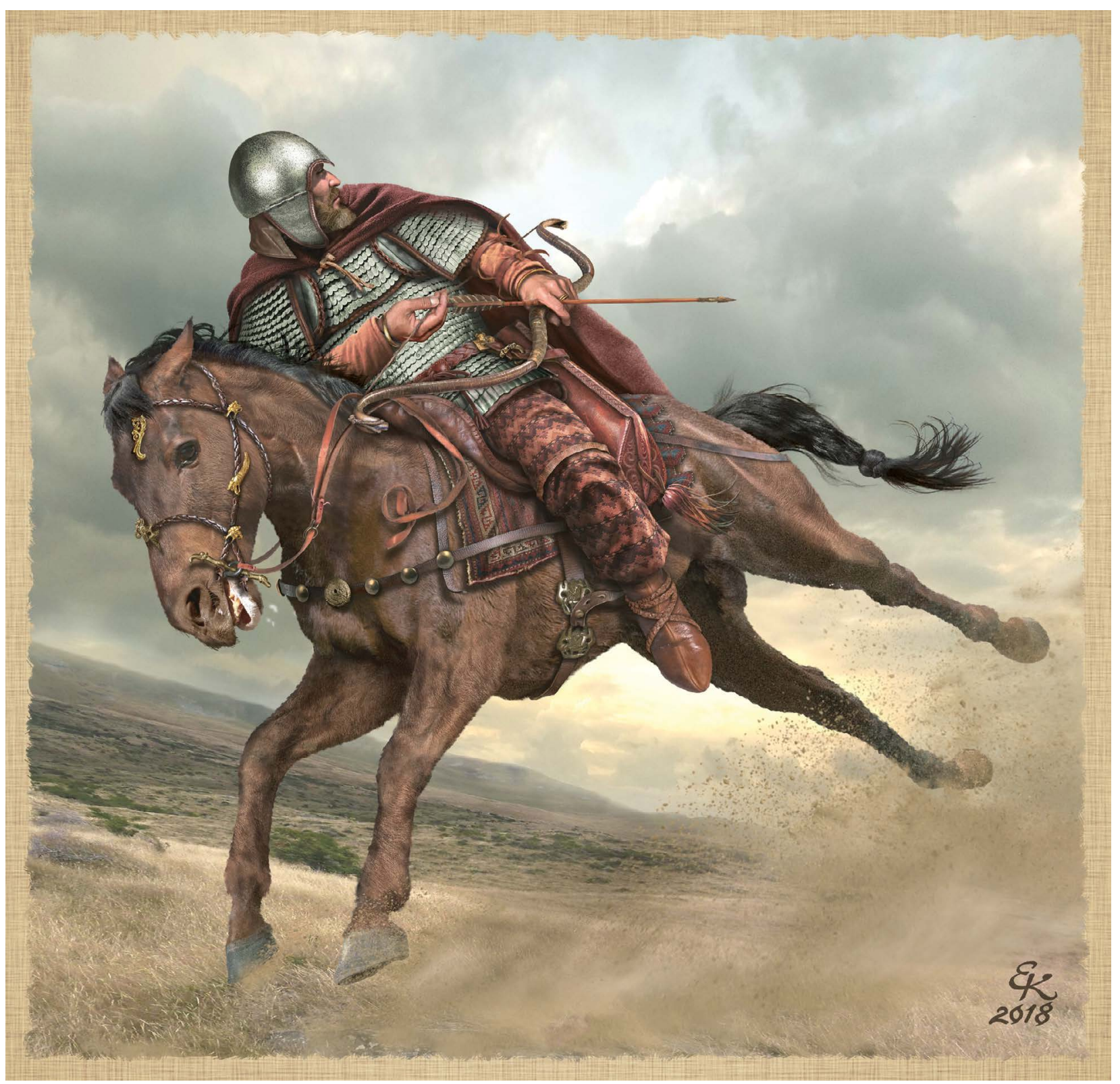

Рис. 1. Реконструкция панциря из Филипповского кругана. Художник Е. Край 
проходило крепление нагрудной и наспинной частей корпуса доспеха. Верхняя часть «лямки» была оформлена в виде полукруга и так же окантована кожаной полосой.

Дополнительная нагрудная защита состояла из двух комплексов крупных пластин (размеры $20 \times 3$ см), скрепленных предположительно ламеллярным способом.

Один из комплексов, возможно правый, сохранился полностью, второй - в виде фрагментов, по которым можно восстановить первоначальный облик и размеры. Размеры первого (правого) комплекса $-10 \times 20$ см. Одна из крайних пластин составлена из двух частей, заходящих друг на друга. Окончания крайних пластин закруглены, общая форма всего комплекса - подпрямоугольная с плавно закругленными углами. По периметру комплекс был окантован кожаной полосой, очевидно загнутой через край и прошитой через дополнительные отверстия. Условно можно выделить внутреннюю и внешнюю сторону комплекса, т. к. на одной из сторон сохранились следы органического материала, возможно кожи. Второй комплекс, предположительно расположенный на левой стороне груди, сохранился хуже, общая форма совпадает с вышеописанным, однако размеры чуть крупнее $-11 \times 20 \mathrm{~cm}$. Вероятно он состоит также из четырех пластин. По краю также прослеживается кожаная окантовка. Система крепления комплексов дополнительной защиты к основному доспеху пока не ясна, как и точное расположение на корпусе дополнительных элементов, но можно представить, что они крепились на ремнях к оплечью.

Оплечье представлено двумя частями (правый и левый наплечник). Каждая часть состоит из одного нижнего ряда длинных пластин и 9рядов крупных, размером $3.5 \times 2.5 \mathrm{~cm}$, чешуйчатых пластин. Нижний ряд состоит из 25-30 штук крупных пластин прямоугольной формы размером $10.5 \times 2$ см. Верхний край нижнего ряда пластин был определенно нашит на основу и на 1.5 см. перекрыт находящим сверху нижним рядом чешуй. Длинные пластины расположены таким образом, что левая пластина перекрывает правую на 1-0.5 см. Нижний и боковые края нижнего ряда были оторочены кожаной полосой, прошитой через дополнительные отверстия, что позволяет полностью определить ширину каждого из наплечников и восстановить первоначальную форму. На внутренней поверхности ряда длинных пластин правого наплечника сохранились остатки органики. Реконструируемые размеры каждого наплечника - около 4550 см. в ширину и 30-35 см в длину.

\section{Доспех из кургана 28 могильника Филипповка 1}

Можно сказать, что доспех представлял короткую (около 30-40 см) пластинчатую защиту корпуса, состоящую из 3-4 горизонтальных рядов пластин, с перекрыванием верхним рядом пластин нижнего, с дополнительными элементами защиты плеч в виде двух наплечников. Точные размеры наплечников определить сложно, но можно утверждать, что они так же состояли из нескольких рядов пластин разного размера и обладали дугообразной формой, причем некоторые пластины были с изгибом для придания этой формы наплечнику.

Отличительной чертой конструкции доспеха было дополнительное усиление её путем скрепления колец и рядов между собой металлическими кольцами через специально сделанные дополнительные отверстия в пластинах. Кольца формировались из фрагментов проволоки, концы колец загибались с внутренней стороны пластин, образуя перехлест. Внутренний диаметр кольца обеспечивал жесткое скрепление пластин.

Подобная техника крепления пластин встречается достаточно редко. В данном случае можно говорить, что изначально доспех был набран классическим чешуйчатым способом с прикреплением верхнего края пластин к органической основе. В дальнейшем в доспех были внесены вышеописанные конструктивные изменения. Очевидно, классическая форма крепления пластин не обеспечивала необходимую степень защиты. Полученная корпусная защита должна была оказаться очень жесткой, т. к. кольца связывают не только соседние пластины в одном ряду, но и в некоторых случаях ряды между собой. Возможно, этим и объясняется достаточно малая длина корпусной части - около 30 см. Использование пластин нестандартных размеров в корпусной части доспеха могло быть вызвано стремлением компенсировать подобную жесткость конструкции.

Две ворворки, обнаруженные in situ рядом с предполагаемым правым краем доспеха, явно связаны с системой застегивания, а отсутствие ременных пряжек может говорить, что система застегивания была реализована скорее всего с помощью шнуров.

Отдельные элементы в обоих исследованных доспехах из Филипповского могильника широкие наплечники и дополнительные нагрудные детали, демонстрируют доспех для воинов, 


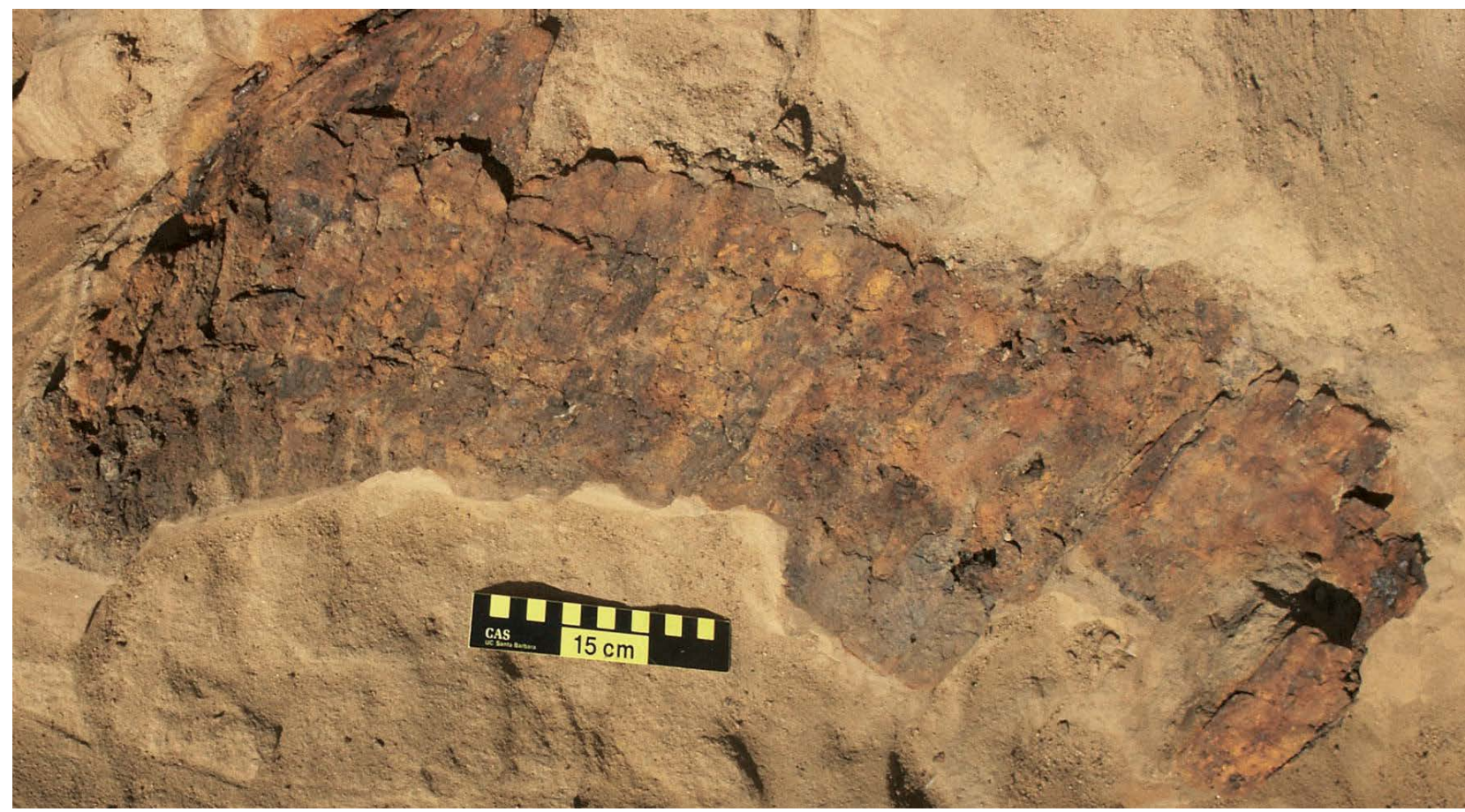

Рис. 2. Панцирь из кургана 28 филипповского могильника

вооруженных длинными мечами и копьями, которые были также найдены в могильнике, в том числе и в погребении 2 кургана 4.

Все из этих конструктивных черт уникальны для доспеха как такового, а также конструкций доспехов Евразии в эпоху до походов Александра Великого. Традиция чешуйчатого доспеха Ближнего Востока зафиксирована в рельефах и находках отдельных пластин (Есаян, 1986). В монографии Черненко (Chernenko, 2006) представлены скифские доспехи, которые известны в большинстве как находки отдельных пластин, а также и целые. Доспех скифского времени - это чешуйчатый доспех (пластины нашиты на органическую основу и соединены между собой через эти отверстия, находящиеся сверху подпрямоугольных пластин), застегивающийся сзади или сбоку. Скифский доспех (из железа и бронзы) нес в себе инновации из кочевой среды (Рябкова, 2010), но также он представлял традиции Ближнего и Среднего Востока (например, фрагмент доспеха из крепости Тайши-Байни, 7 в. до н. э.). Таким образом, скифский доспех мог быть сформирован под влиянием ближневосточной традиции во время скифских походов в Переднюю Азию и трансформировался под влиянием развития наступательного вооружения.

Традиция изготовления чешуйчатого доспеха в середине I тысячелетия до н.э. представлена в виде находок и изобразительных свидетельств в зонах контактов в Передней Азии, Кавказа и соседних территорий кочевого
Причерноморья и Северного Кавказа. Защитное вооружение персов известно из изобразительных источников, таких как рельефы и росписи (например, на греческих вазах), со времени греко-персидских воин. Материальные свидетельства отсутствуют.

В Средней и Внутренней Азии - зоне контактов между Востоком и Западом - находятся изображения образцов защитного вооружения (Древний Хорезм, Бактрия) и деталей железного доспеха, относящихся к периоду Александра Великого (Никоноров, 1997), то есть IV в. до н. э. С этим временем связана и находка части железного доспеха с крупными пластинами из Чирик-Рабата. До этого не известны свидетельства существования защитного вооружения на этих территориях (Горелик, 1980, с.135). Возможно, эта традиция доспехов отражается в материалах могильника Филипповка 1, так как на Южном Урале не было своей традиции изготовления защитного вооружения. Находки отдельных железных, изредка бронзовых пластин относится к к. V - IV вв. до н.э. (Смирнов, 1968, Васильев, 2002, Мещеряков, 2011).

В отношении к материальным свидетельствам древнего защитного вооружения - археологическим находкам из поселений и погребений - эти источники могут быть неполными, потому что существовали отдельные типы защитного вооружения, которые были сделаны из органических материалов (кожа, текстиль) или с использованием таких частей, которые 
не фиксируются археологически. В этом случае уникальны находки кожаных доспехов первого тысячелетия до н. э. в Древнем Китае, которые продолжают восточные традиции доспехов и подтверждают родство с развитием вооружения в кочевой культуре Евразии.

В Китае до периода Цинь (до III в. до н.э.), когда уже сформировалась традиция вооружения (Горелик, 1980, с. 135), доспехи делались из различных материалов, что отражено в найденных артефактах: кожа, кость, бронза (Chinese archaeology, 2010, с.114), железо. Сохранились как пластины эпохи Шань (A preliminary Study..., 2007), так и Западного Чжоу (A preliminary Study..., 2007), где, судя по описаниям и чертежам, представлена конструкция из крупных, разного размера пластин, возможно, ламеллярного крепления.

В вышеописанных традициях не найдены доспехи из органических материалов. Уникальны находки кожаных доспехов первого тысячелетия до н.э. в Древнем Китае, которые продолжают традиции доспехов бронзового века - крупные пластины с ламеллярным способом крепления. В сочетании с броней в виде крупных бронзовых фигурных пластин эта система соответствовала военной тактике колесничного боя с клевцами типа «ge» (Комиссаров, 1988) в период династий Шань и Западного Чжоу. Позже для кавалерии, которая появилась в период Воюющих государств с копьями и длинными мечами, также применялись кожаные доспехи с другой выкройкой. Тем не менее, инновации западного чешуйчатого доспеха вливались в принятую традицию. Интересен найденный в Синьцзяне кожаный доспех из могильника Янхай (Acta archaeologica sinica, 2011, № 1, Шульга, 2010), имитирующий чешуйчатый.

Уникальный источник по истории китайского оборонительного вооружения - глиняная армия в гробнице Цинь Шихуана (A Great wonder..., 2002; Комиссаров, 2010), комплекс которого представляет собой пластинчатую броню ламеллярного крепления, иногда с широкими наплечниками и с подвижной нижней частью рубашки, крепление - ремень с пряжкой сбоку с пуговицами. Также в гробнице найден отдельно находящийся каменный доспех и два металлических.

Железные пластинчатые доспехи широко представлены в эпоху династии Хань (после III в. до н.э.) на вотивных изображениях воинов (A preliminary Study..., 2007, c.165). На территории Внутренней Монголии был найден целый пластинчатый железный доспех эпохи Западная Хань (A preliminary Study..., 2007, с.231), застегивающийся спереди, с длинными пластинами по низу выкройки. Это близкая по крою аналогия представленному нами доспеху.

Во время и до эпохи Цинь, вооружение которой - это сложившаяся традиция, известная по многочисленным примерам обмундирования глиняных воинов армии Цинь Шихуанди, в китайском вооружении господствовал кожаный доспех (Комиссаров, 2010) и различные варианты защитных бронзовых пластин, нашитых на кожаную основу.

В первом тысячелетии до н.э. в Евразии происходили различные контакты между населением Древних Цивилизаций и народами, степи и леса к северу от них, самые главные из них - это передача новшеств в технологиях изготовления общественно значимых вещей.

Авторами исследования разрабатывается еще один доспех из могильника Филипповка 1 - костяной, состоящий из крупных подтрапециевидных пластин с несколькими отверстиями по контуру, то есть с креплением ламеллярным способом.

Все перечисленные конструктивные особенности представленных в исследовании доспехов уникальны в сочетании для доспеха доалександровской эпохи истории вооружения Евразии. Так, обращаясь к историографии защитного вооружения, к середине первого тысячелетия до н. э. можно отметить существование традиции чешуйчатого доспеха в Передней Азии, и скифской традиция доспеха. По свидетельствам Ариана, персы и их наемники были полностью в доспехах. По изобразительным памятникам во время греко-персидских войн персы были все в чешуйчатых доспехах (росписи на древнегреческих вазах). Отдельные чешуйки относятся к мидийским древностям. Погребений с доспехами нет.

Таким образом, традиция пластинчатого нашивного доспеха к середине 1 тыс. до н.э. была распространена в зонах военных контактов Передней Азии, Кавказа и близлежащих кочевых территорий Причерноморья и Северного Кавказа.

Так, в представленных доспехах, которые возможно принесены из походов из Ирана или Передней Азии, есть восточные традиции широких наплечников, ламеллярных деталей, широких пластин, крепления с ворворками. Общая система кроя и передняя застежка встречаются позже в развитой традиции китайского 
доспеха, что, возможно, являлось результатом влияния степного вооружения, смешения традиций. Они не относятся только к скифскому доспеху. Параллельное развитие мировых традиций в инновациях защитного снаряжения происходит на широких территориях. Середина 1 тыс. до н. э. - время, когда проникновение новых идей было спорадическим, но присутствовало и маркировало пути контактов удаленных обществ. Так, в изучаемых нами доспехах, которые, вероятно, были принесены из походов из Ирана или Передней Азии, есть восточные традиции широких наплечников, деталей, скрепленных ламеллярным способом, широких пластин, крепления с ворворками. Общая система кроя и передняя застежка встречается позже этого времени в развитой традиции китайского доспеха.

\section{Литература}

Васильев В. Н., Пшеничнюк Д. Х. К вопросу о защитном вооружениии ранних кочевников Южного Урала в IV в. до н.э.// 1997

Васильев В. Н. Вооружение и военное дело кочевников Южного Урала в VI-II вв. до нашей эры. Уфа. 2001.

Горелик М. В. Оружие Древнего Востока. Москва, 1980

Есаян С.А. Доспех древней Армении. Ереван, 1986

Кожсин П. М. Об иньских колесницах// Ранняя этническая история народов Восточной Азии. М. 1977. С.278-287.

Комиссаров С.А. Комплекс вооружения Древнего Китая. Эпоха поздней бронзы. Н. 1988

Комиссаров С. А., Хачатурян О.А. Мавзолей императора Цинь Шихуанди. Н. 2010.

Мешеряков Д. В. Воинские доспехи в погребальном обряде ранних сарматов// Погребальный обряд ранних кочевников Евразии. VII Международная конференция «Проблемы сарматской археологии и истории». Материалы и исследования по археологии Юга России. Выпуск III. Ростов-на-Дону, 2011.С. 298-306.

Никоноров В.П. The armies of Baktria. 700 B. C. -450 A. D. UK, 1997

Рукавишникова И. В., Рукавишников Д. В. Пластинчатый доспех из погребения №2 кургана №4 могильника Филипповский - 1. //Интерпретация комплекса и реконструкция первоначального облика. Ранние кочевники волго-уральских степей. Оренбург, 2008, с. 105-116.

Рукавишникова И. В., Рукавишников Д. В. Доспех из кургана 28 Филипповского могильника (совместно с Д. В. Рукавишниковым) //Историко-археологический альманах. Вып. 9. Армавир-Краснодар-Москва, 2009,

Рябкова Т.В. Чешуйчатые панцири раннескифского времени. Археологический сборник ГЭ. №38, СПб, 2010, с. 87-107. Смирнов К.Ф. Вооружение савроматов. МИА 101, 1961.

Яблонский Л. Т., Балахванцев А. С. Еще раз к вопросу о датировке надписей из Прохоровки // ВДИ №2. 2009.c. 89-108. A preliminary Study on the history and Restoration of the Armors and helmets Unearthed in China. China, 2007.

Acta archaeologica sinica (Kaogu xuebao) Beijin, 2011, № 1.

Chinese archaeology. Beijin, 2010.

Chernenko E. V., Die Schutzwaffen der Skythen. Berlin, 2006. 


\section{ОБРАЗЫ ВОСТОЧНОЕВРОПЕЙСКОГО СКИФСКОГО ЗВЕРИНОГО СТИЛЯ И КАТЕГОРИИ ВООРУЖЕНИЯ СКИФОВ}

\section{(С УЧЕТОМ НОВЫХ МАТЕРИАЛОВ)}

\section{А. Р. Канторович}

Вопросы взаимосвязи двух компонентов «скифской триады» - вооружения и скифского звериного стиля - одна из актуальных проблем скифологии, в особенности с учетом постоянного прироста археологического материала. В свое время А.М. Хазанов и А.И. Шкурко пришли к выводу о том, что образы скифского звериного стиля в большинстве своем оформляют или украшают элементы вооружения, конское снаряжение и предметы сакрального и социально-культового назначения (Хазанов, Шкурко, 1976. С. 42). Позднее А.И. Мелюкова высказала аналогичное мнение (добавив к вышеприведенному набору такую макрокатегорию, как костюм) и объяснила данное соответствие тем фактом, что «ведущая роль в создании оригинальных сюжетов и образов этого искусства принадлежала аристократии, связанной с войной» (Мелюкова, 1989. С. 101). При этом исследовательница особо выделила из общего репертуара именно образы хищных зверей и хищных птиц. Их помещение на предметы вооружения, конского снаряжения и иные аксессуары всадника и боевого коня расценивалось А.И. Мелюковой в качестве магического средства для усиления «боевых качеств оружия и коня», придания «особой силы, смелости, меткости удара, быстроты воинам-всадникам» (Мелюкова, 1989. С. 101).

Эти выводы, сделанные на материалах, имевшихся в распоряжении исследователей в 19701980-х гг., - как общее положение А. М Хазанова и А.И. Шкурко о тесной корреляции скифского звериного стиля и оружия, так и частное наблюдение А.И. Мелюковой о взаимозависимости образов хищных животных и предметов вооружения, нашли подтверждение спустя десятилетия на массовом материале классифицированных нами изображений восточноевропейского скифского звериного стиля (далее ВСЗС). Статистический анализ, предпринятый на основе собранного нами материала, опубликованного к 2013 г. включительно, продемонстрировал безусловное предпочтение, оказываемое при оформлении предметов вооружения в скифской культуре образам млекопитающих хищников и хищных птиц в противовес образам копытных и иных животных. Это соответствует семантике данных мегаобразов, связанных с темой нападения и уничтожения, с задачей усилить поражающую функцию вооружения (Канторович, 2014. С. 61, 62).

Настоящая статья имеет целью, в развитие упомянутой выше краткой публикации и материалов соответствующего доклада (Канторович, 2015a), дать более подробное освещение образов и мотивов ВСЗС, украшающих/оформляющих предметы вооружения, а также самих категорий этих изделий на накопившемся к настоящему времени материале, с учетом опубликованных за прошедшее время новых изображений ВСЗС. Тем самым будут верифицированы сделанные нами 5 лет назад статистические наблюдения.

В частности, в данной статье учитываются изображения, входящие в «Крымскую коллекцию», как мы предлагаем условно называть обширное собрание бронзовых изделий скифской эпохи, опубликованных С.А.Скорым и Р. В. Зимовцом (2014) и полностью переданных ими в Археологический музей Института археологии НАН Украины. По данным С.А. Скорого и Р. В. Зимовца, это сформированное в 2006-2013 гг. собрание случайных находок. Большинство из них происходит (по сведениям находчиков) с территории Крыма, преимущественно из достаточного компактного района Внутренней гряды Крымских гор и прилегающих к ней зон: из с. Межгорье и северного предгорья Караби-Яйлы, из района Белогорска и горного массива Кубалач, из горного массива Агармыш и Присивашской степи (Скорый, Зимовец, 2014. С. 165-168). Значительно менышее число предметов (по данным находчиков) - из района Керченского п-ова (Скорый, Зимовец, 2014. С. 67, 97, $115,116,124-126)$. На фоне дискуссионности вопроса об изначальном местонахождении изделий

\footnotetext{
“ Статья написана в рамках проекта РФФИ 18-09-00725 А «Скифы в Центральном Предкавказье в VII-IV вв. до н. э.»
} 
«Крымской коллекции», очевидно, происходящих из грабительских раскопок (Медведев, 2015; Гуляев 2016б; Колтухов, Сенаторов 2016. С. 179, 180), а также в силу сомнения в аутентичности некоторых из этих предметов, мы в предыдущих публикациях материалов ВСЗС, в том числе и в контексте декора вооружения, оставляли изображения «Крымской коллекции» за пределами исследуемого корпуса источников и, соответственно, вне общей статистики (Канторович, 2014; 2015a, б; 2017. С. 146, 148, 173, 174. Табл. 1-3; Канторович, 2018. С. 197. Табл. 1).

После недавно проведенного анализа иконографии изображений в зверином стиле из «Крымской коллекции» и интегрирования их в систематику изображений ВСЗС (Канторович, 2019) можно учитывать ее в типологии и статистике. Как было установлено публикаторами, «Крымская коллекция» насчитывает 404 изделия, в том числе 189 предметов вооружения, 205 элементов конского снаряжения и 10 ед., связанных с иными категориями материальной культуры. Почти половину этих вещей (193 ед.) составляют зооморфные изделия, подавляющее большинство из которых выполнены в скифском зверином стиле (Скорый, Зимовец, 2014. С. 14, 15, 143, 152). По нашим подсчетам, если исключить копии, в составе «Крымской коллекции» насчитывается 135 оригинальных изображений, отвечающих канонам скифского звериного стиля. Из них можно с полной уверенностью признать аутентичными 115 изображений, а оставшиеся 20 пока не включены в наш корпус, поскольку либо крайне фрагментированы и в силу этого неясны в образно-видовом отношении, либо резко контрастируют с общим художественным контекстом ВСЗС и их невозможно соотнести ни с одним из выделенных ранее морфологических типов (Канторович, 2019) ${ }^{1}$. «Крымская коллекция» существенно пополняет корпус изображений в скифском зверином стиле. При этом по-прежнему остается открытым вопрос о собственно крымском происхождении ряда предметов из этого собрания ${ }^{2}$.

Итак, нам удалось собрать и проанализировать практически все опубликованные до 2017 г. (включительно) изображения, выполненные в канонах скифо-сибирского звериного стиля, оформляющие предметы различных категорий материальной культуры, происходящие с территории скифской археологической культуры, иначе говоря - из восточноевропейской зоны скифо-сибирского звериного стиля (охватывает зоны степного, лесостепного и северокавказского локальных вариантов скифского звериного стиля) ${ }^{3}$. Всего, таким образом, учтено 2446 оригинальных изображений (не считая копий), дифференцированных по 353 иконографическим/морфологическим типам в результате проведенной морфологической классификации изображений (табл. 1$)^{4}$.

Для каждого иконографического/морфологического типа (в рамках типов часто сочетаются изображения, оформляющие предметы самых разных категорий материальной культуры) нами были установлены хронологические границы, прежде всего на базе хронологической позиции тех изображений конкретного иконографического типа, которые происходят из комплексов, имеющих объективную датировку (на основании античных и передневосточных импортов, а при отсутствии импортов - по типам вооружения и конского снаряжения). Если такие изображения в рамках конкретного типа отсутствовали, основу хронологии типа составляли изображения, имеющие надежно датируемые аналогии. Затем на основании сходства с изображениями, образующими «хронологическое ядро» данного типа, с учетом внутритиповой стилистической или иконографической динамики (при ее

\footnotetext{
1 Возможно, часть этих изображений впоследствии также нужно будет признать аутентичными - в тех случаях, когда их аналоги будут обнаруживаться в достоверных археологических комплексах.

2 С учетом проведенного нами стилистического и статистического анализа находок звериного стиля в Крыму, сделанных до обретения «Крымской коллекции» за почти 200-летнюю историю исследований скифских памятников Крыма (это 108 оригинальных изображений, оформляющих 173 изделия), такой резкий (более чем двукратный) прирост соответствующих предметов для территории Крыма не представляется закономерным (Канторович, 2017. С. 148, 173, 175, 176). Возможны два варианта: либо ряд изделий в публикации С. А. Скорого и Р. В. Зимовца происходит из-за пределов Крыма - в частности, из Прикубанья и Поднепровья, - и они обозначены как крымские их непосредственными находчиками или перекупщиками в целях дезинформации; либо, если все же относиться с доверием к сведениям о зоне происхождения вещей этой коллекции в основном с территории горных массивов Кубалач и Агармыш, а также у с. Межгорье у предгорий Караби-Яйлы (Скорый, Зимовец, 2014. С. 165-167), мы имеем дело с неким не известным ранее крымским центром/центрами производства или хранения изделий в скифском зверином стиле - возможно, с предгорными/горными святилищами.

3 Кроме того, в состав источника вошел и ряд неопубликованных изображений, являющихся результатом собственных раскопок автора или же раскопок, соавтором которых он является (с любезного разрешения остальных авторов раскопок).

4 Ср.: в предыдущих публикациях, посвященных декору вооружения в скифском зверином стиле (Канторович, 2014; 2015a, б), учтено 2169 изображений ВСЗС, которым соответствовало 337 типов.
} 
Таблища 1. Общая статистика изображений и морфологических типов восточноевропейского скифского звериного стиля

\begin{tabular}{|c|c|c|}
\hline $\begin{array}{l}\text { Образно-видовая } \\
\text { принадлежность }\end{array}$ & $\begin{array}{c}\text { Количество оригинальных } \\
\text { изображений }\end{array}$ & $\begin{array}{c}\text { Количество } \\
\text { типов }\end{array}$ \\
\hline Хищники & $\begin{array}{c}638 \\
\text { (полнофигурных изображений }-253, \\
\text { редуцированных }-385 \text { ) }\end{array}$ & $\begin{array}{c}108 \\
\text { (62 типа } \\
\text { полнофигурных, } \\
46 \text { типов } \\
\text { редуцированных) }\end{array}$ \\
\hline Копытные, в том числе: & 845 & 130 \\
\hline Олени & $\begin{array}{c}281 \\
\text { (полнофигурных - 132, редуцированных -149) }\end{array}$ & $\begin{array}{c}43 \\
(22+21)\end{array}$ \\
\hline Лоси & $\begin{array}{c}104 \\
\text { (полнофигурных }-27, \text { редуцированных }-77 \text { ) }\end{array}$ & $\begin{array}{c}17 \\
(6+11)\end{array}$ \\
\hline Горные козлы & $\begin{array}{c}54 \\
\text { (полнофигурных - 39, редуцированных - 15) }\end{array}$ & $\begin{array}{c}12 \\
(8+4)\end{array}$ \\
\hline Бараны & $\begin{array}{c}80 \\
\text { (полнофигурных - 1, редуцированных - 79) }\end{array}$ & $\begin{array}{c}10 \\
(1+9)\end{array}$ \\
\hline Лошади & $\begin{array}{c}113 \\
\text { (полнофигурных - 5, редуцированных - 108) }\end{array}$ & $\begin{array}{c}15 \\
(3+12)\end{array}$ \\
\hline Быки & 5 & 2 \\
\hline Кабаны & $\begin{array}{c}44 \\
\text { (полнофигурных - 10, редуцированных }-34 \text { ) }\end{array}$ & $\begin{array}{c}14 \\
(7+7)\end{array}$ \\
\hline «Оленелоси» & $\begin{array}{c}13 \\
\text { (все - редуцированные) }\end{array}$ & 3 \\
\hline «Лосекозлы» & $\begin{array}{c}21 \\
\text { (все - полнофигурные) }\end{array}$ & 1 \\
\hline «Оленекозлы» & $\begin{array}{c}19 \\
\text { (все - редуцированные) }\end{array}$ & 1 \\
\hline Обособленное ухо копытного & 24 & 2 \\
\hline $\begin{array}{l}\text { Обособленная } \\
\text { нога копытного / копыто }\end{array}$ & 87 & 10 \\
\hline Птицы & $\begin{array}{c}671 \\
\text { (полнофигурных }-84, \\
\text { редуцированных }-587 \text { ) }\end{array}$ & $\begin{array}{c}55 \\
(21+34)\end{array}$ \\
\hline $\begin{array}{l}\text { Синкретические животные, } \\
\text { в том числе: }\end{array}$ & 218 & 46 \\
\hline Грифоны и крылатые львы & $\begin{array}{c}104 \\
\text { (полнофигурных }-61, \text { редуцированных }-43 \text { ) }\end{array}$ & $\begin{array}{c}33 \\
(23+10)\end{array}$ \\
\hline Бараноптицы & 50 & 2 \\
\hline Гибрид грифона и бараноптицы & 2 & 1 \\
\hline $\begin{array}{l}\text { Гибрид грифона и кошачьего } \\
\text { хищника - тупорылый зверь }\end{array}$ & 10 & 1 \\
\hline $\begin{array}{l}\text { Гиппокампы-кони, } \\
\text { грифоногиппокампы и «петушки» }\end{array}$ & 25 & 4 \\
\hline «Лосептица» & 16 & 1 \\
\hline «Оленептица» & 2 & 1 \\
\hline $\begin{array}{l}\text { Комбинация элементов птицы } \\
\text { и неопределенного копытного }\end{array}$ & 8 & 2 \\
\hline Рогатая рыба & 1 & 1 \\
\hline Зайцы & $\begin{array}{c}26 \\
\text { (полнофигурных }-24, \\
\text { редуцированных }-2 \text { ) }\end{array}$ & 5 \\
\hline Верблюды & 6 & 1 \\
\hline Дельфины & 4 & 2 \\
\hline Рыбы & 28 & 3 \\
\hline Неопределенные животные & 10 & 3 \\
\hline итого & $\begin{array}{c}2446 \\
\text { изображений }\end{array}$ & $\begin{array}{c}353 \\
\text { типа }\end{array}$ \\
\hline
\end{tabular}




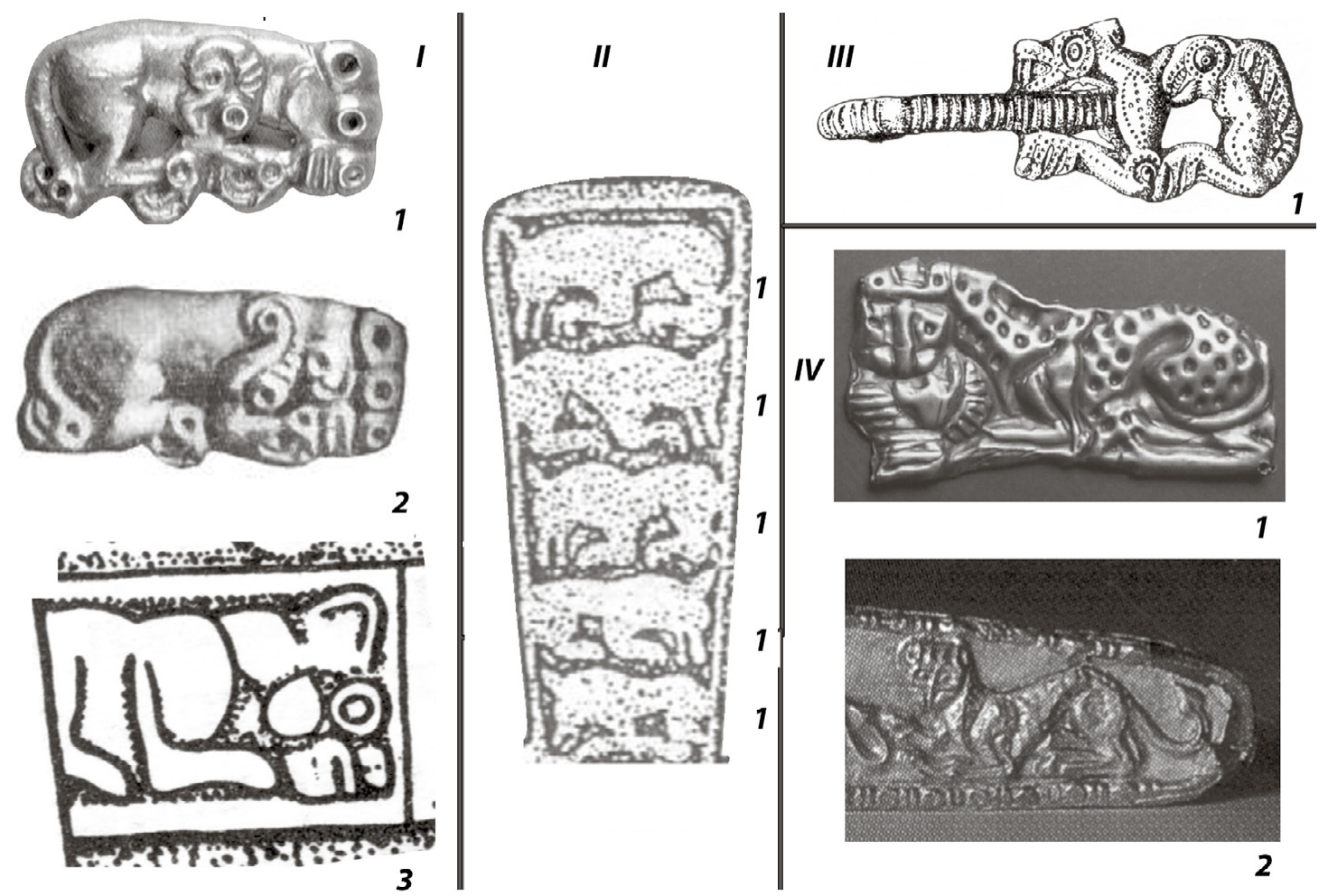

Рис. 1. Хищники в полнофигурном отображении на предметах вооружения (типы Краснознаменско-новозаведенский; Бельско-енкивецкий; Нижнедонской; Архангельско-белозерский). I - Краснознаменско-новозаведенский тип: 1 - с. Деревка, к. 13, «Могила Опишлянка», золотые пластины - аппликации горита, 14 экз. (На краю Ойкумены..., 2002. Кат. 450); 2 - Витова могила, золотые пластины - аппликации горита, 11 экз. (Граков, 1971. Табл. XX); 3 - ст. Манычская Ростовской обл., изображение пластины горита воина, представленного на каменной статуе (Ольховский, Евдокимов, 1994. Кат. 154. Ил. 89); II - Бельско-енкивецкий тип: 1 - Енкивцы, длинная боковая пластина бронзовой крестовидной бляхи «ольвийского типа» (Кулатова, 1995; Могилов, 2008. Рис. 104: 2); III - Нижнедонской тип: 1 - Нижний Дон, случайная находка, железный колчанный (?) крючок, обтянутый золотыми пластинами (Гуляев, 1969. Рис. 7: 8); IV - Архангельско-белозерский тип: 1 - Архангельская слобода, к. 5, п. 1, золотые накладки колчана, 2 экз. (Лесков, 1972. Табл. 35, 39); 2 - Великая Белозерка, основная пластина золотой обкладки ножен меча (Отрощенко, 1984. С. 123)

наличии), устанавливались датировки остальных изображений этого типа.

Изображения в скифском зверином стиле сопровождают предметы вооружения с самого начала существования скифской археологической культуры до момента ее исчезновения или трансформации в позднескифскую культуру (VII - начало III в. до н.э.). Всего на данный момент нами насчитывается 306 изображений (без учета копий, в том числе зеркальных отображений), которым соответствуют 77 морфологических типов (табл. 2).

В настоящей статье все 306 оригинальных изображений ВСЗС, оформляющих/украшающих вооружение, представлены в иллюстрациях на 23 графических таблицах в образно-сюжетном порядке (рис. 1-23), что было невозможно сделать в наших предыдущих публикациях на эту тему, учитывая объективные лимиты. Изображения обозначены арабскими цифрами в рамках соответствующих иконографических типов; если на таблице представлено несколько иконографических типов, типы маркируются римскими цифрами. В подписях к иллюстрациям, которые в целях экономии места выполняют функцию каталога, указаны условные названия иконографических/морфологических типов (для краткости - без дополнительных цифровых классификационных индексов), к которым относятся анализируемые изображения по разработанной нами классификации (см. Канторович, 2015в); здесь же обозначены местонахождение, материал и категория оформляемых предметов, а также количество копий (при их наличии), равно как и публикационные источники изображений 5 . В основном тексте статьи указано лишь количество оригинальных изображений, местонахождения изображений упомянуты в отдельных особо важных случаях.

\footnotetext{
5 Принятые в подписях к рисункам сокращения: к. - курган, п. - погребение.
} 


\section{Образы, сюжеты и мотивы ВСЗС, связанные с вооружением}

Изображения хищников, декорирующих предметы вооружения, представляют персонажей чаще в полнофигурном, реже в редуцированном отображении (табл. 2). В свою очередь среди полнофигурных изображений имеются различные сюжетные схемы хищников. Вопервых, это лежащие звери - как в профиль, припавшие к земле (рис. 1: I, II, III), так и с головой, повернутой анфас (рис. $1: \mathrm{IV}, 1,2$ ) или назад (рис. 3: II, 1-4), в том числе хищник, терзающий голову человека (рис. 1: IV, 1); к сюжету лежащих следует отнести и достаточно представительную серию свернувшихся в кольцо хищников (рис. 2; 3: I, 1-5). Во-вторых, это стоящие или идущие хищники, - как полностью в профиль (рис. 3: III, 1, 2; IV, 1-3; 4), так и с разворотом головы и передней части туловища на зрителя (рис. 5: I, 1; II, 1, 2). В-третьих, это хищники, припавшие к земле передней частью и стоящие на задних ногах (рис. 5: III, 1,2 ; $\mathrm{V}, 1 ; \mathrm{VI}, 1)$, а также с вывернутой на $180^{\circ}$ задней частью туловища (рис. 5: IV, 1).

Хищники в редуцированном исполнении представлены обособленными головами (в том числе с шеями) в профиль (рис. 6: I, 1; II, 1-10) и анфас (рис. 6: III, 1-6; IV, $1 ; 7$ ). Протомы и обособленные конечности хищников, широко распространенные в ВСЗС (табл. 1), на предметах вооружения не известны.

В видовом отношении основной массив лежащих хищников относится к представителям семейства кошачьих, в принципе преобладающим среди хищников в репертуаре ВСЗС (рис. 1: I, 1-3; IV, 1, 2; 2: I, 1-13; II, 1; III, 1; 3: I, 1-5; III, 1, 2; IV, 1-3; 5: I, 1; II, 1, 2; III, 1, 2; IV, 1; VI, 1; 6 : I, 1 ; III, 1-6; IV, 1), во вторую очередь - к хищникам семейства волчьих (рис. 1: II, 1 ; III, 1 ; 2: III, $2 ; 3:$ II, $1-4 ; 5: \mathrm{V}, 1 ; 6:$ II, 10; 7: I, 1-3) и семейства медвежьих (рис. 4: I, 1-11; 7: II, 1-3).

Изображения копытных на предметах вооружения чаще связаны с образом оленя (вообще господствующего в мегаобразе копытных - см. табл. 1), причем в основном в полнофигурном, нежели в редуцированном отображении (табл. 2). Среди полнофигурных изображений преобладают олени, лежащие в жертвенной позе (в том числе так называемый «летящий» олень) (рис. 8; 9: I, 1, 2; II, 1), реже - олени в шаге задних ног с подломленными передними ногами - объекты терзания хищниками (рис. 9: III, 1, 2). Представлены также обособленные головы оленей с рогами, в том числе, терзаемые хищниками (рис. 10: I, 1; II, 1-3). Лоси отображаются на вооружении реже и только в виде обособленных голов (рис. 10: III, 1, 2; IV, 1; V, 1, 2; 11), при том, что в ВСЗС в принципе известны их полнофигурные воплощения (табл. 1, 2). Еще реже представлены горные козлы, в основном полнофигурно (рис. 12: I, 1, 2; II, 1; III, 1), в одном случае - в виде обособленной головы (рис.12: IV, 1). Также редко отображаются горные бараны (рис.12: V, 1; VI, 1) и лошади (рис. 13: I, 1; II, 1-3), и только в виде обособленной головы, при наличии в ВСЗС полнофигурных трактовок этих персонажей (табл. $1,2)$. Известно единичное полнофигурное изображение быка (рис. 13: III, 1), а также немногочисленные отображения кабана - фигуры (рис. 13: IV, 1,$2 ; \mathrm{V}, 1)$ и обособленные головы (рис. 13: VI, 1; VII, 1). Следовательно, все основные образы копытных в той или иной мере нашли свое отражение в декоре вооружения в рамках скифской археологической культуры. Не представлены лишь мотивы обособленной конечности и уха копытного, а также синтетические, «пограничные» мотивы - такие как «оленелоси», «лосекозлы» и «оленекозлы» (табл. 1).

Птицы на предметах вооружения в полнофигурном отображении крайне редки (рис. 14; 15: I, 1); в подавляющем большинстве они представлены мотивом обособленной головы, включая многочисленные элементы зооморфных превращений (рис. 15: II, 1-3; III, 1-13; 16-20). В видовом отношении изображения птиц, соответствующие канонам скифского звериного стиля и помещенные на вооружение в рамках территории восточноевропейского варианта скифо-сибирского звериного стиля, представляют исключительно хищных птиц, о чем свидетельствует характерная форма загнутого клюва. Вероятнее всего (судя также по морфологии полнофигурных персонажей), это птицы отряда соколообразных, или дневных хищных птиц (Falconiformes), подсемейства соколиных (Falconidae). И хотя при оформлении в манере скифского звериного стиля других категорий вещей скифской археологической культуры в редких случаях отображаются и нехищные отряды птиц (в частности, отряд «гусеобразные» (Anzeriformes), семейство «утиные» (Anatidae) с прямым или чуть изогнутым клювом), все же прототипы подавляющего большинства птичьих изображений в ВСЗС относятся именно к хищным птицам, преимущественно соколиным. 
Таблииа 2. Статистика изображений на предметах вооружения

\begin{tabular}{|c|c|c|c|}
\hline $\begin{array}{l}\text { Образно-видовая } \\
\text { принадлежность }\end{array}$ & $\begin{array}{c}\text { Количество оригинальных } \\
\text { изображений, без учета копий }\end{array}$ & $\%$ & $\begin{array}{c}\text { Количество } \\
\text { типов }\end{array}$ \\
\hline Хищники & $\begin{array}{c}87 \\
\text { (полнофигурных }-64 \text {, } \\
\text { редуцированных }-23 \text { ) }\end{array}$ & 28,4 & $\begin{array}{c}25 \\
(19+6)\end{array}$ \\
\hline $\begin{array}{l}\text { Копытные, } \\
\text { В том числе: }\end{array}$ & 54 & 17,6 & 26 \\
\hline Олени & $\begin{array}{c}21 \\
\text { (полнофигурных - 17, } \\
\text { редуцированных - 4) }\end{array}$ & & $\begin{array}{c}9 \\
(7+2)\end{array}$ \\
\hline Лоси & $\begin{array}{c}15 \\
\text { (полнофигурных - 0, } \\
\text { редуцированных - 15) }\end{array}$ & & $\begin{array}{c}4 \\
(0+4)\end{array}$ \\
\hline Горные козлы & $\begin{array}{c}6 \\
\text { (полнофигурных - 5, } \\
\text { редуцированных - 1) }\end{array}$ & & $\begin{array}{c}4 \\
(3+1)\end{array}$ \\
\hline Бараны & $\begin{array}{c}2 \\
\text { (полнофигурных - 0, } \\
\text { редуцированных - 2) }\end{array}$ & & $\begin{array}{c}2 \\
(0+2)\end{array}$ \\
\hline Лошади & $\begin{array}{c}4 \\
\text { (полнофигурных - 0, } \\
\text { редуцированных - 4) }\end{array}$ & & $\begin{array}{c}2 \\
(0+2)\end{array}$ \\
\hline Быки & $\begin{array}{c}1 \\
\text { (полнофигурных - } 1, \\
\text { редуцированных - 0) }\end{array}$ & & $\begin{array}{c}1 \\
(1+0)\end{array}$ \\
\hline Кабаны & $\begin{array}{c}5 \\
\text { (полнофигурных - 3, } \\
\text { редуцированных - 2) }\end{array}$ & & $\begin{array}{c}4 \\
(2+2)\end{array}$ \\
\hline Птицы & $\begin{array}{c}145 \\
\text { (полнофигурных - 4, } \\
\text { редуцированных - 141) }\end{array}$ & 47,4 & $\begin{array}{c}17 \\
(2+15)\end{array}$ \\
\hline $\begin{array}{l}\text { Синкретические животные, } \\
\text { В том числе: }\end{array}$ & 15 & 4,9 & 5 \\
\hline Грифоны и крылатые львы & $\begin{array}{c}4 \\
\text { (полнофигурных -4, } \\
\text { редуцированных - 0) }\end{array}$ & & $\begin{array}{c}2 \\
(2+0)\end{array}$ \\
\hline Бараноптицы & 7 & & 1 \\
\hline $\begin{array}{l}\text { Гиппокампы-кони, } \\
\text { грифоногиппокампы и «петушки» }\end{array}$ & 1 & & 1 \\
\hline $\begin{array}{l}\text { Комбинация элементов птицы и } \\
\text { неопределенного копытного }\end{array}$ & 3 & & 1 \\
\hline Зайцы & $\begin{array}{c}4 \\
\text { (полнофигурных - 2, } \\
\text { редуцированных - 2) }\end{array}$ & 1,3 & $\begin{array}{c}3 \\
(2+1)\end{array}$ \\
\hline Рыбы & 1 & 0,3 & 1 \\
\hline итого & $\begin{array}{c}306 \\
\text { изображений }\end{array}$ & $100 \%$ & $\begin{array}{c}77 \\
\text { типов } \\
\end{array}$ \\
\hline
\end{tabular}

Синкретические животные на предметах вооружения представлены немногочисленными образами полнофигурных грифонов (рис. 21: I, 1-3; II, 1), головок бараноптиц (рис. 21: III, 1-7), грифоно-гиппокампа (рис. 21: IV, 1) и синкретического существа, сочетающего голову хищной птицы и конечность копытного (рис. 22: 1-3). Остальные синкретические образы, известные в ВСЗС, в оформлении вооружения не представлены (табл. 1, 2).
Наконец, среди прочих образов, находящихся за пределами четырех мегаобразов скифского звериного стиля, на предметах вооружения в единичном отображении фигурируют мотивы зайца (в качестве зооморфных превращений) (рис. 23: I, 1; II, 1; III, 1, 2) и рыбы (рис. 23: IV, 1-a, 1-б). Верблюды, дельфины и неопределенные животные, изредка оформляющие в ВСЗС другие категории изделий, на вооружении не зафиксированы. 

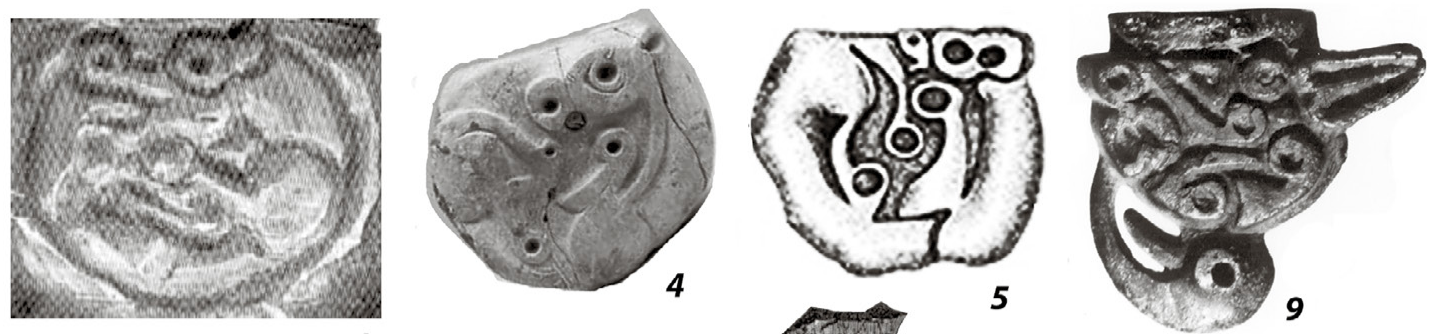

1
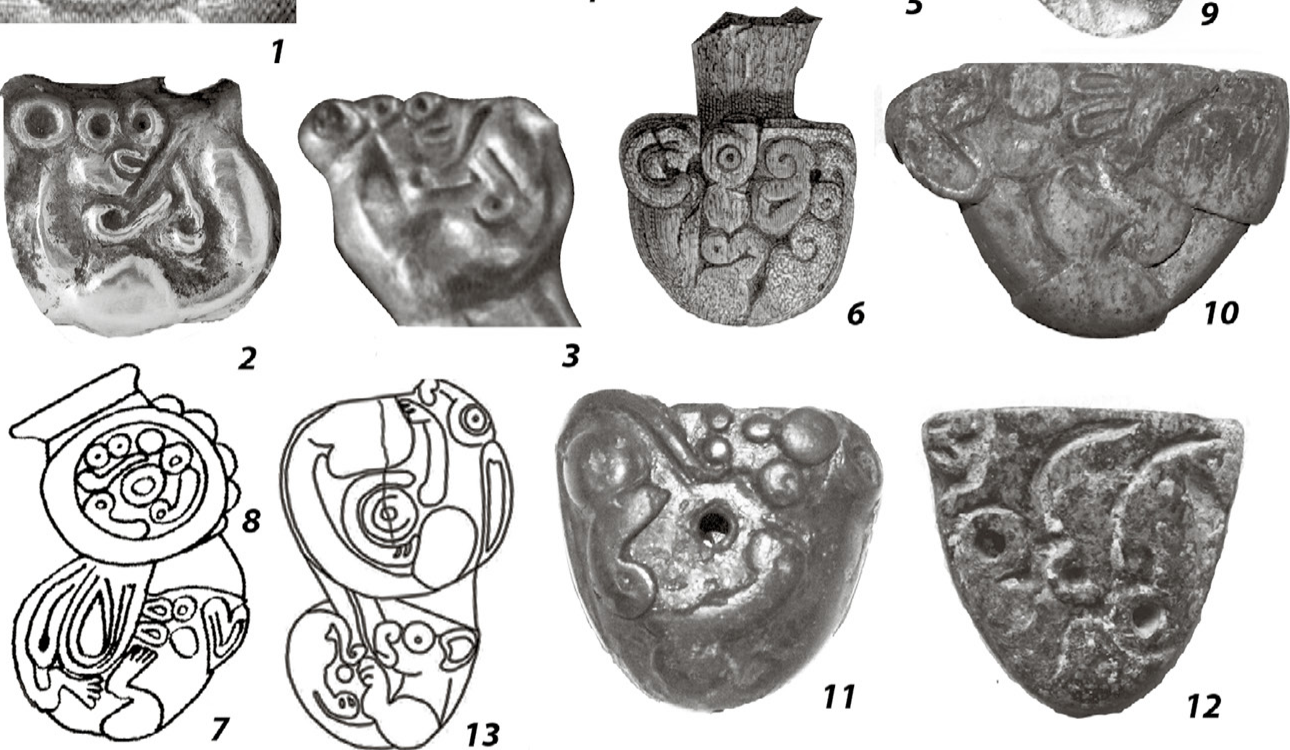

3
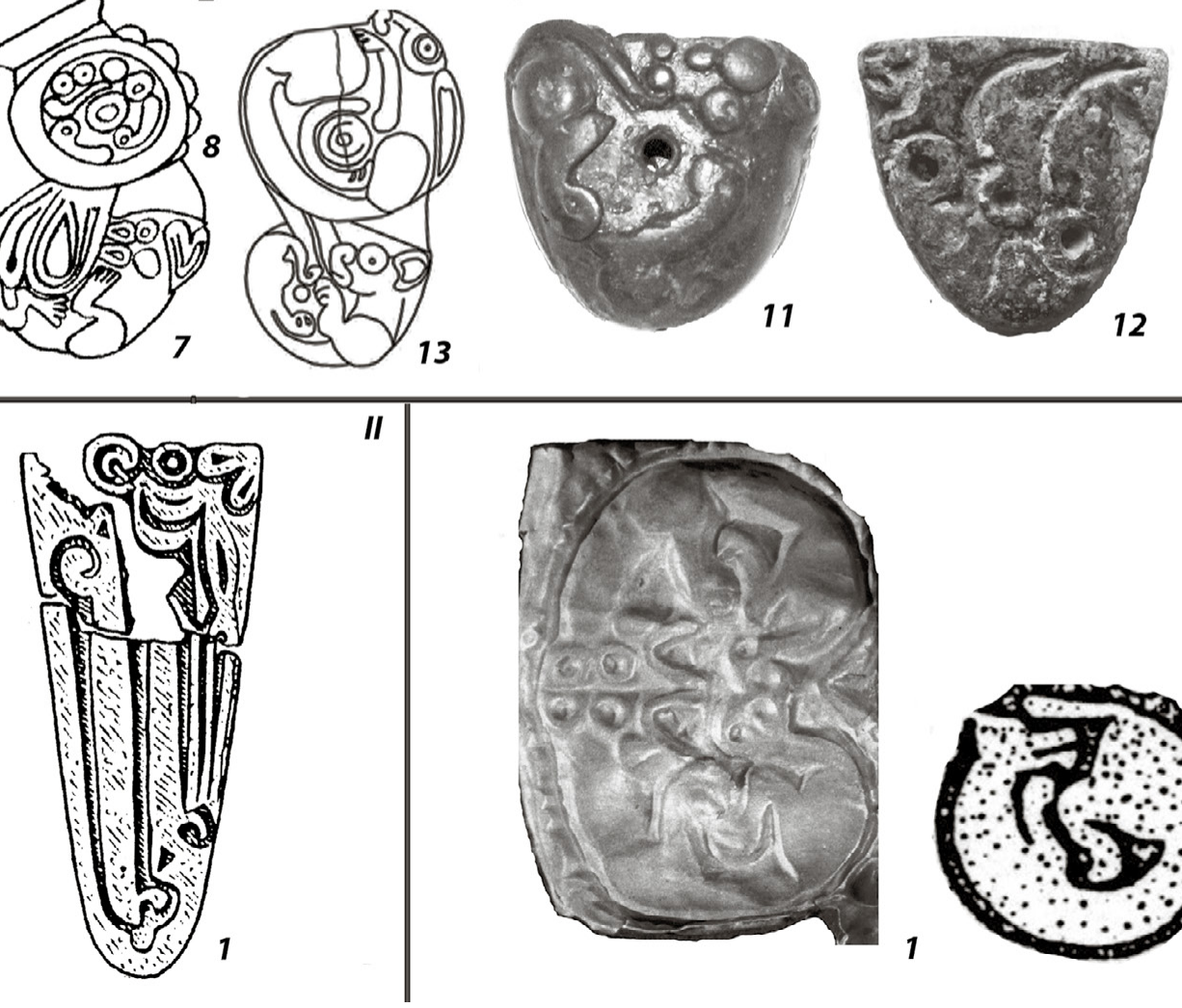

III

Рис. 2. Хищники в полнофигурном отображении на предметах вооружения (типы Келермесско-яблоновский; «Старшая могила»; Кулаковско-ковалевский). I - Келермесско-яблоновский тип. 1-3 - Келермес, к. 1/Ш: 1 - золотая наременная обкладка - портупейная деталь ножен меча, 4 изображения (Галанина, 1997. Кат. 2. Табл. 7); 2, 3 - золотая пластина - накладка на горит (щит?) - заполнение хвоста Келермесской пантеры, 6 изображений, трансформация лап келермесской пантеры, 4 изображения (Галанина, 1997. Кат.13. Табл. 3); 4 - х. Грозный у г. Майкоп, случайная находка, костяная бутероль (Канторович, Эрлих, 2006. Кат. 43); 5 - х. Степной у г. Гудермес, курган, бронзовая бутероль (Ильинская, Тереножкин, 1983. С. 47. Рис. 3); 6 - Дарьевка, к. 2, костяная бутероль (Бобринский, 1894. Фиг. 13); 7, 8 - Новоалександровка, к. 7, п. 8, костяное налучье, хищник на клюве птицы, хищник вокруг глаза птицы (Кореняко, Лукьяшко, 1982. С. 155. Рис. 6: 2); 9 - могильник Фаскау, бронзовая бутероль (Древние бронзы Кавказа..., 2010. Кат. 231); 10 - Нартан, к. 21, костяная бутероль (Батчаев, 1985. Табл. 51: 20; фото А. Р. Канторовича в НМ КБР); 11 - покупка в Майкопе в 1915 г., бронзовая бутероль (Ильинская, Тереножкин, 1983. С. 53. Рис.15, 18; фото А. Р. Канторовича в ГЭ); 12 - хутор Ленинский путь, сборы на месте разрушенного кургана, бронзовая бутероль (Канторович, Шишлов, 2014. Рис. 4); 13 - Западное Бельское городище, зольник 28, помещение 9, налучье из рога оленя (Шрамко, 2015. Ил. 1: 1, 2: 1д, 1и); II - тип «Старшая могила»: 1 - Старшая могила, бронзовая бутероль (Шкурко, 1969. Рис. 1); III - Кулаковско-ковалевский тип: 1 - Острая Томаковская могила, золотая обкладка ножен меча (Артамонов, 1966. Табл. 65, 66); 2 - Енкивцы, центральная пластина бронзовой крестовидной бляхи «ольвийского типа» (Могилов, 2008. Рис. 104: 2) 

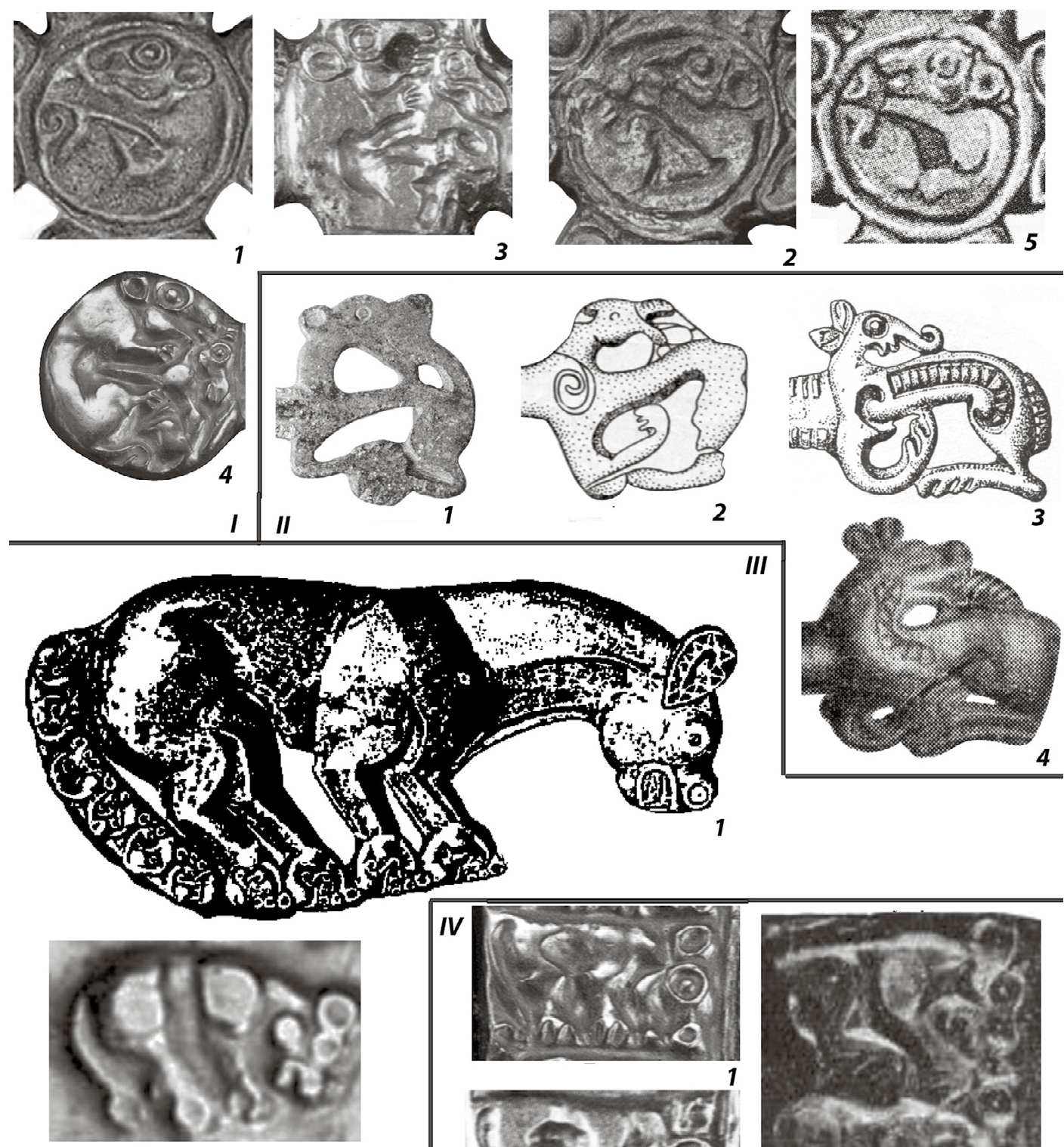

III

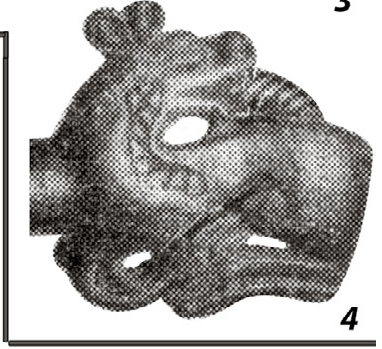

2

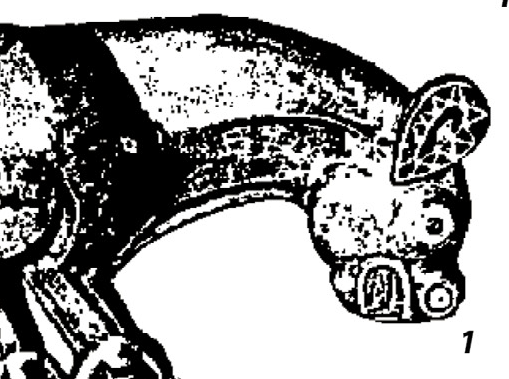

1
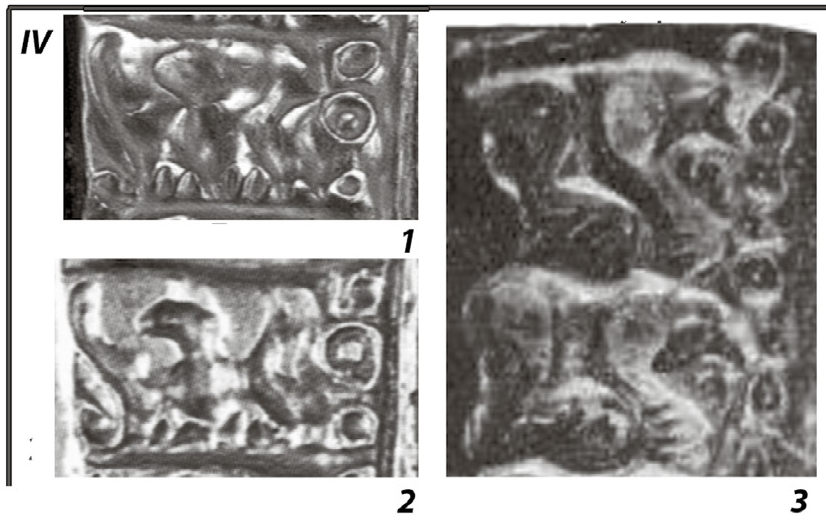

Рис. 3. Хищники в полнофигурном отображении на предметах вооружения (типы Ольвийско-басовский; «Терновое - Семибратние»; Келермесский; Гусарско-Опишлянский) . I - Ольвийско-басовский тип. 1-5 - крестовидные бляхи «ольвийского типа» (1, 2, 5 - бронза, на центральной пластине; 3, 4 - бронза, обтянутая золотым листом, на центральной пластине и на трех боковых): 1 - некрополь Ольвии, п. 12 (1910 г.) (Borovka, 1928. PI. 9); 2 - случайная находка у хут. Дугино, Нижний Дон (L' or des Amazones..., 2001. Cat. 16); 3 - с. Деревка, к. 13, «Могила Опишлянка» (На краю Ойкумены..., 2002. Кат. 450); 4 - с. Гусарка (Gold der Steppe..., 1991. Cat. 93); 5 - случайная находка у хут. Полушкино в Азовском р-не Ростовской обл. (Ильюков, 2016. Рис. 2: 3, 3а); ІІ - тип «Терновое - Семибратние». 1-4 - колчанные (?) крючки, бронзовые (1, 2, 4) и золотой (3): 1 - покупка в Майкопе, 1903 г. (На краю Ойкумены..., 2002. Кат. 489); 2 - ст. Староминская близ Ейска, разрушенное погр. (Гуляев, 1969. Рис. 7: 7); 3 - сборы А. А. Спицына, 1905 г. (Либеров, 1965. Табл. 32: 11); 4 - сборы А. А. Спицына, 1905 г. (Либеров, 1965. Табл. 31: 13); III - Келермесский тип: 1 - Келермес, к.1/Ш, Келермесская пантера - золотая пластина - накладка на горит (щит?) (Галанина, 1997. Кат. 13. Табл. 32); 2 - Келермес, к.4/Ш, золотая пластина - накладка на горит, 32 изображения (Галанина, 1997. Кат. 51. Табл. 5); IV - Гусарско-Опишлянский тип. 1, 2 - крестовидные бляхи «ольвийского типа» (бронза, обтянутая золотым листом), по 4 изображения на длинных боковых пластинах: 1 - с. Гусарка (Gold der Steppe..., 1991. Cat. 93); 2 - с. Деревка, к. 13, «Могила Опишлянка» (На краю Ойкумены..., 2002. Кат. 450); 3 - хут. Шумейко, золотая обкладка ножен меча, 7 изображений (Borovka, 1928. PI. 23A) 

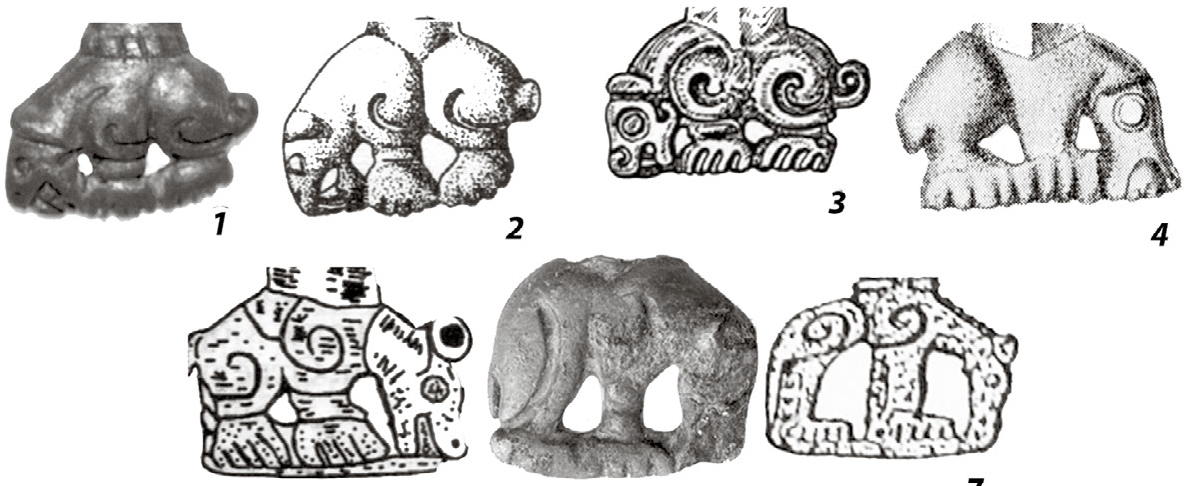

5

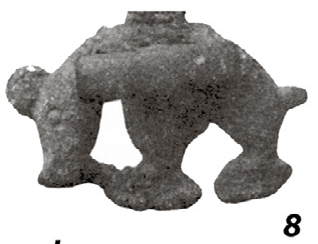

I
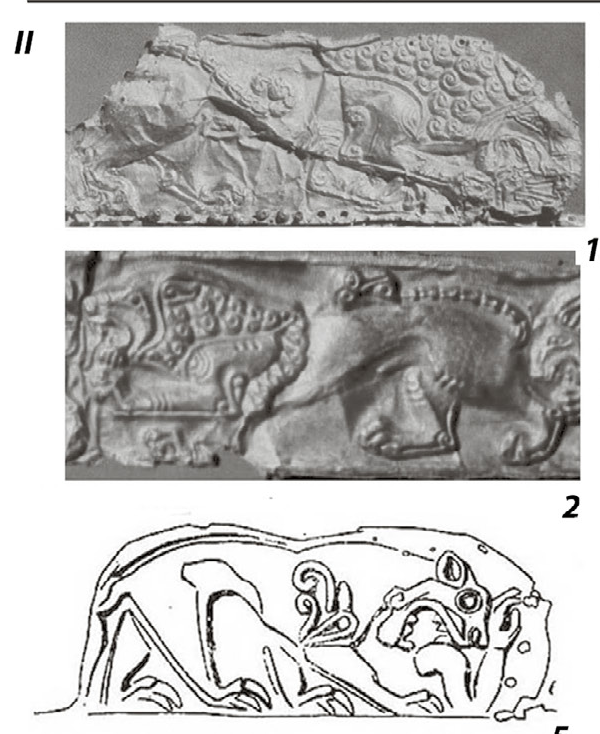

5

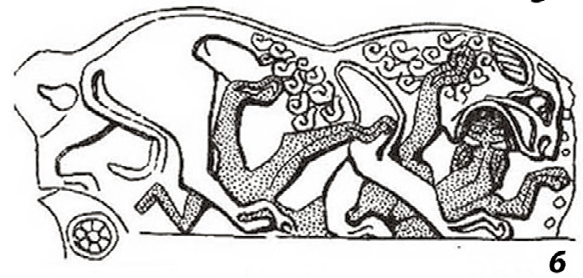

6

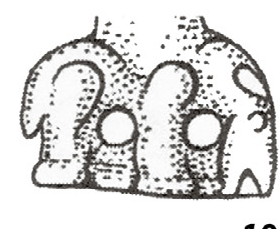

10

\section{7.}

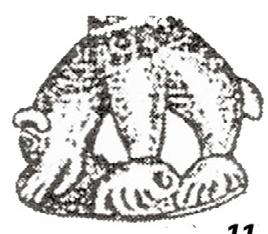

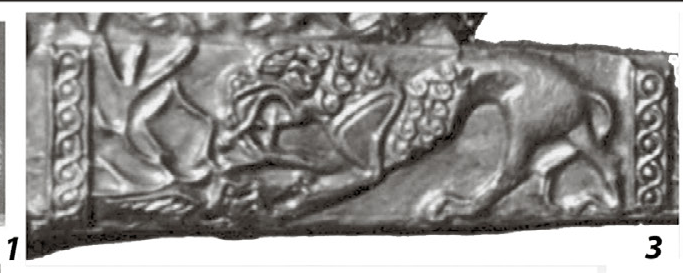
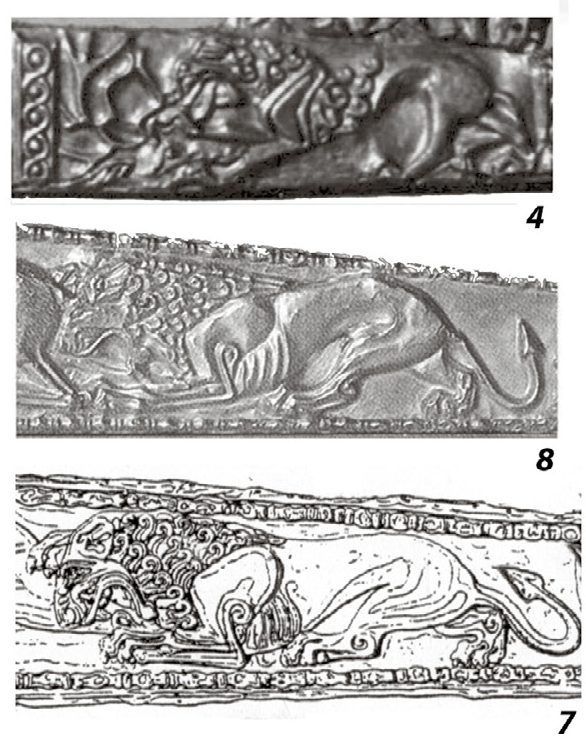

Рис. 4. Хищники в полнофигурном отображении на предметах вооружения (типы Кащеевско-колбинский; Солохско-ушаковский). I - Кащеевско-колбинский тип. 1-11 - колчанные (?) крючки, бронзовые (1-4, 6-11) и серебряный (5): 1 - Кащеевский курган (Максименко, 1983. С. 32, 101, 172. Рис. 18: 15, 14; фото А. Р. Канторовича в АКМ); 2 - Русская Тростянка, к. 1 (Либеров, 1965. Табл. 32: 14); 3 - Колбино, к. 17 (Гуляев, 2010. С. 234. Рис. 17); 4 - Частые курганы, к. 11, раскопки ВУАК (Замятнин, 1946. Рис. 27: 2); 5 - Колбино, к. 1/9 (Савченко, 2001а. Рис. 2: 21); 6 - «Майкопский клад» $\quad$ (Leskov, 2008. Cat. 256); 7 - с. Бажиган, разрушенное погр. (Маслов, Очир-Горяева, 1997. Рис. 2: 14); 8 - городище Красный курган Хомутовского р-на Курской обл., случайная находка (Шпилев, 2012. С. 169. Рис. 3: 4); 9 - Терновое, к. 4 (Савченко, 2001б. Рис. 7: 26); 10 - Староживотинное, к. 38 (Медведев, 2001. С. 13. Рис. 4: 5); 11 - х. Дубовой, к. 6 (Березуцкий, 2006. С. 140. Рис. 2: 4); II - Солохско-ушаковский тип. 1-8 - золотые обкладки ножен мечей: 1, 2 - Елизаветовский могильник (Ушаковский курган), лев на боковой пластине (1) и лев на основной пластине (2), преследующий кабана (Borovka, 1928. PI. 22A); 3-6 - Солоха, боковое погребение, лев на основной пластине у устья ножен (3), лев на основной пластине в центре (4), лев на большой боковой пластине (5), лев на малой боковой пластине (6) (Манцевич, 1987. С. 69-71. Кат. 49); 7 - Куль-Оба (Древности Боспора..., 1854. Табл. XXVI: 2); 8 - Великая Белозерка (Gold der Steppe..., 1991. S. 359. Kat. 89) 


\section{Категории предметов вооружения, оформляемых/украшаемых образами BC3C}

Обратимся к обзору предметов вооружения, происходящих с территории скифской археологической культуры и украшенных или оформленных в скифском зверином стиле. В рамках каждой категории будем придерживаться хронологического порядка.

Основной категорией изделий, декорируемых в скифском зверином стиле, являются акинаки и их аксессуары: украшаются ножны, бутероли и рукояти ${ }^{6}$.

В этой группе изделий наиболее ранний пласт составляют бутероли мечей периода «скифской архаики». Это прежде всего бронзовые и костяные бутероли второй четверти VII третьей четверти VI в. до н.э., оформленные в виде двустороннего изображения свернувшегося в кольцо кошачьего хищника (восемь оригинальных изображений) (рис. 2: I, 4-6, 9-12; II, 1). Они происходят с территории Среднего Поднепровья, Прикубанья и Центрального Предкавказья ${ }^{7}$.

Это также бронзовые бутероли рубежа VIIVI - начала VI в. до н. э., выполненные в виде птичьей головы с шеей, с сильно загнутым (на $180^{\circ}$ ) и раскрытым клювом, упирающимся концом в подклювье, т.е. хищная птица на грани реальности и фантастики (18 изображений) (рис. 17). Поскольку большинство птиц на этих бутеролях показаны с языком в клюве, это сближает их с грифонами, оформляющими ритуальные навершия периода «скифской архаики». Основная их масса происходит с территории Центрального Предкавказья (девять изображений), остальные - из «Крымской коллекции» (четыре изображения), а также с территории Прикубанья, Среднего Поднепровья и Нижнего Поднепровья.

Для периода «скифской классики» $\mathrm{V}$ - начала $\mathrm{IV}$ в. до н.э. традиция зооморфизации бутеролей как таковых практически не свойственна, исключение составляет лишь декоративная бутероль, оформленная в виде фаса хищника («маски»), по сути, выступ ножен на мече конца $\mathrm{V}$ - первой четверти IV в. до н.э. из Бокового погребения царского кургана Солоха (рис. 6: III, 4).

Следующая по времени после бутеролей мечей (если не считать бутероль из Солохи, являющуюся исключением) крупная группа изделий в зверином стиле в рамках категории мечей рукояти акинаков, в том числе их перекрестья и навершия.

В связи с этой группой выделяется масштабный морфологический тип, датируемый концом $\mathrm{VI}-\mathrm{V}$ в. до н. э. и насчитывающий как минимум 52 оригинальных изображения синтетических пар тонких голов хищной птицы, оформляющих в основном антенновидные навершия рукоятей мечей (рис. 19: 1-34, 36-52), а в одном случае перекрестье (рис. 19: 35) ${ }^{8}$. Эти мечи происходят практически со всех территорий, относящихся к скифской археологической культуре или к зоне ее влияния: с территории Среднего Поднепровья, Среднего Подонья, Нижнего Поднепровья и Побужья, Крыма, Прикубанья и Центрального Предкавказья. К этому типу (как оформление перекрестья железного меча) примыкает относящееся к другому морфологическому типу изображение головы птицы с территории Среднего Поднепровья - с единым глазом и двумя мощными антитетическими клювами, закрученными в волюту (рис. 15: III, 13).

На трех держаках рукоятей таких мечей, происходящих из лесостепного Днепровского Левобережья помещена отчетливая протома медведя (рис. 7: II, 1-3)9.

Развитием указанного выше типа изображений на навершиях, предполагающего относительную объемность, является тип уплощенных головок хищных птиц на навершиях мечей конца V - IV в. до н. э. (16 оригинальных изображений), имеющих при этом членистую структуру (возможно, это амбивалентное отображение птичьих голов/когтей) (рис. 20).

Отдельную компактную группу формируют изображения на мечах с территории Нижнего и Среднего Поднепровья, а также

\footnotetext{
6 См. обзор и структурно-семантический анализ декора ножен и бутеролей скифских акинаков VII-V вв. до н. э. и аналогичных им, украшенных в ассиро-уратском, скифском, кобанском и иных стилях: Полидович, 2015.

7 При этом у хищника на бутероли из Фаскау хвост превращен в голову водоплавающей птицы, выполненной в кобанской манере и композиционно соответствующей (в комбинации с хвостом хищника) бронзовым бутеролям, описываемым в следующем абзаце.

8 Очевидно, изначальное число таких изображений было еще большим, но нами в целях статистической точности не учитываются многочисленные антенновидные навершия мечей, которые могли быть оформлены в виде птичьих голов, но в силу качества работы или качества сохранности зооморфная основа в них не прослеживается достаточно четко.

9 В еще одном аналогичном случае такая протома едва читается, поэтому не включается нами в общий подсчет (рис. 19: 46).
} 
Нижнего Подонья; рукояти этих мечей (на перекрестьях, держаках или навершиях) несут на себе изображение лосиной головы, выполненное в рельефе или гравировкой на плоскости самой рукояти, либо на ее золотой обкладке. Эти изображения формируют отдельный морфологический тип конца $\mathrm{V}$ - первой четверти IV в. до н. э. (девять оригинальных изображений) (рис. 11).
Также в одном случае накладка с изображениями антитетических голов хищников помещена на золотой фольге на навершии меча $\mathrm{V}$ в. до н.э. из Центрального Предкавказья (рис. 6: I, 1).

Наконец, еще одна группа украшаемых элементов в рамках категории мечей - золотые обкладки ножен парадных акинаков. Начало этой традиции положено изображениями оленей на боковых лопастях ножен знаменитых
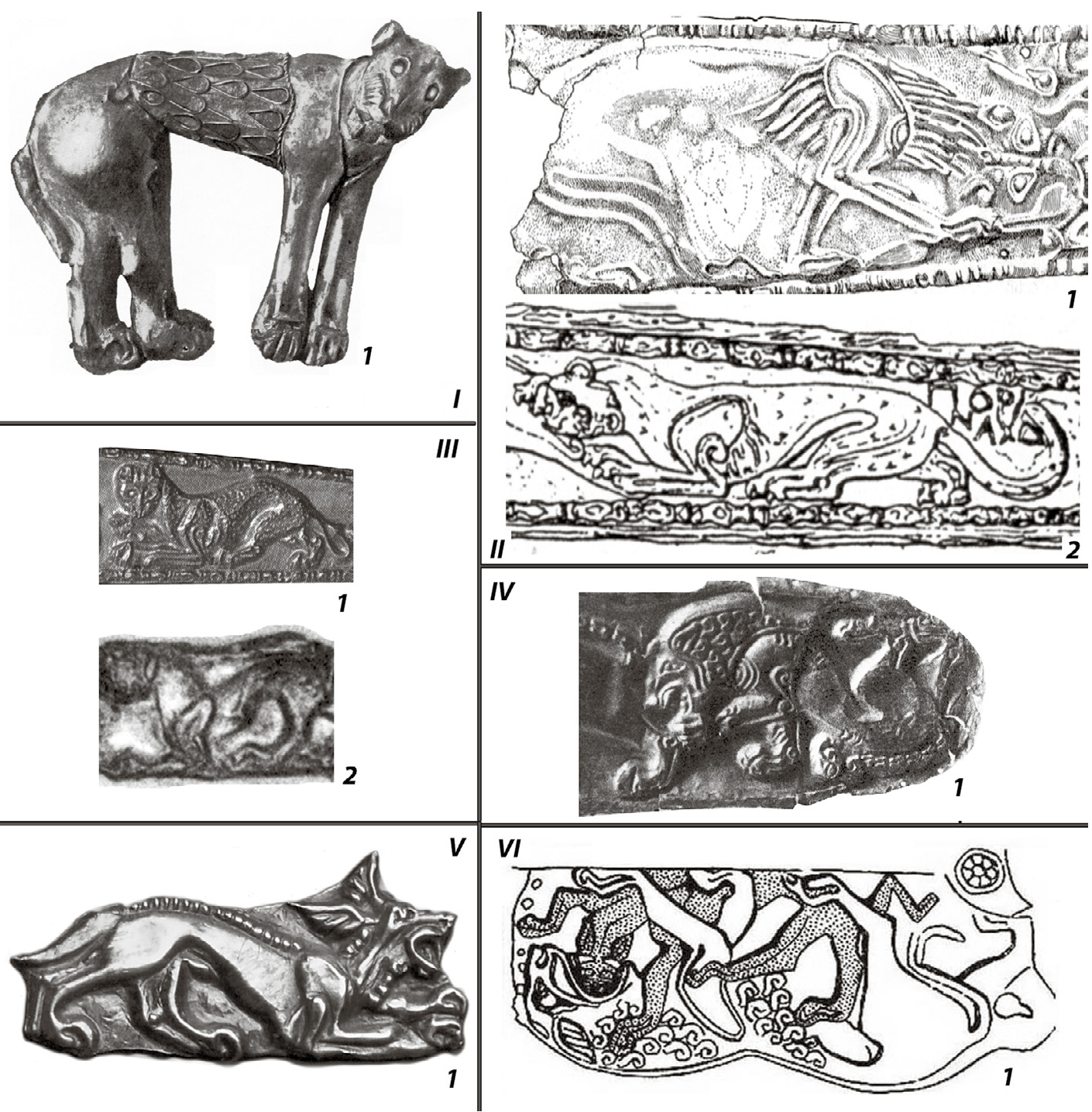

Рис. 5. Хищники в полнофигурном отображении на предметах вооружения (типы «Золотой курган-Макеевка»; Семибратненско-елизаветовский; Белозерско-кульобский; Ушаковский; «Архангельская слобода»; Солохский). І - тип «Золотой курган-Макеевка»: 1 - Золотой курган (№ 5), впускное погребение, позолоченная бронзовая фигура, украшавшая крышку колчана (?) (Borovka, 1928. PI. 16A); II - Семибратненскоелизаветовский тип. 1, 2 - золотые обкладки ножен мечей: 1 - Елизаветовский могильник (к. 10, раскопки 1909 г.), основная пластина (Миллер, 1910. Табл. V. Рис. 2За, б); 2 - Куль-Оба, основная пластина (Древности Боспора..., 1854. Табл. XXVI: 2); III - Белозерско-кульобский тип. 1, 2 - золотые обкладки ножен мечей: 1 - Великая Белозерка, основная пластина, львица позади льва (Gold der Steppe..., 1991. S. 359. Kat. 89); 2 - Солоха, боковое погребение, основная пластина (Манцевич, 1987. С. 69-71. Кат. 49); IV - Ушаковский тип: 1 - Елизаветовский могильник (Ушаковский курган), лев на основной пластине, следующий за бегущим львом (Borovka, 1928. PI. 22A); V - тип «Архангельская слобода»: 1 - Архангельская слобода, к. 5, п. 1, золотые накладки - аппликации колчана, 3 экз. (Лесков, 1972. С. 57. Табл. 35); VI - Солохский тип: 1 - Солоха, боковое погребение, золотая обкладка ножен меча, большая боковая пластина (Манцевич, 1987. С. 69-71. Кат. 49) 

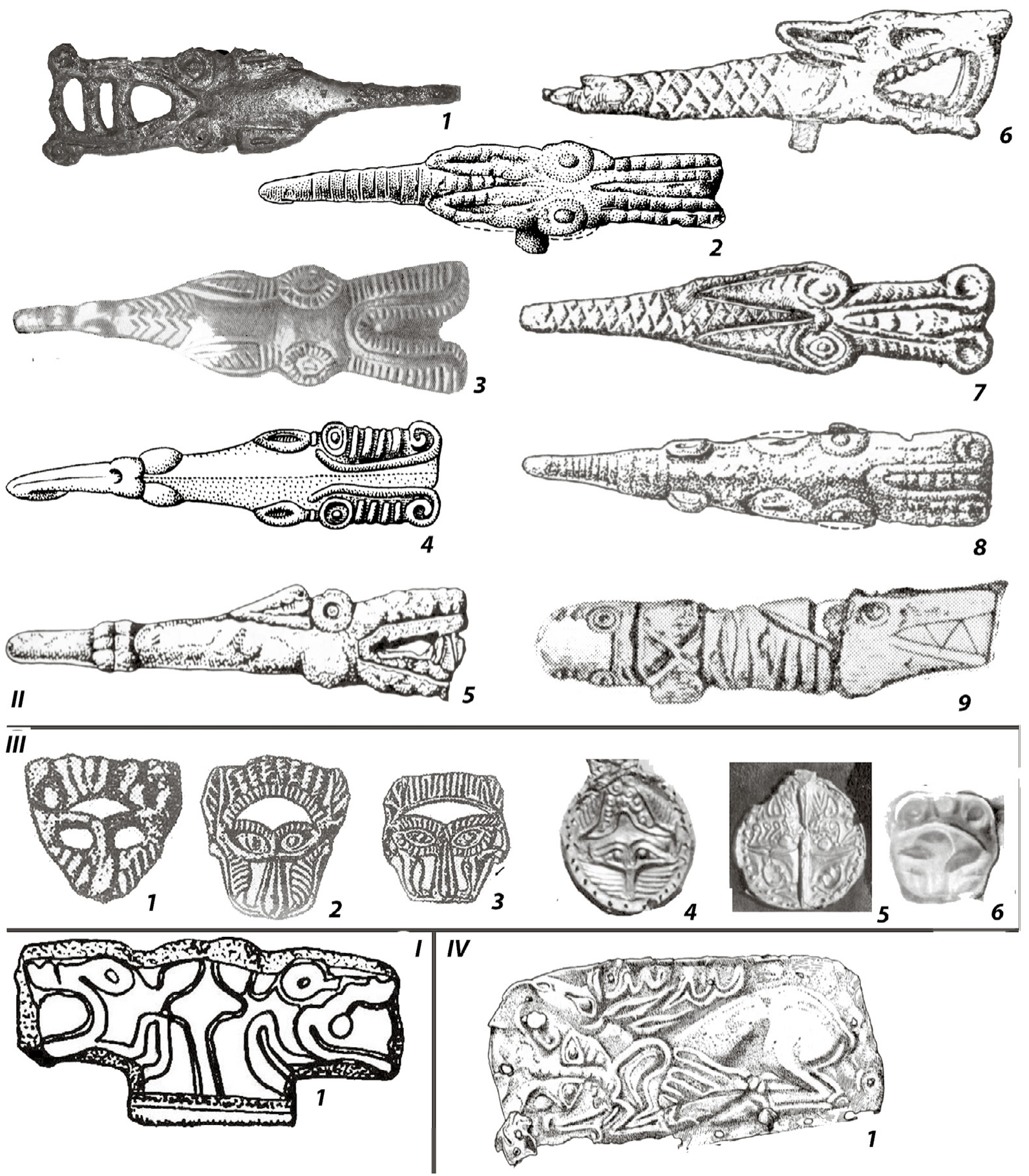

Рис. 6. Хищники в редуцированном отображении на предметах вооружения. Головы плоскостные профили (I, II) и фасы (III, IV). I - Нимфейско-журовский тип: 1 - Ассиновская, к. 1, навершие меча, накладка с изображениями на золотой фольге (Бурков, Маслов, 2007. Рис. 4: 6); II - Роменско-сладковский тип. 1-9 - колчанные (?) крючки, бронзовые $(1,4)$, железные $(2,5-8)$, железный с золотой обтяжкой (3) и костяной (9): 1 - Сладковский могильник, к. 25 (Максименко, 1983. С. 31, 101, 168. Рис. 14: 7); 2 - Мастюгино, к. $32 / 32$ (Либеров, 1965. Табл. 32: 6); 3 - Частые курганы, к. 3, раскопки ВУАК (Либеров, 1965. Табл. 31: 10); 4 - Частые курганы, к.10, раскопки ВУАК; 5 - Русская Тростянка, к. 7 (Пузикова, 2001. Рис. 10: 8); 6, 7 - Мастюгино, к.11/16 (Либеров, 1965. Табл. 32: 1, 2); 8 - Мастюгино, к. 32/32 (Либеров, 1965. Табл. 32: 3); 9 - Мастюгино, к. 34/39 (Пузикова, 2001. рис. 49: 12); III - тип «Берестняги-Солоха»: 1-3 - Толстая могила, Центральная гробница, золотые пластины горита (Мозолевський, 1979. Рис. 47: 2); 4 - Солоха, боковое погр., золотая обкладка бутероли меча (Манцевич, 1987. С. 69-71. Кат. 49); 5 - Дорт-Оба, золотая пластина горита (Артамонов, 1966: Табл. 194); 6 - Острая Томаковская могила, золотая обкладка ножен меча, 10 изображений (Артамонов, 1966. Табл. 65, 66); IV - Елизаветовский тип: 1 - Елизаветовский могильник, к. 10, раскопки 1909 г., боковая пластина золотой обкладки ножен меча (Миллер, 1910. Табл. V. Рис. 23а, б) 
Келермесского и Мельгуновского мечей из комплексов второй половины VII в. до н. э. (рис. 8: $1,2)$; кроме того, та же лопасть Келермесского меча обрамлена на каждой стороне ободком из семи голов хищных птиц (рис. 18: III, l), а золотая наременная обкладка (портупейная деталь ножен) на своих четырех выступах украшена изображениями свернувшегося в кольцо кошачьего хищника (рис. 2: $\mathrm{I}, l)^{10}$.

Данная традиция декорирования ножен - преимущественно многофигурными композициями - продолжается в изделиях с территорий Среднего Поднепровья, Нижнего Поднепровья, Нижнего Подонья и Крыма. Это, прежде всего, мечи из Острой Томаковской могилы (конец VI начало $\mathrm{V}$ в. до н. э.) и из хут. Шумейко (последние десятилетия VI - начало V в. до н.э.). Устье ножен томаковского меча украшено парными синтетическими фигурами свернувшегося хищника (рис. 2: III, 1), а верхняя часть ножен - размещенными по вертикали фасами кошачьего хищника (рис. 6: III, б); устье ножен шумейковского меча заполнено парными синтетическими фигурами горных козлов (рис. 12: I, l), а собственно ножны - фигурами кошачьих хищников, размещенными друг над другом (рис. 3: IV, 3). Далее в хронологическом отношении следуют великолепные парадные мечи IV в. до н. э. - из Солохи, Куль-Обы, Елизаветовского могильника (Ушаковский курган; курган 10 раскопок 1909 г.; курган 1 раскопок 1910 г.) и Великой Белозерки. Их устья оформлены парными синтетическими композициями голов хищной птицы (рис. 18: VII, 1-4), а на основной и боковой пластинах в сценах терзания и преследования и в иных сюжетах представлены хищные и копытные звери в полнофигурном и редуцированном отображении: 15 оригинальных фигур кошачьих хищников - львов, львиц, пантер/леопардов (рис. 1: IV, 2; 4: II, 1-8; 5: II, 1, 2, III, $1,2 ; \mathrm{IV}, 1 ; \mathrm{VI}, 1), 1$ голова кошачьего хищника (рис. 6: IV, 1), 4 фигуры оленя (в том числе одна из них - с трансформацией бедренной выемки в голову хищной птицы) (рис. 9: II, 1, 2; III, 1, 2), 4 головы оленя (в том числе одна - с рогами и шерстной шейной складкой, трансформированными в головы фантастических птиц/ грифонов) (рис. 10: I, 1; II, 1-3; рис. 18: IX, 1, 2), фигура горного козла (рис. 12: II, 1), фигура

${ }^{10}$ Как справедливо отметила А.И. Мелюкова, все остальные части Келермесского и Мельгуновского мечей «украшены в стиле переднеазиатского искусства», т.е. не соответствуют канонам скифского звериного стиля (Мелюкова, 1989. С. 101, 102). 

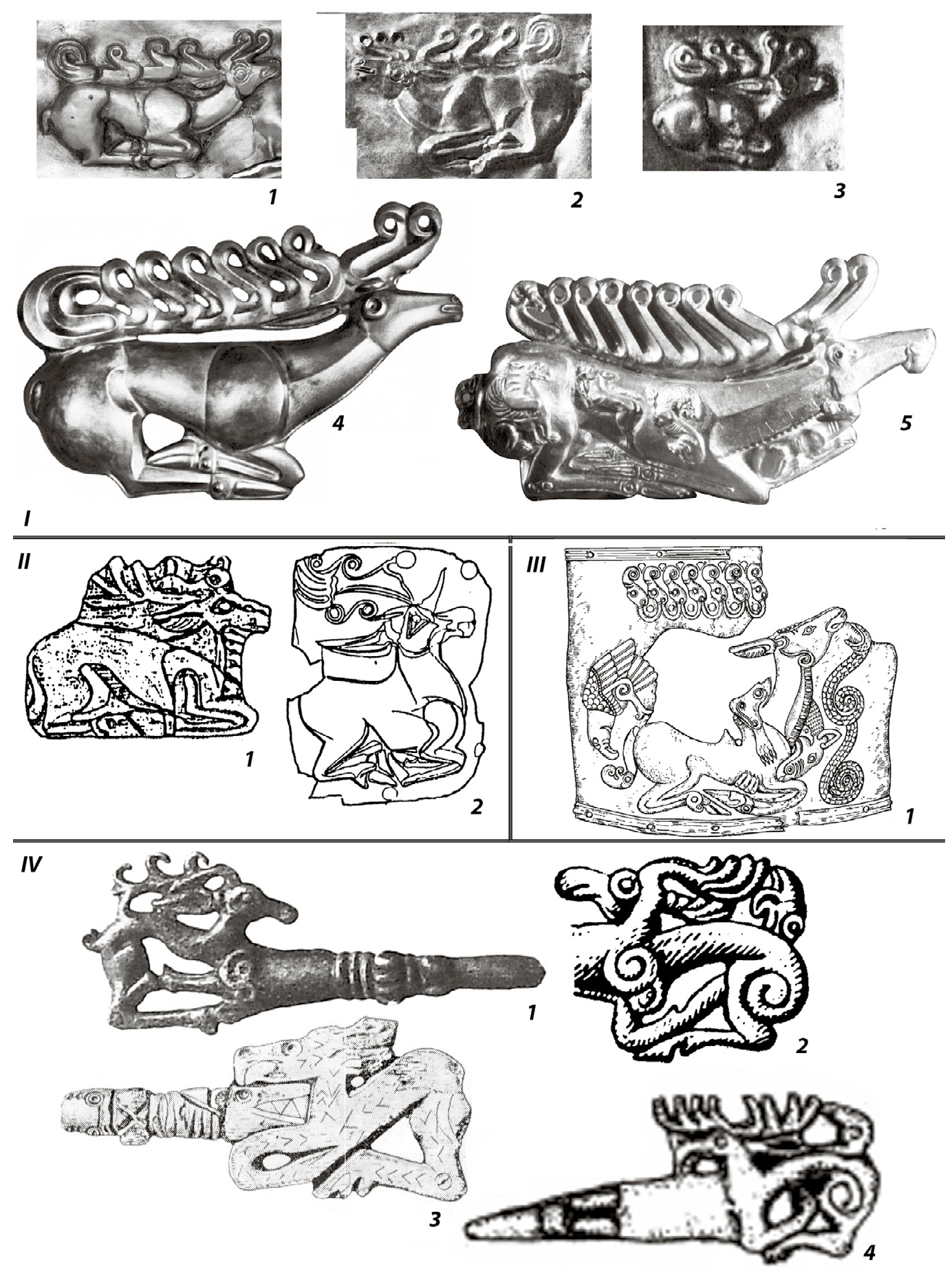

Рис. 8. Копытные на предметах вооружения. Олень в полнофигурном отображении (типы Келермесско-кульобский; Завадско-акмечетский; Ильичевско-журовский; «Александропольский-Частые»). I - Келермесскокульобский тип. 1, 2 - боковые лопасти золотых ножен мечей: 1 - Мельгуновский курган (Алексеев, 2012. С. 118); 2 - Келермес, к. 1/Ш (Галанина, 1997. Кат. 1. Табл. 7, 8); 3 - Келермес, к. 4/Ш, золотая обкладка горита, 24 фигуры (Галанина, 1997. Кат. 51. Табл. 5); 4 - ст. Костромская, 1-й Разменный курган, золотая пластина - накладка на горит (щит?) (Piotrovsky et al., 1986. Fig. 16); 5 - Куль-Оба, золотая пластина - накладка на горит (щит?) (Древности Боспора..., 1854. Табл. XXVI: 1); II - Завадско-акмечетский тип. 1, 2 - золотые накладки колчана: 1 - Архангельская слобода, к. 5, п. 1 (Лесков, 1972. Табл. 36); 2 - Елизаветовская станица, к. 6, раскопки 1909 г., 2 экз. (Артамонов, 1966. С. 77, 78. Табл. 322); III - Ильичевско-журовский тип: 1 - Ильичево, к. 1, п. 6, золотая обкладка колчана (Лесков, 1968. Рис. 7); IV - тип «Александропольский-Частые». 1-4 - колчанные (?) крючки: 1 - Александропольский курган, тождественные золотой и серебряный крючки (Древности Геродотовой..., 1866. С. 3. Табл. І: 3, 4); 2 - Частые курганы, к. 12, бронзовый крючок (Либеров, 1965. Табл. 32: 10); 3 - Мастюгино, к. 34/39, костяной крючок (Пузикова 2001. С. 122. Рис. $49: 12$ ); 4 - к. 5 группы Новоалександровка - Богачевка, п. 1, бронзовый крючок (Колтухов, 2012. Рис.17: 6) 


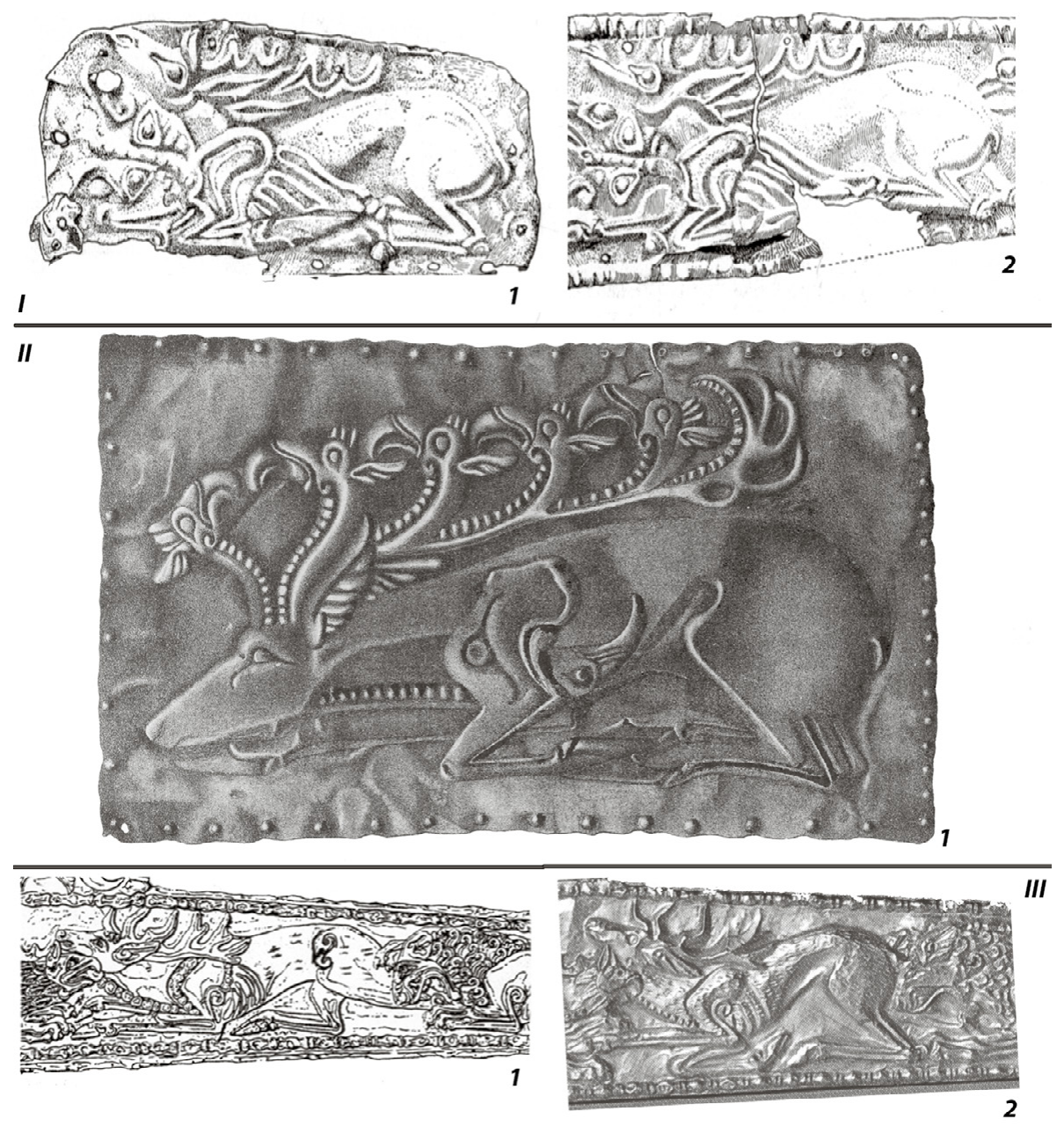

Рис. 9. Копытные на предметах вооружения. Олень в полнофигурном отображении (типы «Смела-Елизаветовская»; Аксютинецкий; Кульобско-белозерский). I - тип «Смела-Елизаветовская»: 1, 2 - Елизаветовский могильник (к. 10, раскопки 1909 г.) основная (1) и боковая (2) пластины золотой обкладки ножен меча (Мил-

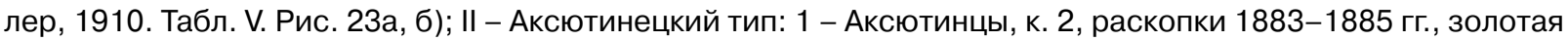
обивка колчана (Бобринский, 1894. Табл. XXI: 3); III - Кульобско-белозерский тип. 1, 2 - золотые обкладки ножен мечей: 1 - Куль-Оба (Древности Боспора..., 1854. Табл. XXVI: 2); 2 - Великая Белозерка (Gold der Steppe..., 1991. S. 359. Kat. 89)

кабана (рис. 13: V, 1), а также 3 фигуры грифонов (рис. 21: I, 1, 2; II, 1) и фигура грифоно-гиппокампа (рис. 21: IV, 1) 11 .

Помимо мечей в скифском зверином стиле, хотя и гораздо реже, оформляется оружие ударного действия и его имитации - это бронзовые молоточки-клевцы, а также бронзовые скипетры/ритуальные секиры (см. Ильинская,
1965. С. 206-211). В рамках скифской археологической культуры молоточки-клевцы образуют компактную группу, состоящую из пяти предметов (оформленных в виде головы хищной птицы, клюв которой соответствует заостренной части клевца), датируемых первой половиной - началом третьей четверти $\mathrm{V}$ в. до н. э. и происходящих с территории Среднего

\footnotetext{
${ }^{11}$ В нашу сводку не включен и соответственно не учитывается в общей статистике массив зооморфных изображений на золотых обкладках рукоятей ряда акинаков - в силу крайнего схематизма и малоразличимости этих миниатюрных изображений, утрате в них каких-либо стилевых признаков. Имеются в виду шесть мечей из Чертомлыка (Древности Геродотовой..., 1872. Табл. XXVII, 3; XL, 9, 12, 14; Алексеев и др., 1991. С. 170, 222, 223. Кат. 72, 184-187), один - из Куль-Обы (Древности Боспора..., 1854, 3.Табл. ХXXI, 7), один - из кургана Кекуватского (Древности Боспора..., 1854. C. 68. Табл. XXVII, 9), один - из Метрополитен-музея, местонахождение неизвестно (Онайко, 1970. Табл. ХII, № 424), два - из Колбино, к.7 и 36 (Савченко, 2004. Рис. 2, 1, 2; Гуляев, 2010. С. 85, 104. Рис. 1, 5; 27, 14), один - из Елизаветовского могильника, Пятибратнего кургана 8 (Шилов, 1962. Рис. 11, 12; L' or des Amazones, 2001. Сat. 88), один - из Великой Белозерки (Отрощенко, 1980. С. 318; 1984. С. 121-126. С. 123; Gold der Steppe..., 1991. S. 359. Cat. 89).

Изначально данные фигуры, в принципе, могли появиться вследствие попытки греческих мастеров подражать скифскому звериному стилю, но в большинстве случаев это было сделано крайне некачественно и схематично.
} 


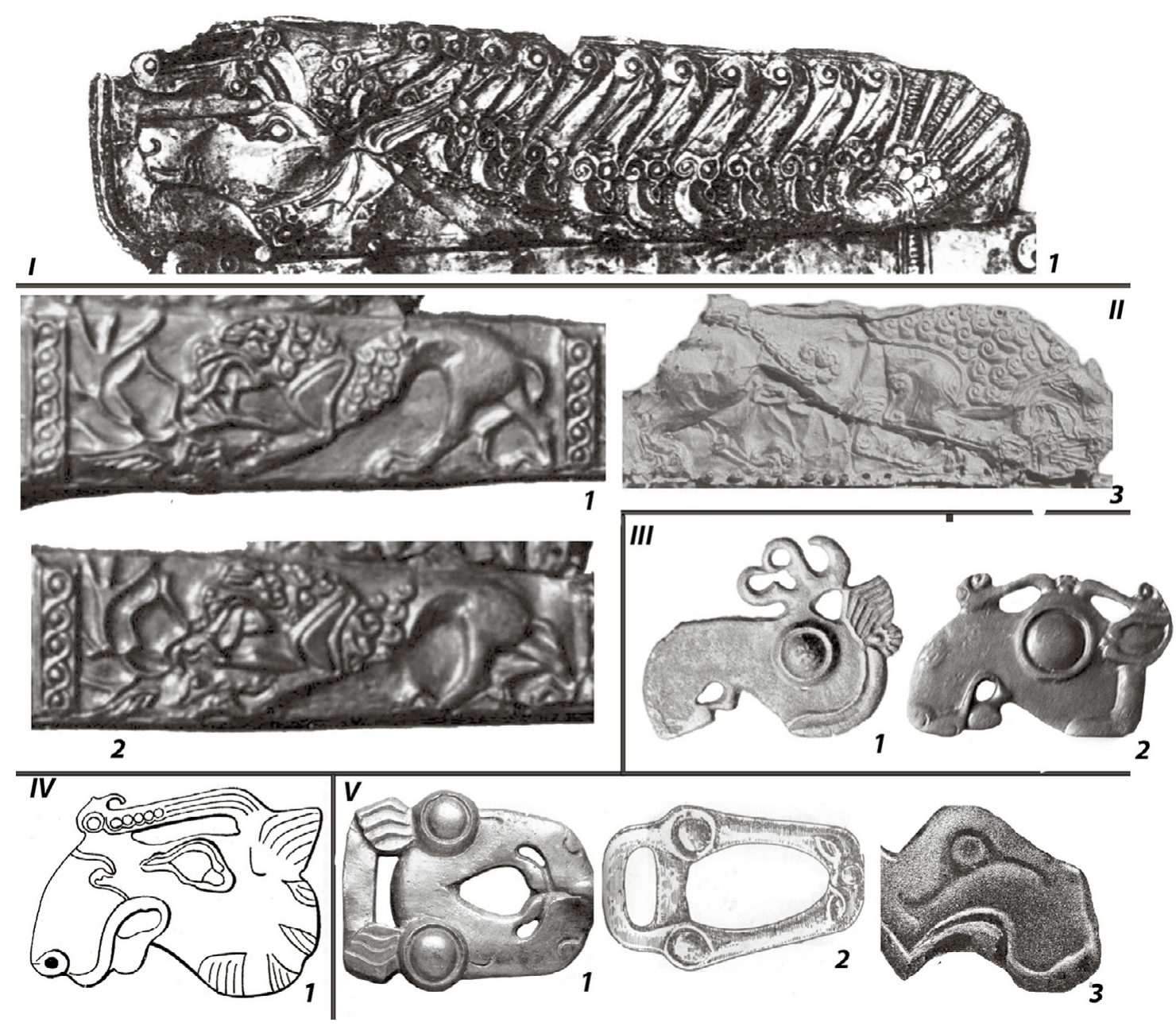

Рис. 10. Копытные на предметах вооружения. Олени (I, II) и лоси (III-V) в редуцированном отображении. I - Елизаветовско-ассиновский тип: 1 - Елизаветовская станица, к. 1, 1910 г., золотая обкладка ножен меча, боковая пластина (Артамонов, 1966. Табл. 324); II - Солохско-бердянский тип. 1-3 - золотые обкладки ножен мечей: 1, 2 - Солоха, боковое погр., голова оленя на основной пластине у устья ножен (1), на основной пластине в центре (2) (Манцевич, 1987. С. 69-71. Кат. 49); 3 - Елизаветовский могильник (Ушаковский курган), голова оленя на боковой пластине (Borovka, 1928. PI. 22A); III - Нимфейско-журовский тип. 1, 2 - бронзовые бляхи - накладки колчана: 1 - курган у с. Новая Розановка (Шапошникова, 1970. Рис. 5); 2 - впускное погр. кургана 7 у г. Мариуполя (Жданова), раскопки 1927 г. (Яценко, 1959. Табл. V: 4; Легенди степу..., 2004. C. 58. Ил. 3); IV - Нимфейско-семибратненский тип: 1 - Нимфейский могильник, п.VI, грабительские раскопки 1868 г. (Эшмолен-музей), бронзовое нагрудное украшение пластинчатого панциря (Vickers, 1979. Tabl. XVI: a); V - Журовско-чигиринский тип. 1, 2 - бронзовые пряжки - застежки панциря: 1 - Журовка, к. B (Borovka, 1928. PI. 5D); 2 - Журовка, к. 400 (Петренко, 1967. Табл. 37: 4); 3 - Аксютинцы, к. 2, раскопки 1883-1885 гг., золотая обивка колчана, на лопатке оленя (Бобринский, 1894. Табл. XXI: 3)

Поднепровья, Нижнего Поднепровья, Нижнего Побужья и, возможно, из Крыма («Крымская коллекция») (рис. 18: V, 1-5). Здесь сама фактура изделия «провоцирует» его зооморфизацию - ср. наблюдение Г. А. Федорова-Давыдова о том, что в скифском зверином стиле «предмет с его функциональным назначением деталей как бы сливается с изображенным на нем животным» (Федоров-Давыдов, 1976. С. 22). ${ }^{12}$ К этой группе примыкает еще один бронзовый топорик-скипетр («Крымская коллекция»), несущий изображение иного типа - с притупленным клювом, но при этом с крупным округлым выступающим глазом и с восковицей, что позволяет трактовать изображение как птичье (рис. 18: VI, 1).

\footnotetext{
${ }^{12} \mathrm{Cp}$. следующее замечание Н. Л. Членовой о данной группе изделий: «...В скифских курганах Причерноморья известны бронзовые молоточки, острый конец которых оформлен в виде головы и клюва хищной птицы. Совершенно очевидно, что этот род оружия ассоциировался с хищной птицей» (Членова, 1967. С. 120).
} 
Самый ранний случай зооморфизации скипетра/pumуальной секиры в скифской археологической культуре - оформление в зверином стиле обуха секиры из Роменского уезда в виде головы барана, переходящей в изогнутую шею (Среднее Поднепровье, вторая половина VII в. до н.э.) (рис. 12: V, 1). Позднее, в VI в. до н. э. обушки скипетров-секир (а в одном случае, наряду с обушком, еще и клинок, что демонстрирует чисто символическое назначение предмета) иногда оформлялись в виде головы лошади; эти три изображения составляют единый изобразительный тип (Среднее Поднепровье) (рис. 13: II, 1,2 ). Еще позднее, в конце VI первой половине V в. до н. э. обушок скипетра-секиры мог быть выполнен в виде ноги копытного, а клинок - в виде головы и шеи хищной птицы (три изображения из Среднего Поднепровья, Крыма и Прикубанья); такое сочетание может трактоваться и как оформление вещи как таковой в виде единого синкретического существа (рис. 22: 1-3) ${ }^{13}$.

Компактную группу составляют происходящие с территории Прикубанья и Центрального Предкавказья бронзовые бутероли копий VI в. до н. э., оформленные в виде головы волка (три изображения) (рис. 7: I, 1-3).

К числу изделий, часто оформляемых и украшаемых в зверином стиле, относятся компоненты стрелкового набора. В частности, в эпоху «скифской архаики» зооморфизируются костяные/роговые налучья. Чаще они трактуются в виде головы бараноптицы/грифобарана - семь изображений (вторая четверть VII - середина VI в. до н.э.) (рис. 21: III, 1-7); при этом одно из налучий (Бельск) несет на себе в качестве зооморфного
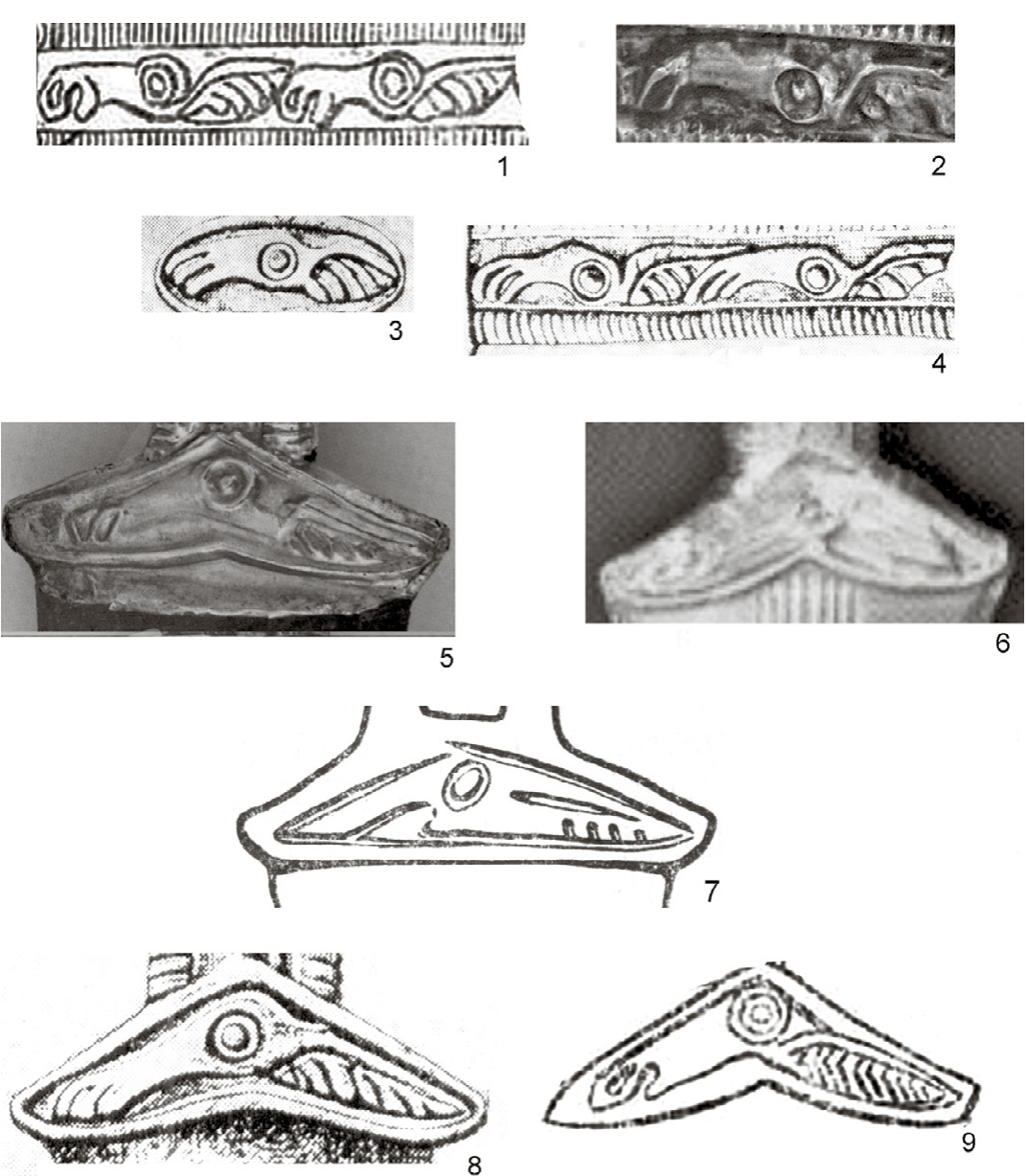

Рис. 11. Копытные на предметах вооружения. Лоси в редуцированном отображении. Солохско-перещепинский тип. 1-9-рукояти железных мечей, двусторонние изображения на золотых обкладках железных рукоятей $(1,2,6)$ и перекрестий $(5,9)$, на навершии железной рукояти (3), на стержне железной рукояти (4), на железном перекрестье $(7,8):$ 1, 9 - Солоха, Боковая могила (Манцевич, 1987. Рис. 4); 2, 5 - Перещепинский могильник, к. 3, п. 2 (Шрамко, 1994. Рис. 7: 1, 4; 8; Національний музей..., 2001. С. 23. Кат. 35); 3, 4, 8 - меч, найденный у с. Ключ Курской обл., случайная находка (Пузикова, 2001. Рис. 1); 6 - могильник Житков II, к. 3, п. 2 (L'or des Amazones..., 2001. Cat. 31); 7 - случайная находка в урочище Хутир, музей с. Медвин Киевской обл. (Ковпаненко, Левченко, 1977. С. 60)

превращения клюва и глаза соответственно фигуру свернувшегося кошачьего хищника и фигуру свернувшегося зайца (рис. 23: II, 1), еще одно (Темир-гора) - фигуру лежащего зайца без передней ноги и обособленную голову зайца в качестве зооморфного превращения рога и клюва (рис. 23: I, 1; III, 1) $)^{14}$, еще одно (Новозаведенное II) - обособленную голову зайца в качестве

\footnotetext{
13 Предположительно аналогичный топорик изображен в руках у скифа на золотых пластинах парадного пояса из кургана 5 у с. Аксютинцы в Лесостепном Поднепровье (Ильинская, 1968. С. 156. Табл. XXII, 6; На краю Ойкумены..., 2002. С. 92. № 398; Конь и всадник..., 2003. С. 29. № 38).

${ }^{14}$ Изображение существа с подогнутыми ногами в основании темиргоринского налучья крайне схематично и неопределимо в видовом отношении, соответственно пока оно нами не учитывается.
} 


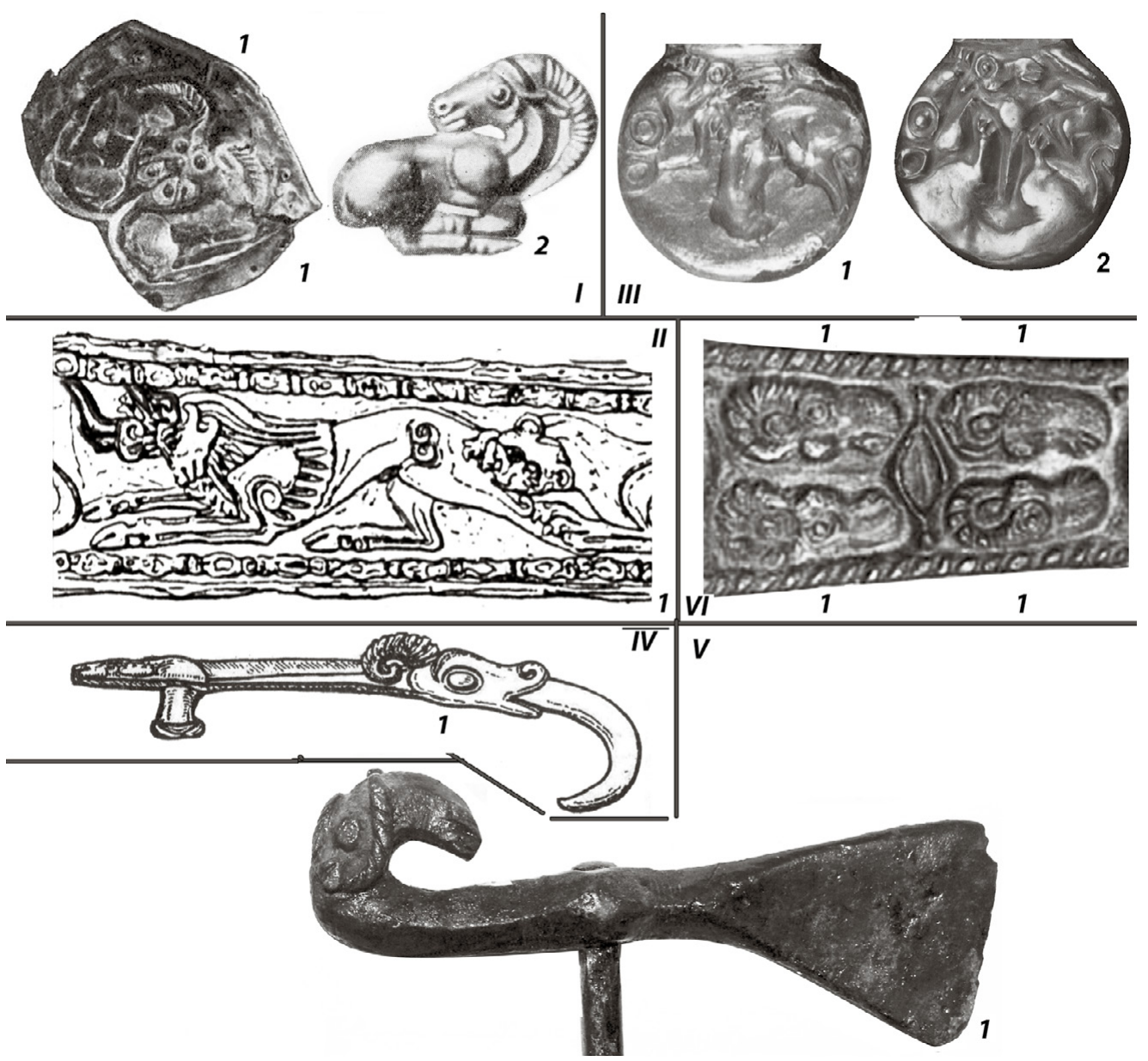

Рис. 12. Копытные на предметах вооружения. Горные козлы в полнофигурном (I-III) и в редуцированном (IV) отображении и горные бараны (V, VI) в редуцированном отображении. I - Бобрицко-ульский тип: 1 - хут. Шумейко, золотая обкладка ножен меча, 2 зеркальных изображения (Borovka, 1928. PI. 23A); 2 - Витова могила, золотые пластины - аппликации горита, 6 экз. (Граков 1971. Табл. XX); II - Кульобский тип: 1 - Куль-Оба, золотая обкладка ножен меча (Древности Боспора..., 1854. Табл. XXVI: 2); III - Опишлянско-гусарский тип. 1, 2 - крестовидные бляхи «ольвийского типа», бронза, обтянутая золотым листом, на центральной пластине и на трех боковых: 1 - с. Деревка, к. 13, «Могила Опишлянка» (На краю Ойкумены..., 2002. Кат. 450); 2 - с. Гусарка (Gold der Steppe..., 1991. Cat. 93); IV - Елизаветинско-колбинский тип: 1 - Колбино, к.17, бронзовый колчанный (?) крючок (Гуляев, 2010. С. 234. Рис.17); V - Келермесско-новозаведенский тип: 1 - Роменский уезд, бронзовый топорик-скипетр (Ильинская, 1968. Рис. 42: 10; фото А. Р. Канторовича в НМИУ); VI - тип «Старшая могила-Ольвия»: 1 - некрополь Ольвии, п.12 (1910 г.), крестовидная бляха «ольвийского типа», 4 изображения на длинной лопасти (Borovka, 1928. PI. 9)

зооморфного превращения клюва (рис. 23: III, 2). Также налучья могут оформляться в виде птичьих голов: это три изображения, одно из которых несет на себе (в качестве зооморфных превращений клюва и глаза) две фигуры свернувшихся кошачьих хищников (середина VII третья четверть VI в. до н.э.) (рис. 15: II, 1-3). Эти налучья происходят с территории Среднего и Нижнего Поднепровья, Нижнего Подонья, Крыма и Ставрополья.

Несколько изображений налучий в виде птичьей головки и других предметов вооружения, украшенных в зверином стиле, присутствуют на ряде антропоморфных скифских каменных изваяний. Это налучья в виде птичьей головки на статуях из Терновки (г. Николаев, Украина), из Киевского музея, из Ольховчика (г. Шахтерск Донецкой обл.), а также крупные бляхи одежды (доспеха?) в виде голов ушастой птицы или грифона и оленя из Краснодарского музея (Преградная?) (Черненко, 1968. С. 37. Рис. 16; Ольховский, Евдокимов, 1994. Кат. 11, 73, 81, 119). Однако в силу относительной неясности данных изображений они в нашу сводку не включены. Исключение сделано лишь для четкого изображения кошачьего хищника на модели горита детали антропоморфного каменного изваяния из ст. Манычской (см. ниже). 


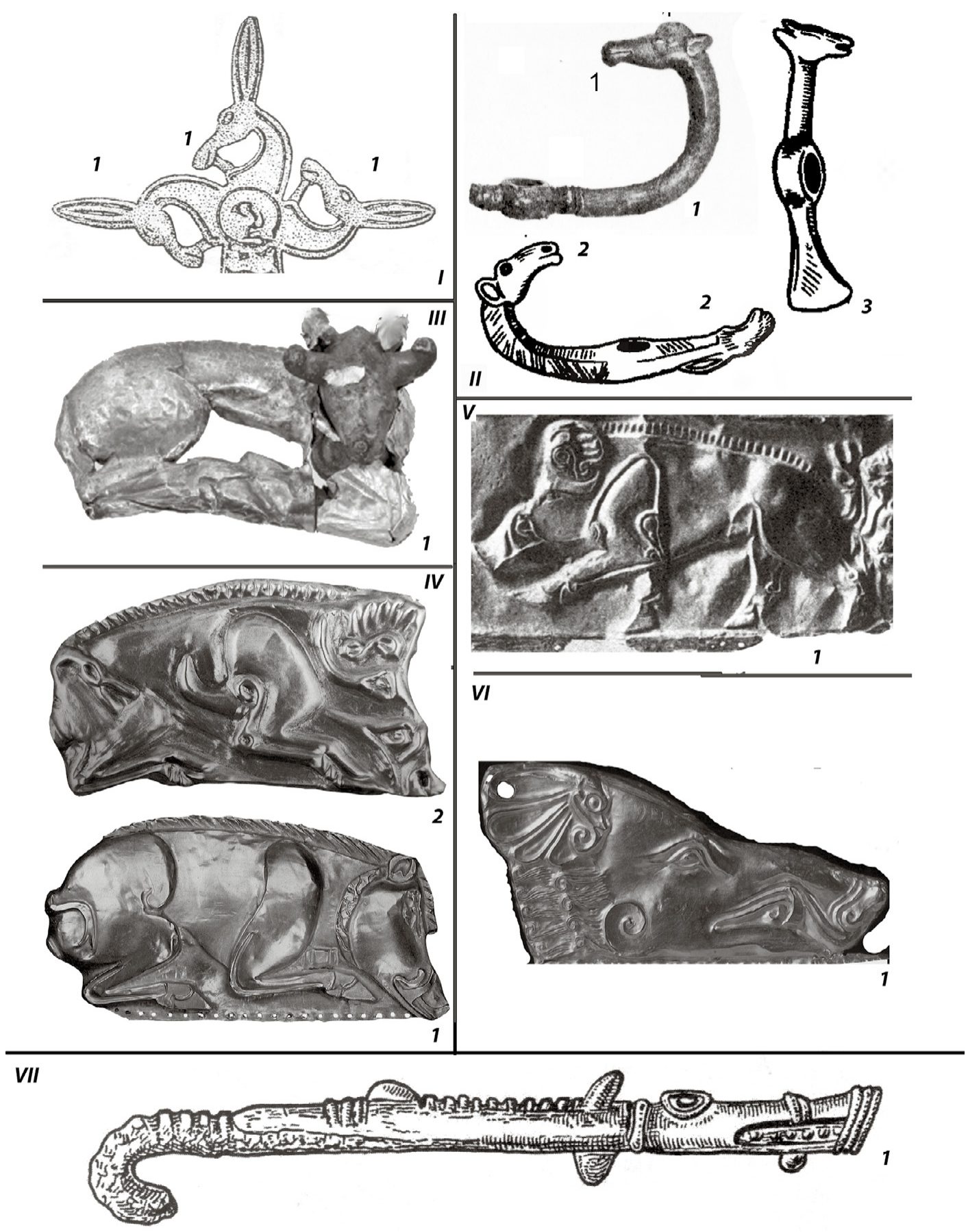

Рис. 13. Копытные на предметах вооружения. Лошади в редуцированном отображении (I, II), бык в полнофигурном отображении (III), кабаны в полнофигурном (IV, V) и в редуцированном (VI, VII) отображении. I - Келермесско-енкивецкий тип: 1 - Енкивцы, короткие боковые пластины бронзовой крестовидной бляхи «ольвийского типа» (Могилов, 2008. Рис. 104: 2); II - Роменский тип. 1-3 - бронзовые топорики-скипетры: 1 - Роменский уезд, с. Будки (Ханенко Б. И. и В. П., 1907. Табл. І, № 430); 2 - Роменский уезд, с. Аксютинцы, раскопки Кибальчича, 2 изображения - на клинке и на обушке (Ильинская, 1968. Рис. 42: 8); 3 - Роменский уезд, курган у с. Ярмолинцы (Ильинская, 1968. Рис. 42: 7); III - Золотоношский тип: 1 - Из Золотоношского уезда Полтавской губернии, собрание Ханенко, бронзовая фигура, плакированная золотой фольгой, - возможно, накладка горита (Грибкова, Полидович, 2013. Рис. 1); IV- Александровско-архангельский тип.

1 - п. 1, к. 6 у с. Александровка (учхоз Самарский), золотая обкладка боковой лопасти ножен меча (Ковалева, Мухопад, 1982. Рис. 5: 3; 6); 2 - Архангельская слобода, к. 5, п. 1, золотые накладки - аппликации колчана, 6 экз. (Лесков, 1972. С. 57. Табл. 35); V - Знаменско-елизаветовский тип. 1 - Елизаветовский могильник (Ушаковский курган), золотая обкладка ножен меча (Borovka, 1928.Tabl. 22A); Vl - Белозерский тип: 1 - Великая Белозерка, боковая лопасть золотой обкладки ножен меча (Gold der Steppe..., 1991. S. 359. Kat. 89); VII - Мастюгинско-колбинский тип: 1 - курган 2 раскопок 1906 г. у с. Мастюгино, бронзово-железный колчанный (?) крючок (Либеров, 1965. Табл. 32: 7) 
В виде зверей и птиц оформляются бляхи или пластины горитов. У истоков этой традиции - знаменитая пантера на золотой бляхе горита (щита?) (с лапами, оформленными в виде свернувшихся в кольцо пантерок и с хвостом, заполненным аналогичными фигурками) (рис. 3: III, 1 ; 2: I, 2, 3) и изображения кошачьих хищников и оленей на золотой обкладке горита (рис. 3 : III, 2; 8: I, 3); данные предметы происходят соответственно из Келермесских курганов $1 / Ш$ и $4 / Ш$ (примерная дата комплексов - вторая половина VII в. до н.э.). Далее по времени следует олень на знаменитой золотой бляхе горита (щита?) из 1-го Разменного кургана у ст. Костромской (рубеж VII-VI - начало VI в до н.э.) (рис. 8: $\mathrm{I}, 4)$. В одном случае такая бляха четко изображена на упомянутой выше модели горита - детали антропоморфного каменного изваяния из ст. Манычской в Нижнем Подонье (конец VII - третья четверть VI в. до н. э.) (рис. 1: I, 3).

Традиция оформления блях и пластин колчана в зверином стиле находит свое продолжение в Среднем Поднепровье: это золотые пластины на колчанах из Витовой могилы и Опишлянки (конец VI - начало V в до н.э.), оформленные в виде кошачьих хищников (рис. 1: I, 1, 2), части тела которых трансформированы в головы хищных птиц (рис. 15: III, 5, б); на колчане из Витовой могилы, кроме того, помещены золотые бляхи в форме горных козлов (рис. 12: I, 2) и головок хищных птиц (рис. 15: III, 8), причем последние также обрамляют умбоновидный центральный выступ колчана (рис. 15: III, 9). Возможно, накладкой на горит является бронзовая скульптурка быка, плакированная золотой фольгой, из Полтавской губернии (первая половина V в. до н.э., собрание Ханенко) (рис. 13: III, 1).

Далее данная традиция продолжается в Нижнем и Среднем Поднепровье и в Крыму: олень (с рогами и хвостом, трансформированными в головы хищных птиц), терзаемый птицей, кошачьим хищником и змеей ${ }^{15}$ на золотой обкладке колчана из Ильичева (первая половина V в. до н. э.) (рис. 8: III, 1; 15: I, 1; III, 3, 4), олень
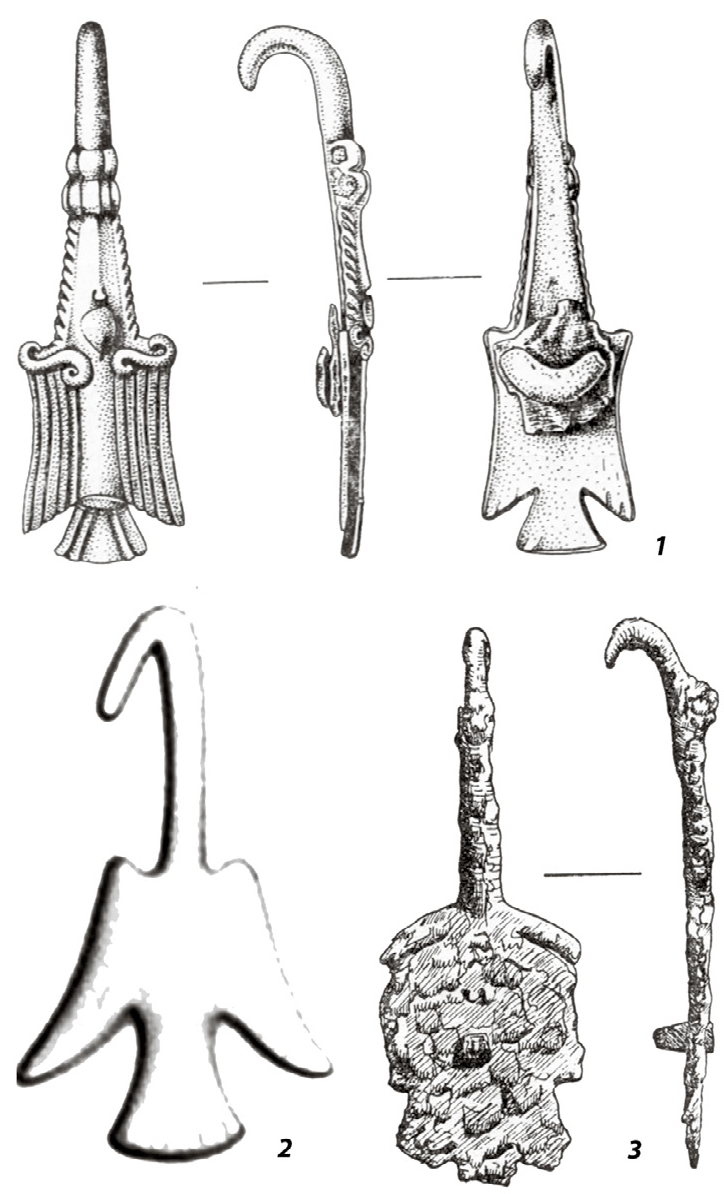

Рис. 14. Птицы в полнофигурном отображении на предметах вооружения. Мастюгинский тип: 1 - Мастюгино, к. 47/30, бронзовый колчанный (?) крючок (Гуляев, 1969. Рис. 7); 2 - Ак-Бурун, золотой колчанный (?) крючок (ОАК за 1876 г. Атлас, Tabl. II: 7); 3 - Мастюгино, к. 2 (1906 г.), он же предположительно к. 29/21 раскопок 1960 г., железный колчанный (?) крючок (Либеров, 1965. Табл. 32: 5)

(с рогами, трансформированными в головы фантастических ушастых птиц/грифонов, с лопаткой в виде головы лося и с головой хищной птицы на животе) на золотой обивке колчана из Аксютинцев, курган 2, раскопки 1883-1885 гг. (первая половина V в. до н.э.) (рис. 9: II, 1; 10: V, 3; 18: II, 1; VIII, 1), позднее - знаменитый олень на золотой бляхе горита (щита?) из Куль-Обы ${ }^{16}$

\footnotetext{
${ }^{15}$ Кошачий хищник и змея на обкладке колчана из Ильичева выполнены не в скифском, а скорее в греко-персидском стиле. Соответственно они не рассматриваются в настоящей работе в качестве самостоятельных объектов исследования и не учитываются в общей статистике.

16 Дополнительные изображения на шее и туловище кульобского оленя (фигуры собаки, льва, зайца и грифона), а также на последнем отростке его рогов (голова барана), как было показано исследователями, выполнены в греческом или в греко-фракийском стиле, практически без элементов скифской традиции или с сильным ее искажением (Артамонов, 1968. С. 13; Королькова (Чежина), Алексеев, 1994. С. 106-108). Соответственно они не рассматриваются в нашей работе в качестве самостоятельных объектов исследования и не учитываются в общей статистике. Исключение сделано для зооморфной трансформации хвоста кульобского оленя, поскольку здесь изображена «ушастая птица», не характерная для греческого репертуара образов (рис. 18: VIII, 2).
} 


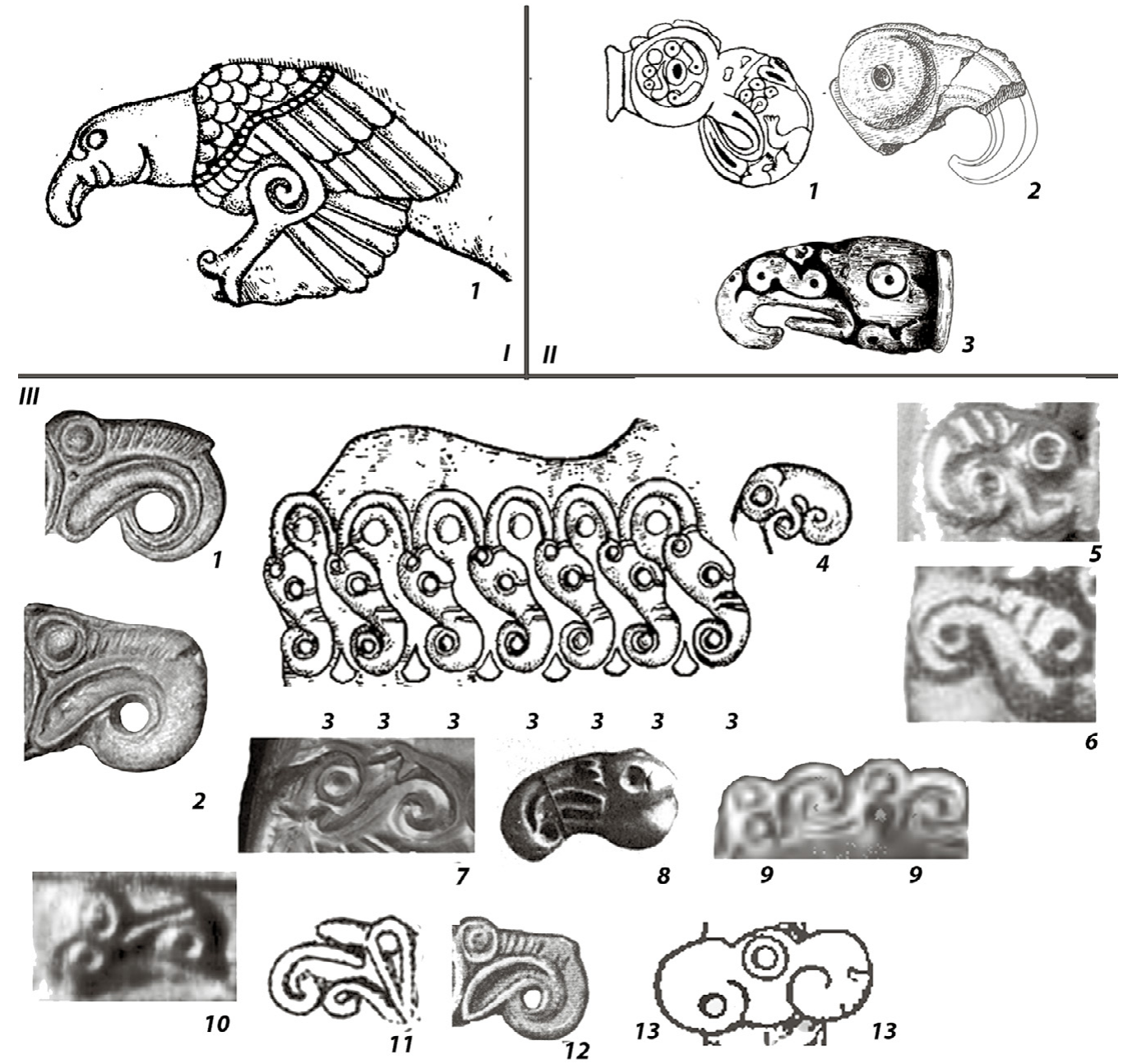

Рис. 15. Птицы в полнофигурном (I) и в редуцированном (II, III) отображении на предметах вооружения. I - Завадско-елизаветовский тип: 1 - Ильичево, к.1, п.6, золотая обкладка колчана (Лесков, 1968. Рис. 7); II - Келермесско-гуляйгородский тип. 1-3 - костяные налучья: 1 - Новоалександровка I, к.7, п.8 (Кореняко, Лукьяшко, 1982. С. 155. Рис. 6: 2); 2 - Красное Знамя, к.1, Южная гробница (Петренко, 2006. Кат. 76. Табл. 74); 3 - с. Нижние Серогозы, к. 3, п. 5 (Браун, 1906. Рис. 6); III - Ольвийско-завадский тип. 1, 2, 12 короткие боковые пластины бронзовых крестовидных блях «ольвийского типа»: 1 - некрополь Ольвии, п. 12 (1910 г.), 3 изображения (Borovka, 1928. PI. 9); 2 - случайная находка у хут. Дугино, Нижний Дон, 3 изображения (L'or des Amazones..., 2001. Cat. 16); 12 - случайная находка у хут. Полушкино в Азовском р-не Ростовской обл., 3 изображения (Ильюков, 2016. Рис. 2: 3, За); 3, 4 - Ильичево, к. 1, п. 6, золотая обкладка колчана, трансформации рогов (3) и хвоста (13) оленя (Лесков, 1968. Рис. 7); 5, 6 - золотые пластины - аппликации горита, трансформация лопатки хищника: 5 - с. Деревка, к. 13, «Могила Опишлянка», 14 экз. (На краю Ойкумены..., 2002. Кат. 450); 6 - Витова могила, 11 экз. (Граков, 1971. Табл. XX); 7 - Великая Белозерка, боковая лопасть золотой обкладки ножен меча, на ухе кабана (Gold der Steppe..., 1991. S. 359. Kat. 89); 8 - Витова могила, золотые бляшки - аппликации горита, 11 экз. (Borovka, 1928. PI. 11F); 9 - Витова могила, обрамление центральной умбоновидной золотой аппликации горита (Граков, 1971. Табл. XX); 10 - Елизаветовский могильник (Ушаковский курган), на хвосте льва, преследующего кабана (Borovka, 1928. Tabl. 22A); 11 - Солоха, боковое погр., на лопатке льва на большой боковой пластине (Манцевич, 1987. С. 69-71. Кат. 49); 13 - Каневский уезд, случайная находка, оформление перекрестья железного меча (Мелюкова, 1964. Табл. 18: 5)

Рис. 16 (справа). Птицы в редуцированном отображении на предметах вооружения. Мастюгинский тип. 1-21 - колчанные (?) крючки: 1 - Мастюгино, к. 32/32 (Либеров, 1965. Табл. 32: 3); 2 - к. 2 раскопок 1906 г. у с. Мастюгино (Либеров, 1965. Табл. 32: 7); 3 - Русская Тростянка, к. 7 (Либеров, 1965. Табл. $32: 9$ ); 4 Мастюгино, к. 34/39 (Гуляев, 1969. Рис. 7: 1, 4); 5 - Частые курганы, к. 10, раскопки ВУАК (Либеров, 1965. Табл. 32: 16); 6 - Средний Дон, сборы А. А. Спицына 1905 г. (Либеров, 1965. Табл. 32: 11); 7 - Нижний Дон, случайная находка (Либеров, 1965. Табл. 32: 15); 8 - Александропольский курган (Древности Геродотовой..., 1866. С. 3. Табл. І: 3, 4); 9 - Частые курганы, к.12, раскопки ВУАК (Либеров, 1965. Табл. 32: 10); 10 - Средний Дон, сборы А. А. Спицына 1905 г. (Либеров, 1965. Табл. 32: 8); 11 - Русская Тростянка, к. 1 (Либеров, 1965. 

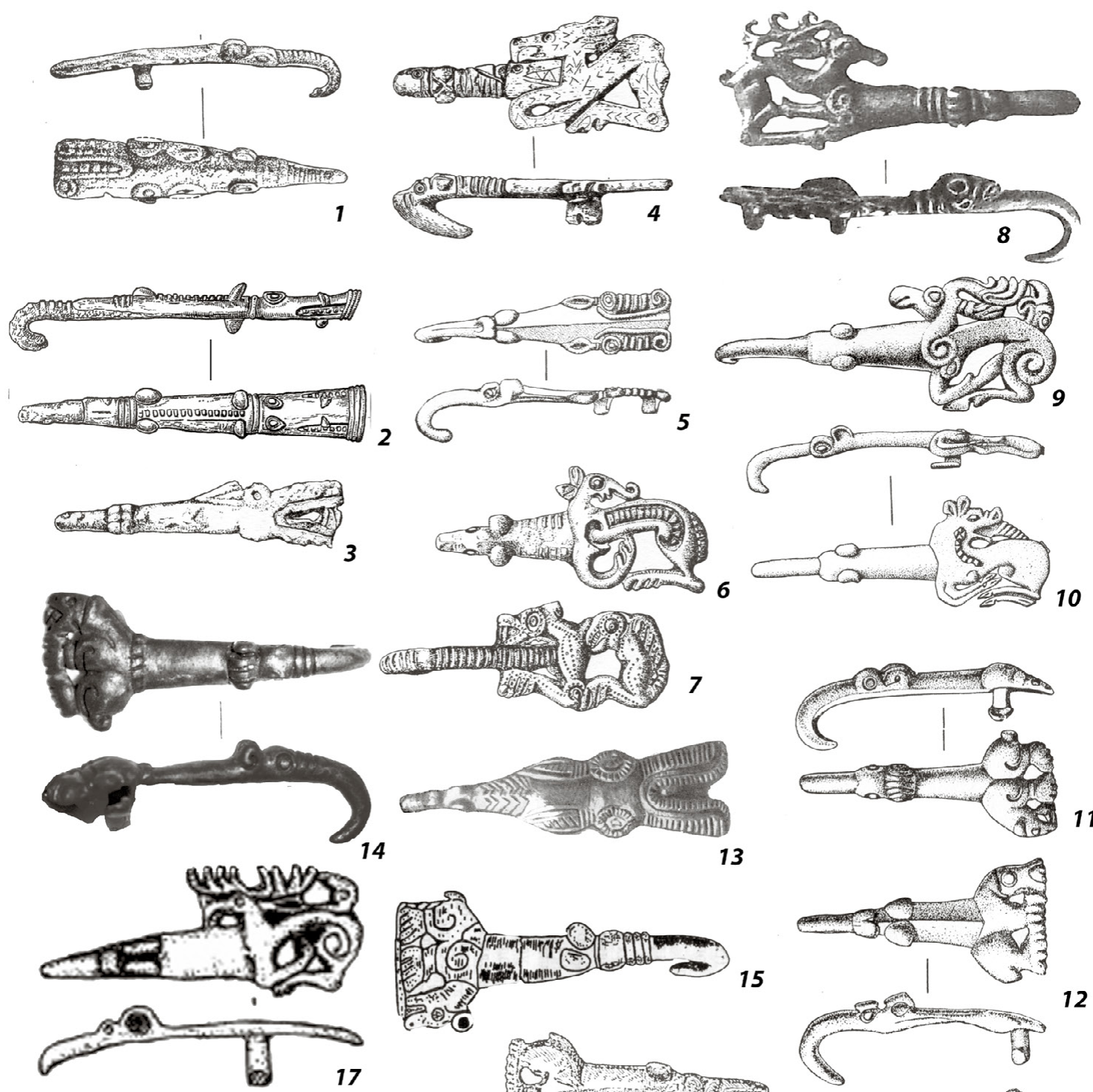

13
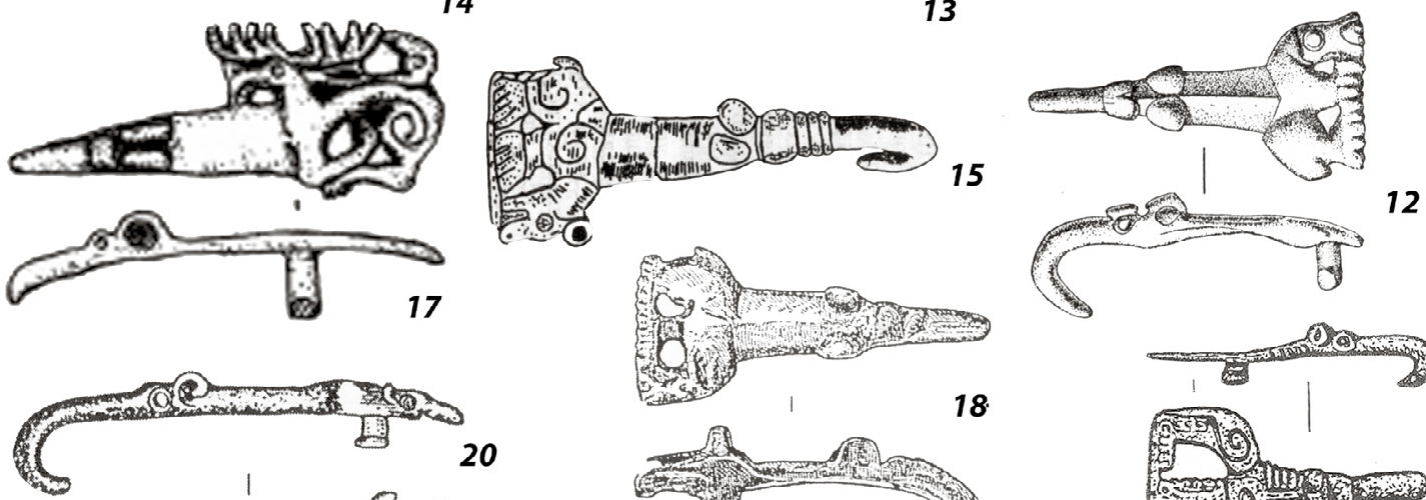

20
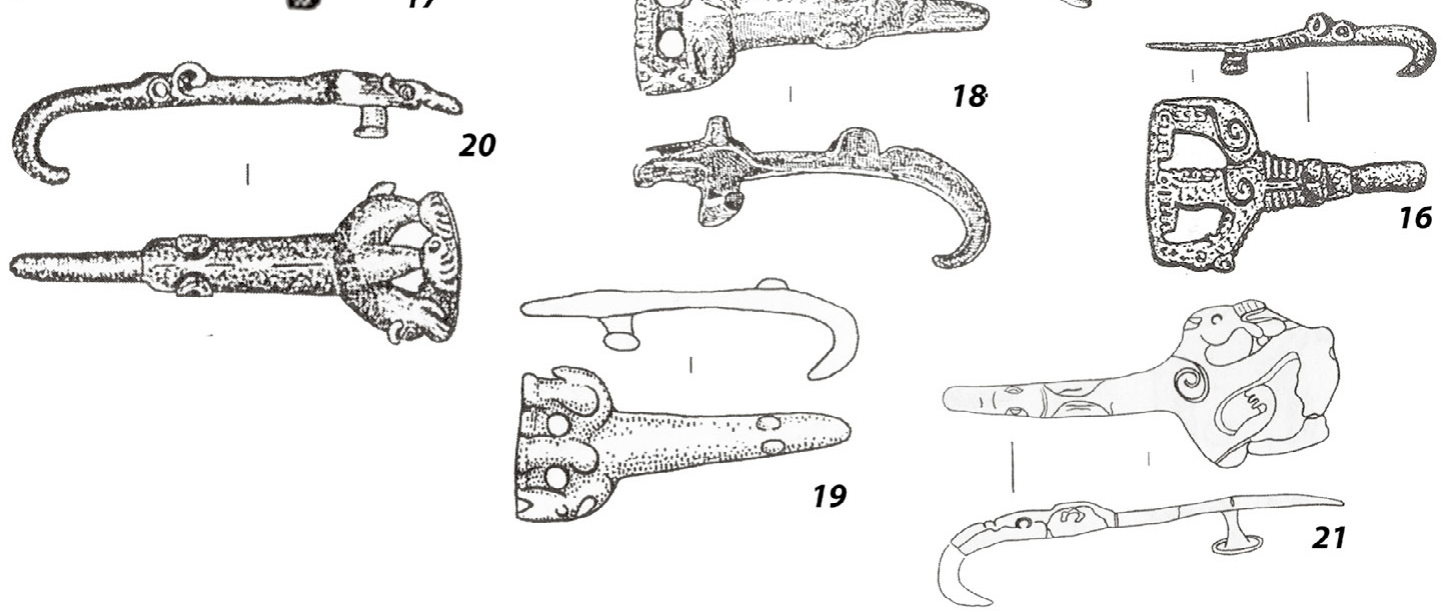

Табл. 32: 14); 12 - Частые курганы, к. 11 (раскопки ВУАК) (Замятнин, 1946. Рис. 27: 2); 13- Частые курганы, к. 3, раскопки ВУАК (Либеров, 1965. Табл. 31: 10); 14 - Кащеевский курган (Максименко, 1983. С. 32, 101, 172. Рис. 18: 14, 15; фото А. Р. Канторовича в АКМ); 15 - Колбино, к. 1/9 (Савченко, 2001а. Рис. 2: 21); 16 - с. Бажиган, разрушенное погр. (Маслов, Очир-Горяева, 1997. Рис. 2: 14); 17 - к. 5 группы Новоалександровка-Богачевка, п. 1 (Колтухов, 2012. Рис.17: 6); 18 - Терновое, к. 4 (Савченко, 2001б. Рис. 7: 26); 19 - Староживотинное, к. 38 (Медведев, 2001. С. 13. Рис. 4: 5); 20 - х. Дубовой, к. 6 (Березуцкий, 2006. С. 140. Рис. 2: 4); 21 - ст. Староминская близ Ейска, разрушенное погр. (Гуляев, 2016. Кат. 26, рис. И.С. Каменецкого). Золото (6); серебро (8, 15); бронза $(5,9-12,14,16-21)$; железо $(1,3,7)$; бронза, железо (2); железо, золотая обтяжка $(7,13)$; кость $(4)$ 


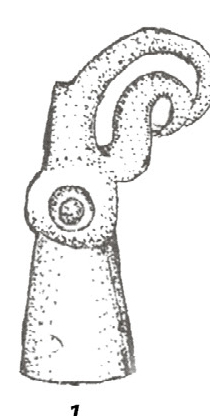

1

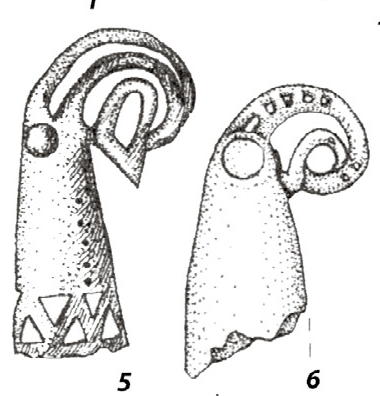

6
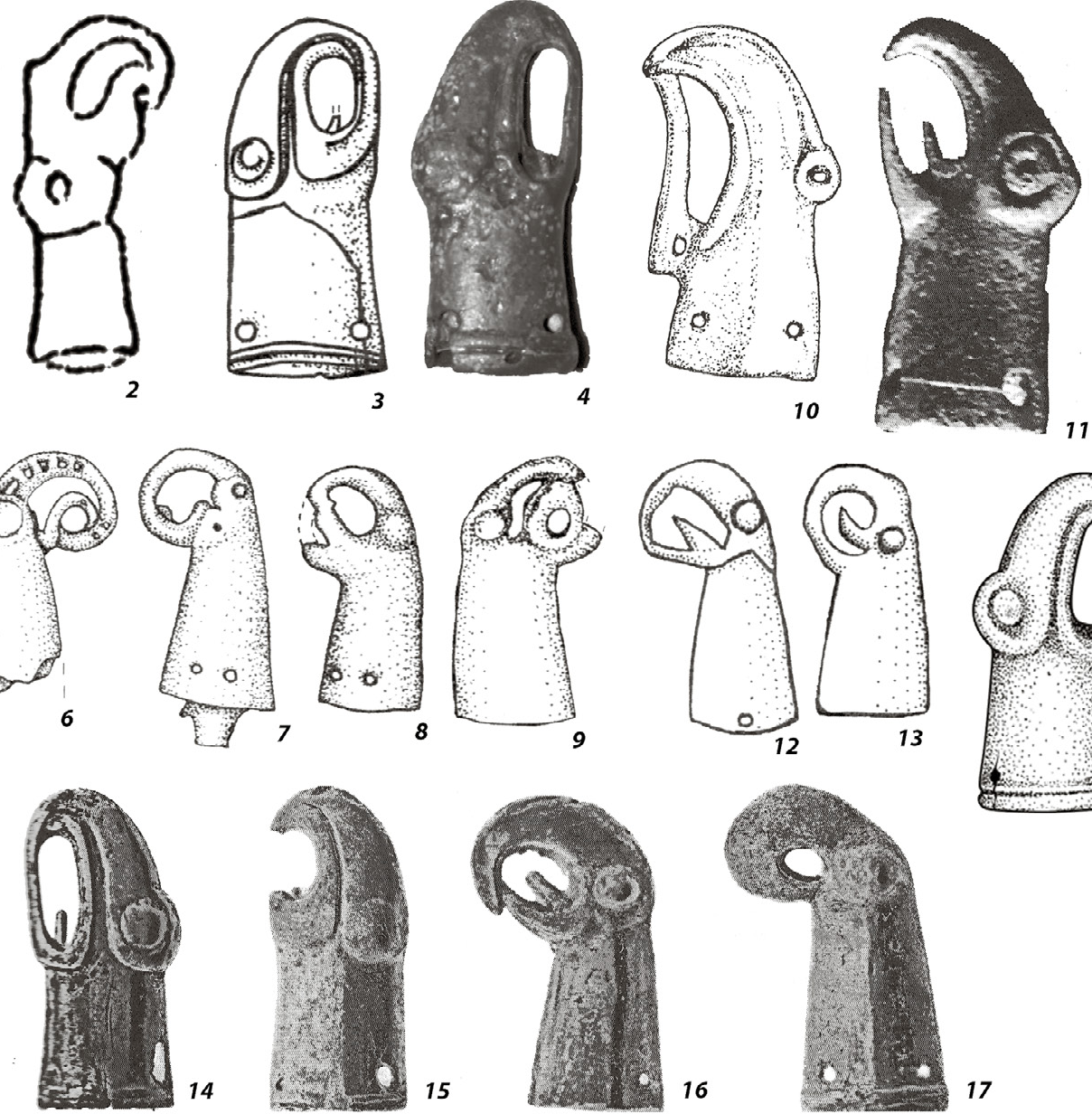

17

Рис. 17. Птицы в редуцированном отображении на предметах вооружения. Роменско-верхнекобанский тип. 1-18 - бронзовые бутероли: 1 - Владимировский могильник, п. 55 (Шишлов и др., 2005. Рис. 3: 10); 2 - из окрестностей Майкопа (Іллінська, 1963. Рис. 2: 5); 3 - Репяховатая могила, п. 2 (Ильинская и др., 1980. Рис. 12: 2); 4 - Березань или о. Левке (Змеиный) (Островерхов, Охотников, 1989. Рис. 3: 6; фото А. Р. Канторовича в ОАМ); 5, 6 - Верхнекобанский могильник (Доманский, 1984. Рис. 28, 29); 7-9 - Фаскау (собрание Коссниерского) (Motzenbăcker, 1996. Taf. 7: 7); 10 - Пашковское городище 5 (Пьянков, 2005. Рис. 1); 11 - «Харьковский клад», Харьковский историч. музей (Зимовец, 2016. С. 77. Рис. 2); 12, 13 - Нижнечегемский могильник, п. 2, п. 7 (Акритас, 1961. Табл. II: 15; III: 9); 14 - «Крымская коллекция» (горный массив Агармыш?) (Скорый, Зимовец 2014. С. 39. Кат. 31; Зимовец, 2016. С. 77. Рис. 1: 1); 15 - «Крымская коллекция» (урочище Алан-тепе в окрестностях Старого Крыма?) (Скорый, Зимовец, 2014. С. 40. Кат. 32); 16 - «Крымская коллекция» (горный массив Кубалач?) (Скорый, Зимовец, 2014. С. 41. Кат. 34); 17 - «Крымская коллекция» (с. Александровка Белогорского р-на?) (Скорый, Зимовец, 2014. С. 41. Кат. 33); 18 - Ниспоренский р-н респ. Молдова (Топал, 2014. С. 23, 24. Рис. 2: 4; 10: 5)

(конец V- начало IV в. до н. э.) (рис. 8: I, 5), олень на золотых обивках горита из Елизаветовского могильника, курган 6, раскопки 1909 г. (первая половина IV в. до н. э.) (рис. 8: II, 2), а также звери на золотых пластинах из погребения 1 кургана 5 у с. Архангельская слобода (конец V - начало IV в. до н. э.) - тигр или леопард, грызущий человеческую голову (рис. 1: IV, l), хищник семейства волчьих (собака?) (рис. 5: V, 1), олень (рис. 8: II, 1) и кабан (рис. 13: IV, 2) ${ }^{17}$. К этой серии примыкают фасы хищников - «маски», оформляющие золотые пластины горита второй четверти-конца IV в. до н. э. из Нижнего Поднепровья (Толстая могила) и Крыма (Дорт-Оба) четыре оригинальных изображения (рис. 6: III, $1-3,5)$, а также фигура грифона на золотой обивке горита из Толстой могилы (рис. 21: I, 1-3). Также в Приазовье известны две бронзовые

\footnotetext{
${ }^{17}$ В контурах заплюсны, хвоста и кабана «читаются» птичьи головы, но данные дополнительные изображения весьма примитивны и не рассматриваются здесь в качестве самостоятельных объектов исследования в силу их явной десемантизированности.
} 


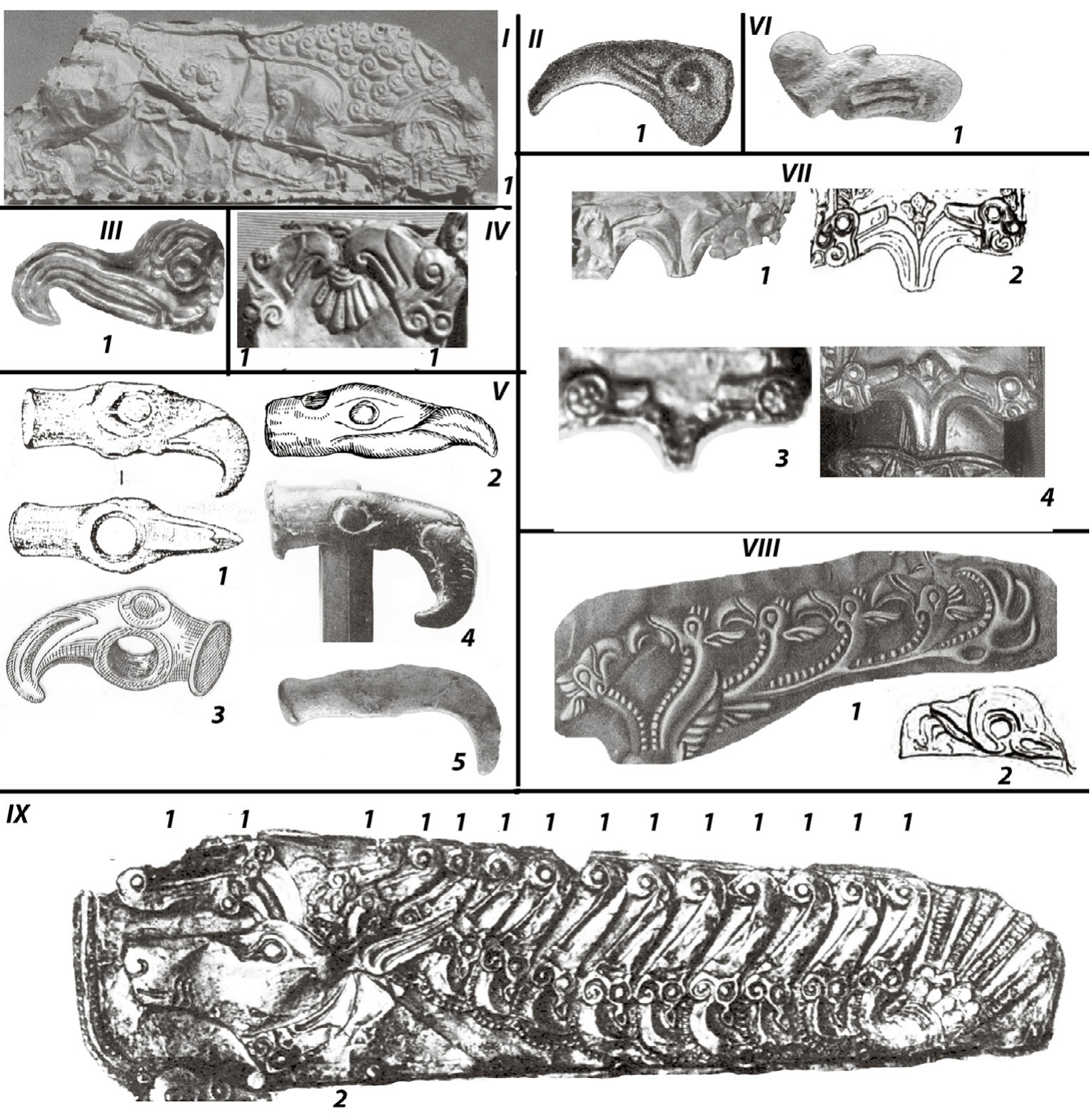

Рис. 18. Птицы в редуцированном отображении на предметах вооружения. I - Семибратненский тип: 1 - Елизаветовский могильник (Ушаковский курган), золотая обкладка ножен меча, лев на боковой пластине, элемент трансформации хвоста (Borovka, 1928. PI. 22A); II - Ольвийско-грищенецкий тип: 1 - Аксютинцы, к. 2 , раскопки 1883-1885 гг., золотая обивка колчана, на животе оленя (Бобринский, 1894. Табл. XXI: 3); III-Жаботинско-герасимовский тип: 1 - Келермес, к. 1/Ш, боковая лопасть золотой обкладки ножен меча, по 7 головок на каждой из сторон (Галанина, 1997. Кат.1. Табл. 7, 8); IV - Майкопско-журовский тип. 1 - Елизаветовская станица, к. 1, 1910 г., золотая обкладка ножен меча, основная пластина (Артамонов, 1966. Табл. 324); V - Кичкасско-пастырский тип. 1, 2 - бронзовые молоточки-клевцы: 1 - из находок Бурачкова (Яценко, 1959. Табл. III: 3); 2 - из к. 25 у с. Кичкас под Запорожьем (Іллінська, 1961. Рис. 11: 7); 3, 4 - бронзовые секирки: 3 - из коллекции Кундревича (Іллінська, 1961. Рис. 11: 5), 4 - из с. Пастырское (Ханенко Б. И. и В. П., 1907. Табл. IV, № 428); 5 - «Крымская коллекция» (с. Партизаны, Кировский р-н?), бронзовый топорик-скипетр (Скорый, Зимовец, 2014. С. 135, 136. Кат. 1/399); VI - Нимфейско-песочинский тип: 1 - «Крымская коллекция» (между селами Айвазовское и Приветное, Кировский р-н?), бронзовый топорик-скипетр (Скорый, Зимовец, 2014. C. 136. Кат. 2/400); VII - Ушаковско-белозерский тип. 1-4 - золотые обкладки ножен мечей, устья ножен: 1 - Елизаветовский могильник (Ушаковский курган) (Borovka, 1928. PI. 22A); 2 - Куль-Оба (Древности Боспора..., 1854. Табл. XXVI: 2); 3 - Солоха, боковое погребение (Артамонов, 1966. Табл. 145); 4 - Великая Белозерка (Gold der Steppe..., 1991. Kat. 89); VIII - Роменско-малокатериновский тип: 1 - Аксютинцы, к. 2, раскопки 1883-1885 гг., золотая обивка колчана, на рогах оленя (Бобринский, 1894. Табл. XXI: 3); 2 - Куль-Оба, золотая пластина - накладка на горит (щит?), на хвосте оленя (Толстой, Кондаков, 1889. Рис. 126); IX - Елизаветовско-елизаветинский тип: 1, 2 - Елизаветовская станица, к. 1, 1910 г., золотая обкладка ножен меча, боковая пластина, на 14 отростках рогов (1) и на шее (2) оленя (Артамонов, 1966. Табл. 324) 

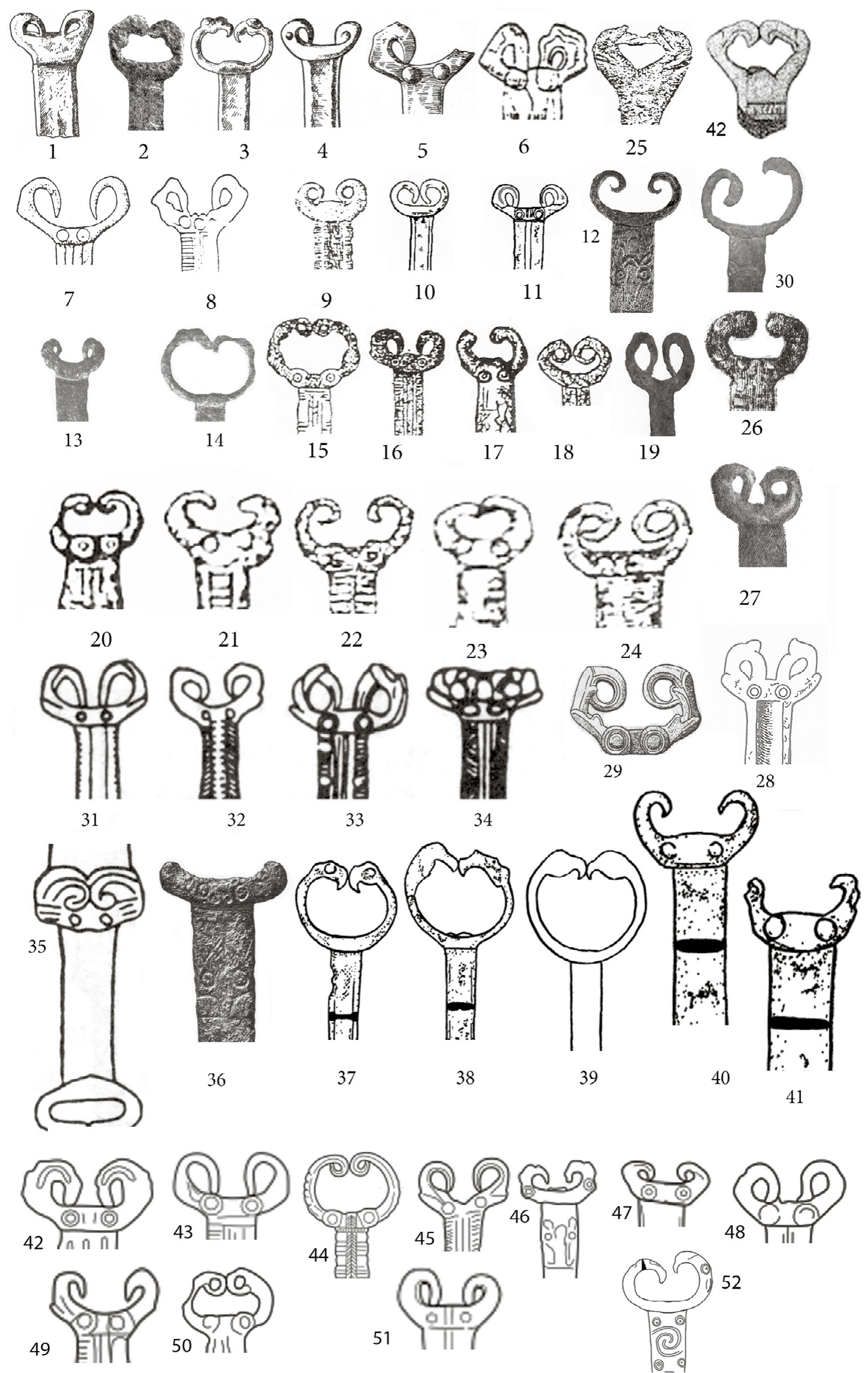
Рис. 19 (слева). Птицы в редуцированном отображении на предметах вооружения. Журовско-уляпский тип. 1-34, 36-52 - навершия рукоятей мечей; 35 - перекрестье меча: 1 - Куриловка, к. 24 (Петренко, 1967. Табл. 30: 10); 2 - Журовка к. 401 (Петренко, 1967. Табл. 30: 11); 3 - с. Гамарня (Петренко, 1967. Табл. 30: 14); 4 - с. Хмельна (Петренко, 1967. Табл. 30: 15); 5 - Берестняги, к.4 (Петренко, 1967. Табл. 30: 16); 6 - Акташский могильник (Бессонова, Скорый, 1986. С. 161, 162. Рис. 4: 1); 7 - Екатеринославская губерния (случайная находка) (Мелюкова, 1964. Табл. 20: 11); 8 - случайная находка на Южном Буге (Гребенников, Недопако, 1984. С. 126-128. Рис. 1); 9 - Шолохово, Днепропетровская обл. (Волкобой и др., 1979. С. 50, 59. Рис. 8: 3); 10 - с. Сахновка Киевского р-на (случайная находка) (Мелюкова, 1964. Табл. 20: 4); 11 - Грищенцы, курган (Мелюкова, 1964. Табл. 20: 10); 12 -Волковцы (Ori..., 2007. С. 243. Рис. 2. Кат. 95); 13 - Уляпский могильник, к. 15, п. 5 (Сокровища..., 1985. Рис. 22. Кат. 131); 14 - Уляпский могильник, к. 15, п. 43 (Сокровища..., 1985. Рис. 22. Кат. 135); 15 - Лечинкай (Прокопенко, 2005. Рис. 91: 40); 16 - ст. Николаевская (Виноградов, 1972. Рис. 3: 3); 17 - Мескер-Юрт (Прокопенко 2005. Рис. 91: 37); 18 - Павлодольская (1984 г.), к. 1, п. 7 (Прокопенко 2005. Рис. 91: 38); 19 - курган на шоссе «Нальчик-Шалушкинское» (1927 г.) (Прокопенко, 2005. Рис. 91: 39; фото А. Р. Канторовича в НМ КБР); 20 - Урус-Мартановский могильник (Ани-Ирзо), к. 1 (1890 г.) (Прокопенко, 2005. Рис. 91: 5); 21 - Ялхой-Мохкский могильник (Прокопенко, 2005. Рис. 91: 8); 22 - Магас (Прокопенко, 2005. Рис. 91: 15); 23- Нальчик (Прокопенко, 2005. Рис. 91: 26); 24 - Кисловодский могильник, п. 1 (1951 г.) (Прокопенко, 2005. Рис. 91: 26); 25 - могильник Фаскау (Прокопенко, 2005. Рис. 91: 25); 26 - Аллероевский 1-й могильник (Виноградов, 1972. Рис. 44: 3); 27 - Нестеровский могильник (Крупнов, 1960. Табл. LXII: 1); 28 - к. 2 (?) у с. Волковцы / курган у с. Мгарь Полтавской обл. (Мелюкова, 1964. Табл. 20: 9; Ильинская, 1968. С. 90. Табл. XLVII: 12; Топал, 2017. Рис. 17: 13; см. замечание Д. А. Топала о проблеме идентификации этого меча (2017. С. 311); 29 - Бельское городище (Мурзін и др., 1999. С. 62. Рис. 3); 30 - с. Кирово Полтавского р-на Полтавской обл., случайная находка в разрушенном кургане (Супруненко, 2002. Рис.1; фото С. А. Задникова); 31 - с. Анна, Среднее Подонье, случайная находка (сл. нах.) (Медведев, 1999. Рис. 51: 14); 32 - Афанасьевка, Среднее Подонье, случайная находка (Медведев, 1999. Рис. 51: 15); 33 - Пиликовка, Среднее Подонье, сл. нах. (Медведев, 1999. Рис. 51: 16); 34 - Садовка, Среднее Подонье, сл. нах. (Либеров, 1971. Рис. 27а: 3; Медведев, 1999. Рис. 51: 17); 35 - Тынково, Среднее Подонье, сл. нах. (Медведев, 1999. Рис. 51: 11); 36 - Волковцы (Ханенко Б.И., Ханенко В.И., 1899. Табл. ІІ: 56); 37 - Анапская, сл. нах. (Новичихин, 2006. Рис. 56: 1); 38 - Могильник у хут. Рассвет, п. 29 (Новичихин, 2006. Рис. 56: 2); 39 - Саук-Дере, подъемный материал (Новичихин, 2006. Рис. 56: 5); 40 - Раевская, сл. нах. (Новичихин, 2006. Рис. 53: 5); 41 - Су-Псех, сл. нах. (Новичихин, 2006. Рис. 54: 1); 42 - Умань (Топал, 2017. Рис. 18: 16); 43 - Гос. Киевский историч. музей (НМИУ) (Топал, 2017. Рис. 18: 17); 44 - могильник Энергетик 3, разрушенное погр. (Березин, Маслов, 2012. С. 32. Рис. 1: 1; Топал. 2017. Рис. 18: 17); 45 - у с. Афанасьевка Советского р-на Курской обл. (Апальков, 1995. Рис. 2, 11; Топал, 2017. Рис. 18: 10); 46 - у с. Канищево Тимского р-на Курской обл. (Воронина, 1962. Рис. 1, 11; Топал. 2017. Рис. 18: 5); 47 - Шалинский могильник (Шрамко и др., 1963. Рис. 4: 8); 48 - Рышканский р-н (Топал, 2017. Рис. 18: 4); 49 - у с. Малый Хомутец Добровского р-на Липецкой обл. (Топал, 2017. Рис. 18: 3); 50 - Луговой могильник, п. 64 (Крупнов, 1960. Рис. 40: 7; Топал, 2017. Рис. 17: 9); 51 - г. Котовск (ныне г. Подольск) Одесской обл., сл. нах. (Топал, 2017. Рис. 16: 14); 52 - Журовка, НМИУ, № Б 46-123 (Мелюкова 1964. Табл, 20: 12). Железо (1-28, 30-52); бронза (29)

бляхи-накладки V в. до н.э., связанные с колчаном, оформленные в виде лосиной головы (курганы у г. Мариуполя (Жданова, раскопки 1927 г.) и у с. Новая Розановка) (рис. 10: III, 1, 2).

Крестовидные бронзовые (в том числе обтянутые золотым листом) бляхи «ольвийского типа» (вторая четверть VI - начало V в. до н.э.), скорее всего, предназначены для крепления горита (Ильинская, 1968. 127; Полідович, 2000. С. 44). Исключение составляет, как известно, лишь только бляха из Волковцев (курган 2 раскопок 1897 г.) Древности Приднепровья, 1899. Табл. XVI, 316; Ильинская, 1968. Рис.37; Scythian Gold..., 1999. Р. 158. Cat. 48; Могилов, 2008. Рис. 104: 1), вероятно, являющаяся элементом конского снаряжения (Ильинская, 1968. С. 127; Полідович 2000. С. 44) ${ }^{18}$.

Данные бляхи оформляются (по лопастям и/или по центру) изображениями хищников; насчитывается 10 случаев изображения оригинальных фигур хищников, в том числе: 8 - кошачьих (рис. 3: I, 1-5; рис. 4: I, 1-3), 2 - волчьего хищника (рис. 1: II, 1; 2: III, 2), а также копытных - полнофигурного горного козла (2 случая изображения) (рис. 12: III, 1, 2) и головы барана (1 случай) (рис. 12: VI, 1$)$, головы лошади (1 случай) (рис. 13: I, 1), и, наконец, головы хищных птиц (3 случая изображения) (рис. 15: III, 1, 2, 12).

Выполненные в зверином стиле крючки, как уже отмечалось, трактуются в литературе

\footnotetext{
${ }^{18}$ Ввиду неясности происхождения известной бляхи «ольвийского типа» из коллекции Боткина (Капошина, 1956. С. 188. Рис. 26), зооморфные изображения на бляхе не включаются нами в общий массив изображений ВСЗС и не учитываются в работе.
} 

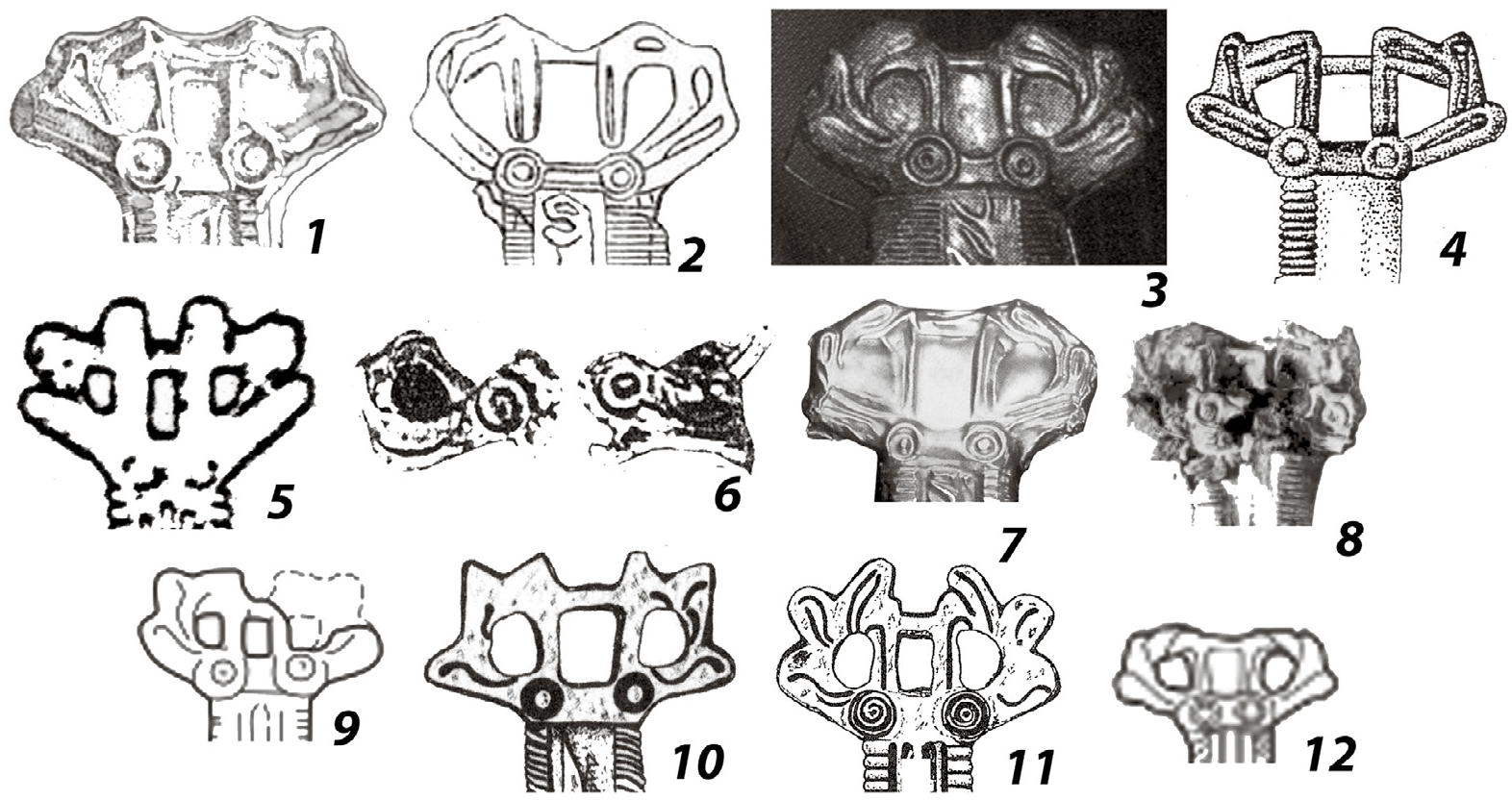

8
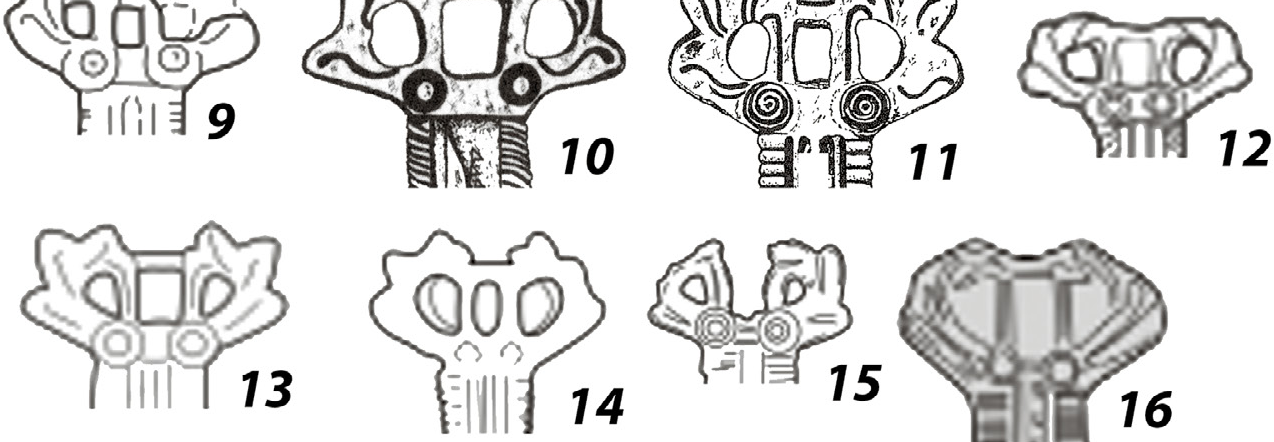

Рис. 20. Птицы в редуцированном отображении на предметах вооружения. Елизаветовско-солохский тип. 1-16 - навершия рукоятей мечей: 1 - Елизаветовский могильник (к. 10, раскопки 1909 г.) (Миллер, 1910. Табл. V. Рис. 23а, б); 2 - Солоха, боковое погр. Манцевич, 1987. Кат. 48); 3 - Великая Белозерка (Gold der Steppe..., 1991. S. 359. Kat. 89); 4 - Петровка (Братченко и др., 1989. С. 171, 172, 174. Рис. 4: 2); 5 - Гладковщина, к. 2. (Григорьев, 1994); 6 - Елизаветовский могильник (Ушаковский курган) (Borovka, 1928. PI. 22A); 7 - Перещепинский могильник, к. 3, п. 2 (Національний музей..., 2001. С. 23. Кат. 35); 8 - могильник Осняги у Бельского городища, к. 4, раскопки В. А. Городцова (Граков, 1971. Табл. ІІ: г; Шрамко, 1987. Рис. 71: 14); 9 - из окрестностей сел Самовицы и Дубинка Чернобаевского р-на Черкасской обл. (Сиволап, Шелехань, 2014. Рис. 1, 4, 4а; Топал. 2017. Рис. 23: 2); 10, 11 - Черкасская обл., сл. нах. в обвале берега р. Ольшанка (правый приток Днепра) у с. Вязовки (Мурзин, Шлайфер, 2011. Рис. 1: 2, 3); 12 - с. Садовка Терновского р-на Воронежской обл., сл. нах. 1966 г. (Максимов, Полесских, 1971. Рис. 2, 4; Топал, 2017. Рис. 20: 6); 13 - С. Пуркарь, к. 7, п. 3 (Агульников и др., 2013. С. 274. Рис. 6, 7; Топал, 2017. Рис. 23: 4); 14 - Гос. Киевский историч. музей (НМИУ) (сл. нах. из Роменского у.) (Мелюкова, 1964. С. 58. Табл. XVIII: 10. Рис. 20: 8); 15 - ограбленное погр. кургана 323 у с. Пилипчичи Переяславского уезда Полтавской обл. (Топал, 2017. Рис. 17: 12); 16 -Аксютинцы, к. 2 (Бобринский, 1894. Табл. XXII: 4). Железо с золотой обкладкой (1-3, 6-8, $16)$; железо $(4,5,9-15)$

Pис. 21 (справа). Синкретические животные в полнофигурном (I, II, IV) и в редуцированном (III) отображении на предметах вооружения. Грифоны (I, II), бараноптицы (III), грифоно-гиппокамп (IV). I - Кульобскобелозерский тип. 1, 2 - золотые обкладки ножен мечей: 1 - Великая Белозерка (Gold der Steppe..., 1991. S. 359. Kat. 89), 2 - Куль-Оба (Древности Боспора..., 1854. Табл. XXVI: 2); 3 - Толстая могила, центральная гробница, золотая обивка горита (Мозолевський, 1979. Рис. 47: 3); II - Солохский тип: 1 - Солоха, боковое погр., золотая обкладка ножен меча (Манцевич, 1987. С. 69-71. Кат. 49); III - Келермесско-новозаведенский тип. Костяные (1-5) и роговые $(6,7)$ налучья: 1 - курган Дюнный в Аксайском р-не Ростовской обл. (Посегун, 2009. Рис. 9: 34); 2 - разрушенное п. 1 кургана 2 у пос. Зеленый Лагерь (Семеновка) под Kaховкой (Leskov, 1974. S. 54. Abb. 74); 3 - Новозаведенное II, к.13 (Петренко и др., 2000. Рис. 5: 1; 2009. Рис. 10: 4); 4 - Темиргора (Яковенко, 1976. С. 128, 130. Рис. 1); 5 - Высочино (Кореняко, Лукьяшко, 1982. Рис. 2: 2); 6 - Западное Бельское городище, зольник 28, пом. 9 (Шрамко, 2015. Ил. 1: 1; 2: 1); 7 - Западное Бельское городище, зольник 13, яма 11 (Шрамко, 2015. Ил. 2: 1, 2); IV - Акимовско-елизаветовский тип: 1 - Елизаветовская станица, к. 1, 1910 г., золотая обкладка ножен меча, основная пластина (Артамонов, 1966. Табл. 324) 

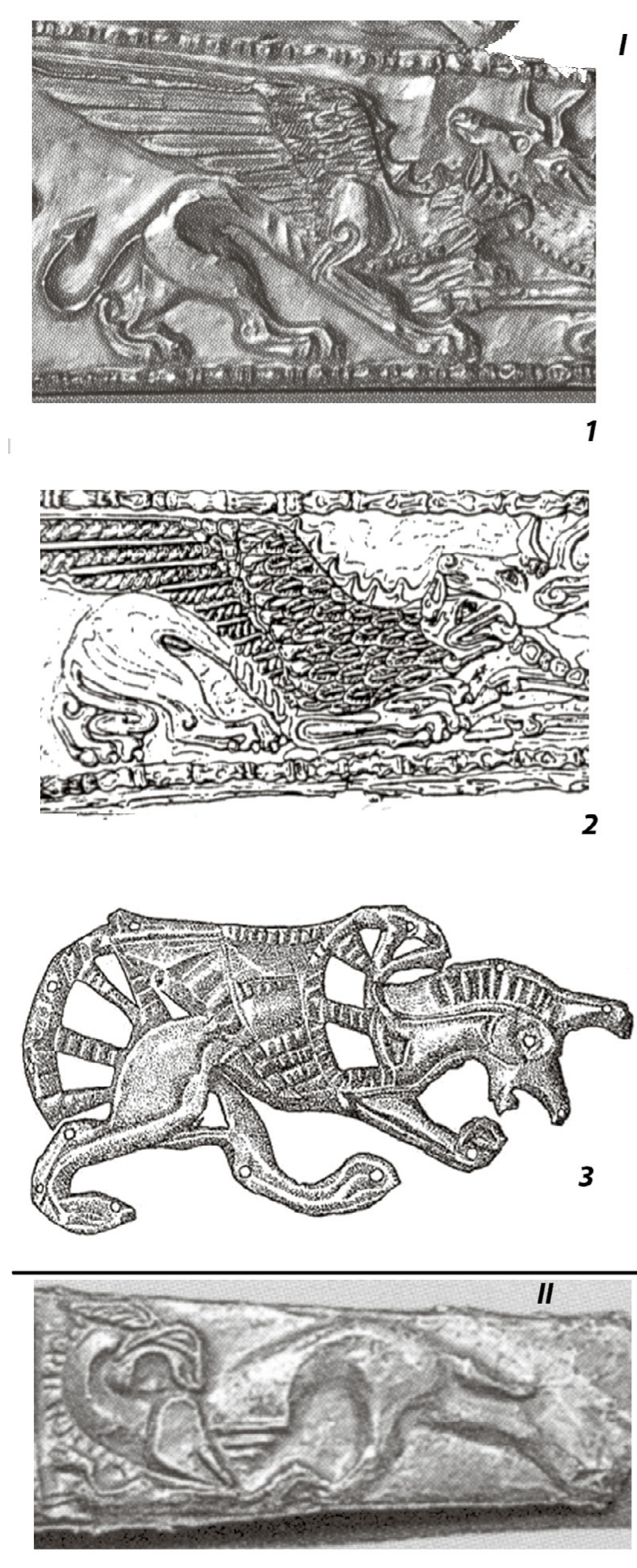
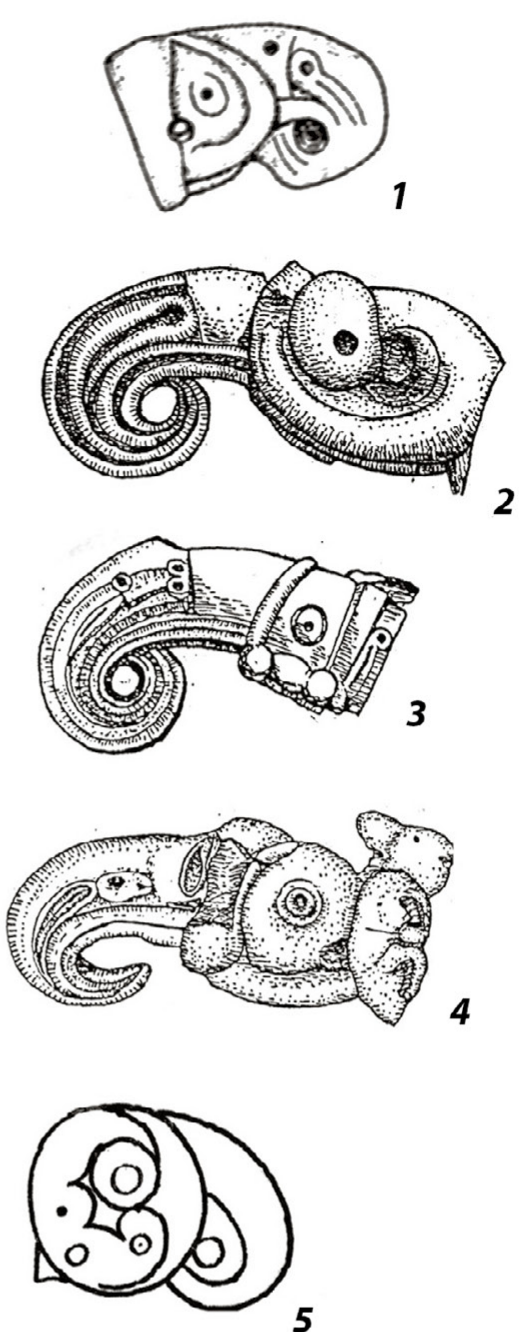

5
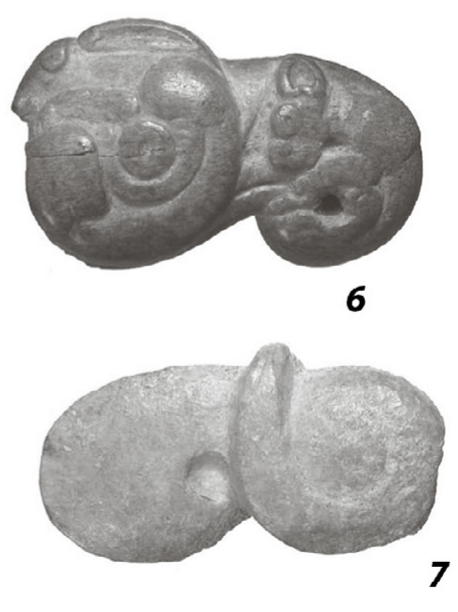

IV

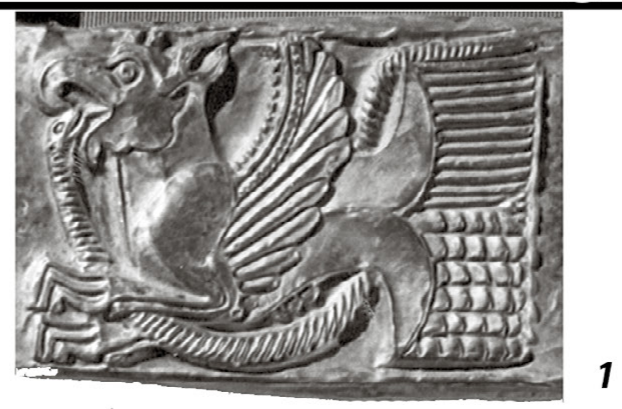


двояко (причем иногда одними и теми же авторами, поскольку одна атрибуция не исключает вторую): либо как элементы костюма - поясные пряжки, застежки кафтана (Rostovzeff, 1929. Р. 42; Либеров, 1965. С. 18, 19; Гуляев, 1969. С. 127; 2016а. С. 66-68), либо как аксессуары вооружсения - средство крепления к поясу или портупейному ремню горита/колчана (Смирнов, 1961. С. 35, 36, 109. Рис. 10; Гуляев, 1969. С. 127; Максименко, 1983. С. 144, 145; Кокорина, Лихтер, 2001. С. 235-238. Рис. 5-7) ${ }^{19}$ или, реже, скрепа ремней портупеи для ножен меча (Либеров, 1965. С. 18; Гуляев, 1969. С. 127; 2016а. С. 68) $)^{20}$. Очевидно, следует согласиться с В.И. Гуляевым и Е.И. Савченко, предполагающими многофункциональное назначение крючков, сочетающее оба варианта (Гуляев, 1969. С. 126, 127; Савченко, 2004. С. 229-241). Во всяком случае, конечное решение в пользу атрибуции крючков как аксессуаров вооружения принято нами с учетом того, что многие исследователи, рассматривавшие данную категорию изделий как феномен, либо прямо настаивают на данной версии, либо, как минимум, не исключают ее.

В скифской археологической культуре 300морфизированые крючки в основном сделаны из бронзы, также из железа, в единичных случаях - из золота, серебра, кости; известны также бронзово-железный крючок и железный крючок с золотой обтяжкой. Они датируются преимущественно в рамках середины V - рубежа IV-III вв. до н.э. (Гуляев, 2016а. С. 6, 59-61), предельно до середины III в. до н. э. (Савченко, 2004. С. 229). Крючки либо оформлены целиком в виде фигуры хищной птицы (3 изображения) (рис. 14: 1-3), либо же загнутый их конец является головой хищной, чаще ушастой, птицы, разной степени отчетливости (21 изображение) (рис. 16: 1-21) ${ }^{21}$, а широкий конец со шпеньком на обороте трактован в виде фигуры медведя (11 изображений) (рис. 4: I, 1-11), фигуры волчьего хищника (5 изображений) (рис. 1: III, 1; 3: II, 1-4), обособленной головы хищника в профиль, иногда образующей с другим аналогичным профилем фас хищника

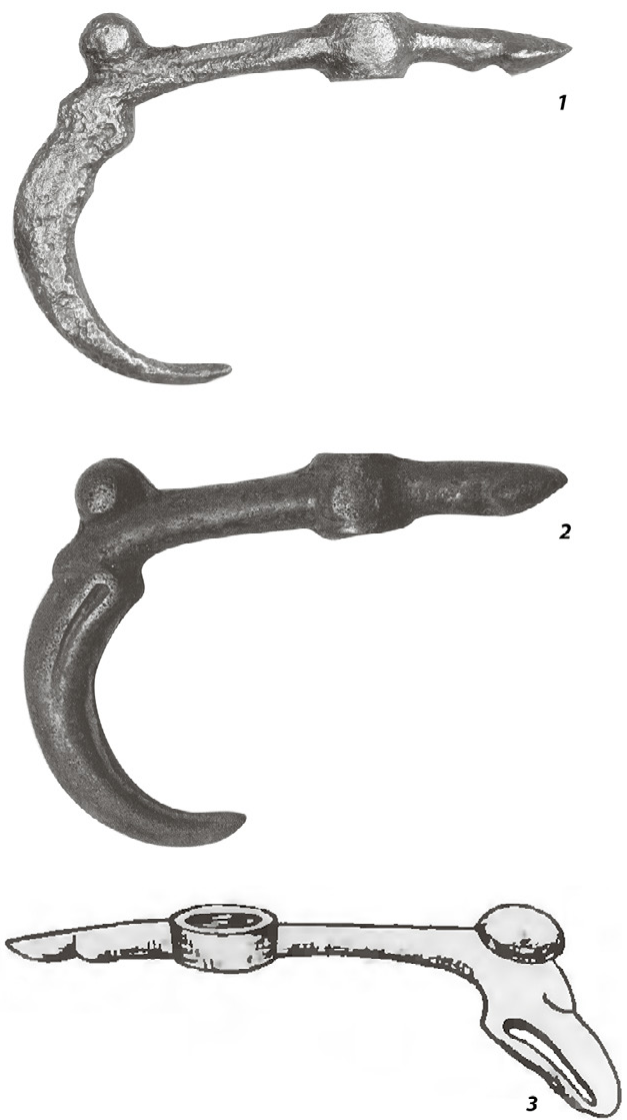

Рис. 22. Синкретические животные в редуцированном отображении на предметах вооружения. Комбинация элементов птицы и неопределенного копытного. 1-3 - бронзовые вотивные топорикискипетры: 1 - аул Тауйхабль (подъемный материал) (Канторович, Эрлих, 2006. Кат. 55); 2 - Аксютинцы, к. 15 в урочище Стайкин Верх (Конь и всадник..., 2003. С. 29. Кат. 39); 3 - с. Долинное, курган Кулаковского (Яковенко, 1976. С. 132. Рис. 5: 3)

(9 изображений) (рис. 6: II, 1-9), фигуры оленя (4 изображения) (рис. 8: IV, 1-4), в виде обособленной головы горного козла (1 изображение) (рис. 12: IV, 1) и головы кабана (1 изображение) (рис. 13: VIII, 1).

С оборонительным вооружением связаны изображения обособленных лосиных голов, оформляющих бронзовые детали панциря V в. до н.э. - панцирные застежки (2 изображения, Среднее Поднепровье) (рис. 10: V, 1, 2) ${ }^{22}$

\footnotetext{
${ }^{19}$ К. Ф. Смирнов исходил из того, что данные крючки обнаруживались в савроматских погребениях «всегда с остатками колчанов или наконечниками стрел» (1961. С. 35); ср. аналогичные наблюдения В.Е. Максименко в отношении нижнедонских памятников скифской и раннесарматской эпох (1983. С. 42, 49, 53, 54, 68).

${ }^{20}$ Исчерпывающая сводка известных на сегодняшний день зооморфных колчанных/поясных крючков скифской эпохи (включая не только крючки, происходящие с территории скифской археологической культуры и рассматриваемые в нашей статье, но и аналогичные предметы из зоны «савроматской» и ананьинской культур), анализ их морфологии и репертуара изображений содержится в монографии В. И. Гуляева (2016а).

${ }^{21}$ Не учитываются крючки, рабочая часть которых десемантизирована, и в результате не прослеживаются никакие детали птицы, за исключением изгиба крючка/клюва.

${ }^{22}$ См. атрибуцию: Бобринский, 1905. С. 12; Петренко, 1967. С. 50.
} 
и нагрудную бляху (1 изображение, Крым) (рис. 10: IV, 1); также фигура рыбы - бронзовая нащитная бляха, датируемая в пределах четвертой четверти V - IV в. до н.э. (Нижнее Поднепровье) (рис. 23: IV, 1-a, 1-б). Кроме того, к данной макрокатегории изделий могут относиться упомянутые выше золотые бляхи с оленями из 1-го Разменного кургана у ст. Костромской и из Куль-Обы (в случае, если придерживаться их традиционной интерпретации как нащитных, а не как колчанных аксессуаров) ${ }^{23}$.

Каково же общее количество предметов вооружения, оформленных или украшенных в зверином стиле на территории скифской археологической культуры? Для фиксации этого показателя требуется, зная количество оригинальных изображений, исключить все случаи совстречаемости изображений на одном предмете (как, например, в многофигурных композициях на обкладках ножен мечей и др.), в том числе и зооморфные превращения частей тела ряда животных, естественно, учитываемые нами как отдельные оригинальные изображения при общем подсчете образов. При этом в случаях декорирования какого-либо изделия одним оригинальным изображением, тиражированным на однородных носителях (например, на золотых бляшках-аппликациях горитов из Витовой могилы и Архангельской слободы), украшаемый предмет учитывался нами как одна единица.

Было установлено (после вычетов случаев совстречаемости изображений одного типа, разных типов и одного образа на одном и том же предмете - в рамках мегаобразов хищников, копытных, птиц, синкретических животных и прочих животных), что 84 предмета несут на себе изображения хищников, 45 - изображения копытных, 133 - изображения птиц, 15 синкретических животных, 4 - прочих; итого 281 изделие. Заметим, что предметов с изображениями хищников значительно больше, чем предметов с изображениями копытных, тогда как еще большее количество изображений птиц (в основном это головы) связано с тем, что здесь были учтены также птицы, являющиеся элементами зооморфных превращений частей тела других животных.

Далее из указанного числа 281 были вычтены случаи совстречаемости изображений

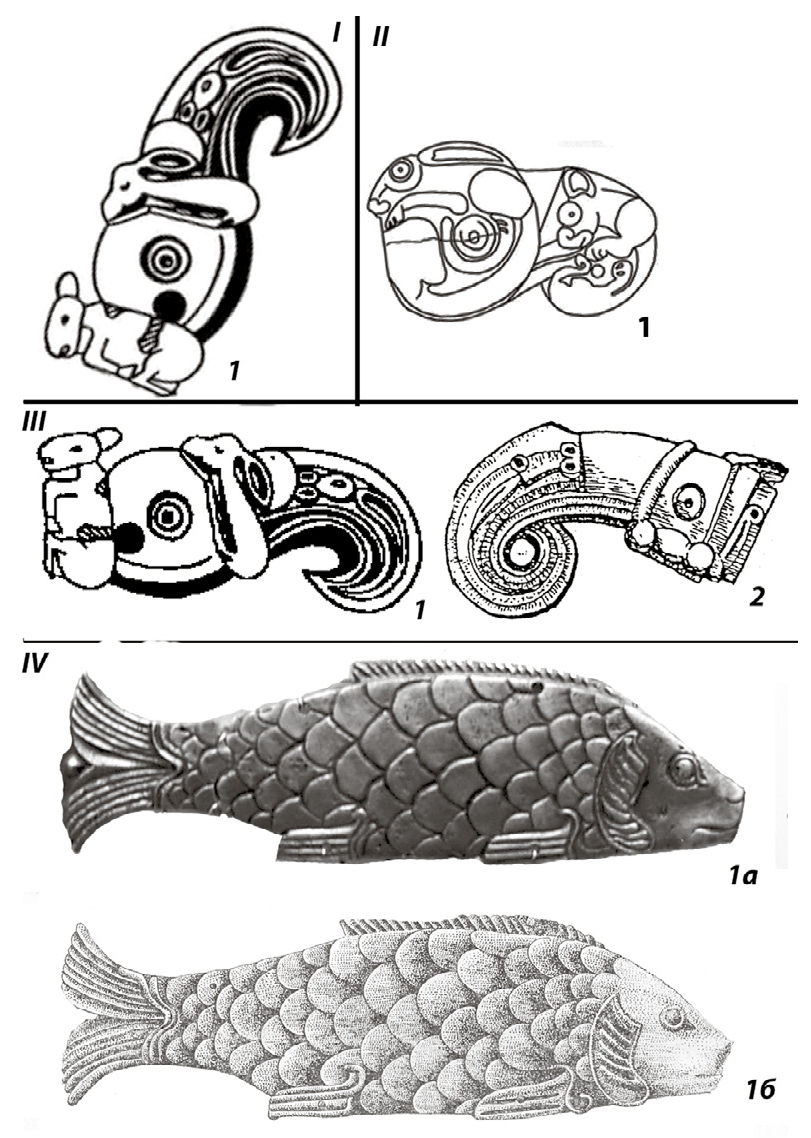

Рис. 23. Прочие животные в полнофигурном (I, II, IV) и в редуцированном (III) отображении на предметах вооружения. Зайцы (I-III) и рыбы (IV). I - Новозаведенско-чертоватовский тип: 1 - Темиргора, Костяное налучье (Яковенко, 1976. С. 128, 130. Рис. 1); II- Бельский тип: 1 - Западное Бельское городище, зольник 28 , пом. 9, роговое налучье (Шрамко, 2015. Ил. 1: 1; 2: 1a-е, з); III - Темиргоринско-новозаведенский тип. Костяные налучья: 1 - Темир-гора (Яковенко, 1976. С. 128, 130. Рис. 1); 2 - Новозаведенное II, к.13 (Петренко и др., 2000. Рис. 5: 1; 2009. Рис. 10: 4); IV - Новозаведенсковолковецкий тип. 1 - г. Орджоникидзе «на Днепропетровщине», курганная группа около шахты 22, к. 12, п. 2, впускное (Тереножкин и др., 1973. Рис. 46: 5; фото А.Р Канторовича в АМ ИА НАНУ)

разных мегаобразов друг с другом (т. е. хищников с копытными, хищников с птицами и т. д., во всех возможных сочетаниях) на одном и том же предмете. Учитывая, что количество таких сочетаний составляет 65 случаев, было установлено окончательное количество предметов вооружения, оформленных или украшенных в зверином стиле на территории скифской археологической культуры: это 216 изделий.

\footnotetext{
23 Зооморфные поясные бляхи были отнесены нами к костюму, хотя они могут рассматриваться и как элемент доспеха (см. Черненко, 1968. С. 64-68), однако они немногочисленны, соответственно их учет/неучет практически не влияет на статистические показатели.
} 


\section{Выводы}

Итак, в декоре вооружения представлены все мегаобразы скифского звериного стиля: хищники, копытные, птицы, синкретические существа; кроме того, отображены также зайцы и рыбы (табл. 2). Однако представлены они неравномерно. Как показывает статистический анализ, результаты которого приведены в табл. 2 и 3 , наиболее часто предметы вооружения украшаются изображениями птиц: 47,4\%; но надо иметь в виду, что здесь учтены и элементы зооморфных превращений деталей других животных. На втором месте по частоте изображения на предметах вооружения - хищники $(28,4 \%)$. Доля копытных менее значительна (17,6\%), доля синкретических существ невелика $(4,9 \%)$.

Параллельные показатели в общем массиве изображений ВСЗС несколько отличаются. Как видно из табл. 3, доля изображений хищников в ВСЗС в целом почти такая же, немного ниже $(26,1 \%)$, доля птиц - значительно ниже $(27,4 \%)$, доля изображений синкретических существ несколько выше $(8,9 \%)$, тогда как изображения копытных в ВСЗС в целом преобладают и составляют около трети (34,5\%). Соответственно, в массиве мегаобраза хищника в ВСЗС доля изображений, оформляющих/декорирующих предметы вооружения составляет 13,6\% (табл. 3), тогда как у копытных этот показатель составляет лишь $6,4 \%$, а у синкретических животных $-6,9 \%$. Наиболее высок данный показатель в рамках мегаобраза птицы: более одной пятой изображений птиц в ВСЗС $(21,6 \%)$ связано, так или иначе, с предметами вооружения - либо как основные изображения, либо как элементы зооморфных превращений анатомических деталей других животных.

В целом же изображения, оформляющие/ украшающие предметы вооружения, составляют в общем массиве изображений ВСЗС существенную долю $-12,5 \%$ (табл. 3$)^{24}$. Интересно, что сегмент морфологических типов, к которым относятся изображения на вооружении (эти типы могут включать и изображения, оформляющие предметы иных категорий материальной культуры), в общем массиве типов ВСЗС еще более значителен: 77 типов из 353, т.е. $21,8 \%$ (табл. 3). Это несомненное свидетельство иконографической многоплановости в декорировании данной макрокатегории изделий, возможно, обусловленной в первую очередь морфологическим разнообразием самих предметов вооружения, что требовало от мастеров широты репертуара и художественного поиска.

Итак, как уже было показано в наших предыдущих работах на имевшемся к тому моменту материале, в связи с вооружением приоритетно отображаются хищные млекопитающие и хищные птицы, причем происшедшее с тех пор накопление новых данных лишь подтвердило тенденцию, отмеченную нами в работе пятилетней давности (табл. 2). Долевые показатели как в целом, так и для конкретных образов, изменились с тех пор незначительно ${ }^{25}$. Сдвиги эти связаны, во-первых, с интегрированием в наш корпус источников массива изображений «Крымской коллекции» (в основном, впрочем, оформляющих конское снаряжение). Во-вторых - с принятым нами решением в настоящей работе отнести зооморфные крючки в конечном счете не к макрокатегории костюма (как в наших предшествующих работах), а к макрокатегории вооружения. Обоснование такого решения приведено выше. Это достаточно многочисленная категория изделий, причем, за редким исключением, один крючок несет на себе сразу два различных изображения, что влияет на статистику.

Насчитывается 216 предметов наступательного и оборонительного вооружения и его аксессуаров, происходящих с территории скифской археологической культуры и несущих изображения, выполненные в скифском зверином стиле. На фоне общего массива предметов наибольшее количество изображений и соответствующих им сюжетов и мотивов связано с акинаками и их аксессуарами, причем эта категория изделий декорируется в данной манере на всем протяжении существования скифской археологической культуры - со второй четверти VII до IV в. до н.э. включительно. Но надо помнить и об объективно большем количестве акинаков на фоне другого наступательного оружия, о масштабности и многосоставности этих изделий, что открывает широкое поле для декорирования рукоятей, ножен, бутеролей и т.д.

\footnotetext{
${ }^{24}$ Но эта доля не столь значительна, как доля изображений, связанных с еще одним компонентом «скифской триады»-предметами конского снаряжения: на них приходится, в соответствии с нашими более ранними подсчетами, почти две трети всего массива изображений ВСЗС (Канторович, 2015б. С. 439, 440. Табл. 3), и произошедший с того времени прирост материала практически не изменил данный показатель.

${ }^{25}$ Так, наблюдается некоторое увеличение (в сравнении с нашими публикациями 2014 и 2015 гг.) общей доли изображений, оформляющих и украшающих предметы вооружения, в общем массиве изображений ВСЗС (с 9,6 до 12,5\%).
} 
Таблииа 3. Статистика изображений на предметах вооружения в контексте общих показателей восточноевропейского скифского звериного стиля (ВСЗС)

\begin{tabular}{|c|c|c|c|c|c|}
\hline \multirow[b]{2}{*}{$\begin{array}{l}\text { Образно-видовая } \\
\text { принадлежность } \\
\text { изображений }\end{array}$} & \multicolumn{2}{|c|}{$\begin{array}{c}\text { Количество } \\
\text { и соответствующая доля } \\
\text { оригинальных изображений }\end{array}$} & \multirow[b]{2}{*}{ 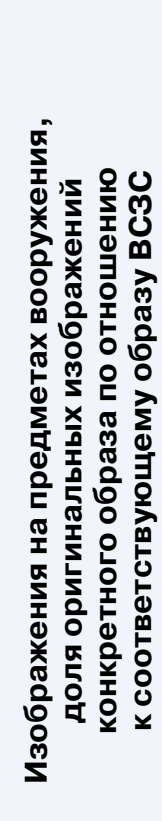 } & \multirow[b]{2}{*}{ 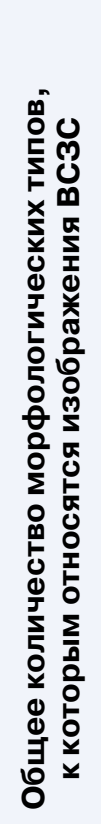 } & \multirow[b]{2}{*}{ 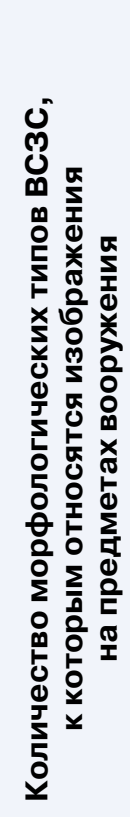 } \\
\hline & $\begin{array}{c}\text { ВсзС } \\
\text { в целом, } \\
\text { количество } \\
\text { и доля в общей } \\
\text { массе } \\
\text { изображений }\end{array}$ & $\begin{array}{c}\text { На предметах } \\
\text { вооружения, } \\
\text { количество } \\
\text { и доля среди } \\
\text { изображений } \\
\text { на предметах } \\
\text { вооружения }\end{array}$ & & & \\
\hline Хищники & $\begin{array}{c}638 \\
26,1 \%\end{array}$ & $\begin{array}{c}87 \\
28,4 \%\end{array}$ & $13,6 \%$ & 108 & 25 \\
\hline Копытные & $\begin{array}{c}845 \\
34,5 \%\end{array}$ & $\begin{array}{c}54 \\
17,6 \%\end{array}$ & $6,4 \%$ & 130 & 26 \\
\hline Птицы & $\begin{array}{c}671 \\
27,4 \%\end{array}$ & $\begin{array}{c}145 \\
47,4 \%\end{array}$ & $21,6 \%$ & 55 & 17 \\
\hline $\begin{array}{l}\text { Синкретические } \\
\text { животные }\end{array}$ & $\begin{array}{l}218 \\
8,9 \%\end{array}$ & $\begin{array}{c}15 \\
4,9 \%\end{array}$ & $6,9 \%$ & 46 & 5 \\
\hline Зайцы & $\begin{array}{c}26 \\
1,1 \%\end{array}$ & $\begin{array}{c}4 \\
1,3 \%\end{array}$ & $15,4 \%$ & 5 & 3 \\
\hline Верблюды & $\begin{array}{c}6 \\
0,25 \%\end{array}$ & 0 & 0 & 1 & 0 \\
\hline Дельфины & $\begin{array}{c}4 \\
0,16 \%\end{array}$ & 0 & 0 & 2 & 0 \\
\hline Рыбы & $\begin{array}{c}28 \\
1,1 \%\end{array}$ & $\begin{array}{c}1 \\
0,3 \%\end{array}$ & $3,6 \%$ & 3 & 1 \\
\hline $\begin{array}{l}\text { Неопределенные } \\
\text { животные }\end{array}$ & $\begin{array}{c}10 \\
0,4 \%\end{array}$ & 0 & 0 & 3 & 0 \\
\hline итого & $\begin{array}{c}2446 \\
\text { изображений } \\
100 \%\end{array}$ & $\begin{array}{c}306 \\
\text { изображений } \\
100 \%\end{array}$ & $12,5 \%$ & $\begin{array}{l}353 \\
\text { типа }\end{array}$ & $\begin{array}{c}77 \\
\text { типов }\end{array}$ \\
\hline
\end{tabular}

Также относительно многочисленную, но гораздо более узкую во временном отношении категорию образуют зооморфные колчанные/ портупейные/поясные крючки середины V начала/середины III в. до н. э. Достаточно длительно сохраняется традиция зооморфизировать бляхи или пластины горитов (со второй половины VII по первую половину IV в. до н. э.).
Значительно реже и не столь длительно декорируются/оформляются в скифском зверином стиле другие категории вооружения, включающие значительно меньше предметов: костяные/ роговые налучья (вторая четверть VII - середина VI в. до н. э.), скипетры/ритуальные секиры (вторая половина VII - первая половина V в. до н. э.) и молоточки-клевцы (первая половина- начало 
третьей четверти V в. до н.э.), бляхи «ольвийского типа» (вторая четверть VI - начало V в. до н.э.), а также бутероли копий (VI в. до н.э.) и детали панциря V в. до н.э. - панцирные застежки и нагрудная бляха.

Таким образом, большинство связанных со скифской археологической культурой категорий наступательного и оборонительного вооружения, включая их аксессуары, так или иначе декорировались/оформлялись в скифском зверином стиле. Исключение составляют шлемы, однако их находки крайне немногочисленны, и надо учитывать, что соответствующую функцию могли выполнять башлыки, в том числе обшитые металлическими чешуйками. Кроме того, не наблюдается декорирования наконечников стрел, хотя теоретически в зверином стиле могли украшаться даже такие миниатюрные предметы, о чем свидетельствуют находки в кургане Аржан 2 в Туве железных наконечников стрел с золотой плакировкой, представляющей изображение хищной птицы, когтящей голову горного козла (Čugunov et al., 2010. Taf. 24: 3).

\section{Литература}

Агульников С. М., Попович С. С., Церна С. В., Топал Д. А. Скифский курган № 7 у с. Пуркарь на Нижнем Днестре // Stratum plus. 2013. № 3. C. 257-284.

Акритас П. Г. Археологическое исследование Чегемского ущелья в 1959 году (из научного отчета) // Сборник статей по истории Кабардино-Балкарии. Вып.9. Нальчик: Кабардино-Балкарское книжное издательство, 1961. С. $177-192$.

Алексеев А. Ю. Золото скифских царей в собрании Эрмитажа. Санкт-Петербург, 2012.

Алексеев А. Ю., Мурзин В.Ю., Ролле Р. Чертомлык (Скифский царский курган IV в. до н. э.). Киев, 1991.

Апальков А. Н. Находки предметов вооружения скифского времени в междуречье Сейма и Сосны // РА. 1995. № 2. C. $149-152$.

Аптекарев А. 3. Комплекс вещей V до н. э. из станицы Старокорсунской // СА. 1986. № 4. С. 245-249.

Артамонов М.И. Сокровища скифских курганов в собрании Государственного Эрмитажа. Прага; Ленинград, 1966. Артамонов М.И. Куль-обский олень // Античная история и культура Средиземноморья и Причерноморья. Ленинград, 1968. C. 9-16.

Батчаев В.М. Древности предскифского и скифского периодов // Археологические исследования на новостройках Кабардино-Балкарии в 1972-1979 гг. Вып. II. Нальчик, 1985. С. 7-115.

Березин Я.Б., Маслов В.Е. Скифский меч из могильника «Энергетик-3» // Историко-археологический альманах. Вып. 11. Армавир; Краснодар; Москва, 2012. С. 32-36.

Березуичкии В.Д. Курганы скифского времени у хут. Дубовой на Среднем Дону (раскопки 2004 г.) // Археологические памятники Восточной Европы. Вып. 12. Воронеж, 2006. С. 138-147.

Бессонова С. С., Скорый С. А. Погребение скифского воина из Акташского могильника в Восточном Крыму // СА. 1986. № 4. С. $158-170$.

Бобринский А. А. Курганы и случайные археологические находки близ местечка Смелы. Т. 2: Дневники раскопок 18871889 гг. Санкт-Петербург, 1894.

Бобринский А. А. Отчет о раскопках, произведенных в 1903 году в Чигиринском уезде Киевской губернии // ИАК. Вып. 14. Санкт-Петербург, 1905. С. 1-43.

Братченко С. Н., Швецьов М. Л., Дубовская О.Р. Курган IV в. до н. э. в бассейне Северского Донца // СА. 1989. № 1. C. $170-177$.

Браун Ф. А. Отчет о раскопках в Таврической губернии в 1898 г. // ИАК. Вып. 19. Санкт-Петербург, 1906. С. 81-116.

Бурков С. Б., Маслов В.Е. Воинские погребения из курганов у станицы Ассиновской // Северный Кавказ и мир кочевников в раннем железном веке. Сб. памяти М.П. Абрамовой. Москва, 2007 (МИАР; вып. 8). С. 295-320.

Виноградов В.Б. Центральный и Северо-Восточный Кавказ в скифское время (VII-IV века до н. э.). Грозный, 1972.

Волкобой С. С., Шалобудов В.Н., Лихачев В.А. Скифский могильник «Славянка» на Днепропетровщине // Курганные древности степного Поднепровья III-І тыс. до н.э. Вып. 3. Днепропетровск, 1979. С. 45-61.

Воронина Р. Ф. О некоторых кинжалах и акинаках Курской области // Лесостепные культуры скифского времени. Москва; Ленинград, 1962 (МИА; № 113). С. 130-133.

Галанина Л.К. Келермесские курганы. «Царские» погребения раннескифской эпохи. Москва, 1997 (Степные народы Евразии; т. 1).

Граков Б. Н. Скифы. Москва, 1971.

Гребенников Ю. С., Недопако Д. П. Скифский меч с Южного Побужья // Вооружение скифов и сарматов. Киев, 1984. C. $126-128$.

Грибкова А. А., Полидович Ю. Б. Фигурка быка скифского времени из собрания Б.И. и В.Н. Ханенко // Археологический альманах. Вып. 30. Донецк, 2013. С. 259-277.

Григорьев В.П. Захоронение тяжеловооруженного скифского воина у с. Гладковщина // Древности скифов. Киев, 1994. C. 63-79. 
Гуляев В. И. Зооморфные крючки скифского периода // Население Среднего Дона в скифское время. Москва, 1969 (МИА; № 151). С. 109-127.

Гуляев В.И. На восточных рубежах Скифии (древности донских скифов). Москва, 2010.

Гуляев В.И. Зооморфные металлические крючки скифского времени в Евразии: каталог и описание. Москва, $2016 \mathrm{a}$.

Гуляев В. И. Рец.: С. Скорый, Р. Зимовец. Скифские древности Крыма. Материалы одной коллекции. Киев. 2014.180 с. // Восток/Oriens. 2016б. № 5. С. 205-208.

Доманский Я. В. Древняя художественная бронза Кавказа в собрании Государственного Эрмитажа. Москва, 1984.

Древние бронзы Кавказа. Альбом / Сост. А.П. Мошинский. Москва, 2010.

Древности Босфора Киммерийского, хранящиеся в Императорском Музее Эрмитажа. Т. I-III. Санкт-Петербург, 1854.

Древности Геродотовой Скифии. Сб. описаний археологических раскопок и находок в Черноморских степях. Вып. II. Санкт-Петербург, 1872.

Замятнин С. Н. Скифский могильник «Частые курганы» под Воронежем (Раскопки Воронежской ученой архивной комиссии 1910-1915 гг.) // СА. 1946. VIII. С. 9-50.

Зимовеи Р.В. О локальных особенностях бронзовых бутеролей в виде головы хищной птицы // Археологія і давня історія Украіни. Вип. 2 (19). Старожитності раннього залізного віку. Киів, 2016. С. 76-88.

Іллінська В. О. Скіфськи сокири // Археологія. 1961. ХІІ. С. 27-52.

Іллінська В.О. Про скіфські навершники // Археологія. 1963. ХV. С. 33-60.

Ильинская В.А. Скифы Днепровского Лесостепного Левобережья. Киев, 1968.

Ильинская В. А., Мозолевский Б. Н., Тереножкин А. И. Курганы VI в. до н. э. у с. Матусов // Скифия и Кавказ. Киев, 1980. C. 31-63.

Ильинская В. А., Тереножски А. И. Скифия VII-IV вв. до н. э. Киев, 1983. 379 с.

Ильюков Л.С. Крестовидные бляхи раннего железного века из степей Восточной Европы // Кавказ и степь на рубеже эпохи поздней бронзы и раннего железа. Материалы междунар. конф., посв. памяти М.Н. Погребовой. Москва, 2016. С. 80-84.

Канторович А.Р. Восточноевропейский скифский звериный стиль и предметы скифского вооружения (статистический анализ) // КСИА. 2014. Вып. 233. С. 56-63.

Канторович А. Р. Восточноевропейский скифский звериный стиль и предметы скифского вооружения // Война и военное дело в скифо-сарматском мире. Материалы междунар. конф., посв. памяти А.И. Мелюковой (Кагальник, 26-29 апреля 2014 г.). Ростов-на-Дону, 2015а. С. 69-73.

Канторович А. Р. Репертуар восточноевропейского скифского звериного стиля, типы изображений и категории украшаемых изделий (статистический анализ) // Проблемы истории, филологии и культуры. 2015б. № 1 (47). С. 431-443.

Канторович А.Р. Скифский звериный стиль Восточной Европы: классификация, типология, хронология, эволюция. Дисс. на соискание уч. степени докт. ист. наук. Москва: Архив ИА РАН, фонд Р-2. 2015 в. 1724 с.

Канторович А. Р. Скифский звериный стиль Крыма как региональный компонент восточноевропейского скифского звериного стиля (репертуар, хронология и статистические показатели) // И музою его была наука. Сб. памяти В. А. Кореняко (1952-2016). Азов, 2017. С. 143-180.

Канторович А. Р. Образно-сюжетный репертуар восточноевропейского скифского звериного стиля: принципы и результаты классифицирования и кодирования // Древности. Исследования. Проблемы. Сб. в честь 70-летия Н.П. Тельнова. Кишинев; Тирасполь, 2018. С. 195-223.

Канторович А.Р. Изображения в скифском зверином стиле на предметах «Крымской коллекции» // Археологія і давня історія України. 2019. 2. С. 430-455.

Канторович А. Р., Шиилов А. В. Зооморфная бутероль из курганной группы «Семигорье» и базовая тенденция в реализации сюжета свернувшегося в кольцо хищника в восточноевропейском скифском зверином стиле // Вестник Южного научного центра РАН. 2014.Т. 10, № 4. С. 85-95.

Канторович А. Р., Эрлих В.Р. Бронзолитейное искусство из курганов Адыгеи (VIII-III века до н. э.). Москва, 2006.

Капошина С. И. О скифских элементах в культуре Ольвии // Ольвия и Нижнее Побужье в античную эпоху. Москва; Ленинград, 1956 (МИА; № 50). С. 211-254.

Ковалева И. Ф., Мухопад С. Е. Скифское погребение к. VI - V в. до н. э. у с. Александровка // Древности степной Скифии. Киев, 1982. С. 91- 101.

Ковпаненко Г. Т., Левченко Б. М. 1977. Сюфський меч з с. Медвин. Археологія 23. С. 60 - 61.

Кокорина Ю. Г., Лихтер Ю.А. Куда смотрит вещь // На акад. Дмитри Сергеевич Раевски. Apotheosis. Миф. 7. София, 2001. C. 233-239.

Колтухов С.Г. Скифы Крымского Присивашья в VII-VI вв. до н.э.: погребальные памятники. Ландшафтно-археологическое районирование археологических памятников Крыма. Симферополь, 2012 (Материалы к археологической карте Крыма; вып. Х).

Колтухов С.Г., Сенаторов С. Н. Скифы Предгорного Крыма VII-IV вв. до н. э. Курганы 1890-1892 и 1895 гг.: (По материалам Н.И. Веселовского и Ю. А. Кулаковского). Симферополь, 2016 (Материалы к археологической карте Крыма; вып. XVII).

Конь и всадник. Взгляд сквозь века. Каталог выставки. Москва, 2003.

Кореняко В.А., Лукьяшко С.И. Новые материалы раннескифского времени на левобережье Нижнего Дона // СА. 1982. № 3. C. 149-164.

Королькова (Чежсиа) Е. Ф., Алексеев А. Ю. Олень из кургана Куль-Оба // Памятники древнего и средневекового искусства. Сб. в память проф. В.И. Равдоникаса. Санкт-Петербург, 1994 (Проблемы археологии; вып. 3). С. $102-109$. 
Крупнов Е. И. Древняя история Северного Кавказа. Москва, 1960.

Кулатова І.М. Хрестовидна бляха скіфськоі доби з Енківець у Посуллі // Полтавський археологічний збірник. 1995 . № 3. C. 130-147.

Легенди степу. Фотоальбом. Донецьк, 2004. 104 с.

Лесков А. М. Богатое скифское погребение из Восточного Крыма // СА № 1. 1968. С. 158-166.

Лесков А. М. Новые сокровища курганов Украины. Ленинград, 1972.

Либеров П. Д. Памятники скифского времени на Среднем Дону. Москва, 1965 (САИ; вып. Д1-31).

Максименко В. Е. Савроматы и сарматы на нижнем Дону. Ростов-на-Дону, 1983.

Максимов Е. К., Полесских М.Р. Заметка об акинаках // СА. 1971. № 2. С. 238-242.

Манцевич А.П. Курган Солоха. Публикация одной коллекции. Ленинград, 1987.

Маслов В.Е., Очир-Горяева М. А. Об общих элементах в культуре нижневолжских кочевников и населения Центрального и Восточного Предкавказья в конце VI - начале IV вв. до н. э. // Степь и Кавказ (культурные традиции). Москва, 1997 (Труды ГИМ; вып. 97). С. 62-74.

Медведев А. П. Ранний железный век лесостепного Подонья. Археология и этнокультурная история I тысячелетия до н. э. Москва, 1999.

Медведев А. П. Раскопки Староживотинного могильника скифского времени // Верхнедонской археологический сборник. Вып. 2. Липецк, 2001. С. 4-14.

Медведев А. П. Новая книга о скифских древностях // Вестник Воронежского гос. ун-та. Серия: История. Политология. Социология. 2015. № 4. С. 136-137.

Мелюкова А. И. Вооружение скифов. Москва, 1964 (САИ; вып. Д1-4).

Мелюкова А. И. Скифское искусство звериного стиля // Степи европейской части СССР в скифо-сарматское время. Москва, 1989 (Археология СССР). С. 100-104.

Миллер А. А. Раскопки в районе древнего Танаиса // ИАК. Вып. 35. Санкт-Петербург, 1910. С. 86-130.

Могилов О.Д. Спорядження коня скіфськоі доби у Лісостепу Східної Свропи Европи. Киів; Кам'янець-Подільський, 2008.

Мозолевський Б. М. Товста Могила. Киів, 1979.

Мурзін В., Ролле Р., Супруненко О. Більске Городище. Київ; Гамбург; Полтава, 1999.

Мурзин В. Ю., Шлайфер В.Г. Два необычных акинака из Черкасской области // Восточноевропейские древности скифской эпохи. Воронеж, 2011. С. 109-113.

На краю Ойкумены. Греки и варвары на северному берегу Понта Эвксинского. Москва, 2002.

Національний музей історії України: Фотоальбом. Киів, 2001.

Новичихин А. М. Население Западного Закубанья в первой половине I тысячелетия до н. э. (по материалам погребальных памятников). Анапа, 2006.

Отчет Императорской археологической комиссии (ОАК) за 1876 г. Санкт-Петербург, 1879.

Ольховский В. С., Евдокимов Г.Л. Скифские изваяния VII-III вв. до н. э. Москва, 1994.

Онайко Н. А. Античный импорт в Приднепровье и Побужье в IV-II вв. до н. э. Москва, 1970 (САИ; вып. Д1-27).

Отрощенко В. В. Исследования в Каменко-Днепровском районе Запорожской обл. // Археологические открытия за 1979 г. Москва, 1980. С. 317-318

Отрощенко В.В. Парадный меч из кургана у с. Великая Белозерка // Вооружение скифов и сарматов. Киев, 1984. С. $121-126$.

Островерхов А. С., Охотников С. Б. О некоторых мотивах скифского звериного стиля на памятниках из собрания Одесского археологического музея // ВДИ. 1989. № 2. С. 50-67.

Петренко В.Г. Правобережье Среднего Приднепровья в V-III вв. до н. э. Москва, 1967 (САИ; вып. Д1-4).

Петренко В.Г. Краснознаменский могильник: элитные курганы раннескифской эпохи на Северном Кавказе. Москва; Берлин; Бордо, 2006 (Corpus tumulorum scythicorum et sarmaticorum; т. 1).

Петренко В.Г., Маслов В.Е., Канторович А. Р. Хронология центральной группы курганов могильника Новозаведенное-ІІ // Скифы и сарматы в VII-III вв. до н. э.: палеоэкология, антропология и археология. Москва, 2000. С. $238-248$.

Петренко В.Г., Маслов В.Е., Канторович А. Р. Погребения подростков в могильнике Новозаведенное-ІІ // Древности скифской эпохи. Сб. памяти А.И. Мелюковой. Москва, 2006 (МИАР; вып. 7). С. 399-423.

Петренко В.Г., Маслов В.Е., Канторович А.Р. Некоторые итоги исследования раннескифского могильника Новозаведенное-ІІ в 1991-2003 гг. // Археологические открытия 1991-2004. Европейская Россия. Москва, 2009. C. 225-234.

Полідович Ю. Б. Скіфські хрестоподібні бляхи // Археологія. 2000. № 1. С. 35-48.

Полидович Ю. Б. Структура и символика декора ножен мечей раннескифского времени // Война и военное дело в скифосарматском мире. Материалы междунар. конф., посв. памяти А.И. Мелюковой (Кагальник, 26-29 апреля 2014 г.). Ростов-на-Дону, 2015. С. 153-161.

Посегун А. А. Раскопки кургана Дюнный в Аксайском районе Ростовской области // Археологические записки. Вып. 6. Ростов-на-Дону, 2009. С. 63-73.

Прокопенко Ю. А. Историко-культурное развитие Центрального Предкавказья во второй половине I тыс. до н.э. Ставрополь, 2005.

Пузикова А.И. Курганные могильники скифского времени Среднего Подонья (публикация комплексов). Москва, 2001.

Пьянков А. В. Бронзовый зооморфный наконечник ножен акинака из фондов Краснодарского музея-заповедника // Древности Евразии от ранней бронзы до раннего средневековья. Памяти В.С. Ольховского. Москва, 2005. С. $448-450$.

Савченко Е.И. «Забытый» курган из раскопок П.Д. Либерова // РА. 2001а. № 4 . С. 153-161. 
Савченко Е.И. Могильник скифского времени «Терновое I - Колбино I» на Среднем Дону (погребальный обряд) // Археология Среднего Дона в скифскую эпоху. Труды Потуданской археологической экспедиции ИА РАН, $1993-2000$ гг. Москва, 2001б. С. 53-143.

Савченко Е.И. Вооружение и предметы снаряжения населения скифского времени на Среднем Дону // Труды Донской (Потуданской) археологической экспедиции ИА РАН 2001-2003 гг. Москва, 2004. С. 151-258.

Сиволап М., Шелехань О. Клинкова зброя скіфського часу в зібранні Черкаського краєзнавчого музею // Наукові записки. Вип. 21. Серія Історичні науки. Кіровоград, 2014. С. 209-217.

Скорый С. А., Зимовеи Р. В. Скифские древности Крыма. Материалы одной коллекции. Киев, 2014.

Смирнов К. Ф. Вооружение савроматов. Москва; Ленинград, 1961 (МИА; № 101).

Сокровища курганов Адыгеи. Москва, 1985.

Супруненко О.Б. Кинджал скіфського часу з-під Полтави // Археологічні відкриття в Украіні 2000-2001. Киів, 2002. C. 247-249.

Тереножкин А. И., Ильинская А. И., Черненко Е. В., Мозолевский Б. Н. Скифские курганы Никопольщины // Скифские древности. Киев, 1973. С. 113-186.

Толстой И. И., Кондаков Н.П. Русские древности в памятниках искусства. Вып. 2. Санкт-Петербург, 1889.

Топал Д. А. Акинаки на западных рубежах Скифии. Находки скифских мечей и кинжалов на территории Республики Молдова // Tyragetia. Serie nouă. 2014. Vol. VIII [XXIII], Nr. 1. C. 7-43.

Топал Д. А. Антенны скифских акинаков. Истоки и эволюция // Археология Евразийских степей. 2017. № 3: Эпоха бронзы и ранний железный век. Материалы III междунар. конф. «Ананьинский мир: культурное пространство, связи, традиции и новации». С. 299-353.

Федоров-Давыдов Г. А. Искусство кочевников и Золотой Орды. Москва, 1976.

Хазанов А. М, Шкурко А. И. Социальные и религиозные основы скифского искусства // Скифо-сибирский звериный стиль в искусстве народов Евразии. Москва, 1976. С. 40-51.

Ханенко Б. И., Ханенко В.И. Древности Приднепровья и побережий Черного моря. Вып. II. Киев, 1899.

Ханенко Б. И. и В.П. Древности Приднепровья и побережий Черного моря. Вып. VI. Киев, 1907.

Черненко Е.В. Скифский доспех. Киев, 1968.

Членова Н.Л. Происхождение и ранняя история племен тагарской культуры. Москва, 1967.

Шапошникова О.Г. Погребение скифского воина на реке Ингул // СА. 1970. № 3. С. 208-212.

Шилов В.П. Золотой клад скифского кургана // Археологические раскопки на Дону. Ростов-на-Дону, 1962. С. 52-69.

Шишлов А. В., Федоренко Н.В., Колпакова А. В., Кононенко А.П. Владимировский могильник - новый памятник скифского времени в Цемесской бухте // На юго-восточных рубежах азиатского Боспора. Москва; Новороссийск, 2005. C. 23-30.

Шкурко А. И. Об изображении свернувшегося в кольцо хищника в искусстве лесостепной Скифии // СА. 1969. № 1. C. 31-39.

Шпилев А.Г. Зооморфные украшения скифского времени из Курской области // Древности Днепровского Левобережья от каменного века до позднего средневековья (к 80-летию со дня рожд. А.И. Пузиковой). Курск, 2012 (Материалы и исследования по археологии Днепровского Левобережья; вып. 4). С. 227-240 .

Шрамко Б. А. Бельское городище скифской эпохи (город Гелон). Киев, 1987.

Шрамко Б. А. Розкопки курганів VII-IV ст. до н.е. поблизу Більська // Археологія. 1994. 4. С. 117-133.

Шрамко Б.А., Солнцев Л. А., Фомин Л.Д. Техника обработки железа в лесостепной и степной Скифии // СА. 1963. C. 3-576.

Шрамко И.Б. Роговые наконечники луков с Западного Бельского городища // Археология без границ. Коллекции, проблемы, исследования, гипотезы. Санкт-Петербург, 2015 (Труды Государственного Эрмитажа; т. LXXVII). C. 487-511.

Яковенко Э. В. Предметы звериного стиля в раннескифских памятниках Крыма // Скифо-сибирский звериный стиль в искусстве народов Евразии. Москва, 1976. С. 128-137.

Яиенко И. В. Скифия VII-V веков до н. э. Москва, 1959 (Труды ГИМ; вып. 36).

Borovka G. Scythian Art. London, 1928.

Čugunov K., Parzinger H., Nagler A. Der skythenzeitliche Fürstenkurgan Aržan 2 in Tuva. Mainz, 2010 (Archäologie in Eurasien; 26. Steppenvölker Eurasiens; 3).

Gold der Steppe. Archäologie der Ukraine. Neumünster, 1991.

L' or des Amazones peuples nomades entre Asie et Europe, VIe siècle av. J.-C. - IVe siècle apr. J.-C. : Musée Cernuschi, Musée des arts de l'Asie de la ville de Paris, 16 mars -15 juillet. Paris, 2001.

Leskov A. M. Die Skythischen Kurgane: die Erforschung der Hügelgräber Südrusslands. Zürich, 1974 (Sondernummer of Antike Welt: Zeitschrift für Archäologie und Urgeschichte, Jg. 5).

Leskov A. M. The Maikop Treasure. Philadelphia, 2008.

Motzenbäcker I. Sammlung Kossnierska. Der Digorishen Formenkreis der kaukasishen Bronzezeit. Berlin, 1996.

Ori dei cavalieri delle Steppe. Milano, 2007.

Piotrovsky B., Galanina L., Grach N. Scythian Art. The legacy of the Scythian world: mid- $7^{\text {th }}$ to $3^{\text {rd }}$ century B.C. Leningrad; Oxford, 1986.

Rostovtzeff M. The Animal Style in South Russia and China. Princeton; New York, 1929.

Scythian Gold. Treasures from Ancient Ukraine. New York, 1999.

Vickers M. Scythian Treasures in Oxford. Oxford, 1979. 


\section{КОНИЧЕСКИЕ КУБКИ В АРЕАЛЕ ЧЕРНЯХОВСКОЙ \\ КУЛЬТУРЫ: КОЛЛЕКЦИЯ ИСТОРИЧЕСКОГО \\ МУЗЕЯ И ОТХОДЫ МАСТЕРСКОЙ В КОМАРОВЕ}

\section{О. С. Румянцева}

Среди стеклянных сосудов из ареала черняховской культуры особое место занимают тонкостенные конические кубки, изготовленные в технике свободного выдувания из бесцветного прозрачного стекла высокого качества. Серия находок подобных сосудов хранится в фондах Государственного исторического музея. Они неоднократно рассматривались в публикациях, посвященных различным аспектам изучения черняховской культуры - прежде всего вопросам хронологии и социальной стратификации ее носителей (см., например: Гопкало, 2011. С. 84-85, там же см. ссылки на более раннюю литературу; 2015. С. 69-71; Казанский, 2011. С. 23; Gavritukhin, 2017). Цель данной публикации - их химико-технологическое изучение, результаты которого проанализированы в свете проблем производства черняховских стеклянных сосудов ${ }^{1}$.

Общая характеристика и хронология. Кубок из погребения 23 могильника Одая (ГИМ 111835. Оп. Б2055/102; Средний Днестр, ныне Черновицкая обл. Украины, раскопки Г.Ф. Никитиной - Никитина, 1996) имеет коническое тулово и уплощенное дно, слегка отогнутый наружу и немного прогнутый на середине высоты венчик (рис. 1: 1). Край сбит со стеклодувной трубки и не обработан дополнительно. Высота сосуда - 11,7 см, диаметр края - 8, диаметр дна - 1,3; толщина стенок составляет $0,15-0,2$, придонной части и дна $-0,3-0,5$ см. Стекло бесцветное прозрачное, высокого качества.

Кубок из погребения 19 могильника Журавка Ольшанская (ГИМ 102062. Оп. 1583/40; Среднее Поднепровье, ныне Черкасская обл. Украины, раскопки Э.А. Сымоновича - Сымонович, 1964. Рис. $1: 3)$ имеет коническое тулово и закругленное дно (рис. 1:2). Венчик слегка выгнут наружу в центральной части, край сбит со стеклодувной трубки и не обработан. Высота сосуда - 11,4 см, диаметр края - 7,2. Кубок имеет очень тонкие стенки толщиной около 1 мм и также изготовлен из бесцветного прозрачного стекла высокого качества.

Кубок из погребения 5 Журавки (ГИМ 102069, Оп. Б 1582/89; Сымонович, 1964. Рис. 1: 2), тулово конической формы, с уплощенным дном, слегка прогнутым наружу венчиком и необработанным краем, сколотым со стеклодувной трубки (рис. 1: 3). Основа кубка выполнена из бесцветного прозрачного стекла высокого качества. Сосуд украшен «аркадами» из накладных стеклянных нитей бесцветного и темно-синего прозрачного стекла. В верхней части тулова наложена толстая поперечная нить бесцветного стекла диаметром около 0,4-0,5 cм. Реконструируемая высота сосуда составляет

Результаты анализа химического состава стекла конических кубков (SEM-EDS, аналитик A. A. Трифонов)

По: Румянцева, Трифонов, неопубликованные данные

\begin{tabular}{|c|c|c|c|c|c|c|c|c|c|c|c|c|c|c|c|c|c|c|}
\hline $\begin{array}{c}\text { № } \\
\text { ח/n }\end{array}$ & Шифр & $\begin{array}{c}\text { Место } \\
\text { находки }\end{array}$ & $\begin{array}{c}\text { Цвет, } \\
\text { прозрачность } \\
\text { стекла }\end{array}$ & $\mathrm{Na}_{2} \mathrm{O}$ & MgO & $\mathrm{Al}_{2} \mathrm{O}_{3}$ & $\mathrm{SiO}_{2}$ & $\mathrm{P}_{2} \mathrm{O}_{5}$ & $\mathrm{SO}_{3}$ & $\mathrm{Cl}$ & $\mathrm{K}_{2} \mathrm{O}$ & $\mathrm{CaO}$ & $\mathrm{TiO}_{2}$ & MnO & $\mathrm{Fe}_{2} \mathrm{O}_{3}$ & $\mathrm{SnO}_{2}$ & $\mathrm{Sb}_{2} \mathrm{O}_{5}$ & $\mathrm{PbO}$ \\
\hline 1 & Од-1 & $\begin{array}{l}\text { Одая, } \\
\text { погр. } 23\end{array}$ & б/ц прозр. & 20,32 & 0,61 & 1,99 & 66,28 & $<0,1$ & 0,15 & 1,27 & 0,31 & 5,14 & $<0,1$ & 0,95 & 0,44 & $<0,1$ & $<0,3$ & $<0,1$ \\
\hline 2 & Жур-2а & $\begin{array}{l}\text { Журавка, } \\
\text { погр. } 5\end{array}$ & б/ц прозр. & 19,34 & 0,59 & 1,91 & 66,53 & $<0,1$ & 0,22 & 1,21 & 0,35 & 5,86 & $<0,1$ & 1,12 & 0,44 & $<0,1$ & $<0,3$ & $<0,1$ \\
\hline 3 & Жур-3 & $\begin{array}{c}\text { Журавка, } \\
\text { погр. } 19\end{array}$ & б/ц прозр. & 19,13 & 0,72 & 2,06 & 67,20 & $<0,1$ & 0,11 & 1,17 & 0,31 & 5,48 & $<0,1$ & 0,92 & 0,45 & $<0,1$ & $<0,3$ & $<0,1$ \\
\hline \multicolumn{4}{|c|}{ Среднее значение } & 19,60 & 0,64 & 1,99 & 66,67 & $<0,1$ & 0,16 & 1,21 & 0,33 & 5,49 & $<0,1$ & 1,00 & 0,44 & $<0,1$ & $<0,3$ & $<0,1$ \\
\hline
\end{tabular}

Примечание: данные в масс. \% оксидов, для хлора - в масс. \%.

\footnotetext{
1 Выражаю благодарность научному сотруднику отдела исторических памятников Государственного исторического музея Г. А. Камелиной за возможность ознакомиться с коллекцией стекла черняховской культуры.
} 
около 16 см, диаметр края - около 10 , диаметр дна - 1,5. Толщина стенок - около 0,2 cм.

В ареале черняховской культуры наиболее архаичные конические кубки - невысокие (10-15 см) и не имеющие декора - синхронизируются с центральноевропейскими фазами С3 и D1, распространяясь не ранее второй четверти, или, вероятнее, середины IV в. (Казанский, 2011. С. 23; Гопкало, 2011. С. 84-85; Gavritukhin, 2017). Именно к таким формам относятся сосуды из погребения 23 могильника Одая (его форма наиболее архаична) и погребения 19 в Журавке (рис. 1: 1, 2). Кубки крупных размеров (высотой более 16 см), в том числе декорированные аркадами синего стекла к этой группе принадлежит находка из погребения 5 Журавки (рис. 1: 3), относятся большинством исследователей к горизонту эпохи Великого переселения народов (Гавритухин, 2007; Гопкало, 2011; Gavritukhin, 2017. Fig. 14: 47, 48 и др.), хотя некоторые специалисты не исключают для них и более раннюю дату (Казанский, 2011. С. 23). Присутствие стеклянного кубка в захоронении считается маркером высокого социального статуса погребенного (Гопкало, 2011. С. 71).

Технологические особенности. Описанные кубки объединяет серия общих технологических признаков, среди которых необработанный край венчика, сбитый со стеклодувной трубки; выделенный переход от венчика к тулову и слегка прогнутый наружу, примерно на середине высоты, венчик (рис. 1: 1a-3a); дно без следа понтии. Эти признаки свидетельствуют об определенной традиции изготовления сосудов - без применения понтии для оформления венчика и обработки его края (Amrein, 2001. P. 22; fig. 12: 2). В этом случае верхняя часть сосуда формовалась, пока мастер удерживал его на стеклодувной трубке, после чего сбивалась по заранее намеченной линии (рис. 2: I); край мог затем быть подшлифован или оставлен без обработки: скол в подобных случаях получался очень ровный (Fünfschilling, 2015. S. 54; Abb. 44: 1-8, 13).

В противоположность описанной практике, в случае использования понтии - железного стержня, который крепился к дну, - верхняя часть сосуда формовалась в горячем состоянии. Удерживая заготовку сосуда (баночку) на стеклодувной трубке, стеклодув или его помощник крепил понтию к ее противоположной стороне - будущему дну. Затем заготовка отделялась от стеклодувной трубки, и дальнейшую работу мастер проводил, держа сосуд на понтии, в горячую формуя его верхнюю часть и оплавляя край, по мере необходимости подогревая заготовку в камере печи. В случае использования данного инструмента в центре на дне сосуда остается след в виде углубления, колечка или небольшого налепа (Fünfschilling, 2015. S. 43, 54; Abb. 33; 44: 9-12).

Диагностические отходы производства и возможная продукиия мастерской в Комарове. Применение техники изготовления выдувных сосудов без использования понтии хорошо выявляется не только по готовым изделиям, но и по 

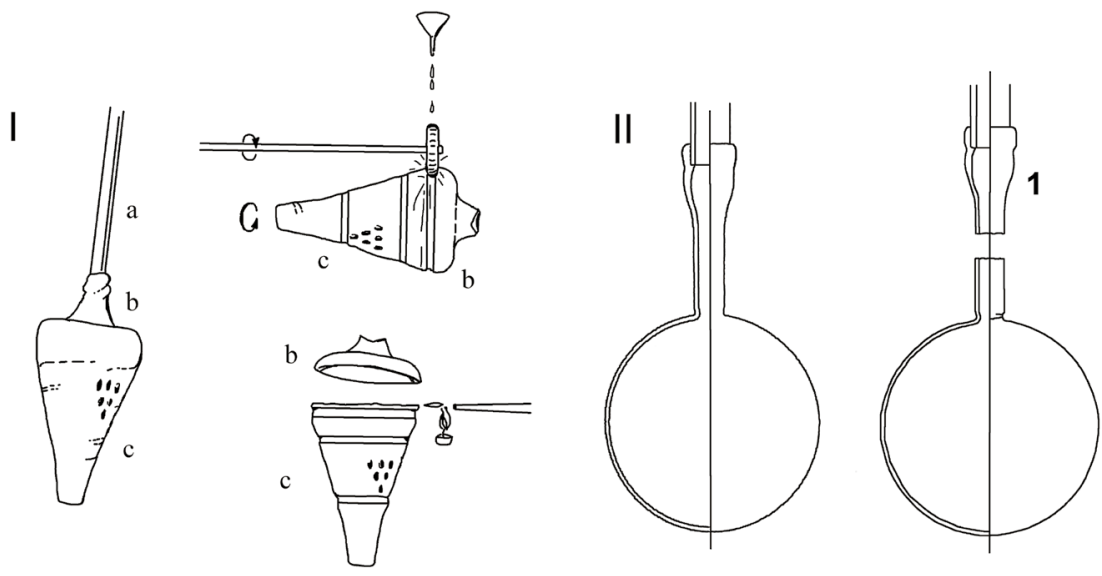

III
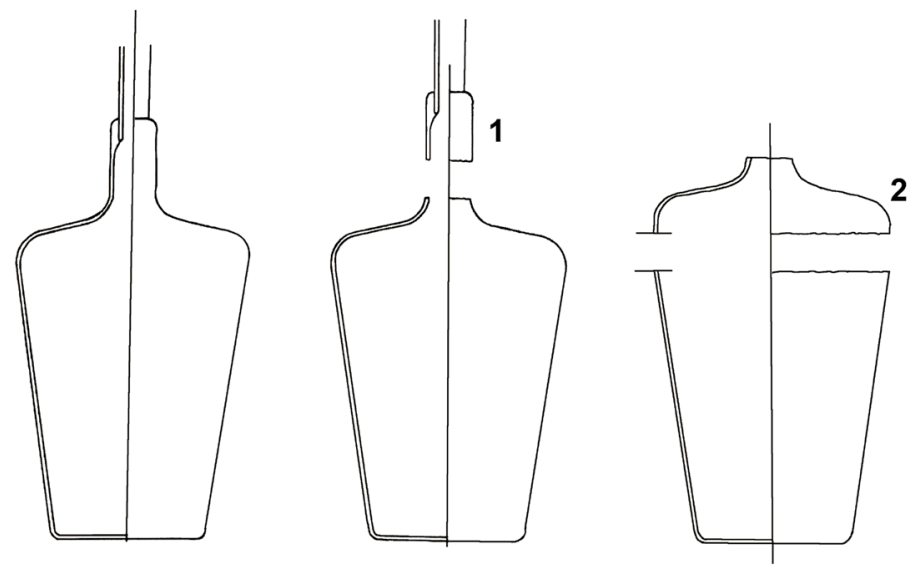

Рис. 2. Приемы изготовления выдувных сосудов и характерные отходы производства. I - схема изготовления выдувного сосуда без горячего формования и обработки края (по: Weinberg, Goldstein, 1988);

II, III - схемы образования колпачков различных типов при отделении сосуда от стеклодувной трубки: 1 - цилиндрические колпачки;

2 - сферические/воронкообразные колпачки (по: Amrein, 2001. Fig. 12) диагностическим и может получаться при использовании любой из двух техник (Amrein, 2001. P. 22; fig. 12: 1; 14, 15) (рис. 2: II, 1; III, 1, 2).

Колпачки обеих форм и цилиндрической, и полусферической/воронкообразной - обнаружены на поселении черняховской культуры Комаров на Среднем Днестре, на котором изучена единственная за пределами Римской империи стеклоделательная мастерская позднеримского времени (см., например: Смішко, 1964; Щапова, 1978)². Из 182 находок 47 представлены фрагментами воронкообразных колпачков (рис. 3), которые составляют более четверти от общего количества этого вида отходов. Эти данные существенно дополняют сведения об основных видах продукции мастерской в Комарове - ранее к ним относились прежде всего чаши или кубки с оплавленным краем (Щапова, 1978; 1983. Рис. 39: 2-4, 6, 8, 19, 20), близкие типу Is-42, 85 / AR 80-82, 98, 103 (Isings, 1957; Rutti, 1991;

специфическим отходам, встречающимся среди материалов стеклодувных мастерских. Диагностическим в этом случае является колпачок - излишек стекла, который оставался на стеклодувной трубке после отделения от нее заготовки сосуда (рис. 2: II, 1; III, 1, 2). Его часть, наиболее удаленная от инструмента, имеет в этом случае форму, близкую к полусферической или воронкообразной (рис. 2: III, 2) (Amrein, 2001. P. 22; fig. 12: 2). Край при этом получается очень прямой и ровный, а его диаметр соответствует диаметру края сосуда. В случае если использовалась понтия, колпачки имеют форму, близкую цилиндрической, а их диаметр примерно соответствует диаметру стеклодувной трубки (рис. 2: II, 1). Этот тип колпачков не является
Fünfschilling, 2015), находки которых действительно наиболее массово представлены на поселении (доля венчиков с оплавленным краем составляет почти половины верхних частей сосудов из коллекции), и среди них есть экземпляры с производственным браком (Rumyantseva, Belikov, 2017. P. 260).

Наличие воронкообразных колпачков означает, что по меньшей мере часть продукции мастерской составляли сосуды, формовавшиеся без использования понтии, с необработанным или подшлифованным, а не оплавленным краем. Край сохранился у 13 колпачков данного типа, и в ряде случаев по ним удается определить диаметр краев сосудов - у большинства он составляет 9-12 см, а толщина стенок колеблется

\footnotetext{
2 Все данные по Комаровскому поселению приведены в данной публикации на основе изучения коллекции стекла из раскопок М. Ю. Смишко 1956-1969 гг., хранящейся в фондах Института украиноведения НАН Украины. Выражаю благодарность В.Н. Войнаровскому, А. С. Сытнику и Н. С. Бандривскому за любезно предоставленную мне возможность работы с данной коллекцией.
} 
от 0,15-0,2 до 0,3-0,4 (рис. 3). Преобладающий цвет стекла таких колпачков - оливковый прозрачный, однако среди них немало экземпляров стекла бесцветного или имеющего зелено-голубой или светло-зеленый оттенок.

Судя по перечисленным признакам, конические кубки - один из наиболее вероятных видов продукции мастерской в Комарове. Учитывая довольно большой диаметр края - 9-12 см, на эту роль претендуют в первую очередь поздние формы больших размеров, производившиеся, предположительно, в эпоху Великого переселения народов.

Морфологически определимые фрагменты, которые могли принадлежать коническим кубкам, в коллекции комаровского стекла немногочисленны. Это небольшая серия венчиков с необработанным краем, по форме типичным для сосудов данного типа (хотя и не только для них) (рис. 4: 1-6), а также стенки с прошлифованным линейным декором (рис. 4: 7-9), которые могли
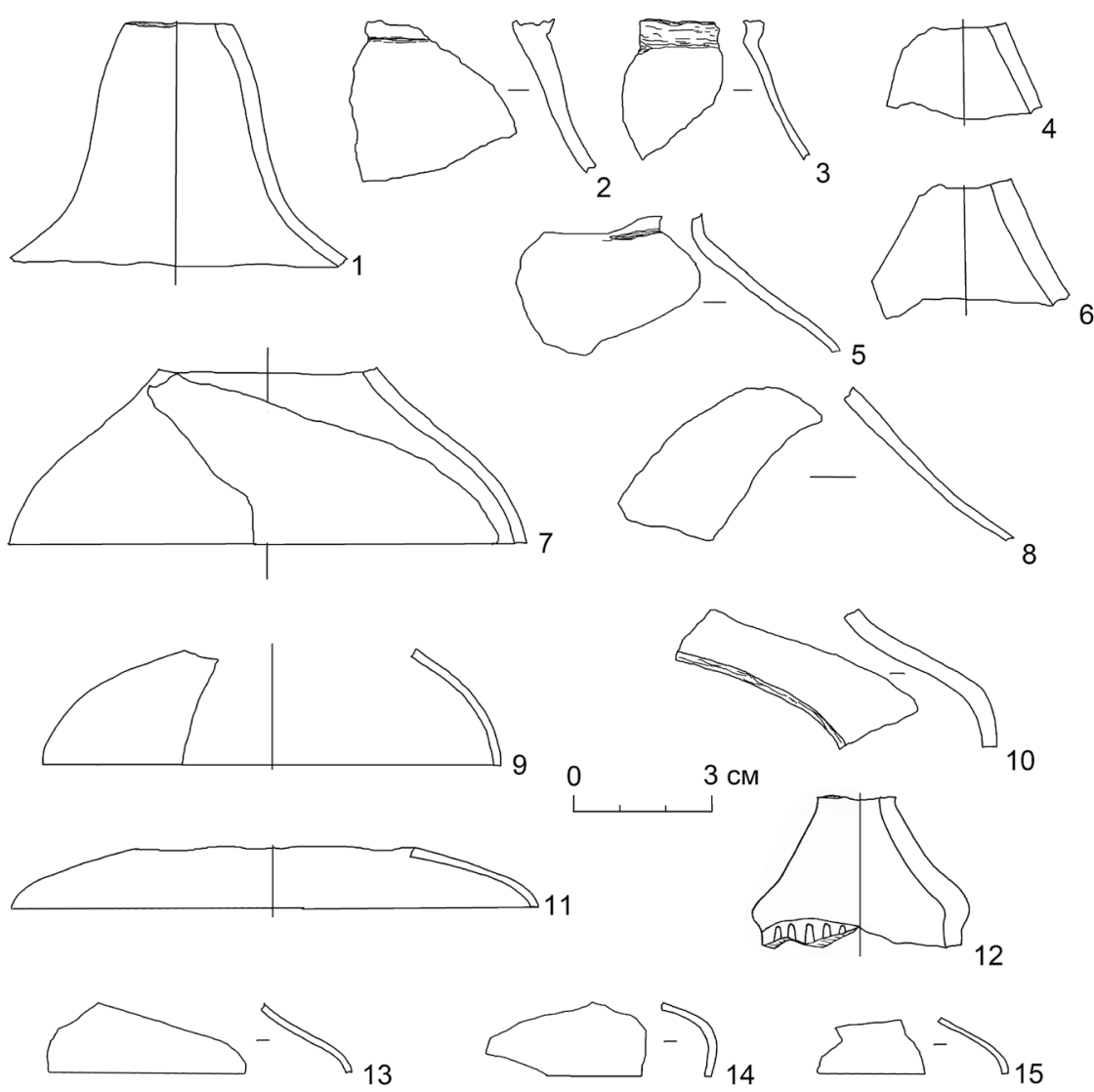

Рис. 3. Примеры отходов стеклодувного производства - колпачов с поселения Комаров, свидетельствующие о производстве сосудов без горячей обработки края. 1 - 1957 г., раскоп III, кв. А-24, гл. 0,4м; 2-1956 г., раскоп I, кв. К-27, гл. 0,4 м; 3, 13, 15 - 1965 г., раскоп V, кв. Б-22, пласт 3 (у стеклоделательной печи); 4, 6, 7, 10 - без адреса; 5, 8 - 1957 г., раскоп III, кв. Б-33, пласт 4; 9, 11 - 1965 г., раскоп V, кв. Б-12-16, пласт 4 (недалеко от стеклоделательной печи); 12 - 1957 г., раскоп III, кВ. В-48, пласт 3; 14 - 1965 г., раскоп V, кв. Б-11, 13, 26, пласт 3; кв. Б-14, 18, пласт 4 (недалеко от стеклоделательной печи). Рисунки А. М. Ефремовой, О. С. Румянцевой относиться к кубкам типа 47f по Л. Баркоци (Barcóczi, 1988. S. 85), или Гавриловка-35 по системе Г. Рау (Rau, 1972; Румянцева, 2014. C. 410; рис. 8: 104106). Однако продукция мастерской совершенно необязательно должна быть массово представлена находками на памятнике: большая часть ее, вероятно, вывозилась отсюда, а использованное в быту стекло собиралось для вторичного применения в производстве. Именно стеклобоем, предназначенным для вторичной переработки, представлено, вероятно, значительное (если не большинство) происходящих с памятника находок (Румянцева, 2016, 2017б). Производственный брак также мог на месте подвергаться вторичной переработке: в Комарове он представлен единичными фрагментами сосудов.

Нужно отметить, что в целом именно при производстве кубков техника формования

выдувных сосудов без применения понтии практиковалась наиболее широко. Х. Амрайн, отмечая принадлежность характерных для нее колпачков преимущественно к производственным комплексам IV в., предполагала их связь с произошедшими в этот период технологическими изменениями, выразившимися, в частности, в распространении производившихся таким образом конических кубков (Amrein, 2001. Р. 32). При этом нужно учитывать, что применение той или иной техники может быть обусловлено не только хронологической, но и региональной спецификой. В частности, для территории Северо-Западной Швейцарии наличие необработанного края характерно для кубков на протяжении I-IV вв., хотя сосуды этой категории с оплавленным краем спорадически появляются - например, 
во II-III вв. (Fünfschilling, 2015. S. 54). Отсутствие горячей обработки края характеризует и некоторые другие формы, например, ранние формы бальзамариев, некоторые бутыли и пр. (Fünfschilling, 2015. S. 54, 55).

Какие еще виды сосудов, имеющих необработанный край, могли бы быть среди продукции мастерской в Комарове, кроме конических кубков? К этой группе безусловно относится посуда с «оптическим» декором: факт ее производства здесь подтверждается находками на поселении рифленых форм для ее изготовления, а также колпачком с участком рифленого декора (рис. 3: 12) (Румянцева, 2017a). Венчики рифленых сосудов, обнаруженные на поселении, имеют края без признаков горячей обработки: у тонкостенных сосудов они сбиты со стеклодувной трубки и не обработаны (рис. 4: 11), у толстостенного край тщательно зашлифован (рис. 4: 12).

Начиная со второй половины или, скорее, последней трети/конца III в., на территории Римской империи распространяется еще один тип сосудов - чаши типа Is 96 / AR 60, имеющие сферическую форму и вертикальный, как правило, слегка прогнутый наружу венчик с краем, сбитым со стеклодувной трубки. Они становятся особенно популярны в Империи в IV в. (Isings,1957. P. 113, 114; Rütti, 1991; Fünfschilling, 2015. S. 330-332). В ареале черняховской культуры они практически не получили распространения. Единичные фрагменты подобных форм обнаружены на поселении Комаров (рис. 4: 10), однако нужно учитывать, что многие находки здесь представляют собой стеклобой, предназначенный для вторичного использования в производстве, в том числе, вероятно, и привозной (Румянцева, 2017б). В качестве редких находок в ареале культуры встречается поздняя разновидность этой формы с декором синими налепами (Сымонович, 1964. Рис. 1: 1; Шультце, Любичев, 2012. С. 411; рис. 4: 6; Gavritukhin, 2017, fig. 14: 7), однако это, вероятнее всего, импортные образцы (Gavritukhin, 2017), происхождение которых вряд ли стоит связывать с мастерской в Комарове, хотя с формальной точки зрения это невозможно и полностью исключить: продукция данного типа не оставляет специфических отходов, которые могли бы указывать на ее локальное производство.

Прочие формы тонкостенной выдувной посуды не получают широкого распространения в ареале черняховской культуры. Конические кубки, таким образом, можно считать в числе одного из наиболее вероятных видов продукции мастерской в Комарове. Для уточнения хронологии мастерской важно, что все перечисленные выше сосуды, выполненные без использования понтии, которые могли бы, следовательно, производиться в Комарове, датируются не ранее IV в. (преимущественно - начиная с середины столетия). Таким образом, еще на основании одного источника подтверждается уточненная нами ранее дата мастерской - не ранее середины IV - начало V в. ${ }^{3}$ (Румянцева, Щербаков, 2016; Румянцева, 2017a, б).

Химический состав стекла. Все три рассматриваемых здесь кубка выполнены из бесцветного стекла высокого качества, состав которого отличается низким содержанием нежелательных примесей: алюминия (около $2 \%)$, железа $(0,44 \%)$, титана (менее $0,1 \%$ ), а также кальция $(5,49 \%)$, при высокой концентрации натрия (19,6\%) (см. таблица 1). В качестве обесцвечивателя использован марганец. Стекло подобного состава ассоциируется с серией 3.2 (Foy et al., 2003), распространенной на широкой территории, включающей Западную Европу, Балканы и Северную Африку (Schibille et al., 2017; Cholakova, Rehren, 2018)4. В настоящее время нижняя хронологическая граница распространения стекла, относящегося по составу к серии 3.2 , широко определяется IV в. (Cholakova, Rehren, 2018) ${ }^{4}$. Бесцветное стекло, напоминающее своим видом горный хрусталь, особенно ценилось в Римской империи в рассматриваемый период, и именно оно шло на производство престижных категорий стеклянной посуды, часто украшавшейся также шлифованным декором (Jackson, 2005. P. 763). До конца III - первой половины IV в. римские мастера использовали с этой целью стекло состава, очень близкого рассматриваемому, но обесцвеченное сурьмой (группа 4 по: Foy et al., 2003) - оно имело наивысшее качество среди бесцветного прозрачного материала, доступного стеклоделам этой эпохи (среди многих публикаций см., например: Foster, Jackson, 2010).

Считается, что производством стекла обеих групп (серии 3.2 и группы 4) занимались центры, работающие на сырье из одного или географически близких регионов, которые в IV в. из-за проблем со снабжением сурьмой вынуждены были перейти на менее эффективный

\footnotetext{
3 О хронологии посуды с рифленым декором см. Румянцева, 2017a.

4 Ранее стекло подобного состава ассоциировалось также с группой НІМТ2, однако впоследствии исследователями обоснован тезис о разном геохимическом происхождении стекла серии 3.2 и HIMT (Cholakova et al., 2016).
} 
обесцвечиватель - марганец (Schibille et al., 2017; см. также Cholakova, Rehren, 2018). Эти центры экспортировали свою продукцию в форме стекла-сырца на широком пространстве Римской империи, снабжая сырьем мастерские по производству готовых изделий (ссылки по теме см. Румянцева, 2011, 2015). Ранее для стекла с подобными геохимическими характеристиками предполагалось сиро-палестинское происхождение (Foy et al., 2003), однако на сегодня наиболее вероятным представляется египетское (Rosenow, Rehren, 2014; Schibille et al., 2017; Cholakova, Rehren, 2018).

Стекло-сырец обеих групп - обесцвеченное сурьмой (группа 4) и марганцем (серия 3.2) встречено на поселении Комаров, куда оно поступало в виде полуфабрикатов, на которых работала мастерская (Румянцева, Щербаков, 2016) ${ }^{5}$. Изучение состава стекла кубков из ареала черняховской культуры показало, что стекло этих составов использовалось в производстве наиболее «престижных» типов кубков позднего этапа черняховской культуры - Straume-VII, VIII и конических, и в еe ареале верхняя граница распространения стекла, обесцвеченного сурьмой, определяется второй половиной или концом IV - V в. (Rumyantseva et al., in print). На материалах черняховской культуры хронологическую преемственность группы 4 и серии 3.2 установить не удается - складывается впечатление, что во второй половине IV - начале V в. они сосуществовали. Для рассматриваемого сюжета важно, что наличие сырца серии 3.2 среди материалов Комарова является дополнительным подтверждением того, что в существовавшей здесь мастерской могли производиться, среди прочего, и конические кубки.
Итоги. Проведенный анализ говорит о том, что конические стеклянные кубки, находимые в ареале черняховской культуры, в первую очередь высокие формы, характерные для эпохи Великого переселения народов, могли быть среди продукции Комаровской стеклоделательной мастерской на Среднем Днестре или аналогичных ей центров, которые, возможно, существовали в ареале черняховской культуры в синхронное время. Это подтверждается данными технологического анализа кубков и одновременно отходов стеклодувного производства с поселения Комаров. Обнаруженные здесь

\footnotetext{
5 Стекло-сырец серии 3.2 из Комарова в данных публикациях ассоциировано с группой НІМТ 2 (см. сноску 4).
} 
колпачки - отход производства, маркирующий применение техники изготовления сосудов без использования понтии. Производимые подобным способом формы, как конические кубки, так и другие, типичны для позднего этапа черняховской культуры (начиная с IV в., вероятнее всего, не ранее его середины). Таким образом, полученный вывод - еще один независимый аргумент в пользу отнесения мастерской именно к этому периоду, подтверждая ранее полученные нами выводы о хронологии существовавшего здесь стеклоделательного комплекса (Румянцева, Щербаков, 2016; Румянцева, 2017а, б). Сравнительное изучение состава стекла кубков и полуфабрикатов (стекла-сырца) с поселения Комаров также подтверждают такую возможность. Вероятное применение мастерами в Комарове двух различных практик изготовления стеклянных сосудов - при помощи понтии и без нее - свидетельствуют, скорее всего, о существовании по меньшей мере двух этапов ее активности. Рассмотренный сюжет иллюстрирует тезис о производстве на позднем этапе существования мастерской престижных категорий сосудов для социальной верхушки черняховского общества, к которым относились конические кубки, сделанные из бесцветного стекла высокого качества.

\section{Литература}

Гавритухин И. О. Днепровское лесостепное Левобережье. Финал черняховской культуры // Восточная Европа в середине І тысячелетия н. э. / Отв. ред. И. О. Гавритухин, А. М. Обломский (Раннеславянский мир. Вып. 9). М.: ИА РАН, 2007. C. $9-23$.

Гопкало О.В. Относительная хронология мужских погребений черняховской культуры. К постановке проблемы // Черняхівська культура: матеріали досліджень / Ред. О.В.Петраускас, Р. Г. Шишкин. (ОIUM. № 1). Київ; Луцьк: IА НАН України; IIО НПУ ім. М.П. Драгоманова, 2011. С. 66-96.

Гопкало О. В. Стеклянные изделия в ареале культуры Сынтана-де-Муреш/Черняхов (социологический аспект) // Стекло Восточной Европы с древности до начала ХХ в. / Отв. ред . П.Г. Гайдуков. СПб.: Нестор-История, 2015. С. 65-81.

Казанский М. М. Радагайс и конец черняховской культуры // Черняхівська культура: матеріали досліджень / Ред. О.В. Петраускас, Р.Г. Шишкин. (ОIUМ. № 1). Київ; Луцьк: IA НАН України; ІІО НПУ ім. М.П. Драгоманова, 2011. С. 22-32.

Никитина Г. Ф. Могильники черняховской культуры в Северной Буковине и Бессарабии. М.: Наука, 1996. 181 с.

Румянцева О.С. Стеклоделательное производство в римское время и эпоху раннего средневековья: источники, факты, гипотезы // РА. 2011. № 3. С. 86-97.

Румянцева О.С. Стеклянные сосуды со шлифованным декором и хронология поселения Комаров // Проблемы взаимодействия населения Восточной Европы в эпоху Великого переселения народов / Отв. ред. А. М. Обломский (Раннеславянский мир. Вып. 15). М.: Издательство ИА РАН, 2014. С. 401-427.

Румянцева О.С. Стекло I тыс. н. э.: происхождение и распространение по данным химического состава и изотопного анализа // КСИА. 2015. Вып. 237. С. 20-49.

Румянцева О.С. Литое стекло с поселения черняховской культуры Комаров: престижная посуда или сырье стеклоделательной мастерской? КСИА. 2016. Вып. 245. Ч. 1. С. 203-218.

Румянцева О.С. Рифленые формы и находки рифленого стекла с поселения черняховской культуры Комаров: к вопросу о хронологии и видах продукции стекольной мастерской // Европа от Латена до Средневековья: варварский мир и рождение славянских культур: К 60-летию А.М. Обломского (Раннеславянский мир. Вып. 19) / Отв. ред. В.Е. Родинкова, О.С. Румянцева. М.: ИА РАН, 2017а. С. 193-204.

Румянцева О.С. Стеклоделие за лимесом: новые данные об организации производства и хронологии мастерской в Комарове // Stratum plus. 2017б. № 4. C. 141-164.

Румянцева О. С., Щербаков И. Б. Стекло-сырец с поселения Комаров на Среднем Днестре: химический состав и данные о характере и хронологии стеклоделательного комплекса позднеримского времени // Stratum plus. 2016 . № 4. C. 299-315.

Смішко М. Ю. Поселення III-IV ст. н.е. із слідами скляного виробництва біля с. Комарів Чернівецької області // МДАПВ. 5. Київ., 1964. С. 67-80.

Сымонович Э. А. Стеклянные кубки из Журавки // КСИА. Вып. 102. М.: Наука, 1964. С. 8-12.

Шультие Э., Любичев М.В. Хронология могильника черняховской культуры Войтенки 1 (Восточная Украина) (по материалам раскопок 2005-2009 гг.) // Лесная и лесостепная зоны Восточной Европы в эпохи римских влияний и Великого переселения народов. Конференция 3 / Под ред. А. М. Воронцова, И. О. Гавритухина. Тула: Гос. музейзаповедник «Куликово поле, 2012. С. 409-463.

Щапова Ю.Л. Мастерская по производству стекла у с. Комарово (III-IV вв.) // СА. 1978. №3. С. 230-242.

Щапова Ю.Л. Очерки истории древнего стеклоделия (по материалам долины Нила, Ближнего Востока и Европы. М.: Изд-во Московского университета, 1983. $200 \mathrm{C}$. 
Amrein H. L' atelier de verriers d'Avenches: l'artisanat du verre au milieu du Ier siècle apres J.-C. // Cahiers d'archéologie romande. N 87. Aventicum XI. Lausanne, 2001.174 p.

Barkóczi L. Pannonische Glassfunde in Ungarn. Studia archaeological IX. Budapest: Aedes Akademiae Scientiarum Hungarucae, 1988. 223 S., 117 Taf.

Cholakova A., Rehren Th., Freestone I. C. Compositional identification of 6th c. AD glass from the Lower Danube // JAS: Reports. 2016. Nr. 7. P. 625-632.

Cholakova A., Rehren Th. A Late Antique manganese-decolourised glass composition: interpreting patterns and mechanisms of distribution // Things that Travelled: Mediterranean Glass in the First Millennium CE / D. Rosenow, M. Phelps, A. Meek, I. Freestone (eds.). London: UCL Press. P. 46-71.

Foster H.E., Jackson C.M. The composition of late Romano-British colourless vessel glass: glass production and consumption // JAS. 2010. Vol. 37. P. 3068-3080.

Foy D., Picon M., Vichy M., Thirion-Merle V. Caractérisation des verres de la fin de l'Antiquité en Méditerranée occidentale: l'émergence de nouveaux courants commerciaux // Échanges et commerce du verre dans le monde antique. Actes du colloque de l'Association française pour l'archéologie du verre. Aix-en-Provence et Marseille, 7-9 juin 2001 / D. Foy, M.-D. Nenna (eds.). Montagnac : Éditions Monique Mergoil. P. 41-85.

Fünfschilling S. Die römischen Gläser aus Augst and Kaiseraugst. Kommentierter Formenkatalog und ausgewählte Neufunde 1981-2010 aus Augusta Raurica (Forschungen in Augst 51). Augst: Museum Augusta Raurica, 2015. 708S.

Gavritukhin I. Glass vessels of the final of the Chernyakhov culture // Na hranicích impéria - Extra fines imperii. Jaroslavu Tejralovi k 80. narozeninám. Brno: Masarykova univerzita; Archeologický ústav Akademie věd, ČR, Brno, v.v.i.: Munipress, 2017. P. 83-109.

Isings C. Roman Glass from Dated Finds. Groningen / Djakarta: J.B. Wolters, 1957. 185 p.

Jackson C.M. Making colourless glass in the Roman period // Archaeometry. 2005. Vol. 47 (4). P. 763-780.

Rau G. Körpergräber mit Glasbeigaben des 4. nachchristlichen Jahrhunderts im Oder-Weichsel-Raum // Acta praehistorica et archaeologica. 1972. Nr 3. Berlin. S. 109-214.

Rosenow D., Rehren Th. Herding cats - Roman to Late Antique glass groups from Budastis, northern Egypt // JAS. 2014. Vol. 49. P. 170-184.

Rumyantseva O., Belikov C. A Late Roman Glass Workshop at Komarov (Middle Dniester) and the Problem of the Origin of 'Barbarian' Facet Cut Beakers // Annales du 20e Congrès de l'Association Internationale pour l'Histoire du Verre / Ed. S. Wolf, A. de Pury-Gysel. Romont: Verlag Marie Leidorf GmbH, 2017. P. 257-264.

Rumyantseva O., Lyubichev M., Petrauskas O., Chervyakovskaya M., Khanin D., Trifonov A. 'Barbarian' beakers with facet cut decoration: composition, origin, social and cultural context // Annales du 21e Congrès de l'Association Internationale pour l'Histoire du Verre. Istanbul. In print.

Rütti B. Die römischen Gläser aus Augst und Kaiseraugst (Forschungen in Augst 13/1, 2). Augst: Römermuseum, 1991. Bd. 1: 370 S., 276 Abb., 61 Tab.

Schibille N., Sterrett-Krause A., Freestone I. C. Glass groups, glass supply and recycling in late Roman Carthage // Archaeological and Anthropological Sciences. 2017. Vol. 9 (6). P. 1223-1241.

Weinberg G.D., Goldstein S. M. The Glass Vessels // Excavations at Jalame, Site of a Glass Factory in Late Roman Palestine / Ed. Weinberg G. D. Columbia: University of Missouri Press, 1988. P. 38-102 


\section{ВПУСКНЫЕ КОЧЕВНИЧЕСКИЕ ПОГРЕБЕНИЯ \\ XII-XIII ВВ. В КУРГАНАХ КЕРЧЕНСКОГО \\ ПОЛУОСТРОВА, ИССЛЕДОВАННЫЕ В 2017 Г.}

\section{М. Ю. Меньшиков, И.В.Рукавишникова, \\ Н. Ю. Горболь, Ж. А. Юнкин}

В ходе спасательных археологических работ в Крыму в 2017 г. на Керченском п-ове исследовано три комплекса средневековых кочевнических погребений, содержавших четыре ингумации (рис. 1). В кургане 3 курганной группы Фонтан 1 обнаружены парное погребение мужчины и женщины и конструкция, перекрывавшая фрагменты человеческих костей (рис. 2). В кургане 2 курганной группы Фонтан 2 расчищено одиночное мужское погребение (рис. 3). В кургане 1 группы (из трех курганов) Ивановка найдено женское погребение с «чучелом» коня (рис. 4).

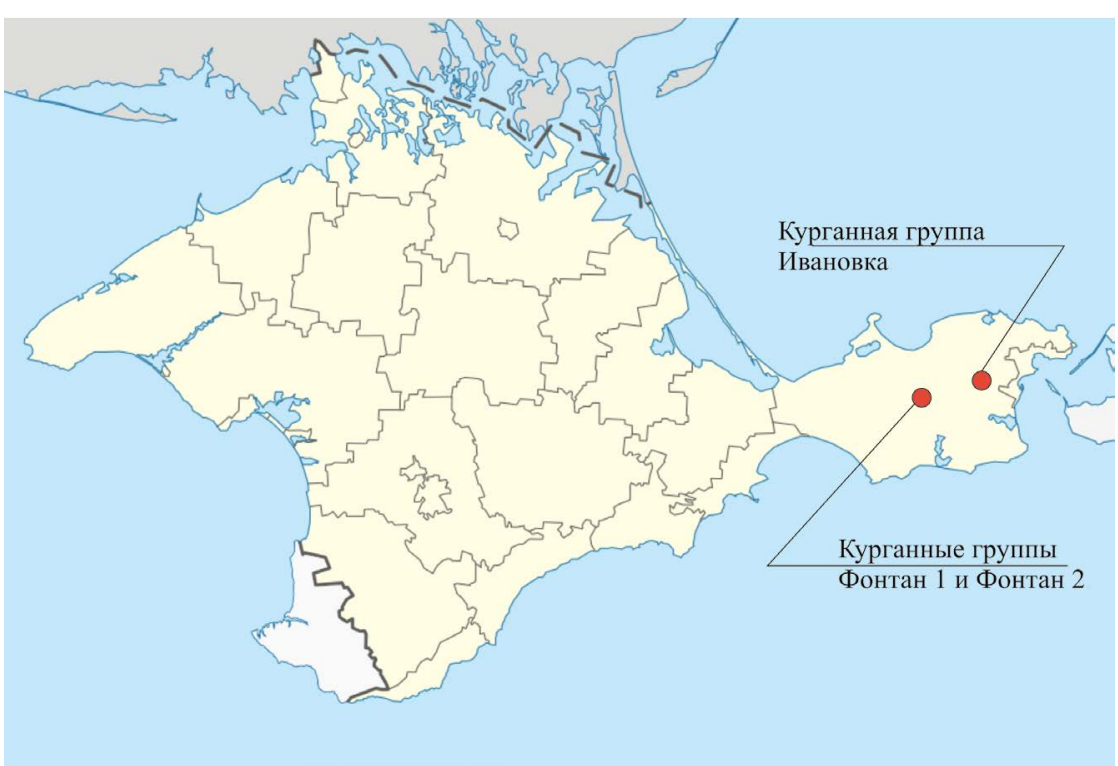

Рис. 1. Схема Крымского полуострова с размещением памятников

Все исследованные комплексы были впущены или пристроены к ранее существовавшим курганам, в основе которых лежали погребения бронзового века. Помимо традиционного инвентаря, характерного для захоронений этой эпохи, надмогильные конструкции имеют необычную каменную архитектуру, позволяющую предварительно выделить некий локальный вариант погребальных сооружений в регионе. Аналогии обнаруженной погребальной архитектуры авторам неизвестны. Несмотря на то что все исследованные захоронения впускные или пристроены к более ранним курганам эпохи бронзы, средневековые погребальные сооружения играют важную роль в облике кургана, и изменения, связанные с привнесенной средневековой архитектурой, могут служить хроноиндикаторами при определении датировок еще не исследованных археологическими раскопками погребальных памятников.

Наиболее яркий и хорошо сохранившийся погребальный комплекс исследован в кургане 3 курганной группы Фонтан 1.
К существовавшей в эпоху бронзы сложной архитектурной конструкции, перекрытой курганом, с юга были пристроены две параллельных линии из камней, выполненные в технике постелистой кладки (рис. 2). Длина этих кладок - около 14 м. Расстояние между ними - около 7 м. Между линиями камней обнаружено два погребения (№ 4 и 5). К востоку от восточной линии камней расчищено два небольших каменных заклада размерами $100 \times 100$ и $100 \times 140$ см. Под ними найдены фрагменты костей человека. В совокупности это представляло собой единовременный погребальный средневековый комплекс.

Погребение 4. В южной части погребальной конструкции между параллельными каменными стенами было расположено погребение 4 (рис. 5). Перекрытие погребения представляет собой массив плотно уложенных необработанных камней размером до $20 \mathrm{~cm}$. Сложенные камни образуют подовальную в плане конструкцию, сплошь заполненную камнем. Размеры конструкции $-270 \times 50-70$ см. В западной части перпендикулярно длинной оси перекрытия 
лежит одиночный каменный блок. Размеры блока - около $50 \times 30 \times 20 \mathrm{~cm}$. После снятия камней закладки расчищено еще одно скопление камней более крупного размера, которое находилось в западной части ямы и перекрывало только грудь погребенной. Помимо скопления камней под закладом выявлены следы деревянных тонких плах, вытянутых по длинным краям могильной ямы и фактически маркирующих ее границы на уровне погребения. Само погребение было совершено вытянуто на спине, головой на запад с незначительным отклонением к югу. Руки сложены вдоль тела, кости правой руки скелета повреждены землероями и перемещены. Инвентарь погребения представлен двумя кольцевыми бронзовыми серьгами или височными кольцами. Правая серьга разрушена землероями. В районе пояса на костях прослежены остатки железного шила (рис. 6).

Серьги или височные кольца (рис. 6: 2, 3). Украшение изготовлено из бронзовой несомкнутой трубочки с диаметром сечения около 4 мм. Внутри трубочки прослежены остатки органического вещества серого цвета. Внешний диаметр кольца украшения - около 27 мм. Часть трубочки отогнута, вероятно, серьги или височные кольца имели форму спирали.

Погребение 5 (рис. 7) было перекрыто мощным закладом из ломаного камня, в котором в ходе раскопок расчищен корень антропоморфной стелы. Яма погребения не читалась. В могилу помещены скелет мужчины и останки лошади. Погребение человека совершено вытянуто на спине, головой на запад с небольшим отклонением к югу, руки расположены вдоль тела. Скелет принадлежал мужчине возрастом 35-45 лет. Реконструируемая длина тела - около $175 \mathrm{~cm}^{1}$. У погребенного прослеживается травма левой плечевой кости. К северу от скелета человека на том же уровне был помещен неполный скелет лошади, лежавший на правом боку, головой на запад. От скелета лошади в погребении обнаружены в анатомической сохранности кости ног без бедренных костей, голова, шея и хвост. Инвентарь представлен большим количеством предметов из металла, кости и рога ${ }^{2}$. Справа (к югу) от скелета человека была помещена сабля, лежавшая лезвием от погребенного, а также положенные между саблей и телом погребенного остатки колчана с железными наконечниками стрел и роговые пластины

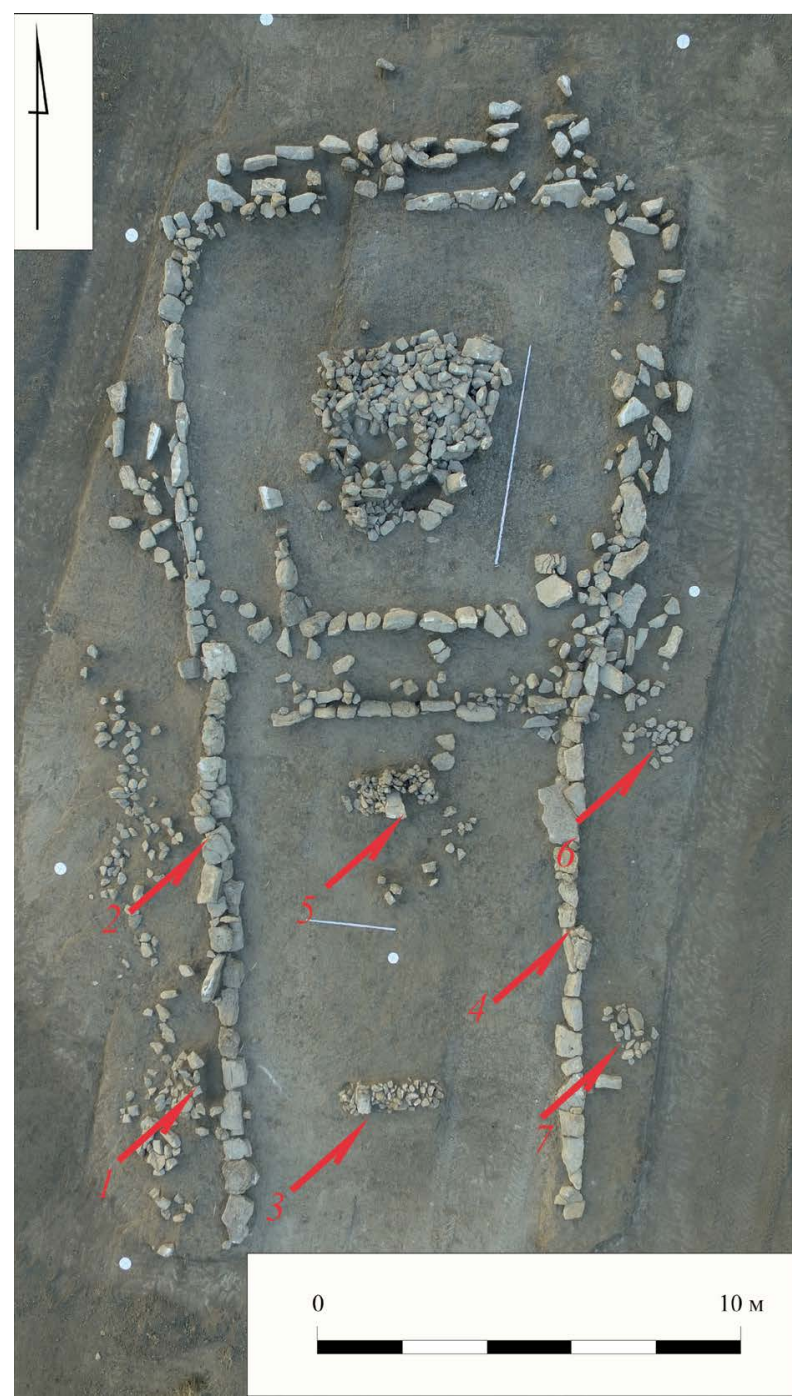

Рис. 2. Курганная группа Фонтан 1, курган 3. Ортофото. Стрелками обозначены: 1 - «карман» с внешней стороны западной каменной выкладки; 2 - западная средневековая меридиональная каменная выкладка; 3 - погр. 4; 4 - восточная средневековая меридиональная каменная выкладка; 5 - погр. 5; 6, 7 - объекты 10 и 11 - каменные заклады, перекрывающие фрагменты человеческих костей

от составного лука. Под головой у мужчины был расположен фрагмент бараньей ноги из нескольких костей в анатомической сохранности. Под костями погребенного найден фрагмент копыта, возможно, перемещенный грызунами, и два куска киновари или охры. На скелете лошади в центре лежали два стремени, две подпружные пряжки, две костяные ворворки, обнаружены также следы органической ткани, вероятно, остатки потника или иного конского покрытия. Среди тлена ткани найден фрагмент кончика обломанного костяного наконечника

\footnotetext{
1 Здесь и далее все антропологические определения выполнены д.и.н. М. В. Добровольской.

2 Все остеологические определения предварительны, выполнены к.и.н. Л.В. Яворской в поле.
} 


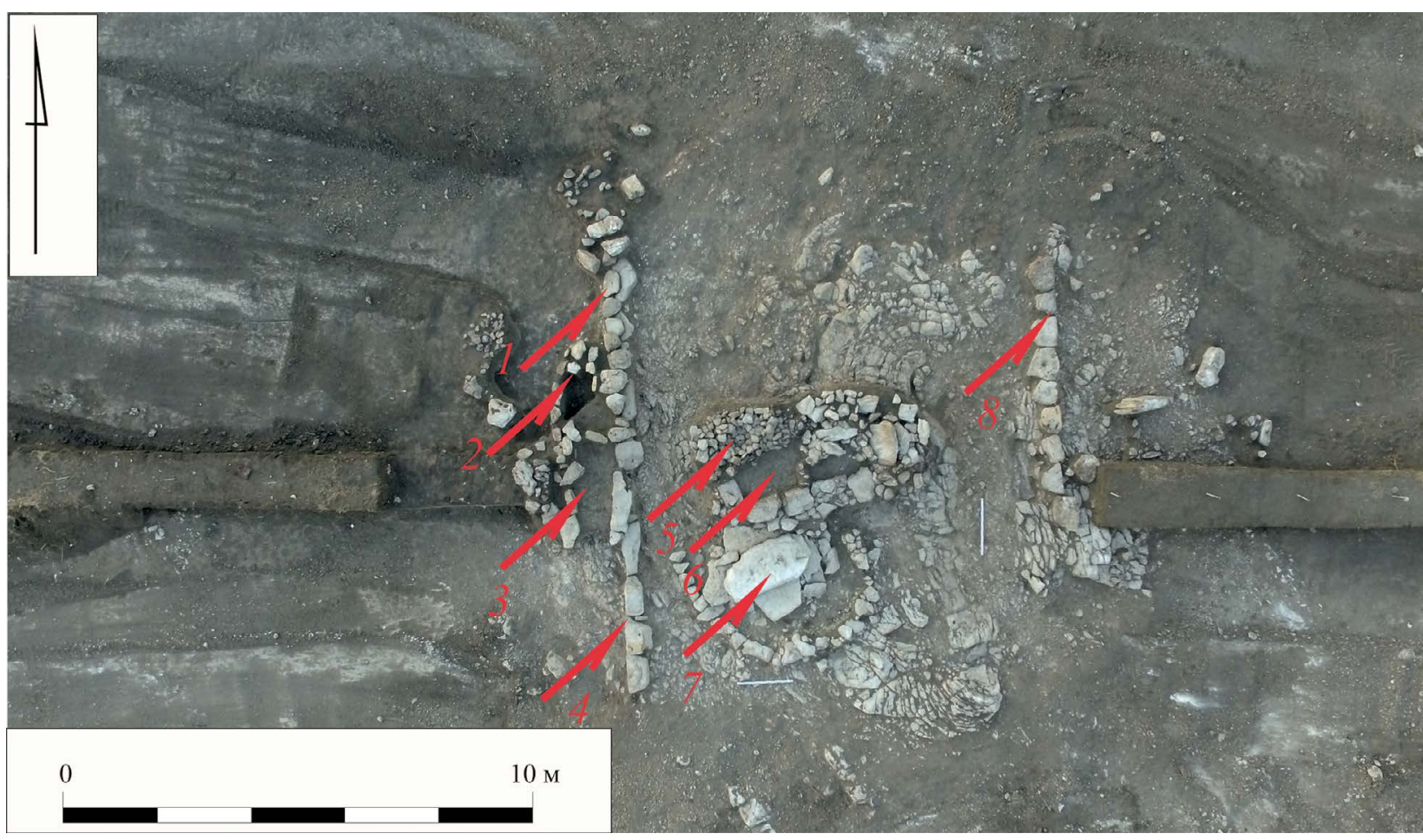

Рис. 3. Курганная группа Фонтан 2, курган 2. Ортофото. Стрелками обозначены: 1 - северная часть западной меридиональной выкладки в два ряда камней; 2 - ранний «карман» с внешней стороны западной каменной выкладки; 3 - поздний «карман» с внешней стороны западной каменной выкладки; 4 - южная часть западной меридиональной выкладки в один ряд; 5 - кольцевая выкладка из камней над средневековым кочевническим погребением; 6 - скифский впускной склеп; 7 - основное погребение кургана эпохи бронзы; 8 - восточная меридиональная выкладка в один ряд

или шиловидного предмета. В районе челюстей расчищены железные удила. Несмотря на недостаточную сохранность железных предметов, на основании морфологии предмета можно сделать предварительные выводы о датировках.

Форма погребения. Следуя типологии кочевнических погребений, предложенной Г. А. Федоровым-Давыдовым, погребение 5 можно отнести к Отделу Б типу II (1966. С. 124). Скелет лежит вытянуто на спине, головой на запад, к северу от него на одном с ним уровне положено «чучело» лошади, также ориентированное головой на запад.

Наконечники стрел (рис. 8: 1-6) ${ }^{3}$. Между локтем правой руки и телом погребенного обнаружено спекшееся скопление наконечников стрел, которые лежали острием на запад, в сторону головы погребенного. Несмотря на плохую сохранность наконечников, после реставрации удалось частично восстановить морфологию четырех из шести изделий. Два наконечника (рис. 8: 1,6) сильно поражены коррозией и соотнести их с типологическими схемами не удалось. Для определения разновидностей наконечников использовалась типология, предложенная А. Ф. Медведевым (1966).

Первый наконечник (рис. 8: 2) наиболее близок к типу 61 (Медведев, 1966. С. 73); второй (рис. 8: 3) можно отнести к типу 52 (Медведев, 1966. С. 70); третий (рис. 8: 4) - к типу 40 (Медведев, 1966. С. 64, 65); четвертый (рис. 8: 5) наиболее близок к типу 53 (Медведев, 1966. С. 70).

По мнению А.Ф. Медведева, два из четыpex опознаваемых наконечников близки к типам, которые преимущественно бытуют лишь до конца XI в. Однако некоторая вариативность форм находок позволяет поместить их в список исключений, предложенных А.Ф. Медведевым, который отмечает, что отдельные разновидности форм наконечников типов 61 и 53, хоть и редко, но встречаются на памятниках вплоть до XIV в. В связи с накоплением материала за последние годы границы бытования некоторых типов, предложенные в 1966 г., могут быть расширены.

Детали оковок и портупеи колчана или налуча (рис. 8: 7-13) В районе обнаружения накладок

\footnotetext{
3 Рисунки находок выполнены И. В. Якубовской.
} 
на лук и наконечников стрел найдены многочисленные детали оковок колчана и/или налуча (рис. 5: 7). Некоторые фрагменты, вероятно, перемещены грызунами, на что указывает значительное удаление друг от друга трех фрагментов от одной колчанной железной петли (рис. 8: 8). По-идимому, часть найденных рядом с деталями лука железных колец и пряжек - фрагменты портупеи для ношения саадачного комплекта (рис. 8: 9-12). Диаметр трех колец и округлой пряжки с язычком - около 27-28 мм. Также, вероятно, к комплексу налуча относится роговая шестиконечная ворворка или пуговица, обнаруженная рядом с роговой накладкой на животе у погребенного (находка 1). Ее размеры $15 \times 24$ мм (рис. 8: 13). В литературе имеются упоминания о том, что саадачный комплект мог застегиваться для предохранения лука и стрел от не-

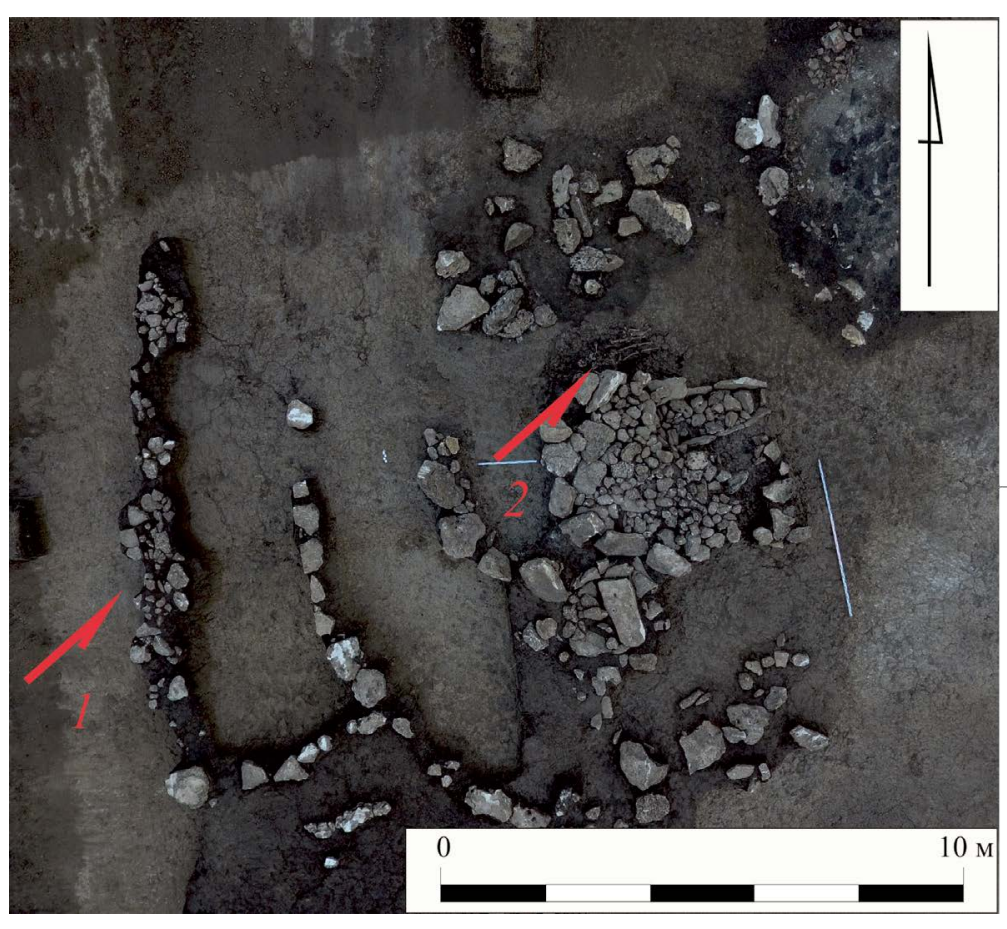

Рис. 4. Курганная группа Ивановка, курган 1. Ортофото. Стрелками обозначены: 1 - центральная сохранившаяся часть западной меридиональной выкладки; 2 - погр. 1 погоды (Медведев, 1966. С. 22). Пред-

положение о застегивании саадака костяной пуговицей было высказано и автором публикации о раскопанном в 1998 г. близком по времени погребении в кургане I курганной группы Кара-Тобе (Лагутин, 1998. С. 160). Расположение находки 1 позволяет предположить, что с ее помощью мог фиксироваться клапан, закрывающий налуч.

Роговая и костяная накладки на лук (рис. 8: $14,15)$. В районе правой тазовой кости погребенного найдена прямоугольная в плане и незначительно изогнутая роговая накладка (находка 18) (рис. 8: 15). Сечение накладки представляет собой дугу окружности. Длина изделия - 270 мм, ширина - 23-24. Угол, который образовывает накладка, составляет $163^{\circ}$. Вероятно, данное изделие является тыльной (?) центральной накладкой лука. Аналогичная по форме и близкая по размерам накладка обнаружена в погребении 1 кургана 1 западного участка некрополя Танаиса (Ларенок, 2001. С. 75). При этом погребение содержало и другие составные элементы сложного лука, в том числе фронтальные и боковые срединные накладки (Ларенок, 2001. Табл. 88: 1106-1111).

Под роговой накладкой найдена костяная накладка худшей сохранности, длиной около 150 мм и шириной до 23 (рис. 8: 14). Данная накладка, вероятно, фронтальная (?). Каждая накладка имеет на одной из поверхностей частые насечки, улучшавшие сцепление поверхностей при поклейке. Обращает на себя внимание отсутствие в погребении срединных боковых и концевых накладок. Последнее, по мнению ряда исследователей, является хронологическим признаком для луков ХІ в (Сейдалиев, 2011. С. 229). Однако учитывая необычный в целом комплект накладок, в данном случае этот признак не однозначен для датировки.

Стремена (рис. 9: 1, 2). Оба стремени близки по форме к типу VII, выделенному А.Н. Кирпичниковым (1973. С. 86.), или типу ДІІІ с несильно выгнутой подножкой по типологии Г.А. Федорова-Давыдова (1966. С. 13) и С. А. Плетневой (1973. C. 15). Такие стремена характерны, по мнению упомянутых выше исследователей, для памятников XII - начала XIII в. и широко распространены среди черноклобуцких древностей.

Ворворки или пуговицьл (рис. 9: 3, 4). Рядом со стременами и подпружными пряжками расчищены два костяных круглых изделия с отверстиями посередине. Изделия имеют подтрапециевидное сечение, диаметр около 20 мм, высоту около 6, диаметр отверстия около 6-7 мм. Одна из поверхностей не очень аккуратно орнаментирована пятью группами двойных насечек по внешнему краю. Вполне вероятно использование этих изделий в качестве конского снаряжения как ограничителей веревок, входящих в состав верхового комплекта. Однако на памятниках Средней Азии и Казахстана в слоях 


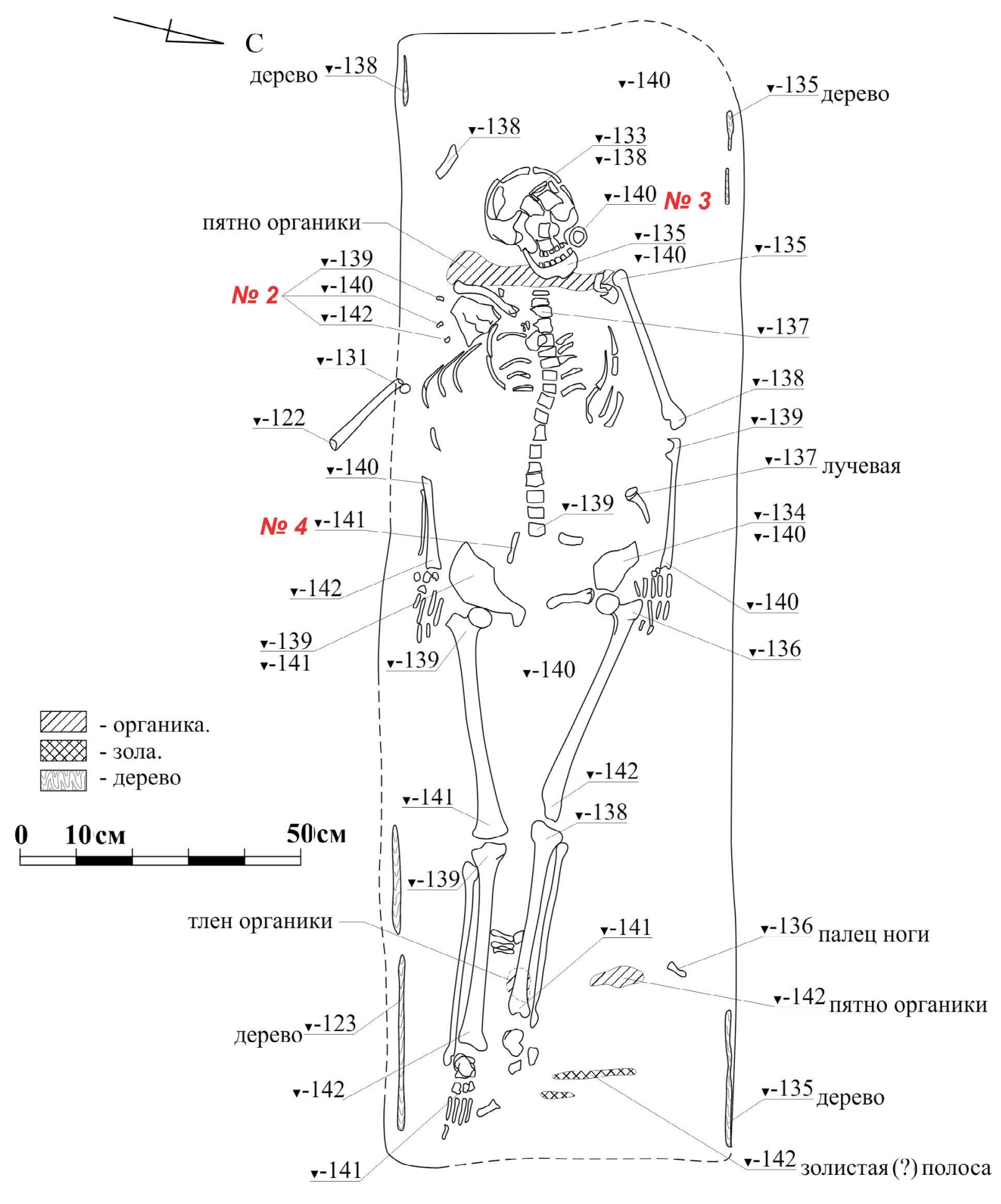

Рис. 5. Курганная группа Фонтан 1, курган 3. План погребения 4. Индивидуальные находки: 1 - наковальня каменная; 2 - серьга бронзовая, фрагменты (3 шт.); 3 - серьга бронзовая, фрагменты; 4 - шило (?) железное

$\mathrm{X}-\mathrm{XIV}$ вв. данная широко распространенная категория находок интерпретируется как пуговицы (Путешествие..., 2016. С. 136, 183, 184). Для установления точного назначения рассматриваемых находок на данный момент недостаточно информации, возможно, изделия были полифункциональными.
Потник. В районе предполагаемого хребта чучела коня прослежено скопление органики, которое, вероятно, являлось потником или иным тканевым покровом спины лошади. Именно с этой тканью вместе были положены стремена, две подпружные пряжки и две костяные ворворки. Также в остатках органики обнаружен кончик 
обломанного костяного острия (рис. 9: 5). Данный предмет может быть фрагментом проколки, наконечника стрелы, булавки или другого изделия. Длина сохранившейся части - около 10 мм.

Подпружные пряжки (рис. 9: $6,7)$. Рядом с комплектом конского седельного снаряжения найдены две круглые железные подпружные пряжки с язычками. Диаметр пряжек - около 60 мм. Сечение подтрапециевидное.

Удила (рис. 9: 8) расчищены в районе челюстей коня. Двусоставные или коленчатые удила типа ГІ по типологии Г. А. Федорова-Давыдова (1966. С. 18, 20; Плетнева, 1973. С. 15). Диаметр колец - до 45 мм. Подобный тип имеет широчайшее бытование, как по географии, так и по хронологии.

Сабля (рис. 10: 1). Как было отмечено выше, клинок располагался справа от погребенного. Сохранность металла плохая, но реконструировать пропорции вполне возможно. Общая длина полотна сабли вместе с хвостовиком - около 1070 мм, длина лезвия - 968. Ширина клинка около 42 мм - клинок сильно раздут в районе перекрестия. Кривизна полосы, измеренная по методике А.Н. Кирпичникова (1966. С. 74. Рис. 19) составляет 50 мм, по методике С. А. Плетневой (1973. С. 18. Рис. 5) - 35 мм. Рукоять имела небольшой выгиб в сторону лезвия. На плоском хвостовике прослежено не менее трех заклепок для фиксации деревянной рукояти. С тыльной стороны рукояти располагалось навершие. Такие формы наверший не отмечены в работе А.Н. Кирпичникова (1966. С. 64. Рис. 13), но при этом широко распространены, в том числе на Западном Кавказе. Подобный тип наверший выделяет У. Ю. Кочкаров (2008. С. 29, 30. Табл. XVI). Частью рассматриваемого навершия является и тонкая железная пластина, сохранившаяся длина которой - 73 мм, ширина - 10-12, оба ее конца обломаны. На одной из сторон пластины прослежены прикипевшие остатки дерева, через дерево и пластину проходят остатки клепочного гвоздя. У. Ю. Кочкаров в своем исследовании утверждает, что подобные навершия характерны для клинков XII-XIII вв. Аналогичное навершие имеет сабля и из погребения (XII - начало
XIII в.) в кургане у хут. Пролетарского Кореновского р-на Краснодарского края (Зеленский, 1997. С. 90).

На самой рукояти рассматриваемой нами сабли отмечены остатки двух видов дерева (на момент написания статьи определение пород еще не выполнено) - светло-серого и темнокоричневого цветов, светлая древесина также прослежена на устье ножен. Перекрестие незначительно опущено вниз, короткие ответвления имеют шаровидные окончания. Типологически перекрестие сабли наиболее близко к выделенному А.Н. Кирпичниковым типу I (1966. Рис. 13). На перекрестии выявлены следы медной пайки. Сохранился фрагмент широкой пластинчатой оковки ножен с антабкой, которая представляет собой неподвижное кольцо для подвешивания ножен.

Пряжка железная поясная (?) (рис. 10: 2) найдена в районе пояса погребенного. Рамка пряжки подокруглой формы, диаметр - около $3,3 \mathrm{~cm}$.

Пуговича (?) костяная (рис. 10: 3) обнаружена на уровне пояса под левой рукой погребенного, ниже лежащего ножа. Диаметр - 32 мм. Сечение трапециевидное. Высота - около 4 мм, диаметр отверстия - до 5 мм. Возможно, изделие связано с поясной сумкой, в которой мог лежать кусок охры.

Нож железный (рис. 10: 4) найден лежащим вдоль мизинца левой руки погребенного. Его общая длина - около 10,5 см. Длина лезвия - около

\footnotetext{
4 Кочкаров, 2008. С. 29-30
} 


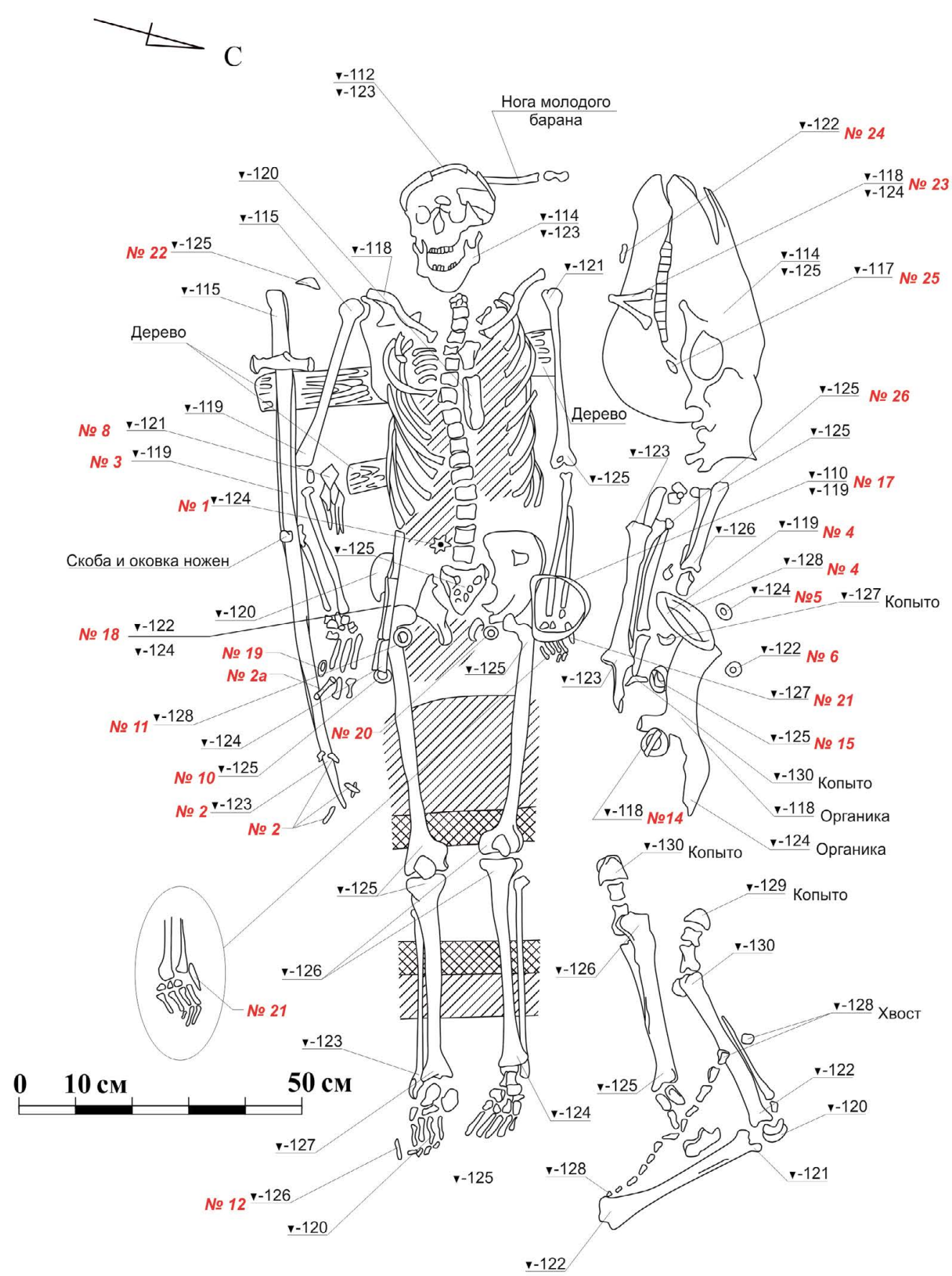

Под всем телом погребенного - подстилка из органики желтого цвета (войлок?). Шयл Под ногами две полосы светло-серой органики (зола? камыш?)

Под плечевыми костями, вероятно, доска (1), лежащая поперек могилы.

Под локтевыми костями также лежат остатки дерева - доска (2)

Рис. 7. Курганная группа Фонтан 1, курган 3. План погребения 5.

Индивидуальные находки: 1 - Ворворка или пуговица (?) на саадак роговая; 2 - Оковка колчана железная, фрагменты; 2 - Петля колчанная железная, фрагменты; 3 - сабля железная; 4 - Стремя железное; 5 - Ворворка костяная; 6 - Ворворка костяная; 7 - Охра (под саблей в районе ножен); 8 - Наконечники стрел железные; 9 - Охра (под находкой 21; 10 Пряжка железная; 11 кольцо (пряжка?) железное; 12 - Оковка колчана (?), фрагмент; 13 - Пуговица (?) костяная. Под находкой № 21; 14 - Пряжка железная; 15 - Пряжка железная; 16 - Наконечник роговой. В остатках органика (попоны?); 17 - Стремя железное; 18 - Накладка на лук роговая; 19 - Кольцо железное; 20 - Кольцо железное; б/н - кость животного (барана); 21 - Нож железный (под ним охра и находка № 13); 22 - Фрагмент копыта лошади; 23 - Удила конские железные; 24 - Кольцо железное, деталь удил; 25 - Кольцо железное, деталь удил; 26 - Предмет железный; 27 - Пластина костяная, фрагменты (под находкой № 18); 28 - Пряжка железная 

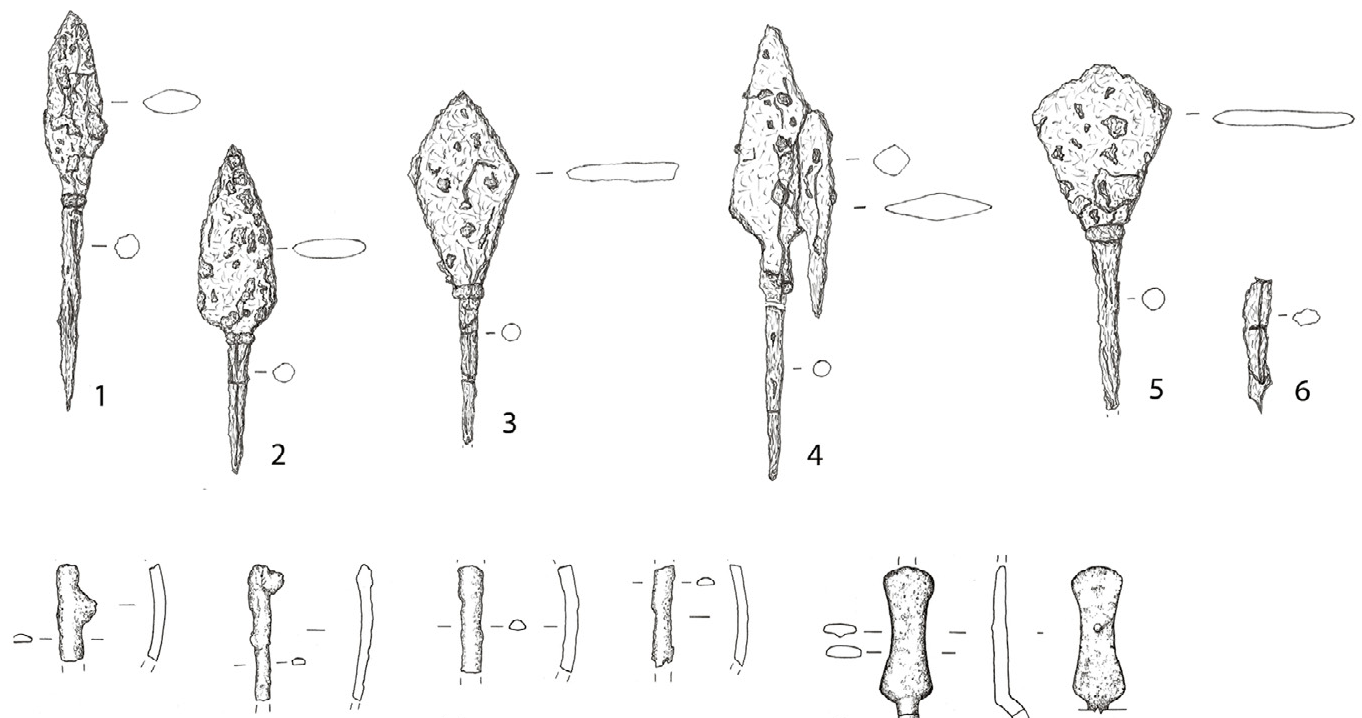

$b_{1}^{1} \circ \int_{1}^{1}$

b-

-
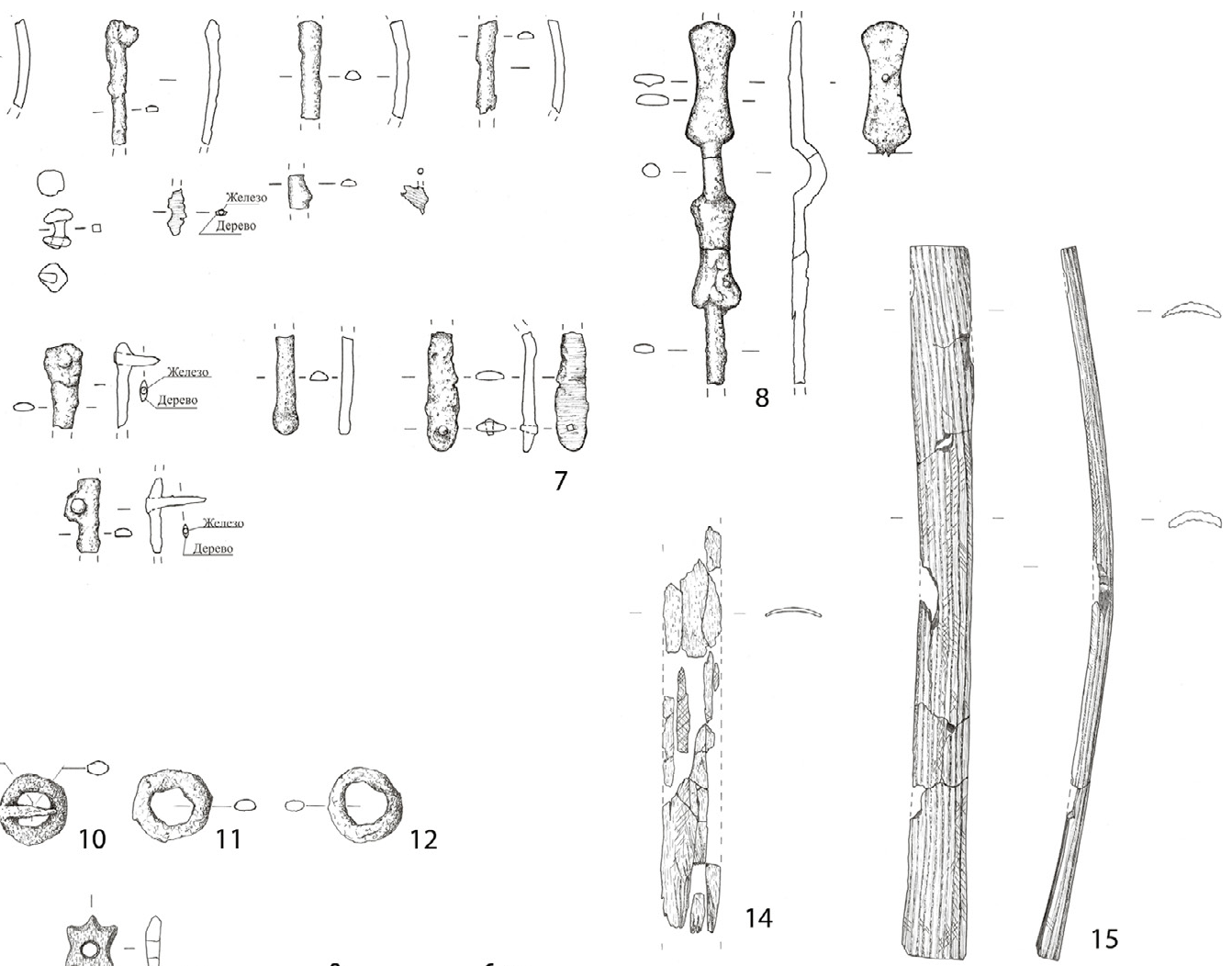

Рис. 8. Инвентарь погребения 5, курган 3, курганная группа Фонтан 1. Комплекс снаряжения лучника: 1-6 - наконечники стрел и фрагмент (находка № 8); 7, 8 - детали оковки колчана и колчанная петля (находки № 2, 12); 9-12 - кольца и пряжки портупейные (находки № 10, 11, 19, 20); 13 - ворворка или пуговица на саадак (?) (находка № 1); 14 - накладка на лук (находка № 27); 15 - накладка на лук (находка № 18). 1-12 - железо; 13, 15 - рог; 14 - кость

7,5 см. По типологии Г. А. Федорова-Давыдова его можно отнести к типу I (1966. С. 85). Нож прямой, с прямой спинкой. Наличие или отсутствие выступов при переходе от лезвия к черешку не удалось проследить из-за коррозии. Лезвие имеет подтреугольное сечение.

Пруток железный. В районе передних ног коня, между эпифизами был обнаружен фрагмент сильно корродированного железного прутка длиной около 4 см и диаметром около 0,7 (находка № 26). Возможно, данное расположение находки не является положением in situ.

Курган 2 курганной группы Фонтан 2 содержал погребение эпохи бронзы, склеп скифского времени и впускное погребение средневекового кочевника (рис. 3). В процессе сооружения впускного средневекового погребения воина-кочевника частично разобрана северная стенка скифского каменного склепа. Возможно, часть камней этого склепа вторично была использована при сооружении элементов 

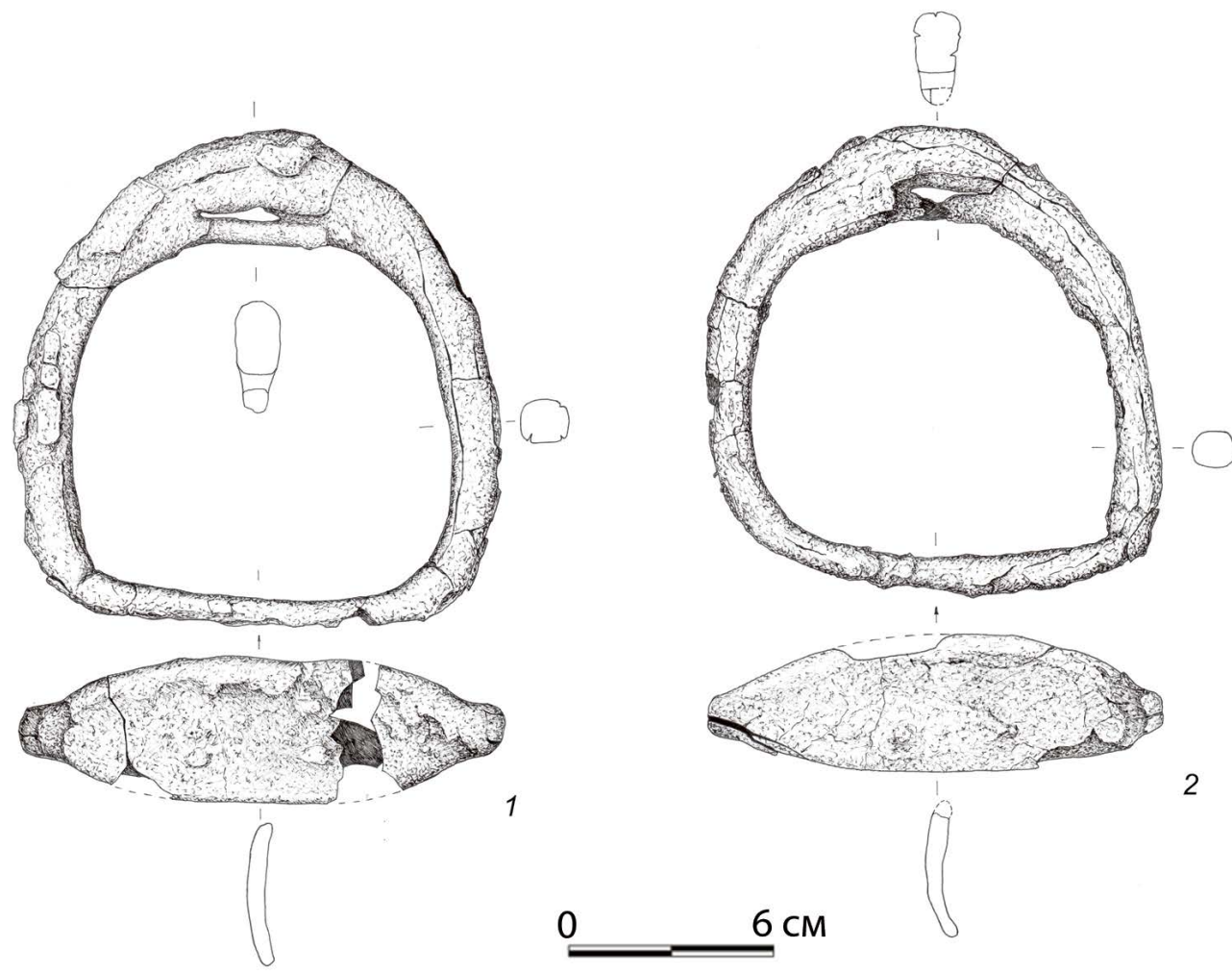

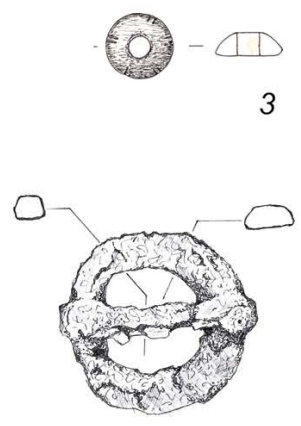

6
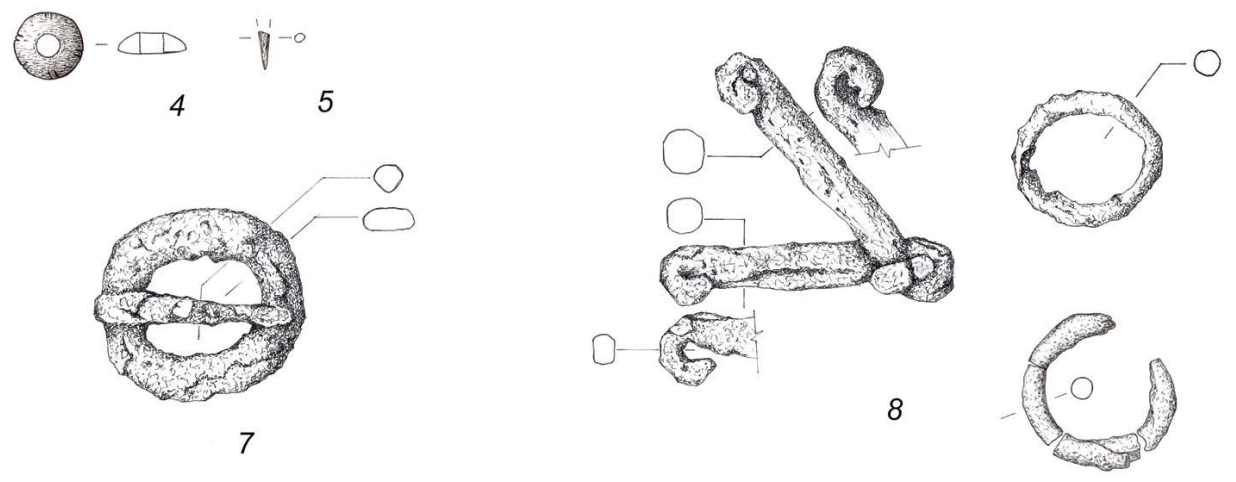

Рис. 9. Находки из погребения 5, курган 3, курганная группа Фонтан 1. Комплекс снаряжения верхового коня: 1, 2 - стремена (находки № 4, 17); 3, 4 - ворворки или пуговицы (находки № 5, 6); 5 - наконечник, фрагмент (находка № 16); 6, 7 - пряжки подпружные (находки № 14, 15); 8 - удила (находки № 23-25). 1, 2, 6, 7, 8 - железо; 3, 4 - кость; 5 - рог

средневековой погребальной архитектуры. Как и в случае с описанным выше погребением, данный средневековый погребальный комплекс имел элементы внешней архитектуры. С востока и запада от могилы были сооружены две линии камней. Кладка постелистая, вытянута меридионально. Расстояние между параллельными линиями - около 8 м, длина западной каменной линейной выкладки - около 10. Восточная, вероятно, имела аналогичную протяженность, но сохранилось около 6 м. Остальное было, скорее всего, разобрано при сооружении блиндажа времен Великой Отечественной войны, расположенного у подошвы кургана. Западная линейная кладка, вероятно, подновлялась в скором времени после сооружения погребения, так как в северной части западная кладка имеет второй вышележащий ряд камней, положенный на первоначальный ряд. Эти две кладки западного ряда отличаются друг от друга качеством и пропорциями камней. Как и в случае с архитектурой кургана 3 курганного могильника Фонтан 1, с запада к стенке примыкает аналогичная внешняя конструкция 
в виде двух каменных «карманов». Каждый из «карманов» кладкой перевязан с одним из двух уровней каменных линий. Находки в «карманах» не обнаружены.

Могила воина-кочевника была плотно забутована камнем, а в верхней части существовала кольцевидная выкладка из камня, в которой находился зуб лошади. В дальнейшем зубы той же особи прослежены среди камней забутовки и грунтового заполнения могильной ямы, куда они могли быть перемещены грызунами. Это позволяет предположить, что в «кольце» был лошадиный череп или, что менее вероятно, располагался деревянный столб, фиксированный камнями, на котором находился череп. Само погребение находилось в неглубоко впущенной в скальное основание яме на глубине 108-120 см от современной дневной поверхности кургана (рис. 11). Погребенный был уложен вытянуто головой на запад с небольшим отклонением к югу. Скелет принадлежал мужчине старше 50 лет европеоидной внешности, с широким низким лицом. Кости кистей рук имеют функциональную асимметрию. На черепе прослежена заросшая травма лобной кости. Длина тела - около $165 \mathrm{~cm}$.

В качестве погребального инвентаря были помещены традиционные для кочевнических захоронений предметы: детали составного лука и саадака, сабля, стремена, железные пряжки, на поясе справа - нож, а слева, вероятно, размещался мешочек, в котором лежали оселок, кресальный кремень с железным прутком и третий моляр, принадлежавший другому человеку. Очевидно, мешок имел бронзовую пуговицу, которую сохранить не удалось. Такие поясные сумки - не редкость среди сопроводительного инвентаря средневековых кочевников (Лагутин, 1998. С. 160). Поясные мешочки, содержавшие среди прочего человеческие зубы, встречались и в других кочевнических погребениях (Андрух, Тощев, 2009. С. 140). Человеческие зубы и другие вещи, помещенные в поясную сумку в кочевническом погребении, иногда рассматривались в отечественной литературе как набор
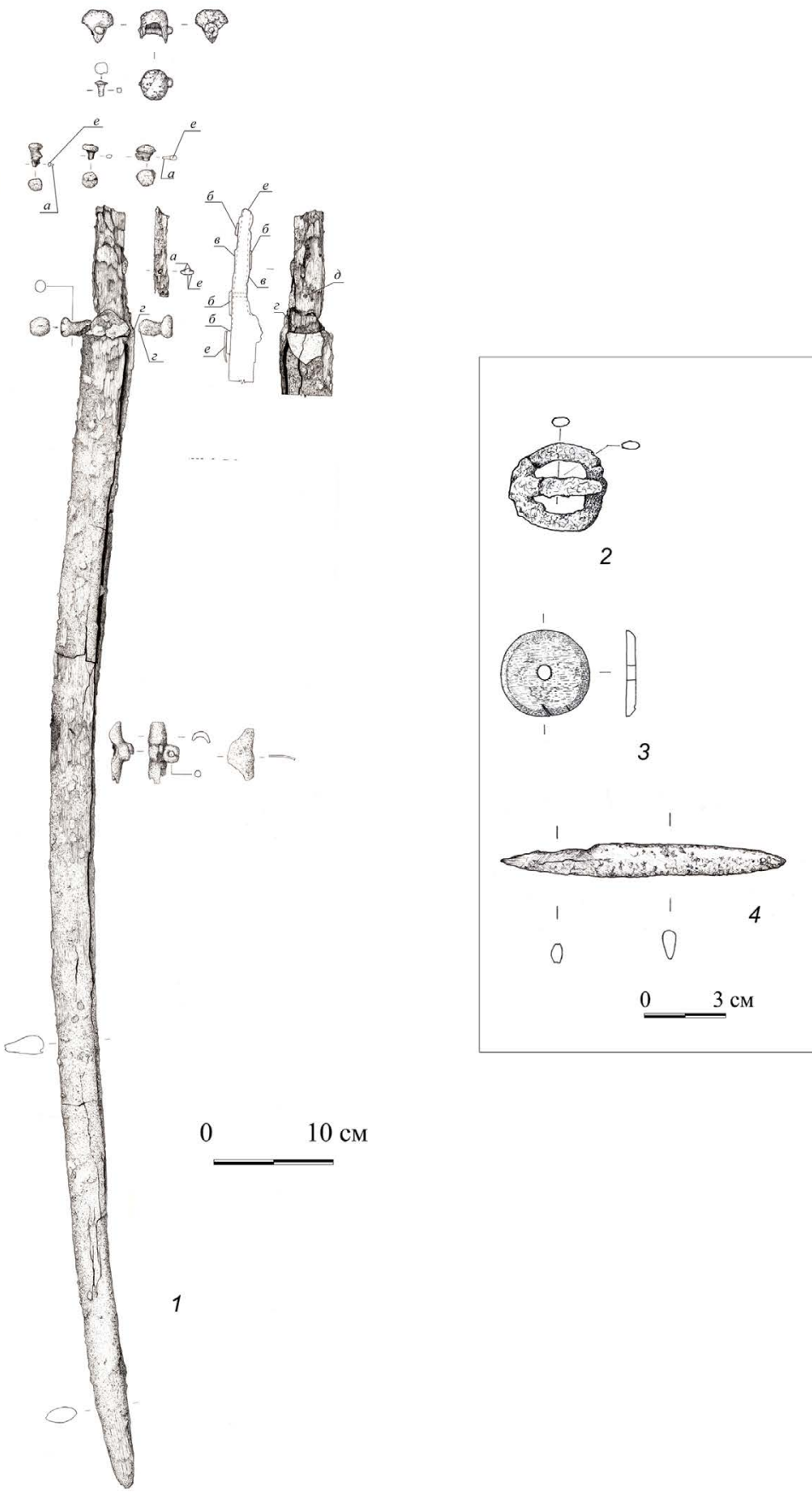

Рис. 10. Находки из погребения 5, курган 3, курганная группа Фонтан 1. Сабля, детали сабельного комплекта и предметы с пояса погребенного: 1 - сабля, буквами обозначены различные элементы и материалы (а - дерево; б - светло-серая древесина; в - темно-коричневая древесина; г - медь; д - клепка железная; е - железо). Находка № 3; 2 - пряжка поясная (?) (находка № 28); 3 - пуговица (находка № 13); 4 - нож (находка № 21). 2, 4 - железо; 3 - кость сакральных предметов (Кубарев, 2005. С. 58). Зуб, найденный в мешке с кремнем, железными прутками и оселком, скорее может представлять собой трофей, так как выдрать третий маляр у живого человека представляется проблематичным, а набор погребального инвентаря не предполагает, что носитель мог быть лекарем. Часть 


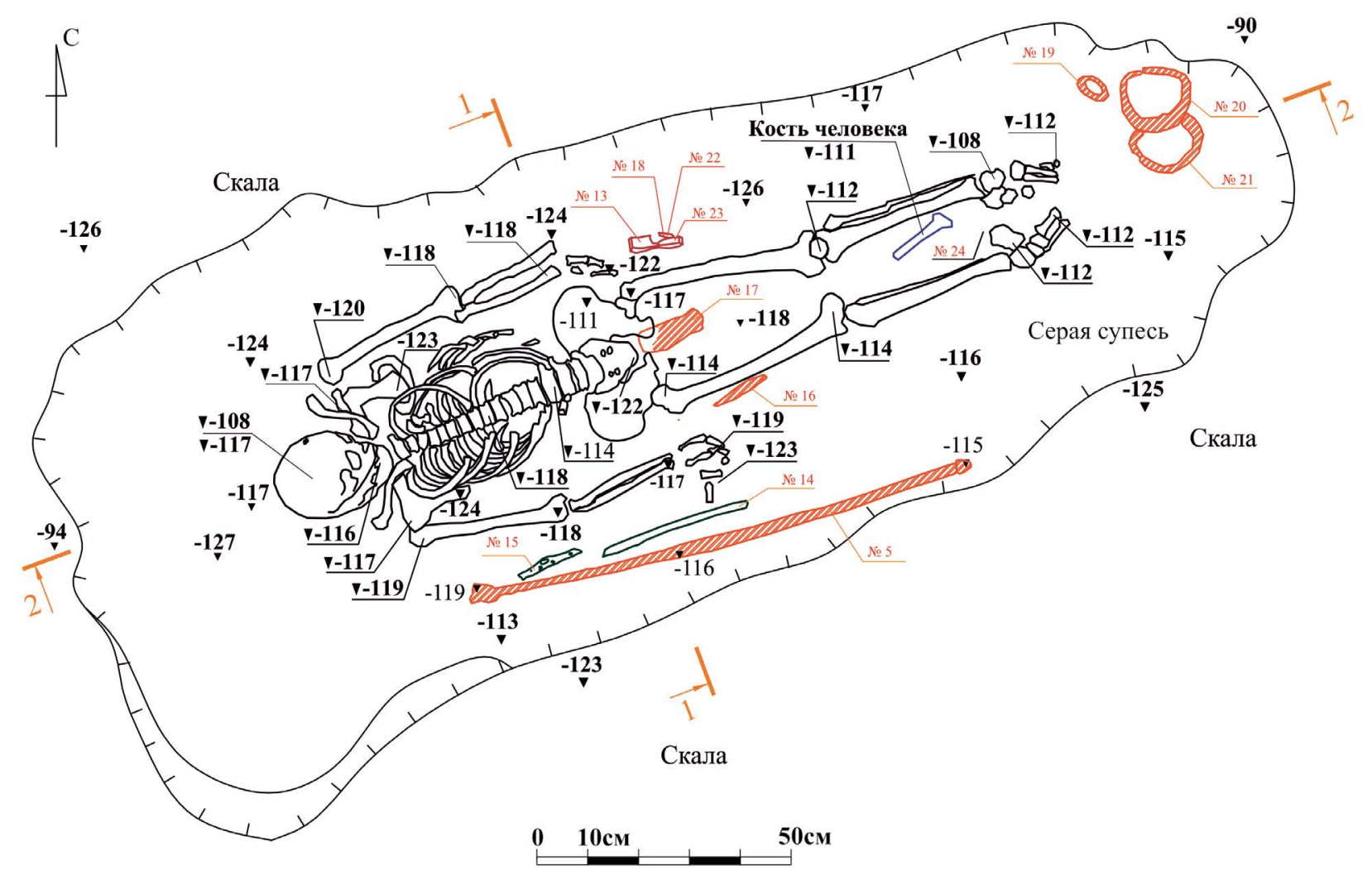

Рис. 11. Курганная группа Фонтан 2, курган 2. План погребения 2.

Индивидуальные находки: 5 - Сабля железная; 13 - Оселок каменный; 14 - Накладка на лук роговая; 15 - Петля колчанная роговая; 16 - Нож железный; 17 - Тесло железное; 18 Изделие бронзовое, пуговица (?); 19 - Пряжка железная подпружная; 20 - Стремя железное (северное); 21 - Стремя железное (южное); 22 - Кресало железное с кремнём; 23 Предмет железный, фрагмент

предметов, которые также входили в инвентарь средневекового погребения, были перемещены грызунами и найдены как в скифском склепе, так и в погребении эпохи бронзы. Под тазовыми костями обнаружено железное тесло, которое, судя по расположению, могло послужить причиной смерти погребенного (рис. 12, 13).

Обращает на себя внимание положение стоп. Судя по тому, как притянуты пальцы ног погребенного, нижняя часть тела перед положением в могилу была плотно спеленута. Также следует отметить необычную деформацию позвоночного столба. Складывается впечатление, что тело после смерти окоченело в полусидячем положении и только потом было разогнуто. При этом крестец погребенного относительно таза расположен, как у сидящего человека. Под головой в качестве погребальной пищи был положен фрагмент ноги молодого теленка.

Форма погребения. Конструктивные особенности погребения позволяют в общих чертах отнести обряд к Отделу Б по типологии, предложенной Г. А. Федоровым-Давыдовым (1966. С. 124-126). Однако среди типов захоронений, описанных в рамках этой системы, нет полных аналогий рассматриваемому погребению. Наличие кольцевой выкладки из камня с остатками черепа в нем поверх плотной каменной забутовки могильной ямы не отмечено авторами настоящей статьи ранее в литературе.

Роговая накладка на лук. Справа от погребенного найдена роговая изогнутая в плане накладка (рис. 14: 1). Длина изделия - 286 мм, ширина до 15 , толщина - до 5. Сечение сегментовидное. Форма накладки и ее расположение в погребении позволяют предположить, что это боковая накладка на плечо лука. Взаиморасположение саадачной петли и данного изделия также говорит в пользу такой версии (рис. 11). Если допустить, что саадачный комплект был положен в погребение в порядке ношения, то расположение этой накладки ниже саадачной петли говорит о том, что накладка связана с нижним плечом лука, который на половину или две трети вставлен в налуч. Однако странно, что это единственная роговая деталь лука, найденная in situ. Близкие по форме накладки происходят из погребения, исследованного в Калиновском курганном могильнике 54/1. 
Однако там схожие по изгибу накладки были в комплекте и со срединными, и с концевыми (Шилов, 1959. С. 401, 512. Рис. 71: 3, 14). Автор раскопок интерпретировал данную деталь как боковую накладку на плечо, стыкующуюся с концевой накладкой с вырезом под тетиву. Возможная интерпретация рассматриваемой нами накладки как следов ремонта лука или дополнительного усиления одного плеча кажется маловероятной, однако иных предположений пока нет.

Еще одна костяная накладка (рис. 14: 2) обнаружена в скифском склепе на удалении не менее метра от первоначального возможного места расположения. В склеп она была вынесена грызунами, как и ряд других предметов из средневекового погребения. Третий фрагмент, возможно, костяной накладки также был найден в перемещенном состоянии в заполнении могильной ямы (рис. 14: 3).

Петля саадачная (рис. 14: 4) найдена справа от погребенного на уровне плечевой кости. Подобные петли имеют широкий хронологический период бытования и встречаются вплоть до слоев XIV в. в Великом Новгороде. По типологии Г. А. Федорова-Давыдова (1966. С. 32) данное изделие можно отнести к типу AIV.

Стремена. Южное стремя (рис. 15: 1) по расположению в погребении близко по форме к типу VII по типологии А.Н. Кирпичникова (1973. С. 86) или типу ДІІІ по типологии Г. А. Федорова-Давыдова с несильно выгнутой подножкой (Федоров-Давыдов, 1966. С. 13; Плетнева, 1973. С. 15) - аналогично найденным в описанном выше погребении 5. Северное стремя (рис. 15: 2) на основании наличия выступа под прорезью можно отнести к типу ГІ по типологии Г.А. Федорова-Давыдова (1966. СС. 12, 15), считавшего, что такие стремена также характерны для слоев XII - начала XIII в. Ситуация, когда в средневековом кочевническом погребении встречаются разнотипные стремена, не редка для данной группы памятников (Плетнева, 1973. Рис. 3: 3, 4; Шалобудов, 1982; Ларенок, Ларенок, 2005. Рис. 4: 12, 13).

Удила (рис. 15: 3, 4). Сохранились лишь фрагменты, скорее всего, двусоставных удил с фрагментами подвижного кольца. Реконструируемый диаметр колец - около 45 мм. Вероятно, как и в погребении 5, данные удила можно отнести к типу ГІ по типологии Г. А. Федорова-Давыдова (Федоров-Давыдов, 1966. С. 18, 20; Плетнева, 1973. С. 15). Удила разрушены грызунами, и один фрагмент перетащен на расстояние более 1,5 м в соседнее погребение более раннего времени.

Ворворка или пуговица (?) (рис. 15: 5). В заполнении скифского склепа найдено костяное изделие, круглое в плане с отверстием посередине, сечение трапециевидное. Диаметр 25 мм, диаметр отверстия - 5, высота - 5 . Подобные предметы характерны для средневековых кочевнических погребений, Г. А. Федоров-Давыдов определяет их как пуговицы, тип БIV (1966. С. 71). В скифский склеп данный предмет был перенесен грызунами, о чем 
говорит и его расположение не на погребенных, а в грунтовом заполнении.

Подпружные пряжки. In situ обнаружена одна пряжка, которая находилась рядом со стременами. Она имеет подовальную форму рамки с прямой осью для язычка (рис. 15: 7). Фрагменты еще одной пряжки, возможно, также подпружной (рис. 15: 6), найдены в стороне от погребения, куда они были вынесены грызунами.

Сабля (рис. 16: 1) сильно пострадала от грызунов. Хвостовик сабли обнаружен в норе на расстоянии не менее метра от первоначального расположения. Ход был прорыт в известняковом скальном основании кургана. Несмотря на то что клинок сильно корродирован и железо раздуто, можно достаточно точно реконструировать размеры сабли. Общая длина полотна сабли вместе с хвостовиком - не менее 1100 мм, длина лезвия - 1000. Ширина клинка - около 44 мм. Кривизна полосы - 43 мм по системе измерений А.Н. Кирпичникова (1966) или 24 мм по С. А. Плетневой (1973). Рукоять имела небольшой выгиб в сторону лезвия. На плоском хвостовике прослежено не менее двух заклепок для фиксации деревянной рукояти. В конце хвостовика на дереве рукояти сохранились с одной стороны фрагменты железа, возможно, остатки навершия рукояти. Удалось проследить фрагменты разрушенного короткого железного перекрестия с участками медной пайки. Перекрестие сильно пострадало от коррозии, и уверенно говорить о форме сложно, но очевидно, что перекрестие было с короткими горизонтальными отростками и либо имело брусковидную форму, либо окончания были оформлены в виде шаров. Фрагментарно сохранились детали двух оковок ножен с круглыми петлями для ношения сабли. У острия клинка расчищено окончание сабельных ножен, представляющее собой простую железную пластину, свернутую в подовальную в сечении трубочку с несведенными концами. Ширина пластины - около 30 мм, общие размеры изделия -34 × 20. Подобные окончания ножен, по мнению ряда исследователей, датируются

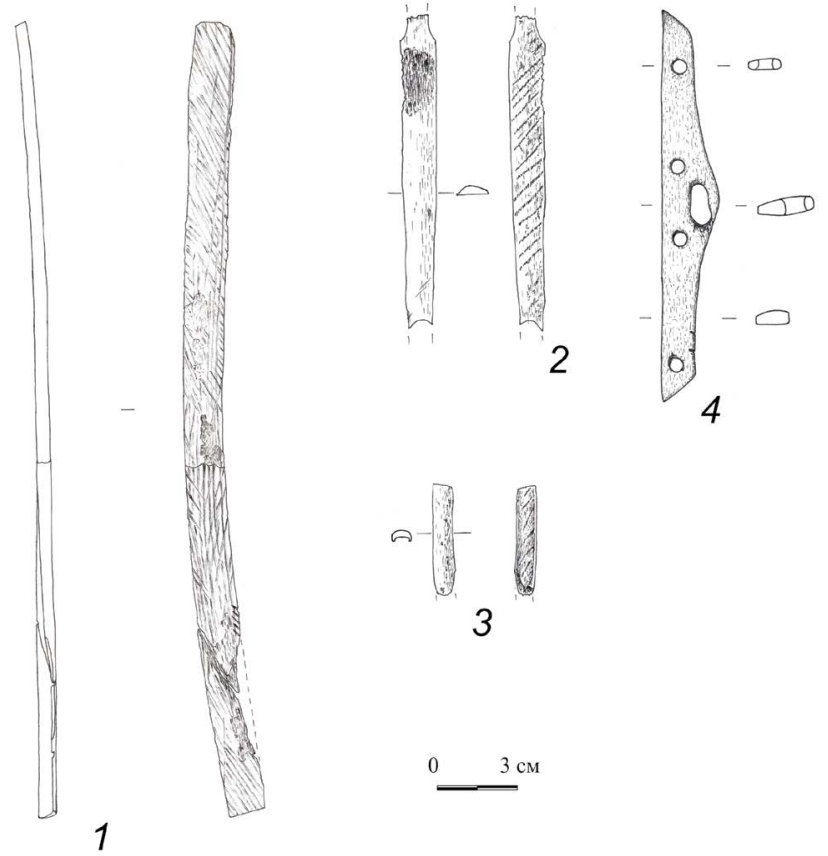

1

Рис. 14. Находки из погребения 2, курган 2, курганная группа Фонтан 2. Комплекс снаряжения лучника: 1 - накладка на лук (находка № 14); 2, 3 - накладка на лук (?), фрагмент (находки № 26, 27); 4 - петля саадачная (находка № 15). 1 - рог олений; 2-4 - кость

XII - началом XIII в. (Плетнева, 1973. С. 17, 18; Зеленский, 1997. С. 90).

Поясная сумка. Одним из интереснейших объектов в погребении можно считать поясную сумку, располагавшуюся слева на поясе погребенного. Ткань сумки не сохранилась, но взаиморасположение предметов, которые в ней находились, позволяет говорить о ее наличии. В сумке находились каменный оселок со следами сработанности со всех сторон (рис. 16: 2); железный пруток (рис. 16: 3), прикипевший к кремню (рис. 16: 4); еще один фрагмент железного прутка (рис. 16: 5). Также к этому комплексу относятся фрагменты дутой бронзовой пуговицы с горизонтальным швом (рис. 16: 6). В публикации Г.А. Федорова-Давыдова такое изделие выделено в тип АII (1966. С. 70). Кроме того, как сказано выше, в сумке находился зуб человека.

Нож (рис. 16: 7) найден справа от тазовых костей, вероятно, располагался на поясе. Находку можно отнести к типу I по типологии Г.А. Федорова-Давыдова (1966. С. 85). Нож прямой, с прямой спинкой. Наличие или отсутствие выступов при переходе от лезвия к черешку изза коррозии проследить не удалось. Лезвие и черешок имеют подтреугольное сечение.

Тесло железное (рис. 17: 1) - одна из самых неожиданных находок в погребении. Его ширина - до 

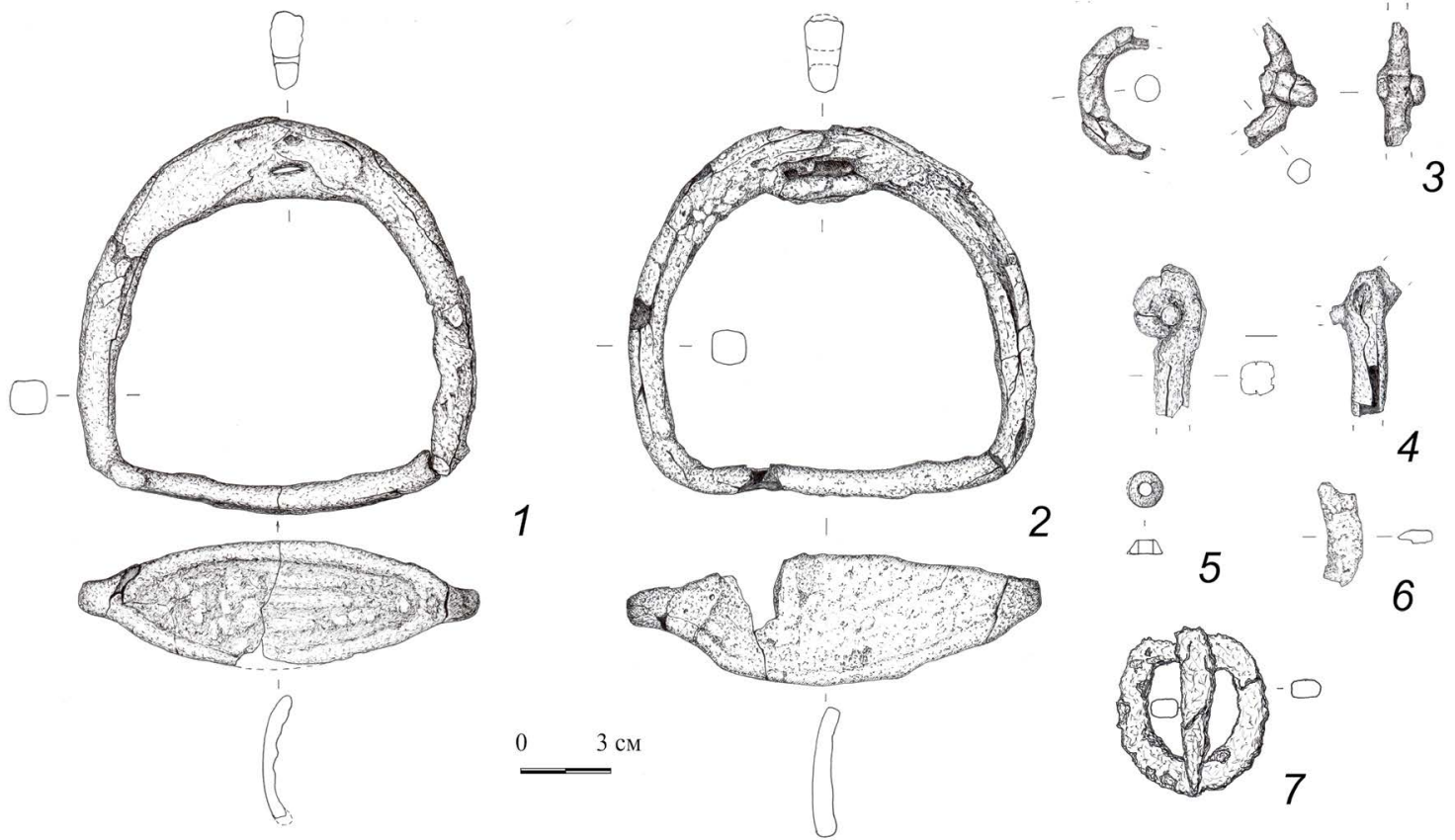

Рис. 15. Находки из погребения 2, курган 2, курганная группа Фонтан 2. Комплекс снаряжения верхового коня: 1, 2 - стремена (находки № 20, 21); 3, 4 - удила, фрагменты (находки № 8, 28; один фрагмент вынесен грызунами и обнаружен в погр. 3 - находка № 1); 5 - ворворка или пуговица, найдена в заполнении ямы погр. 1, куда, вероятно, перенесена грызунами (находка № 5); 6 - пряжка подпружная (?), фрагмент (находка № 2); 7 - пряжка подпружная (?) (находка № 19). 1-4, 6, 7 - железо; 5 - кость

4,5 см, общая длина - около 12,3, длина втулки около 4. Толщина рабочей части - до 1,5 см. Тесло выполнено достаточно грубо - у единой массивной пластины выделен участок, который свернут в не до конца сведенную втулку. Внутри втулки прослежены остатки дерева. Сами по себе тесла - нередкая находка в погребениях тюркоязычных кочевников конца I - начала II тыс. (Кубарев, 2005. С. 72-74; Дашковский, 2017. С. 112), однако, обращает на себя внимание расположение тесла. Рабочая часть инструмента достаточно глубоко заведена внутрь тазовых костей (рис. 12, 13), что вкупе с расположением крестца и деформированным позвоночным столбом позволяет высказать предположение, что в данном случае это не погребальный инвентарь, а орудие казни.

Предмет железный (рис. 17: 2). В заполнении могильной ямы обнаружен предмет, который представляет собой скипевшиеся фрагменты пластин треугольного сечения. Размеры предмета $-3 \times 2 \times 3 \mathrm{~cm}$.

Камень со следами охры (рис. 17: 3). В заполнении могильной ямы найден плоский подпрямоугольный камень размерами $9 \times 6 \times 2$ см. Поверхность камня (светлый песчаник?) имеет следы затертостей, на нем с одной из сторон прослежены следы втертой красной краски охры или киновари.
Предмет железный (рис. 17: 4) найден в заполнении могильной ямы. Он представляет собой фрагмент изделия, выполненного из железного округлого в сечении прутка диаметром около 0,4 см. Размеры сохранившейся части предмета $-3 \times 1$ см. Возможно, это фрагмент рамки пряжки.

Пряжки. В погребении обнаружены три железные пряжки, которые могут быть отнесены к поясным и/или портупейным (рис. 17: 5-7). Одна пряжка - с прямоугольной рамкой, ремень к подобным пряжкам присоединялся с помощью прямоугольного приемника (рис. 17: 5). Сечение рамки подпрямоугольное. Размеры пряжки $30 \times 23$ мм. Такие пряжки в типологии Г.А. Федорова-Давыдова наиболее близки к форме бронзовых пряжек типа IБІІІ (1966. С. 44.), аналогичные пряжки из железа в данной работе не упоминаются.

Вторая пряжка - с подтреугольной, близкой к лировидной рамкой, заостренной на конце, и неподвижным щитком из двух параллельных пластин (рис. 17: 6). Размеры - $38 \times 27$ мм. Данный вид наиболее близок к типу IIB по типологии Г. А. Федорова-Давыдова (1966. С. 47), однако, полных аналогий выявить не удалось. Третья пряжка - круглая, сечение рамки подокруглое (рис. 17: 7). Диаметр пряжки - около 30 мм. 
Курган Ивановка. Погребение 1 расположено в северной части кургана, который имеет значительные разрушения в ходе хозяйственной деятельности человека в XX в. В западной части кургана выявлен объект 3, который представлял собой линейную кладку из камня. Линия включает в себя как крупные камни размером до $50 \mathrm{~cm}$, так и камни чуть меньше - до 25 см. Направление линии камней - близко к С-Ю. Ширина линии из камней доходит до 1 м (рис. 4). Сохранившаяся длина линии камней около 8 м, с севера, вероятно, кладка срезана вместе с полой кургана, а с южной стороны уничтожена перекопом, заполненным мусором - железом и бетоном, поэтому возможно линия камней изначально была больше.

Данный объект может быть интерпретирован как западная частично сохранившаяся часть параллельной средневековой каменной выкладки, аналогичной тем, что прослежены в описанных выше курганах. При этом восточная часть параллельной каменной выкладки могла быть полностью уничтожена в XX в., так как на участке, где она могла бы располагаться, грунт был снят практически до материка.

Северная пола кургана была сильно разрушена и в связи с этим у выявленного погребения не удалось проследить какой-либо надмогильной конструкции, как и пятна ямы. Сохранилась лишь южная стенка могилы. Скелет лежит вытянуто на спине, головой на запад с небольшим отклонением к югу. Кости скелета имеют очень плохую сохранность, отсутствуют кости кистей рук, челюсть перемещена. Все погребение сильно потревожено землероями (рис. 18).

Вдоль ноги скелета человека с северной стороны лежат две ноги лошади - от берцовой кости до копыт. Одна нога лошади, которая ближе к скелету человека, вытянута, вторая согнута в суставе. Восточнее копыт - хвост лошади. За черепом с южной стороны найдена нижняя челюсть лошади. Место могильной ямы погребения, где лежит челюсть лошади, перекрывается на 15 см двумя камнями из кольцевой внешней обкладки объекта эпохи бронзы. Возможно, могила имела подбой вдоль южной стенки, который зашел под камни более ранней конструкции, но нельзя исключать вариант, что камни чуть сместились в заполнение могильной ямы постфактум.

Инвентарь представлен украшениями и элементами одежды.

Глазчатая стеклянная бусина. В районе левых нижних ребер погребенного найдена цилиндрическая глазчатая бусина из стекла (рис. 19: 1). Длина бусины - 17 мм, диаметр до 10. Состояние бусины позволяет высказать предположение, что перед попаданием в погребение она побывала в огне.

Предмет железный, фрагмент (рис. 19: 2). Севернее бусины на 5 см обнаружен фрагмент железного предмета продолговатой формы.

Железная пряжка (рис. 19: 3) обнаружена в районе левого плеча погребенной. Пряжка 

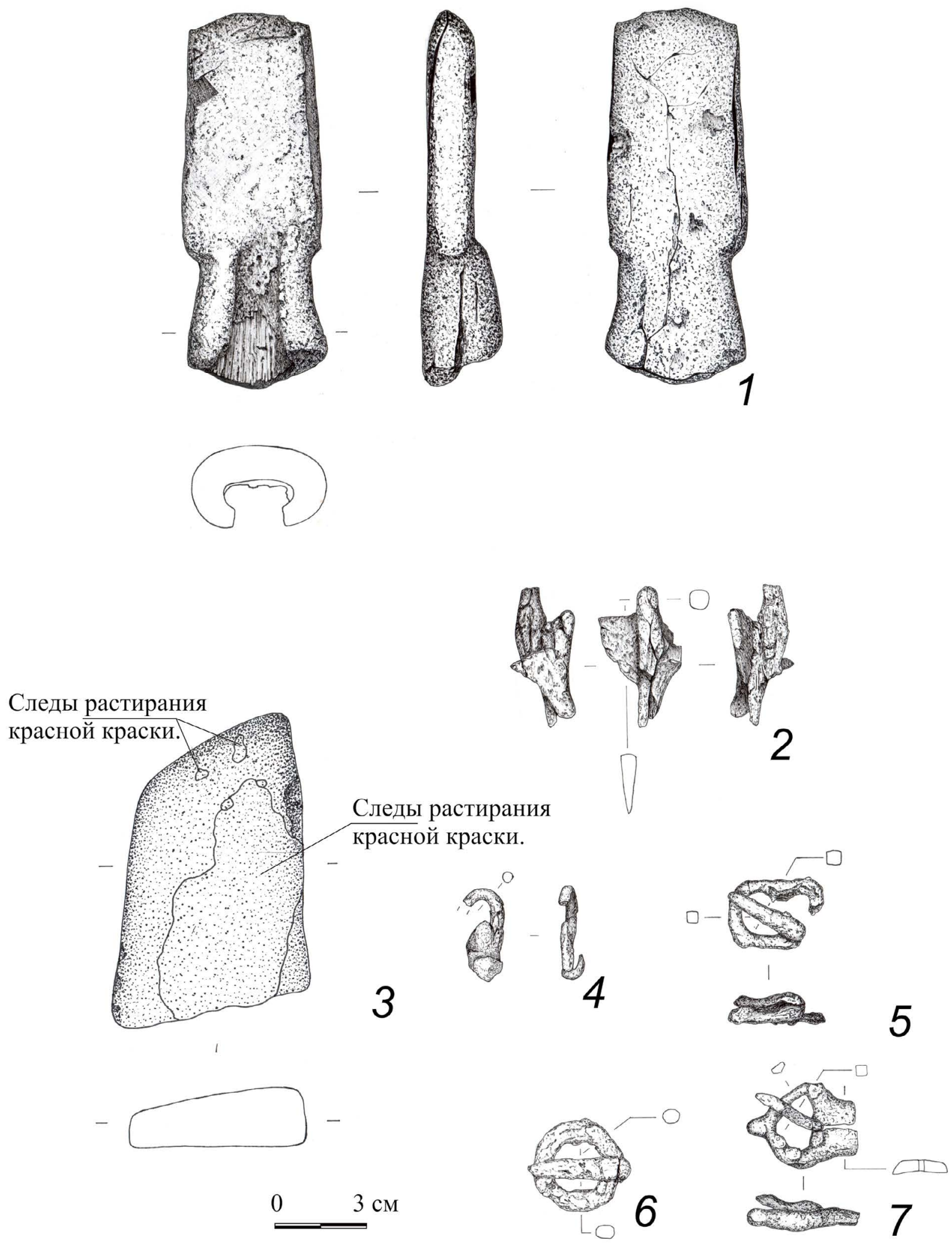

Рис. 17. Курганная группа Фонтан 2, курган 2. Погребение 2. Находки: 1 - тесло (находка № 17); 2, 4 - неопределенный предмет (находки № 12, 7); 3 - камень со следами затертости и стирания охры или киновари на поверхности (находка № 3); 5-7 - пряжка (находки № 6, 10), 7 - из заполнения склепа. 1, 2, 4-7 - железо 


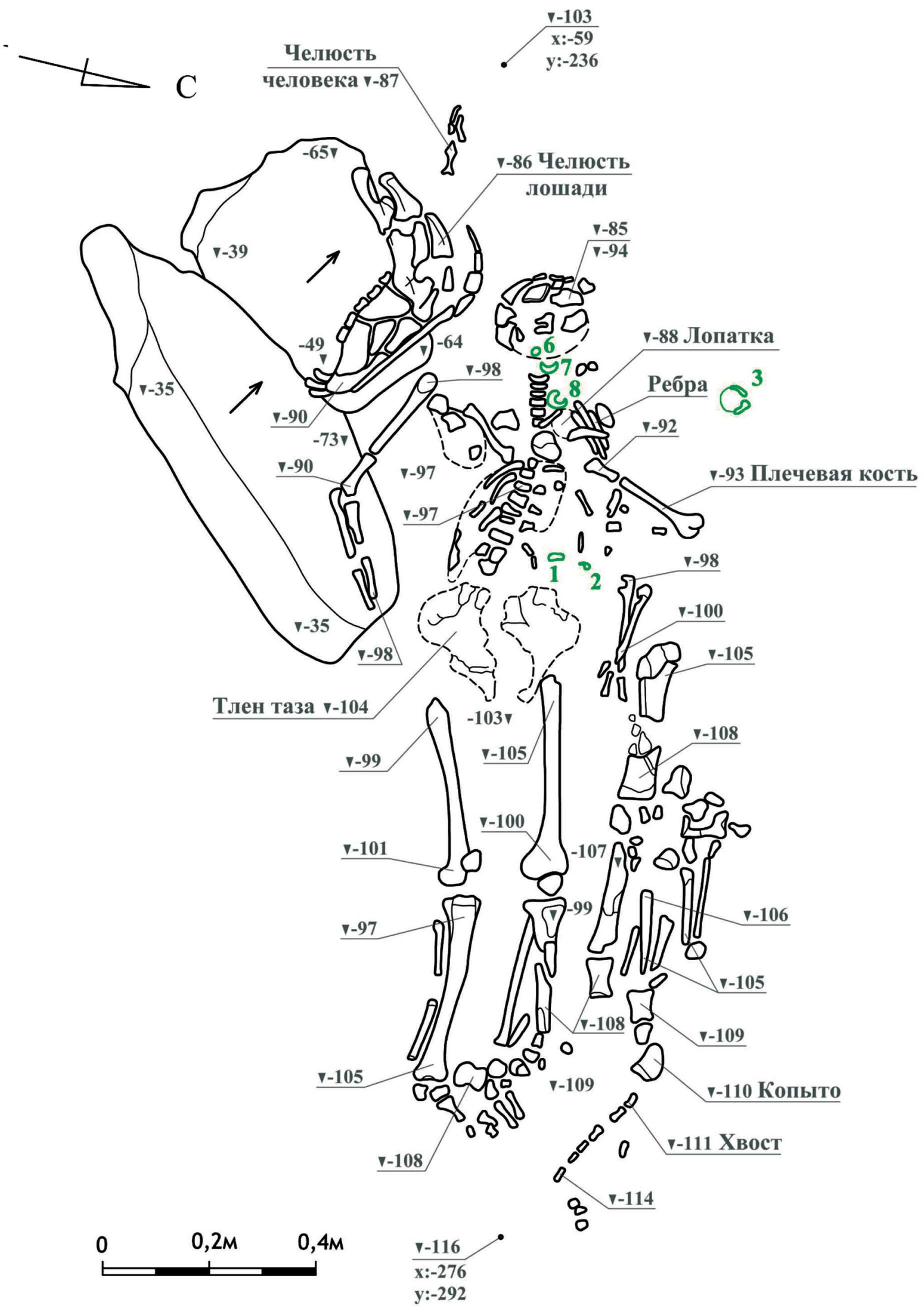

Рис. 18. Курганная группа Ивановка, курган 1. План погребения 1.

Индивидуальные находки: 1 - Бусина цилиндрическая глазчатая стеклянная; 2 - Предмет железный (фрагмент); 3 - Предмет железный (фрагмент), пряжка?; 4 - Ракушка морская (при переборке в районе таза); 5 Окислы бронзы (в районе поясницы); 6 - Подвеска бронзовая; 7 - Серьга бронзовая (западная); 8 - Серьга бронзовая (восточная) 


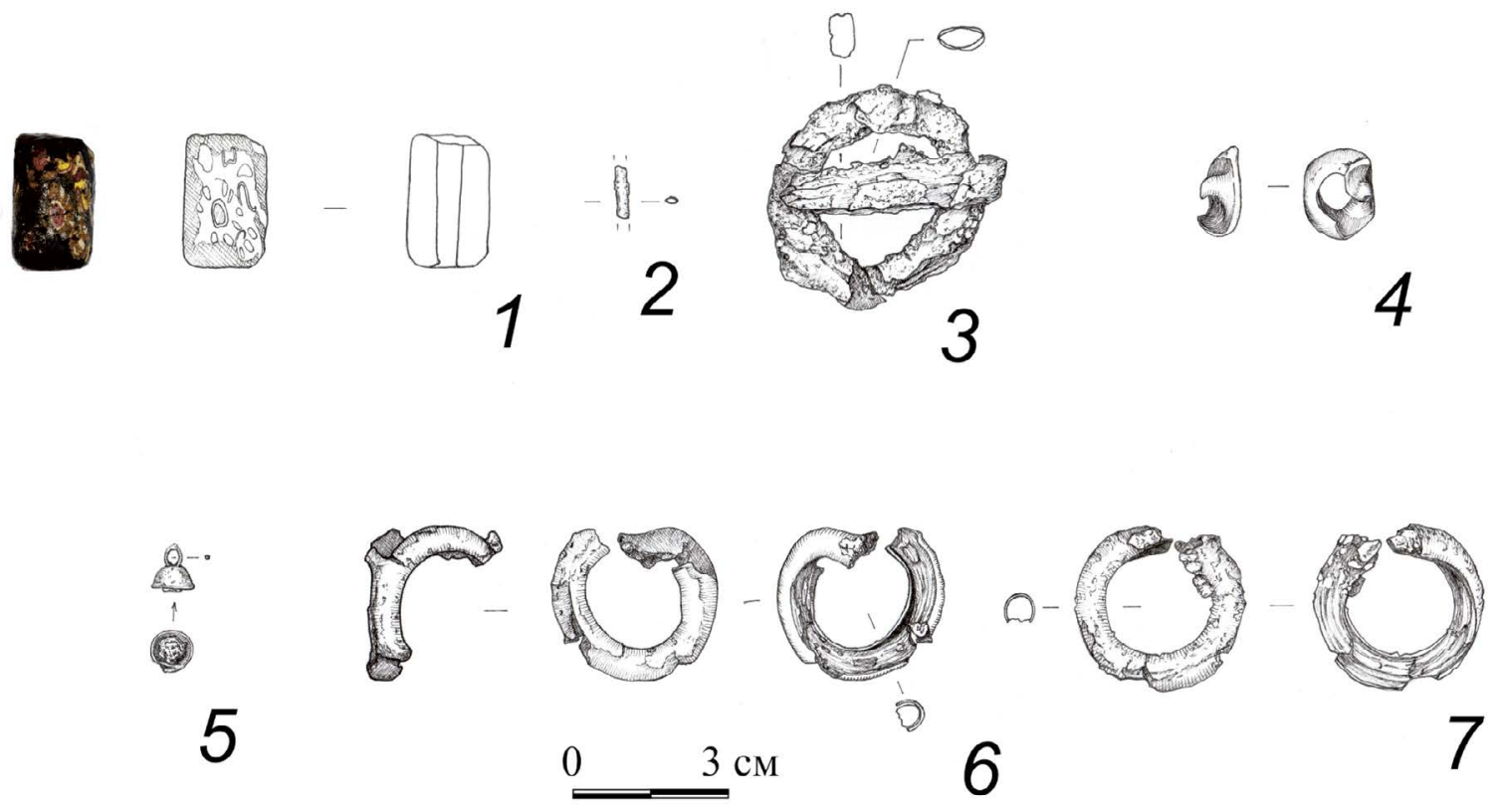

Рис. 19. Курганная группа Ивановка, курган 1. Инвентарь погребения: 1 - бусина стеклянная глазчатая (находка № 1); 2 - предмет железный, фрагмент (находка № 2); 3 - пряжка железная (находка № 3); 4 - раковина морская, фрагмент (находка № 4); 5 - пуговица (?) бронзовая, фрагмент (находка № 6); 6, 7 - серьги или височные кольца, бронза (находки № 7, 8)

имеет подокруглую рамку диаметром около 27 мм. Сечение рамки линзовидное.

Бронзовая пуговища? (рис. 19: 5) обнаружена в районе шейных позвонков. Представляет собой полусферическое изделие с ушком, вероятно, вторая часть полусферы была утрачена в процессе бытования. Диаметр полусферы около 5 мм.

Бронзовые серьги или височные кольца (рис. 19: 6, 7). Под скелетом в районе шейных позвонков найдены две бронзовые серьги или височные кольца с сечением в виде несомкнутой трубочки. Внутри трубочек сохранились остатки органического вещества серого цвета.

В нижней части спины под скелетом прослежена линза органики серого цвета и четыре пластины до 2 мм каждая, сечением в форме полумесяца. Также в заполнении в области таза найден фрагмент морской раковины (рис. 19: 4).

Особенности погребального обряда, наличие серег (или височных колец), аналогичных обнаруженным в погребении 4 кургана 3 курганной группы Фонтан 1, а также сохранившаяся часть параллельной линейной каменной выкладки позволяют отнести данное впускное кочевническое погребение к той же хронологической группе, что и все другие, рассмотренные в данной статье.

Выводы. Маловероятно, что такая яркая каменная архитектура ранее не замечена исследователями в курганах, содержавших средневековые кочевнические погребения. Полагаем, что наличие каменной погребальной конструкции, включающей две меридиональные параллельные кладки камней при единой ориентировке погребений, является узким локальным как территориальным, так и хронологическим признаком. В связи с этим вещи, происходящие из четырех исследованных погребений в трех комплексах, можно считать достаточно близкими друг к другу по временной шкале. Несмотря на то что большинство предметов в составе погребального инвентаря имеет широкие даты бытования, взаимная корреляция таких элементов, как стремена, удила, сабли и их детали, саадачная пластина, а также сам обряд погребения позволяет высказать предположение, что изученные комплексы были сооружены в XII - начале XIII в. Косвенно это подтверждается отсутствием в погребениях узких хронологических маркеров более раннего и более позднего периодов.

Особый интерес представляют найденные детали сложносоставного лука. Все обнаруженные роговые и костяные накладки выходят за пределы привычных традиционных наборов пластин, используемых для усиления кибити. Отсутствие концевых и срединных накладок привычных форм позволяет предполагать некие оригинальные варианты изготовления луков 
в микрорегионе. Наличие в погребении 2 кургана 2 курганного могильника Фонтан 2 единичной боковой накладки, которая может быть предварительно интерпретирована как боковая накладка плеча лука, допускает возможность проведенного ремонта и замены композитных вставок сложносоставного лука.

Также примечательна находка зуба лошади в каменном кольце над забутовкой погребения и перемещенных грызунами зубов той же особи в заполнении. Контекст обнаружения позволяет уверенно утверждать, что над погребением был, как минимум, помещен череп коня. Таким образом, несмотря на то что само погребение не содержит останков животного, правило наличия коня, который отнесет всадника в мир предков (хойлго морин - монг., койло ат - тюрк.), было соблюдено. Если бы конструкция была исключительно земляной, как это часто бывает с кочевническими погребениями рассматриваемого периода, то вероятность проследить присутствие коня в погребальном обряде при подобном расположении черепа была бы ничтожной.

Помещение черепа, шкуры или других фрагментов туши верхового коня не в саму могилу, а на возвышенности рядом хорошо известно по этнографическим и археологическим данным (Кубарев, 1978. С. 95. Рис. 9). Конь, уносящий хозяина в мир предков, - обязательная часть похоронного ритуала, что прослеживалось в архаичных кочевых обществах вплоть до начала XX в. (Цыденова, 2007. С. 328, 329; Гыргеева, 2009. С. 150). Данная традиция - общая для тюркских и монгольских народов и имеет сходное название. Это позволяет предположить, что она восходит к эпохе средневековья (Патаева, 2015. С. 36). Когда останки коня отсутствуют непосредственно в погребении, возможно, они должны были располагаться рядом. В рассмотренном выше случае - в каменном кольце над могильной ямой. Таким образом, исследование в 2017 г. комплекса кургана 2 курганной группы Фонтан 2 допускает, что выделенные в работе Г.А. Федорова-Давыдова группы погребений, не сопровождавшихся конем, все-таки могли иметь ритуальное захоронение лошади. Но останки или «чучело» помещались не в могилу, а на дневной поверхности. При наличии земляной насыпи фрагменты туши коня, помещенные поверх курганной насыпи или же на искусственном органическом возвышении, археологи могли не проследить.

Вещевой комплекс в описанных выше захоронениях может говорить о различиях в социальных статусах погребенных мужчин. Погребение 5 кургана 3 курганной группы Фонтан 1 имеет более сложную в исполнении архитектуру. Также следует отметить, что в качестве инвентаря в это погребение положены два одинаковых стремени, в отличие от погребения 2 кургана 2 курганной группы Фонтан 2. В погребении 5, возможно, лежала более современная на тот момент сабля, имеющая больший изгиб и более изящное «модное» перекрестие.

Видимо, погребение 2 принадлежит опытному пожилому воину, который пользовался более дешевым, устаревшим, но привычным снаряжением. С одной стороны, его доход не позволял заменить полностью комплект стремян в случае утраты одного из них, может быть, ему это и не требовалось. С другой стороны, характер вероятной смерти погребенного не исключает, что он остался без собственного снаряжения. Если он был казнен врагами, то соплеменники могли забрать его тело без оружия. В этом случае в качестве инвентаря, возможно, положены чужие вещи не первого уровня ценности. Этим можно было бы объяснить разнотипность стремян, ремонтированный лук и устаревший клинок. Мужчина же из погребения 5 похоронен с полным, соответствующим тенденциям своего времени, комплектом снаряжения, в котором все элементы уверенно укладываются в единый хронологический период.

\section{Литература}

Андрух С.И., Тощев Г.Н. Могильник Мамай-Гора. Кн. IV. Запорожье, 2009.

Дашковский П.К. Погребения енисейских кыргызов на Алтае (по материалам могильников Коргон-І и Чинета-II) // III Международный конгресс средневековой археологии евразийских степей «Между Востоком и Западом: движение культур, технологий и империй» / Отв. ред.: Н.Н. Крадин, А. Г. Ситдиков. Владивосток, 2017. С. 110-115.

Гьргеева К.А. К погребальной обрядности бурятского шамана: способ кремации // Сибирский сборник-1: Погребальный обряд народов Сибири и сопредельных территорий. Материалы VII Сибирских чтений. Кн. 2. Санкт-Петербург, 2009. C. $147-151$. 
Зеленский Ю. В. Позднекочевническое погребение со шлемом из степного Прикубанья // Историко-археологический альманах. Вып. 3. Армавир, 1997. С. 89-91.

Кирпичников А.Н. Древнерусское оружие. Вып. І: Мечи и сабли IX-XIII вв. Москва, 1966 (САИ; вып. ЕI-36).

Кирпичников А. Н. Снаряжение всадника и верхового коня на Руси IX-XIII вв. Ленинград, 1973.

Кочкаров У.Ю. Вооружение воинов Северо-Западного Предкавказья VIII-XIV вв. (оружие ближнего боя). Москва, 2008.

Кубарев В. Д. Древнетюркский поминальный комплекс на Дьёр-Тебе // Древние культуры Алтая и Западной Сибири. Новосибирск, 1978. С. 86-98.

Кубарев Г.В. Культура древних тюрок Алтая (по материалам погребальных памятников). Новосибирск, 2005.

Лагутин А.Б. Погребение средневекового кочевника у села Прибрежное в северо-западном Крыму // РА. 1998 . № 3. C. $156-163$.

Ларенок В. А., Ларенок П. А. Погребение кочевника-тюрка из могильника Северный-II // VII Донские археологические чтения. Ростов-на-Дону, 2005. С. 16-41.

Ларенок П.А. Средневековые погребения западного участка грунтового некрополя Танаиса // Арсеньева Т. М., Безуглов С.И., Толочко И.В. Некрополь Танаиса. Раскопки 1981-1995 гг. Москва, 2001. С. 73-84.

Медведев А. Ф. Ручное метательное оружие. Лук, стрелы, самострел. Москва, 1966 (САИ; вып. Е1-36).

Патаева В.Д. Традиционная обрядность у тюркских и монгольских народов // Вестник Бурятского государственного университета. Гуманитарные исследования Внутренней Азии. 2015. Вып. 1. С. 34-37.

Плетнева С. А., 1973. Древности Черных клобуков. Москва, 1973 (САИ; вып. Е1-19).

Путешествие Ибн Фадлана: Волжский путь от Багдада до Булгара. Каталог выставки / Гос. Эрмитаж. Москва, 2016.

Сейдалиев Э. И. Метательное оружие кочевников Северного Причерноморья и Крыма в XI-XIV вв. // Праці Центру пам'яткознавства. 2011. Вип. 20. С. 226-234.

Федоров-Давыдов Г.А. Кочевники Восточной Европы под властью золотоордынских ханов. Археологические памятники. Москва, 1966.

Цыљенова Д. Ц. Похоронно-погребальный обряд агинских бурят // Проблемы истории, филологии, культуры. Вып. XVIII. Магнитогорск, 2007. С. 325-346.

Шалобудов В. Н. Позднекочевнический могильник XIV в. у с. Котовка // Древности степного Поднепровья (III-I тыс. до н.э.). Днепропетровск, 1982. С. 60-68.

Шилов В. П. Калиновский курганный могильник // Древности Нижнего Поволжья. (Итоги работ Сталинградской археологической экспедиции). Т. І. Москва, 1959 (МИА; № 60). С. 323-523. 


\section{ШЛЕМ ИЗ КОМПЛЕКСА З МОГИЛЬНИКА У ХУТОРА ИМ. КАРЛА МАРКСА}

\section{С. Ю. Каинов, М. Ю. Меньшиков, И. В. Рукавишникова}

В 2015 г. отряд Института археологии РАН исследовал грунтовый могильник, расположенный на северной окраине хут. им. Карла Маркса в 4 км от пос. Киевское Крымского р-на Краснодарского края. Памятник находился на территории пахотного поля в низкой пойме р. Кубань на пологой террасе левого берега р. Адагум.

Ранее на основании разведочных данных памятник был определен как курган и поставлен на государственную охрану ${ }^{1}$. В начале полевых работ 2015 г. на пашне найдены фрагменты человеческих костей, но детальная топосъемка рельефа не выявила признаков насыпи на участке исследования. Раскоп был заложен на основании поворотных точек, указанных в материалах разведок. В ходе работ стало понятно, что исследуемый некрополь скорее является грунтовым могильником и курганный характер памятника был указан ошибочно.

Всего на территории некрополя исследовано 18 погребально-поминальных комплексов, из которых 14 принадлежали к одной этно-культурной группе, а 4 ингумации относились к иным культурным традициям. Информация о результатах исследования могильника постепенно вводится в научный оборот (Рукавишникова и др., 2017, 2018; Культурный мост ..., 2018. С. 116-139).

В ходе раскопок некрополя найдено большое количество предметов вооружения и снаряжения всадника и верхового коня, в том числе изготовленных из серебра. По составу комплекса вооружения выделяется погребение 3, где был найден набор наступательного и защитного вооружения: шлем, кольчуга, сабля или палаш, наконечник копья и наконечник стрелы. Данная статья посвящена публикации шлема.
Комплекс 3, представляющий собой кремационное безурновое погребение, исследован в центральной части некрополя под слоем глубокой плантажной вспашки на уровне $-80 \mathrm{~cm}$ (рис. 1). Признаки ямы, впущенной сверху, не выявлены, так как комплекс находился сразу под слоем пашни.

Погребальный инвентарь в основном представлен набором предметов вооружения. На поверхности материка лежали кольчуга, представляющая собой конгломерат размерами $44 \times 28 \mathrm{~cm}$; фрагменты сильно деформированного железного шлема с кольчужной бармицей; красноглиняный круговой кувшин с носиком и плоским дном (рис. 2А: 1). Внутри сосуда находилось фрагментированное дно другого подобного сосуда. Под кувшином найдены фрагмент тонкой стенки кругового сосуда и угольки, двулопастной небольшой железный наконечник стрелы; наконечник железного копья; согнутая сабля (или палаш) в нескольких фрагментах. Пространство между находками было заполнено кальцинированными костями ${ }^{2}$, среди которых обнаружены фрагменты кольца из медного сплава (рис. 2A: 4).

Сохранность всех металлических предметов, найденных в погребении, очень плохая. Их морфологические особенности выявлены и в ряде случаев реконструированы на основании информации, полученной в результате фрагментарных расчисток.

Наконечник стрель (рис. 2А: 3). Сохранился фрагмент верхней части пера, с ромбовидным сечением. Наиболее вероятно, что это обломок наконечника стрелы с пером ромбовидной формы.

\footnotetext{
1 Приказ управления по охране, реставрации и эксплуатации историко-культурных ценностей (наследия) Краснодарского края от 14.12.2007 г. № 24 .

2 По заключению М.В. Добровольской, в захоронении обнаружены кальцинированные кости двух индивидуумов, один из которых - женщина старше 40 лет. Определить половозрастную принадлежность второго индивидуума не представляется возможным. Отмечен только больший размер костей по сравнению с костями первого индивидуума (Добровольская, 2016. Л. 66, 67).
} 

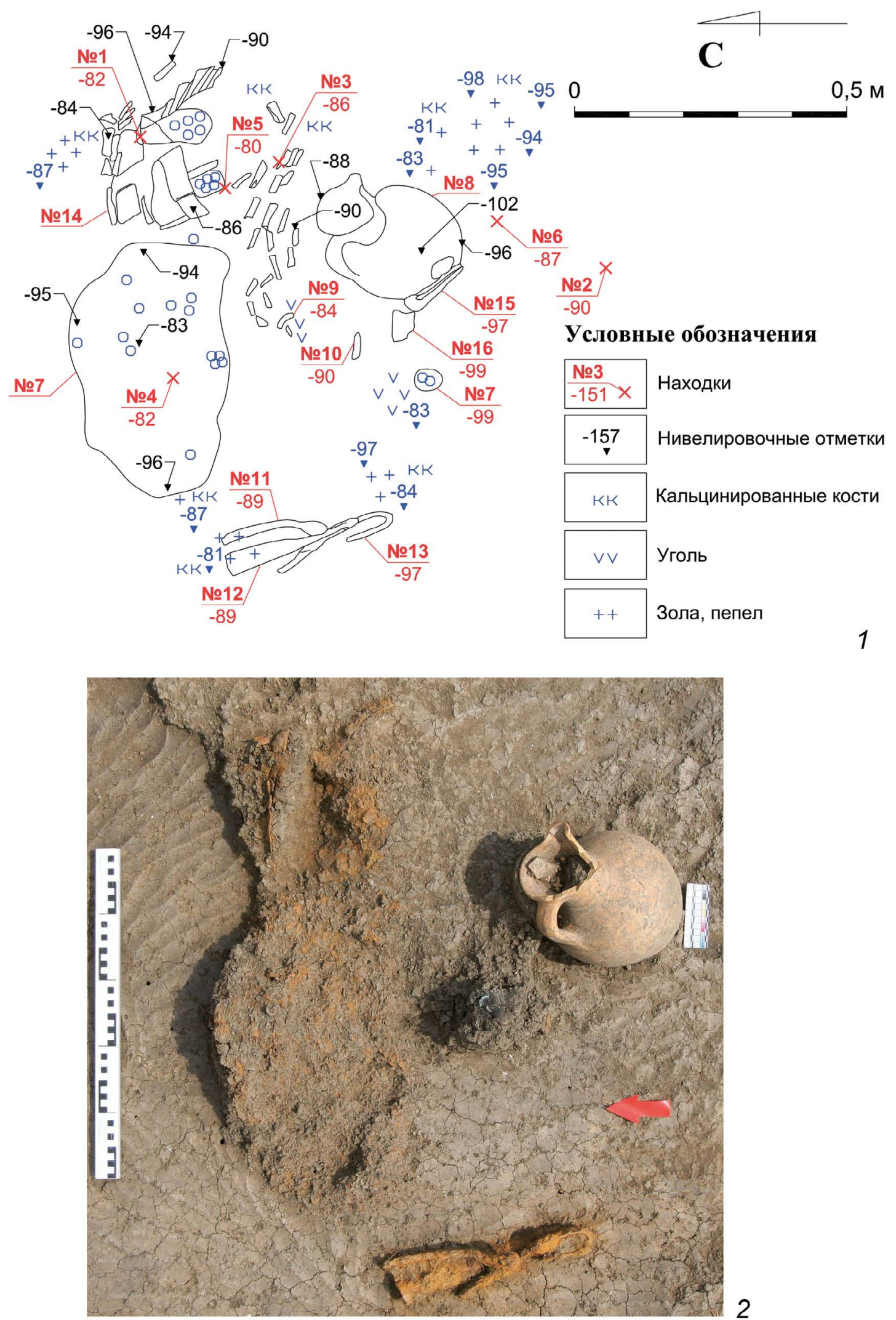

Рис. 1. Комплекс 3 могильника у хут. Карла Маркса. Находки, отмеченные на чертеже: 1 - предмет железный; 2 - кольца кольчужного железного фрагмент; 3 - сосуда керамического фрагмент; 4 - предмет железный; 5 - кольца кольчужного железного фрагмент; 6 - предмет (кольцо -?) железный; 7 - кольчуга железная; 8 - сосуд керамический; 9 - кольца бронзового фрагмент; 10 - наконечник стрелы железный; 11 - сабли железной фрагмент; 12 - наконечник копья железный; 13 - сабли железной фрагмент; 14 - шлем с бармицей железный; 15 - предмет железный; 16 - сосуда керамического фрагмент; 17 - сосуда керамического фрагмент 


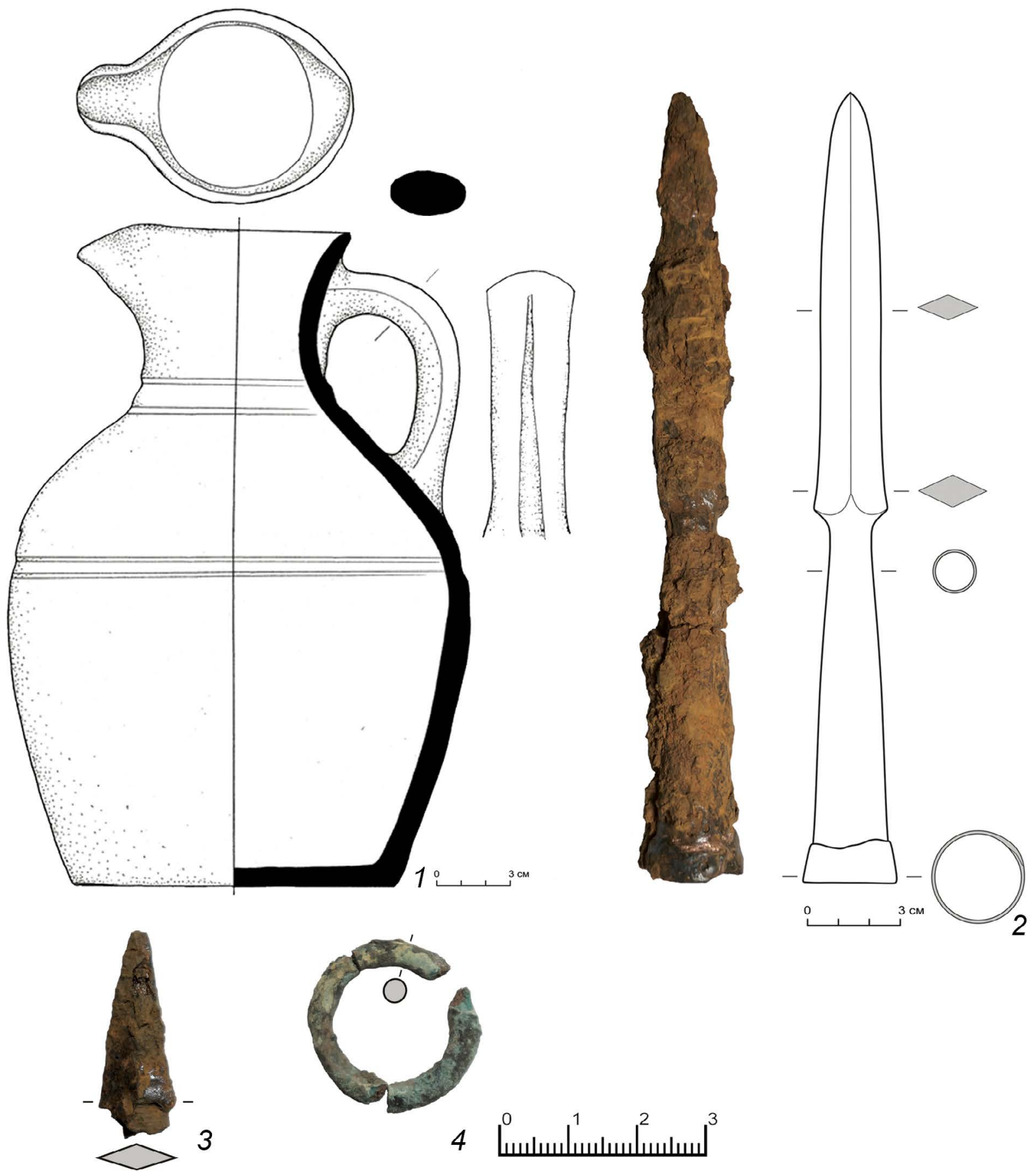

Рис. 2А. Комплекс 3: 1 - сосуд; 2 - наконечник копья, 3 - фрагмент наконечника стрелы; 4 - кольцо. 1 - глина; 2, 3 - железо; 4 - медный сплав

Наконечник копья (рис. 2А: 2). Общая длина -26 см, длина пера - 14. Перо вытянутой пулевидной формы, с небольшим сужением в нижней части и расширением при переходе к втулке (иногда такую форму называют «пламевидной»). Сечение пера - ромбовидное. Наибольшая ширина пера - 24 мм. Переход от пера к втулке оформлен в виде плечиков. Длина втулки - около 12 см. Сечение втулки ближе к переходу в перо овальное, на протяжении большей части длины круглое. В нижней части втулки при помощи припоя на основе меди напаяно железное кольцо с неровным верхним краем. Высота кольца 9-13 мм. Концы кольца также спаяны между собой. Толщина кольца - около 1,5 мм.

Схожие по морфологическим характеристикам наконечники были широко распространены у восточноевропейских кочевников в VIII-X вв. 


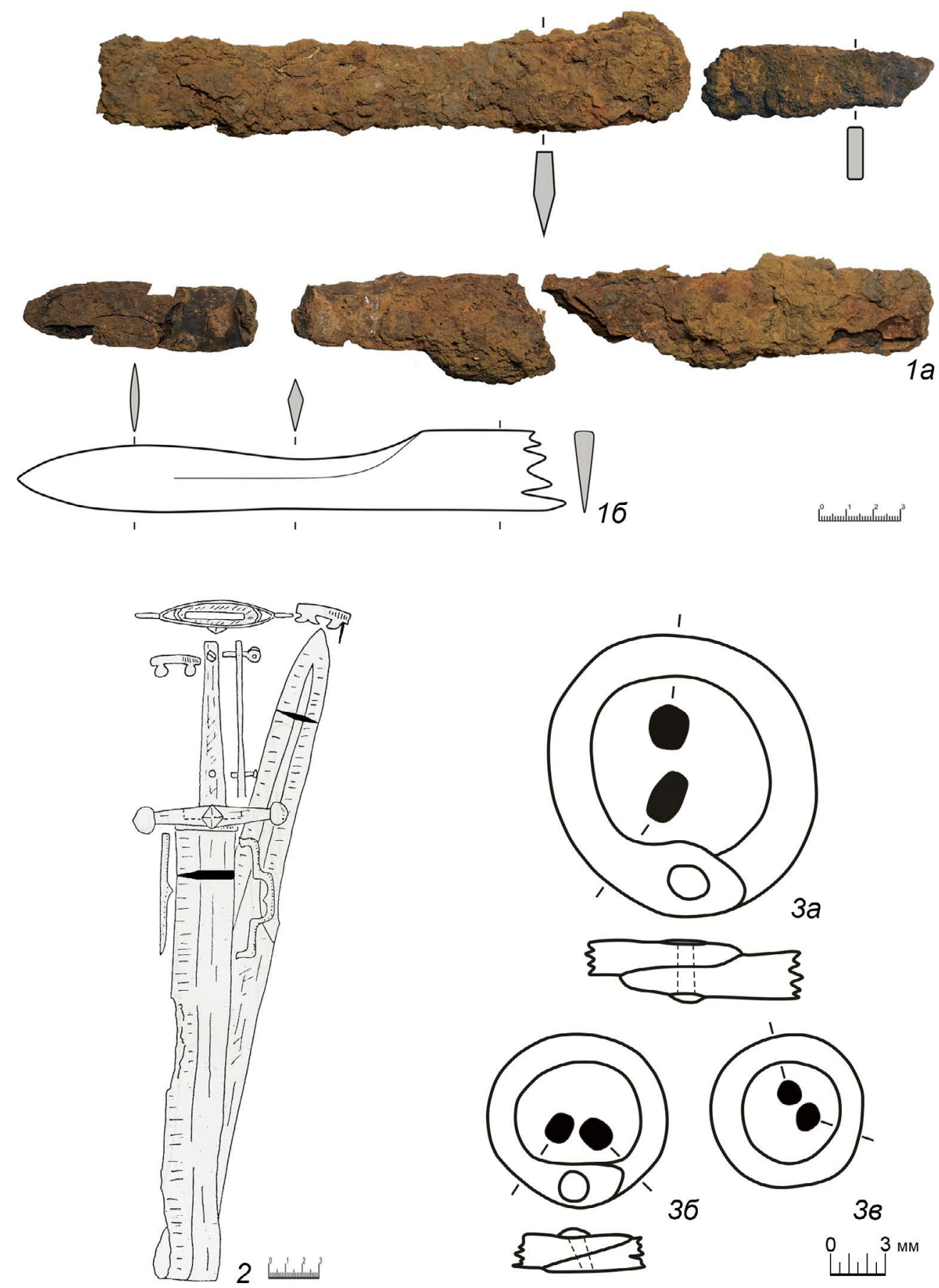

Рис. 2Б. Комплекс 3: 1а - сабля (палаш); 16 - реконструкция нижней части клинка;

2 - сабля из погребения 252 Сухогомольшанского могильника;

3 - кольчужные кольца (а - кольцо от кольчуги; б, в - кольца от бармицы). 1-3 - железо

и относятся к наконечникам пик - типу копий, как предполагают, прежде всего предназначенных для поражения противника в доспехах (Крыганов, 1987. С. 97-99).

Наконечники-пики с пером пламевидной формы выделены в отдельный тип (тип III, отдел I) в типологии наконечников копий, предложенной для памятников VIII - начала IX в. Доно-Донецкого региона С.И. Владимировым
(Владимиров, 2016). По данным автора в указанном регионе известно всего два таких наконечника - подъемный материал с территории Кочетокского могильника и в комплексе у с. Тополи. С.И. Владимиров не исключает, что пламевидная форма пера - результат неоднократной заточки (Владимиров, 2016. С. 285).

Палаш или слабоизогнутая сабля (рис. 2Б: 1a). В погребении был положен только клинок, 
согнутый и сломанный на несколько частей. Общая длина клинка - не менее 62 см. Никаких деталей рукояти (перекрестие, навершие и др.), в также деталей ножен, не найдено ${ }^{3}$.

К сожалению, плохая сохранность обломков клинка не позволяет предположить реконструкцию в полном виде и точно определить вид оружия (сабля или палаш). Тем не менее, в результате фрагментарных расчисток удалось зафиксировать особенности и предложить графическую реконструкцию нижней части клинка (рис. 2Б: 1б).

Клинок отличает окончание в виде пламевидного обоюдоострого лезвия с сечением в форме неравностороннего ромба, переходящего в линзовидное сечение. Крайне редко встречается такая особенность, как верхняя грань острия, находящаяся ниже общей линии обуха клинка. Чаще всего верхняя грань раскованного на два лезвия острия продолжает линию обуха, реже располагается выше нее. Дать однозначный ответ на вопрос, чем была вызвана подобная форма острия клинка, затруднительно. Вероятно, она служила для увеличения пробивающего эффекта при нанесении колющего удара.

Единственная известная авторам аналогия подобному оформлению острия - сабля из погребения 252 Сухогомольшанского могильника (Харьковская обл., Украина), которое датируется второй четвертью VIII - началом IX в. (Крыганов, 1989. Рис. 2, 3; Аксенов, Михеев, 2006. С. 163$)^{4}$ (рис. 2Б: 2).

Кольчуга 5 была помещена в погребение в сложенном виде. Очень плохая сохранность металла не позволяет охарактеризовать какиелибо особенности ее покроя ${ }^{6}$.

Расчищенные фрагменты кольчужного полотна демонстрируют плетение, при котором каждое кольцо соединяется с четырьмя соседними. Насколько это было возможно проследить, все кольца кольчуги клепаные. Форма колец овальная, размеры $-14 \times 16$ мм $^{7}$ (рис. 2Б: $3 a)$. Сечение колец на основной части - подквадратное, размеры - 2,2 × 2,5 мм; ближе к месту склепки - подпрямоугольное, размеры 1,8 × 2,9 мм. Длина клепки - 3,5 мм, один ее конец оформлен в виде полусферической головки, второй - расклепан почти «заподлицо». Наложение одной «лапки» на другую - 6,7 мм.

Целые кольчуги в погребениях последней четверти I тыс. н.э. на территории Северо-Западного Кавказа встречаются редко. Одна из них была найдена в погребении 106 могильника Казазово (вторая половина VIII в.), еще одна в разрушенном погребении могильника Дюрсо (IX в.) (Каминский, 1991. С. 148, 149; Крым..., 2003. C. 204).

Шлем еще до помещения в погребение подвергся деформации, возможно, связанной с какими-то ритуальными действиями. Корпус шлема был разделен на отдельные пластины, на которых фиксируются удары, исказившие первоначальную форму. Отломано было и навершие шлема. Помимо деформаций, связанных с обрядовыми действиями, на сохранность шлема крайне негативное влияние оказало тысячелетнее нахождение в земле. Все пластины шлема сильно фрагментированы (рис. 3).

Тем не менее очевидно, что корпус шлема был сформирован из четырех пластин подтреугольной формы с двумя вариантами оформления боковых краев - у двух пластин они были прямыми, у двух других - волнистыми ${ }^{8}$ (рис. 4). Расстояние между вершинами выступов у пластин с волнистым краем - 3,5-4 см. Предположительно количество выступов равнялось пяти. Расстояние между нижним выступом и краем пластины - около 20 мм. В вершине каждого

\footnotetext{
3 В Отчете и в последующих публикациях указано, что в погребении обнаружена «рукоять составная с обоймой и тыльником» (Рукавишникова, 2016. С. 24). В ходе реставрационных работ выяснено, что предмет не имеет отношения к деталям клинкового оружия.

4 А.Р. Крыганов предлагал датировать перекрестия, аналогичные зафиксированному на сабле погребения 252 Сухогомольшанского могильника, концом IX - началом XI в. (Крыганов, 1987. С. 108). Это мнение было оспорено В. С. Аксеновым и В.К. Михеевым, которые датировали появление перекрестий «с овальными, лепестковыми плоскими расширениями на концах» серединой - второй половиной VIII в. (Аксенов, Михеев, 2006. С. 107). А. М. Голубев также широко датирует перекрестия с плоскими концами второй половиной VIII - первой половиной IX в. (2018. Рис. 7).

5 О том, что в погребение был помещен именно корпусной доспех - кольчуга, а не ее фрагменты, свидетельствует компактное расположение большого объема кольчужного полотна.

6 Кольчуга, найденная погребении 106 могильника Казазово (вторая половина VIII в.), была длиной примерно до колен и была снабжена глубокими разрезами спереди и сзади, косым воротом с глубоким запа́хом и рукавами «до середины плечевых костей» (Каминский, 1991. С. 148, 149).

7 Приведены точные параметры одного полностью расчищенного кольца.

8 Определить первоначальное расположение значительной части обломков пластин в настоящее время не представляется возможным ввиду плохой сохранности и сильной фрагментированности.
} 

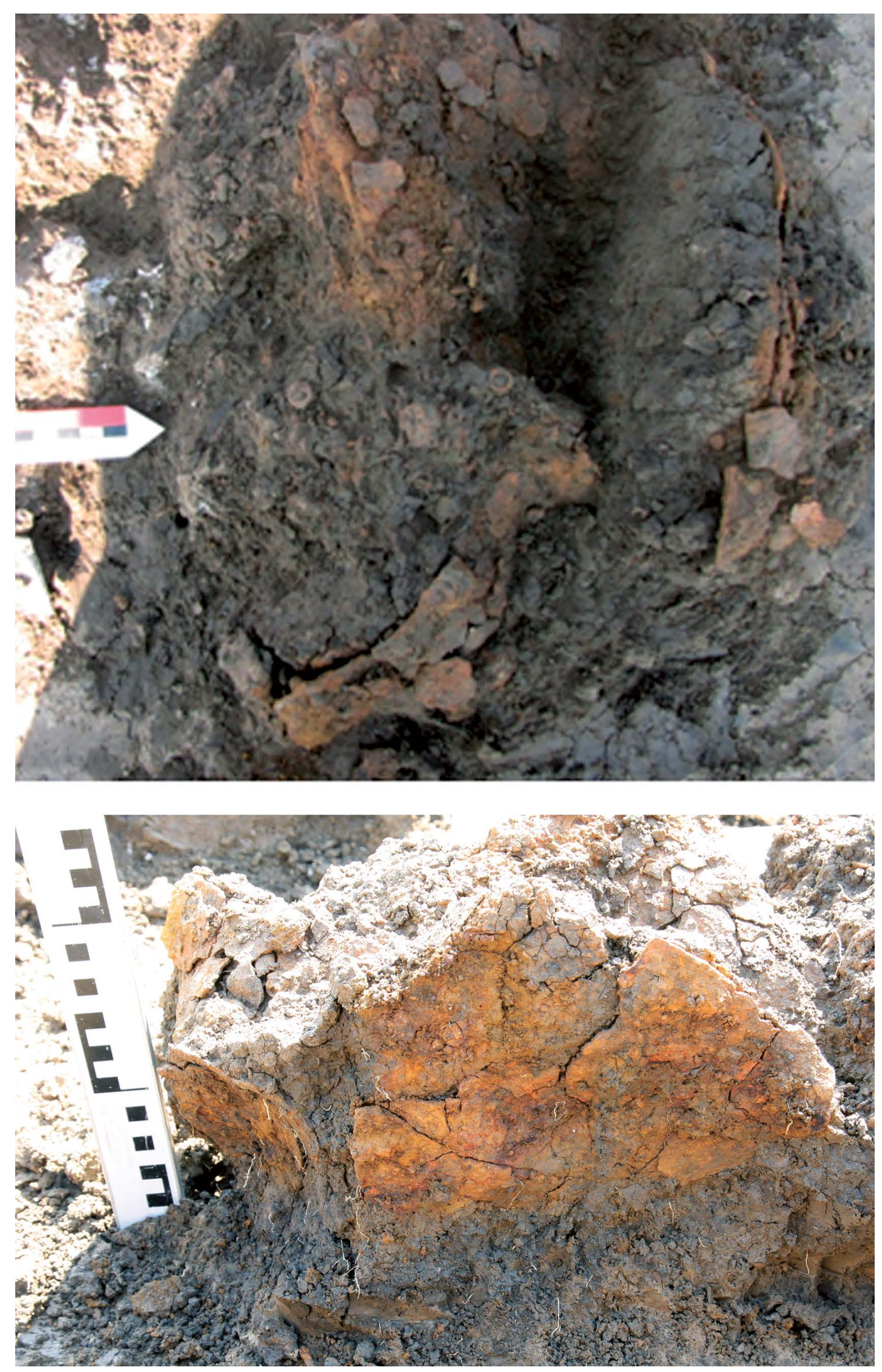

Рис. 3. Комплекс 3. Развал железного шлема 

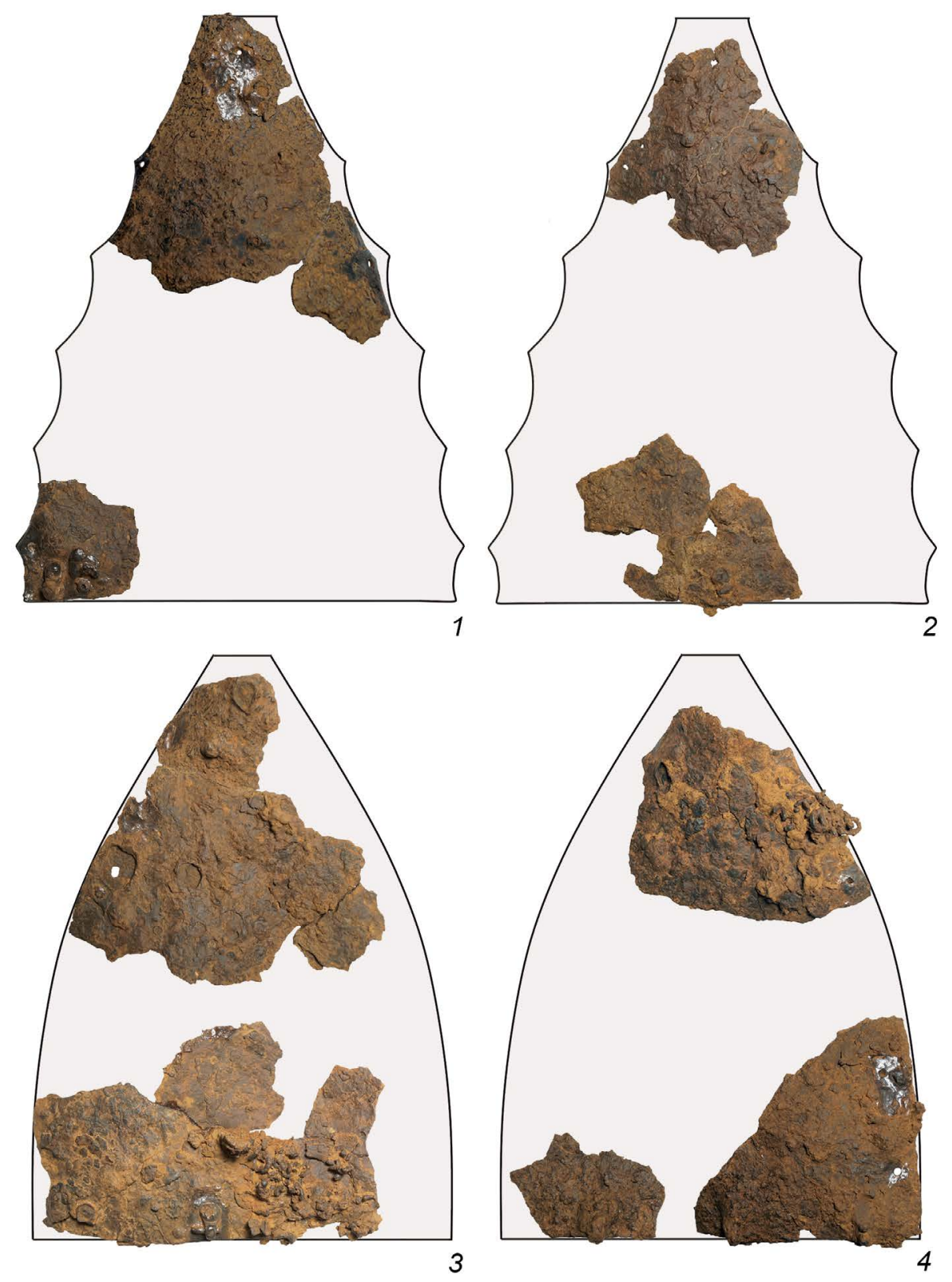

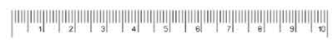

Рис. 4. Вариант реконструкции пластин (1-4) шлема из комплекса 3

выступа расположены отверстия диаметром 2,5-3 мм, в которых находились клепки, скреплявшие пластины между собой (рис. 5: 6). Расстояние от края выступа до центра отверстия 4-7 мм. Такие же отверстия есть и на боковых краях пластин с ровным краем. Расстояние от края пластины до центра отверстия - 9-10 мм.

В верхней части пластины дополнительно скреплялись навершием воронковидной формы (рис. 5: 1-3) ${ }^{9}$. Высота навершия - 64 мм. Основание в плане овальной формы, поперечный диаметр - 50 мм, продольный диаметр - 57 мм.
По всей видимости, навершие свернуто из листа. Способ соединения краев не ясен, но следы пайки медным сплавом при расчистке не выявлены. Навершие оканчивается массивной четырехгранной втулкой на круглом основании. Внутренний размер втулки $-5 \times 6$ мм. К корпусу шлема навершие крепится посредством четырех клепок, расположенных на продольной и поперечной осях. Диаметр одной сохранившейся головки клепки - 4 мм.

На одном из обломков налобной пластины сохранился небольшой фрагмент накладной детали,

\footnotetext{
9 Благодарим сотрудников ООО «Диагностика-М» за проведение рентгенографических исследований навершия шлема.
} 

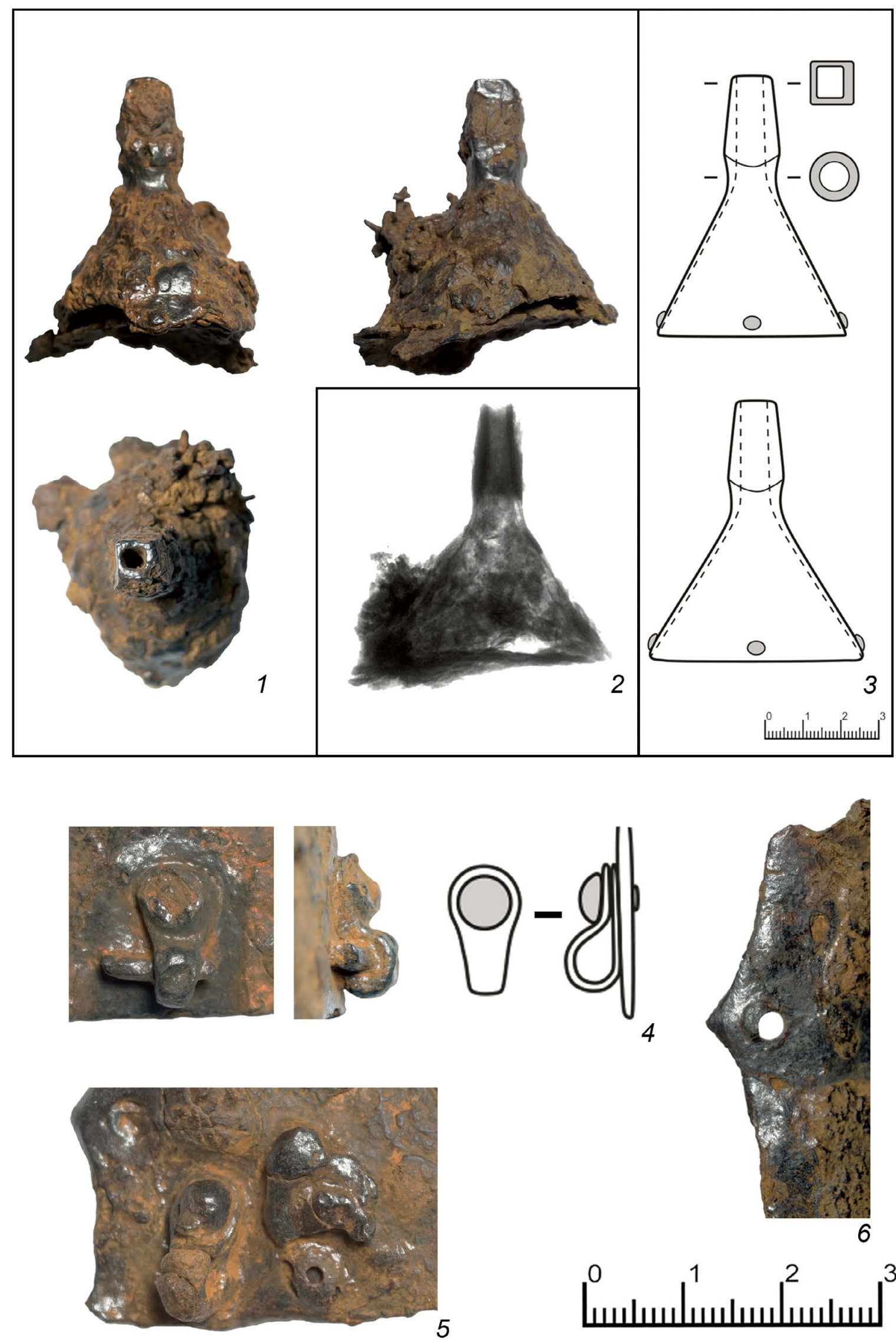

6

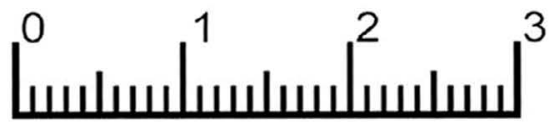

Рис. 5. Детали шлема: 1 - навершие; 2 - рентгенография навершия; 3 - реконструкция навершия; 4 - петля для подвеса бармицы; 5 - фрагмент накладных «бровей» на налобной пластине; 6 - элемент оформления края налобной или назатыльной пластины 
приклепанной к пластине (рис. 5: 5). Рядом с ней была также зафиксирована петля, состоящая из свернутой пополам полоски, концы которой приклепаны к пластине шлема. Высота петли - 15 мм. Диаметр шляпки клепки - 5 мм. Подобные петли были расположены и на остальных трех пластинах, формирующих корпус шлема. Расстояние между петлями - 45-50 мм. Внутри двух петель сохранились остатки железной проволоки диаметром около 2 мм (рис. 5: 4). Проволока служила для подвешивания кольчужной бармицы, защищавшей шею, плечи и нижнюю часть лица воина. Фрагменты бармицы найдены рядом со шлемом. Она состояла из клепаных и цельных колец. Клепаные кольца овальной формы ${ }^{10}$, размерами 9,6 × 10 мм (рис. 2Б: 3б). Сечение проволоки колец подквадратное, размеры - 1,4-1,5 × 1,9-2 мм. Цельные кольца округлой формы, диаметром 8,5 мм (внутренний диаметр 5,25,4 мм) (рис. 2Б: 3в). Сечение проволоки кольца - от округлого (1,3 мм) до овального $(1,3 \times 1,6$ мм). Длина клепки - 2,5 мм, один ее конец оформлен в виде полусферической головки, второй - расклепан «заподлицо». Наложение одной «лапки» на другую - 4,7 мм. Сохранность кольчужного полотна бармицы не позволяет восстановить ее покрой ${ }^{11}$.

Полученная в ходе изучения фрагментов шлема информация позволяет предложить вариант реконструкции боевого наголовья из комплекса 3 могильника у хут. Карла Маркса (рис. 6). Это шлем сфероконической формы, корпус которого сформирован из четырех пластин, склепанных друг с другом таким образом, что налобная и назатыльная пластины, края которых оформлены волнистыми выступами, наложены поверх боковых. В верхней части шлема при помощи клепок крепится навершие, увеличивающее конструктивную прочность шлема и одновременно служившее для размещения в нем нашлемного украшения в виде перьевого или волосяного «султана». В нижней части налобной пластины приклепана накладная профилированная деталь в виде «бровей» ${ }^{12}$.
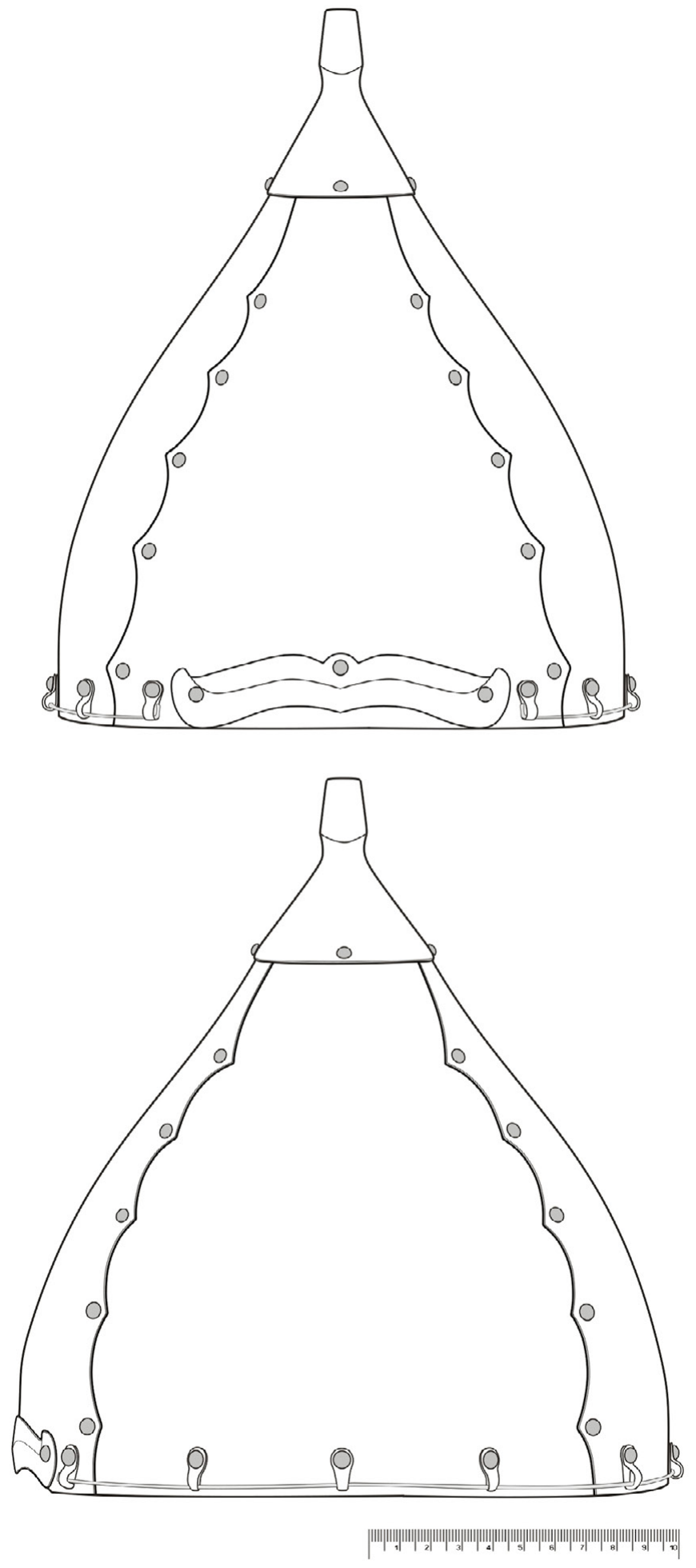

Рис. 6. Реконструкция шлема из комплекса 3 могильника у хут. Карла Маркса

\footnotetext{
${ }^{10}$ Приведены размеры одного клепаного и одного цельного колец.

${ }^{11}$ Бармица на шлеме из погребения 106 Казазовского могильника по форме представляла собой цилиндр с вырезом для лица (Каминский, Каминская-Цокур, 1997. Рис. 7: 2).

12 Форма этой детали гипотетически реконструирована на основе как материала из археологических раскопок (шлем из «Оскола», шлем из могильника Дюрсо (погр. 161), так и шлема из частной коллекции, использованного для создания 3D-реконструкции (Культурный мост..., 2018. С. 118, 119).
} 
Помимо орнаментальной функции она усиливала прочность налобной пластины. В нижней части шлема по всему периметру (кроме предличной зоны) приклепаны петли, в которые продета железная проволока, служившая для подвешивания кольчужной бармицы.

Шлемы с конструкцией корпуса, при которой передняя и задняя пластины накладываются на боковые, появляются на территории Восточной Европы в VIII в. Наиболее ранний шлем подобной конструкции найден около 1869 г. крестьянами из деревни Столбище при случайных обстоятельствах в разрушенном погребении «в 4 верстах к западу от правого берега р. Оскол, в овраге у вершины Попова леса. В ингумационном погребении кроме шлема, находившегося на голове погребенного, были найдены кольчуга, меч (?), золотые византийские монеты, золотые и серебряные ременные украшения и др. предметы. На основании ременной гарнитуры А.В. Комар датирует погребение 745-770 гг. (1999. C. 129, 132).

К настоящему времени одним из авторов статьи собрана информация о находках более 60 целых и фрагментированных шлемов, а также их отдельных деталей, которые можно отнести к ранней группе (VIII-XII? вв.) ${ }^{13}$ боевых наголовий описанной конструктивной схемы. К сожалению, подавляющее количество находок лишено контекста, что делает невозможной их датировку на основе археологического материала.

Тем не менее, есть возможность предварительно в общих чертах представить эволюцию этой группы шлемов. Одним из наиболее информативных для построения эволюции признаков, с нашей точки зрения, является оформление краев налобной и назатыльной пластин. У самого раннего шлема - шлема из «Оскола» (третья четверть VIII в.) - края пластин снабжены Черная могила
IX? B. $\quad 3 / 3$ IX B. $\quad 4 / 4 X-1 / 4 \mathrm{XI}$ в.

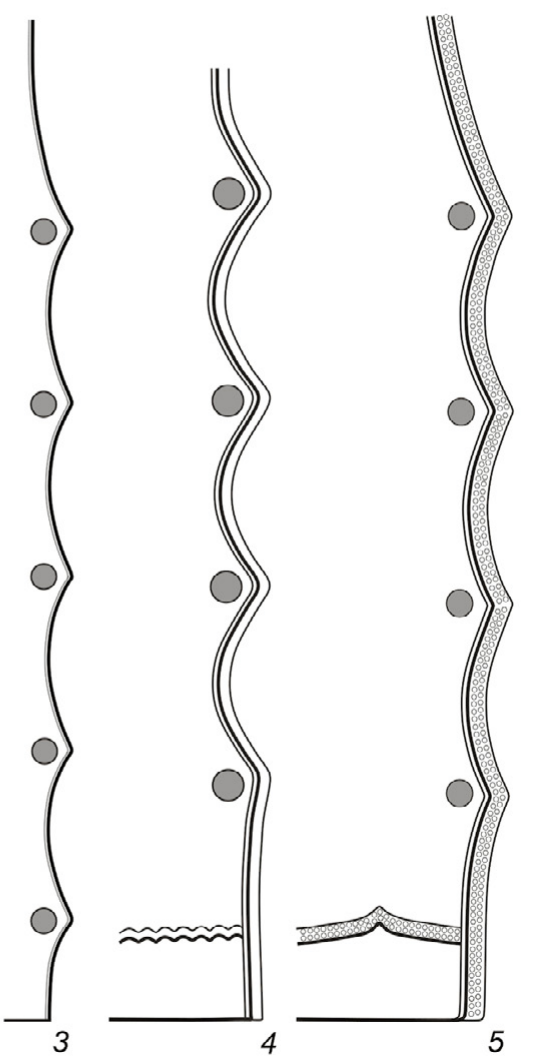

Рис. 7. Оформление краев налобных и назатыльных пластин боевых наголовий: 1 - «Оскол»; 2 - Дюрсо, погр. 161; 3 - комплекс 3 могильника у хут. Карла Маркса; 4 - погребение у с. Манвеловка; 5 - курган

глубокими полукруглыми вырезами (рис. 7: 1). В каждом месте наложения налобной и назатыльной пластин на боковые они соединяются при помощи пяти заклепок с крупными шляпками, обтянутыми листом из медного сплава.

Дальнейшее развитие боевых наголовий этой группы представлено шлемом из кремационного погребения 161 могильника Дюрсо, датирующееся IX в. ${ }^{14}$ (Крым..., 2003. С. 203, 204) (рис. 7: 2). Вместо одного глубокого полукруглого выреза края пластин оформлены двумя небольшими вырезами также полукруглой формы. Остальные участки на краях пластин незначительно вдавлены.

Новые явления в оформлении шлемов этой группы фиксирует боевое наголовье из погребения у с. Манвеловка, которое А. В. Комар (2011. С. 69) относит к памятникам субботцевского типа, связанных с древними венграми и датирующихся в рамках 836-895 гг. (см. Чурилова,

\footnotetext{
${ }^{13}$ Шлемы поздней группы (XIII-XIV вв.) при сохранении конструкции отличаются прямыми краями пластин и в целом значительно более простой отделкой (Двуреченский и др., 2012. С. 10-17).

${ }^{14}$ Подобное оформление пластин отмечено у шлема, найденного на территории Молдаванского кремационного могильника.
} 
1986. Рис. 2; Каинов, Каменский, 2013. Рис. 8: 1). Края передней и задней пластины оформлены четырьмя равновеликими волнообразными выступами (рис. 7: 4). Конструктивную прочность нижней части корпуса обеспечивает венец, охватывающий большую часть нижнего края корпуса шлема. На передней пластине венец совмещен c «трезубцем» - накладной фигурной композицией. Под переднюю и заднюю пластины корпуca, под верхнюю квадратную пластину, а также под детали «трезубца» подложены полоски из медного сплава. Никакой орнаментации на них не прослеживается. На венце расположены скобы ( $\Omega$-образные) для крепления бармицы.

Некоторые конструктивные и орнаментальные приемы, впервые зафиксированные на шлеме из Манвеловки, нашли свое развитие в шлемах X в., апогеем которого стали так называемые шлемы типа Черной могилы, по нашему мнению, относящиеся ко времени никак не раньше второй половины X в. ${ }^{15}$ Края налобной и назатыльной пластин оформлены четырьмя выступами (рис. 7: 5), в нижней части шлема приклепан венец, на налобной пластине расположен накладной «трезубец». В то же время на этих шлемах появляются новые характерные особенности - накладные бляхи, крепящиеся к боковым пластинам, обтяжка пластин корпуса золоченым листом из медного сплава, плакировка серебром железных накладных деталей («трезубец», боковые бляхи), а также венца и навершия. Крепление бармицы осуществлялось как на $\Omega$-образных скобах (как на шлеме из Манвеловки), так и на технологически более сложном подвесе, сформированном из подогнутого края венца ${ }^{16}$ (см. Кирпичников, 2009. Рис. 7, 10).

Края налобной и назатыльной пластин шлема из могильника у хут. Карла Маркса оформлены в виде равновеликих волнообразных выступов, как на шлеме из Манвеловки (рис. 7: 3). Но в отличие от последнего, выступов не четыре, а пять. Также у шлема из могильника у хут. Карла Маркса отсутствует венец и сохраняются и другие признаки, характерные для более ранних шлемов, фигурная накладка на переднюю пластину в виде «бровей», конструкция петель для подвеса бармицы (как у шлемов из Дюрсо/161 и Молдаванского могильника) $)^{17}$. Таким образом, этот шлем занимает промежуточное положение между шлемом Дюрсо/161 и шлемом из Манвеловки.

Могильник у хут. Карла Маркса был предварительно датирован IX-X вв. (Рукавишникова и др., 2018. С. 364). Представленный в статье анализ морфологических и конструктивных особенностей шлема из этого могильника позволяет предположить, что погребальный комплекс 3 наиболее вероятно относится к IX в.

\section{Литература}

Аксенов В. С., Михеев В.К. Население Хазарского каганата в памятниках истории и культуры. «Сухогомольшанский могильник VIII-X вв.» // Хазарский альманах. Т. 5. Киев; Харьков, 2006.

Владимиров С. И. Наконечники копий населения лесостепной зоны Доно-Донецкого региона во второй половине VIII - начале Х в. (салтово-маяцкая культура) // Археология восточноевропейской лесостепи. Воронеж, 2016. C. $280-291$.

\footnotetext{
${ }^{15}$ AMS-датирование образцов из кургана Черная могила позволило обоснованно предположить, что кремация была совершена в интервале 980-1025 гг. (Шишлина и др., 2017. С. 399). Более ранние датированные комплексы с подобными шлемами не известны.

${ }^{16}$ Наряду с «золочеными» наголовьями существовали и более простые шлемы без позолоченной обтяжки - например шлем из Великого Новгорода (пластина с Дубошина раскопа) и шлем из Геленджика (Каинов, Каменский, $2013 ;$ Папакін, 2017. Рис. 3: 11 (изображенный в последней статье на рис. 3: 16 шлем с неизвестным местом находки, на самом деле является прорисовкой фотографии шлема из Геленджика)).

Стоит отметить, что четырехчастевые шлемы X-XI вв. не были представлены исключительно золочеными наголовьями типа Черной могилы и их более простыми вариантами. Шлем из кургана Гульбище демонстрирует существование еще одной линии развития.

${ }^{17}$ Схожее оформление края фиксируется у шлема, найденного около города Печ (Венгрия) (Каинов, Каменский, 2013. Рис. 8: 3). Но у него нет дополнительной защиты лица (наносник) или усиления передней пластины («брови») и петли под бармичный подвес ближе к $\Omega$-образным скобам. Также под пластины корпуса подложена «выпушка» из листа медного сплава, украшенная одним рядом выпуклостей, - деталь, получившая развитие в Х в. Исходя из этого можно предположить, что шлем из Печа занимает более позднюю хронологическую позицию по отношению к наголовью из могильника у хут. Карла Маркса.
} 
Голубев А. М. Хронология салтовских памятников Верхнего Подонцовья в контексте венгерской проблематики // 3. Nemzetközi Korai Magyar Történeti Régészeti Konferencia. Budapest, 2018. C. 367-400.

Двуреченский О.В., Барышев А. В., Бирюков П. В. Шелом черкасский. Москва, Тула, 2012.

Добровольская М.В. Антропологическое описание анализируемых костных останков из «кургана» Карла Маркса // Рукавишникова И.В. Отчет о проведении археологических раскопок кургана Карла Маркса в Крымском районе Краснодарского края в 2015 г. // Архив ИА РАН. Ф. Р-1. 2016.

Каинов С. Ю., Каменский А.Н. О неизвестной находке фрагмента шлема с Дубошина раскопа в Великом Новгороде // Новгород и Новгородская земля. История и археология. Вып. 27. Великий Новгород, 2013. С. 179-189.

Каминский В. Н. Вооружение племен аланской культуры Северного Кавказа I-XIII вв.: дис. ... канд. ист. наук. Владикавказ, 1991.

Каминский В. Н., Каминская-Цокур И. В. Вооружение племен Северного Кавказа в раннем средневековье // Историко-археологический альманах. Вып. 3. Армавир, 1997. С. 61-69.

Кирпичников А. Н. Раннесредневековые золоченые шлемы. Новые находки и наблюдения. Санкт-Петербург, 2009.

Комар А. В. Предсалтовские и раннесалтовские горизонты Восточной Европы (вопросы хронологии) // Vita Antiqua. 1999. № 2. C. 111-136.

Комар А. В. Древние мадьяры Этелькеза: перспективы исследований // Археологія і давня історія України. Вип. 7: Мадяри в Середньому Подніпров 'ї. Київ, 2011. С. 21-78.

Крыганов А.В. Вооружение и конское снаряжение кочевников юга Восточной Европы VII-X вв.: дис. ... канд. ист. наук. Харьков, 1987.

Крыганов А. В. Вооружение и войско населения салтово-маяцкой культуры (по материалам могильников с обрядом трупосожжения) // Проблемы археологии Поднепровья. Днепропетровск, 1989. С. 98-114.

Крым, Северо-Восточное Причерноморье и Закавказье в эпоху средневековья. IV-XIII вв. Москва, 2003 (Археология).

Культурный мост: из прошлого в настоящее. Каталог выставки. Москва, 2018.

Папакін А. Шоломи у контексті східних контактів Русі та Польщі (X - початок XI ст.) // Історія давньої зброї. Дослідження 2016. Київ, 2017. С. 351-366.

Рукавишникова И. В. Отчет о проведении археологических раскопок кургана Карла Маркса в Крымском районе Краснодарского края в 2015 г. // Архив ИА РАН. Ф. Р-1. 2016. № ???

Рукавишникова И. В., Меньшиков М.Ю., Воробьев И. И. Исследования погребальных памятников в Краснодарском крае // Археологические открытия. 2015 год. Москва, 2017. С. 240-243.

Рукавишникова И. В., Меньшиков М.Ю., Воробъев И.И. Исследования нового биритуального могильника хазарского времени на Северо-Западном Кавказе // Кавказ в системе культурных связей Евразии в древности и средневековье. XXX «Крупновские чтения». Карачаевск, 2018. С. 361-364.

Чурилова Л.Н. Погребение с серебряной маской у села Манвеловка на Днепропетровщине // СА. 1986. № 4. С. $261-266$.

Шиилина Н. И., ван дер Плихт Й., Севастьянов В. С., Кузнецова О. В., Мурашева В. В., Панин А. В., Каинов С. Ю., Зозуля С. С., Шевиов А. О. Радиоуглеродное AMS-датирование экспонатов Исторического музея: результат и обсуждение // Известия Самарского научного центра Российской академии наук. 2017. Т. 19, № 3 (2). С. $398-405$. 


\section{И. А. Дружинина, В. Н. Чхаидзе}

Святилище Реком - один из интереснейших средневековых памятников Северного Кавказа, возникшее, по всей видимости, в начале XIV в. на землях, принадлежавших могущественному аланскому роду Царазонта. Фольклорная традиция прочно связывает Реком с народным героем Ос-Багатаром.

Научный интерес к святилищу не ослабевает вот уже более двух веков. С его изучением связаны имена В. С. Толстого, В.Б. Пфафа, В. Ф. Миллера, А.С. и П.С. Уваровых, А.А. Миллера, Б. А. Калоева, Е. Г. Пчелиной и др. Самым обстоятельным исследованием этого памятника является монография В.А. Кузнецова (1990). В этой работе автор на научной основе рассмотрел версию, согласно которой святилище Реком было связано с именем одного из последних царевичей Алании - Ос-Багатаром, чьи деяния запечатлены в «Анонимном грузинском хронографе» XIV в. (Грузинский..., 1987. С. 136, 198, 210-212; Жамтаагмцерели, 2005. С. 94, 143, 154,

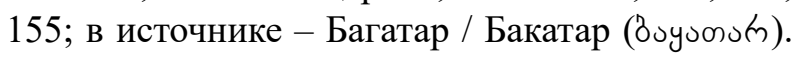
Согласно предположению В.А. Кузнецова, ОсБагатар был выходцем из рода Царазонта, после его гибели в 1306 г. (в 1304 г. - по В. Н. Гамрекели и Г.В. Цулая - см.: Цулая Г. В., 1980. С. 208; ср.: Столетняя Летопись. С. 211-212) Ос-Багатар был похоронен на родовом кладбище в Нузале, в склепообразной церкви, предназначенной для наиболее выдающихся представителей рода.

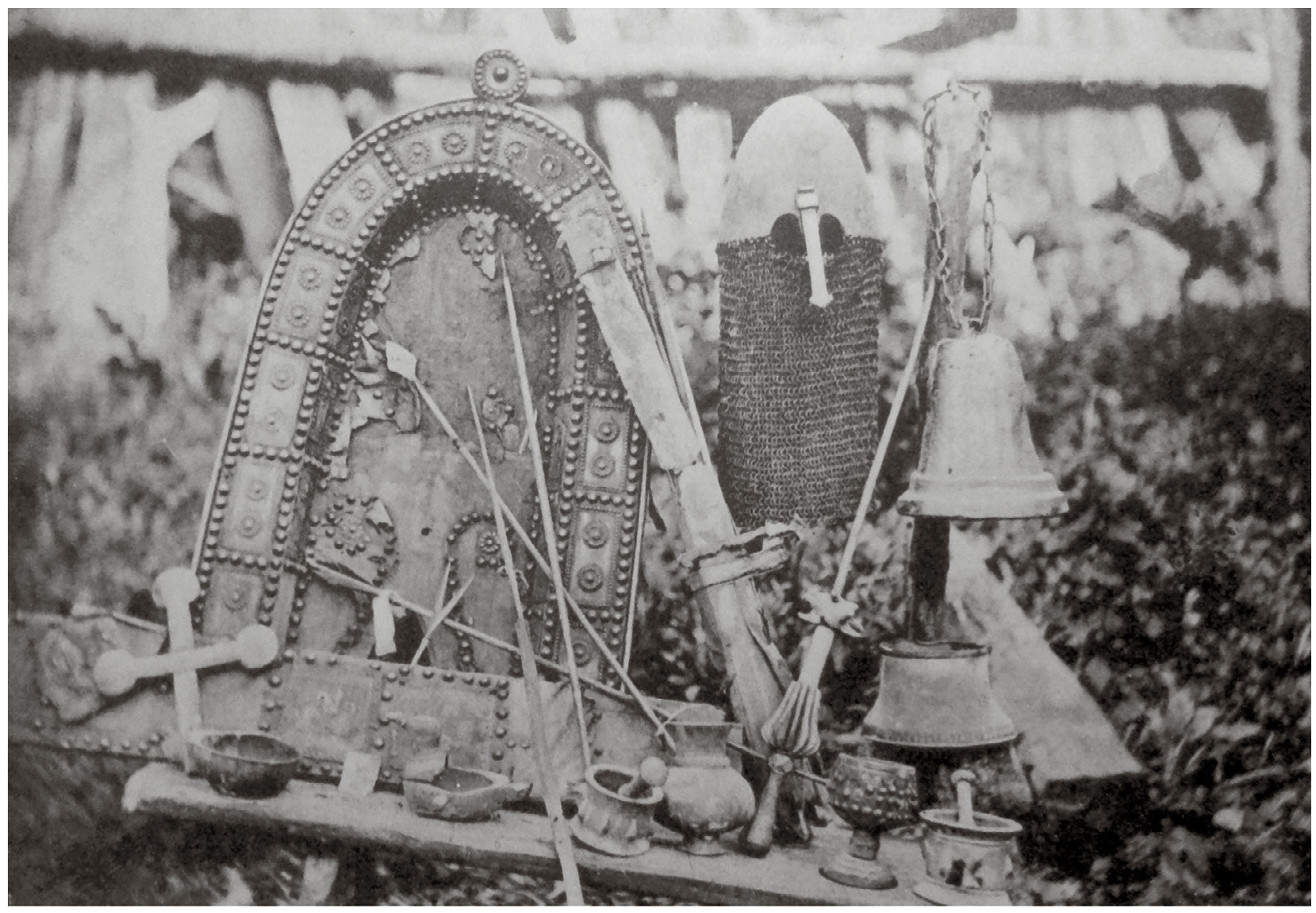

Рис. 1. Предметы из святилища Реком (по: Nioradze, 1923) 
(Иная точка зрения представлена в работе Д. В. Белецкого (2004.С. 52), посвященной Нузальскому храму.) Поскольку в Алании существовал военно-дружинный культ божества Уастырджи (Св. Георгий) и героев, к числу которых был причислен и Ос-Багатар, в Рекоме было создано мужское воинское святилище, куда из Нузальской церкви были перенесены доспехи и оружие Ос-Багатара (Кузнецов, 1988; 1990. С. 96-100).

Одним из весомых аргументов в пользу версии В.А. Кузнецова могло бы стать хронологическое и «статусное» соответствие предметов воинской экипировки из Рекома. Действительно, среди нескольких тысяч находок - ритуальных приношений - был выявлен ряд престижных предметов вооружения, которые фольклорная традиция связывала с Ос-Багатаром. Их описания оставлены посещавшими святилище исследователями и путешественниками, самое раннее из которых относится к концу XVIII в. Следует заметить, что перечень этих элитарных находок весьма разнится от сообщения к сообщению. Так, В.С. Толстой, осмотревший памятник в 1847 г., называет «круглый остроконечный стальной шишак, а стальною полосою опускающуюся перед лицом и с назатыльником из кольчуги» (цит. по: Кузнецов, 1990. С. 6, 7). В.Б. Пфаф, побывавший в святилище в 1869 г., описывает «железный рыцарский шлем с приделанным к нему для защиты плеч панцирем и колчан, наполненный стрелами», а также «копье, которое по преданию принадлежало осетинскому народному герою Осибагатару» (Пфаф, 1871. С. 139-141). В 1879 г. П.С. Уварова уже не обнаружила среди хранящихся в святилище предметов копья и колчана, но отметила «бронзовый пернач о восьми перьях» (Уварова, 1887. С. 62, 63). Помимо того, В.Б. Антоновичем, по сообщению исследовательницы, был найден пернач «железный о шести перьях (подобный тем, которые употреблялись в казачестве)» (Уварова, 1887. С. 64). В свою очередь, А. С. Уваров упомянул о находке в Рекоме двух бронзовых перначей (Уваров, 1910. С. 84).

Среди предметов, хранящихся внутри святилища, П.С. Уварова описывает «знаменитый шлем Осабаготора»: «миссорка шлема стальная; вдоль лба идет накладная пластинка; пространство для глаз вырезано; забрало и назатыльник из мелкой плетеной кольчуги», который, как полагала

исследовательница, «судя по отделке, может в действительности быть отнесен к XIV ст., - время, в котором по преданию жил этот осетинский богатырь» (Уварова, 1887. С. 63, 64).

В сообщении анонимного автора Н.С. в № 108 «Терских ведомостей» за 1892 г. перечислены «высокий и тяжелый стальной шлем с забралом и частью назатыльника из мелкой кольчуги», «пара стальных наручников», часть «панциря из мелкой кольчуги», «кожаный колчан, набитый стрелами» и «железный пернач» (Периодическая печать..., 1978. С. 79).

Ныне все эти предметы утрачены. Вплоть до последнего времени считалось, что их изображения также не сохранились, за исключением двух рисунков шлема, довольно отличающихся друг от друга, выполненных В. Б. Пфафом и А.А. Миллером. На основе сравнительного анализа рисунка В.Б. Пфафа и изображений шлемов на тебризских миниатюрах второй четвертисередины XIV в. М. В. Горелик связал происхождение шлема Ос-Багатара с Северо-Западным Ираном (1983. С. 263, 265). Е.И. Нарожный, отдав предпочтение рисунку А.А. Миллера, также остановился на ирано-хулагуидской атрибуции находки из Рекома (Нарожный, 2003. С. 118, 119). Эти выводы авторы соотносят с информацией «Анонимного хронографа XIV в.», согласно которому Ос-Багатар, бывший в числе северокавказских алан, занимавших антиордынскую позицию и вынужденных переселиться после 1263 г. на территорию подчиненной ильханам Грузии, 
сыграл выдающуюся роль в хулагуидско-джучидском противостоянии (Жамтаагмцерели, 2005. C. 154, 155).

Что касается сведений об остальных предметах из «комплекса вооружения» ОсБагатара, то к ним исследователи относили достаточно подробное описание долгое время хранящегося в святилище пернача (Нарожный, Чахкиев, 2003. С. 130; Сланов, 2007. С. 85). Это описание оставил анонимный путешественник Н. С. в заметке «В Осетии. Цейское ущелье», где содержится перечень обнаруженных в Рекоме предметов, среди которых был «железный пернач с мас-
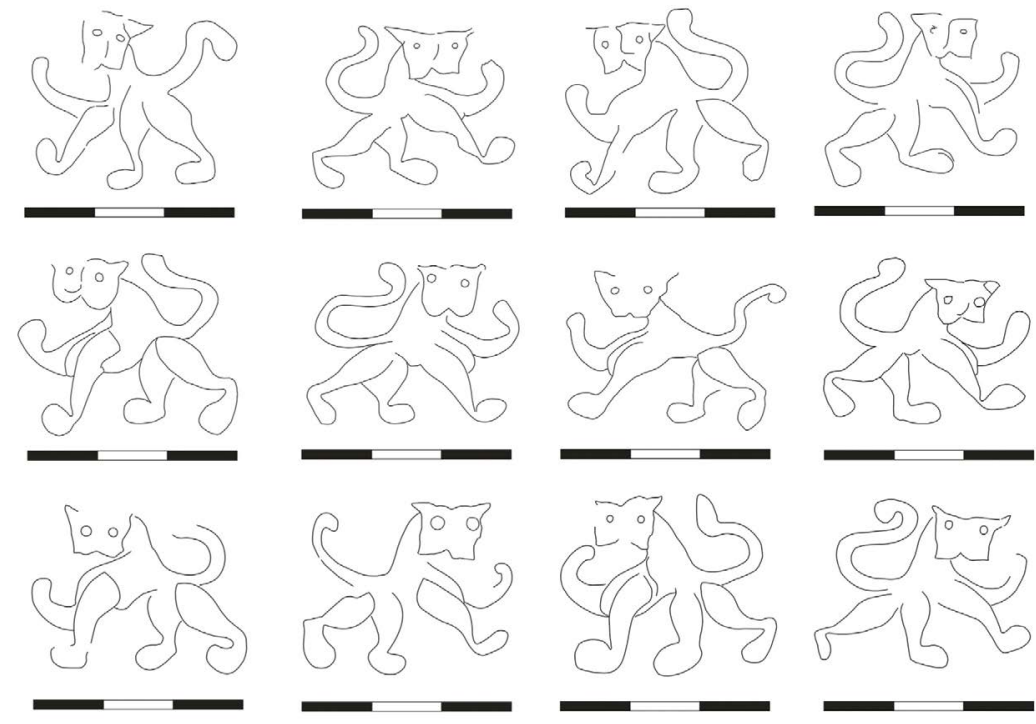

Рис. 3. Изображения кошачьих хищников на гранях шестопера из святилища Реком сивною шишкою на одном конце и с шестью симметрическими выступам под шишкою, расположенными по массивному цилиндру; продолжением цилиндра служит тонкий длинный стержень; длина всего пернача около $3 / 4$ арш.» (Периодическая печать..., 1978. С. 79).

А.А. Сланов ошибочно соотнес описанный Н. С. пернач из Рекома с хранящимся в Венском музее навершием бронзовой булавы с четырьмя выступами, происходящим из случайных находок с территории Северной Осетии, хотя автор и отметил явное несоответствие в описании находки из Рекома анонимного автора и музейного экспоната Венского музея (Сланов, 2007. С. 85. Табл. XXV: 7). К тому же в 1900 г. «венская булава» уже была опубликована П.С. Уваровой (и отнесена при этом к находкам из с. Фаскау) (1900. С. 277. Рис. 212), в то время как в «Описи имущества часовни Реком», составленной в мае 1903 г., все еще значился пернач на длинном железном стержне (Дарчиев, 2011. С. 39, 40).

Однако в 1923 г. Георгий Капланович Ниорадзе (1886-1951) опубликовал в книге «Горные осетины и их страна. Антрополого-этнографическое исследование кавказского народа» фотографию предметов из Рекома (Nioradze, 1923. Taf. 10) (рис. 1). Обстоятельный анализ предметов вооружения (шлема, наконечников стрел, пернача и булавы), изображенных на фотоснимке в работе Г.К. Ниорадзе, провел А. В. Дарчиев (2011). Из нескольких десятков находок для нас важны запечатленные справа внизу фотоснимка длинный стержень, увенчанный набалдашником с граненым «яблоком» в основании (бунчук?), на который нанизаны пернач с 12-лопастным навершием и длинной втулкой и навершие булавы с пирамидальными шипами (типа «моргенштерн»). Здесь следует подчеркнуть, что ни в одном из известных описаний предметов вооружения из Рекома пернач с 12-ю ударными гранями не упомянут, исследователи называли шестопер и 8-гранный пернач.

Допуская, что у навершия булавы было шесть пирамидальных выступов, а также учитывая случайный порядок в расположении предметов на стержне с набалдашником, как и сам их набор, данную группу предметов с фотоснимка можно соотнести с описанием, оставленным Н.С., в том числе упомянутым «железным перначом с шестью симметрическими выступами под массивной шишкой» (Периодическая печать..., 1978. С. 79). Но представлялось вероятным и то, что помимо пернача и булавы, изображенных на фотографии из книги Г.К. Ниорадзе, существовало и другое навершие - шестопер, который описал анонимный автор Н.С. и который был некогда надет на стержень бунчука, но затем заменен на 12-гранный пернач, который и попал на фотоснимок.

И такой шестопер был обнаружен нами при работе с кавказской коллекцией находок, собранных П.С. Уваровой и хранящихся в Государственном историческом музее. В графе о месте находки шестопера в музейной описи значится: «Терская обл., Владикавказский окр., святилище Реком. Из собрания Уваровой П.С.». (Коллекционная опись, № 1530 В) (Дружинина, 2012. С. 16, 17; Дружинина, Чхаидзе, 2013. С. 77). 

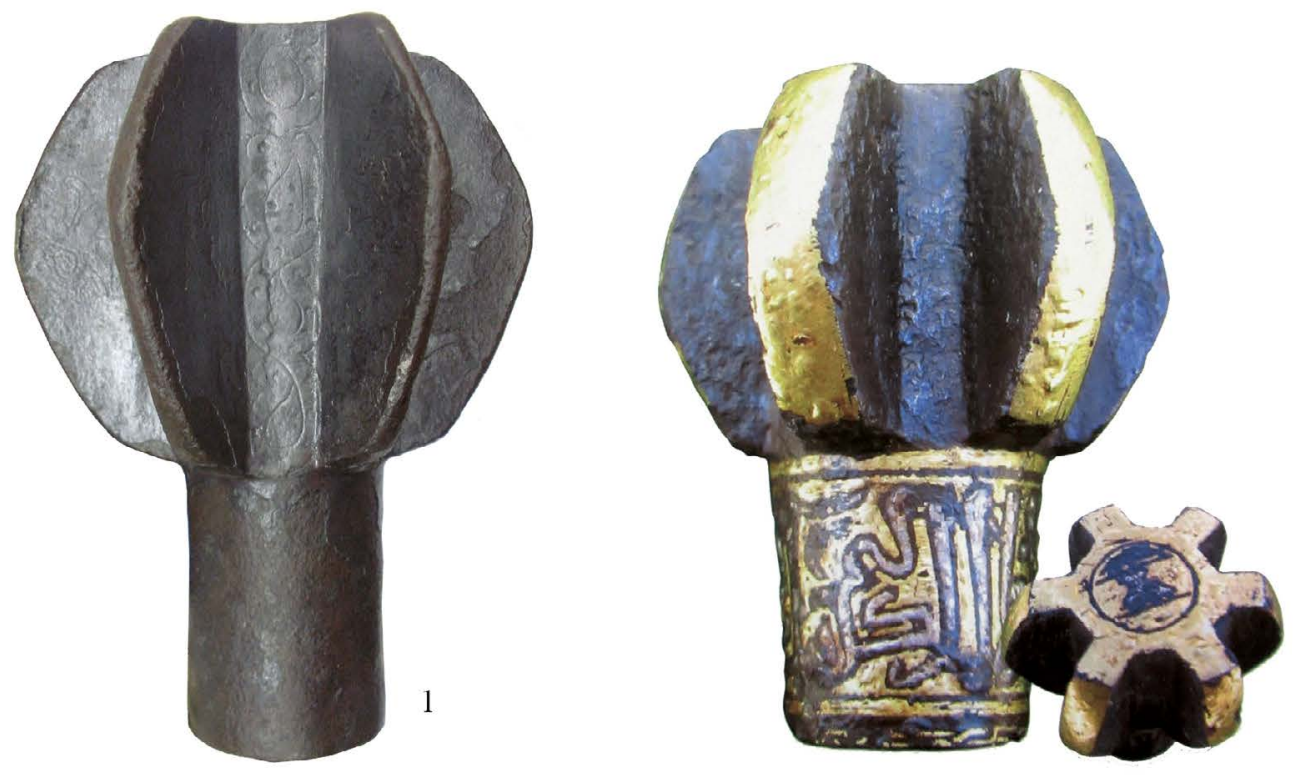

2
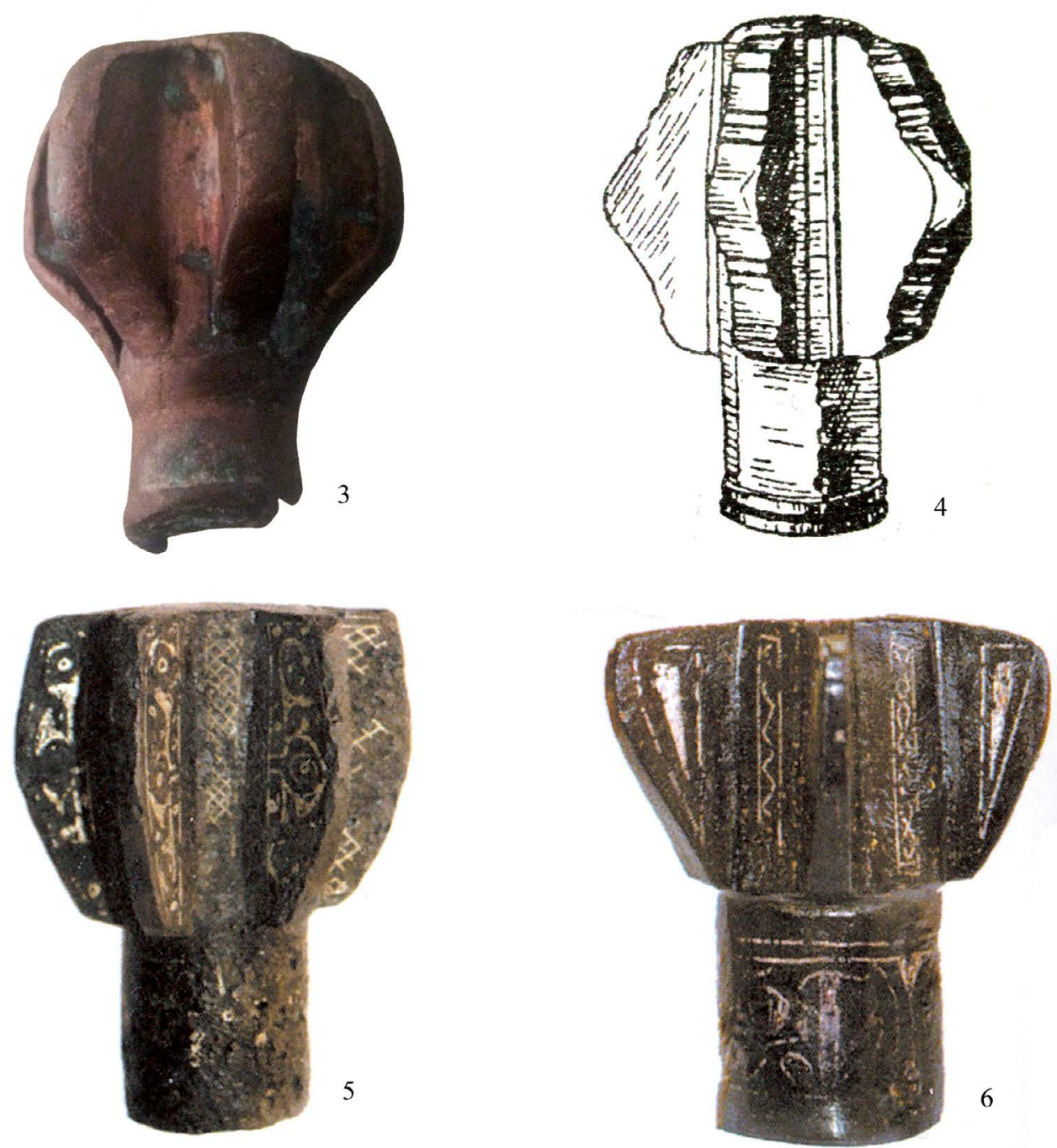

Рис. 4. Шестопер из Рекома (1) и его аналогии: 2 - шестопер из погр. Бэлэбани II/1-2 (Тараклийский р-н, Молдова) (Гукин, 2013. Рис. 39); 3 - шестопер из музея Сванетии (Грузия) (Svaneti Museum, 2014. P. 38); 4 - шестопер из окрестностей золотоордынского города Маджары (Северный Кавказ) (Нарожный, Чахкиев, 2003. Рис. 3: 6); 5, 6 - шестоперы из Болгарии (Vatevi Collection) (Popov, 2015. № 414, 448) 

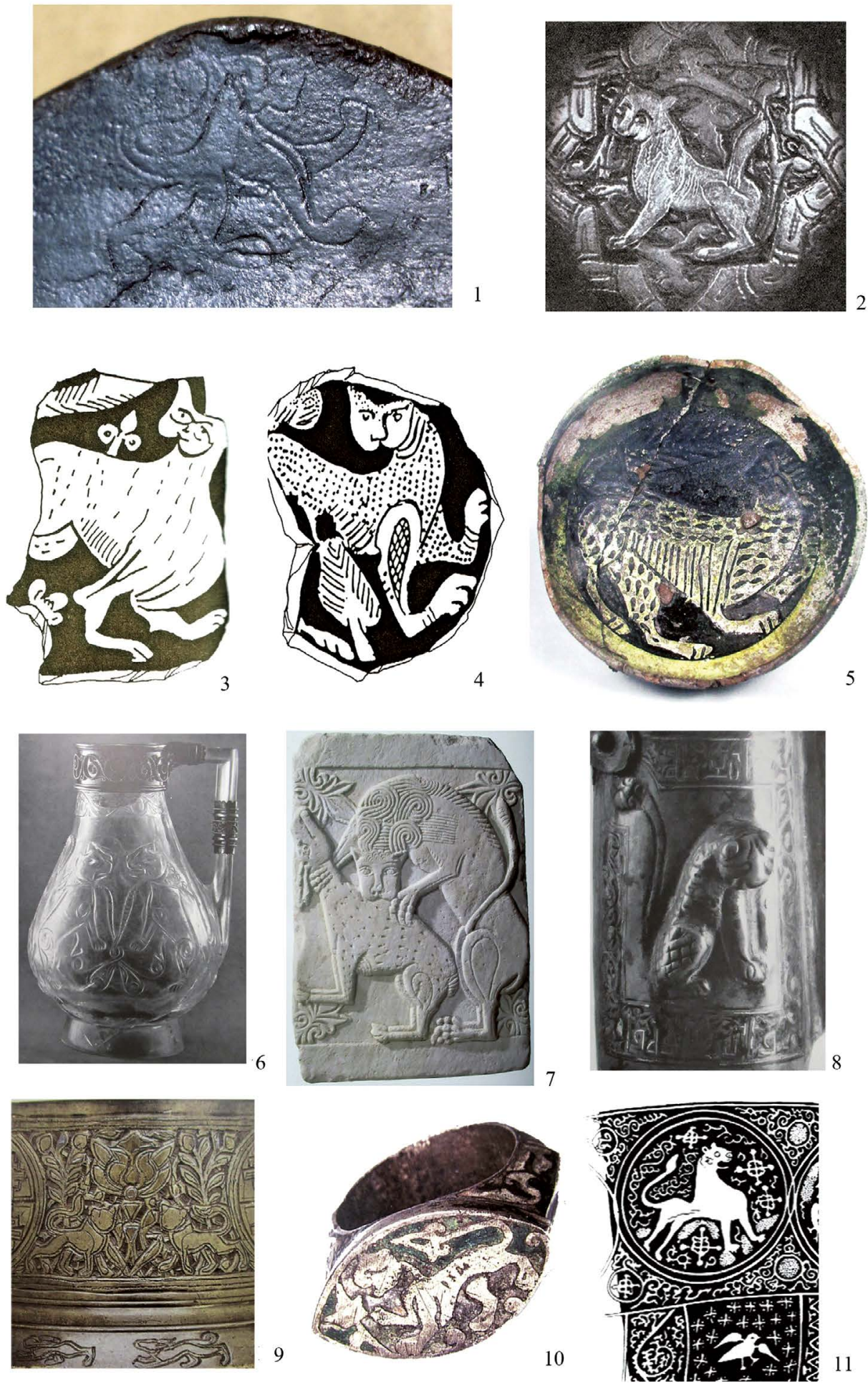

Рис. 5. Изображение кошачьих хищников на шестопере из Рекома (1), в византийской и ближневосточной традиции XI-XIV вв.: 2 - медальон серебряной чаши из с. Вильгорт, XII в. (Даркевич, 1975. Рис. 19); 3 - фрагмент византийской поливной чаши из Несебра, вторая половина XIV в. (Бочаров, 2005. Рис. 3: 1); 4 - фрагмент византийской поливной чаши из Белгород-Днестровского, вторая половина XIV в. (Бочаров, 2005. Рис. 3: 2); 5 - чаша-кубок с изображением леопарда, Херсонес, XIII в. (Залесская, 2011. Рис. 399); 6 - кувшин из горного хрусталя. Египет, XI в. (Веймарн, 1974. Кат. 72); 7 - мраморная плита со сценой «Лев, убивающий лань», Афины, поздний X - первая половина XI в. (Византия сквозь века, 2017. Кат. 56); 8 - умывальный прибор бронзовый, деталь. Иран, XII в. (Веймарн, 1974. Кат. 146); 9 - подсвечник латунный с серебряной инкрустацией, деталь. Сирия, XIV в. (Притула, 2008б); 10 - перстень, серебро, эмаль. Сирия, XIII-XIV вв. (Иванов, 2015); 11 - стеклянная византийская бутыль, XII - первая четверть XIII в. The Cornig Museum of Glass, New York (Whitehouse, 1998. Fig. 2: 5) 

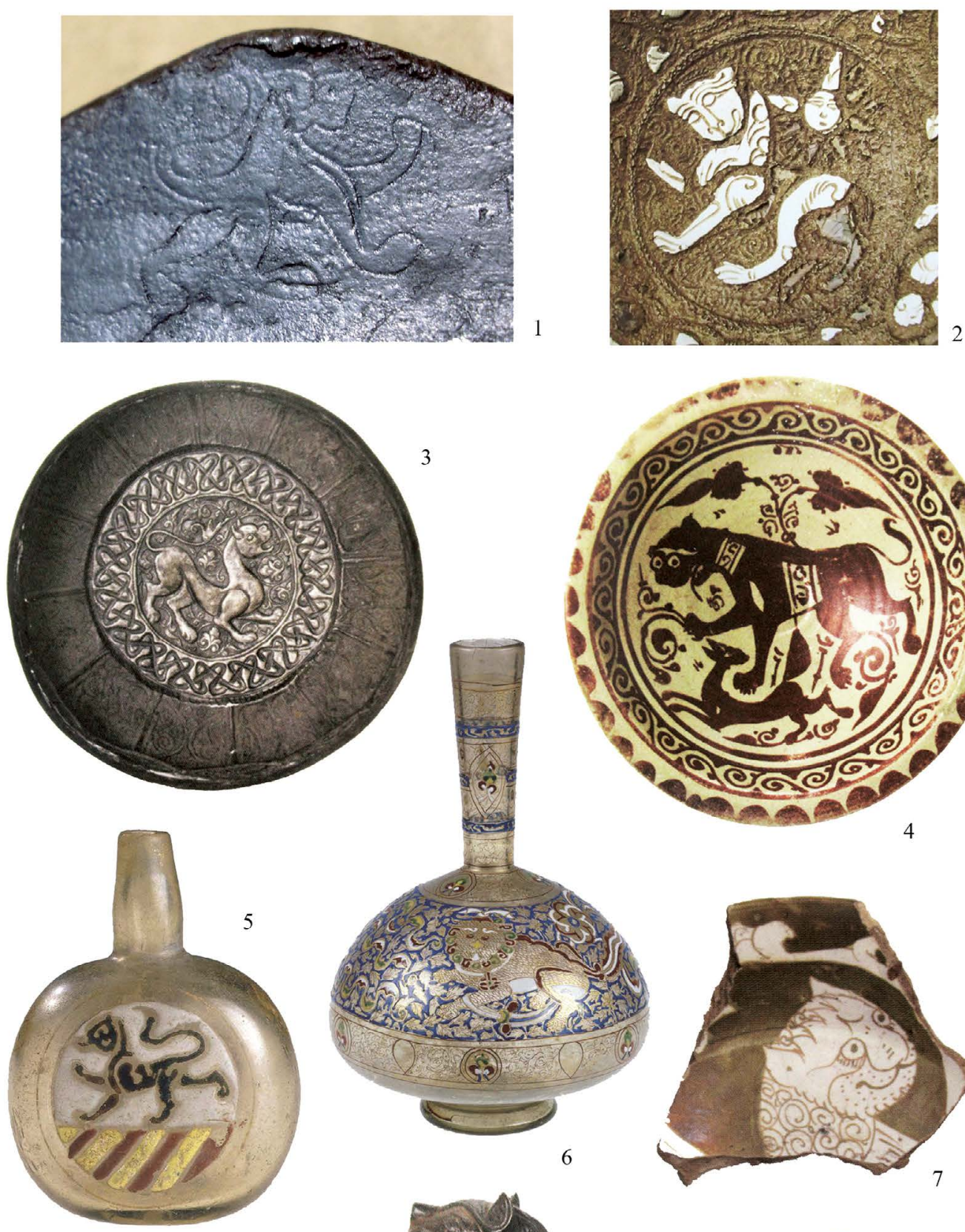

6

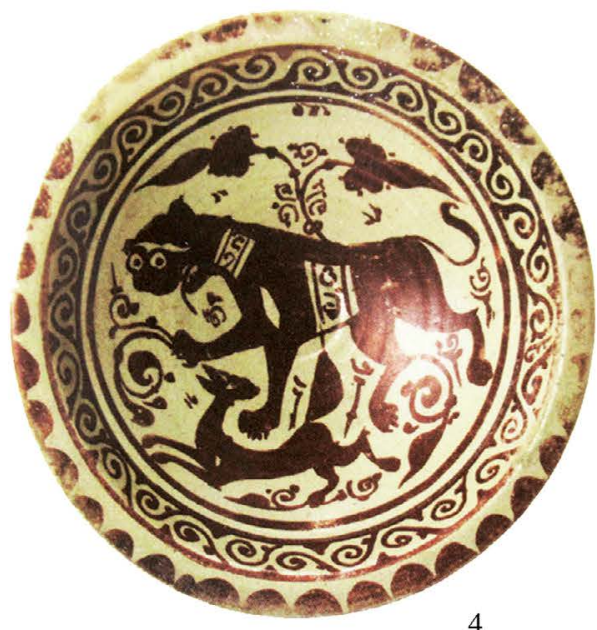

4
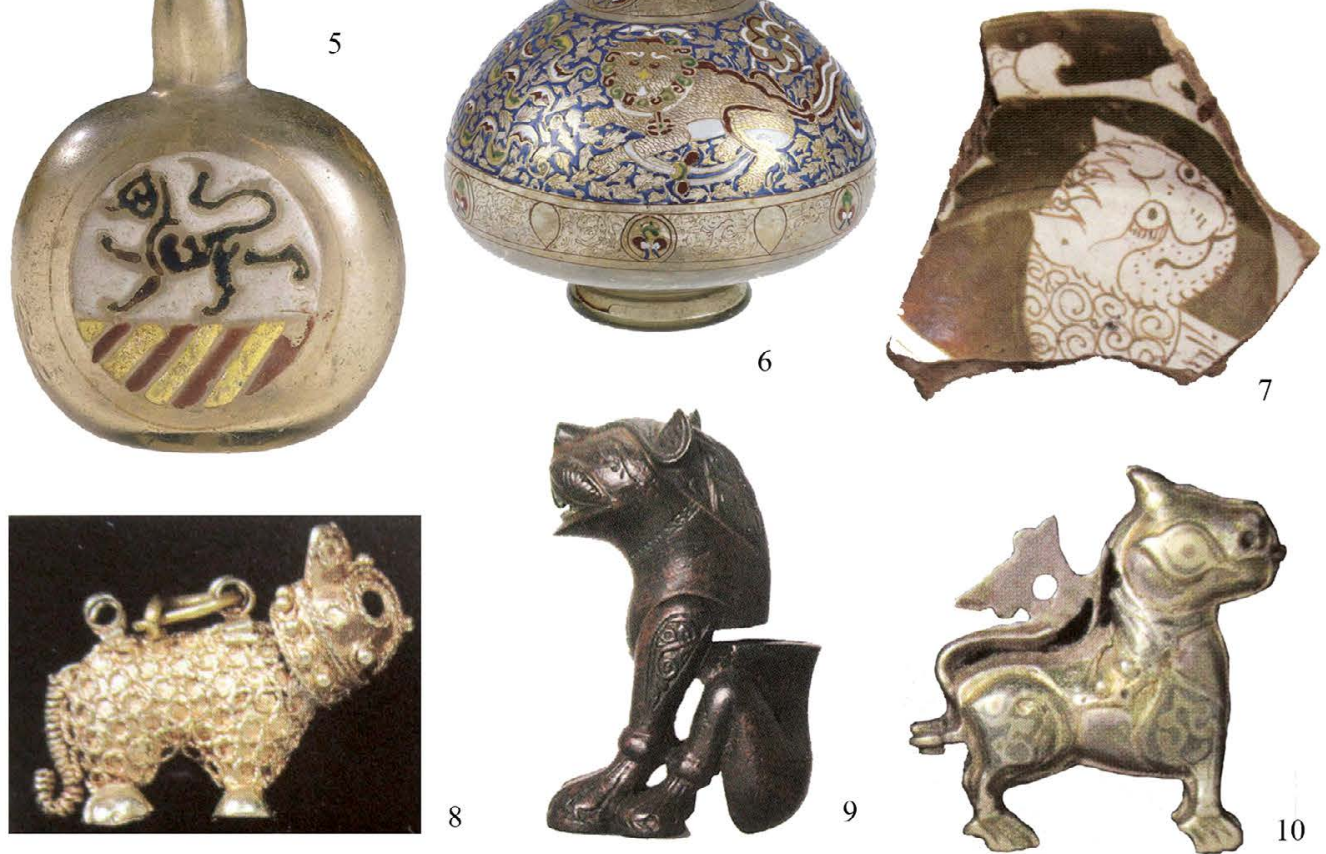

Pис. 6. Изображение кошачьих хищников на шестопере из Рекома (1) и памятниках Ближнего Востока XI-XIV вв.: 2 - ложка латунная с позолотой и серебрением, деталь. Сирия, 1250-1270 гг. (Притула, 2008а); 3 - серебряная чаша. Анатолия, первая половина XIII в. (Khalili Nasser, 2008. P. 112); 4 - люстровая тарелка. Сирия, XII в. (Khalili Nasser, 2008. Р. 95); 5 - стеклянный парфюмерный флакон. Сирия, 1260-1277 гг. (Carboni, Whitehouse, 2002. P. 246); 6 - стеклянный сосуд. Сирия, поздний XIII в. (Carboni, Whitehouse, 2002. P. 257); 7 - фрагмент люстровой тарелки. Египет, X-XI вв. (Khalili Nasser, 2008. P. 91); 8 - золотая серьга в форме льва. Иран, XII в. (Khalili Nasser, 2008. P. 134); 9 - сидящий лев (подставка под поднос?). Иран, XII-XIII вв. (Khalili Nasser, 2008. Р. 112); 10 - серебряный медальон. Иран, XII в. (Khalili Nasser, 2008. P. 134) 

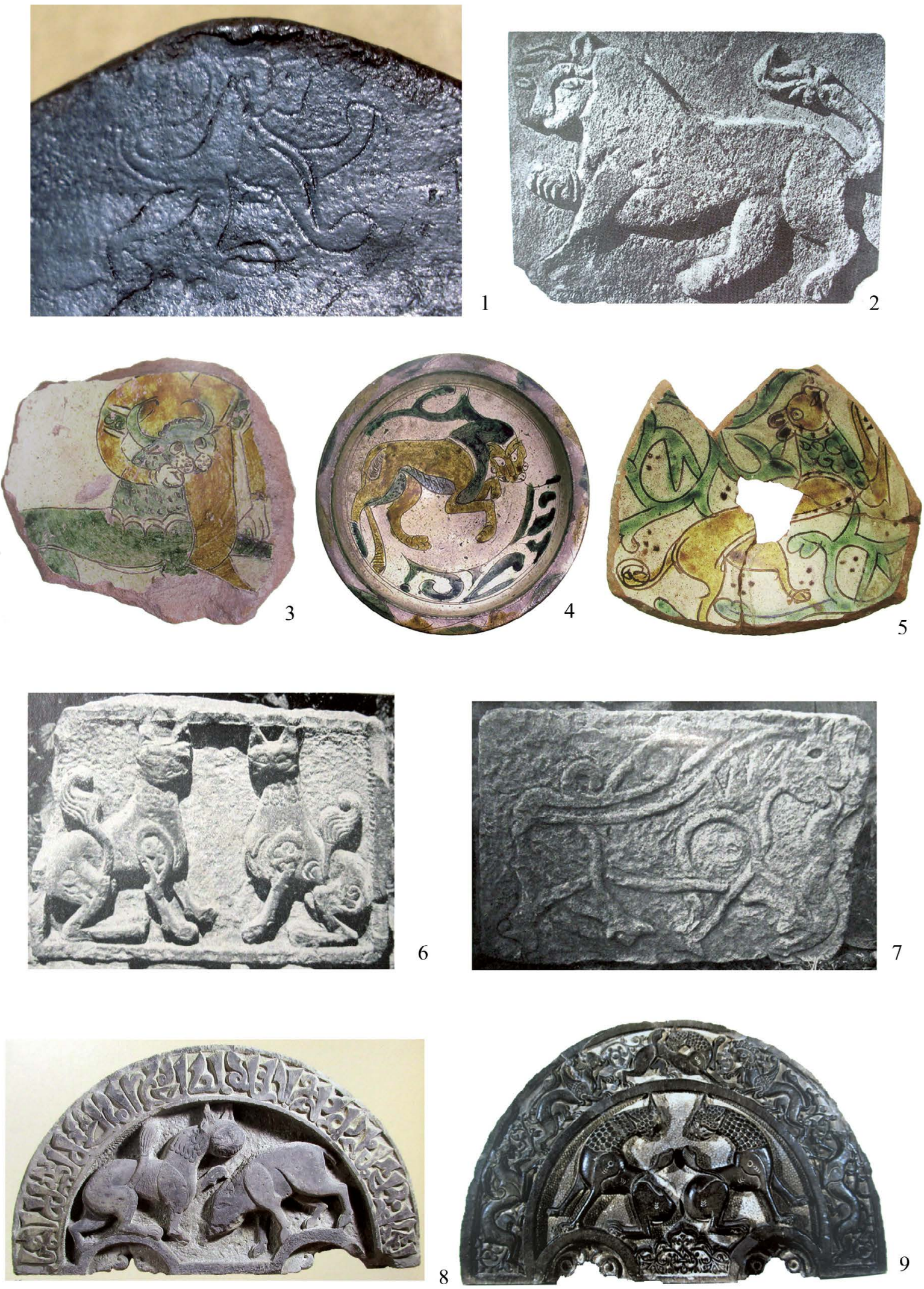

Рис. 7. Изображение льва на шестопере из Рекома (1) и изобразительных памятниках Кавказа (XII-XIV вв.): 2 - рельеф из Ани (Армения), XIII в. (Аракелян, 2003. Таб. 160: 6); 3 - поливная чаша из Жинвали (Грузия), XII-XIII вв. (Ceramics..., 2013. № 109); 4 - поливная чаша из Каспи (Грузия), XII-XIII вв. (Ceramics..., 2013. № 115); 5 - поливная чаша из Тбилиси, XII-XIII вв. (Ceramics..., 2013. № 117); 6 - рельеф из аула Кубачи (Дагестан), XIV в. (Башкиров, 1931. Таб. 33); 7 - рельеф из аула Амузга (Дагестан) (Башкиров, 1931. Таб. 86); 8, 9 - тимпаны из аула Кубачи (Дагестан), XIV в. (Иванов, 2008; Доде, 2010. С. 90) 
Шестопер (рис. 2) железный, сверху покрыт тонким слоем белого металла, проводилось плакирование или лужение предмета. На поверхности заметны следы плакировочной сетки. Слой белого металла сохранился не на всей ударной части шестопера. Общая длина навершия составляет 12 см, ширина (по противопоставленным радиально расходящимся от втулки граням) 8,3 см. Толщина ударных граней $-0,5-0,7$ см. Втулка сквозная, наружная длина втулки до перехода в «перья» - 4,6 см. Диаметр втулки внешний $-3,3$ см, внутренний -3 . Вес предмета -850 г.

На каждой грани шестопера с обеих сторон изображен кошачий хищник, по всей видимости, лев (рис. 3). Он изображен стоя, с поднятой передней лапой, обращенной к голове. На каждой из шести граней с одной стороны зверь развернут корпусом влево, с другой стороны - вправо. На всех 12 изображениях голова хищника повернута в фас. Общий абрис головы - формы перевернутой трапеции. Глаза обозначены кружками, линия рта - двумя сходящимися дугами, одной линией, в некоторых случаях ломаной, намечен нос животного, на нескольких изображениях заметны линии ушей. Хвост высоко поднят, $\mathrm{S}$-образной формы, на конце его небольшое утолщение. Изображения льва довольно условны, непропорциональны (маленькое тело, большая шея, массивная голова, на некоторых изображениях отдельной линией обозначена грудь животного). При этом несколькими точными линиями мастер сумел создать образ величавого и мощного животного. Поверхность втулки между гранями орнаментирована (мотив вьющегося побега).

К числу северокавказских аналогий рекомовскому навершию следует отнести шестопер из окрестностей золотоордынского города Маджары, обнаруженный в 1972 г. при обвале берега р. Кума близ г. Буденновск на Ставрополье, но его вертикальные выступы имеют подтреугольную форму с незначительно вогнутыми гранями (Нарожный, Чахкиев, 2003. С. 130. Рис. 3: 6) (рис. 4: 4). Сходен с рекомовским образцом и шестопер «из северного Предкавказья», опубликованный М.В. Гореликом (2002. С. 66, 67. № 20), а также экземпляр из музея Сванетии (Svaneti Museum, 2014. Р. 38) (рис. 4: 3).

Самая близкая аналогия рекомовской находке - шестопер из элитарного воинского комплекса Бэлэбани II/1-2, выявленного на территории Тараклийского р-на Молдовы (рис. 4: 2). Эта находка указывает на высокий социальный статус погребенного. Втулка шестопера и ребра перьев позолочены. На глухой втулке сверху изображен трехполосный мамлюкский герб. Центральной частью герба («ранка») является чаша, символ высокого воинского чина владельца герба - виночерпия (Sava, 1996. P. 192. Fig. 7: 1, 8; Кулешов, Азыбова, 2011. С. 92, 93. Рис. 1, 2; Гукин, 2013. Рис. 39). На втулке выгравирована куфическая арабская надпись. Шестопер датируется 60-ми гг. XIII в. - 10-ми гг. XIV в. - периодом наиболее тесных контактов Золотой Орды и мамлюкского Египта, откуда и происходит пернач (Кулешов, Абызова, 2011. С. 94). Не противоречит этому выводу и датировка всего комплекса находок из погребения Бэлэбани II/1-2, включающего предметы защитного и наступательного вооружения, детали конского снаряжения, которые в целом можно отнести к XIV в. (Sava, 1996. P. 191-193).

Рекомовскую находку от шестопера из могильника Бэлэбани II отличает, помимо декора, сквозная втулка, большая общая длина предмета и меньшая толщина ударных граней. Близкие по форме шестоперы известны в Болгарии (Vatevi Collection) (Popov, 2015. P. 280, 404. № 414, 448) (рис. 4: 5, 6). Типологически близкие находки происходят также с территории Болгарии (Археология на Добруджа..., 2006. С. 23), Южной Украины (Кирпичников, Медведев, 1985. С. 341. Табл. 129: 13; Горелик, 2002. С. 66, 67. № 17). По форме граней шестоперу из Рекома близко навершие из Пронска (Рязанская обл.) (Кирпичников, Медведев, 1985. С. 341. Табл. 129: 12).

Исследователи относят перначи к категории статусного оружия (Кирпичников, Медведев, 1985. С. 311; Чахкиев, 1986. С. 8; Горелик, 2002. С. 20; Воронцов, 2011. С. 59). Они демонстрировали не только принадлежность к элите, но и ранг их владельцев в военной и политической иерархии. На средневековых миниатюрах перначи изображены в руках тяжеловооруженных всадников, воинов элитных подразделений и правителей (Горелик, 2002. С. 20, 67-71; Тhe Legacy of Chenghis Khan..., 2003. P. 135, 147, 154, 155, 166. Fig. 161, 172, 182, 184, 194; Milošević, 2016. Р. 79, 80, 86, 89. Fig. 30, 34, 37). Считается, что с XIV в. это оружие становится атрибутом военачальника (Кирпичников, Медведев, 1985. C. 311), с его помощью осуществлялось управление войсковыми соединениями во время боя (Кушкумбаев, 2012. С. 205).

Булава или пернач рассматривается в качестве атрибутов и символов власти и у Джучидов, и у Хулагуидов наряду с такими инсигниями, как «золотой шатер, трон с "подушкой власти", зонт, корона, государев флаг, государственная печать, пайцзы, воинский барабан, халат 
с геральдическими символами, воинские пояса, жезлы, мужские шапки-орбелге и женский головной убор боктаг» (Юрченко, 2013. С. 87). По свидетельству Рашид-ад-Дина, военные ярлыки Хулагуидов имели тамгу с изображением лука, булавы и сабли (1946. С. 276).

В научной литературе представлены разные мнения о путях проникновения перначей на территорию Золотой Орды (центральноазиатском, ближневосточном, русском, черноклобуцком) (см. Горелик, 2002. С. 20; 2008. С. 168; Нарожный, Чахкиев, 2003. С. 134-137; Галкин, 2007. С. 289; Воронцов, 2011. С. 61, 62; Кушкумбаев, 2012. С. 201-204). При этом исследователи единодушны в том, что на Северный Кавказ шестоперы попадали по каналам импорта. С местными мастерами производство подобного оружия не связывается.

Анализ географии северокавказских находок (Нарожный, Чахкиев, 2003. С. 127-130; Дружинина, 2017. С. 96, 97) показывает, что подавляющее большинство шестоперов выявлено в восточных районах края, главным образом, в горах Ингушетии и Северной Осетии. Сосредоточение находок в этом регионе Кавказа более чем выразительно. Объяснение можно было бы искать в близости к зимним кочевьям монгольской ставки в Предкавказье - известно, что перначами были вооружены кэшигтен из личной гвардии хана. Однако ни в одном из кочевнических погребальных комплексов XIII-XIV вв., выявленных на территории степного Прикубанья и особенно Центрального Предкавказья, где отмечается высокая концентрация погребений тяжеловооруженных воинов с металлическим защитным вооружением, составлявших элиту монгольского войска (Чхаидзе, Дружинина, 2013), шестоперы не обнаружены. Единичные находки известны на территории Волго-Донского междуречья (Мыськов, 2015. С. 117. Табл. XIX: 2). Ближайшее кочевническое захоронение с шестопером - погребение могильника Вербовый Лог-IV - 13/1 в междуречье Дона и Сала (Гармашов, 1991. С. 117. Рис. 32: 12; Горелик, 2002. С. 67. № 22; Нарожный, Чахкиев, 2003. С. 130. Рис. 3: 7).

Более вероятным представляется поступление шестоперов из Хулагуидского Ирана (Нарожный, Чахкиев, 2003. С. 137). В данной связи особого внимания заслуживает тот факт, что северокавказские погребальные комплексы, в которых были найдены шестоперы, выявлены в горной полосе, подчиненной военной и административной власти Джучидов в значительно меньшей степени, чем равнинные районы.
Само наличие подобных предметов в горных районах Центрального Кавказа, долгое время находившихся под прямым политическим, религиозным, культурным влиянием Грузии, в свою очередь в XIII в. оказавшейся в вассальной зависимости от Ильханата, может рассматриваться в качестве одного из свидетельств активного участия местных сил в военно-политическом противостоянии Джучидов и Хулагуидов.

По-видимому, именно через Грузию к горцам Северного Кавказа поступали предметы вооружения из Ирана, а также и собственно грузинского производства. На территории Картли обнаружено значительное количество наверший перначей как XIII-XIV вв., так и более позднего времени (Отчет..., 1904. С. 144. Рис. 260, 261; Чартолани, 1976. С. 50, 51. Табл. ХXX-XXXII; Svaneti Museum, 2014. Р. 38. № 28-30, 38) (рис. 4: 3). А.С. Уваров, подчеркивая значительное число находок перначей у сванов, даже заметил, что «Сванетия может считаться настоящею родиною этого оружия» (Уваров, 1910. С. 84).

В решении вопроса о месте происхождения шестопера из Рекома большое значение имеет анализ стилистических особенностей элементов его декора. Изображения кошачьих хищников, в том числе львов и барсов, с поднятой передней лапой - распространенный орнаментальный образ, воплощающий в себе идею сильной власти. Образ льва, как и его иконография, пришел из стран Востока и стал излюбленной геральдической эмблемой правителей христианского и исламского миров (Даркевич, 1975. С. 190; Campbell, Heald, 2007. Р. 181). Изображения льва на оружии и доспехах символизировали силу и могущество их владельца.

Форма и мотив декора находят широчайший круг аналогий на керамике, стекле, металле, архитектурных деталях, геральдических знаках на мамлюкских монетах (Whitehouse, 1998. P. 151; Saracenic Heraldry, 1999. P1. I: 1-8, V: 2; Хилленбранд, 2008. С. 223, 276. Рис. 4: 39; 5: 22) (рис. 5-8). Но наиболее близкими аналогиями таким особенностям рекомовских львов, как схематичный и весьма характерный абрис головы, ее разворот в фас, пропорции тела, высоко поднятый хвост и его S-видная форма, являются изображения кошачьих хищников на поливной византийской посуде (Бочаров, 2005. С. 314. Рис. 3: 1, 2; Залесская, 2011. С. 189. Рис. 399) (рис. 5: 3-5), на предметах торевтики (Притула, 2008б; Иванов, 2015) (рис. 5: 9; 6: 2) и посуде (Carboni, Whitehouse, 2002. Р. 246) (рис. 6: 5) 

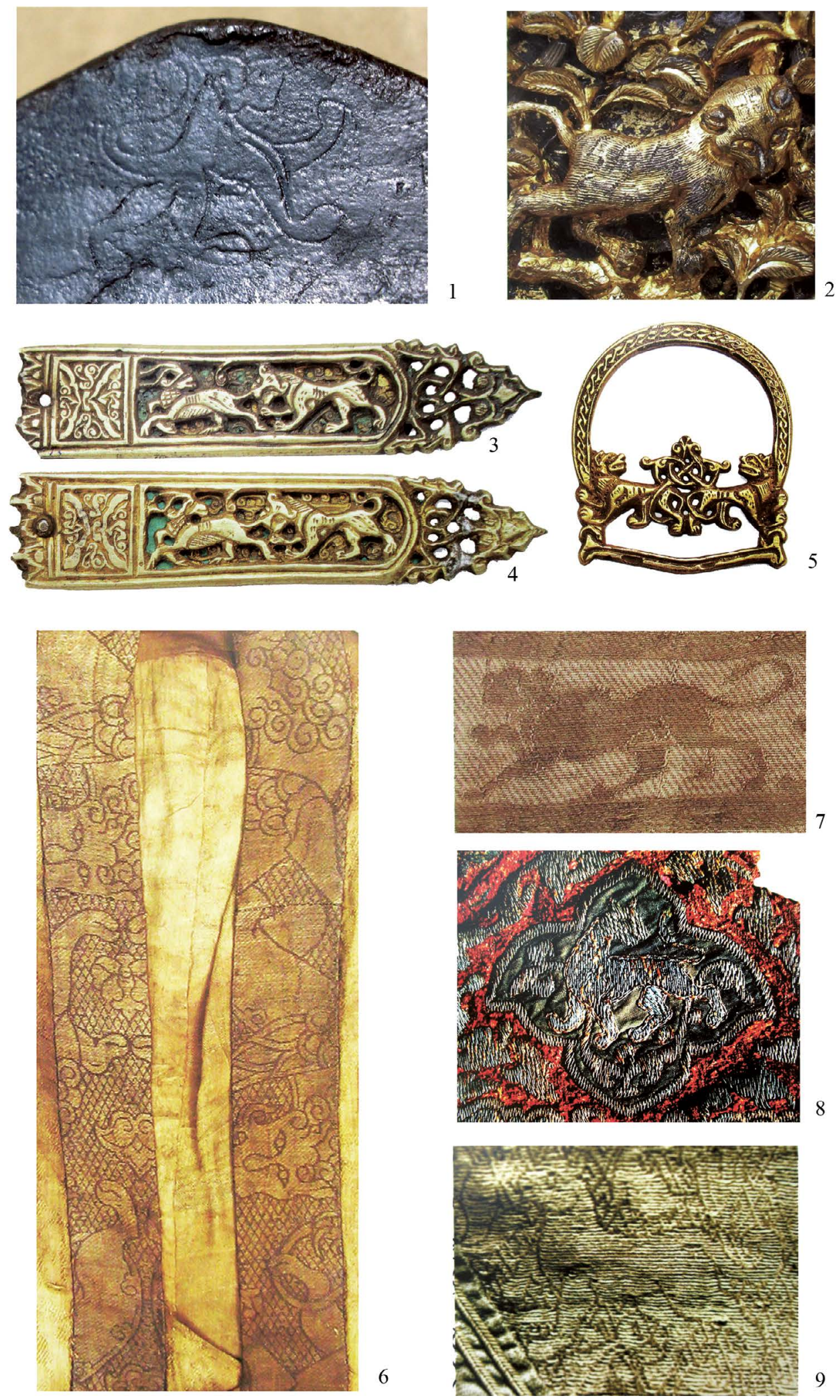

Рис. 8. Изображение льва на шестопере из Рекома (1) и произведениях мастеров Монгольских государств (XIII-XIV вв.): 2 - бляха ременная. Центральная Азия или Северный Китай, XIII - рубеж XIV в. (Крамаровский М. Г., 2013); 3, 4 - поясные наконечники. Золотая Орда, Крым, XIV-XV вв. (Крамаровский М. Г., 2000а); 5 - пряжка от поясного набора. Золотая Орда, Крым, XIV-XV вв. (Крамаровский М. Г., 2000б. №131); 6 - ворот кафтана. Империя Юань, кон. XIII-XIV вв. (Ласикова Г. В., 2013б); 7 - фрагмент халата. Империя Юань, XIV вв. (Ласикова Г.В., 2013а. С. 170); 8 - фрагмент аппликации и вышивки на головном уборе, Могильник Джухта, Ставропольский край, кон. XIII-XIV вв. (Доде 3. В., 2010. С. 82. Рис. 45); 8 - фрагмент орнамента ткани от «чехлов» для сапог. Империя Юань. Китайский национальный музей шелка, Ханчжоу (Доде 3. В., 2010. С. 83. Рис. 46) 


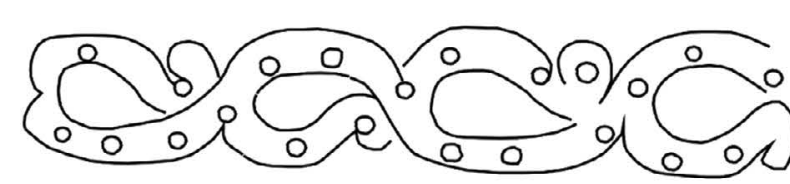

1
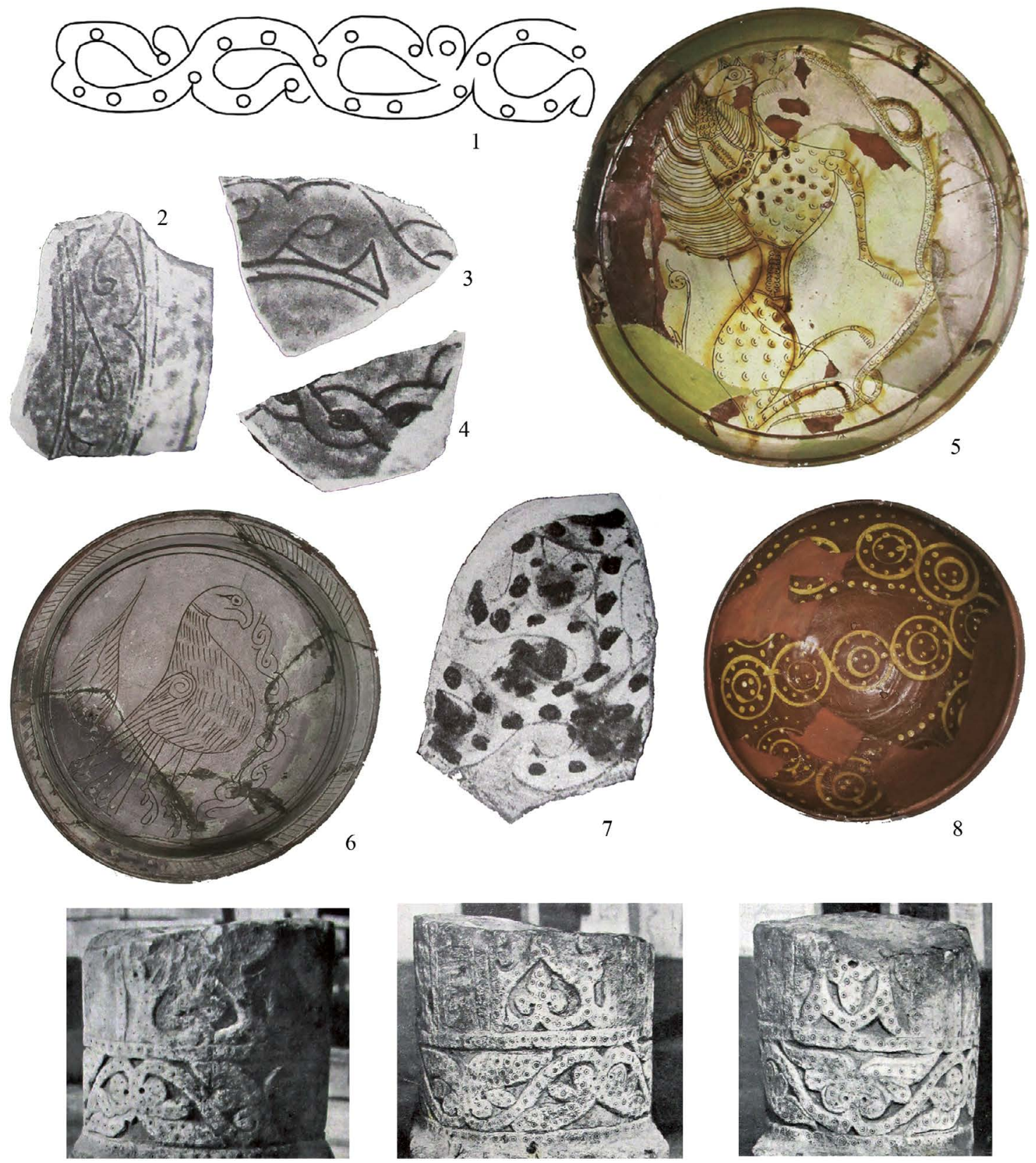

9

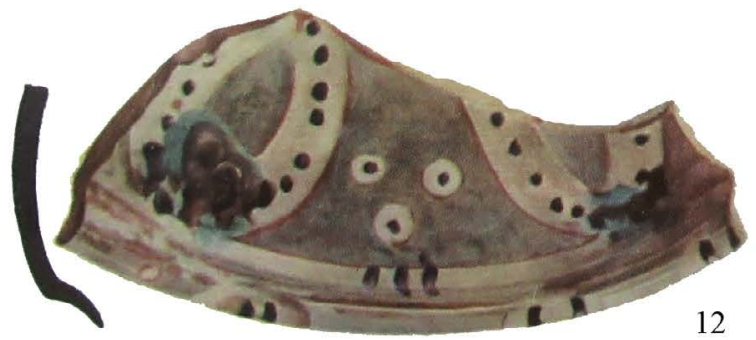

10

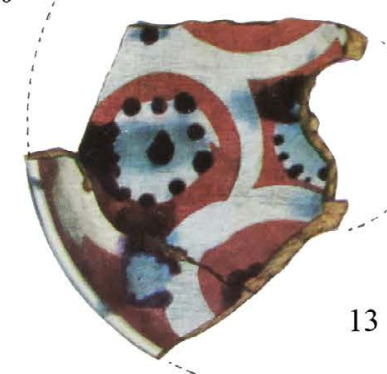

11

Рис. 9. Орнамент на втулке шестопера из Рекома (1) и его аналогии: 2-4 - фрагменты поливных тарелок. Тбилиси, IX-XIII вв. (Мицишвили, 1979. Таб. VI: 1); 5 - византийская чаша с изображением борьбы грифона со змеем. Херсонес, XIII в. (Залесская, 2011. Кат. 342); 6 - византийская чаша с изображением птицы. Херсонес, XIII в. (Залесская, 2011. Кат. 363); 7 - фрагмент поливной тарелки. Тбилиси, XIII в. (Мицишвили, 1979. Таб. LXI: 1); 8 - миска с росписью ангобом. Византия, XIII в. (Залесская, 2011. Кат. 375); 9-11 - фрагменты колонн с рельефными изображениями. Даргинский округ, средневековый Дагестан (Башкиров, 1931. Таб. 88-90); 12, 13 - фрагменты поливной керамики. Телави (Грузия), IX-X вв. (Чикоидзе, 1979. Таб. III) 
из Сирии, а также на наконечниках поясов, обнаруженных в золотоордынском Крыму (Крамаровский, 2000а. С. 92. Кат. № 115, 116) (рис. 8: $3,4)$, что, однако, не исключает их малоазийского происхождения.

Украшающему втулку шестопера между гранями орнаменту в виде плетенки или стилизованного побега, при всем разнообразии его типов и вариантов (см., например: рис. 9: 2-4, 7) (Мицишвили, 1979. С. 73, 75. Таб. VI: 1; LXI: 1), точных аналогий найти не удалось, но, как представляется, он входит в круг постсельджукских ближневосточных орнаментальных элементов.

Особенность рекомовских плетенок - «точкование» (нанесение точек, кружков) самих звеньев цепи или самого стебля лозы (а не фона, что является довольно распространенным вариантом декора). Возможно, этот орнамент восходит к изображениям чешуи извивающихся змей в сценах их терзания грифонами или другими хищниками, хорошо известных по изобразительным памятникам средневекового Востока (Башкиров, 1931. С. 114. Таб. 86; Залесская, 2011. С. 172-174. Кат. 363) (рис. 7: 7; 9: 5). Плетенки, побеги, лозы, украшенные точкованием, довольно часто встречаются в декоре изделий из глины и камня Византии (Залесская, 2011. С. 179. Кат. 375) (рис. 9: 8), Грузии (Мицишвили, 1979.
C. 73. Таб. VI: 1; Чикоидзе, 1979. С. 31. Таб. III) (рис. 9: 2, 12, 13) Азербайджана (Якобсон, 1959. C. 230, 231. Рис. 3. Табл. VII, VIII, XVI, XXI, XXVII, XXVIII, XXXIV; Ибрагимов, 2000. С. 90, 93. Рис. 28, 30) и Дагестана (Башкиров, 1931. С. 114. Таб. 88-90) (рис. 9: 9-11).

В целом, особенности шестопера и элементов его орнамента, а также приведенные аналогии, позволяют сделать вывод о ближневосточном или провинциально-византийском происхождении находки из Рекома, на орнаментацию которой в обоих случаях оказали влияние изобразительные традиции мастеров Восточного Кавказа. По аналогии с шестопером из могильника Бэлэбани II навершие из осетинского святилища можно датировать второй половиной XIII - началом XIV в. Таким образом, шестопер из Рекома (хран. ГИМ, № 1530 В) - единственная сохранившаяся находка, которую с известной долей осторожности можно отнести к комплексу престижных предметов вооружения, связываемых с известным историческим персонажем конца XIII - начала XIV в. Ос-Багатаром. Этот выдающийся военачальник и политический деятель проводил военные акции против ряда грузинских городов с целью захвата территории на южном склоне Кавказского хребта и обеспечил переселение части алан в предгорья Шида-Картли.

\section{Литература}

\section{Источники:}

Жамтаагмиерели. Анонимный грузинский «Хронограф» XIV века / Пер. со старогруз. Г.В. Цулая. Вып. І. Текст. Москва, 2005.

Рашид-ад-Дин. Сборник летописей. Т. ІІІ. Москва, 1946.

Столетняя Летопись: Грузинский анонимный историк XIV века. Столетняя летопись. Критический текст, исследование, примечания Р. К. Кикнадзе / Памятники грузинской литературы. VI. Тбилиси, Мецниереба, 1987. 265 с. (на груз. яз.)

\section{Публикации:}

Аракелян Б. Н. Армения в IX-XIII веках // Крым, Северо-Восточное Причерноморье и Закавказье в эпоху средневековья. IV-XIII века. Москва, 2003 (Археология). С. 332-350.

Археология на Добруджа. По материали на регионален исторически музей Добрич. Добрич, 2006.

Башкиров А. С. Искусство Дагестана. Резные камни. Москва, 1931.

Белеикий Д. В. Заметки о Нузальском храме // Историко-филологический архив. Вып. 2. Владикавказ, 2004. С. $22-57$.

Бочаров С.Г. Группа византийских поливных чаш второй половины XIV в. // Поливная керамика Средиземноморья и Причерноморья X-XVIII вв. Киев, 2005. С. 306-323.

Веймарн Б. В. Искусство арабских стран и Ирана VII-XVII веков. Москва, 1974.

Византия сквозь века. Санкт-Петербург, 2017.

Воронцов И. А. Предметы ударного вооружения золотоордынского времени с территории Нижнего Поволжья // Военное дело Золотой Орды: проблемы и перспективы изучения. Казань, 2011. С. 59-62. 
Галкин Л. Л. Две булавы из городов Улуса Джучи (XIV век) // История и культура Улуса Джучи. Казань, 2007. С. $288-292$.

Гармашов А. И. Позднекочевническое погребение с шестопером в междуречье Дона и Сала // Историко-археологические исследования в г. Азове и на Нижнем Дону. Тез. докл. к семинару в 1990 г. Вып. 10. Азов, 1991. С. 110-123.

Горелик М. В. Монголо-татарское оборонительное вооружение второй половины XIV - начала XV в. // Куликовская битва в истории и культуре нашей Родины. Москва, 1983. С. 244-269.

Горелик М. В. Армии монголо-татар X-XIV веков. Воинское искусство, снаряжение, оружие. Москва, 2002.

Гукин В. Д. Булава-шестопер или навершие жезла // Юрченко А. Г. Элита Монгольской империи: время праздников, время казней. Санкт-Петербург, 2013. С. 374-375.

Даркевич В. П. Светское искусство Византии. Произведения византийского художественного ремесла в Восточной Европе Х-ХІІІ века. Москва, 1975.

Дарчиев А.В. О некоторых реликвиях из святилища Реком. Владикавказ, 2011.

Доде 3. В. Кубачинские рельефы. Новый взгляд на древние камни. Москва, 2010 (Материалы по изучению историко-культурного наследия Северного Кавказа; вып. Х).

Дружинина И. А. Комплекс предметов вооружения из святилища Реком как источник по истории Ближневосточно-Кав-

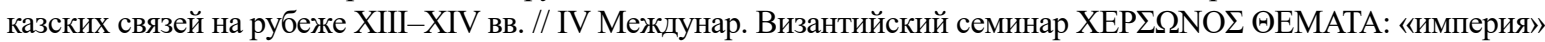
и «полис». Тез. докл. Севастополь, 2012. С. 15-17.

Дружинина И. А. Шестопер из кургана у станицы Абинская (по материалам раскопок В.Г. Тизенгаузена в Кубанской области, 1879 г.) // Археология евразийских степей. 2017. № 5. С. 96-104.

Дружинина И.А., Чхаидзе В.Н. О старых и новых находках предметов вооружения из североосетинского святилища Реком // Очерки средневековой археологии Кавказа. Москва, 2013. С. 74-81.

Залесская В.Н. Памятники византийского прикладного искусства. Византийская керамика IX-XV веков. Каталог коллекции. Санкт-Петербург, 2011.

Ибрагимов Б. И. Средневековый город Киран. Баку; Москва, 2000.

Иванов А. А. Кат. № 95. Тимпан, Дагестан, Кубачи // Во дворцах и в шатрах. Исламский мир от Китая до Европы. Каталог выставки. Гос. Эрмитаж. Санкт-Петербург, 2008. С. 124.

Иванов А. А. Кат. № 91. Перстень. Северная Месопотамия, Джазира // «Подарок созерцающим». Странствия Ибн Баттуты. Каталог выставки. Гос. Эрмитаж. Санкт-Петербург, 2015. С. 216.

Кирпичников А.Н., Медведев А. Ф. Вооружение // Древняя Русь. Город, замок, село. Москва, 1985 (Археология СССР). С. 298-363.

Крамаровский М.Г. Наконечники пояса // Сокровища Золотой Орды. Каталог выставки. Санкт-Петербург, 2000а. Кат. № 115, 116.

Крамаровский М.Г. Кат. № 130-133. Четыре пряжки от поясного набора // Сокровища Золотой Орды. Каталог выставки. Санкт-Петербург, 2000б. С. 108.

Крамаровский М.Г. Гарнитура поясного набора или украшения конского убора // Классическое искусство исламского мира IX-XIX веков. Девяносто девять имен Всевышнего. Москва, 2013. С. 43-44.

Кузнецов В. А. Нузальская церковь, Давид-Сослан и Ос-Бакатар // XV Крупновские чтения по археологии Северного Кавказа. Тез. докл. Махачкала, 1988. С. 75-76.

Кузнецов В. А. Реком, Нузал и Царазонта. Владикавказ, 1990.

Кулешов Ю.А., Абызова Е.Н. Два предмета мамлюкского вооружения с территории Молдовы как иллюстрация путей формирования золотоордынского комплекса вооружения // Военное дело Золотой Орды: проблемы и перспективы изучения. Материалы круглого стола, проведенного в рамках междунар. Золотоордынского Форума. Казань, 2011. C. $92-100$.

Кушкумбаев А. К. Комплекс ударного оружия (палицы, булавы, кистени) воинов Улуса Джучи // Военное дело Улуса Джучи и его наследников. Астана, 2012. С. 199-219.

Ласикова Г.В. Халат. Империя Юань. XIV в. // Классическое искусство исламского мира IX-XIX веков. Девяносто девять имен Всевышнего. Москва, 2013а. С. 170-171.

Ласикова Г. В. Халат женский. Империя Юань. Конец XIII - XIV в. // Классическое искусство исламского мира IXXIX веков. Девяносто девять имен Всевышнего. Москва, 2013б. С. 178-179.

Мицишвили М.Н. Производство поливной керамики в средневековом Тбилиси (IX-XIII вв.). Тбилиси, 1979. (на груз. яз.).

Мыськов Е. П. Кочевники Волго-Донских степей в эпоху Золотой Орды. Волгоград, 2015.

Нарожный Е. И. О шлемах из сел. Ярыш-Марды и святилища Реком (Чечня и Северная Осетия) // Материалы и исследования по археологии Северного Кавказа. Вып. 2. Армавир, 2003. С. 112-125.

Нарожный Е. И., Чахкиев Д. Ю. О находках некоторых образцов ударного и защитного вооружения на Северном Кавказе (XIII-XV вв.) // Материалы и исследования по археологии Северного Кавказа. Вып. 2. Армавир, 2003. С. 126-153.

Отчет имп. Археологической комиссии (ОАК) за 1902 г. Санкт-Петербург, 1904.

Периодическая печать Кавказа об Осетии и осетинах. Кн. 3 / Сост. Л. А. Чибиров. Цхинвали, 1987.

Притула А. Д. Кат. № 60. Ложка // Во дворцах и в шатрах. Исламский мир от Китая до Европы. Каталог выставки. Гос. Эрмитаж. Санкт-Петербург, 2008а. С. 83.

Притула А. Д. Кат. № 70. Подсвечник // Во дворцах и в шатрах. Исламский мир от Китая до Европы. Каталог выставки. Гос. Эрмитаж. Санкт-Петербург, 2008б. С. 90-91.

Пфаф В.Б. Путешествие по ущельям Северной Осетии // Сборник сведений о Кавказе. Т. 1. Тифлис, 1871. С. $127-176$.

Романчук А. И. Глазурованная посуда поздневизантийского Херсона. Портовый район. Екатеринбург, 2003 (Античная древность и средние века). 
Сланов А. А. Военное дело алан I-XV вв. Владикавказ, 2007.

Уваров А. С. Булава или Пернач // А. С. Уваров. Сборник мелких трудов. Т. ІІ. Москва, 1910. С. 84-88.

Уварова П. С. Кавказ. Путевые заметки. Т. 1. Москва, 1887.

Уварова П. С. Могильники Северного Кавказа. Москва, 1900 (Материалы по археологии Кавказа; вып. VIII).

Хилленбранд К. Крестовые походы. Взгляд с Востока: мусульманская перспектива. Санкт-Петербург, 2008.

Цулая Г. В. Грузинский «Хронограф» XIV в. о народах Кавказа // Кавказский этнографический сборник. Вып. VII. Отв. ред. В.К. Гарданов. М.: Наука, 1980. С. 193-208.

Чартолани Ш.Г. Материалы по археологии Сванети. Ч. 1. Тбилиси, 1976. (на груз. яз.).

Чахкиев Д. Ю. Оружие и вопросы военного искусства позднесредневековых вайнахов (XIII-XVIII вв.) (археолого-этнографическое исследование): автореф. дис. ... канд. ист. наук. Москва, 1986.

Чикоидзе Ц. Н. Город Телави. Тбилиси, 1979. (на груз. яз.).

Чхаидзе В. Н., Дружсинина И. А. Отражение социальной стратификации в погребальной обрядности кочевников степного Предкавказья золотоордынского времени: продолжение дискуссии // Поволжская археология. 2013. № 2. С. $171-178$.

Юрченко А. Г. Элита Монгольской империи: время праздников, время казней. Санкт-Петербург, 2013.

Якобсон А. Л. Художественная керамика Байлакана (Орен-Кала) (По материалам раскопок 1953-1955 гг.) // Труды Азербайджанской (Орен-Калинской) археологической экспедиции. Т. І. 1953-1955 гг. Москва; Ленинград, 1959 (МИА; № 67). C. 228-302.

Campbell E., Heald A. A new date for 'Class A, Type II A' stirrup-strap mounts, and some observations on their distribution // Medieval archaeology. 2007. Vol. 51. P. 178-184.

Carboni S., Whitehouse D. Glass of the Sultans. New York, 2002.

Ceramics in medieval Georgia. Tbilisi, 2013.

Khalili Nasser D. Islamic art and culture. Timeline and history. Cairo, 2008.

Milošević A. Iz armatorija srednjovjekovnog Bribira (From the Armoury of Medieval Bribir) // Starohrvatska prosvjeta. III. serija svezak 43/2016. Split, 2016. P. 49-89.

Nioradze G. Die Berg-Ossen und ihr Land. Eine anthropologish-etnographische untersuchung eines Kaukasischen volkes. Berlin, 1923.

Popov S. The Maces from the Present Bulgarian Lands (10th-17th c. AD). Vatevi Collection. Sofia, 2015.

Saracenic Heraldry. A survey by L.A. Mayer. Oxford, 1999.

Sava E. Necropola Tumulară Bălăbani - II // Arheologia Moldovei. 1996. XIX. P. 191-220.

Svaneti Museum. Catalog. Tbilisi, 2014.

The Legacy of Genghis Khan. Courtly Art and Culture in Western Asia, 1256-1353 / Eds. L. Komaroff, S. Carboni. New York, 2003.

Whitehouse D. Byzantine gilded glass // Gilded and Enamelled Glass from the Middle East. London, 1998. C. 4-7. 


\section{ПЕРЕДЕЛАННЫЙ «БАЦИНЕТ» \\ ИЗ КОЛЛЕКЦИИ ОТДЕЛА ОРУЖИЯ \\ ГОСУДАРСТВЕННОГО ИСТОРИЧЕСКОГО МУЗЕЯ}

\section{Ю. А. Кулешов, В. В. Веселитская}

В коллекции отдела оружия Государственного Исторического Музея хранится уникальный шлем, инв. № ГИМ 82474/ ор $14981^{1}$. В среде отечественных оружиеведов за ним закрепилось неофициальное название «Рязанский бацинет». Откуда взялось это название, доподлинно установить не представляется возможным. Между тем, представленный шлем не имеет никакого отношения ни к территории Руси, ни к древнерусскому комплексу вооружения. Шлем был передан музею в 1948 году из Центрального музея Красной Армии. В инвентарных книгах данный предмет был записан как: «Шапка железная. Западная Европа, XIV-XV вв.».

Шлем (Рис. 1) представляет собой боевое наголовье, изготовленное из листового железа, свёрнутого в воронку и сваренного кузнечной сваркой. Достаточно широкий шов выполнен внахлёст, а затем раскован. Границы шва определяются по типичным дефектам, возникающим при кузнечной сварке. В данном случае это частичное расслоение нижнего края шлема или так называемая малая прочность околошовных участков ковки (Рис. 2,4), а также непровары, то есть участки, где не произошло сцепление поверхностей при сварке, а затем нижний или верхний слой выгорел в процессе повторного нагревания. В результате, видимо, произошёл так называемый пережог, из-за которого в образовавшейся прорехе стал виден второй слой металла (Рис. 2,1-3) (Шмаков 1990, 144). Дефекты фиксируются как на внутренней, так и на внешней поверхности шлема: от района левой брови, и далее по часовой стрелке до центра затылка.

Внешне сам шлем имеет достаточно сложную форму. Верхняя часть сфероконической тульи оформлена в виде заваленного назад конуса, при этом сама задняя стенка выполнена чуть вогнутой снизу и сверху. Вероятно, это не запланированная проекция, а последствия, вызванные расковкой шва, необходимой для увеличения диаметра заготовки. В ходе этого процесса изначально полученный конус повело, что является типичным дефектом при такой операции (Шмаков 1990, 122-124).

Затем верхнюю часть отрихтовали посредством внешней ковки на шпераке, для чего поверхность была разделена чеканкой на десять секторов вертикальными гранями.

Здесь стоит сделать отступление. На первый взгляд можно предположить, что подобным образом оружейники пытались усилить поверхность шлема. Однако наличие граней на шлеме свидетельствует о том, что шлем вероятно подвергся рихтовке для придания ему симметричности. Данная операция крайне важна и необходима для шлемов со сварной конструкцией ${ }^{2}$.

Нижняя часть тульи имеет форму невысокого усечённого конуса, полученного путем опускания края с последующей рихтовкой. Затем поверхность была разделена чеканкой на десять вертикальных секторов. Следует отметить, что нижние секторы не являются продолжением верхних: их границы смещены так, что они проходят по центру верхних секторов, а сами грани, являющиеся границами секторов, соединены между собой горизонтальными перемычками, пущенными под небольшим углом. В результате нижняя часть тульи получила вид невысокого венца, оформленного под тиару.

В лицевой части с левой стороны вдоль нижнего достаточно неровного края шлема пробито четыре отверстия (Рис. 1,1-2). Первое отверстие диаметром 3,5 мм расположено на высоте 1,1 см от нижнего края, второе и третье диаметром 3 мм на высоте 1,5 см и 1,4 см, и четвёртое отверстие диаметром 3,5 мм на высоте 1 см от края пробито дважды, одно в одно. Чуть

\footnotetext{
1 Пользуясь случаем авторы хотели бы выразить благодарность с.н.с. Отдела археологии ГИМ к.и.н. С. Ю. Каинову, за неоценимую помощь в подготовке данной работы.

2 Пользуясь случаем авторы хотели бы поблагодарить реставратора ВИМАИВиВС, г. Санкт-Петербург, А.Г. Панкратова за помощь в ряде технических наблюдений.
} 


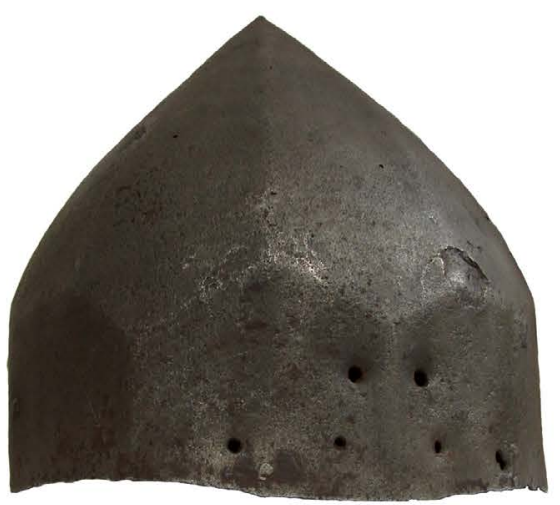

1

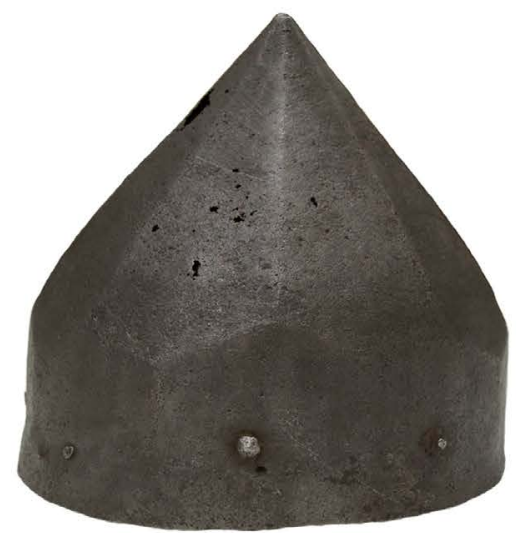

2

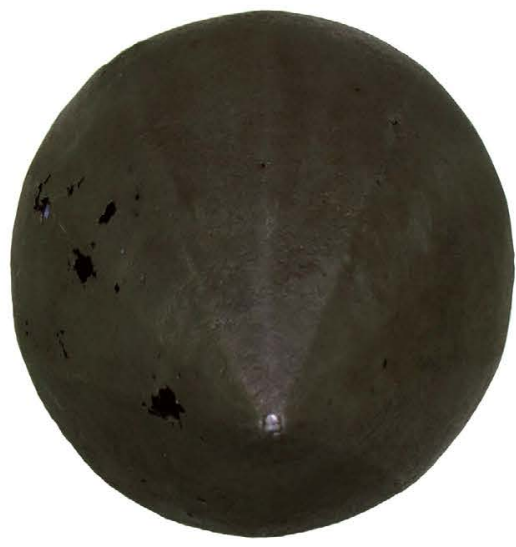

5

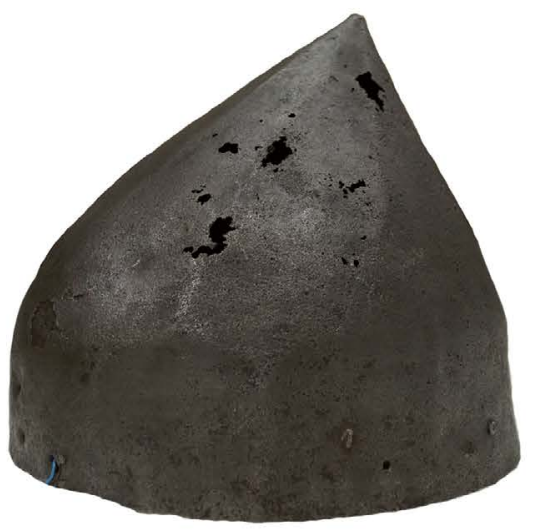

3

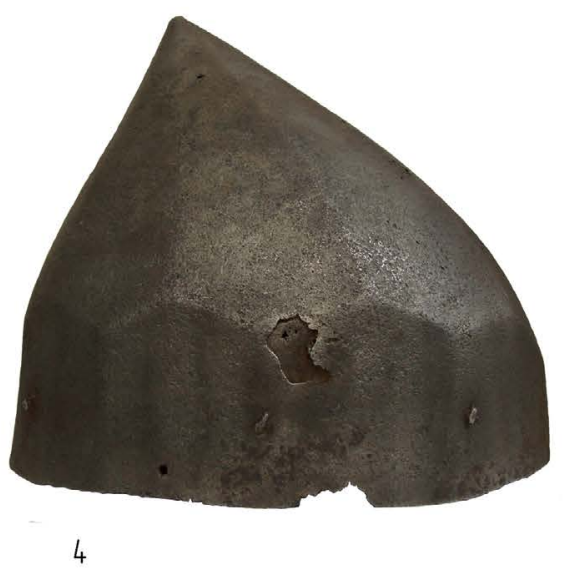

Рис. І. Шлем из коллекции Отдела оружия ГИМ, инв. № ОР 14981, общий вид; 1 - Вид спереди; 2 - Вид сзади; 3 - Вид с права; 4 - Вид слева; 5 - Вид сверху

выше второго и третьего отверстий пробито ещё по одному отверстию. Оба отверстия располагаются на расстоянии 3,3 см от нижнего края, а их диаметр - 3,5 мм. Все отверстия пробиты грубо, с чуть вдавленными внутрь краями (Рис. 2,3 ).

Снизу по периметру шлема имеется шесть отверстий, заглушенных заклёпками. Первое по часовой стрелке отверстие располагается в районе правого виска на высоте 2,6 см от нижнего края, второе располагается в районе правого уха на высоте 2,5 cм, третье отверстие расположено с правой стороны затылка на высоте 2,8 см, четвёртое отверстие расположено по центру затылка на высоте 3 см, пятое отверстие расположено с левой стороны затылка на высоте 2,2 см, и шестое располагается в районе левого уха на высоте 2,8 см. Все заклепки, заглушающие отверстия, кроме четвёртой, вставлены шляпками изнутри 


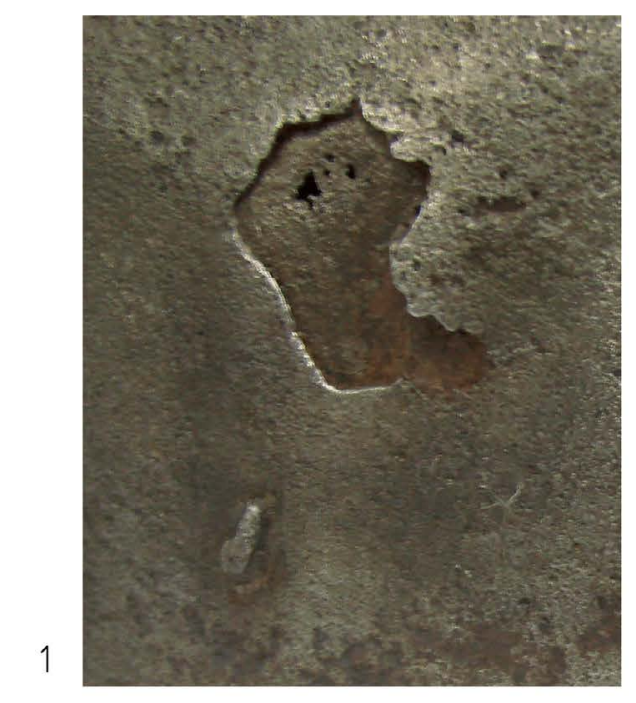

2
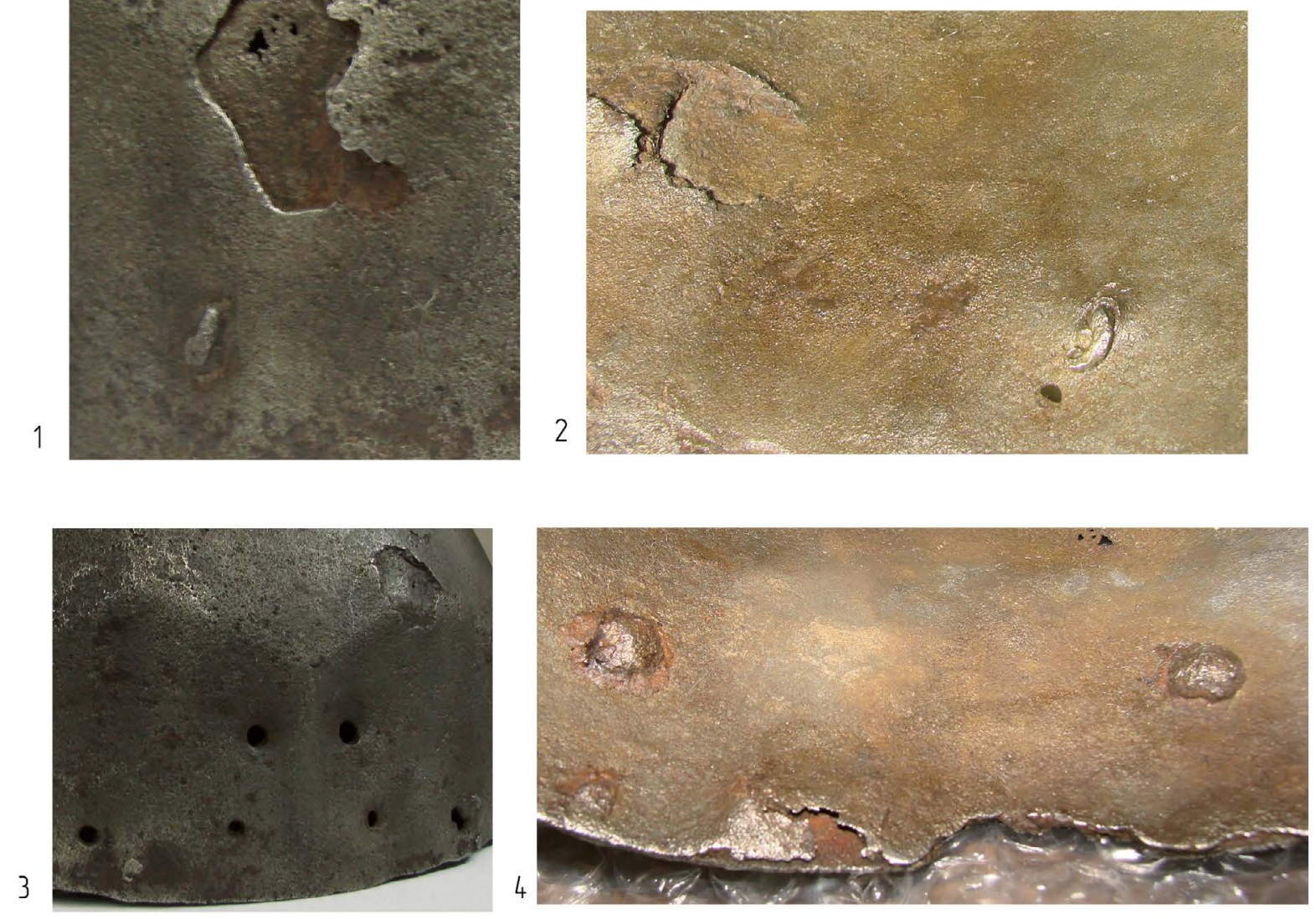

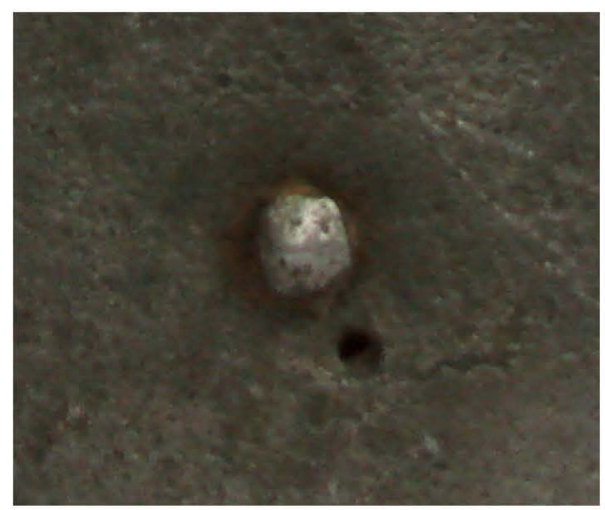

5

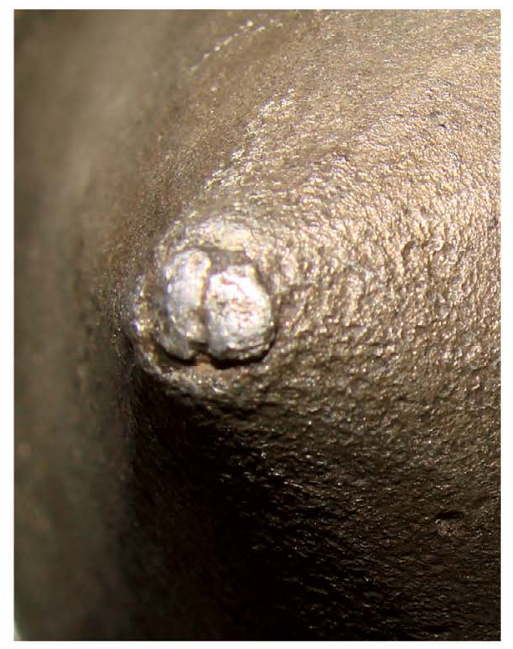

6

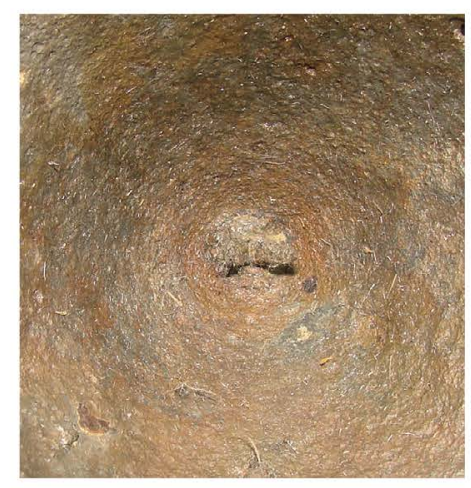

7

Рис. 2. Шлем из коллекции Отдела оружия ГИМ, инв. № ОР 14981, детали; 1 - Непровар с внешней стороны шлема, в районе правого уха, одновременно хорошо видна загнутая снаружи ножка заклёпки; 2 - Непровар с внутренней стороны шлема, в районе затылка, одновременно хорошо видна загнутая изнутри ножка заклёпки; 3 - Группа вторичных монтажных отверстий в лицевой части шлема, одновременно хорошо виден непровар в районе окончания левой брови и заглушенное заклёпкой одно из четырёх первоначальных монтажных отверстий; 4 - малая прочность околошовных участков ковки на торцевой части шлема, с правой стороны затылка, одновременно хорошо видны головки заклёпок изнутри тулии и следы органики под ними; 5 - Головка 4-й заклёпки снаружи шлема и одно из четырёх первоначальных монтажных отверстий; 6 - Заглушенное шпеньками технологическое отверстие на верху шлема; 7 - Разведённые изнутри ножки шпеньков заглушающих технологическое отверстие на верху шлема 
так, что между ними и стенкой шлема присутствует небольшой зазор. Под шляпками заклёпок сохранились следы окислившейся органики (Рис. 2,4). Несмотря на то, что головка третьей заклёпки обломана, длина ножки и следы органики вокруг позволяют сделать вывод, что она также была вставлена изнутри. Снаружи ножки заклёпок в первом, втором, третьем и шестом случаях согнуты ударом молотка (Рис. 2,1). Ножка пятой заклёпки снаружи согнута и скручена в спираль диаметром 0,7 см, четвёртая заклёпка вставлена шляпкой снаружи, её диаметр 1,5 cм. (Рис. 2,5). Изнутри ножка этой заклёпки согнута, вокруг нее также прослеживаются следы органики, а между загибом и стенкой шлема присутствует небольшой зазор. (Рис. 2,2).

Чуть ниже ряда заглушенных отверстий с каждой стороны шлема находятся ещё по одному достаточно ровному по сравнению с предыдущими отверстию. В лицевой части шлема отверстие расположено чуть левее и ниже первого отверстия, выше описанной группы из шести отверстий на высоте 0,7 см от нижнего края, оно заглушено относительно аккуратной заклёпкой с круглой плоской головкой (Рис. 2,3). Два отверстия располагаются в районе ушей. Правое пробито на высоте 0,9 cм от нижнего края шлема, а левое - на высоте 1,7 cм. В обоих случаях диаметр отверстий 3 мм. На затылке отверстие пробито на высоте 3 см от нижнего края шлема, его диаметр 2,5 мм (Рис. 2,5).

Неровность нижнего края, а также небрежность, с которой пробита группа отверстий с левой стороны в лицевой части в совокупности с неаккуратным монтажем заклёпок в заглушенных отверстиях, позволяют сделать предположение, что шлем подвергся переделке, в ходе которой была удалена нижняя часть.

На макушке шлем имеет технологическое отверстие, заглушенное двумя небольшими шпеньками. Снаружи оба шпенька раскованы, а изнутри их ножки разведены в разные стороны (Рис. 2,6-7).

Общая высота шлема - 18,9 см, снизу шлем имеет овальную форму диаметром 20,6×22,3 cм и весом $-0,76$ кг.

На сегодняшний день шлем находится в удовлетворительном состоянии. С левой стороны, там, где нет шва, в верхней части тульи имеются несколько прорех, образовавшихся в результате коррозийных процессов (Рис. 1,3). Местами на поверхности шлема просматриваются следы абразива, но сказать однозначно, что это следы полировки, или позднейшей чистки не представляется возможным.
Представленный шлем ранее не становился предметом специального исследования. Однако английский ученый Дэвид Николл (David Nicolle), опубликовавший прежде изображение шлема в одной из своих работ, высказал предположение о том, что данное боевое наголовье является переделанным итальянским шлемом типа бацинет путём удаления у него нижней части (Nicoll 1995, 113).

Действительно, если мы обратимся к геометрии тульи шлемов типа бацинет, то увидим некое сходство с геометрией тульи шлема из коллекции ГИМ. Это и послужило основанием для Дэвида Николла считать, что исследуемое боевое наголовье в первоначальном виде представляло собой шлем типа бацинет. Между тем, на несостоятельность высказанной версии указывает именно рихтовка чеканными гранями шлема из ГИМ.

Во-первых, нам не известно ни одного шлема типа бацинет, дошедшего до наших дней, а стоит заметить, что их сохранился не один десяток (Strong 2018), который бы имел прочеканенную гранями тулью. Более того, как ранее удалось установить одному из авторов данной работы, большинство изображений, которые ранее предлагалось считать изображениями бацинетов с прочеканенный гранями, на самом деле являются изображениями шлемов иного типа (Кулешов 2019б, 231-235).

Во-вторых, если попробовать на тулье бацинета условно провести линию демонтажа нижней части даже в нескольких вариациях, то либо нижние прочеканенные грани должны будут располагаться на шлеме из ГИМ под углом, в то время как они располагаются вертикально, либо не получается исходная геометрия (Рис. 3).

Между тем нам известна ещё одна группа шлемов, для которой характерна одношовная сварная конструкция из листового железа с разгонкой шва и последующей рихтовкой в виде гранения. У данных шлемов также наблюдается асимметрия тульи, выраженная, как и в нашем случае, в виде завала назад. Речь идёт о недавно выделенной одним из авторов настоящей работы серии византийских саладов - боевых наголовий с дополнительным защитным элементом в виде назатыльника (Рис. 4,1-3), которые уверенно можно связать или с византийским производством напрямую, или с византийскими оружейными технологиями. На сегодняшний день к ним отнесены шесть шлемов, из которых три подверглись переделке и были обрезаны. Все они соотносятся с так называемым Халкисским 
кладом, а период их бытования определяется между 1330 и 1440 г. (Кулешов 2019б, 231-235).

Мы неслучайно обратили внимание на эту группу, так как помимо схожих технологических приёмов, в целом три вышеупомянутых шлема, подвергшихся переделке, в нынешнем виде очень близки публикуемому шлему (Рис. 4,4-7). Особо обращает на себя внимание схожий в обоих случаях изгиб задней стенки тульи. Что касается шлемов типа византийский салад, то тут данная проекция является результатом отгиба назатыльника. Это даёт нам основание полагать, что подобная проекция задней стенки у исследуемого шлема также вызвана отгибом тульи снизу.

В то же время публикуемый шлем не может принадлежать к этой группе. У затронутой серии шлемов снизу обязательно располагается несколько рядов отверстий: для фиксации подкладки, подшлемника и под крепления бармицы - вервейсы. Из-за специфической посадки шлемов на голове и наличия у них назатыльника эти отверстия пробиты под углом. При демонтаже нижней части ряды отверстий частично сохраняются, что хорошо прослеживается на трёх подвергшихся переделке образцах (Кулешов 2019б, 226-229).

Существует ещё одна группа шлемов, которая является производной от предыдущей группы, схожа технологически и очень близка внешне шлемам типа византийский салад. Ранее один из авторов данной публикации уже затрагивал эту группу боевых наголовий в одной из своих работ. Но тогда им были выделены только два представителя затронутой серии (Кулешов 2019a, 231-235). Речь идёт о парадном шлеме короля Франции Карла VI (13801422 гг), найденном в 1984 г. в ходе раскопок Квадратного двора (Cour Carrée) бывшей королевской резиденции Лувр, г. Париж, Франция (Рис. 5,1) и шлеме из собрания L'Armeria Reale,
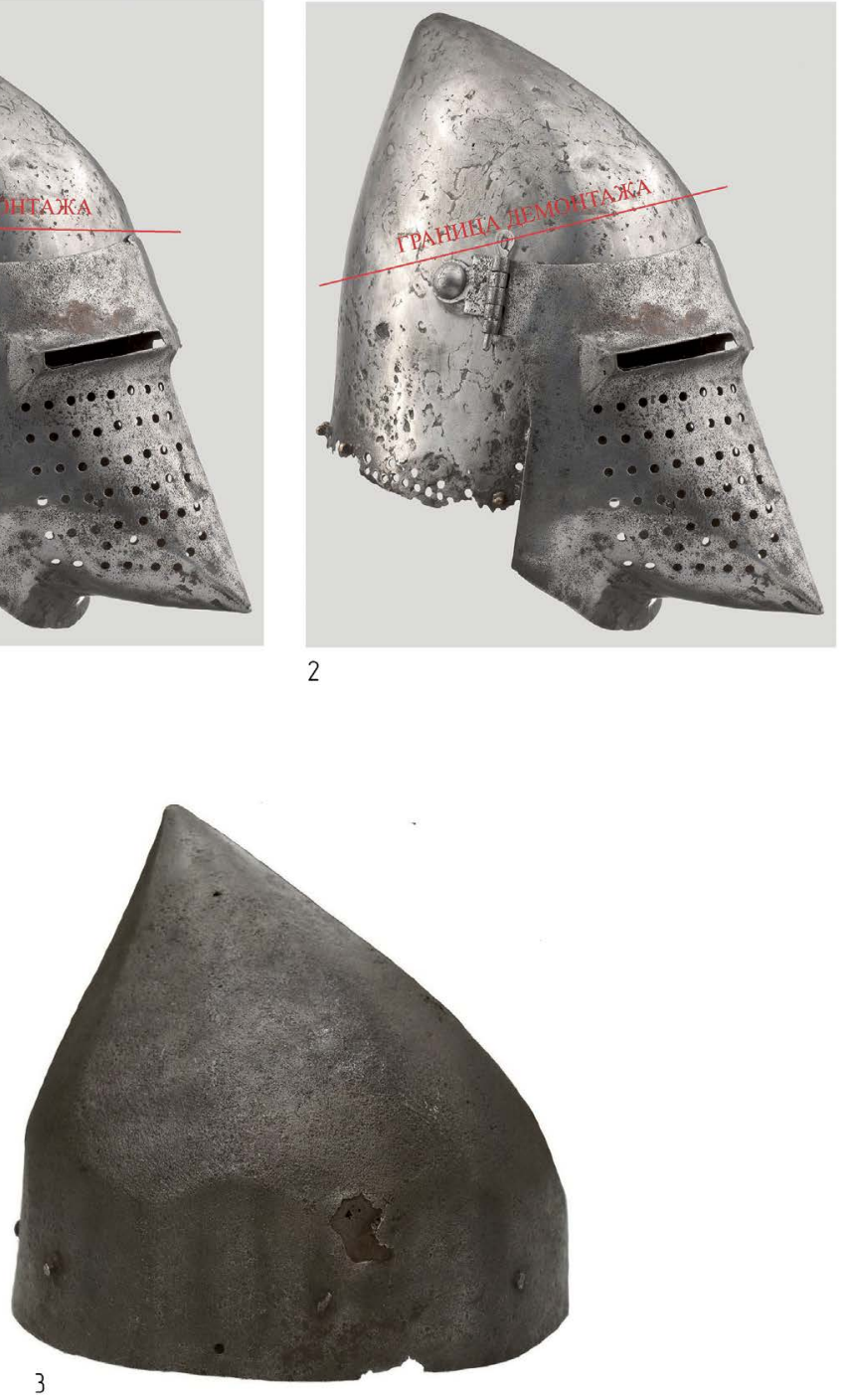

Рис. 3. Наглядные примеры несовместимости границы демонтажа; 1-2 - Шлем типа бацинет; 3 - Шлем из коллекции Отдела оружия Гим

г. Турин, Италия, инв. № Е3 (Рис. 5,2). Рассмотрев их, исследователь пришёл к выводу, что шлемы подобного типа появились в итало-византийской среде Северного Причерноморья вследствие работы оружейников-колонистов на внешний восточноевропейский рынок. В Золотой Орде, основном потребителе этой продукции, в качестве дополнительного защитного элемента боевых наголовий был распространён козырёк, в тоже время, для византийской оружейной традиции таким элементом являлся назатыльник. Как показывает дошедший до нас материал, решение оказалось простым. Не меняя технологий изготовления, мастера попросту перевернули конструкцию задом наперёд, чуть изменив угол наклона назатыльника, который тут же стал козырьком. В то же время выделенная группа имеет и назатыльник. То есть данные шлемы имеют два дополнительных 


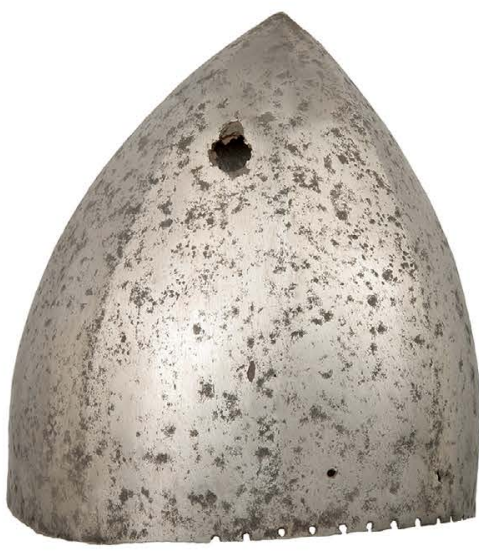

4

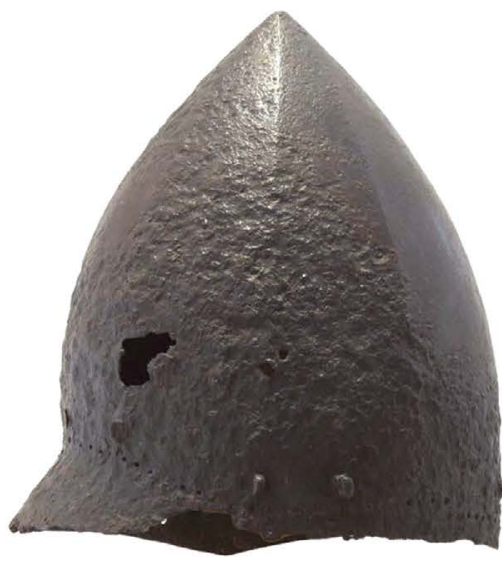

1

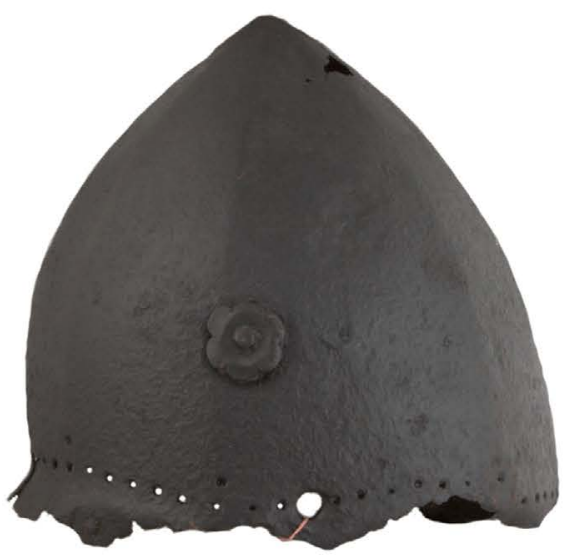

6

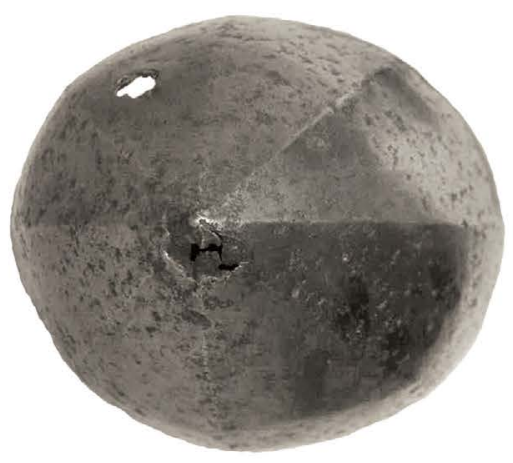

5

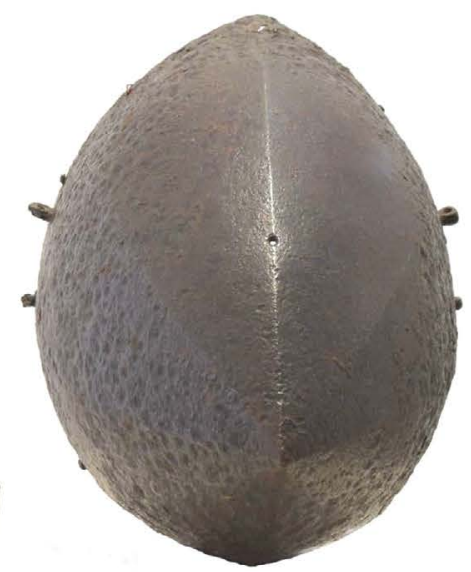

3

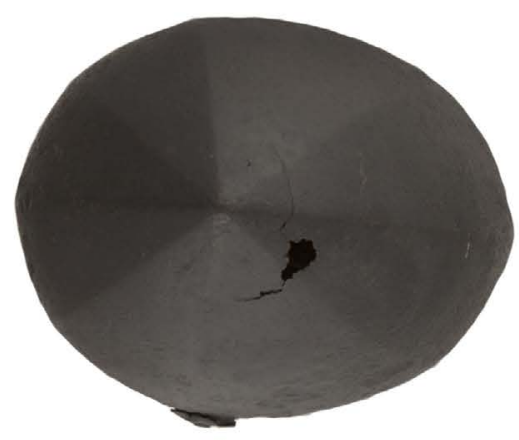

7

Рис. 4. Шлемы группы типа византийский салад: 1-3 - Византийский салад из коллекции Musée de l'Armée, г. Париж, Франция, инв. № М.Ро.676, происхождение неизвестно; 4-5 - Византийский салад подвергшийся переделке из коллекции The Metropolitan Museum of Art, г. Нью-Йорк, США, инв. № 29.158.44, предположительно происходит из Халкисского клада; 6-7 - Византийский салад подвергшийся переделке из коллекции Ethnikó Istorikó Mouseîo г. Афины, Греция, инв. № B27, происходит из Халкисского клада 

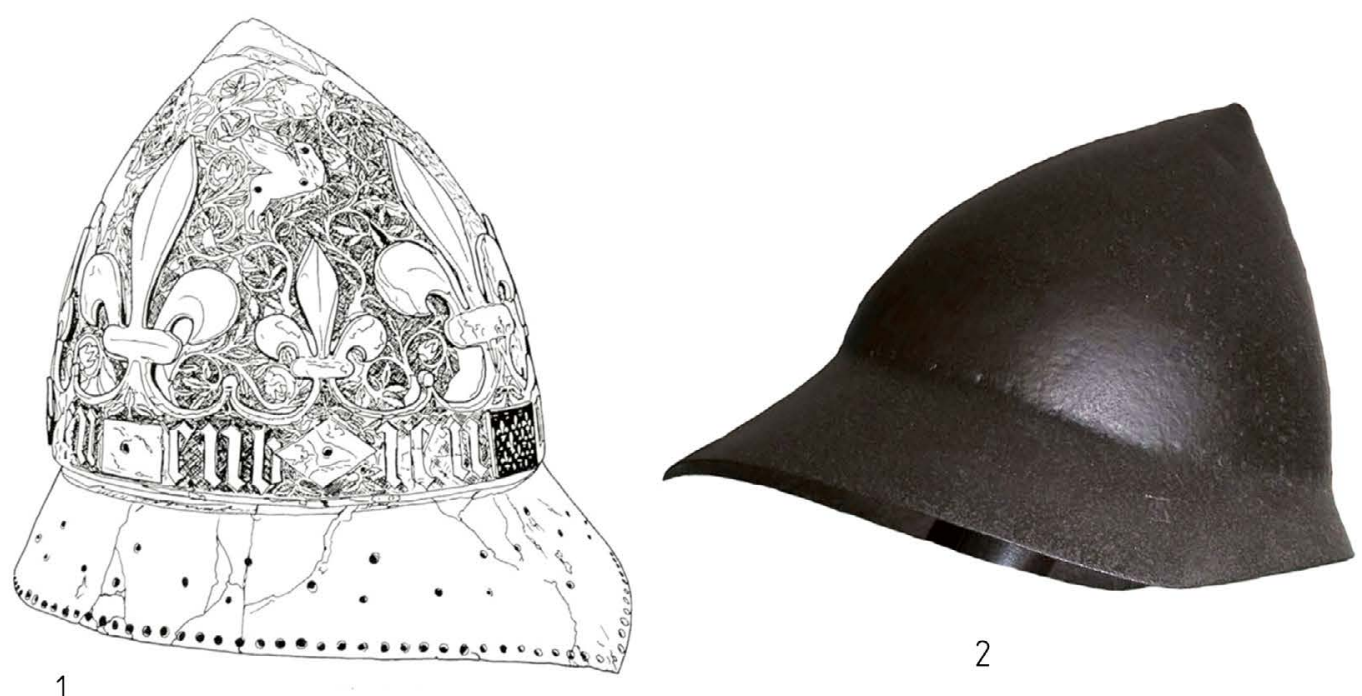

2
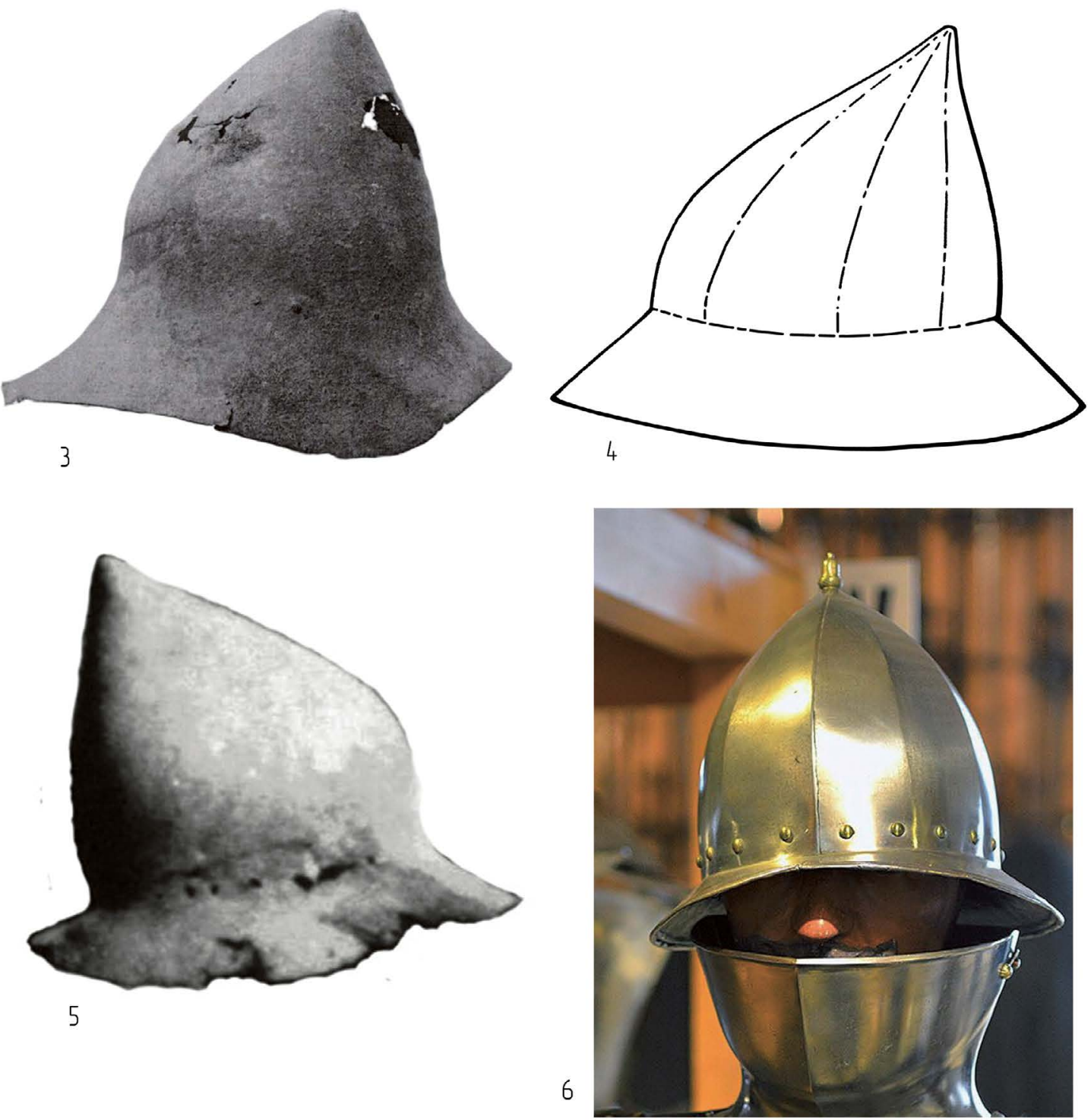

Рис. 5. Шлемы группы типа ранний бургиньот: 1 - Парадный шлем типа ранний бургиньот короля Франции Карла VI (1380-1422); 2 - Ранний бургиньот из собрания L'Armeria Reale, г. Турин, Италия, инв. № E3; 3-4 - Ранние бургиньоты из бывшей коллекции австро-венгерского графа Ганса Вильчека; 5 - Ранний бургиньот из экспозиции бывшего Военного музея в г. Стамбул, Турция; 6 - Ранний бургиньот из коллекции Musée de l'Armée, г. Париж, Франция, инв. № H 230 
защитных элемента в виде козырька и назатыльника, сочетая таким образом оружейные традиции мастеров-колонистов и византийских бронников (Кулешов 2019a, 235).

В пользу легитимности полученных выводов свидетельствуют и ряд других шлемов, дошедших до наших дней, которые вне всяких сомнений относятся к выделенной группе, но ранее оказались по ряду причин вне рамок затронутого исследования.

Два первых шлема известны по бывшей коллекции крупнейшего гуманитария АвстроВенгерской Империи последних десятилетий её существования графа Ганса Вильчека (Hans Wilczek). Первый из них представляет собой боевое наголовье, свёрнутое из листового железа с последующей разгонкой сварного шва, внешняя граница нахлёста читается в районе левого виска. Купол шлема имеет форму близкую к сфероконической, но при этом несколько заломлен назад. Снизу шлема расположены поля, переход к которым оформлен в виде высокого венца, по форме близкого к усечённому конусу. Поля имеют сложный профиль, спереди и сзади они отогнуты под углом $45^{\circ}$. При этом сзади они имеют округлую форму, в то время как спереди оформлены под заострённый козырёк, а по бокам они опущены практически вертикально, под углом $180^{\circ}$, имитируя науши. При переходе венца в поля по периметру шлема располагается редкая цепь заклёпок, спереди она пущена под углом сверху вниз до района висков, а далее идёт горизонтально. Вне всяких сомнений это следы монтажа подшлемника.

Шлем имеет значительные утраты: правая сторона практически полностью разрушена, с левой стороны затылка располагается большая дыра, образованная коррозией. В лицевой части имеются небольшие коррозионные дыры, появившиеся вероятно на месте расслоения шва. К сожалению, поступление этого уникального экземпляра в коллекцию остаётся невыясненным (Рис. 5,3).

Второй шлем представляет собой боевое наголовье с тульей сфероконической формы, несколько заваленной назад. Он явно сварен из листового железа, о чём свидетельствует разделение тульи на восемь граней - следы рихтовки после такой операции. Снизу шлема под углом $45^{\circ}$ располагаются поля, передняя часть которых чуть более вытянута, чем задняя.
В отличие от первого шлема, данный экземпляр неплохо сохранился. Но как и в предыдущем случае, его происхождение остаётся неизвестным (Рис. 5,4).

Третий шлем известен только по фотографии, сделанной в 1920 г. в экспозиции Военного музея в Стамбуле (Турция) основателем и почётным куратором Департамента оружия и доспехов The Metropolitan Museum of Art, г. НьюЙорк, одним из крупнейших коллекционеров оружия в США начала ХХ в. Башфордом Дином (Bashford Dean). Шлем представляет собой боевое наголовье со сфероконической тульей, несколько заваленной назад. Снизу шлема располагаются небольшие по отношению к размерам тульи поля, переход к которым оформлен в виде высокого венца по форме, близкой к усечённому конусу. Поля местами незначительно деформированы, но явно имеют сложный профиль. Так, спереди они оформлены в виде козырька, а от висков расширяются как полноценные поля. Рядом с переходом полей в козырёк фиксируется рубленый след, позволяющий предположить, что это следы деформации, вызванные ударом. Между тем при такой деформации непременно должно было повести и купол шлема. Более того, на фото отчётливо видно, что козырёк несколько шире полей и имеет округлый изгиб в фас. При переходе венца в поля на шлеме видна редкая цепь отверстий, которая служила для монтажа подшлемника. Судя по фото, шлем неплохо сохранился и имеет незначительные повреждения. В отношении происхождения шлема можно предполагать, что он является трофеем, захваченным турками в ходе одной из балканских компаний, как и большинство европейского вооружения, хранящегося в начале XX в. в так называемом арсенале Св.Ирины, где первоначально располагался Военный музей (Рис. 5,5).

И четвёртый шлем происходит из коллекции Musée de l'Armée, г. Париж, Франция, инв. № Н 230. В настоящее время он передан на временную экспозицию «Historial Jeanne d'Arc», открытую в Palais archiépiscopal de Rouen. ${ }^{3} \mathrm{OH}$ весьма близок предыдущему шлему. Тулья сфероконической формы несколько заваленная назад, сварена из двух половин с осевым швом, который имеет одну весьма интересную деталь: верхний край левой половины тульи был согнут под углом $90^{\circ}$ по направлению к правой половине тульи, тем самым формируя полку для

\footnotetext{
3 Пользуясь случаем авторы хотели бы поблагодарить главного куратора Департамента оружия и доспехов Musée de l'Armée, г. Париж, Франция, Оливье Ренодо (Olivier Renaudeau) за уточнения.
} 
сварочного шва. Поверхность тульи разделена на восемь граней - следы рихтовки. Снизу тульи по всему периметру расположено шестнадцать заклёпок из жёлтого металла с крупными полусферическими головками. Края шлема, отогнутые под углом $45^{\circ}$, формируют поля, передняя часть которых чуть более вытянута, чем задняя. По всей окружности края полей отвальцованы внутрь. На макушке тульи закреплено цилиндрическое навершие из жёлтого металла с основанием в виде широкого кольца, поверхность которого гравирована в косую сетку. Заканчивается навершие невысоким стержнем. Шлем великолепно сохранился (Рис. 5, 6).

Таким образом, мы имеем группу шлемов, которая наиболее близка по конструктивным элементам и внешнему облику к шлему из коллекции ГИМ. Прежде всего, следует обратить внимание на схожесть таких характеристик, как: точная форма тульи, завал купола шлема назад, практически прямая задняя стенка и наличие венца по форме близкого к усечённому конусу. В то же время следы обрезки нижнего края шлема указывают на то, что снизу располагались дополнительные конструктивные элементы. А изгиб проекции задней стенки позволяет сделать вывод, что в задней части шлема эти конструктивные элементы имели отгиб.

Подтверждения тому, что наша атрибутация верна, мы можем видеть на примере ещё одного шлема из коллекции Musée de l'Armée, г. Париж, Франция, инв. №Н. Ро. 261 (Рис. 6,3).

Речь идёт о шлеме типа морион, который сварен из листового железа, внешний шов располагается в районе левого виска. Сфероконический купол шлема, с чуть заваленной назад макушкой, разделён чеканкой на шесть секторов вертикальными гранями. Следует ометить, что чеканка наведена двумя уровнями, а нижняя часть выполнена в виде тиары, как и на исследуемом шлеме из ГИМ. Снизу шлема располагаются поля, спереди и сзади они задраны вверх, а по бокам отогнуты вниз под углом $45^{\circ}$. По центру полей прочеканена грань, а нижняя граница полей оформлена в виде скрученного жгута. По венцу шлема, в районе перехода тульи в поля, расположена цепь заклёпок с круглыми шайбами из жёлтого металла. Подобным металлом обтянуты и головки заклёпок. На одной заклепке утрачены обтяжка и шайба. При этом с одной заклёпки обтяжка содрана, отсутствует под ней и шайба. Сзади шлема одной из заклёпок фиксируется гнездо под плюмаж в виде пластинки с полуовальным сечением.
В музее шлем датируют 1560 г. (Reverseau 1982, 36, № 53).

Таким образом, перед нами шлем с сходной по конструкции и отделке тульи и дополнительным защитным элементом в виде полей, несколько отличающихся от той защиты, что мы видим на группе шлемов, привлечённых нами в качестве аналогии к исследуемому шлему.

Здесь нужно сделать отступление. Дело в том, что боевые наголовья типа морион в сформировавшемся виде, как известно, появляются достаточно поздно, около середины XVI в. (фон Винклерь 1894, 146). История происхождения морионов весьма туманна, большинство исследователей склоняются к версии, что данный тип шлемов является вершиной развития боевых наголовий типа айзенхут/шапель/капеллина (Laking 1921, 193; Tavares 2012, 3-5). Между тем, их развитие представляется нам более сложным. Например, есть версия, что данный тип шлема возник под влиянием боевых наголовий типа бургиньот, в частности их поздней разновидности (Релић 2011, 209). Более того, ряд дошедших до наших дней бургиньотов имеет форму практически идентичную морионам, но в отличие от последних они снабжены подвижными наушами (Ffoulkes 1916, № II, 32; Müller, Kunter 1984, 170, № 88-89). Для таких шлемов даже появился специальный термин морион-бургиньот (Curtis 1978, 288-289). Помимо схожести основных конструктивных элементов, для этого есть и другие основания. Так в документах 1-й половины XVI в., разновидности боевых наголовий типа бургиньот периодически обозначали и термином морион (Laking 1921, 193-194). В то же время шлемы, которые тот или иной исследователь выдаёт за ранние морионы (Laking 1921, 194, № 1269), другие специалисты таковыми не считают (Воссіа 1982, 26, 75, № 29, D; Müller, Kunter 1984, 170, № 92).

Мы неслучайно акцентировали на этом внимание. Дело в том, что в вышеуказанной работе, где одним из авторов настоящей статьи была первоначально выделена группа шлемов, производных от византийских саладов, которые были отнесены к типу ранних бургиньотов. Основанием для этого послужил тот факт, что у затронутого типа шлемов дополнительный защитный элемент выполнен не просто в виде полей, а в нём целенаправленно проработаны козырёк и назатыльник, хотя и смыкающиеся вместе. Сочетание этих двух защитных элементов характерно именно для боевых наголовий типа бургиньот (Кулешов 2019a, 235). 

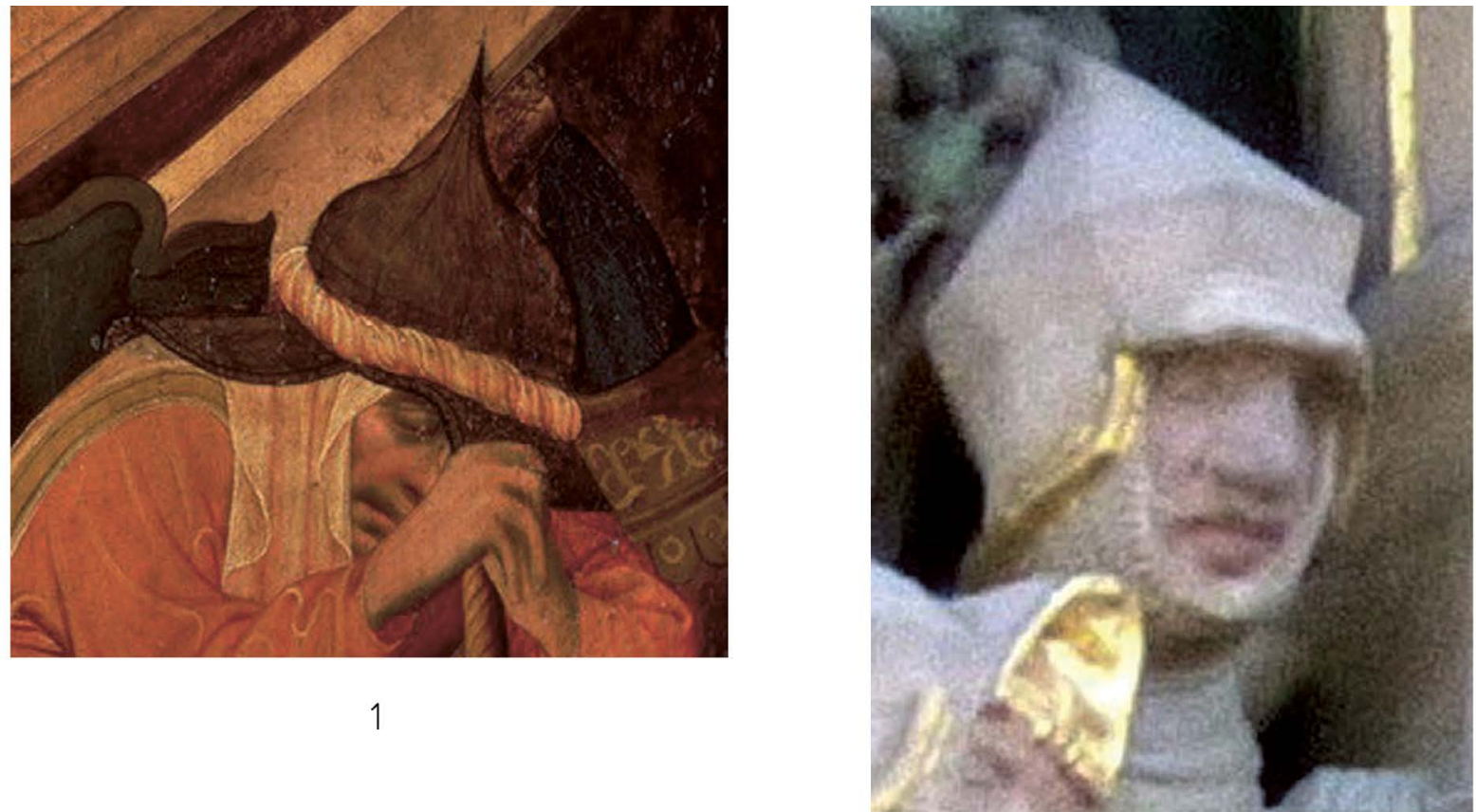

2

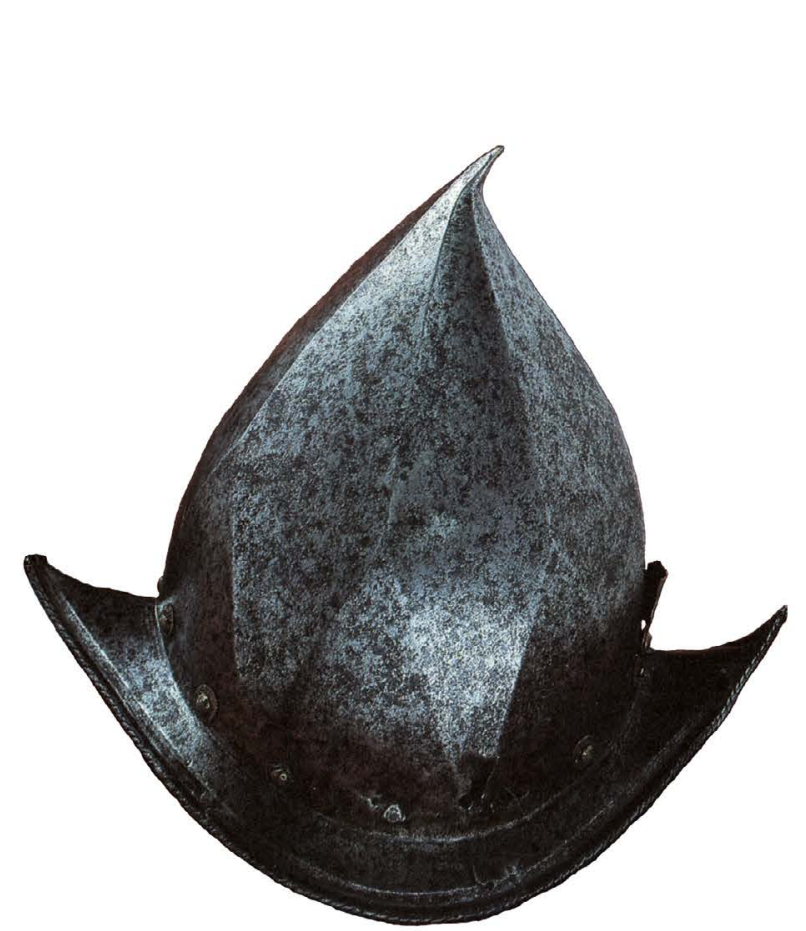

3

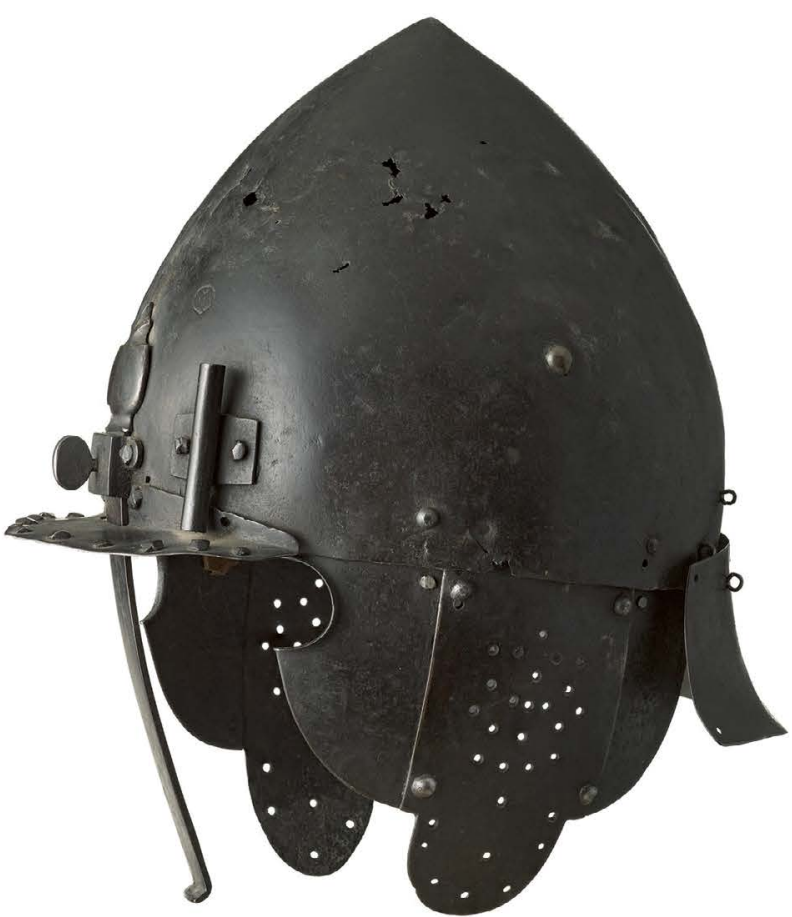

4

Рис. 6. 1 - Фрагмент сцены «Спящая стража» с правой внутренней створки Thomas-Altar из собрания Hamburger Kunsthalle, Германия; 2 - Фрагмент сцены «Спящая стража» на Loste-Retabel из Schweriner Dom St.Marien und St. Johannis, земля Мекленбург-Передняя Померания, Германия; 3 - Шлем типа морион из Musée de l'Armé е, г.Париж, Франция, инв. № H. Ро. 261; 4 - Пример оформления смещённой плюмажной втулкой на турецком шлеме, переделанном из европейского шлема типа византийский салад, коллекция Royal Armouries, г. Лидс, Великобритания, начало XVII вв. 
Таким образом, по нашему мнению шлем из коллекции Musée de l'Armée можно считать более поздним представителем эволюционного ряда одной группы шлемов. Исходя из вышесказанного, шлем из собрания ГИМ можно отнести к представителям ранней серии данной группы шлемов. Подтверждение этому можно видеть в оформлении перехода венца в поля на шлеме из французского собрания и на шлеме из ГИМ. Так нижний край венца у шлема из Musée de l'Armée выполнен неровным, a в лицевой и задней частях имеются подтреугольные вырезы из-за формы и угла наклона полей. При такой выкройке, если предполагать демонтаж нижней части шлема, мы не получим профиля, как у публикуемого шлема. Венец в исходном варианте окажется очень не высоким, а боковые грани купола попросту сползут вниз, то есть окажутся значительно ниже передних и задних. Подтверждение факта бытования боевых наголовий с тульей, как у публикуемого шлема и нижней частью, характерной для ранних представителей этой серии шлемов, мы находим в изобразительных источниках.

Первый подобный шлем мы видим на одном из воинов в сцене «Спящая стража» на правой внутренней створке Thomas-Altar из собрания Hamburger Kunsthalle, Германия, который был написан голландским художником Мастером Франке (Meister Francke) по заказу купцов Гамбурга между 1424-1430 гг. И хотя воины в интересующей нас сцене представлены в мифическом образе, а их оружие стилизовано, схожий с нашим шлем легко узнаваем. На крайнем правом стражнике мы видим сфероконический шлем, тулья которого завалена назад. Вся поверхность тульи, включая венец, граница которого показана горизонтальной линей, разделена чеканными вертикальными гранями на секторы. Снизу шлема расположены дополнительные элементы в виде козырька и широкого назатальника (Рис. 6,1).
Второе изображение можно видеть на воине в сцене «Спящая стража» на Loste-Retabel из Schweriner Dom St.Marien und St. Johannis, земля Мекленбург-Передняя Померания, Германия, который был подарен храму Шверинским епископом Конрадом Лостом (Conrad Loste) в 1495 г. Само создание алтаря датируют серединой-концом 1-й трети XV в.

В верхнем левом углу центральной части алтаря на стоящем стражнике мы видим боевое наголовье со сфероконической тульей, чуть заваленной назад. Вся поверхность тульи, включая венец, граница которого показана горизонтальной линей, разделена чеканными вертикальными гранями на сектора. Снизу шлема расположены дополнительные элементы в виде козырька и широких полуполей (Рис. 6,2).

Таким образом, перед нами полное подтверждение полученных выше выводов. Что касается датировки публикуемого шлема, то вероятно его появление на основании двух выше приведённых изображений на алтарных 
створках германских храмов, стоит относить не ранее чем к концу 1-й трети XV в.

В отношении второй жизни шлема, то есть его переделки, датирующим признаком является группа отверстий в лицевой части с левой стороны. Схема их расположения указывает на то, что на шлеме хотели смонтировать плюмажную втулку. Этот элемент получает распространение на боевых наголовьях в южно-европейском регионе на рубеже XVI-XVII в. (Рис.6,4). В пользу высказанной даты свидетельствует переделки других типов европейских позднесредневековых шлемов, относящихся к этому периоду (Robinson 1953, 35-37) (Рис. 7).

\section{Литература}

фон Винклеръ П. Оружіе: Руководство къ исторіи, описанію и изображенію ручного оружія съ древнъйших временъ до начала ХІХ въка. - СПб., 1894.

Кулешов Ю. А. Позднесредневековый шлем из собрания Козьмодемьянского культурно-исторического музейного комплекса (к вопросу о традициях и технологиях оружейного производства Генуэзской Газарии) // Земля наша велика и обильна: сборник статей, посвященный 90-летию А.Н. Кирпичникова. - СПб., 2019а.

Кулешов Ю.А. К проблеме выделения византийских боевых наголовий (на примере одной группы шлемов) // Сборник научных трудов научного семинара «Военная археология» при Институте Археологии РАН. Вып. 5. - М., 20196.

Релић К. Р. Шлемови типа кабасет и морион из збирке војного музеја у Београдую. // Војни музеј - Вестник: часопис за историју, музеологију и уметност. T. LVII. № 8 (38). - Београд, 2011.

Шмаков В.Г. Кузнеца в современном хозяйстве. - М., 1990.

Boccia L. G. Dizionari terminologici Armi defensive dal Medioevo all'Età Moàerna. - Firenze, 1982.

Curtis H. M. 2,500 Years of European Helmets: 800 B.C.-1700 A.D. - North Hollywood, 1978.

Ffoulkes Ch. J. Inventory and survey of the armouries of the Tower of London. Vol. I. - London, 1916.

Laking G.F. A Record of European Armour and Arms. Vol. IV.- London, 1921.

Müller H., Kunter F. Europäische Helme aus der Sammlung des Museums für Deutsche Geschichte. - Berlin, 1984.

Nicoll D. Medieval Warfare Source Book. Vol. II: Christian Europe and Its Neighbors. - London, 1995.

Reverseau J-P. Musée de l'Armée Paris: Les armes et la vie. - Paris, 1982.

Robinson H. R. A converted helmet and some early barbute and armets // Journal of Arms and Armour Society. Vol. 1. No. 3 (September 1953). - London, 1953.

Strong D. W. Surviving Examples of Early Plate Armour 1300-1430: Volume I: Bascinets. - Chicago, 2018.

Tavares J. The Morion: An Introduction to its Development, Form, and Function // The Bulletin of The American Society of Arms Collectors. № 105. - New York, 2012. 


\section{МАНЬЧЖУРСКИЕ НАКОНЕЧНИКИ СТРЕЛ ИЗ КУЛЬТУРНОГО СЛОЯ АЛБАЗИНСКОГО ОСТРОГА}

\section{А. Н. Черкасов, Р. С. Веретюшкин, А. М. Пастухов}

Один из героических и драматических эпизодов освоения русскими землепроходцами Приамурья в XVII в. связан с Албазинским острогом - а именно, «Албазинское сидение», когда албазинские казаки и служилые люди несколько лет выдерживали осаду Албазина, противостоя превосходящему численно и по вооружению маньчжурскому («богдойскому» русских источников) войску.

Албазинский острог находится на Верхнем Амуре и впервые упоминается в письменных источниках под 1650 г. в связи с походом в Приамурье отряда Ерофея Хабарова. Тогда казаками Хабарова был захвачен городок даурского князя Албазы, в котором они перезимовали. Затем городок был оставлен и восстановлен как русский острог только в 1665 г. отрядом беглых казаков Никифора Черниговского, пришедших на Амур с Лены. С этого момента Албазин начал активно развиваться, став центром русского освоения
Приамурья. В 1682 г. русское поселение при остроге получило официальный статус уездного центра.

Успешное освоение албазинцами Приамурья вызвало беспокойство маньчжур, завершивших к тому времени покорение Китая и основавших династию Цин. При императоре Канси был разработан план противодействия русским, который предполагал постепенное продвижение маньчжурских войск на Амур, создание опорных баз и разрушение русских поселений. В 1682 г. был разрушен находящейся на р. Долонец (левый приток р. Зея) Долонский острог, в 1683 г. - находящийся на другом левом притоке Зеи - р. Селемджа Селембинский острог, в начале 1684 г. - Верхозейский острог.

В июне 1685 г. манчьжурские войска подошли к Албазину и начали штурм. Боевые действия продолжались недолго, цинским войскам с помощью артиллерии удалось разрушить

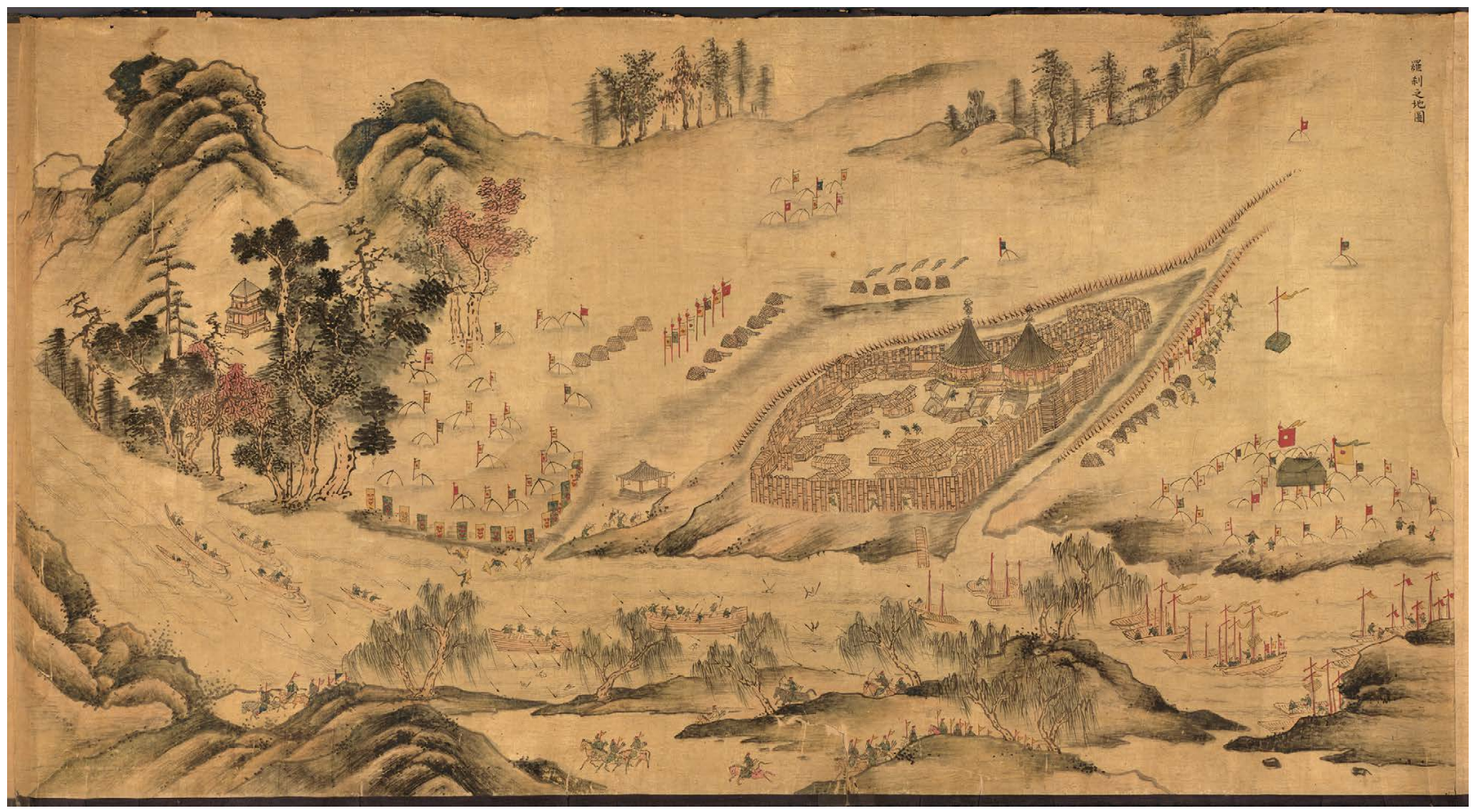

Рис. 1. Первая осада Албазинского острога. Рисунок из китайского атласа Aihun, Luosha, Taiwan, Nei Menggu tu (1697-1722 гг.) 


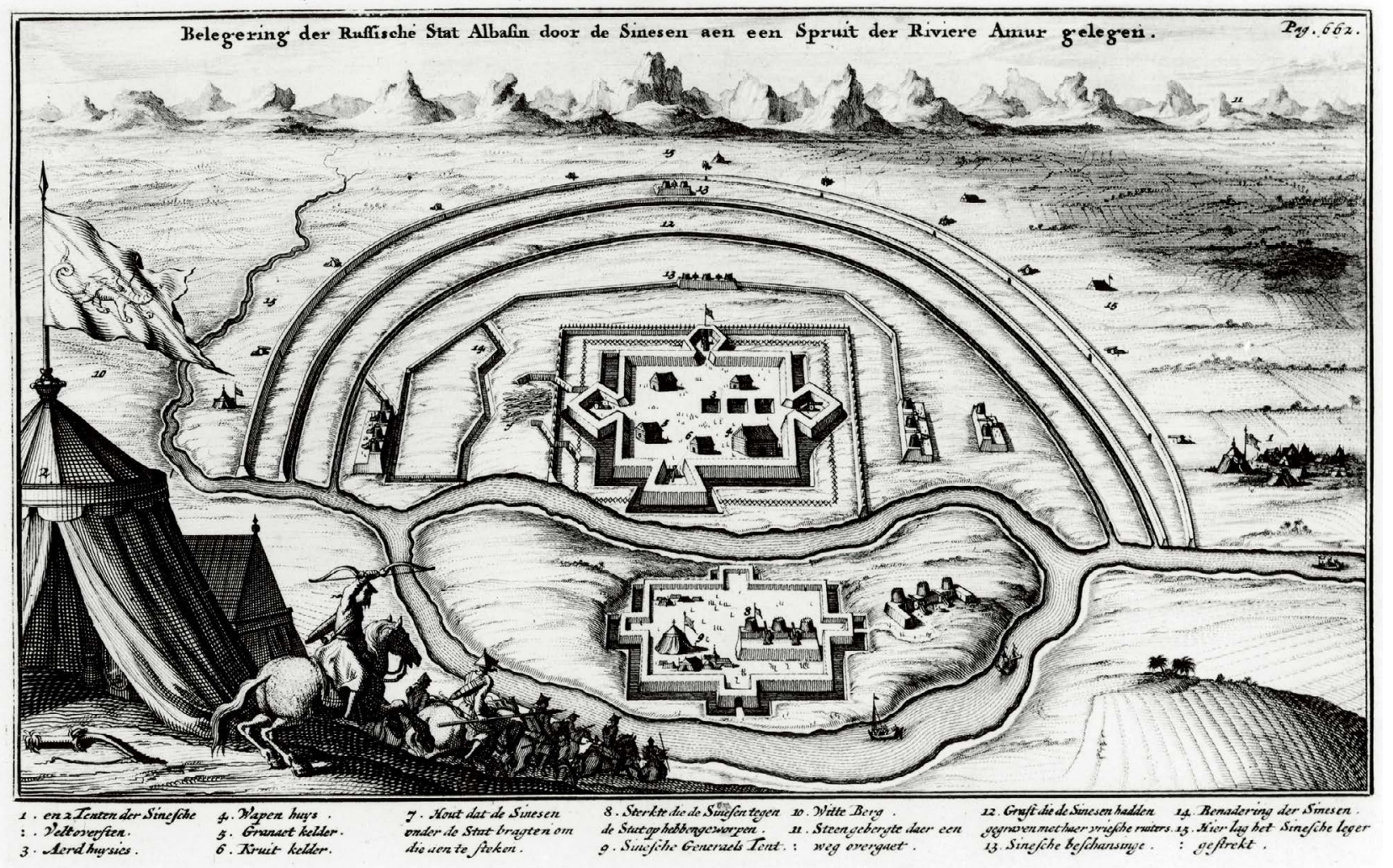

Рис. 2. Вторая осада Албазинского острога. Гравюра из книги Николааса Витсена «Северная и восточная Тартария» (1705 г.)

деревянные сооружения крепости, его защитники были вынуждены заключить перемирие и оставить острог (рис. 1). Однако маньчжуры также покинули Албазин, уйдя вниз по Амуру. Воспользовавшись этим, русские вернулись и восстановили крепость с земляными укреплениями, способными противостоять артиллерийскому огню. Это позволило во время нападения на город маньчжур в 1686 г. успешно оборонять его до конца года. Затем боевые действия перешли из «горячей» в «холодную» фазу и началась долгая блокада острога маньчжурскими войсками, известная, как «Албазинское сидение» (рис. 2). Она продлилась до 1689 г., когда был подписан Нерчинский мирный договор между Российским государством и Цинской империей, по условиям которого Россия отказалась от Приамурья. Эти территории были возвращены Россией лишь в середине XIX в.

Маньчжурская армия, которой противостояли защитники Албазина, была хорошо организована и вооружена. Существует представление, что маньчжуры - это кочевой народ, а их армия - иррегулярное кочевническое войско. Это ошибочный стереотип, маньчжуры, будучи наследниками чжурчжэньской империи Цзинь (1115-1234), использовали достижения китай-

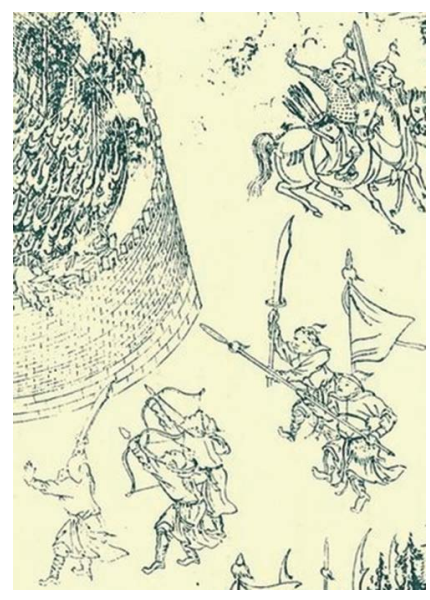

Рис. 3. Осада города с применением зажигательных стрел. Китайская гравюра на дереве (1635 г.). ской цивилизации, а также успешно перенимали опыт европейских специалистов военного дела. Им удалось создать армию Нового времени, передовую для Дальневосточного региона, хотя и имеющую определенную ориентальную специфику.

Маньчжуры были хорошими всадниками, но, повторим, никак не кочевниками, хотя конница играла значительную роль в цинских вооруженных силах. Другой важной составляющей маньчжурской армии была пехота, вооруженная древковым и клинковым оружием, а также мощными луками, способными стрелять стрелами с тяжелыми наконечниками (рис. 3).

Хорошая организация, грамотное взаимодействие конницы и пехоты позволяло цинским войскам решать широкий круг военных задач. В соответствии с требованиями времени маньчжуры уделяли особое внимание огнестрельному 


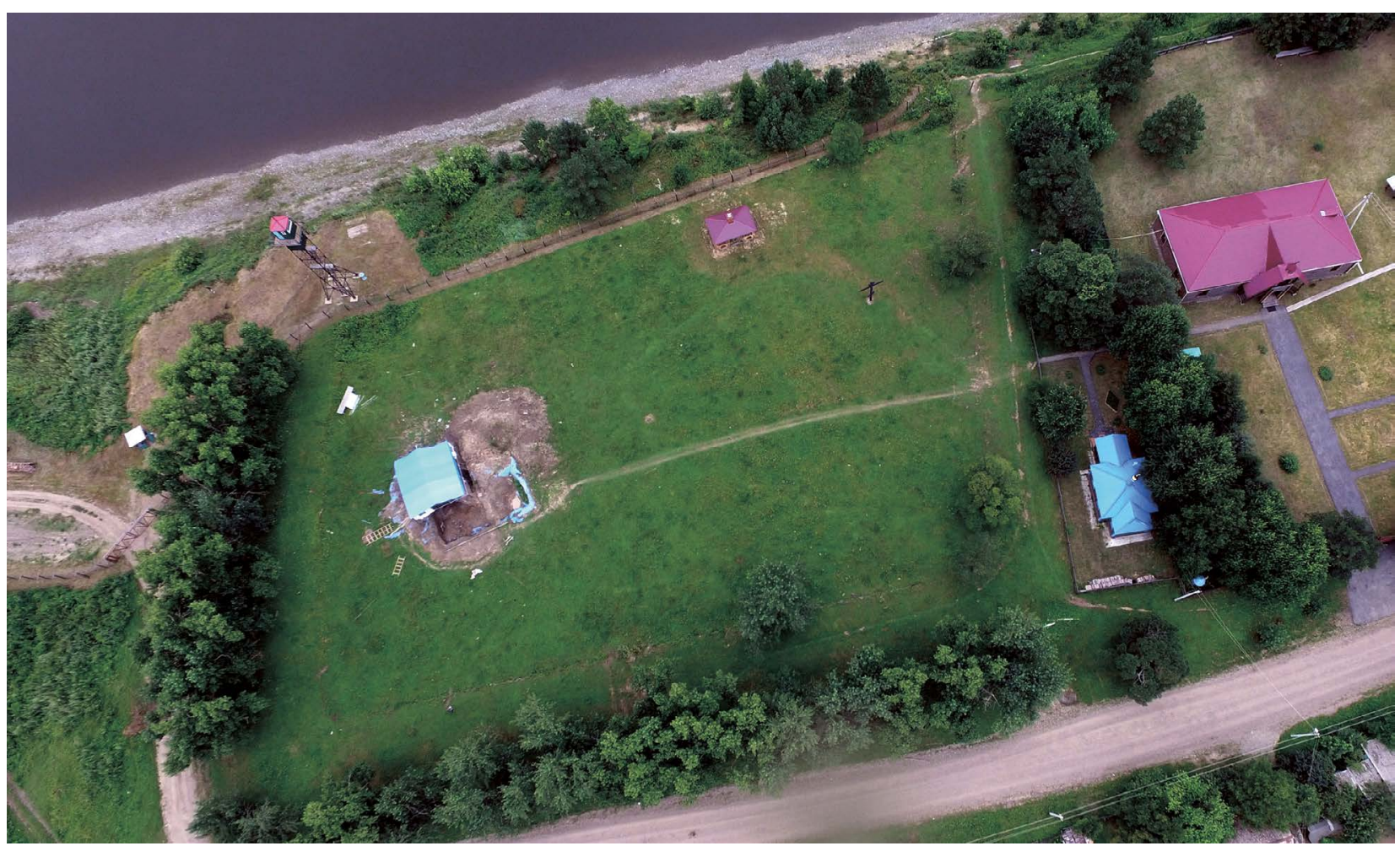

Рис. 4. Вид сверху на Албазинский острог (2016 г.)

оружию, которым была вооружена часть воинов, которые были объединены в отдельные отряды. Важная составляющая цинской армии - артиллерия, причем маньчжуры использовали как полевые пушки, действующие против живой силы противника, так и крупнокалиберные, «проломные», способные разрушать укрепления.

Хорошая организация маньчжурской армии, ее многочисленность, достигнутая на «приамурском театре» на момент походов на Албазин, наличие и успешное использование огнестрельного оружия стали причиной того, что русские служилые люди, до этого успешно справлявшиеся с любым сопротивлением аборигенных народов Сибири и Дальнего Востока, встретили достойного противника, от которого даже стали терпеть поражения. Так, маньчжурами были взяты русские остроги по р. Зея, достаточно быстро был разрушен Албазин в первую осаду в 1685 г. Лишь увеличение русского гарнизона и перестройка крепости с учетом необходимости противостоять артиллерийскому огню позволили албазинцам успешно обороняться во время «Албазинского сидения».

Албазинский острог исследуется археологически с 70-х гг. ХХ в. Сначала (1974-1976, 1979-1980 гг.) там работали археологи из Новосибирска и Благовещенска в составе отряда Северо-Азиатской комплексной экспедиции Института истории, филологии и философии $\mathrm{CO} \mathrm{AH}$
СССР под руководством В.В. Сухих и С.Г. Глинского. С 1989 по 2002 г. памятник исследовал Амурский археологический отряд Института истории, археологии и этнографии народов Дальнего Востока ДВО РАН под руководством А. Р. Артемьева. В 2007 и в 2013 гг. на остроге работала экспедиция Центра по сохранению историко-культурного наследия Амурской области под руководством Д. П. Волкова. С 2011 по 2016 г. на территории Албазинского острога проводила исследования Албазинская археологическая экспедиция под руководством А.Н. Черкасова, созданная Фондом «Петропавловск» и Центром по сохранению историко-культурного наследия Амурской области.

Албазинской археологической экспедицией был исследован культурный слой острога на территории трех раскопов: I и III находились, примыкая друг к другу, в центре крепости, II раскоп разрезал земляной вал крепости (рис. 4,5 ). В ходе раскопок обнаружены погребения защитников Албазина - два массовых захоронения-скудельни, устроенные в частично заглубленных постройках, и более десятка одиночных захоронений в гробах и в ямах.

Несмотря на активное применение маньчжурами огнестрельного оружия, луки - метательное оружие дальнего боя - играли не меньшее значение в боевых действиях. Подтверждение этому частые находки в культурном слое Албазинского 
острога железных наконечников стрел. Именно им и посвящена настоящая работа.

В китайских письменных источниках отмечается, что стрелы производились в соответствии с определенными требованиями в правительственных мастерских и централизованно распределялись среди различных родов войск, разных государственных чинов.

Их описание представлено в кодексе «Хуанчао лицчи туии», составленном в 1759 г., одобренном императором Цяньлуном в 1760 г. и повторно изданным в 1766 г. В 1899 г. текст кодекса с накопившимися дополнениями и изменениями был включен в состав нового кодекса «Циньдин Да Цин хуйдянь ту». В современных китайских энциклопедиях указывается, что «в Восьмизнаменных войсках наследственному гуну ${ }^{1}$, пожалованному титулом от императора (иичжи миньгун) [выдавали] 550 [стрел], хоу, бо, иззы и наню с шагом в 50 [стрел] $]^{2}$, изинчэ-дувэй -250 стрел, цุи-дувэй и юньц̧и-вэй - с шагом в 50 [стрел] $]^{4}$.

Военным чинам от 1 до 5 рангов - смотря [по тому, носят ли они аристократические титулы] иззы [или] нань, от 6-го ранга и ниже по 100 [стрел]. Гражданским чинам 1 и 2 рангасмотря [по тому, носят ли они аристократические титулы] иззы [или] нань, столичным чиновникам 3 ранга - как военному чину 2 ранга, столичным чиновникам 4 ранга, цензорам (кэдао), телохранителям (ланчжун) - как военному чину 3 ранга, юань вайлану - как военному чину 4 ранга, делопроизводителю (чжуии), церемониймейстеру (минцзань), принятым в Академию Сынов Отечества (Гоцззыцзянь) за заслуги предков (иньизяньшэн) - как военному чину 5 ранга, писарю (битэии) - как военному чину 6 ранга, хуцззюнь, ияяньфэн, линцуй ${ }^{5}$ - каждому по 70 стрел, конному латнику - по 50 стрел, пешему воину -40 стрел» ${ }^{6}$.
В нашем случае интересны последние строки - нормы распределения стрел среди конных латников и пеших воинов, которые непосредственно принимали участие в осаде Албазина. Среди изготовленных в правительственных мастерских стрел были типы чжаньцзянь и мэйчжэньцзянь.

Чжаньцзянь дословно означало «военная стрела», для нее характерен тяжелый плоский и широкий черешковый наконечник ромбической формы (рис. 6: 2). Второе название, мэйчжэньизянь, означало «сливовая игла», она имела вытянутый ланцетовидный наконечник (рис. 6: 3, 4).

В современных китайских энциклопедиях и словарях эти стрелы описывали следующим образом:

«Стрелы для чиновников и солдат имели древки из березы или ивы длиной 3 чи (96 см) со стальными наконечниками длиной 3 иунь (9,6 см), передняя часть древка была отделана берестой и [имела оперение из] перьев аиста, у чиновников в промежутке между перьями писали имя и должность владельца, у солдат - имя, конец древка со стороны оперения окрашивался красным лаком» 7 .

К сожалению, в культурном слое Албазинского острога не сохранились древки стрел и мы лишены такого интересного источника, по которому могли бы узнать имена солдат.

Кроме того, известно, сколько каких материалов выделялось для производства стрел:

«Для стрел конных и пеших воинов [использовались] - для древка дерево, 3 пера для оперения и кора монгольского персика (мэнтао) для отделки, для приклеивания рыбьего клея 1 иянь (3,73 г.), бычьих сухожилий 4 фэнь (ок. 1,5 г.), нити из шелка-сырца как и тунгового масла - по 3 фэнь (ок. 1,2 г.), киновари 2 фэнь (ок. 0,75 г.), столярного клея 5 фэнь (ок. 2 г.), стальной наконечник - в соответствии с установленными образцами» ${ }^{8}$.

\footnotetext{
1 При династии Цин - титул китайской и маньчжурской аристократии, не относящейся к императорскому клану. Этот и другие аристократические титулы жаловались императором за заслуги и делились на наследственные и личные, не передаваемые по наследству (как правило, сын пожалованного аристократи-ческим титулом наследовал титул, который был ниже титула, пожалованного его отцу, на одну ступень, и так - вплоть до полного исчезновения титула в роду, если указом не было оговорено вечное наследование изначального титула). Далее следуют другие, не относящиеся к императорскому клану, аристократические титулы империи Цин в нисходящем порядке.

2 Таким образом, каждому следующему титулу выдавали на 50 стрел меньше.

3 Букв. «военачальник легких колесниц» - один из низших аристократических титулов. Далее следуют аристократические титулы в нисходящем порядке.

4 См. прим. 9.

5 Младшие воинские чины в системе «Восьми Знамен».

${ }^{6} \mathrm{http} / / / \mathrm{www} \cdot h i s t o r y c h i n a . n e t / q s b k / j x / 394243 . s h t m l$

7 http://www.historychina.net/qsbk/jx/394243.shtml

8 http://www.historychina.net/qsbk/jx/394243.shtml
} 


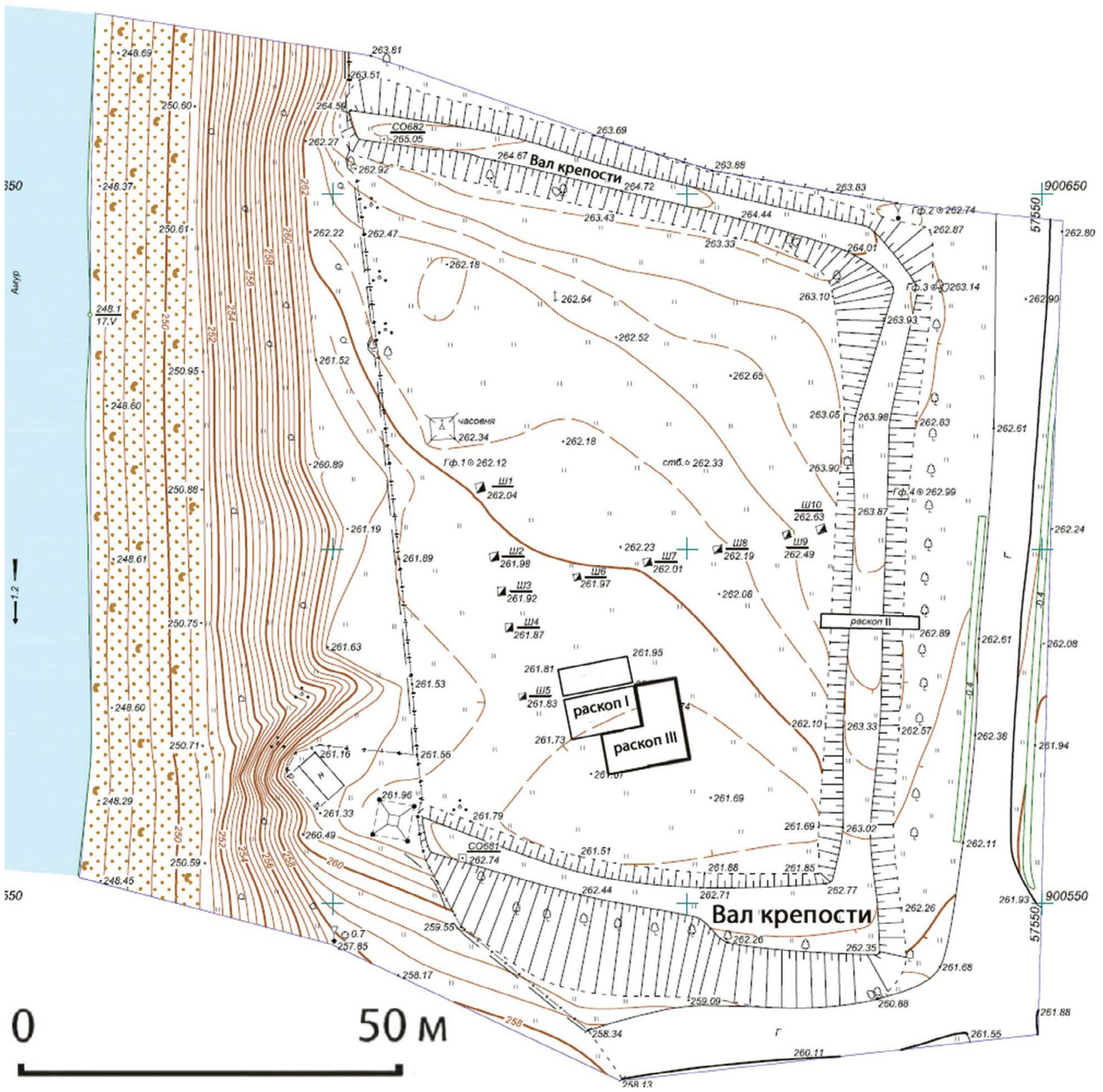

Рис. 5. Топоплан Албазинского острога с раскопами (2012 г.)

В кодексе «Хуанчао лици туши» приводится следующее описание стрелы «сливовая игла» мэйчжэньизянь: «Почтительно докладываю, что по уложениям правящей династии стрела «сливовая игла» [имеет] древко из березы длиной 2 чи 8 иунь (89,6 см.), железный наконечник длиной 3 иунь 2 фэнь (10,24 см.), шириной 4 фэнь $(1,28 \text { см. })^{9}$. Передняя часть древка отделана черной корой персика (рис. 6,1 ). [Использованы] перья ястреба/подорлика. Конец древка в промежутке между перьями - красного цвета.
Около выкрашенного красным [лаком] участка [древко] обмотано берестой черной березы. Используется на войне» ${ }^{10}$.

Изображение стрелы мэйчжэньизянь, записываемой другими иероглифами, в которых первый иероглиф «дикая слива» заменялся иероглифом «бровь», появилось уже в сочинении Мао Юаньи (1594 - около 1640) «Убэй чжи» (1621, букв. «Записки о военной подготовке»).

Наконечник стрелы мэйчжэньизянь (рис. 6: $3,4)$ был хорошо приспособлен для того, чтобы

\footnotetext{
9 Размеры приводятся исходя из современного значения чи -32 см, цунь $-3,2$, и фэнь $-0,32$. В период Цин они отличались от современных крайне незначительно или же совпадали, в случае, если использовалась обычная, а не строительная или текстильная система мер.

${ }^{10} \mathrm{http}: / /$ www.historychina.net/qsbk/jx/394243.shtml
} 
пробивать распространенные в Китае и сопредельных странах конца XVI - первой половины XVII в. набивные (маньчж. олбо) и пластинчато-нашивные панцири (маньчж. укшин).

Чжаньизянь с уплощенным ромбическим черешковым наконечником весом около 1 лян (37,3 г) (рис. 6: 2) применялся в качестве общераспространенной стрелы - если стрелы мэйчжэньизянь выдавались в первую очередь столичным войскам Восьми Знамен, то эти стрелы, носившие маньчжурское название сирдан, использовались повсеместно как знаменными войсками, так и китайскими воинами из войск Зеленого Знамени.

По данным У. Теобальда, в ходе покорения горной области Цзиньчуань (1771-1776) войска использовали около 20 тыс. стрел мэйчжэньизянь, отправленных в Цзиньчуань с выступившими в поход войсками из столицы, и около 480 тыс. стрел сирдан. Первые упоминания о стрелах сирдан в цинских источниках относятся к 1704 г., когда название стрелы сирдан, продублированное ее китайским переводом чжаньизянь, появляется в «Полном большом словаре».

Длина этих стрел составляла около $105 \mathrm{~cm}$, толщина древка - 0,11-0,12. Детальные измерения реальных образцов стрел сирдан из старых коллекций были проведены голландским исследователем и антикваром Петером Деккером. По его данным, линейные размеры стрел отличались весьма слабо, но мог наблюдаться разновес от 80 до 122 г., притом, что большая часть стрел весила около 100 г. Полученные им результаты он привел в виде схем с подробным указанием размеров стрелы в разных точках наконечника и древка (рис. 7) [https://www.mandarinmansion. com/article/measurements-qing-war-arrow]

В ходе раскопок Албазинской археологической экспедиции, работавшей на памятнике с 2011 по 2016 г., найдено 23 наконечника стрел. Их фотографии представлены в таблице в порядке их обнаружения по годам ведения археологических работ (рис. 8-14). В 2012 г. было обнаружено девять наконечников (№ 1-9), в 2013 г. - два (№ 10, 11), в 2014 г. - шесть (№ 12-17), в 2015 г. два (№ 18, 19), в 2016 г. - четыре (№ 20-23).
Все обнаруженные стрелы, за исключением № 8 и 9, относятся к типу «сливовая игла» мэйчжэньизянь. Все наконечники выполнены с достаточно высоким уровнем стандартизации и качества, что подтверждает сведения о централизованном производстве стрел в цинских мастерских.

У них вытянутое ланцетовидное перо, которое сужаясь переходит в длинную шейку, завершающуюся уступом, после чего идет длинный тонкий насад. Длина пера - около 4 см, длина пера с шейкой, т.е. длина наконечника, идущего после древка стрелы, колеблется от 9,5 до 10 см. Длина насада разная, так как не у всех наконечником он сохранился полностью - от 4 до 7 см. Длина наконечника с максимально сохранившимся насадом составляла до 17 см. Ширина пера $-1,3$ см, у некоторых чуть меньше, но это могло быть связано с худшей сохранностью металла.

Данные обмеры соответствуют размерам по ширине и длине, указанным в «Хуанчао лици туши», если учесть, что имеется в виду длина наконечника без насада, который уходит внутрь тела древка.

«Почтительно докладываю, что по уложениям правящей династии стрела «сливовая игла» [имеет] древко из березы длиной 2 чи 8 иунь (89,6 см), железный наконечник длиной 3 иунь 2 фэнь (10,24 см), шириной 4 фэнь $(1,28 \mathrm{~cm}) »^{11}$.

В современной китайской энциклопедии указана несколько отличающаяся длина: «Стрелы для чиновников и солдат имели древки из березы или ивы длиной 3 чи (96 см) со стальными наконечниками длиной 3 иунь $\left(9,6\right.$ см)» ${ }^{12}$.

Так или иначе, диапазон приведенных в источниках длин наконечников стрел соответствует

\footnotetext{
${ }^{11} \mathrm{http}: / / w w w \cdot h i s t o r y c h i n a . n e t / q s b k / j x / 394243 . s h t m l$

${ }^{12} \mathrm{http}: / /$ www.historychina.net/qsbk/jx/394243.shtml
} 
Lengths and thicknesses of a Qing war arrow

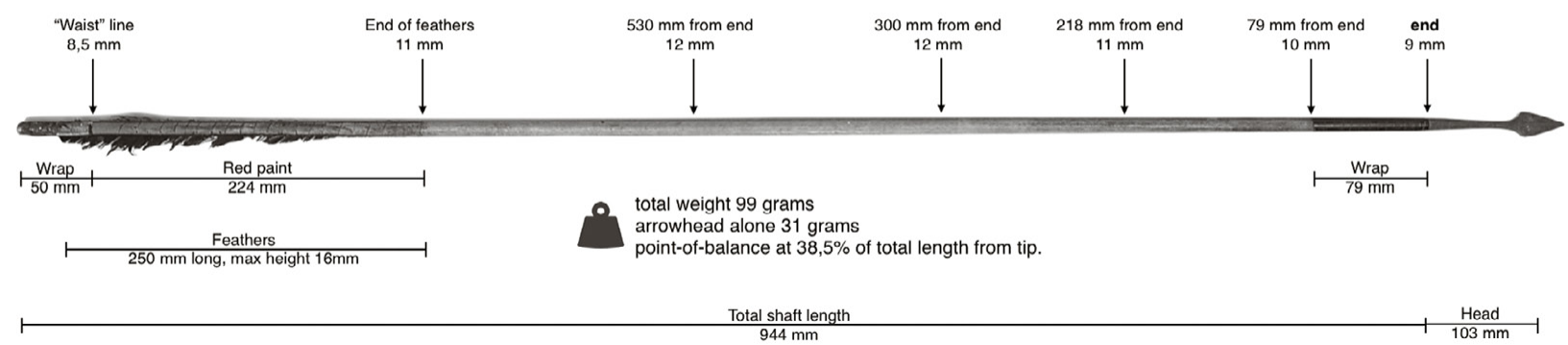

Рис. 7. Маньчжурская стрела «сирдан» (по https://www.mandarinmansion.com/article/measurements-qingwar-arrow)

размерам наконечников, обнаруженных в культурном слое Албазинского острога.

Наконечники № 8 и 9 (рис. 9) отличаются от остальных. Образец № 8 - не типичный. Имея ромбовидное перо, по форме этот наконечник похож на чжаньизянь или сирдан (рис. 6: 2), но отличается по пропорциям - у него более вытянутые перо и шейка. Длина наконечника без насада - около 12 см, ширина - 1,6. Схожие разновидности сирдана использовались в цинской армии, но реже, в том числе и из-за сложности в ковке. Обычно они изготавливались для высокопоставленных офицеров и для парадных случаев.

Наконечник № 9 отличается и от мэйчжэньизянь, и от сирдана. У него подтреугольное короткое перо с отогнутыми назад шипами, его длина до основания - около 3 см, длинная узкая шейка $-5,4$, насад длиной около 5 . Таким образом, его общая длина - около 13,4 cм, длина наконечника без насада - 8,4. Ширина пера -2 см.

$\mathrm{C}$ определенной натяжкой его можно отнести к типу сирдан, у которого ромбовидное перо трансформировалось в треугольное с отогнутыми назад шипами. Надо отметить, что наконечник был обнаружен не в слое острога, а в его окрестностях - на территории с. Албазино. Его нашел на своем огороде один из жителей и передал сотрудникам экспедиции. Возможно, он не относится к боевым маньчжурским стрелам, а использовался для охоты.

Два наконечника стрелы, найденные в 2016 г., обернуты берестой (рис. 14: 22, 23). При реставрации береста была снята, но на фотографиях, сделанных до реставрации, хорошо видны остатки бересты, которыми были
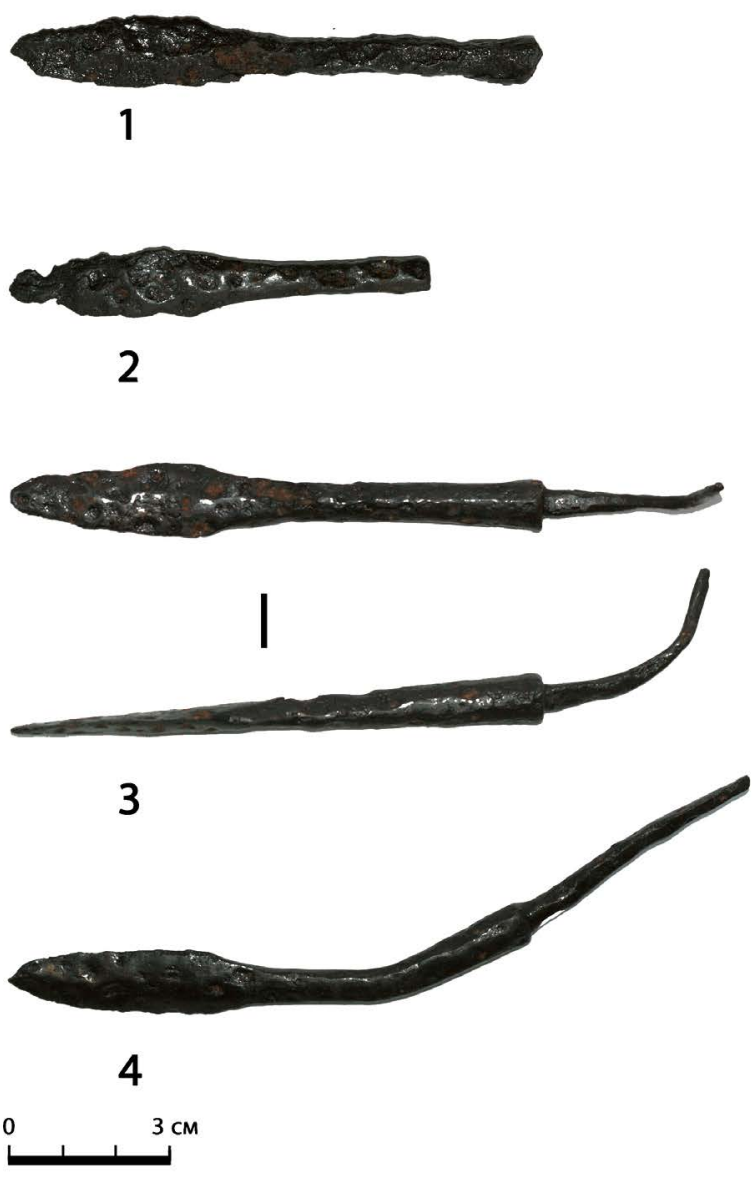

Рис. 8. Албазинский острог. Стрелы. Находки 2012 г. (№ 1-4)

обмотаны стрелы. Из цитированных выше китайских энциклопедий известно, что при изготовлении стрел использовалась береста для их обмотки: «Стрелы для чиновников и солдат имели древки из березы или ивы... передняя часть древка была отделана берестой» ${ }^{13}$.

${ }^{13}$ http://www.historychina.net/qsbk/jx/394243.shtml 
Однако на наконечнике хорошо видно, что береста покрывала не только древко, но и шейку, и перо наконечника (рис. 14: 22), что нефункционально. Возможно, берестой к наконечнику стрелы что-либо крепилось, например зажигательные смеси для поджигания строений, или же сама береста пропитывалась такими смесями. Незакрытым оставалось только острие стрелы, чтобы обеспечить вонзание стрелы в мишень. Известно о применении подобных огненных стрел в цинской армии, при этом зажигательные смеси помещались в какие-либо емкости, которые крепились к стреле (рис. 15, 16).

Об использовании подобных стрел монгольскими войсками доносил Федор Головин в 1688 г., который был отправлен для заключения мирного договора с Цинской империей и на тот момент находился в Селенгинске: «Февраля в 29 день в ночи часу в 9-м [1 час ночи] ударили на Селенгинской с трех сторон мунгальские воинские люди, и пущали в город стрель зажигальные с медными трупками, и бросали с огнем пуки тростяные. И был бой до света. И милостию божиею и счастием великих государей от города их отбили и зажечь города и слобод не дали» ${ }^{14}$.

Из русских источников известно, что деревянные сооружения Албазинского острога были подожжены, помимо прочего, подобными огненными стрелами. Об этом рассказал пашенный крестьянин Василий Никифоров при его допросе в Якутском остроге: «И бой у них был один день с утра до вечера. И пушечные ядра сквозь острог проходили, и церковь Божию, и государевы житничные хлебные анбары сквозь пушками пробивали, и пущали на острог и на церковь, и на дворы огненые стрельь. А те стрель длиною по полутора и по два и полтретья [2,5] аршина. И стреляют теми стрелами ис станку. И теми огнеными стрелами острог и церковь Божию, и дворы тутошных жилетцких людей зажгли (выделено нами. А. Ч., Р.В., А.П.)》 ${ }^{15}$.

Действительно, огненные стрелы могли запускаться не только с помощью луков. Могли использоваться специальные станки для запуска подобных стрел-ракет (рис. 17).

Часть стрел из коллекции Албазинской экспедиции деформирована - насад согнут под

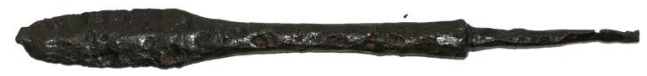

5

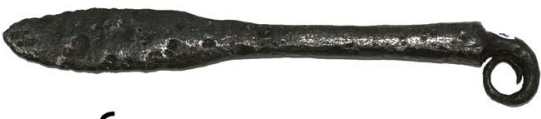

6

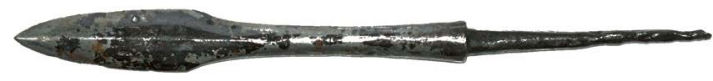

7

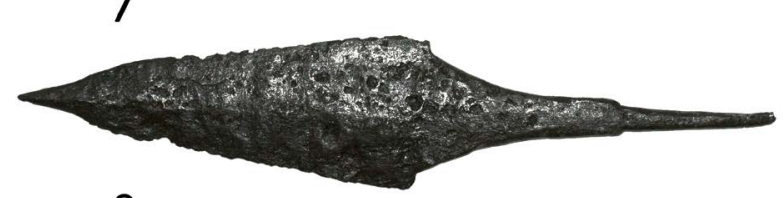

8

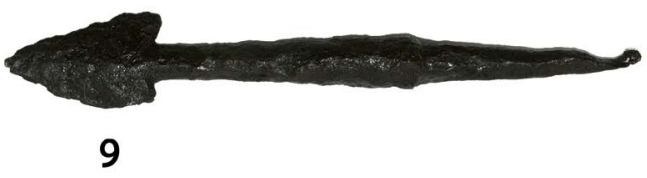

0

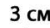

Рис. 9. Албазинский острог. Стрелы. Находки 2012 г. (№ 5-9)

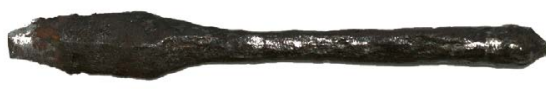

10

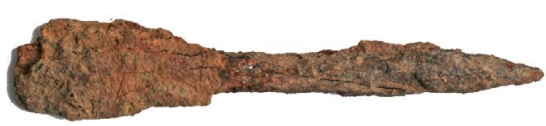

до реставрации

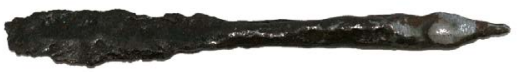

после реставрации

11

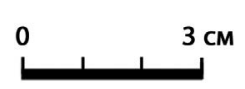

Рис. 10. Албазинский острог. Стрелы. Находки 2013 г. (№ 10, 11)

\footnotetext{
${ }^{14}$ РГАДА (Российский государственный архив древних актов). Ф. Сношения России с Китаем, 1685. Д. № 2, ч. 2. Л. 462/469об.

${ }^{15}$ Красноштанов, с. 251, 252.
} 


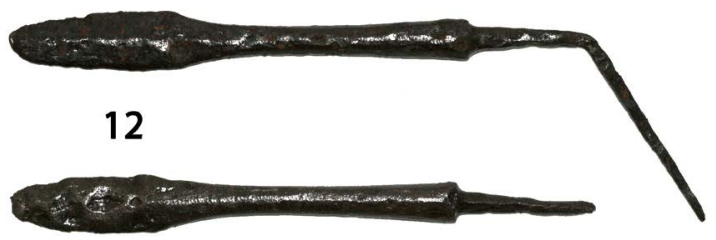

13

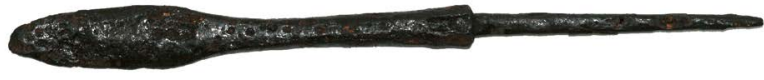

14

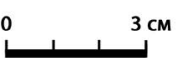

Рис. 11. Албазинский острог. Стрелы.

Находки 2014 г. (№ 12-14)

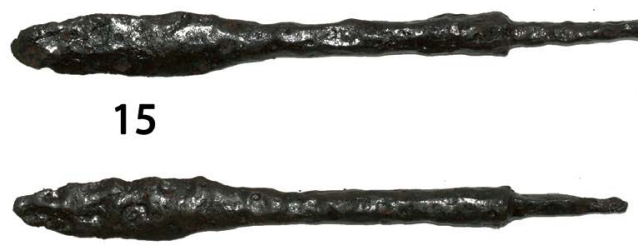

16

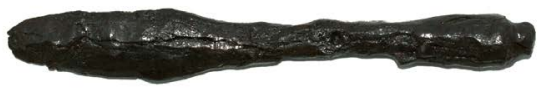

17

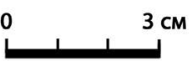

Рис. 12. Албазинский острог. Стрелы. Находки 2014 г. (№ 15-17)

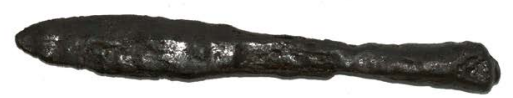

18

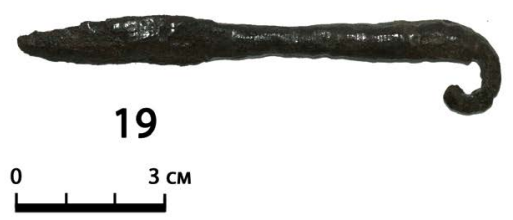

Рис. 13. Албазинский острог. Стрелы. Находки 2015 г. (№ 18, 19)

тупым углом (рис. $8: 3,4 ; 11: 12$ ). Возможно, это последствием сильного удара стрелы о твердую поверхность, которую она не смогла пробить. В результате кинетическая энергия деформировала железный наконечник.

У нескольких стрел тонкий черешок-насад согнут не просто под углом, а в один-полтора оборота (рис. 9: 6; 13: 19; 14: 21). Такая деформация невозможна от удара, она возникает только

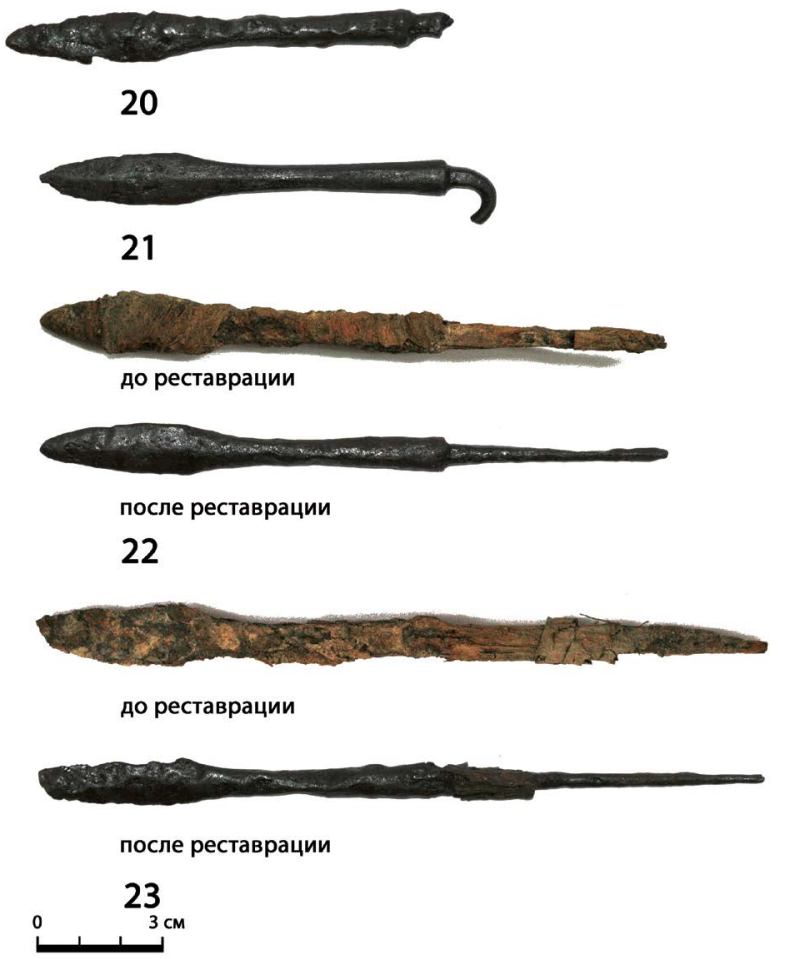

Рис.14. Албазинский острог. Стрелы. Находки 2016 г. (№ 20-23)

в случае, если выполнена специально. Можно предположить, что такие стрелы были повторно использованы в каком-либо качестве, отличном от их основного назначения, например как петли для крепления чего-либо.

Другой пример повторного использования наконечник стрелы № 11 (рис. 10: 11), найденный в заполнении хозяйственной ямы. У него был обломан насад, оставшаяся часть шейки заточена и переделана под острие, очевидно, для использования в качестве шила. При его обнаружении в ходе раскопок находка была принята за нож, только после реставрации и очистки от окислов стало ясно, что это фрагмент наконечника стрелы.

Весь трагизм событий «Албазинского сидения» отразился в находке стрел № 18 и 19. Они были обнаружены в 2015 г. при расчистке одного из погребений в деревянном гробу. Для крепежа деталей гроба использовались железные наконечники стрел мэйчжэньизянь, которые выполняли функцию гвоздей (рис. 13: $18,19)$. У наконечника стрелы № 19 насад был загнут почти в целый оборот, очевидно, его деформация произошла при заколачивании в доску. Вероятно, по схожей причине были согнуты насады у других подобных найденных наконечников. 


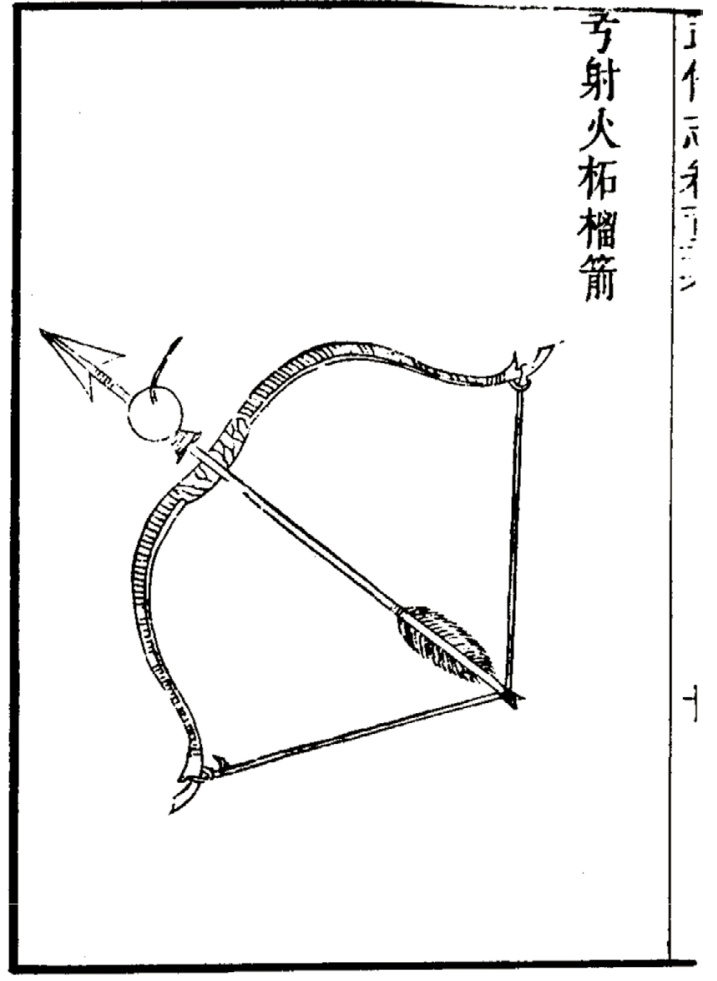

При нанесении мест находок наконечников стрел на план (рис. 18, 19) выяснилось, что они не располагаются равномерно по всей площади раскопа, а сконцентрированы на отдельных участках, которые совпадают с местами расположения сооружений - в полуземлянках, использованных под скудельни, в хозяйственных ямах. Лишь несколько наконечников стрел располагалось вне сооружений, в культурном слое раскопов.
Рис. 15. Лук и зажигательная стрела «гуншэ хо чжэлю цзянь» (гранат) с прикрепленной емкостью с горючей смесью. По трактату Мао Юаньи «Убэй чжи» (1629 г.)

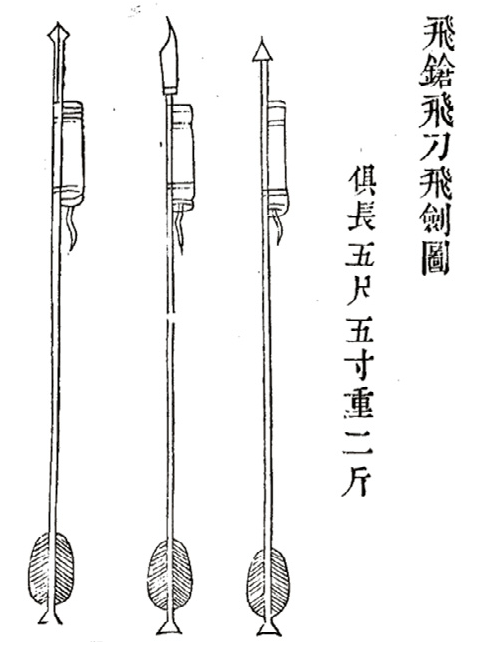

Рис. 16. Стрелы «фэйцян», «фэйдао» и «Фэйцзян » (слева направо) с прикрепленными цилиндрическими емкостями с горючей смесью. Длина - 3 чи 5 цунь (ок. 160 см.), вес 2 цзинь (1200 г.) По трактату Мао Юаньи «Убэй чжи» (1629 г.)

Очевидно это объясняется тем, что выступающие стены и крыши сооружений становились вольными или невольными мишенями, в них попадали летящие стрелы и падали рядом или внутрь. Другой причиной было то, что в условиях блокады стрелы тщательно собирались осажденными, их железные наконечники использовались защитниками острога как гвозди, проколки и другие приспособления и поэтому оказывались либо в хозяйственных ямах, либо в жилых сооружениях.

Проведенное исследование такой

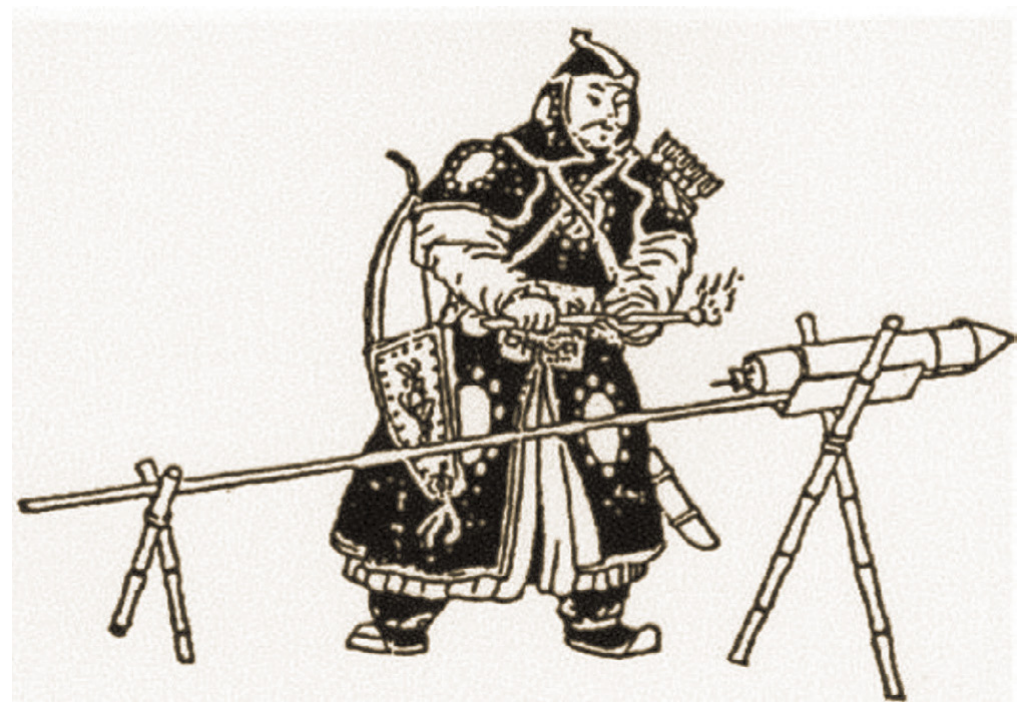

Рис. 17. Современная реконструкция маньчжурского воина, запускающего огненную стрелу со станка категории находок, как наконечники стрел из культурного слоя Албазинского острога дает представление о характере вооружения осаждавших крепость маньчжурских войск, а также углубляет картину осадного быта защитников русской твердыни. Продолжение изучения данного материала, наряду с анализом имеющихся находок стрелково-пушечных боеприпасов, полученных Албазинской археологической экспедицией с территории острога, позволит существенно уточнить картину развернувшейся в конце XVII в. вокруг Албазина военной операции маньчжурских войск и оборонительных действий русского населения Приамурья. 


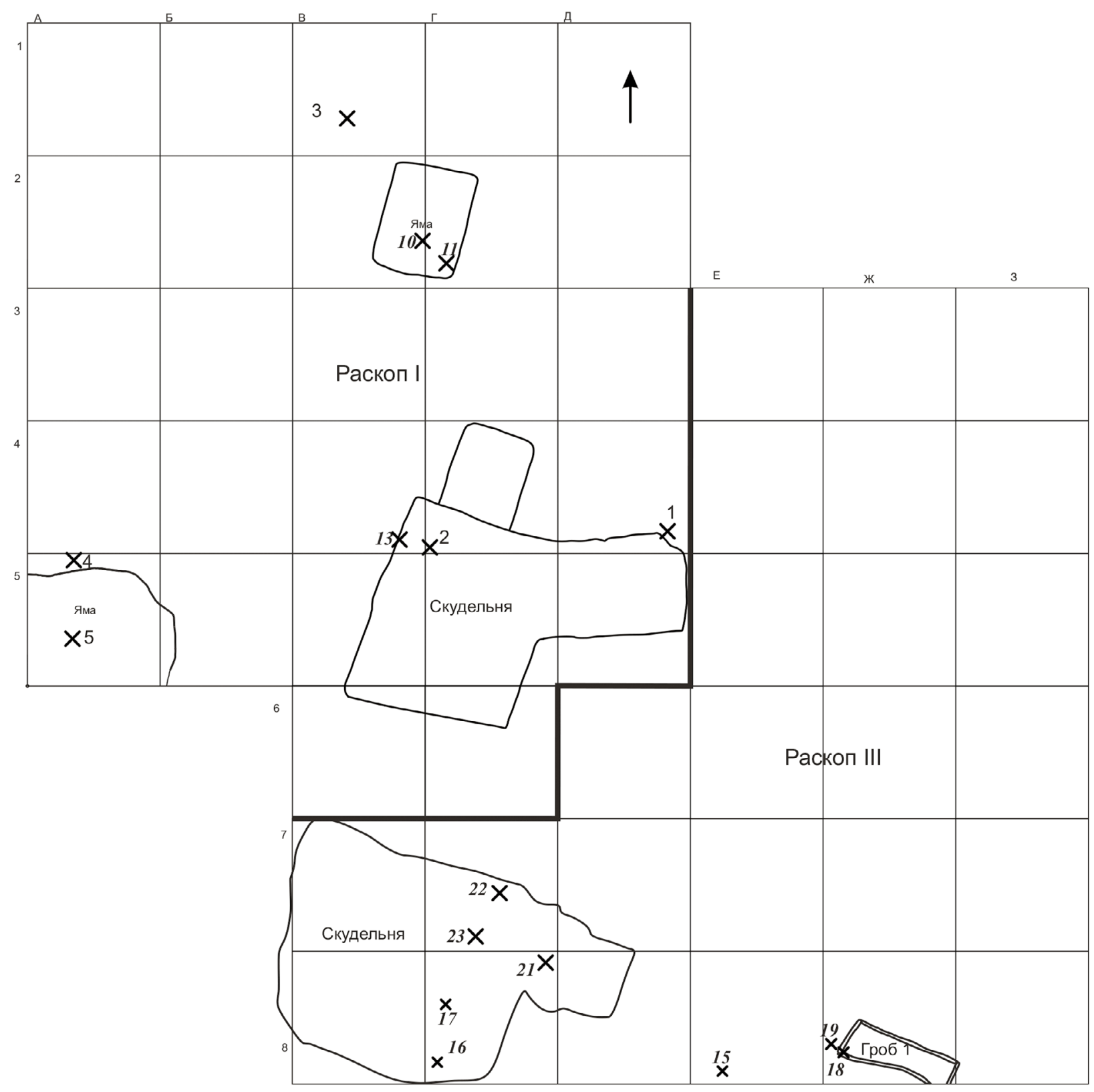

Рис. 18. Местонахождение наконечников стрел на раскопах I, III

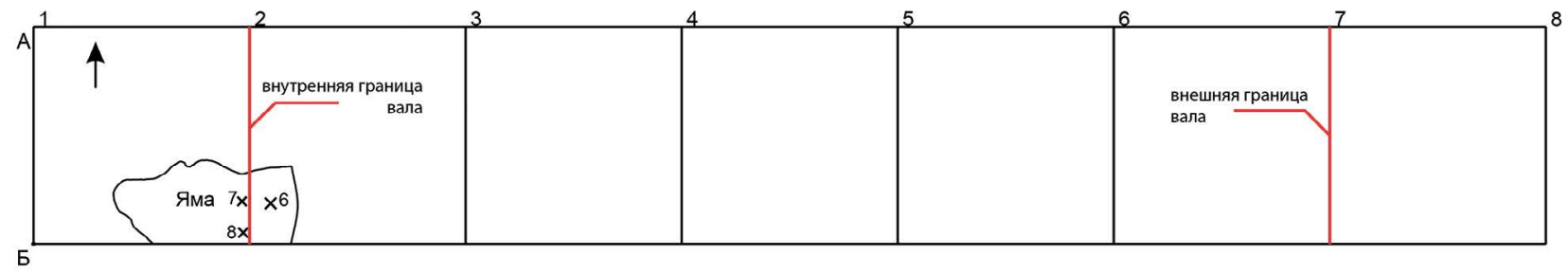

Рис. 19. Местонахождение наконечников стрел на раскопе II 


\section{Литература}

http://www.historychina.net/qsbk/jx/394243.shtml

Чжунго гудай циу дацыдянь; Бинци. Синцзюй. Шицзячжуан, Хэбэй цзяоюй чубаньшэ, 2004.

Хуанчао лици туши. Янчжоу, Гуанлин шушэ, 2004.

Албазинский острог. История, археология, антропология народов Приамурья. Новосибирск, 2019.

Артьемьев А. Р. Города и остроги Забайкалья и Приамурья во второй половине XVII-XVIII вв. Владивосток, 1999.

Красноштанов Г.Б. Никифор Романов Черниговский: документальное повествование. Иркутск, 2008. 


\section{вОПрОсы \\ СРЕДНЕВЕКОВОЙ ГЕОГРАФИИ НИЖНЕГО ПОВОЛЖЬЯ}

\section{Д. Ф. Мадуров}

В Сирийской археологической экспедиции мы часто шутили на исторические темы. Когда дагестанцы начинали утверждать, что они алародии, я тут же объявлял себя сапиром. Диму Рукавишникова мы величали «Дима-башкир», и он сам всячески подчеркивал свое происхождение, повесив над своей кроватью бунчук с хвостом из собственных волос. «Ты башкир, я сувар, в таком случае мы булгары, чьи прадеды отражали экспансию монголов. Не из рода ли усергенов твои предки?..» Дмитрий не был чужд поискам исторических корней своего народа и открыто интересовался домонгольским периодом.

После очередной шутки по поводу заметок Ибн Фадлана я прозрел, что речь в них идет о полу-

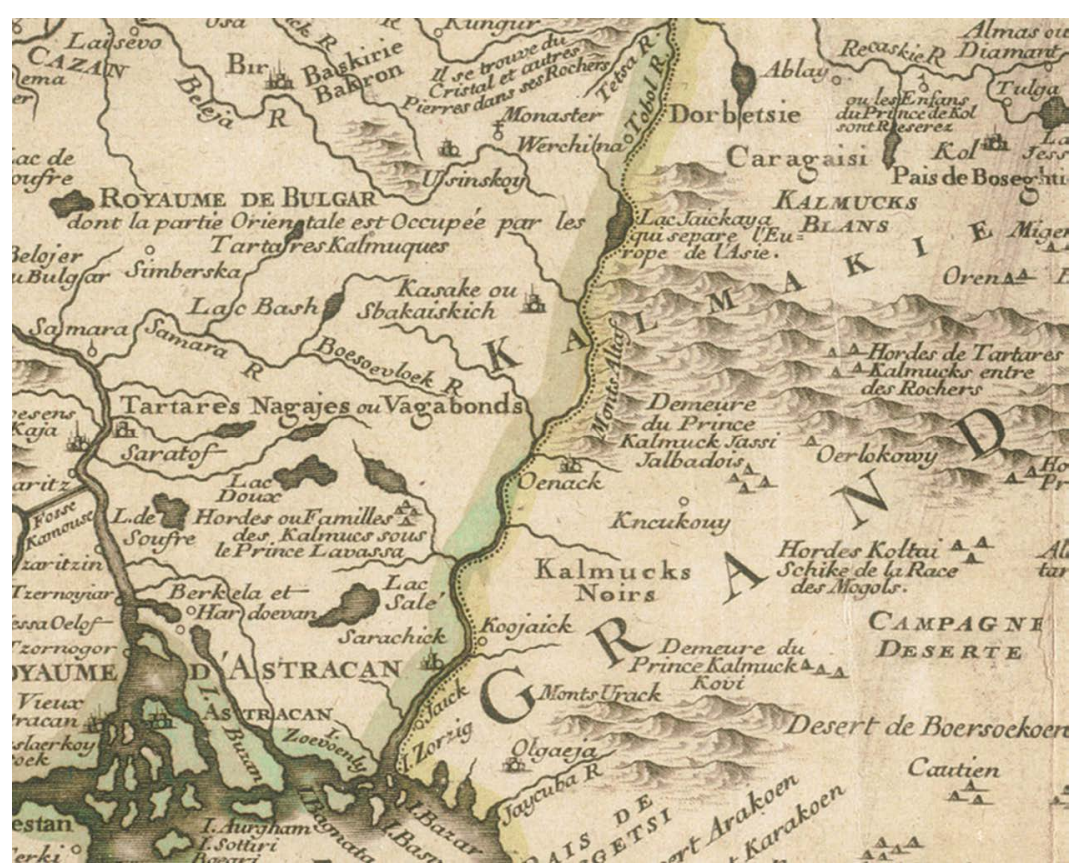

Рис. 1. Фрагмент карты Николаса Корнелисзона Витсена (Nicolaes Cornelisz. Witsen) (1641-1717) «Nieuwe Landkaarte, Nicolaes Witsen» (Wladimiroff, 2008) чившем распространение в IX в. из Индии вишнаитском религиозном движении вирашиваизма (лингаята) (Мадуров, 2012). Дмитрий гордился всеми своими предками, и за это мы его уважали. Уважали, конечно, не только за это. Заслуги его в работе месопотамской экспедиции трудно переоценить. В те времена не было коптеров, а экспедиции как воздух необходимы были снимки общего вида Телль Хазны I с воздуха. И Дмитрий сумел организовать это: собрал дистанционный пульт для фотокамеры, сконструировал подвеску для фотоаппарата, привез мини-дирижабль, наполнил его гелием. Его «Винни Пух» оказал неоценимую помощь нашей экспедиции. А чего стоила его работа по построению 3D-модели раскопанной части телля!

Список хазарских городов в труде АлМукаддаси (около 946/947 - около 1000) выглядит так: «Города при Итиле: Булгар, Семендер, Сувар, Беганд, Кайшва, Байдау, Хамлидж и Беленджер» (Караулов, 1908. С. 3; см. Хвольсон,
1869. С. 45). Часть упомянутых здесь городов пережила события 969-982 гг. и продолжила существование в новых государственных образованиях IX-XIII вв. Рассмотрим же города Нижней Волги из этого списка.

Семендер сегодня вполне уверенно локализуется на месте пригорода Махачкалы - Таркинского городища. В свою очередь, Тарки (Терки) вполне корректно обозначен в «Landkaarte» 1722 г. Николоса Витсена (рис. 1) (Мадуров, 2018. C. 115).

Беганд. Городом Беганд Ал-Мукаддаси можно сопоставить с городом Бджкенд географа ал-Хамадани (Агаджанов, 1969. С. 162). Об этом городе почти нет никаких сведений. Единственное, что может помочь в его локализации это карта: «Nieuwe Landkaarte, Nicolaes Witsen», на которой обозначен восточней Астрахани через рукав Волги о. Бузан, а южней его о. Багната (рис. 2) (Мадуров, 2018. С. 115). 


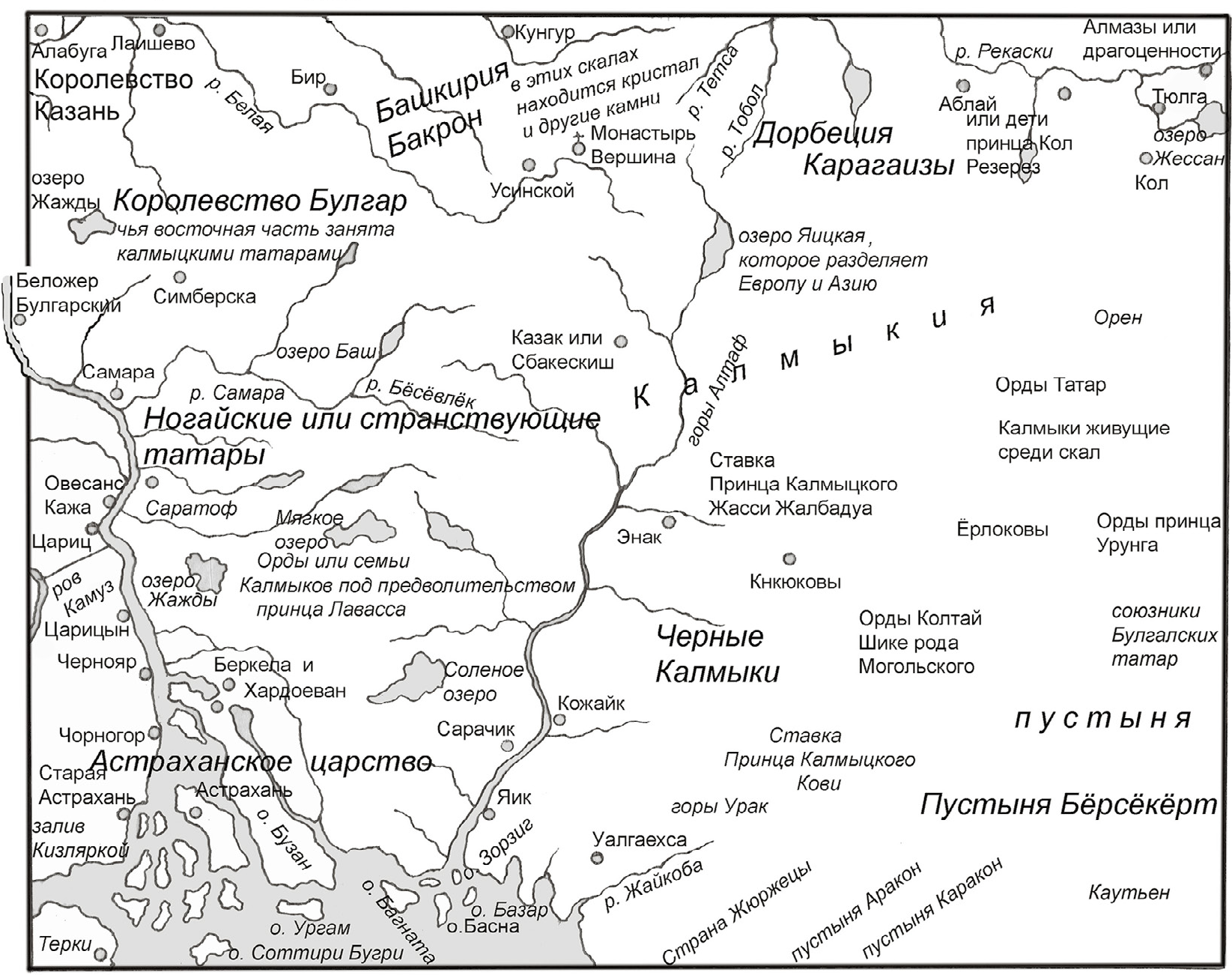

Les Etats du Czar ou Empereur des Russes en Europe et enAsie, Nicholas De Fer/Benard (1722) op basis van gegevens Witsen.

Рис. 2. Владения Царя и Императора России (русских) в Европе и в Азии, Николас де Фен Бенар (1722) по сведениям Витсена (перевод со старофранцузского Александра Блинова)

Итиль. Город делится на две части, западная, где проживал хакан и которая находится как бы на острове, называется Хазаран (Хозран) (Йакут ал-Хамави, 2006. С. 811; см. Калинина, 1976. С. 16). Итиль, как мы предполагаем, из-за трансгрессии оказался на дне Каспия. Последнее упоминание о нем связано с нашествием монголов (Рашид ад-Дин, 2002. С. 37, 38).

Кайшва. Это также малоизвестный город каганата. Единственная зацепка в его локализации это «Landkaarte» 1722 г. Николоса Витсена (Мадуров, 2018. С. 115). Между городами Саратов и Царицын (Волгоград) чуть выше волока к р. Дон (ров Камуз) обозначено Ovesens Каја «Овесанс Кажа» (рис. 1). Указать более точно местонахождение «Кажа» можно лишь условно выделив в этом районе городище до монгольского периода, так как на самой карте в этом месте небольшая путаница между обозначениями городов.
Беленджер (от боланд джор (фарси) «длинная расселина») сопоставляют с Верхнечирюртовским (Плетнева, 1999. С. 180-185) либо Шелковским городищем (Дагестанские... 1993). Средневековыми авторами на территории Дагестана упоминались два исторических Беленджера, один из них Чога Беленджер располагался на юге республики. Ибн Халдун (1332 г.) сообщает: «...и на востоке страна Бертасов (Bertas) и на северо-востоке - страна Булгар (Bulgares), и на юго-востоке - земля Беленджеров (Belendjer), которая окружена здесь горной частью Сиахкух» (Hammer-Purgstall, 1827. Р. 19). Речь идет о Беленджере, находящемся на севере Дагестана. Но в таком случае как быть с упоминанием Беленджера в числе волжских городов у АлМукаддаси (Караулов, 1908. С. 3)?

Ибн Фадлан упоминает переселенцев из области Баранджар (Беленджер) в количестве «пяти тысяч душ женщин и мужчин, уже всех 
принявших ислам», обосновавшихся в пределах Булгарии (см. Ковалевский, 1956. С. 135-141). Город «Беложер Булгарский» на карте Николаса Корнелисзона Витсена обозначен на левобережье Средней Волги примерно в районе Старой Майны (рис. 2) (Мадуров, 2018. С. 115).

Хамлиджс - «главный город хазар», по свидетельству Ибн Хордадбеха. Ибн Руста, повидимому, дает второе название населенного пункта: «главным городом у них (хазар) Сарашень, рядом с которым лежит другой город, по имени Хаб-Нела» (Хабнела, Габ-Нела) (Хвольсон, 1869; см. Караулов, 1903. С. 45). Хамлех [Хамлих] - «главный город хазар» - Ибн Хордадбехом отмечен выше Итиля по Волге (Хамлед, «Хамледж») (Караулов, 1903. С. 17). Хӑмӑл на чувашском «стебель», часть жнивья без колоса и корневища. Возможно, это один и тот же тип топонима, распространенный по Волге: Хамлех (Хамлах) и летописный топоним Хомол (ПСРЛ, 2007. С. 41).

Бейда. Судя по расположению на карте альИдриси, Самосдельское городище можно сопоставить с городом Бейда. Находки вторично использованного обожженного кирпича в постройках этого городища свидетельствуют о наличии здесь когда-то дворца хакана (Васильев, 2012a. С. 14). Такой дворец мог находиться только в столичном городе хазар, а таких было несколько: Хазаран-Итиль, Семендер, Бейда.

Бейда на карте аль-Идриси указана западней Итиля (Мадуров, 2018. Цв. вкл.). Трудно предположить, что Бейда находилась в степной, безводной зоне. Скорей всего, локализация этого города как-то связана с одним из рукавов Волги. На карте Московии Гесселя Герритса (1613/1614 г.), напечатанной В. Я. Блау в 1635 г., один из средних рукавов устья Волги назван Belda (Волков, 2010. С. 41. Рис. 5).

Сарашень (Сар'а-ш-н) И. Марквартом читается как Сарыгшар (тюрк. «желтый город»), можно перевести, как «белый». В свое время предполагалось: «Байде на реке Танабис (Дон). Это известная в русской истории Белая Вежа» (Караулов, 1908. С. 20).

По мнению филологов, чувашские сарӑ «желтый, красивый» и шурӑ «белый» в древности составляли одно слово (Дыбо, 2015). В таком случае Сарашень в переводе на арабский язык будет означать «бейда» (белый) (ةضبي).

Арабские географы очень подробно наносили на карты хорошо знакомые им южные города хазар. Но чем северней, тем менее достоверными становились сведения. На карте мира
аль-Идриси город Хамлидж указан значительно севернее Итиля и Бейды. Ибн Хордадбех помещает его в самое устье Волги: «От Джурджана до Хамлиджа, расположенного в конце [устья] реки, которая течет из страны славян (ас-Сакалиба) и впадает в море Джурджан, по морю при попутном ветре 8 дней [пути]» (Ибн Хордадбех, 1996. С. 109). В таком понимании, Итиль - это не единый город, а мегалополис, образование, состоящее из нескольких разрозненных городов в дельте Волги.

Хазаран. Столица хазар была перенесена в Итиль в первой половине VIII в. Одна из частей города Итиль (Атиль), по сведениям Ибн Хаукала (Х в.), называется Хазаран. Согласно «Дербенд-наме», в 854/855 г. именно западную часть Итиля Хазран (Хозран) захватил Абу Муса Буга Тюрк Старший: «Затем он (Махаммад) ходил на хазар (Хозран), победил их и наложил на них подушную подать» (Минорский, 1963. С. 46; см. Мадуров, 2018. С. 15). Ту самую, западную часть столицы, в которой, по сведению Йакута, живет хакан в своем кирпичном дворце (Йакут ал-Хамави, 2006. С. 811; см. Калинина, 1976. С. 16). Закат Хазарана и разрушение кирпичного дворца могли состояться в 968/69 г.: «...русы (в этом году) разрушили: Булгар и Хазаран» (Древняя Русь..., 2009. С. 92).

Сияx. Д.А. Хвольсон приводит текст Ибн Саида, в котором до конца не читается название города: «Саксин - знаменитый город, который лежит под 67 и 53 широты. На востоке от него находится город Суах (или Муах), который также известен и зависим от первого» (Хвольсон, 1869; см. Заходер, 1962. С. 66). Существовали предположения, что речь здесь может идти о городе Сувар. Непрочтенное название Cyax (Myax) на этой широте может относиться к поселению, примыкающему к мифическим «горам Сиях», обрамляющим Каспий с севера на карте ал-Идриси.

Суммеркент. Раскопки на городище $\mathrm{Ca}-$ мосделки укрепляли исследователей в мысли о тождественности его с Саксином, но это лишь видимое сходство. Ибн ал-Факих ал-Хамадани так описывает масштаб этого города: «Саксин - это город (шахр), больше его нет города в Туркестане, (город) имеет в окружности 6 фарсахов; в этой (же) благоустроенной области (имеются) другие его города - Скркенд, Узкенд (и) Бджкенд. Жителей его (Саксина) беспокоят племена кыпчаков и йемеков. В этой области (вилайет) нет реки, кроме Атила. Его (Саксин) обитатели живут в шатрах; все население этого города - мусульмане, как 
я слышал от некоторых купцов» (Агаджанов, 1969. C. 162).

Гильом Рубрук, посетивший эти места в 1254 г., пишет: «Кроме того, Этилия образует четыре меньших рукава, так что мы переправлялись через эту реку на судах в 7 местах. При среднем рукаве находится город по имени Суммеркент, не имеющий стен; но, когда река разливается, город окружается водой. Раньше чем взять его, татары стояли под ним 8 лет. А жили в нем аланы и сарацины» (Джованни..., 1997. С. 180). По-видимому, название Суммеркент, где кент «город», восходит к алтайскому сумер «вершина» либо самар «священный». Возможно, это чувашское самӑр «тучный». Очевидно, что Скркенд - это Суммеркент, упомянутый Ибн ал-Факих ал-Хамадани (Агаджанов, 1969. С. 162). Д. В. Васильев полагает, что с Суммеркентом можно сопоставить малоизученное городище Мошаик на территории Астрахани (Васильев, 2012б; см. Пачкалов, 2011. С. 125). Но для этого необходимо доказать исключительную обороноспособность города.

Саксин вовсе не указан ни на одной карте, а между тем, по сведениям доминиканского монаха Рихарда и косвенным сведениям Ибн Биби, он находился на пути из Крыма на Волге. Степи Астраханской области, примыкающие к Волге и Ахтубе, представляют собой пустыню с солоноватой артезианской водой - место рискованное для ведения даже кочевого хозяйства. И значит, город мог возникнуть на одном из рукавов p. Волги. И этому есть подтверждение в тексте Джамаля аль-Карши (Кураши) (1230-1315): «Бату взошел на престол своего деда Чингиз-хана в 623/1226 году. Стольным городом его государства был Сарай - новый город, расположенный на (реке) Сифсин» (Образование..., 2008. С. 70).

По сведениям Джувейни (1223/1226-1283), на курултай по поводу восшествия на трон Гуюк-хана «из земель Саксина и Булгара Бату, который не явился лично, прислал своего старшего брата Хорду и младших братьев Сибана, Берке, Беркечера и Тока-Темура...» (Образование..., 2008. C. 59).

По сведению аль-Гарнати, расстояние между Булгаром и Саксином составляет 40 дней: «А за этими реками и горами на несколько дней пути протянулась земля, вся покрытая солью, красной, и белой, и синей, и разных других цветов. Наполняют ею суда и везут по этой реке в Булгар. А между Саджсином и Булгаром по этой реке (надо плыть) сорок дней» (Большаков, Монгайт, 1971).
Вниз по Волге от Булгара до Самосдельского городища расстояние около 1130 км. При движении по довольно быстрому в те времена течению реки Волги путники вполне могли преодолеть это расстояние за 40 дней при скорости 28-29 км в сутки.

«Саджсин, в нем сорок племен гузов, и у каждого племени - отдельный эмир... А в середине города живет эмир жителей Булгара, у них есть большая соборная мечеть, в которой совершается пятничное моление, и вокруг нее живут булгарцы. И есть еще соборная мечеть, другая, в которой молится народность, которую называют "жители Сувара", она тоже многочисленна» (Большаков, Монгайт, 1971). Махмуд Кашгари относит Саксин к области Сувар: «Сансин - город близ Булгар. Это ас-Сувар» (Махмуд ал-Кашгари, 2005. С. 409).

В списке городов Улуса Джучи Саксин стоит ниже Укека (Увек): «...Судак, Саксин, Укек, Булгар...» (Тизенгаузен, 1884. С. 236). Саксин был столичным городом довольно обширной территории, в письме брата Юлиана вместе с Булгаром они названы: «величайшими языческими царствами: Сасцией, Фулгарией» (Аннинский, 1940. С. 78). Вспомним русские летописи 6737 (1229): «Саксини . и Половци възбьгоша из низу к Болгаром перед Татары . и сторожеве Болгарьскыи прибъгоша бьєни $\overline{\mathrm{W}}$ Татарь . близь рькъ єиже имА Æикъ (Лаврентьевская..., 2017. С. $626,627$. Л. 156 об.).

Еще Г.А. Федоров-Давыдов замечал, что персидские источники золотоордынского периода не знают народа «саксины», это название области, населенной кыпчаками (Федоров-Давыдов, 1969. С. 258, 259). Совсем другую, пеструю этническую картину рисуют домонгольские путешественники.

Границы Саксина отмечаются средневековыми историографами. Ад-Димашки (ум. в 1327 г.) называет Азовское «морем Саксинским» (Большаков, Монгайт, 1971; ср.: Reinaud, Geopr. d'Aboulf., 1848 trad. C. 286. Прим. 2; см. Гаркави, 1870. С. 166). Далее в повествовании «река Русов и Сакалиба», под которой он, вероятно, разумеет Дон, вытекает из гор Саксинских. Йакут ал-Хамави указывает на пограничную роль крепости Мингышлак, находящейся на одноименном п-ове Мангышлак: «Минкишлак - неприступная крепость во владениях Хорезма, она находится между Хорезмом, Саксином и страной русов, около моря, в которое впадает Джейхун» (Садр ад-Дин, 1980. Прим. 42 к гл. 14). 
Бенедикт Поляк (Fr. Benedicto Polono, XIII в.), спутник и переводчик Иоанна де Плано Карпини в его поездке к монголам (1245-1247), в своем отчете под названием «Hystoria Tartarorum» отмечает: «...братья, которые шли через Команию, имели справа от себя землю саксинов, которых мы считаем готами...» (Алемань, 2003. С. 208). Францисканские монахи приняли саксинов, жителей страны со столицей Саксин, за саксов.

Обороноспособность городов Саксина стала легендой. Плано Карпини в главе «О землях, которые оказали им мужественное сопротивление», так описал это противостояние: «Имена земель, оказавших им мужественное сопротивление и доселе еще не подчиненных им, суть следующие: великая Индия, Мангия, некая часть Аланов, некая часть Китаев, Саксы и пытались завоевать их, но те сделали машины против их машин и сломали все машины Татар, так что те из-за машин и баллист не смогли приблизиться к городу для сражения; наконец они сделали дорогу под землею и вскочили в город; и одни пытались зажечь город, а другие сражались. Жители же города назначили одну часть населения для тушения огня, а другая часть храбро сразилась с теми, которые вошли в город, и многих из них убила, а других ранила, заставляя их вернуться к своим; а сами Татары, видя, что не могут ничего сделать и что многие из них умирают, удалились от них» (Образование..., 2008. С. 268).

Это сведение подтверждает и Матфей Парижский в «Послании доминиканского и францисканского монахов о тартарах» (1242 г..): «Рассказывали нам беженцы из земли той, главным образом в Саксонии, что землю ту с крепостями они атаковали с помощью тридцати двух осадных устройств» (Образование..., 2008. С. 306).

История о защитниках Саксина вдохновляла европейцев к сопротивлению агрессору. В своей работе «Hystoria Tartarorum», изложенной 30 июля 1247 г., Ц. де Бридиа повествует: «А если в землях, которые они захватили, остались города или укрепленные замки, где может вестись натиск стрелами и метание машинами и где запасы, продукты и питье или дрова кончаются, создавшееся положение может исправить мужество и смелость людей [находящихся в осаде]. Подобно тому, как случилось в земле древних саксонцев, которые часто малым количеством выходили из города и убивали многих из тартар, и пока женщины гасили подожженный тартарами город, мужчины защищали кольцевую стену; а когда тартары проникли в центр города по подземному ходу, то [осажденные] перебили [многих], а остальных обратили в бегство. Люди совершенно не могут скрываться в лесах, где летом и зимой их можно обнаружить. Они [тартары] выслеживают людей, словно диких зверей. Однако безопасно [находиться] в море и в местах вышеперечисленных» (Bridia, 1967. [60]).

Большая часть исследователей склоняется в своих мнениях к тому, чтобы отождествить Саксин и Суммеркент. Но есть описание сопротивления города Суммеркента и населения саксинов, но нет описания сопротивления города Саксина.

Город Саксин, скорее всего, нам не найти. Географ Ибн Аяс, передающий в сокращенном виде известия Казвини об этом городе, прибавляет следующее: «Ныне наводнила вода (протекающей мимо реки) эту страну так, что и следов строений не осталось. Прежде же Саксин быль столицей царя этой земли» (Рукопись СанктПетербургского университета, № 109. Л. 83). Ныне эта рукопись находится в архиве Института восточных рукописей РАН г. Санкт-Петербург.

Бурmac. Буртасы в источниках выступают как самостоятельная этническо-территориальная единица, то воюющая с хазарами, то входящая в булгарскую державу, согласно сведению Мухаммеда Насир ад-Дин Туси (1201/2-1273/4), «Одна из них [находится] на окраине вилайата Гуз, рядом с Булгаром. Их около 2000 мужей [живущих] в лесах, а подчиняются они булгарам» (Nasir-eddin Tusi, 1868. S. 294).

Йакут под 1218 г. свидетельствует: «От Идиля столицы хазаров - до города Буртаса считается 20 дней пути (езды)» (Селиванов, 1890). В своих комментариях к карте мира ал-Идриси, писал: «От (земли) Буртас до (земли) Баджнак десять дней, а от (города) Исил до (земли) Баджнак один месяц пути. От [города] Исил до [города] Булгар по дороге степью около месяца, а по воде - два месяца, это вверх по воде, а вниз по реке - около двадцати дней пути» (Коновалова, 2006. С. 111).

Попробуем посчитать. Город Итиль на карте ал-Идриси находился южней Бейды. От известного нам места, Самосдельского городища, отмерим переходы в 30 км $\times 20$ дней, получаем район нынешнего города Камышина. Именно в этой широте на левобережье и стоит искать город Буртас. Логично было бы предположить, что появление этого города в левобережной части могло быть не случайным, а связанным с какой-то рекой, впадающей в Волгу. Это умозаключение заставляет нас обратить свой взор на р. Большой Иргиз, ведь по сообщению Шамс 
ад-Дин ад-Димашки, «Буртасы селятся по реке Буртас, которая впадает в Волгу» (Марджани, 2005. С. 62, 63). В бассейне р. Большой Иргиз или Елатьма, а может и еще какого-то соседнего левобережного притока р. Волги продуктивны поиски города Буртас, столицы княжества Ведин (Мадуров, 2018. С. 62-73).

Отметим, что земля буртас на карте Абуль Туси простирается и в правобережной зоне Волги (Мадуров, 2018. Цв. вкл.). Ибн Руста сообщает: «Страна их как в ширину, так и в длину простирается на 17 дней пути»; «Земля Буртасов лежит между Хозарскою и Болгарскою землями, на расстоянии пятнадцатидневного пути от первой» (Хвольсон, 1869. С. 19-21). Разница в 5 дней между местоположением города и началом его земель приводит к выводу о местоположении земли буртас южней их столичного города на полторы сотни километров. Значит, их южные земли начинались от северных пригородных территорий нынешнего Волгограда. Логично было бы представить, что границей земель могла быть поворотная часть р. Волги.

«От земли Буртасов до земли этих болгар три дня пути», - повествует Ибн Руста (см. Хвольсон, 1869. С. 19-21). Как определить южные рубежи земли серебряных булгар? В этом нам может оказать помощь археологическая карта. Согласно ей, наиболее южные городища булгар находятся в районе Самарской Луки. Три перехода - это около 90 км.

Поиски самых северных пределов буртасов южных границ булгарских городов Среднего Поволжья заставляют нас внимательней отнестись к городищам Самарской области. Но эти поиски пока нельзя признать успешными

Городок Стеньки Разина, Змеиный; (ранний железный век - городецкая культура, средневековье - XIII-XIV вв.) в Саратовской области больше всего подходит под описание упомянутого Антонием Дженкинсом в 1558 г. городища крымчаков: «22 июня мы миновали большую реку Самару, текущую чрез Ногайскую землю в Волгу. 28 июня мы проехали высокий холм, на котором некогда крымцы построили крепость, теперь уже разрушающуюся. Этот холм находится на половине пути от Казани до Астрахани (весь путь 200 лье), под 51²7' шир. Здесь на берегу растет молодковый корень, вьющийся по земле как виноград...» (Середонин, 1885. C. 38,39$)$.

Крепость возникла здесь не случайно, фактически это пограничье между степной и лесной частями Поволжья. В таком случае междуречье рек Урал (Яик) и Большой Иргиз образует естественный рубеж. Отметим, что именно в этом направлении вдоль реки с востока бежали саксины во время монгольского вторжения 1229 г. (Лаврентьевская..., 2017. С. 626,627 . Л. 156 об.).

Таким образом, сведения о местоположении многих до монгольских городов еще сохраняются в картах начала XVIII в., а отдельные города представлены в средневековой географии под двумя названиями, местным и арабским.

\section{Эпилог}

В качестве эпилога хотелось бы еще раз вспомнить Дмитрия Рукавишникова, и воспоминания эти наполнены незабвенным теплом. Экспедиция - место, где все твои положительные и отрицательные стороны не скроешь. От восторженной бравады первых дней и до разбитых от усталости и проявившихся недомоганий заключительных дней экспедиции, Дмитрий был источником положительных эмоций. Он делал все, что было в его силах для достижения общего успеха, и было приятно наблюдать его жизнелюбие.

Повседневная работа приносила удовольствие, утомляло же монотонное однообразие. Мы прекрасно понимали в каком фантастическом месте планеты мы находимся, нам хотелось увидеть большего. И здесь, каюсь, проявился мой авантюризм. У местных наемных работников - молодых арабов-сеидов и курдов особо ценились китайские ножички-выкидники, ими то я и подкупил одного парня, Ясина, и как только начальник экспедиции отправился на послеполуденную сиесту, к дому неподалеку подъезжал мотоциклист, с которым мы отправлялись в путешествие по соседним достопримечательностям - теллям. Так я посетил знаменитый Телль Асвад, известный еще по раскопкам Макса Маллована. Было время пофотографировать сырцовую архитектуру местных жителей, их быт, благо здесь почти везде жили наши рабочие, с большой радостью и, в то же время, с грустью в глазах, показывающих свои нищие жилища.

О своих вылазках и маршрутах я всегда предупреждал некоторых коллег и по прибытию назад живописно рассказывал о том, что видел, показывал фото. Такие самоволки были довольно редки, после одной из таких вылазок Дмитрий попросил взять его с собой. Тут я призадумался, нужен второй мотоцикл - «Да нет, нас один выдержит!», ножей не оставалось, Дмитрий вытащил свой. Ясин рассказал, что знает одно очень красивое 
место. «Далеко?», - «Нет, километров 30, под Хассеке». «Не успеем, мудир (начальник) проснется, рискованно». Но все решили, едем.

На следующий день, как только в своей палатке мудир уснул, мы потихоньку пробрались к отстоящему от нашей базы дому, туда подъехал Ясин. Я сел за ним на арабскую Хонду, следом Дмитрий, мотоцикл под тяжестью его грузного тела осел до предела. Чтоб не видно было, что мы иностранцы, лица укутали «арафатками», на глазах очки, хотя российские камуфляжные штаны Димы нещадно выдавали нас.

Ясин гнал по кочкам и иде-

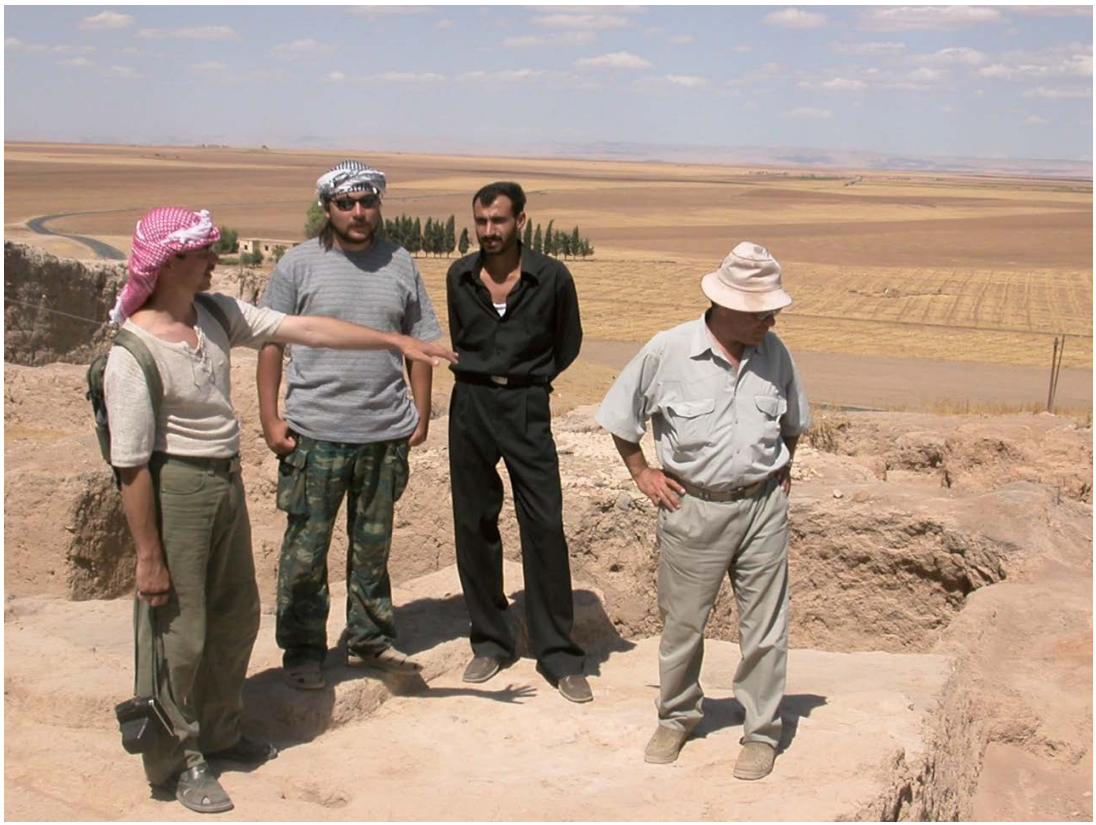

Рис. 3. На раскопках в Сирии ально ровному сирийскому шоссе на пределе, а я молил про себя, «лишь бы выдержали рессоры». Километров через 40 мы оказались у дамбы, перегородившей реку Хабур. Глазам не верилось, среди пустынных пейзажей, среди черных камней перед нами раскинулось рукотворное озеро. Столько воды!

Сам Ясин купаться не полез, а сел любоваться пейзажем. Я бы и сам не полез, но вычитал до этого, что шистосоматоза, в отличие от вод Нила, здесь нет. Мы полезли купаться, какое это был счастье! Стояла середина октября, а здесь палящее солнце. Тело, забывшее что такое прохлада, и растрескавшаяся от сухости кожа получили незабвенное удовольствие. Мы со смехом плескались, и капли всеми гранями бриллиантов искрились на безмятежно голубом фоне неба.
Bсе прошло гладко, а вечером на археологической базе мы делились впечатлениями с коллегами.

Так уж получилось, что Дмитрий Рукавишников в последующие сезоны работал уже в Египте, в Гизе, а мне досталась почетная работа продолжить его раскопки на восточном участке Телль Хазны I. То, что он исследовал, было вскрыто четко и профессионально. До этого я делал все чертежи, а потому чувствовал, чего не хватает для полноты информации и, как мне думается, мне не было бы стыдно перед Дмитрием. По крайней мере, коллега по раскопкам Шахмардан Назимович как-то сказал мне: «Восточный участок был признан эталонным», надеюсь, это был не просто комплимент.

\section{Литература}

Агаджанов С. Г. Очерки истории огузов и туркмен Средней Азии XI-XIII вв. Ашхабад, 1969.

Алемань А. Аланы в древних и средневековых письменных источниках. Москва, 2003.

Аннинский С. А. Известия венгерских миссионеров XIII-XIV вв. о татарах и Восточной Европе // Исторический архив. № 3. Москва; Ленинград, 1940. С. 71-112.

Большаков О.Г., Монгайт А.Л. Путешествие Абу-Хамида ал-Гарнати в Восточную и Центральную Европу (11311153 гг.). Москва, 1971.

Васильев Д. В. Где находились город и область Саксин? (Постановка проблемы) // Каспийский регион: политика, экономика, культура. 2012а. № 4 (33). С. 13-20.

Васильев Д. В. О взаиморасположении городов Сарай, Суммеркент и Хаджи-Тархан // Вопросы истории и археологии Западного Казахстана. 2012б. Вып. 12, № 1. С. 264-269.

Волков И.В. Путешествие по Волге Амброджио Контарини в 1476 году и епископа Дионисия в 1379 году (историкогеографический очерк) // Золотоордынское время / Ред. А. В. Евглевский. Донецк, 2010 (Степи Евразии в эпоху Средневековья; т. 8). 
Гаркави А.Я. Сказания мусульманских писателей о славянах и русских (с половины VII века до конца Х века по Р. Х.). Санкт-Петербург, 1870.

Дагестанские исторические сочинения / Ред.: А.Р. Шихсаидов, Т.М. Айтберов, Г.М.-Р. Оразаев. Москва, 1993. [Электронный ресурc]. URL: http://vashaktiv.ru/texts/d/dag_hr_derbent_name_pred.php.

Джованни дель Плано Карпини. История Монгалов. 3-е изд. Москва, 1997 (Путешествия и путешественники).

Древняя Русь в свете зарубежных источников: хрестоматия: в 5 т. / Под ред. Т. Н. Джаксон, И. Г. Коноваловой, А. В. Подосинова. Т. 3: Восточные источники. Москва, 2009.

Дьбо А. В. Булгарские заимствования в венгерском языке. 2015. [Электронный ресурc]. URL: http://postnauka.ru/ video/55756.

Заходер Б.Н. Каспийский свод сведений о Восточной Европе. Т. 1: Горган и Поволжье в IX-X вв. Москва, 1962.

Ибн Хордадбех. Книга путей и стран. М., 1986. [Электронный ресурс]. URL: http://www.vostlit.info/Texts/rus2/Hordabeh/ frametext8.htm.

Йакут ал-Хамави. Волжская Булгария и Великая степь // История татар с древнейших времен: в 7 т. Т. 2. / Отв. ред.: Ф. Хузин, С. Кляшторный. Казань, 2006. С. 803-818.

Калинина Т. М. Древняя Русь и страны Востока в Х веке (Средневековые арабо-персидские источники о Руси): дис. ... канд. ист. наук. Москва, 1976.

Караулов Н. А. Сведения арабских писателей о Кавказе Армении и Адербейджане // Сборник материалов для описания местностей и племен Кавказа. Вып. 32. Тифлис, 1903. С. 1-63.

Караулов Н. А. Сведения арабских географов IX и Х веков по Р. Хр. о Кавказе, Армении и Адербейджане. Тифлис, 1908 (Сборник материалов для описания местностей и племен Кавказа; вып. 38).

Ковалевский А. П. Книга Ахмеда ибн Фадлана о его путешествии на Волгу в 921-922 гг.: статьи, переводы и комментарии. Харьков, 1956.

Коновалова И.Г. Ал-Идриси о странах и народах Восточной Европы: текст, перевод, комментарий. Москва, 2006.

Лаврентьевская летопись: текст, перевод, исследования / Подг. текста, пер. и исслед. Г.Н. Прохорова. Санкт-Петербург, 2017.

Мадуров Д. Ф. Брахманизм серебряных болгар // Істория релігій в Україні. Науковий Щорічник. Кн. 1. Львів, 2012. С. $36-41$.

Мадуров Д. Ф. Серебряная Булгария: основные вехи истории. Санкт-Петербург, 2018.

Марджани Шихабуддин. Извлечение вестей о состоянии Казани и Булгара (Мустафад ал-ахбар фи ахвали Казан ва Булгар). Ч. 1. Казань, 2005.

Махмуд ал-Кашгари. Диван лугат ат-турк / Пер., предисл. и коммент. 3.-А. М. Ауэзовой. Алматы, 2005.

Минорский В. Ф. История Ширвана и Дербенда X-XI веков. Москва, 1963.

Образование Золотой Орды. Улус Джучи Монгольской империи (1207-1266). Источники по истории Золотой Орды: от выделения удела Джучи до начала правления первого суверенного хана / Сост. М. С. Гатин, Л. Ф. Абзалова, А. Г. Юрченко. Казань, 2008.

Пачкалов А. В. Города Нижнего Поволжья в XIII в. // Вопросы истории и археологии средневековых кочевников и Золотой Орды: Сб. статей памяти В.П. Костюкова / Отв. ред. и сост.: Д. В. Марыксин, Д. В. Васильев. Астрахань, 2011. С. 121-130.

Плетнева С.А. Очерки хазарской археологии. Москва; Иерусалим, 1999.

ПСРЛ. Т. 18. Симеоновская летопись. Москва, 2007.

Рашид ад-Дин. Сборник летописей в трех томах. Т. 1. Москва; Ленинград. 1952 (переизд.: Москва, 2002).

Садр ад-Дин Али ал-Хусайни. Ахбар ад-даулат ас-сельджукийа. Москва, 1980. [Электронный ресурc]. URL: http://www. vostlit.info/Texts/Dokumenty/Persien/XII/1140-1160/Katib/1-20/4.phtml?id=7551 / коммент. 16.

Селиванов А. Ф. Материалы для истории буртасов. Пенза, 1890. [Электронный ресурс]. URL: http://www.vostlit.info/ Texts/ rus/Jakut/pred2.phtml?id=1510.

Середонин С. М. Известия англичан о России XVI в.: Ченслер, Дженкинсон, Рандольф, Баус // Чтения Общества истории и древностей российских (ЧОИДР). Кн. 4. Москва, 1885.

Тизенгаузен В. Г. Сборник материалов, относящихся к истории Золотой Орды. Извлечения из сочинений арабских. Т. 1. Санкт-Петербург, 1884.

Федоров-Давыдов Г.А. Город и область Саксин в XII-XIV вв. // Древности Восточной Европы. Москва, 1969 (МИА; № 169). С. 253-261.

Хвольсон Д.А. Известия о хозарах, буртасах, болгарах, мадьярах, славянах и русах Абу-Али Ахмеда бен Омар ибн Даста, неизвестного доселе арабского писателя начала Х века, по рукописи Британского музея; первый раз издал, перевел и объяснил Д.А. Хвольсон. Санкт-Петербург, 1869.

Bridia C. de. 1967. Hystoria Tartarorum C. de Bridia monachi / Ed. et annot. A. Önnerfors. Berlin, 1967. [Electronic resource]. URL: http://www.agnuz.info/app/webroot/library/187/529/page10.htm.

Hammer-Purgstall, Josef von. 1827. Sur les origines russes.: Extraits de manuscrits orientaux adressés à Mgr. Le Comte N. de Romanzoff, chanclier de l'empire de Russie dans une suite de lettres depius l'an 1816 jusq'à l'an 1825 - St. Pétersborg. St. Pétersborg, 1827.

Nasir-eddin Tusi // Melgunof G. Das südliche Ufer des Kaspischen Meeres, oder Die Nordprovinzen Persiens. Leipzig, 1868.

Reinaud M. Introduction générale a la Gographie des Orientax. in Gographie d'Aboulf da, I. Paris 1848

Wladimiroff I. De kaart van een verzwegen vriendschap. Nicolaes Witsen en Andrej Winius en de Nederlandse cartografie van Rusland. Groningen, 2008 (Baltic Studies; 10). 
Мы могли бы служить в разведке, мы могли бы играть в кино! Mbl, как птицы, садимся на разные ветки и засыпаем в метро.

Вынесенные в эпиграф строки песни повествуют о любовной истории, но для меня они больше ассоциируются с моим поколением, ну и я часто ее слышал в музыкальном плейлисте из компьютера Димы Рукавишникова в знаменитой комнате в Институте археологии. И поэтому она у меня ассоциируется и с ним.

Действительно, мы могли многое - от войны до искусства. Мы были универсалами, но при этом досконально старались разобраться в тех вопросах, которыми занимались, мы могли весело гулять, и также тяжело и упорно работать. Мы бодрствовали допоздна, расходились за полночь и спали уже в метро. Потому что каждому нужно было ехать далеко - в наши спальные районы, а то и за пределы города - например, как Димке в подмосковный Троицк.

Мои воспоминания о Диме отрывочны, прошло много времени, память многое исказила, каждый из нас, рассказывая о том или ином, любил приврать. Но я помню его так, как помню.

Мы познакомились в московском университете на кафедре археологии на втором курсе в 1996 году. Я учился, восстановившись после армии, большинство, как Дима, поступили после школы, кто-то, как Макс Меньшиков (Шамиль), восстановились после академотпуска. Было бы не правильно сказать, что Дима Рукавишников выделялся своим характером и внешностью среди однокурсников, у нас все были яркие незаурядные личности и все друг друга стоили. Но он бросался в глаза своей восточной внешностью. Мы узнали, что в его жилах течет башкирская кровь и поэтому прозвали его Башкир. Это стремление молодежи называть друг друга по кличкам, так, как индейцы дают имена согласно заслугам человека. Дима был Башкиром,
Макс Меньшиков стал Шамилем, меня прозвали Че Геварой, Ирину Рукавишникову (будущую жену Димы) до сих пор многие называют Кариной или Радугой. Многие стали серьезными взрослыми людьми, но память о прозвищах осталась. На археологической практике в Новгороде мы так и жили в одном номере - Башкир, Шамиль и Че. И жили дружно и весело.

Он действительно был из какого-то знатного башкирского рода, рассказывал, что в Башкирии у них есть родовые земли, на которых он регулярно бывает и даже выполнял свой кочевой долг - пас скот. Так что, Башкир был если не от сохи, то уж точно от кнута.

Но Башкиром его называл только круг университетских друзей, друзья по реконструкторской тусовке называли его Индейцем. Вообще у Димы было много друзей. И друзей самых разных кругов общения. В этом он был многолик.

Он поступил на исторический факультет в МГУ, но прежде он был одним из лучших в информатике и даже стал призером какой-то из олимпиад. Впоследствии это станет важной частью его жизни, именно он провел первый интернет в Институте археологии, он еще на заре компьютеризации и интернета показал, как взламывать сайты, чаты и форумы. Именно это тогда нам, мечтающим о мировой революции, наверное, было нужно. Он был одним из первых, кто применял эти знания в археологии, развивая геоинформационные технологии, а затем, занявшись аэрофотосъемкой, для чего использовал целый дирижабль. Это сейчас у каждого второго археолога есть личный дрон для аэрофотосъемок, когда-то же это было фантастикой.

Впоследствии он серьезно занялся компьютерными технологиями, это стало его одним 
из основных занятий, одним из бизнесов. Для меня все это темный лес, и я спрашивал его коллег по работе, и как у него получалось что-то? Ты что, говорили мне, он был очень хорош, замечательно разбирался, как системщик и архитектор он был одним из лучших. Что это на самом деле значит, я не знаю, но верю людям на слово.

Он был одним из первых победителей турниров по историческому фехтованию, был своим в реконструкторской тусовке, и даже благодаря своим умениям подрабатывал как фехтовальщик в театре.

Помнится, как-то мы сидели, общались, и он вдруг засобирался куда-то. «Куда ты? - спросили мы его. - Побудь с нами. Ведь хорошо сидим». «Не, не могу, - сказал он. - У моей знакомой сегодня концерт в каком-то доме культуры, она волнуется, стесняется, надо пойти поддержать ее». Потом эта знакомая стала известна как Хелависа из группы «Мельница». У Хелависы есть песня, посвященная Марине Цветаевой, называется «Двери Тамерлана». Так вот на самом деле она про Башкира. Каждый из нас, кто слушает ее, вспоминает прежде всего Диму.

Мы как-то с другом брали интервью у Эдуарда Лимонова в Бункере - бывшем штабе нацболов на Фрунзенской, мой друг Филипп Сальников, хороший фотограф, сделал в Бункере небольшую сессию. Там висел во всю стену плакат с Фантомасом, на фоне которого очень удачно было делать портреты. Потом мы показали эти фотографии Башкиру. И он как своих знакомых стал называть нацболов, которых мы тогда отфотографировали.

Именно Дима познакомил меня с анархизмом, делился анархической литературой, познакомил с людьми из анархистской тусовки.

Казалось, он знает всех и знает обо всем.

Это был человек какой-то невероятной мудрости, неожиданной для его возраста. Он мог быть лихим, мог быть отчаянным, но когда надо, он обладал невероятной трезвостью и волей. Он не спешил, не суетился, и всегда справлялся с любой задачей.

Не случайно, он всегда был востребован как археолог - он работал на Сахалине, в Тыве, Средней Азии, Египте и Сирии.

Он был очень надежен, ты всегда знал, что если что, к нему всегда можно было обратиться за помощью. Когда в эпоху студенчества понадобились деньги в долларах, чтобы помочь отмазать товарища, пострадавшего от ментов, он без раздумья дал все, что у него было.

Когда мне нужно было доделать, скомпоновать, отредактировать и распечатать курсовую работу, а это, как обычно, делается в последний день и последний час, он без раздумий запер меня на ночь в своем кабинете в Институте археологии, предоставив в полное распоряжение компьютер и принтер.

Когда в 1999 году бомбили Белград, я собрался к американскому посольству протестовать. Кого позвать с собой? Башкира. Он был в своей знаменитой косухе и бейсболке. Мы затарились склянками с чернилами, жестяными банками Кока-колы и пошли забрасывать американское посольство.

Я, как и многие другие, знали, что в затруднительной ситуации можно обратиться к Башкиру - по бытовому вопросу, за советом, за помощью в решении научной проблемы. И обращался, и получал помощь.

Но сам он никогда никого не просил. А если просил, то не для себя, а для друзей.

Он был двужильный и сам на себе все тянул. Экспедиции, работу, дом, который он построил с нуля в подмосковном лесу. Сегодня он в Крыму, завтра в Египте, послезавтра в Узбекистане. Но у материального тела есть свои пределы, которых не хотел знать его дух. И хотя его тело проиграло, дух победил. Он до самого конца демонстрировал свою несгибаемую волю. 


\section{Студент МГУ}
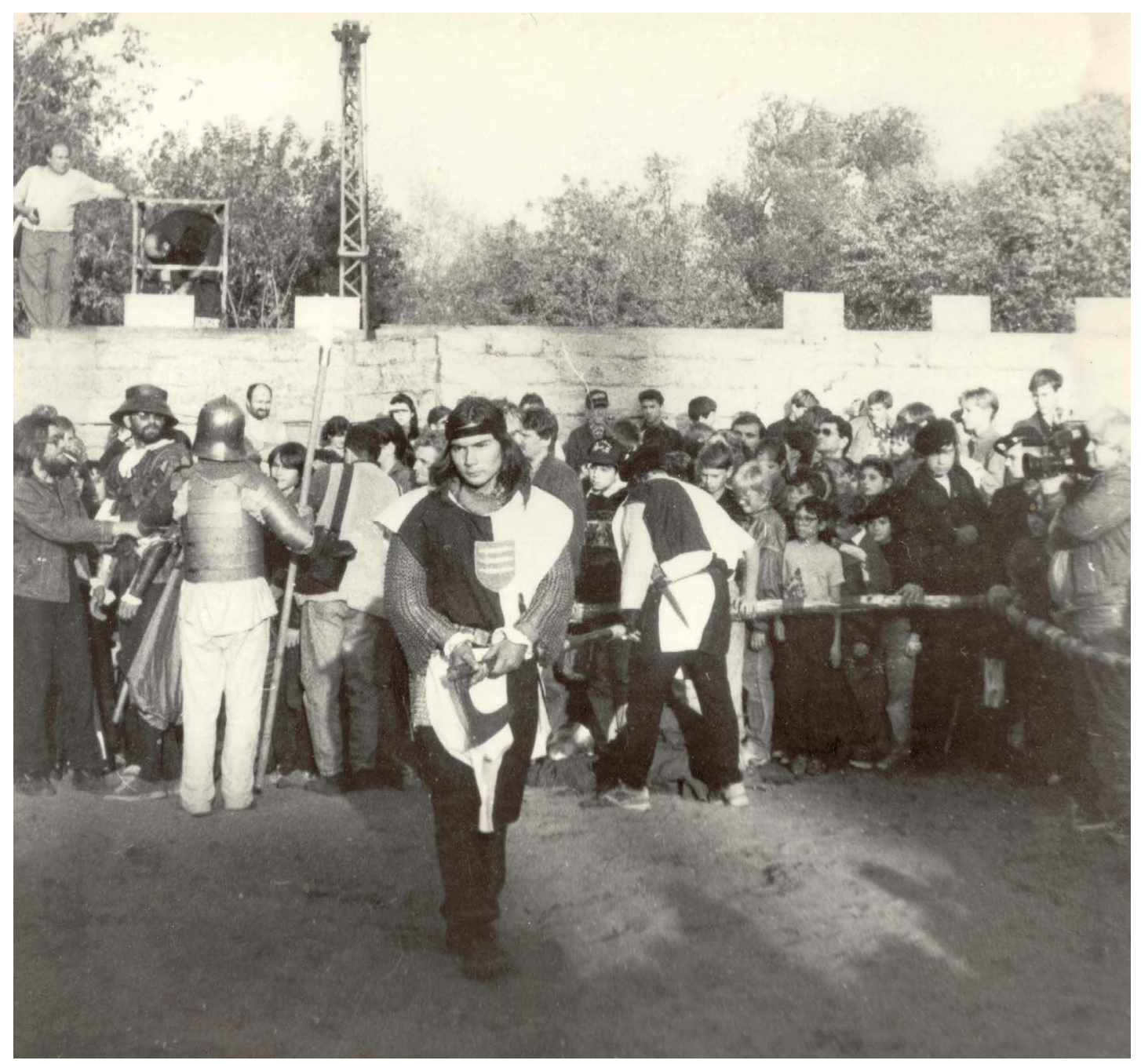

1994.

Москва,

Сетунь,

турнир

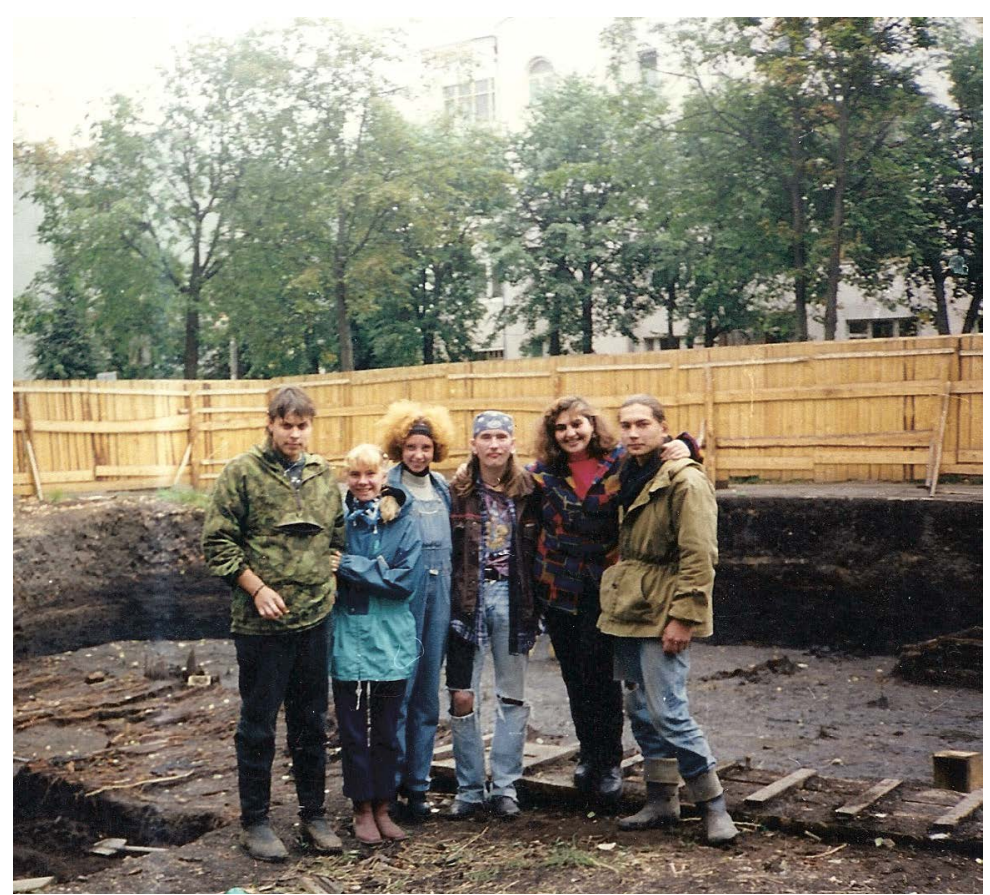

1997. Новгород. Новгородская археологическая экспедиция

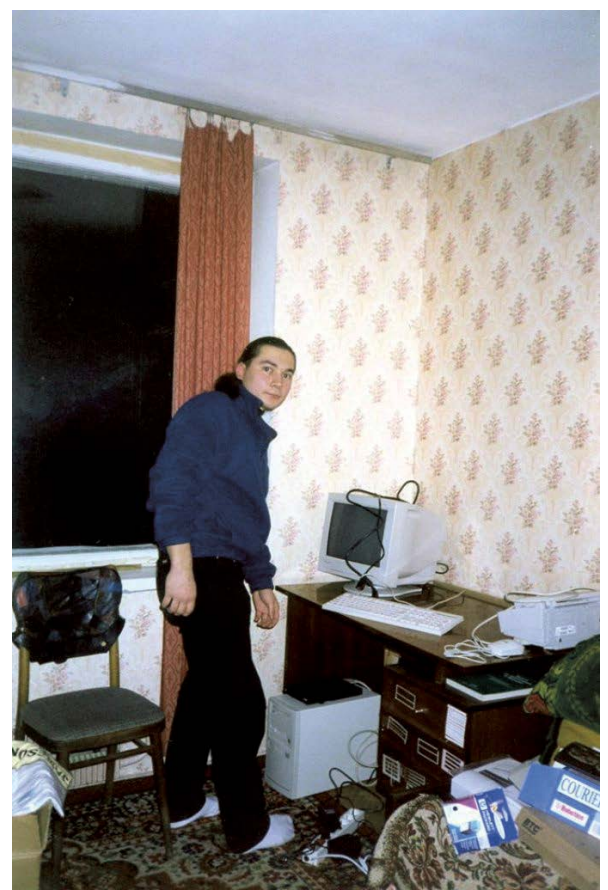

1998. МГУ 


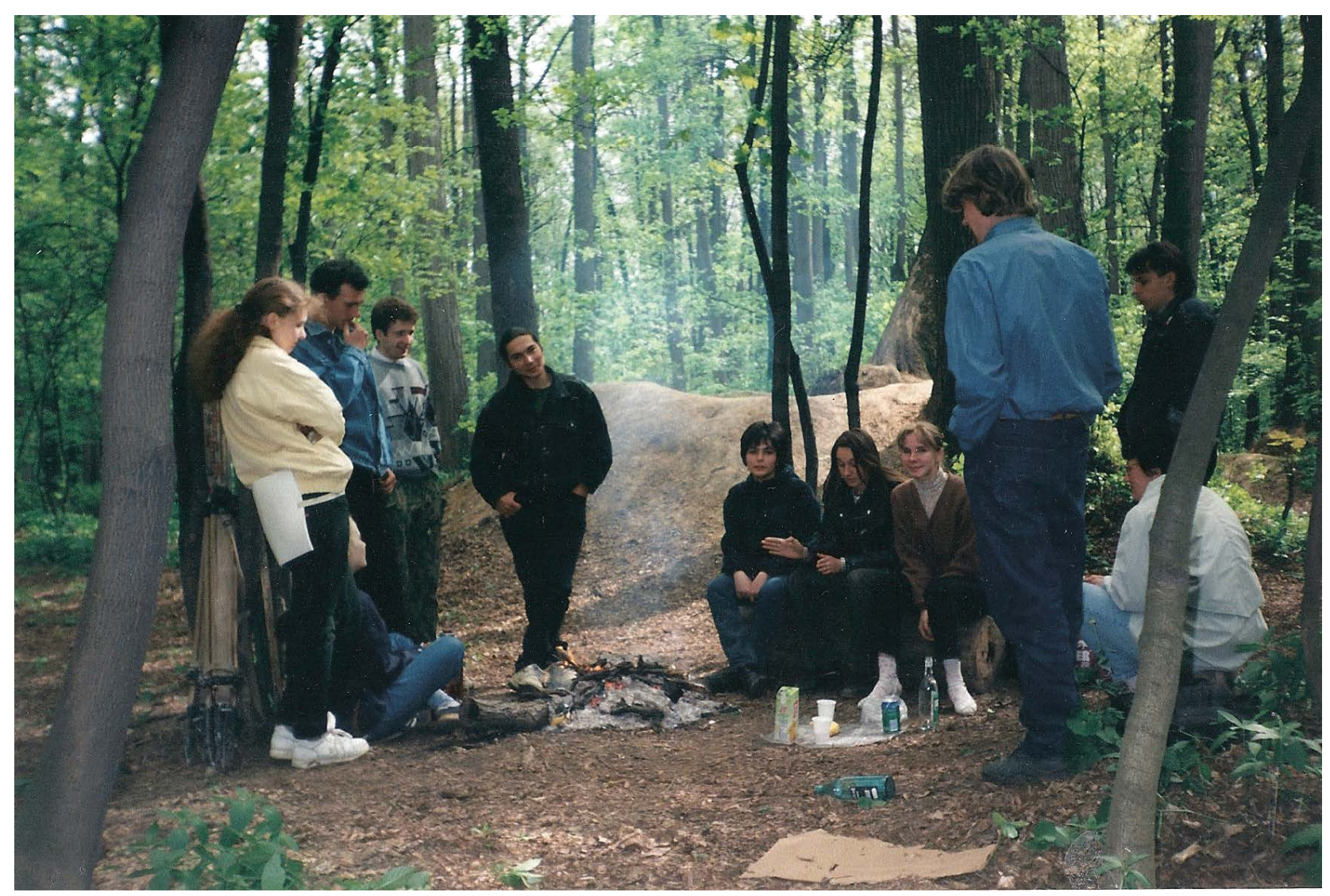

1997. Москва. Практическое занятие кафедры археологии МгУ. Царицыно

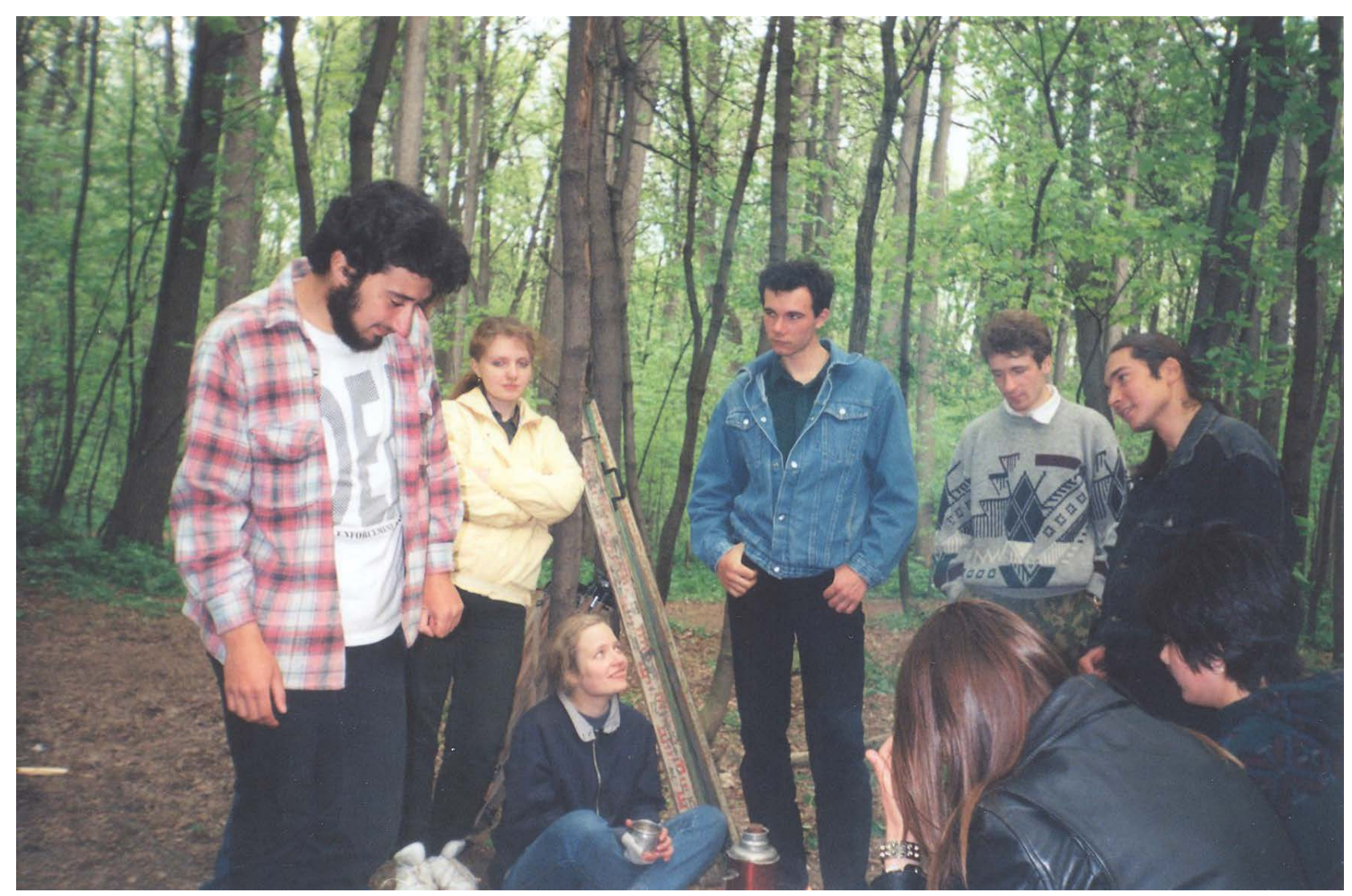

1997. Москва. Практическое занятие кафедры археологии Мгу. Царицыно 


\section{Россия. Разведки. 2004-2014}

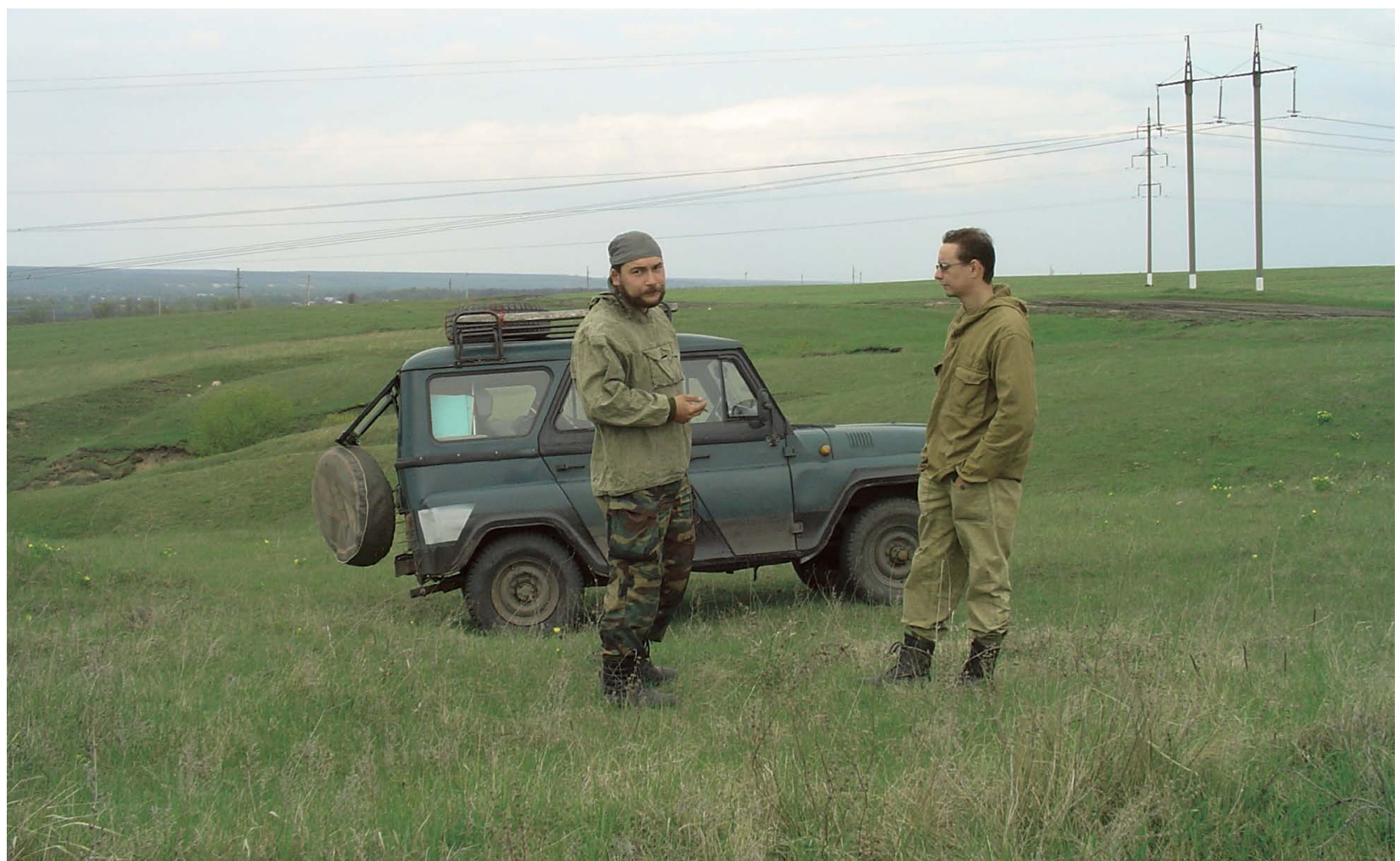

2004. Белгородская область. Разведки Института археологии РАН

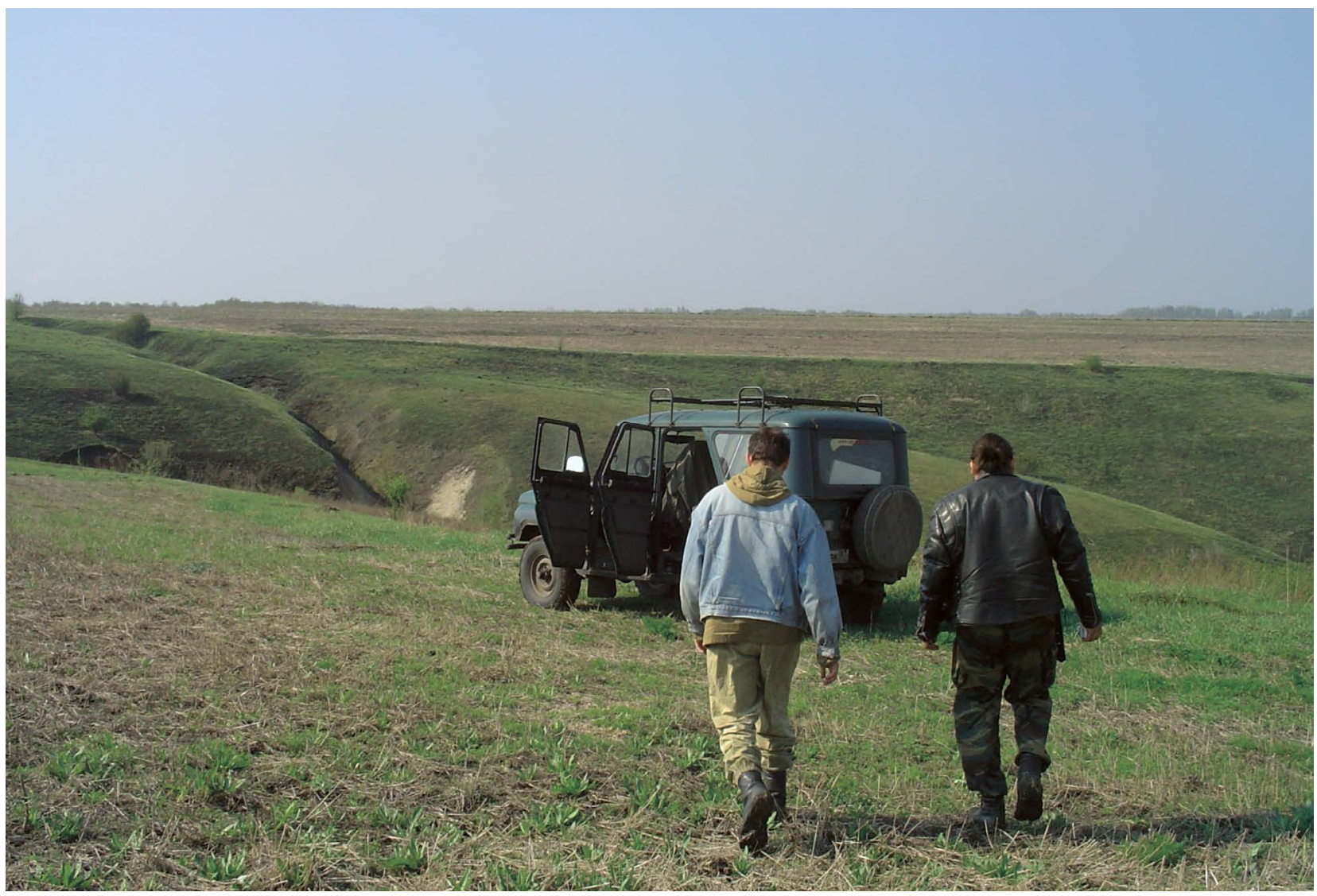

2004. Белгородская область. Разведки Института археологии РАН 


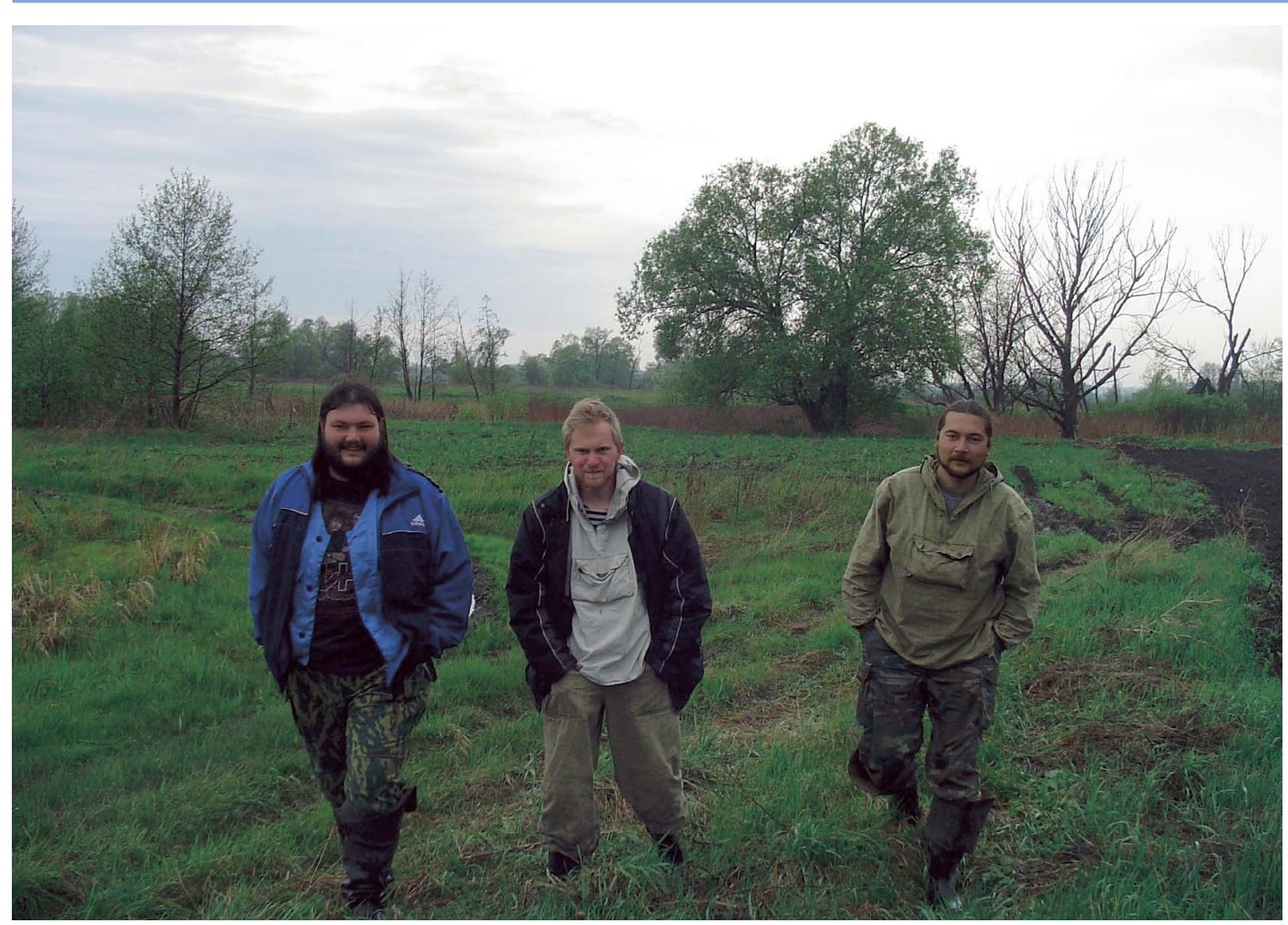

2005. Белгородская область. Разведки Института археологии РАН

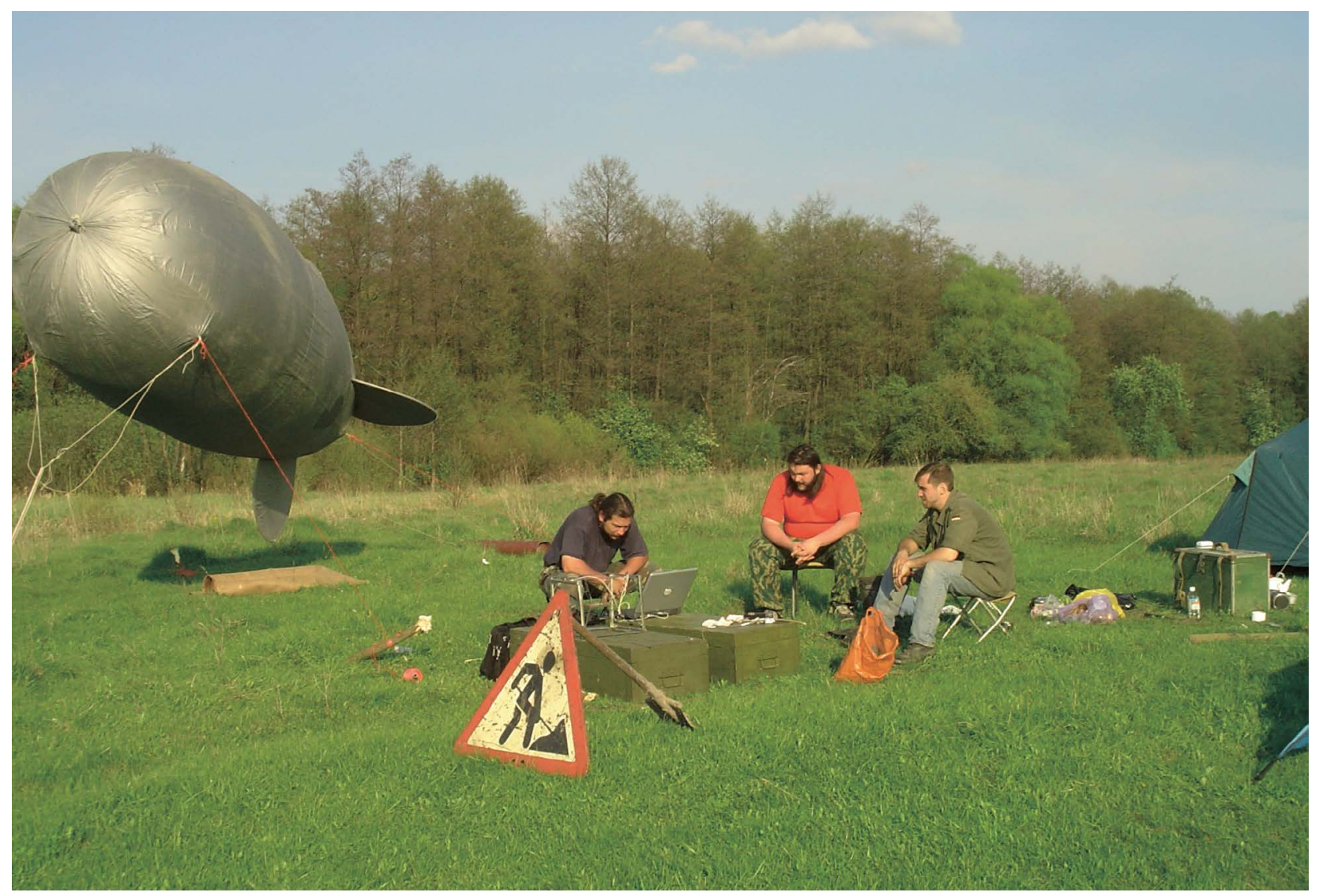




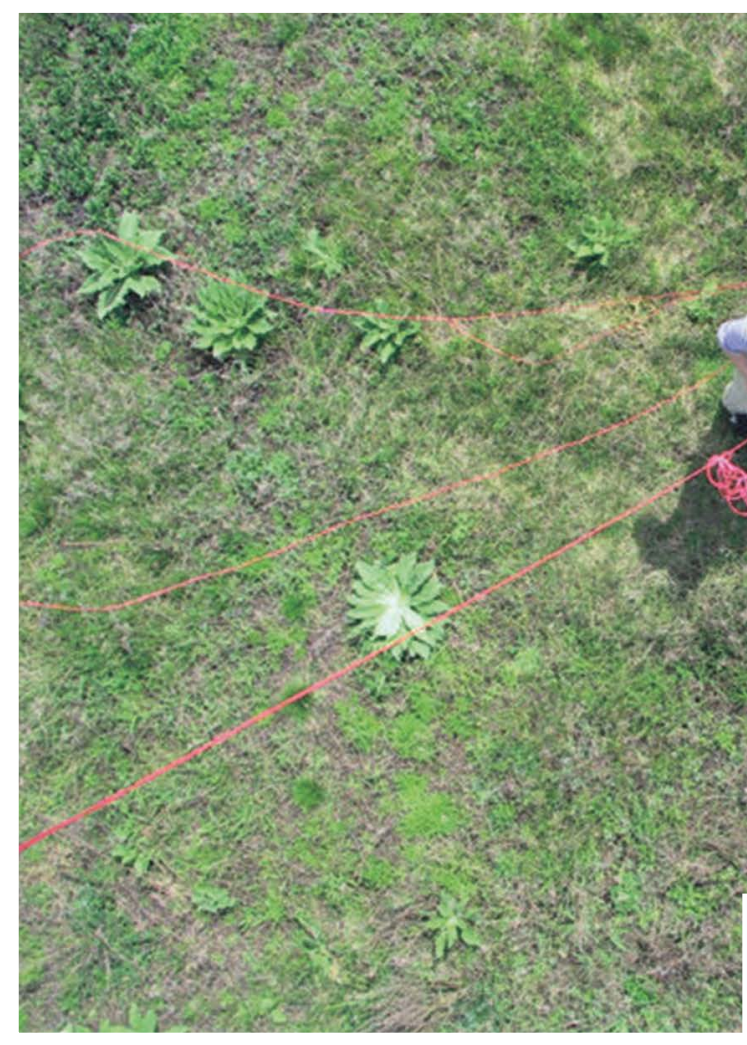

2005. Белгородская область.

Разведки Института археологии РАН.

Фотосъемка с аэростата

2005. Белгородская область. Разведки Института археологии РАН

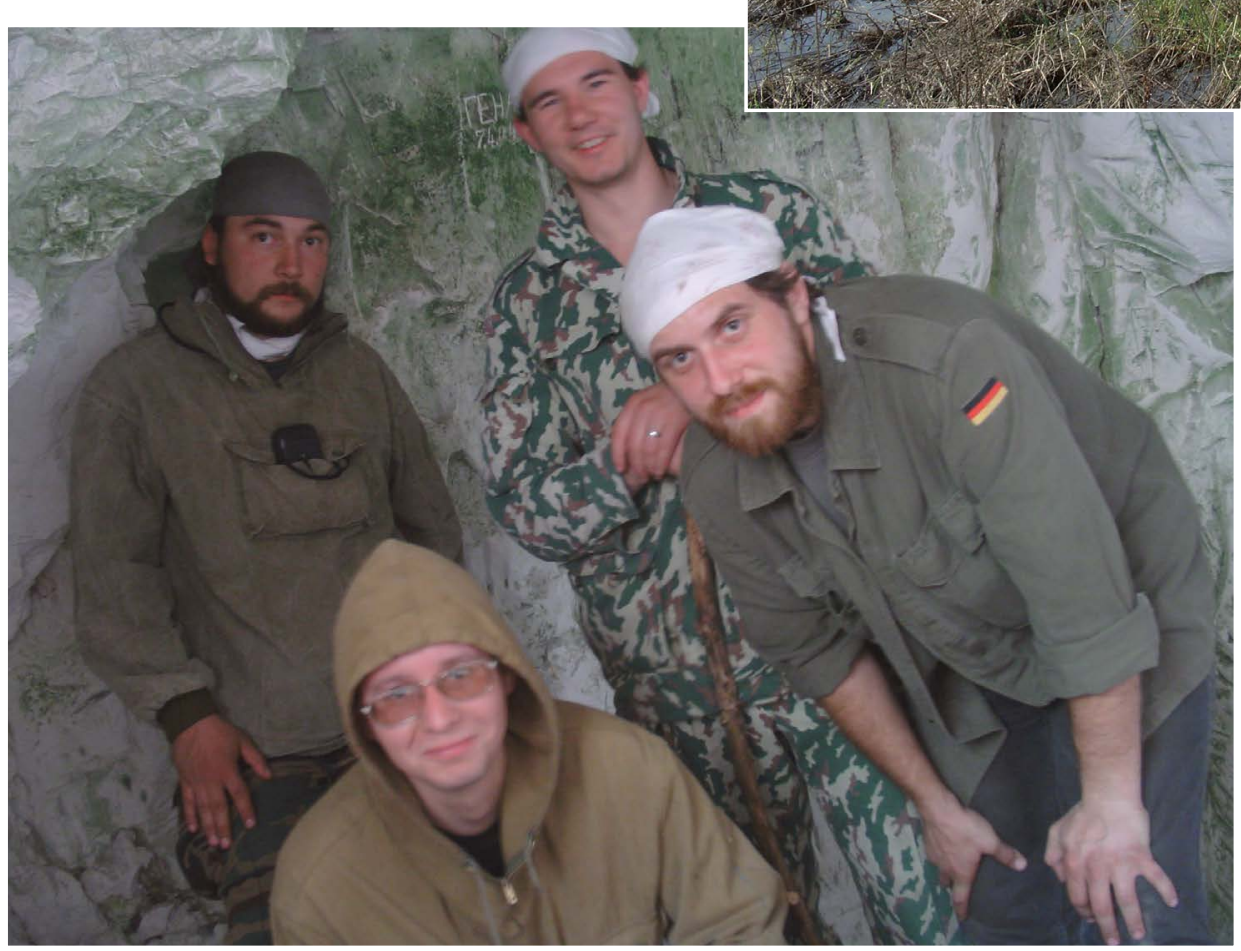

2005.

Белгородская область.

Разведки Института археологии РАН 

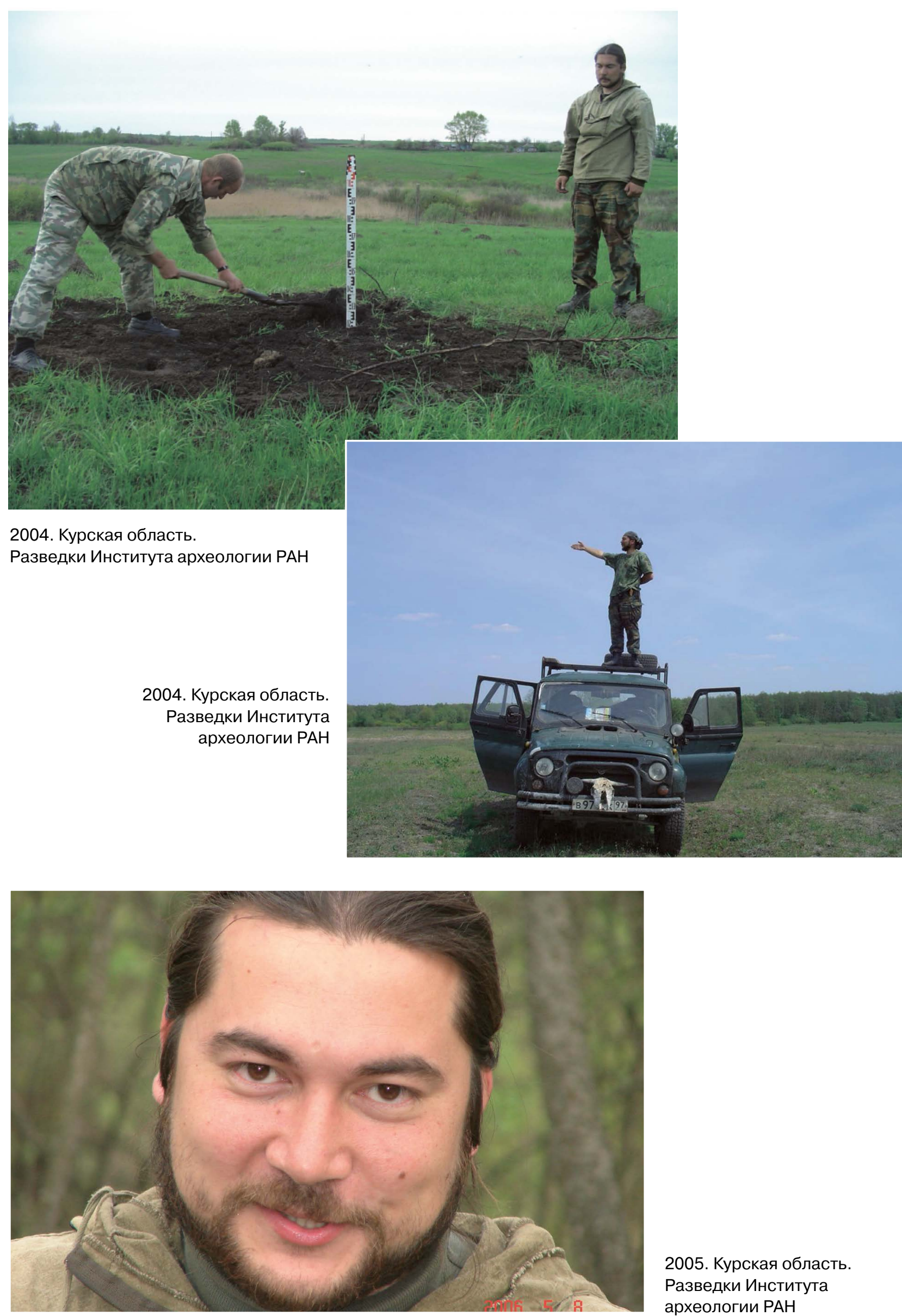

2005. Курская область.

Разведки Института археологии РАН 


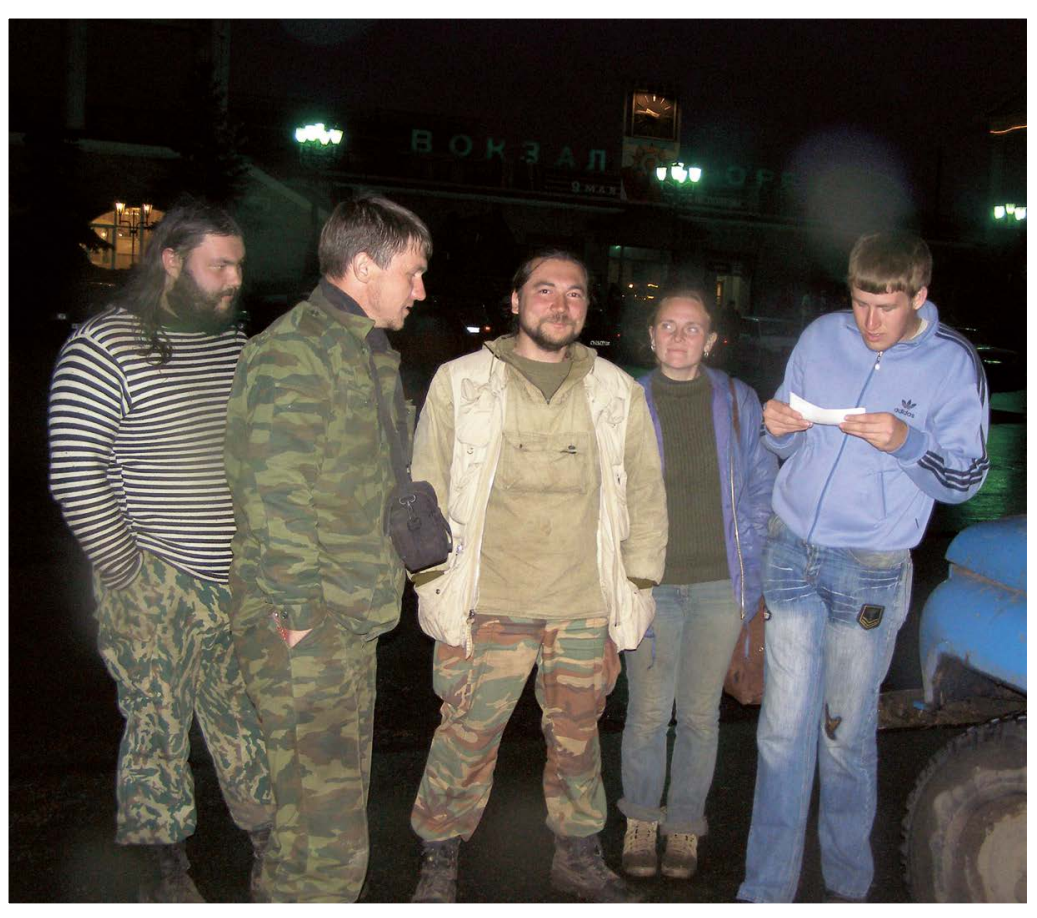

2007. Орловская область.

Разведки Института археологии РАН

2010. Саратовская область. Разведки Института археологии РАН

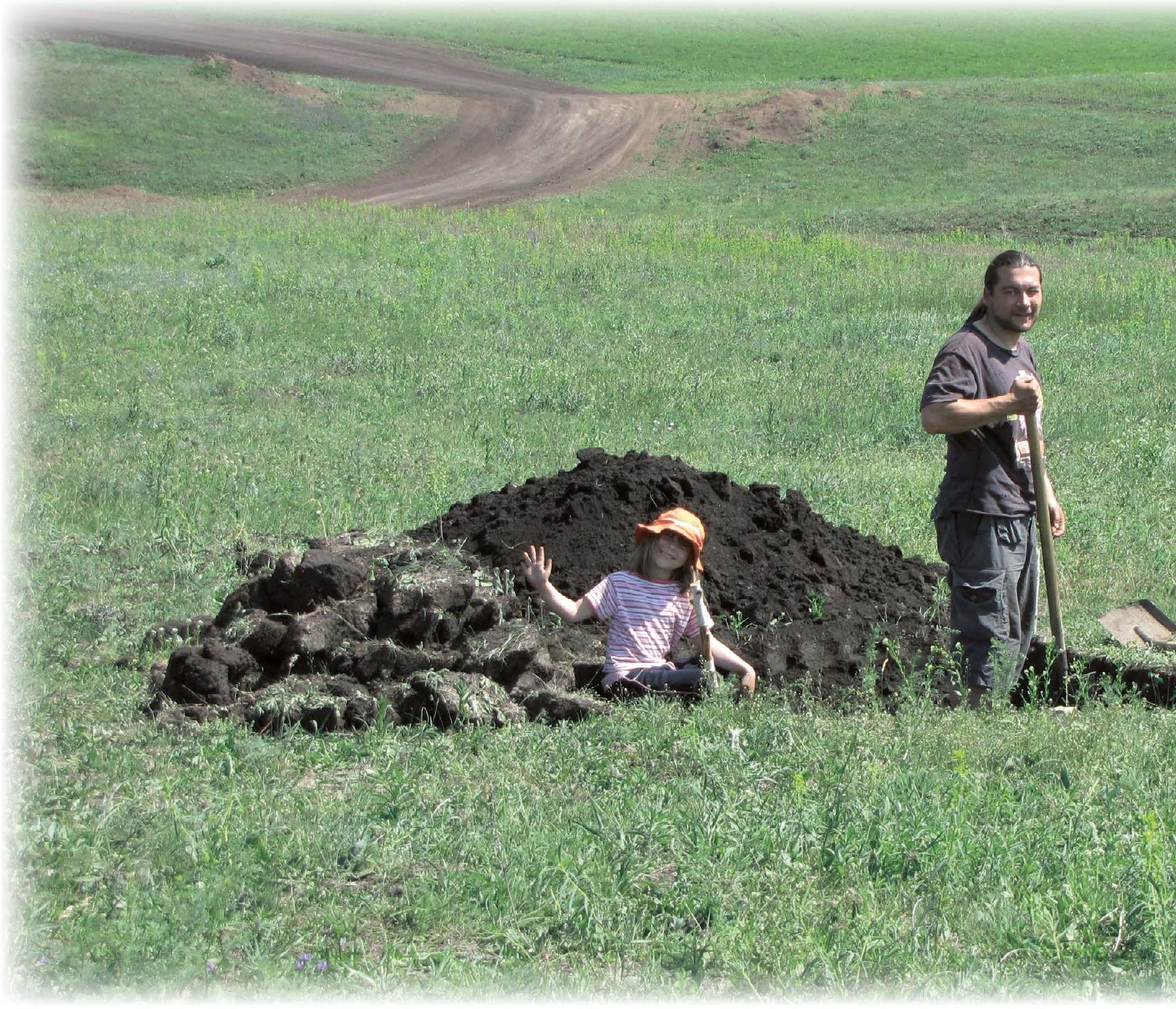




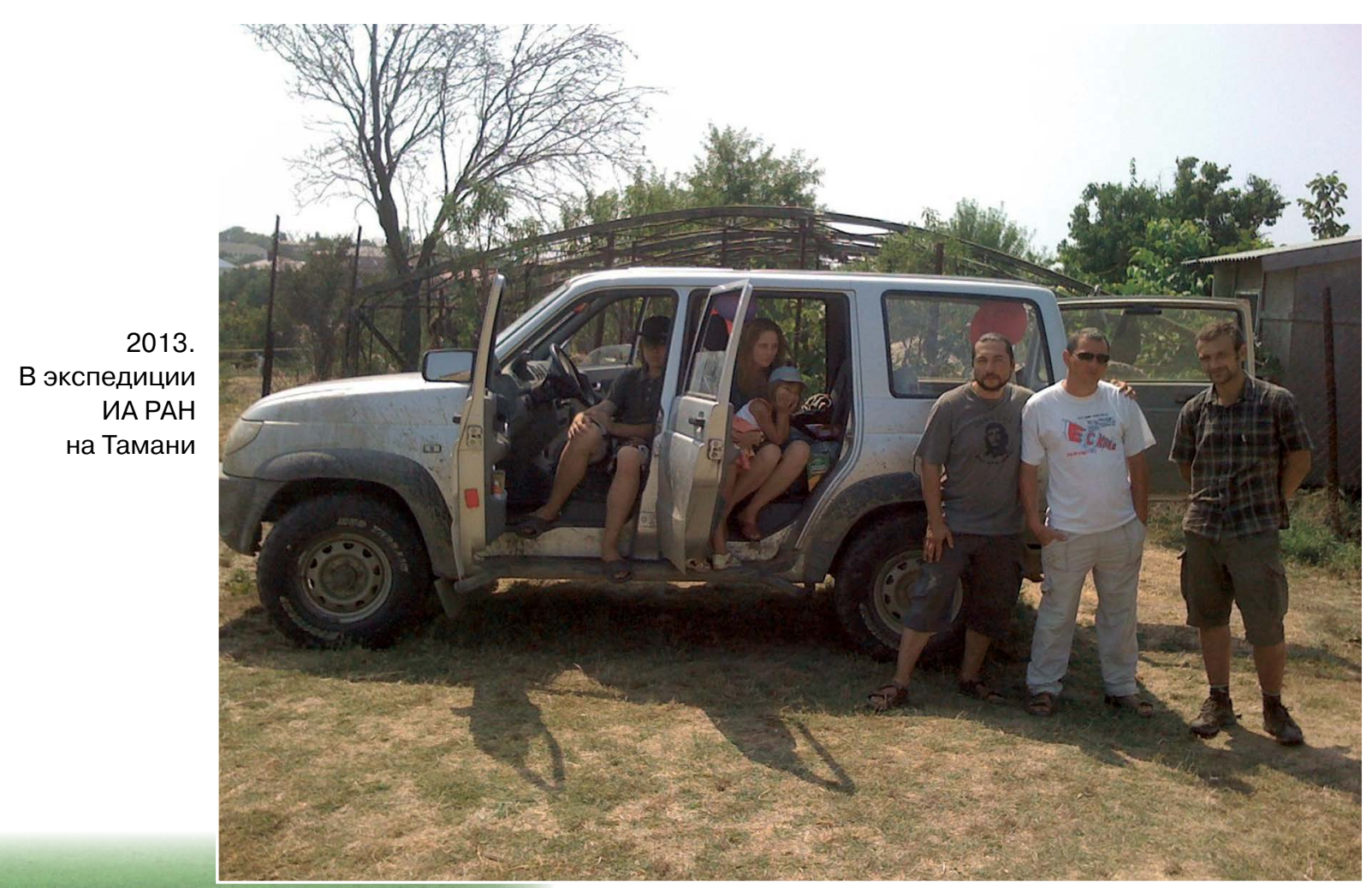

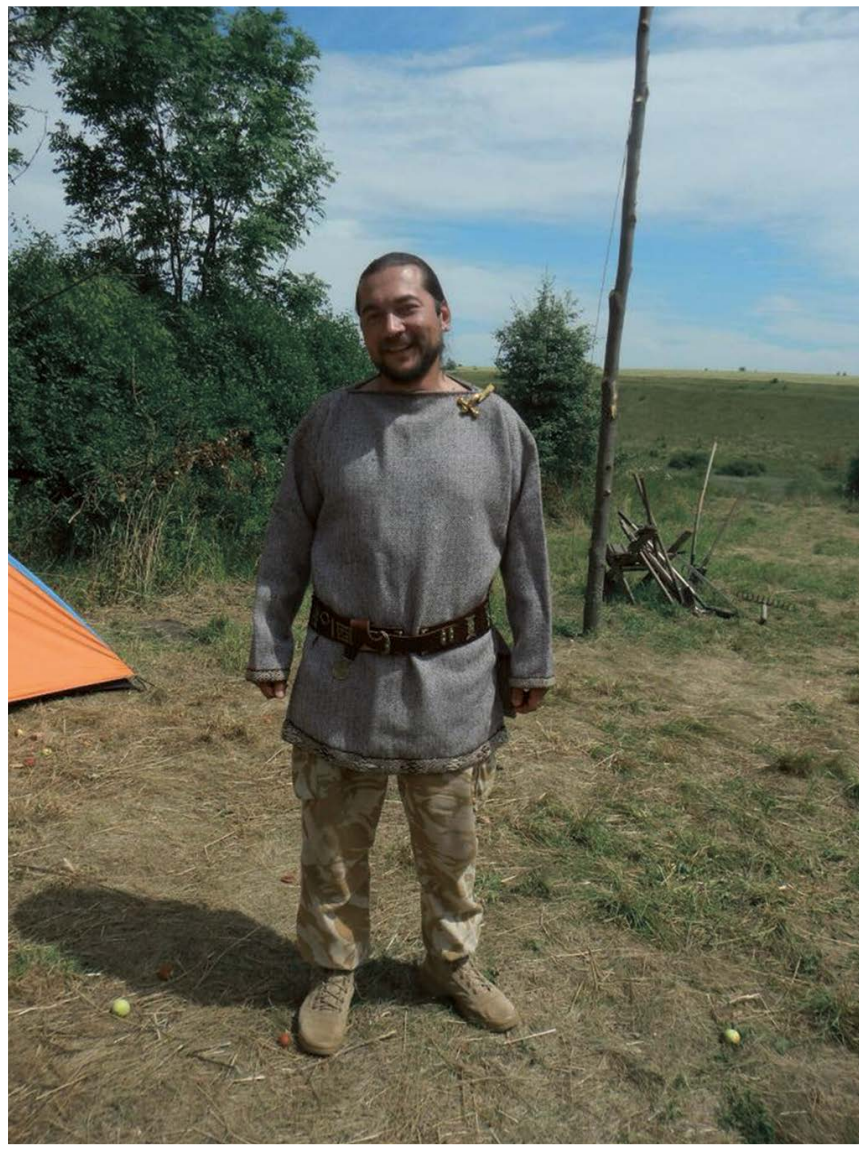

2014. Курская область.

Экспедиция Института археологии РАН 


\section{Сирия. 2005}

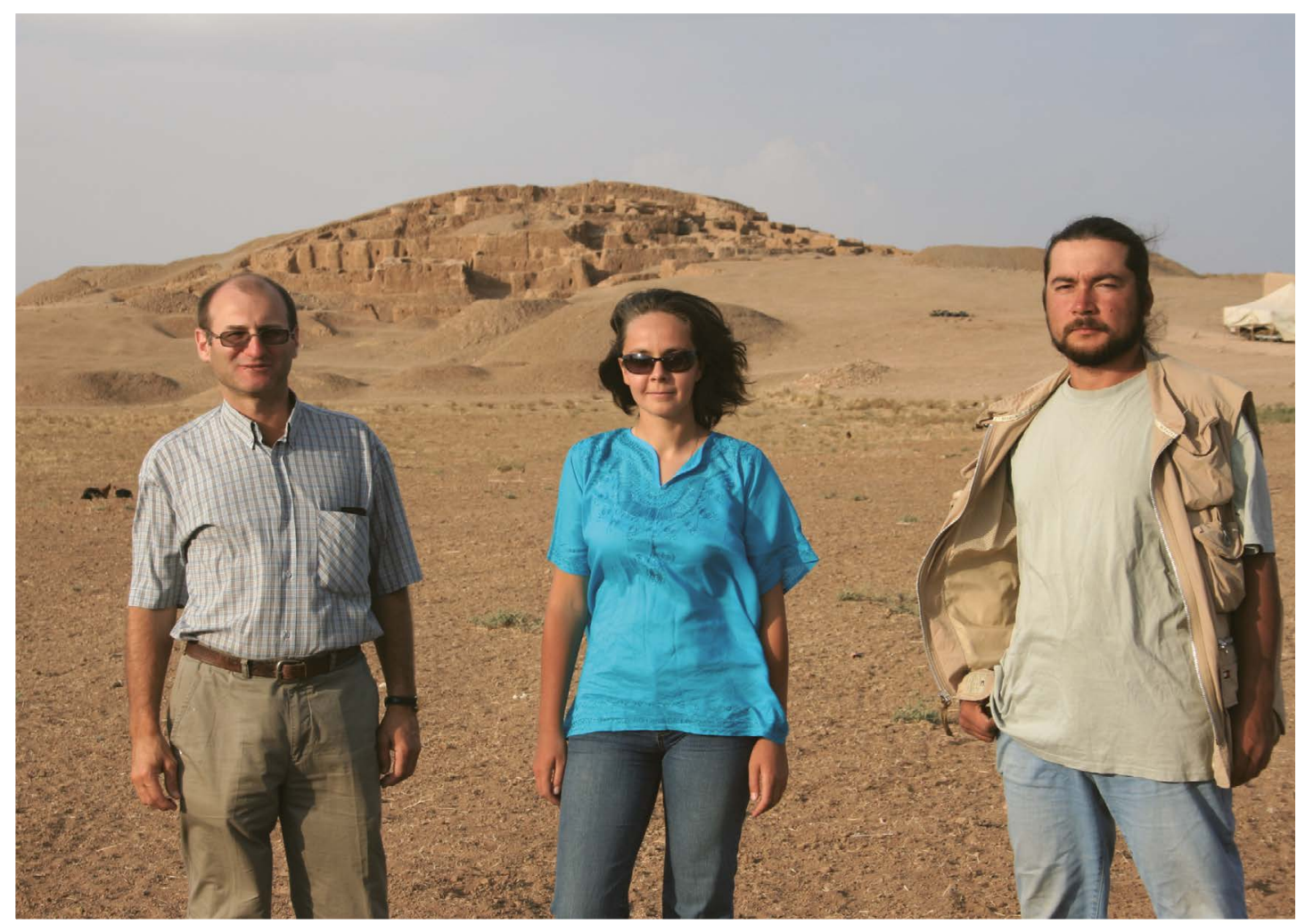

2005. Тель-Хазна. Экспедиция ИА РАН в Сирии

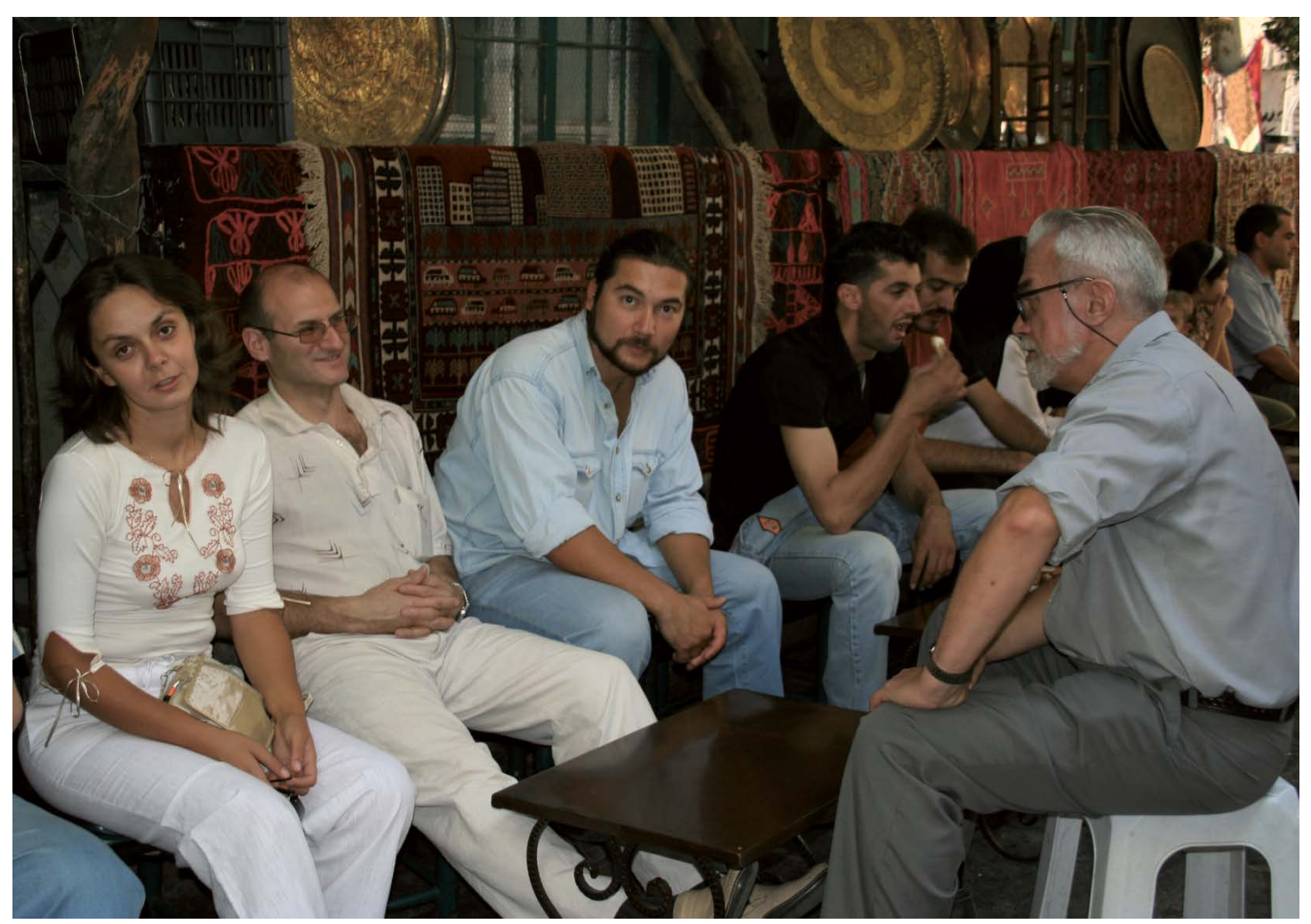

2005. Дамаск. Экспедиция ИА РАН в Сирии 


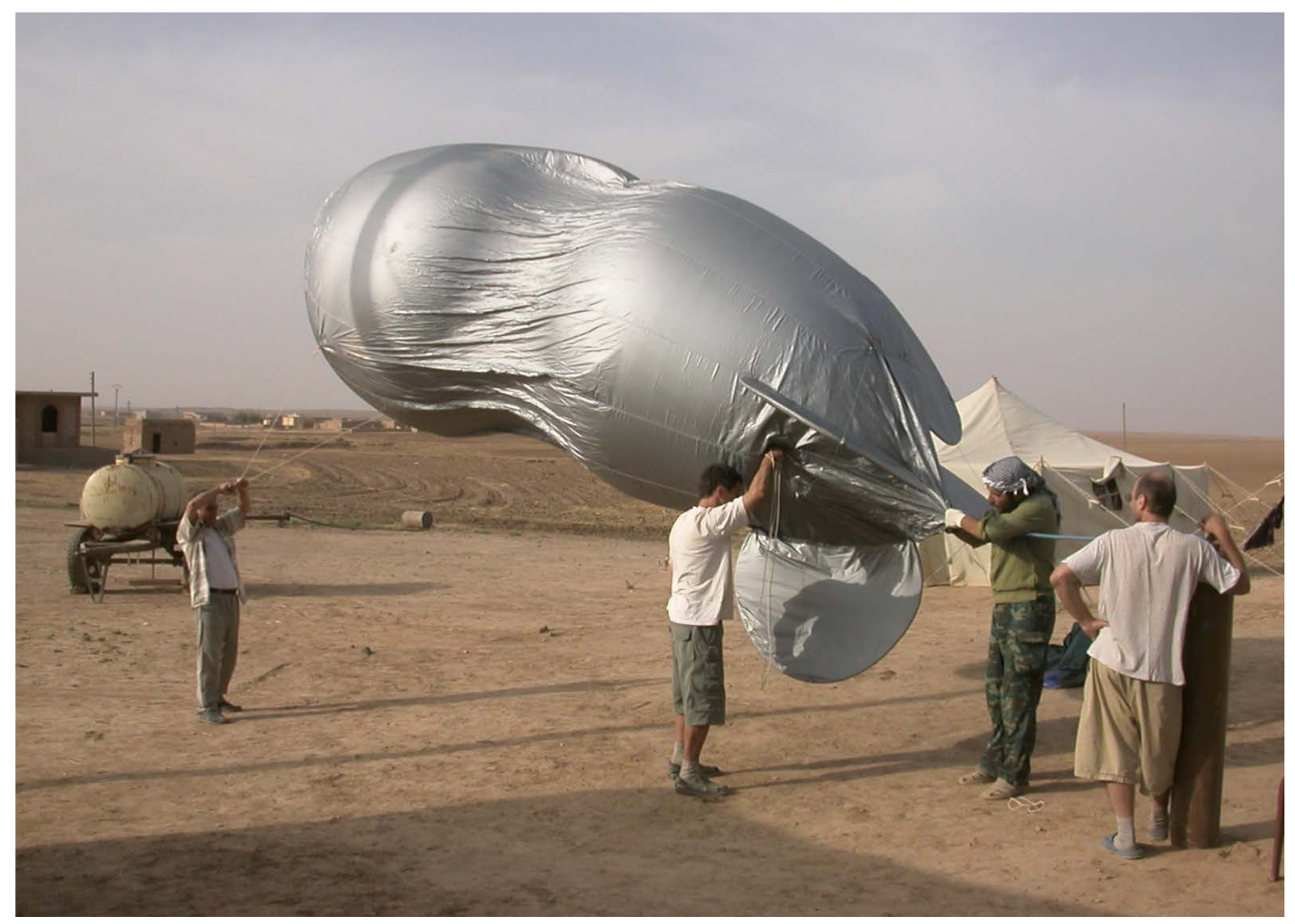

2005. Тель-Хазна. Экспедиция ИА РАН в Сирии. Фотосъемка с аэростатом

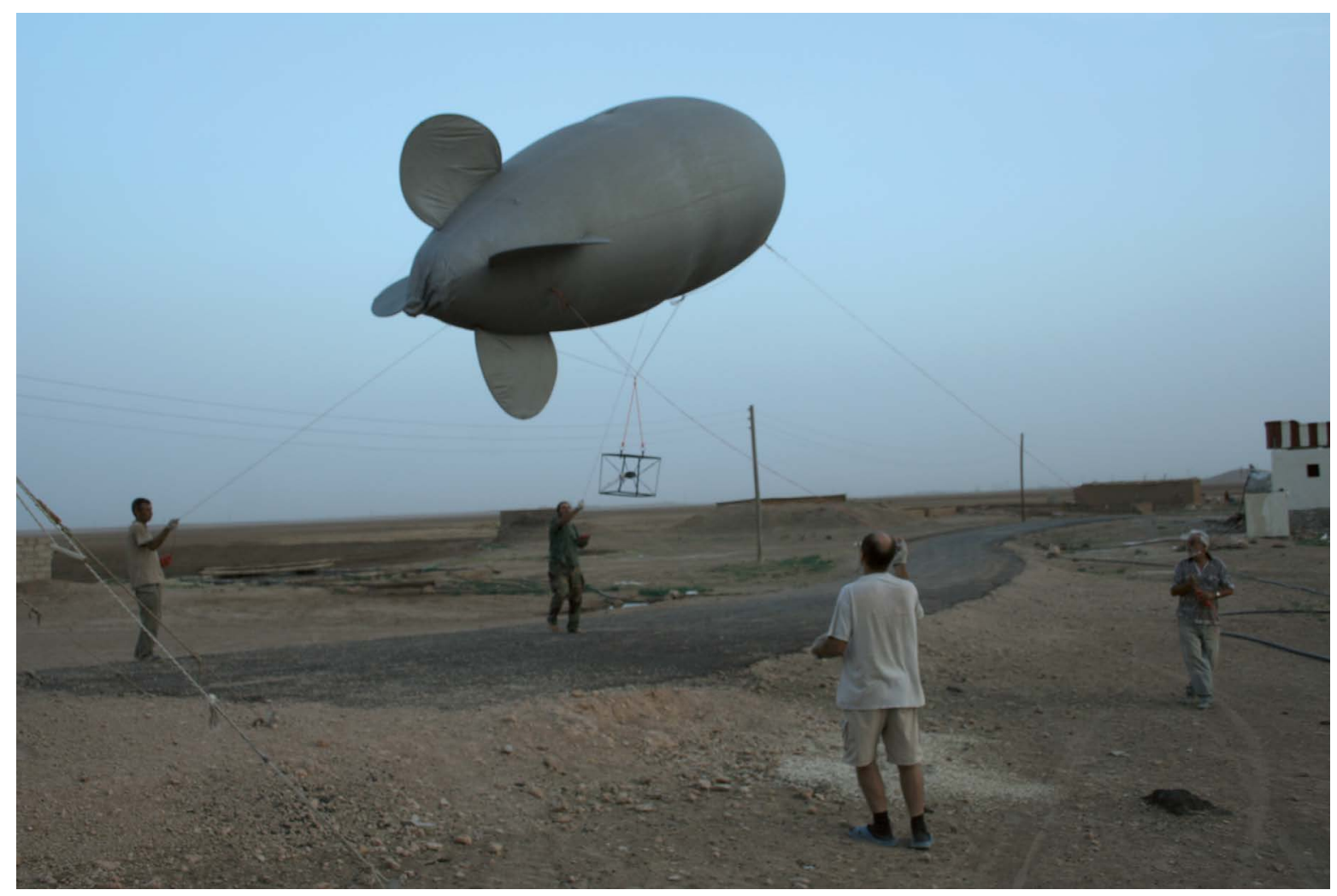

2005. Тель-Хазна. Экспедиция ИА РАН в Сирии. Фотосъемка с аэростатом 


\section{Египет. 2005-2007}

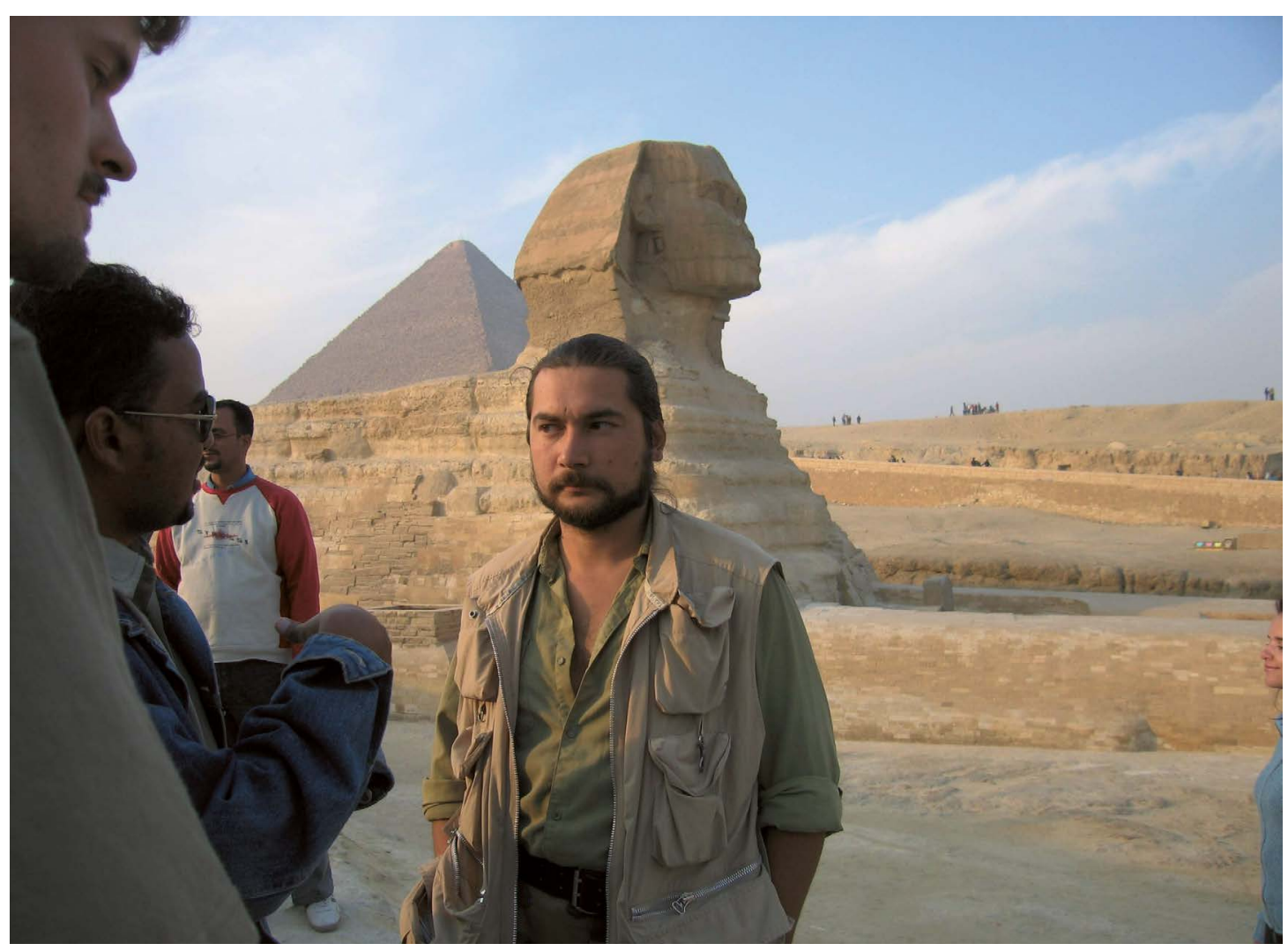

2005. Гиза. Каир. Экспедиция РАН в Египте

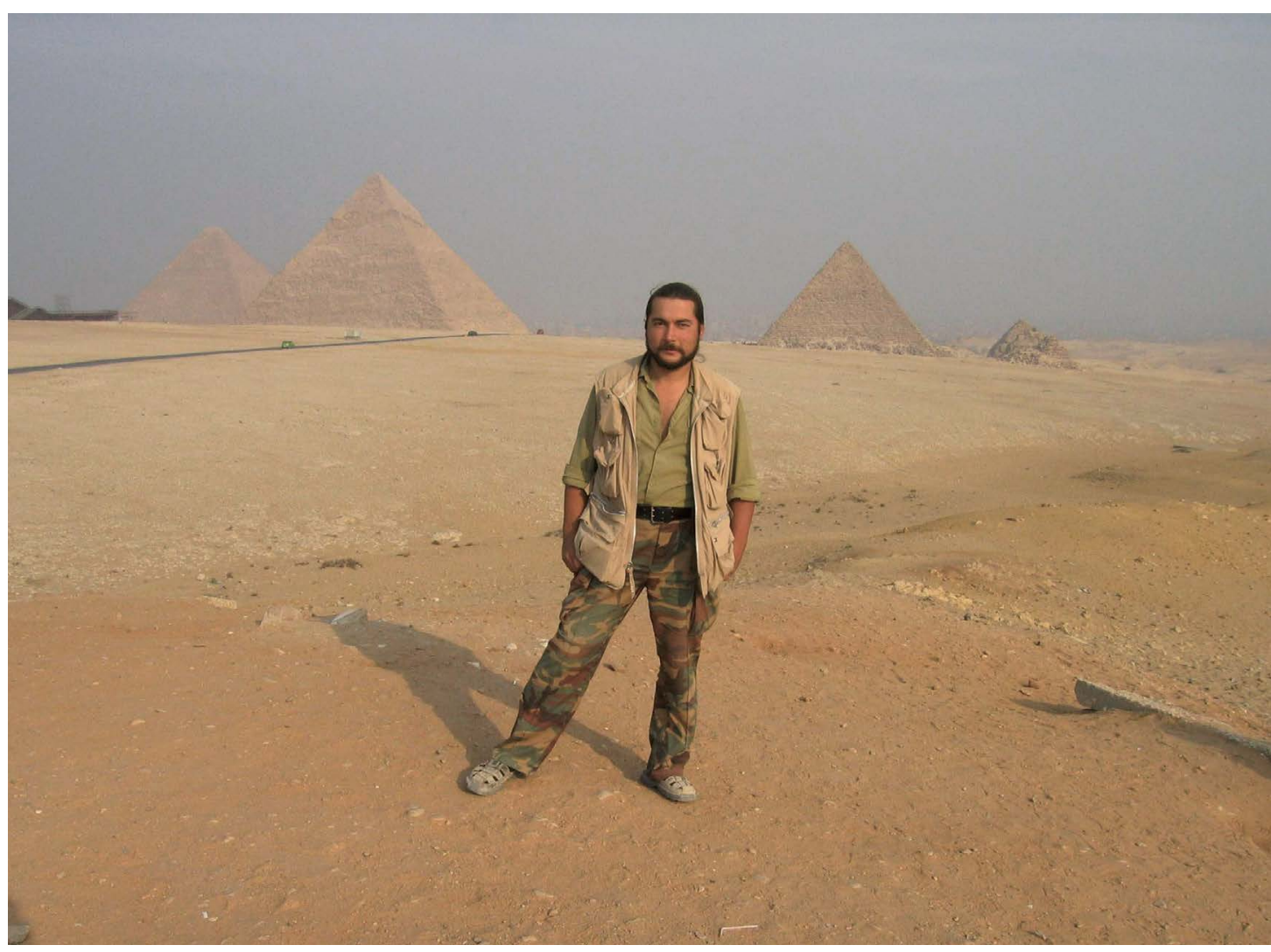




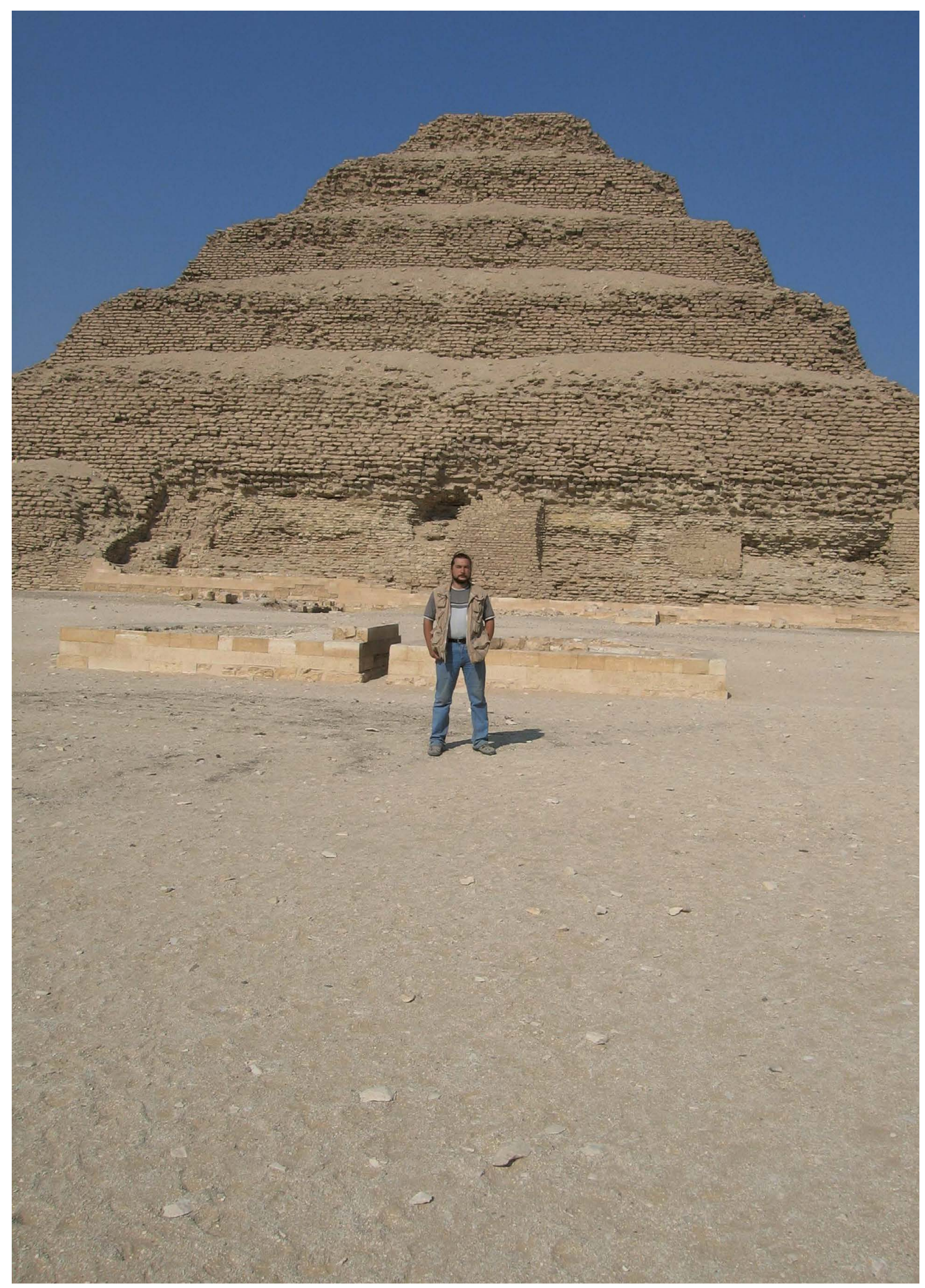




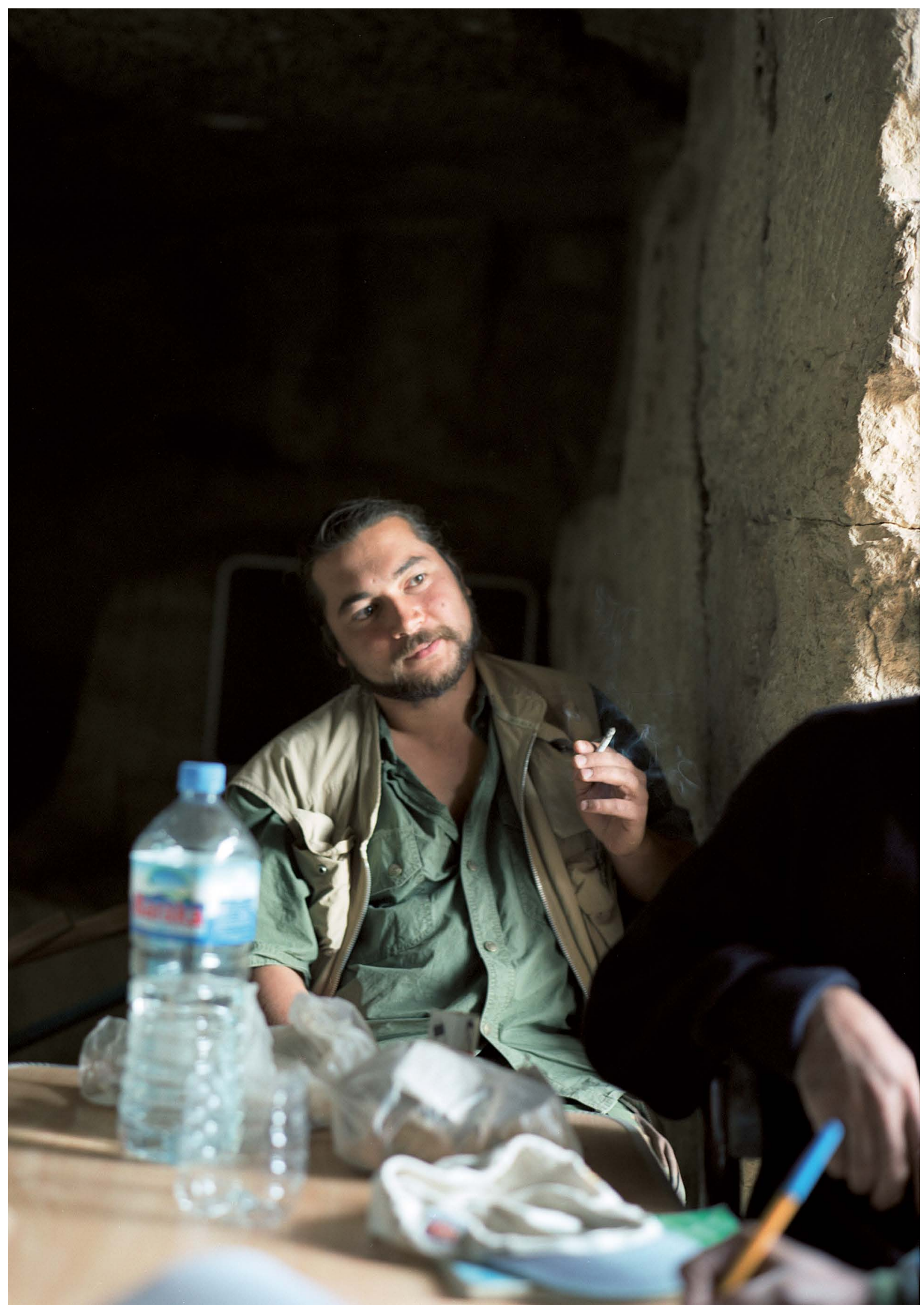

2005. Гиза. Каир. Экспедиция РАН в Египте 


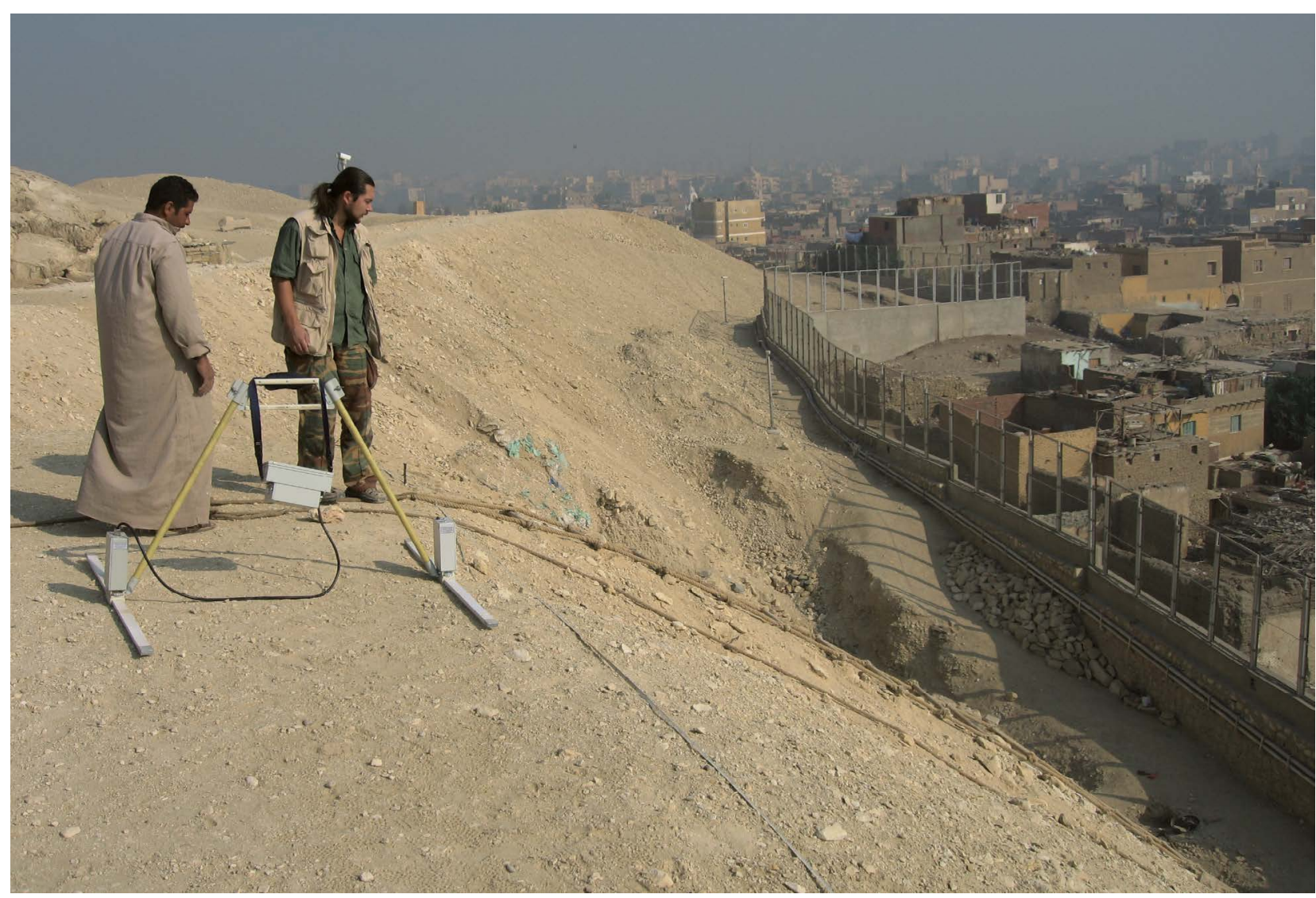

2006. Гиза. Каир. Экспедиция РАН в Египте. Работа с георадаром

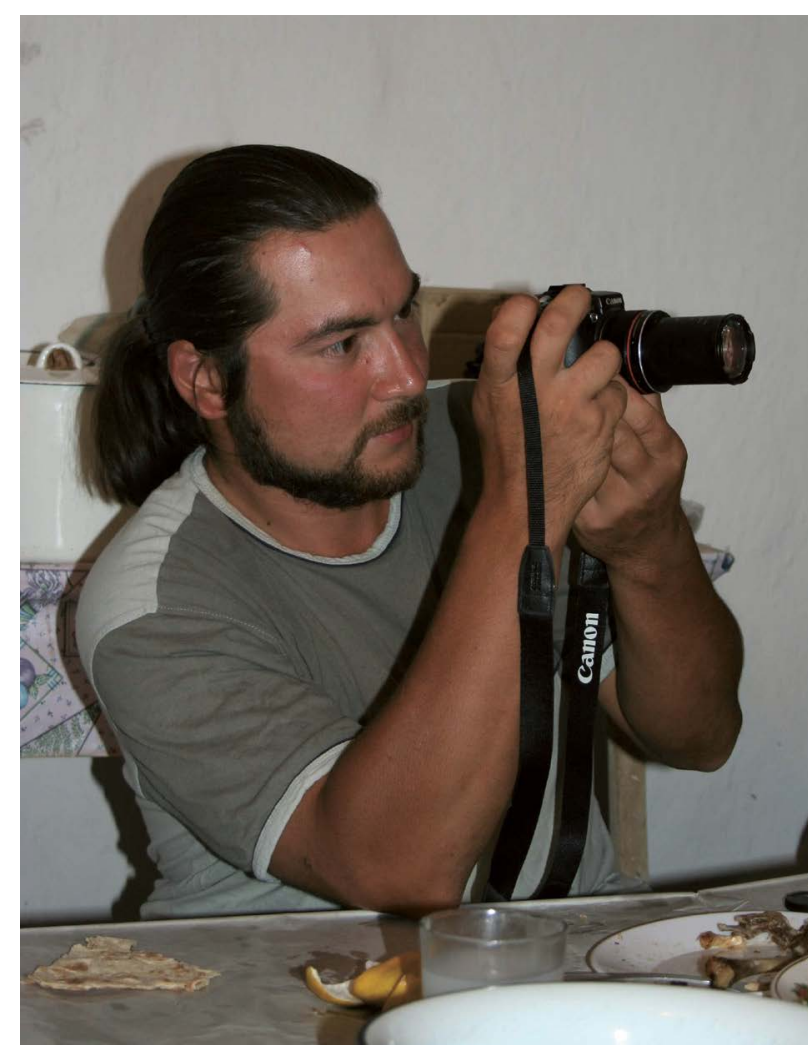

2007. Гиза. Каир. Экспедиция РАН в Египте 


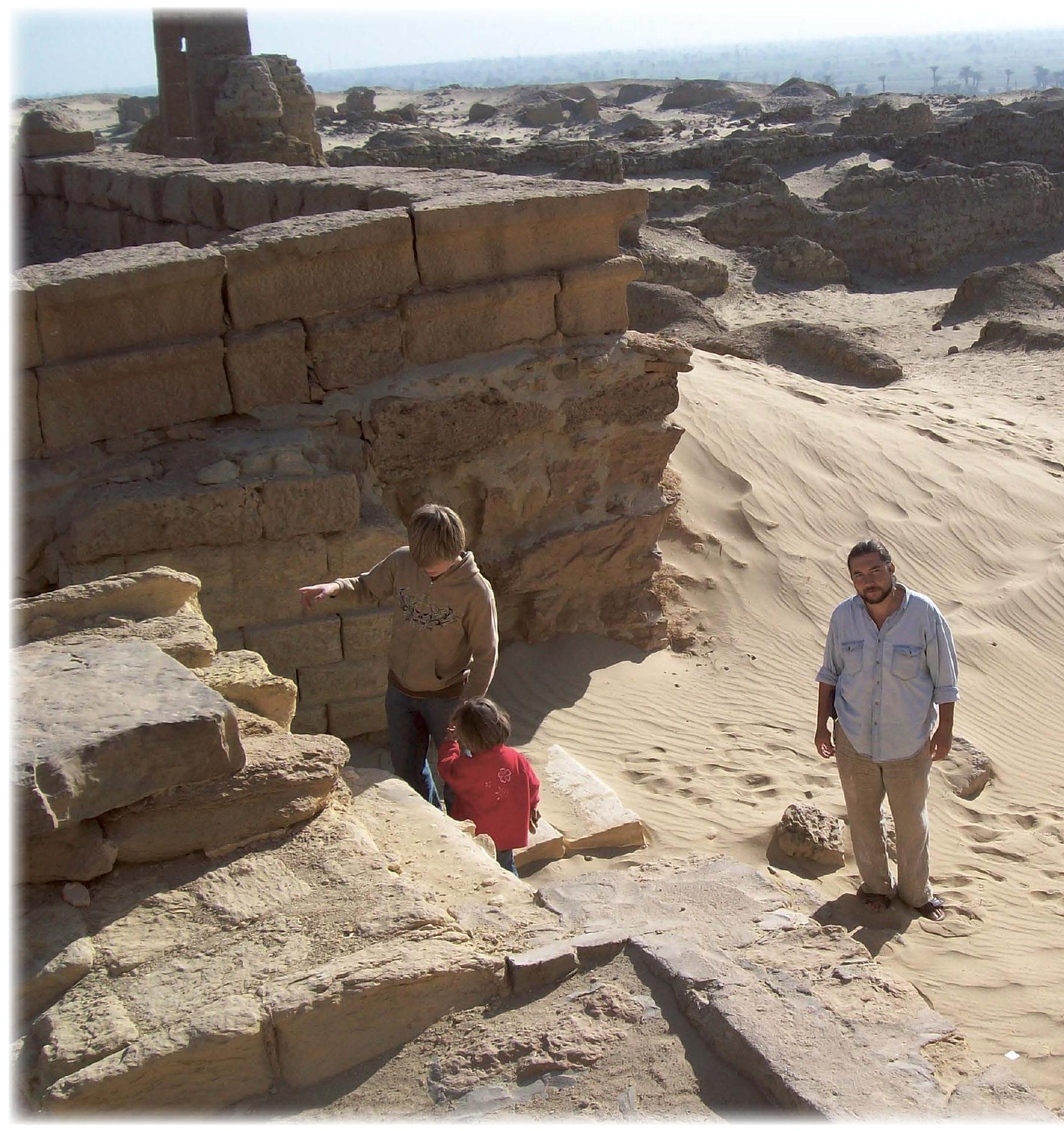

2007. Фаюм. Экспедиция РАН в Египте 
2013. Монголия. Экспедиция ИА РАН. Путь в экспедицию
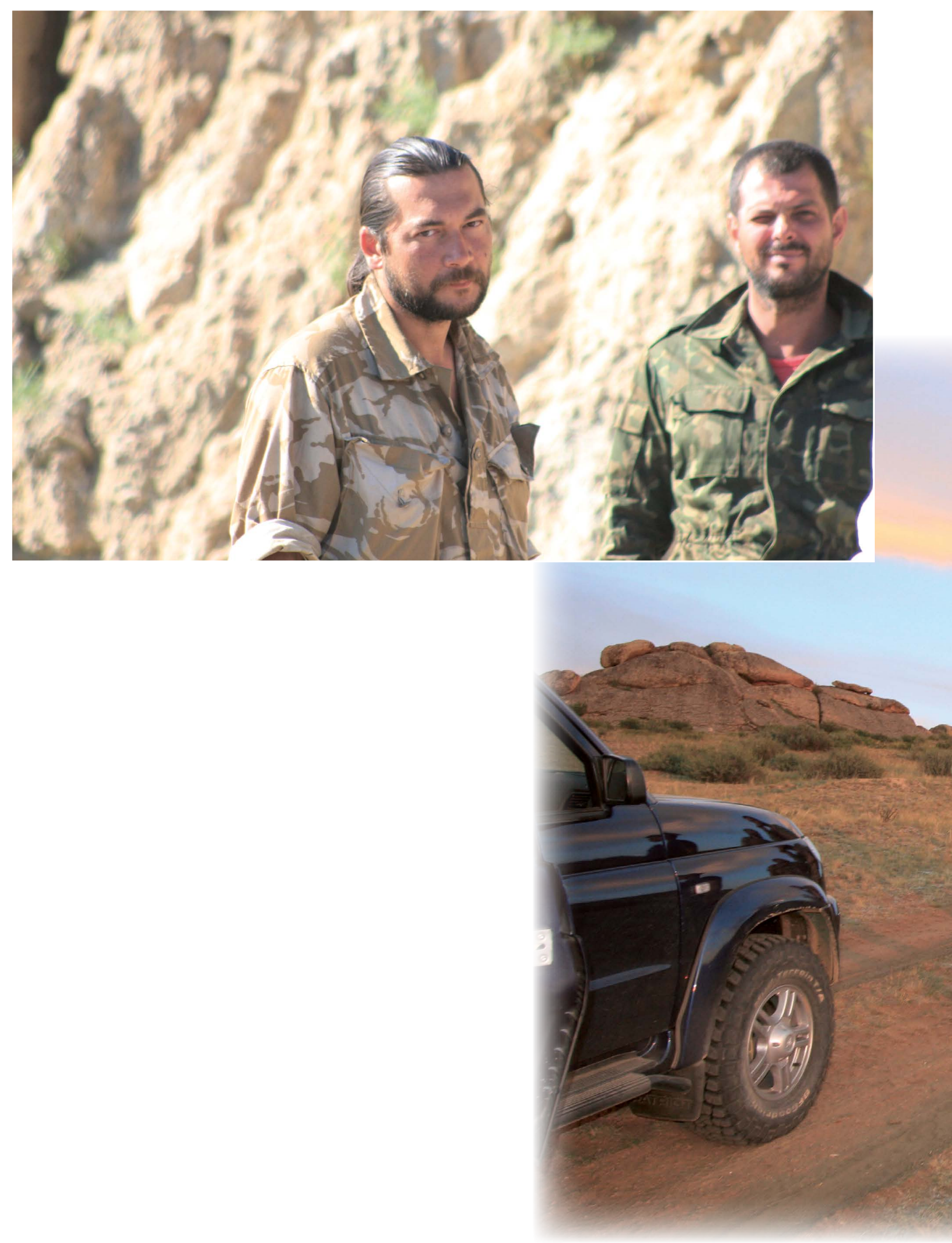


\section{Тува. 2012-2016}

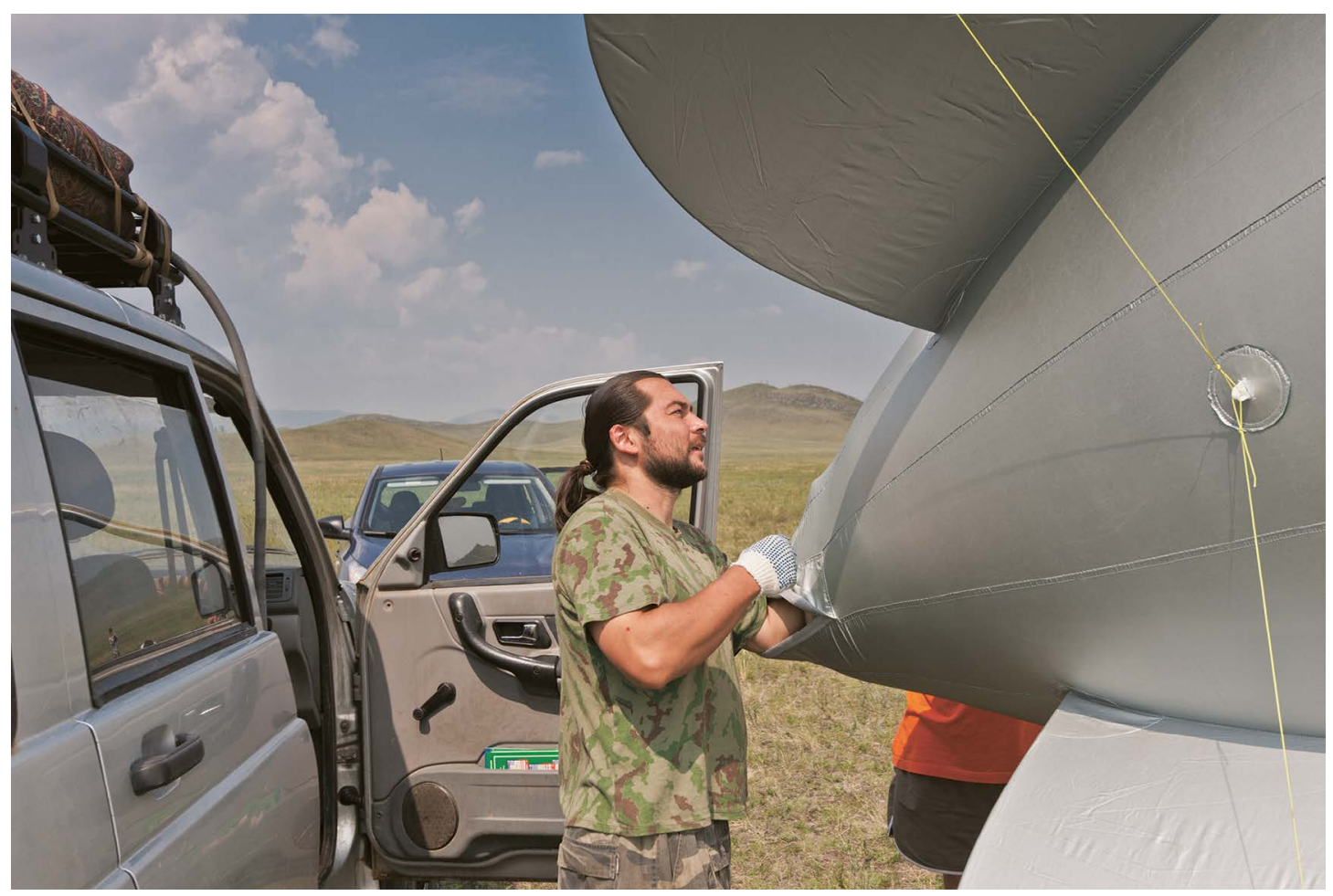

2012. Тува. Долина царей. Фотосъемка с аэростатом. Экспедиция ИА РАН

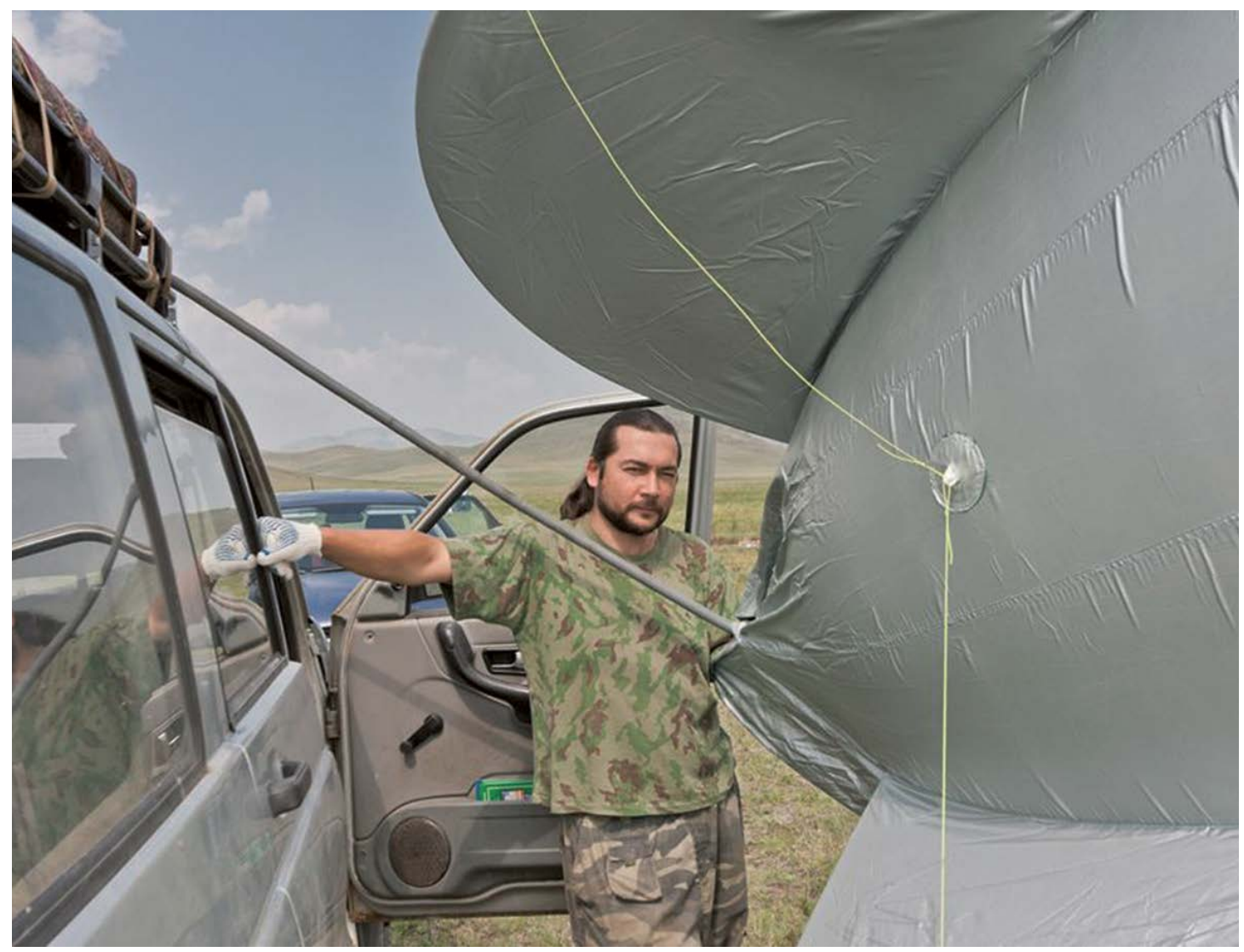

2012. Тува. Долина царей. Фотосъемка с аэростатом. Экспедиция ИА РАН 


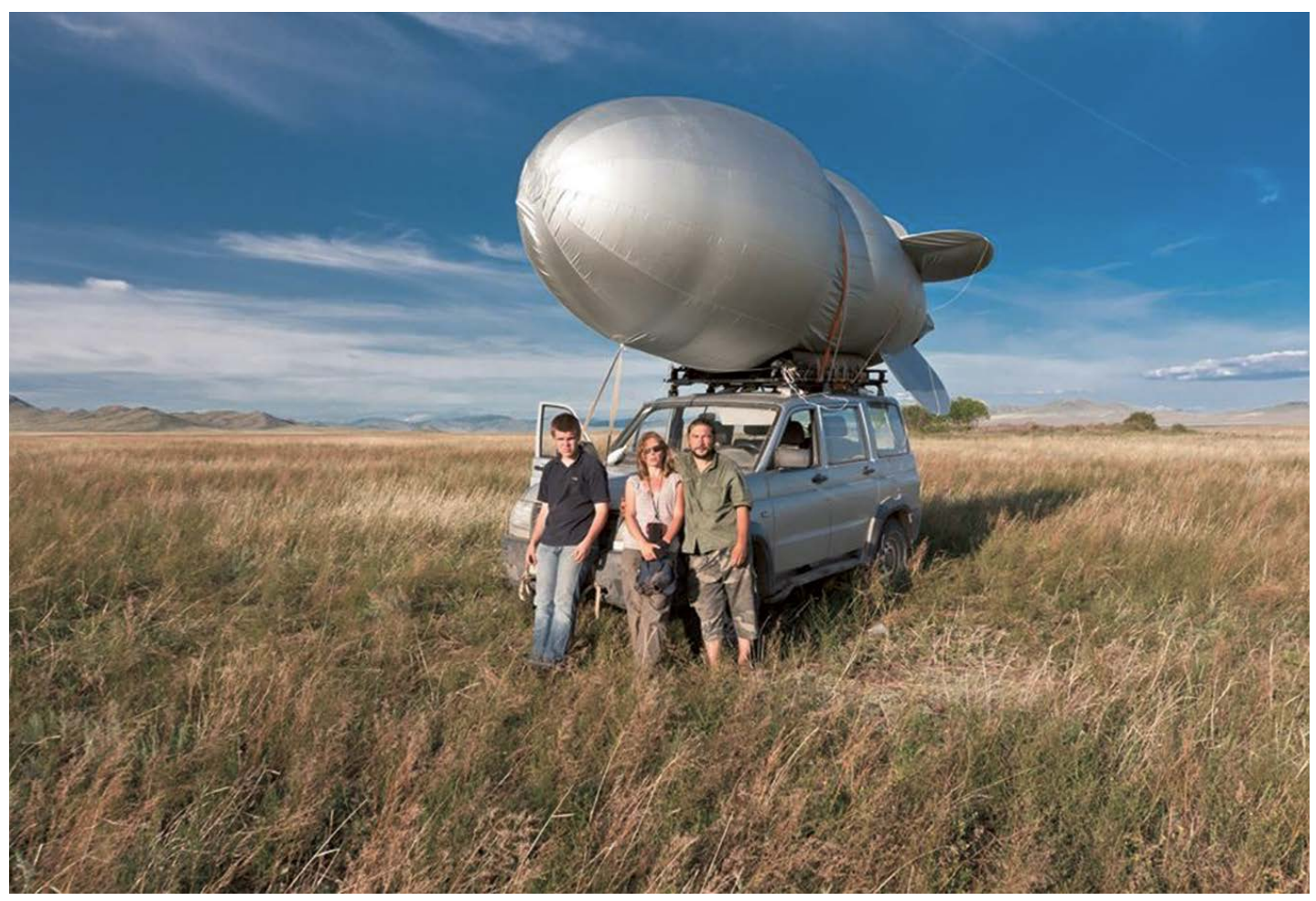

2012. Тува. Долина царей. Фотосъемка с аэростатом. Экспедиция ИА РАН

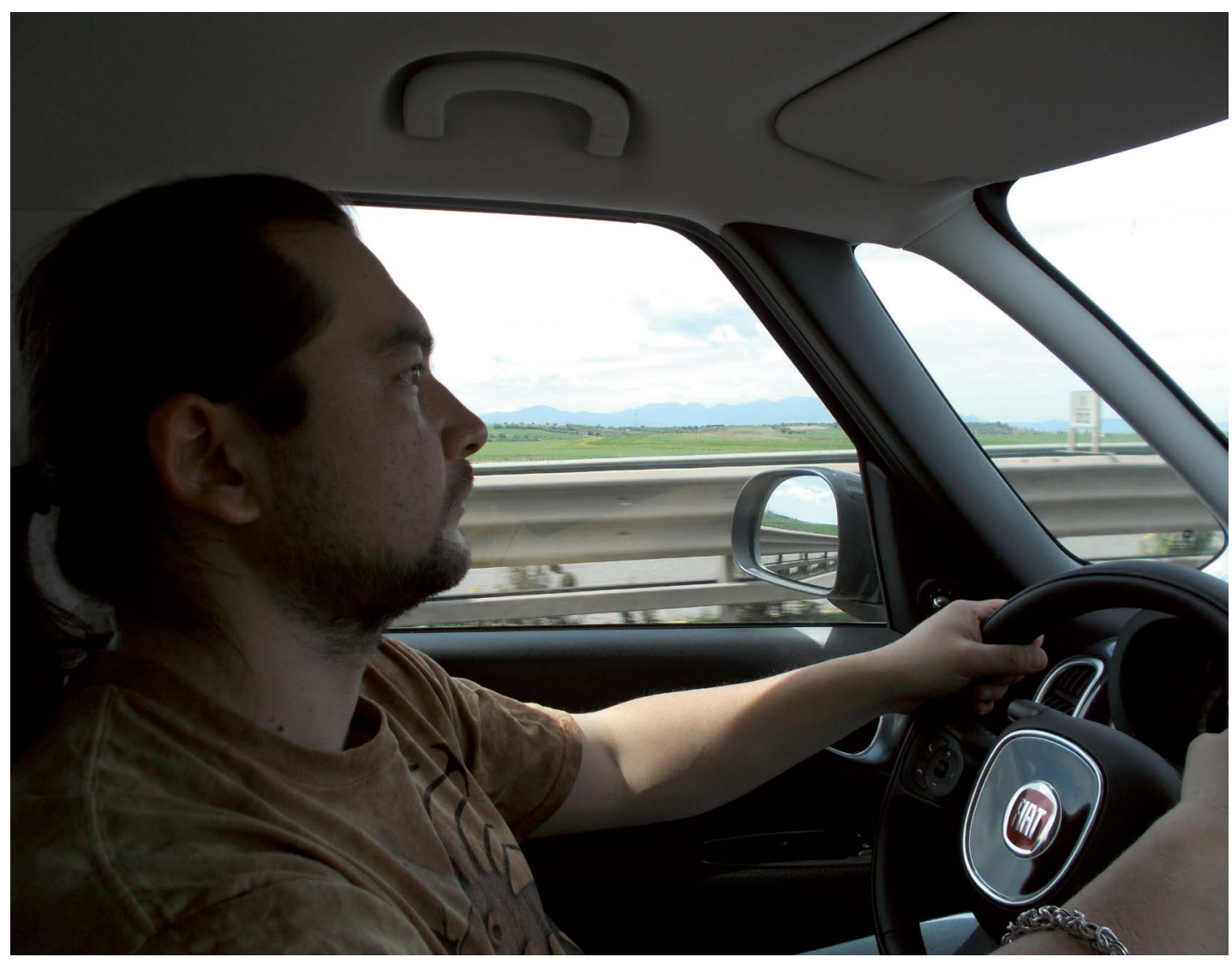

2013. Тува. Путь в экспедицию. Экспедиция ИА РАН 


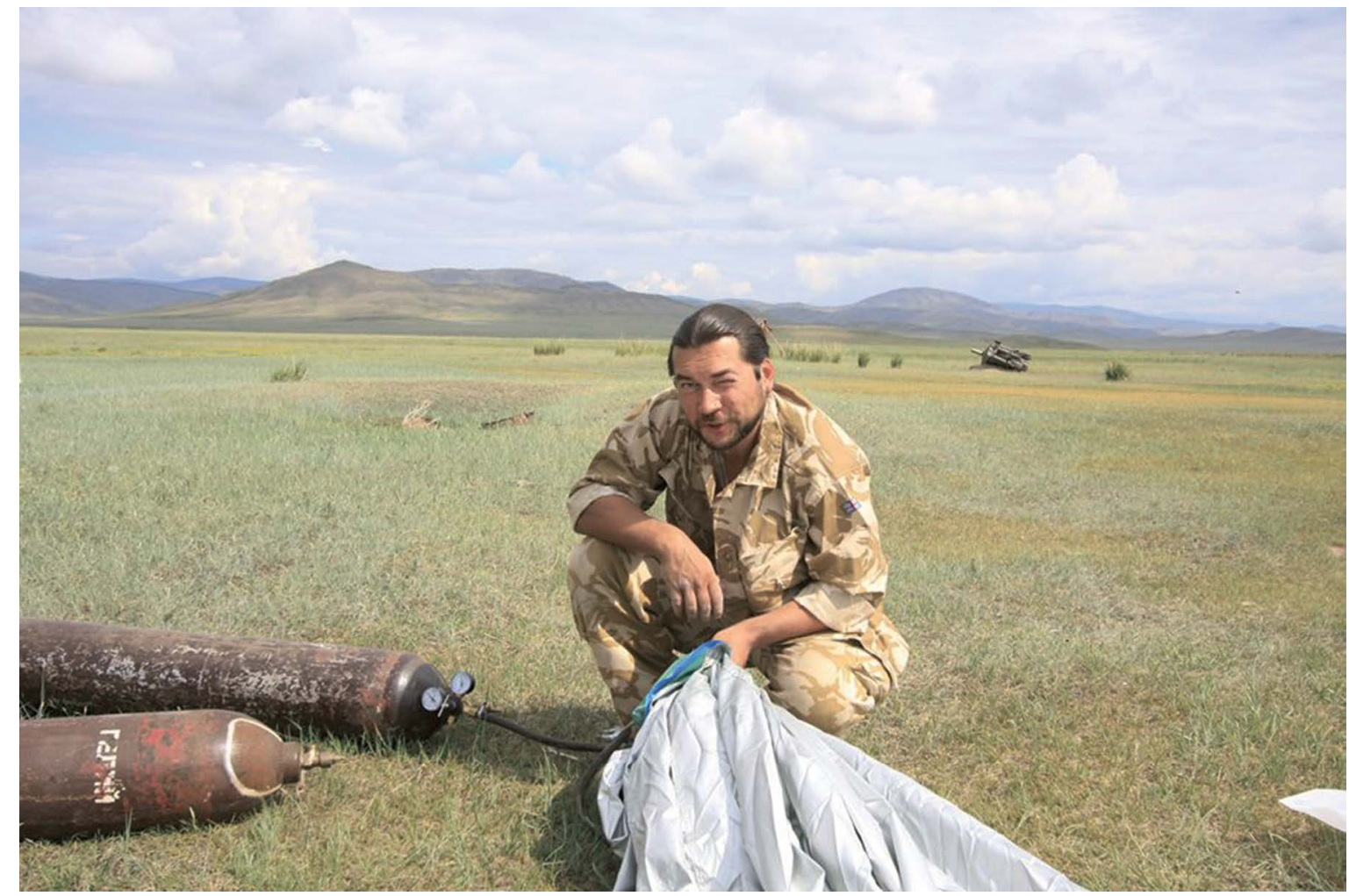

2013. Тува. Долина царей. Фотосъемка с аэростатом. Экспедиция ИА РАН

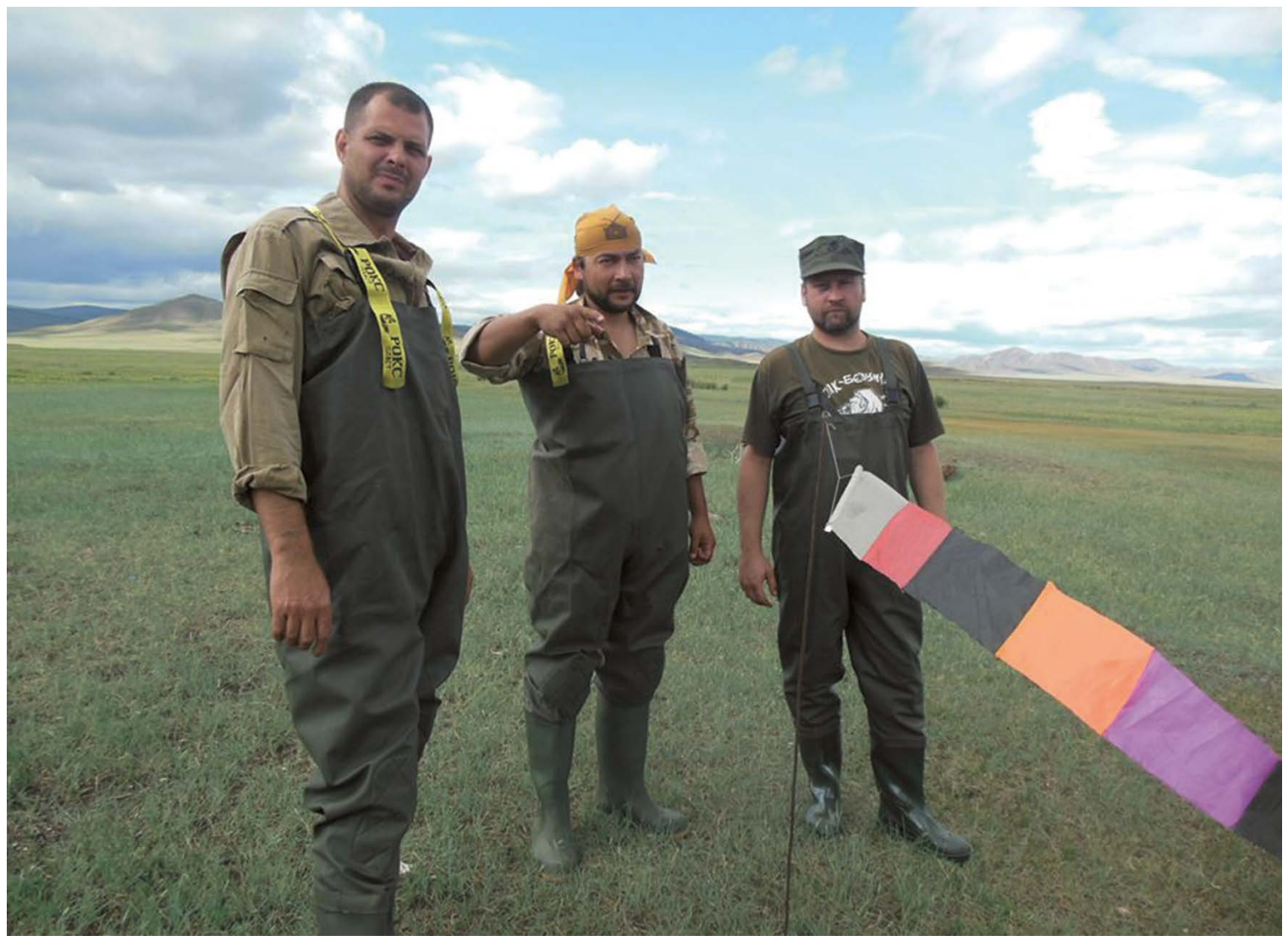

2013. Тува. Долина царей. Фотосъемка с аэростатом. Экспедиция ИА РАН 


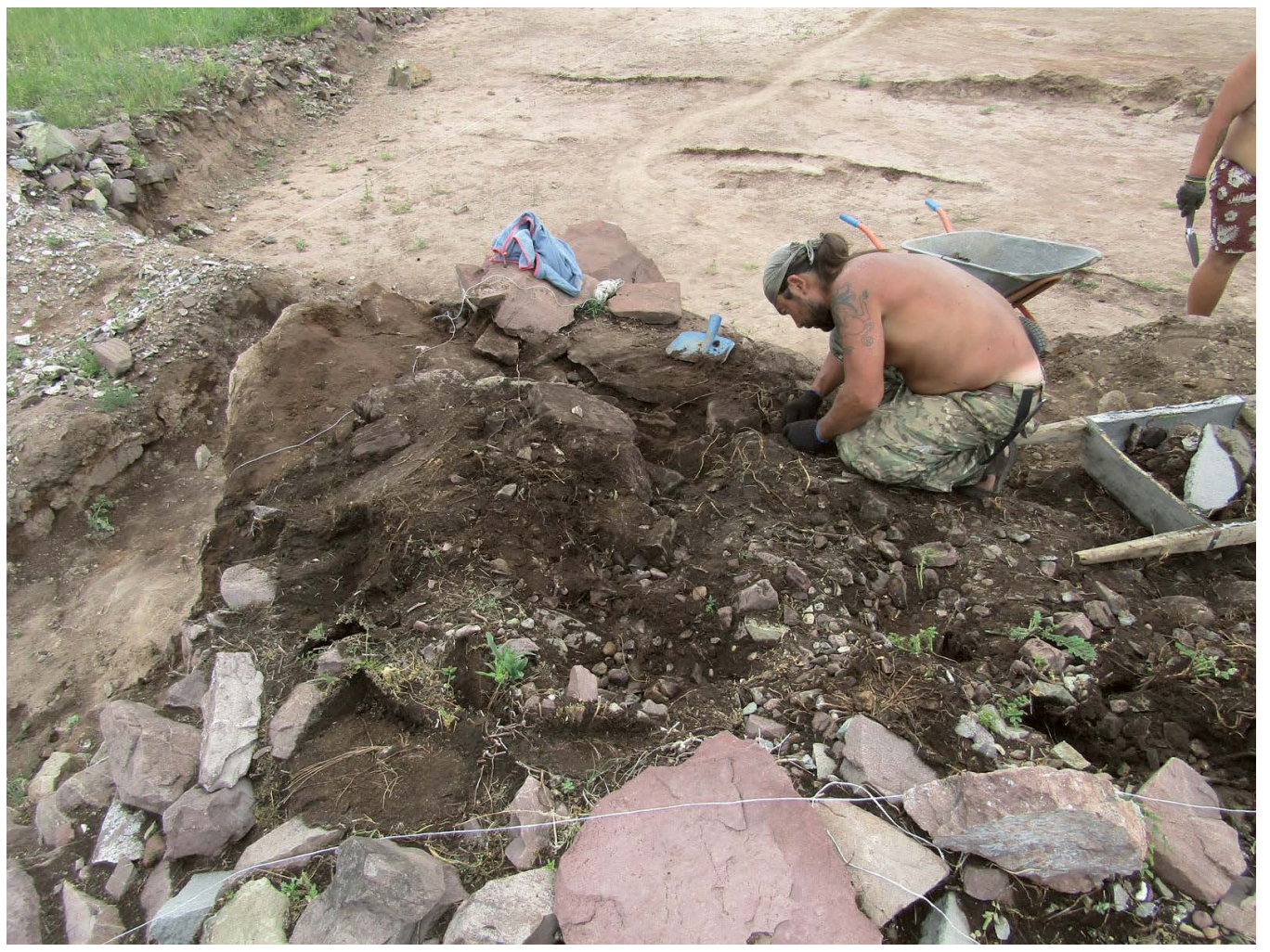

2016. Тува. Долина царей. Раскопки Аржана 5. Экспедиция ИА РАН

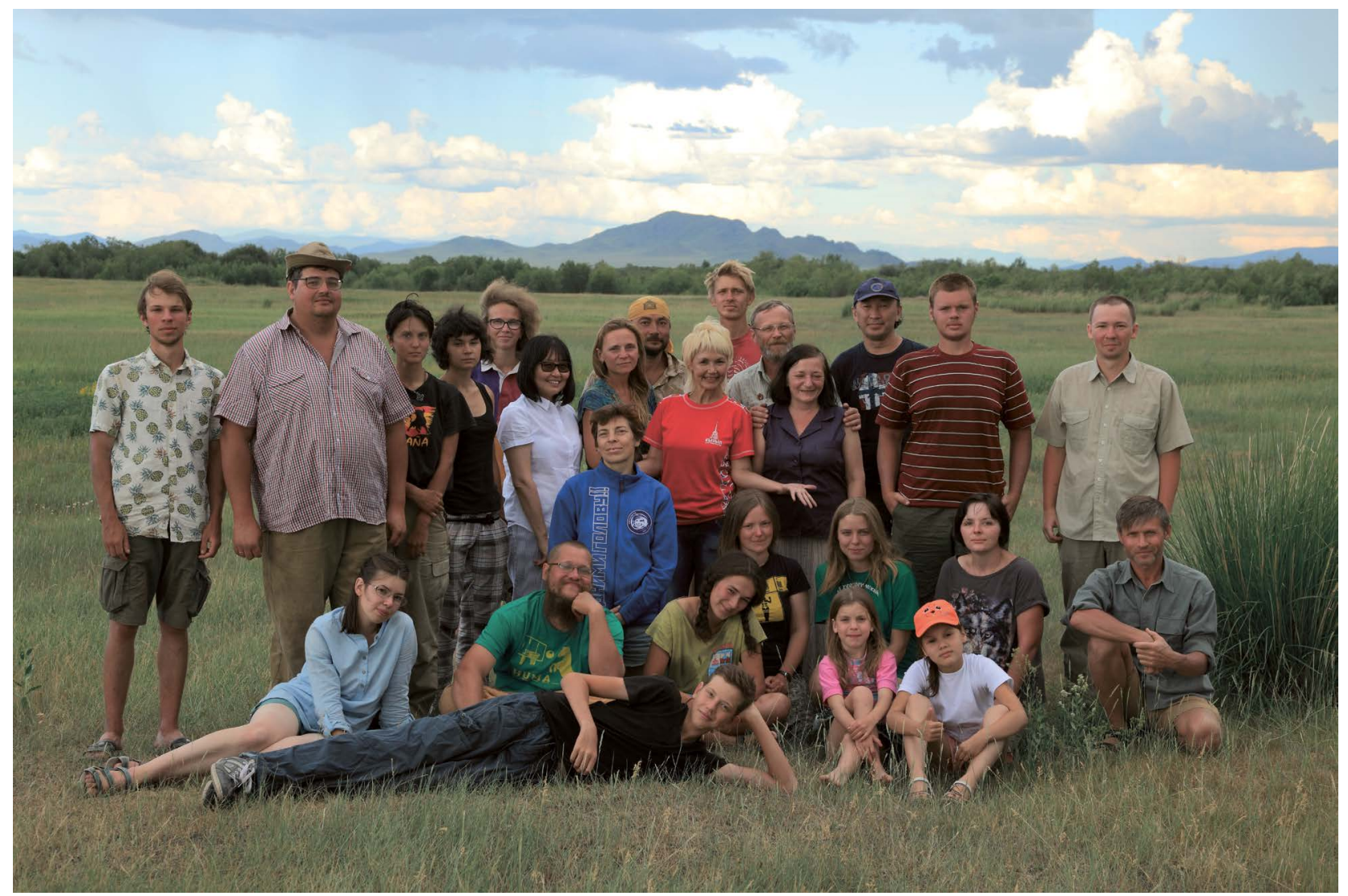


Узбекистан. 2012-2015

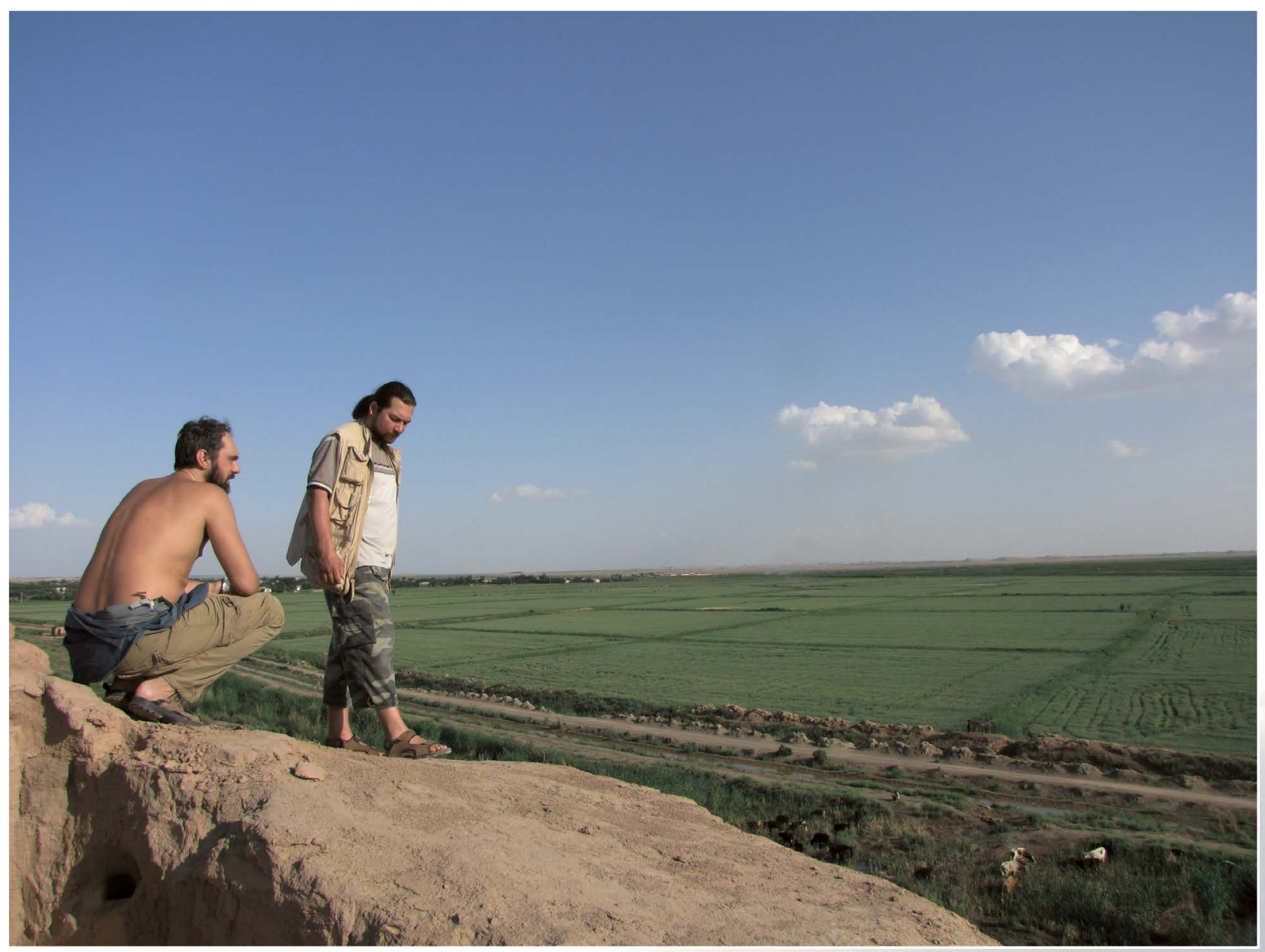

2012. Узбекистан. Кампыр-тепа.

Экспедиция ИА РАН

2015. Узбекистан.

Разведки.

Экспедиция ИА РАН 


\section{Домашние фото}

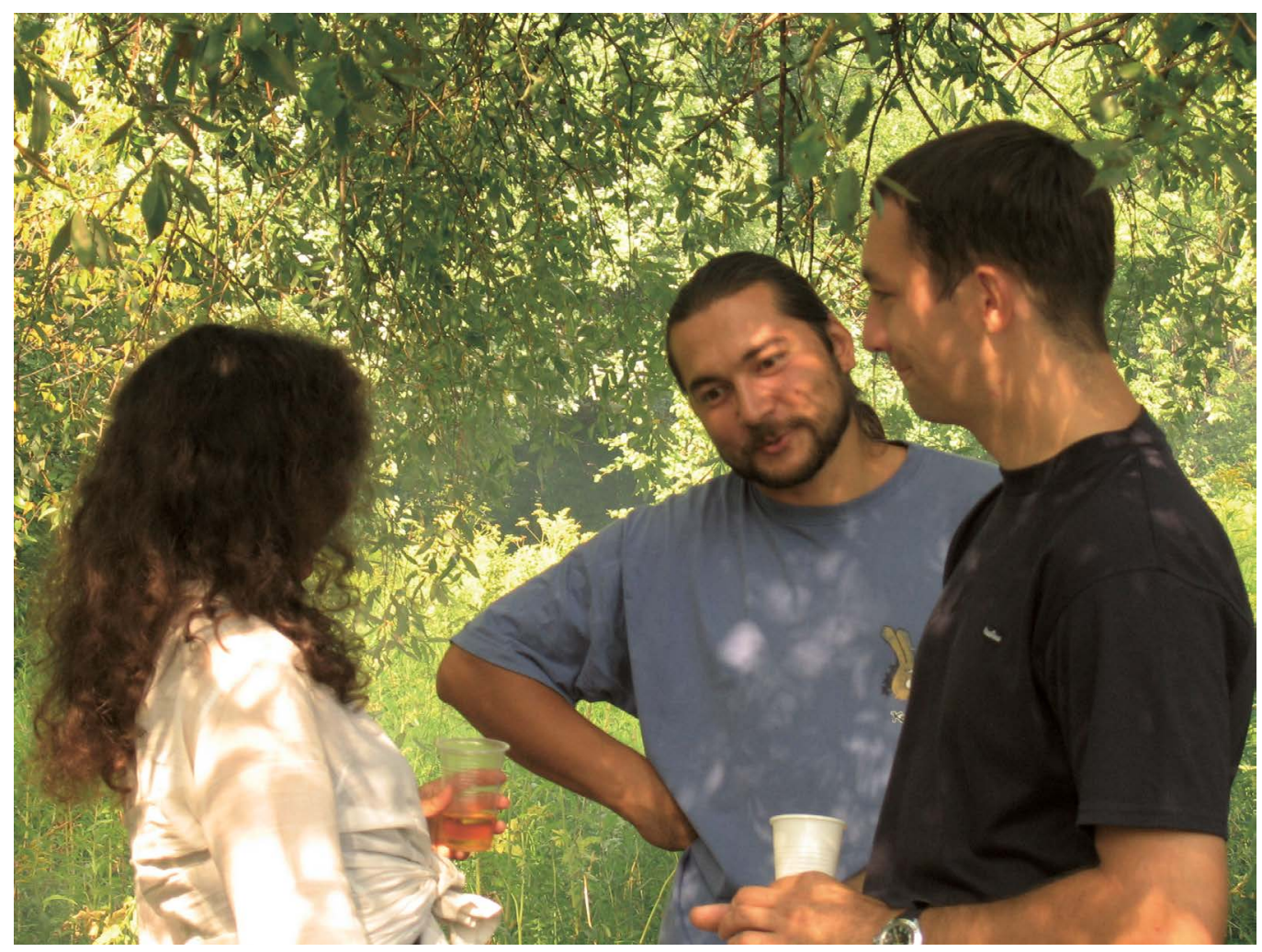

2005. День археолога в Москве

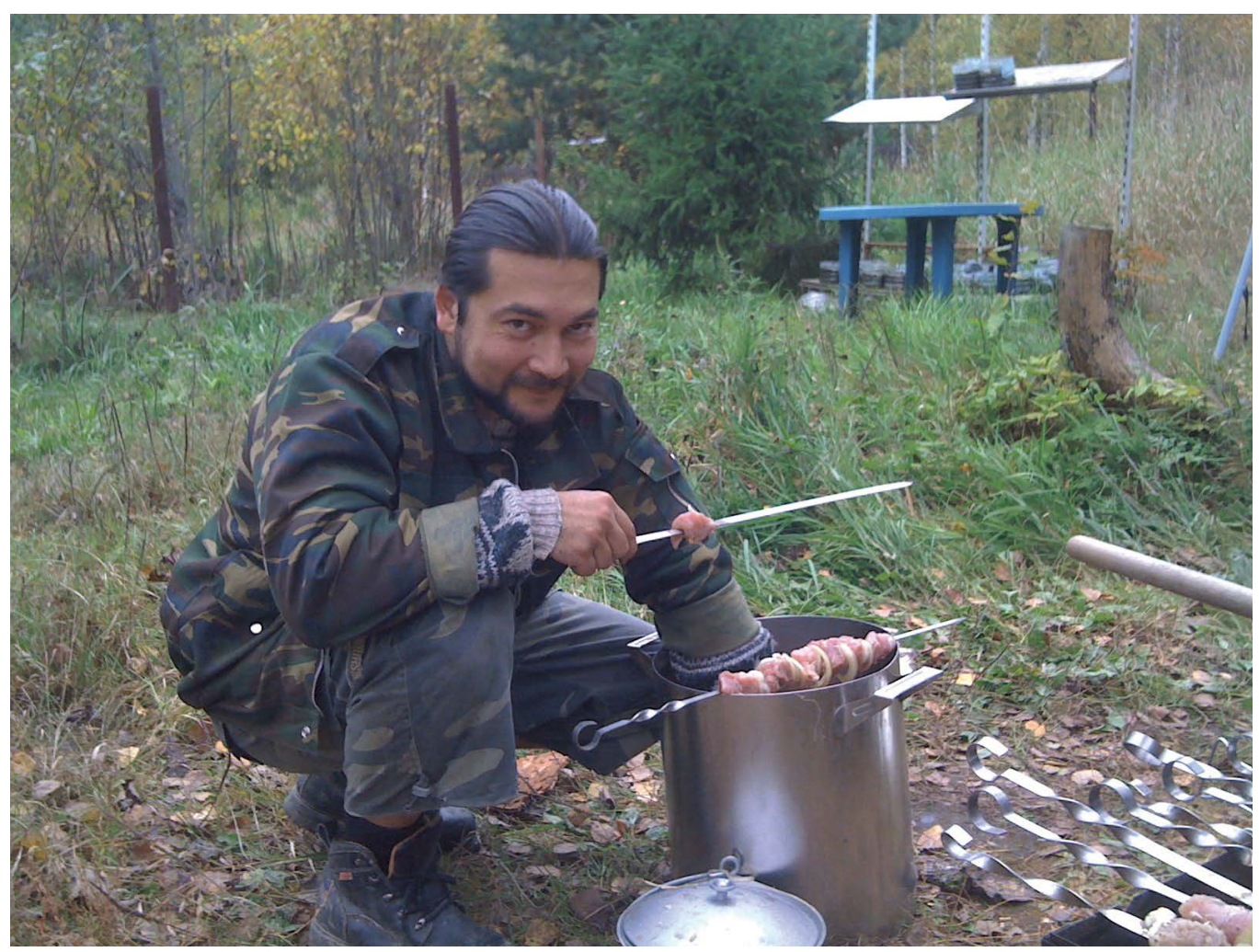

2011. День рождения Димы. Шишкин лес 


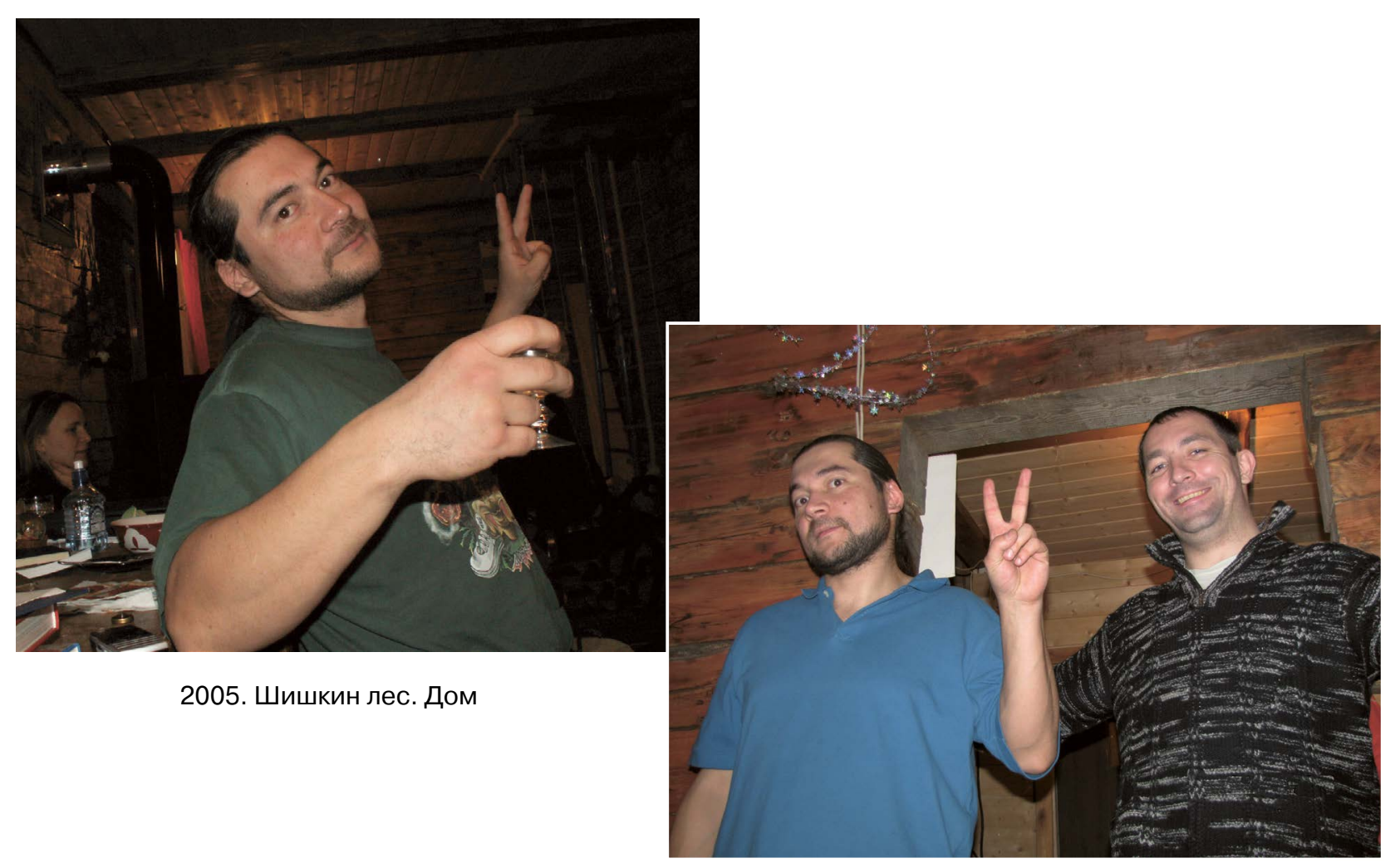

2011. Шишкин лес. Дом

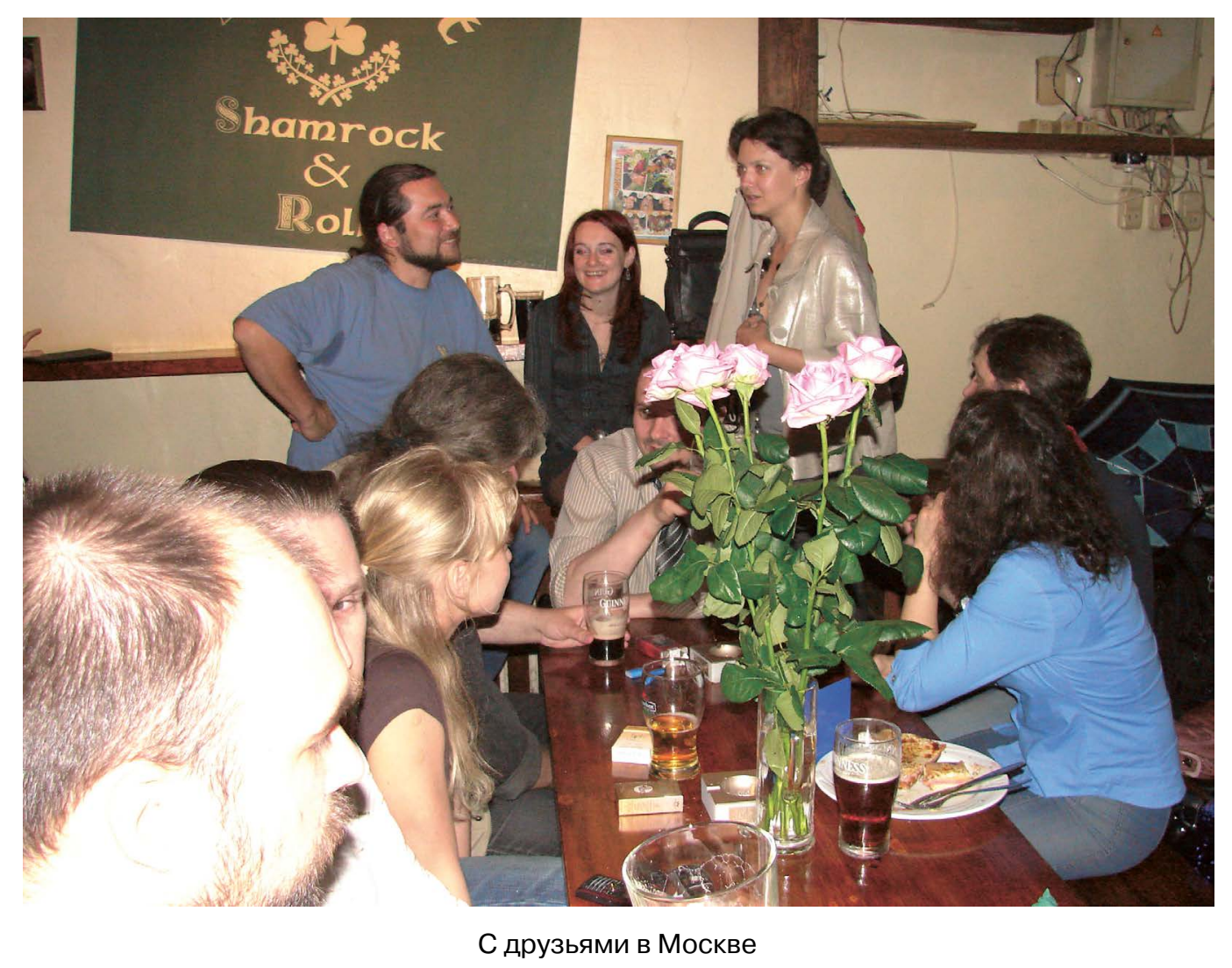




\section{Список сокращений}

\begin{tabular}{|c|c|}
\hline $\mathrm{AO}$ & - Археологические открытия \\
\hline ВДИ & - Вестник древней истории \\
\hline ГУК нПЦ ОИПиК & $\begin{array}{l}\text { - Краевое государственное бюджетное учреждение } \\
\text { «Хабаровский краевой центр охраны памятников истории и культуры» }\end{array}$ \\
\hline ГЭ & - Государственный Эрмитаж \\
\hline IA HAH & - Інститут археології Національної академії наук України \\
\hline ИИАЭ ДВО РАН & $\begin{array}{l}\text { - Институт истории, археологии и этнографии народов Дальнего Востока } \\
\text { Дальневосточного отделения РАН }\end{array}$ \\
\hline ИАК & - Известия Императорской Археологической Комиссии \\
\hline ИА РАН & - Институт археологии РАН \\
\hline КГОМА & - Курский государственный областной музей археологии \\
\hline КГУ & - Курский государственный университет \\
\hline КОИХМ & - Калининградский областной историко-художественный музей \\
\hline КСИА & - Краткие сообщения Института археологии РАН \\
\hline МАИЭТ & - Материалы по археологии, истории и этнографии Таврии \\
\hline МГУ & - Московский государственный университет имени М. В. Ломоносова \\
\hline МИА & - Материалы и исследования по археологии СССР \\
\hline МИАР & - Материалы и исследования по археологии России \\
\hline OAK & - Отчеты Императорской Археологической Комиссии \\
\hline ПСРЛ & - Полное собрание русских летописей \\
\hline CA & - Советская археология \\
\hline САИ & - Археология СССР. Свод археологических источников \\
\hline МДАПВ & - Матеріали і дослідження з археології Прикарпаття і Волині \\
\hline ТувГУ & - Тувинский государственный университет \\
\hline ЧОИДР & - Чтения Общества истории и древностей российских \\
\hline JAS & - Journal of Archaeological Science \\
\hline RGZM & - Römisch-Germanisches Zentralmuseum \\
\hline
\end{tabular}




\section{Сведения об авторах}

Амиров Шахмардан Назимович (Институт археологии РАН)

Вальчак Сергей Борисович (Институт археологии РАН)

Веретюшкин Роман Сергеевич (Институт археологии юго-востока Руси при Курском Государственном университете)

Веселитская Виктория Владимировна (Государственный исторический музей)

Ветохов Сергей Вячеславович (Институт востоковедения РАН)

Гладченков Александр Андреевич (Институт истории, археологии и этнографии народов Дальнего Востока ДВО РАН)

Горболь Николай Юрьевич (Российский университет дружбы народов)

Двуреченская Нигора Давлятовна (Институт археологии РАН)

Двуреченский Олег Викторович (Институт археологии РАН)

Дружинина Инга Александровна (Институт археологии РАН)

Коробов Дмитрий Сергеевич (Институт археологии РАН)

Каинов Сергей Юрьевич (Государственный исторический музей)

Канторович Анатолий Робертович (Московский государственный университет имени М.В. Ломоносова)

Клюев Николай Александрович (Институт истории, археологии и этнографии народов Дальнего Востока ДВО РАН)

Кулешов Юрий Алексеевич (проблемный семинар «Военная археология» при Институте археологии РАН)

Ласкин Артур Робертович (Хабаровский краевой центр охраны памятников истории и культуры)

Лебедев Максим Александрович (Институт востоковедения РАН)

Мадуров Дмитрий Федорович (АНО «Центр стратегических исследований Ульяновской области»)

Малых Светлана Евгеньевна (Институт востоковедения РАН)

Меньшиков Максим Юрьевич (Институт археологии РАН)

Морозов Павел Алексеевич (Институт земного магнетизма, ионосферы и распространения радиоволн имени Н.В. Пушкова РАН)

Мунчаев Рауф Магомедович (Институт археологии РАН)

Пастухов Алексей Михайлович (Фонд «Петропавловск»)

Радюш Олег Александрович (Институт археологии РАН)

Рукавишникова Ирина Викторовна (Институт археологии РАН)

Румянцева Ольга Сергеевна (Институт археологии РАН)

Слепцов Игорь Юрьевич (Институт истории, археологии и этнографии народов Дальнего Востока ДВО РАН)

Черкасов Андрей Николаевич (Фонд «Петропавловск»)

Чугунов Константин Владимирович (Институт истории материальной культуры РАН)

Чхаидзе Виктор Николаевич (Институт археологии РАН)

Юнкин Жамиль Алиевич (Институт археологии РАН) 


\section{Научное издание}

\section{Древние памятники, культуры и прогресс}

A caelo usque ad centrum. A potentia ad actum. Ad honores

Редактор: Г.Г. Король

Корректор: Н. И. Пепелина

Верстка: Т.Н. Бруссель

Подписано к печати 01.10.2020

Формат 60×84/8. Уч.-изд. л. 30,8.

Тираж 300 экз. Заказ №

Институт археологии РАН

117292, Москва, ул. Дмитрия Ульянова, 19

Отпечатано с электронной версии заказчика

В типографии ООО «Красногорский полиграфический комбинат» 107140, г. Москва, пер. 1-й Красносельский, д. 3, оф. 17

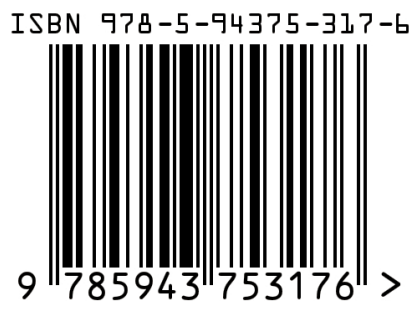

